\title{
Grace-ful Reading: \\ Theology and Narrative in \\ The Works of John Bunyan
}

Thesis submitted for the degree of

Doctor of Philosophy

at the University of Leicester

by

Michael T. Davies BA (Oxon)

Department of English

University of Leicester

December 1997 
UMI Number: U105034

All rights reserved

\section{INFORMATION TO ALL USERS}

The quality of this reproduction is dependent upon the quality of the copy submitted.

In the unlikely event that the author did not send a complete manuscript and there are missing pages, these will be noted. Also, if material had to be removed, a note will indicate the deletion.

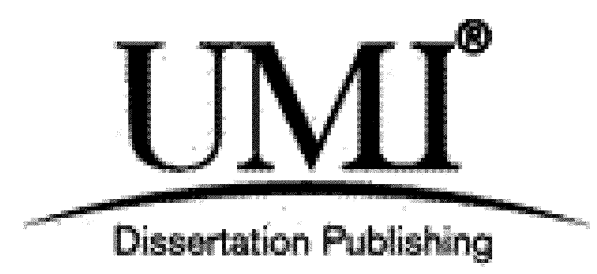

UMI U105034

Published by ProQuest LLC 2013. Copyright in the Dissertation held by the Author.

Microform Edition (c) ProQuest LLC.

All rights reserved. This work is protected against unauthorized copying under Title 17, United States Code.

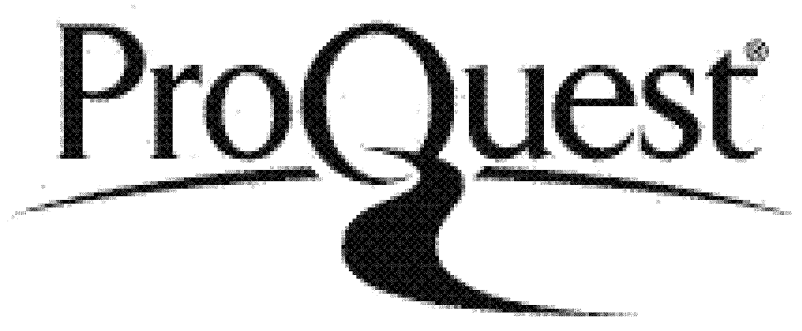

ProQuest LLC

789 East Eisenhower Parkway

P.O. Box 1346

Ann Arbor, MI 48106-1346 


\title{
Grace-ful Reading: Theology and Narrative in The Works of John Bunyan
}

\author{
Thesis submitted for the degree of Doctor of Philosophy \\ at the University of Leicester by Michael T. Davies \\ December 1997
}

This thesis challenges the literary tradition of reading Bunyan's narrative works separately from the theology that fundamentally informs them. It argues that a full understanding of texts like Grace Abounding to the Chief of Sinners and The Pilgrim's Progress is possible only through a more accurate appraisal of Bunyan's religious doctrines, and a critical practice that pays due attention to Bunyan's Nonconformist poetics.

'Grace-ful Reading' regards Bunyan's theology in terms very different from those of the abhorrent Calvinism that studies often emphasise. Bunyan's narratives are understood here as propounding a doctrine of Law and grace that is essentially accommodating and comforting. Moreover, in terms of the experiential nature of Bunyan's theology, this thesis aims to demonstrate that his narrative works are constructed according to a specific purpose - to teach the reader about reading the self and the Word in terms of a faith that is experimental rather than rational.

Consequently, 'Grace-ful Reading' views Bunyan's narrative works as attempting to elicit a specifically doctrinal reader-response, one that foregrounds spiritual understanding over anything knowable and reasonable. Indeed, Bunyan's texts teach about grace, faith, and spiritual perception by frustrating the reader's rational expectations of them as narratives. Hence, Bunyan's textual procedures are considered as essentially anti-narrative, his spiritual autobiography and spiritualised allegories effectively curtailing any 'historical' interest in them as moralistic or imaginative fables.

'Grace-ful Reading' offers a more detailed and contextually situated understanding of Bunyan's doctrines while exploring the textuality of his writings through a contemporary, even postmodernist narrative discourse.

This study is organised into six chapters. Chapter 1 specifically addresses Bunyan's theology while Grace Abounding and The Pilgrim's Progress receive extensive analysis in chapters 2 and 3, 4 and 5 respectively. Chapter 6 assesses The Life and Death of Mr. Badman, The Holy War, and The Pilgrim's Progress, Part II as sequels to Bunyan's most popular allegory. 


\section{Contents}

Thesis Abstract

ii

Acknowledgements

iv

A Note on the Texts and Abbreviations

$\mathbf{v}$

Introduction

1

1. A Comfortable Doctrine: Bunyan's Theology of Grace

2. Bunyan's Exceeding Maze: Doctoring and Doctrine in Grace Abounding to the Chief of Sinners

3. Of Things Seen and Unseen: Grace-ful Reading and Narrative Practice in Bunyan's Grace Abounding

4. Into an Allegory: Method, Metaphor and the Apology of The Pilgrim's Progress

5. 'Sweet fiction and sweet truth': Theology and Narrative in The Pilgrim's Progress

6. First Amongst Sequels: John Bunyan's Other Allegories 


\section{Acknowledgements}

This thesis has been completed only with the help of a number of individuals and academic bodies to whom I am most grateful. First and foremost, I would like to thank my supervisor, Professor Vincent Newey of Leicester University's English Department, both for his professional and personal support for this research project. Without Professor Newey's backing and confidence, I would not have been given the opportunity to come to Leicester and write this thesis at all. Over the past four years, his faith in me has indeed been as a 'Mill-post at my back'.

I would also like to acknowledge the University of Leicester Faculty of Arts Research Budget Centre for funding essential trips to the British Library and Bedford Central Library during the period of my Scholarship at Leicester, and for enabling me to attend (and participate in) the first International John Bunyan Society Conference at the University of Alberta, Canada, in October 1995. Gratitude must also be expressed to the University of Leicester's Academic Registrar, Kathy Williams, as well as the Higher Degrees Office, for extending the writing-up period of this thesis and kindly waiving any further registration fees.

On a personal level, I would like to thank my mum and dad (and my family as a whole) for their encouragement and concern throughout my years of study, as well as the friends who have made the writing of this thesis a thoroughly pleasurable, sociable, and (though only at the worst times) an endurable thing to do: especially David Salter, Mike and Andy Hagiioannu, Greg Walker and Pete Smith, and, of course, Carina Vitti (who has waited with the most patience of all for this to be finished). 


\section{A Note on the Texts and Abbreviations}

The editions of Bunyan's narrative works referred to in this thesis are: The Pilgrim's Progress (Parts I and II), ed. by James Blanton Wharey, 2nd edn, rev. by Roger Sharrock (Oxford: Clarendon Press, 1960), Grace Abounding to the Chief of Sinners, ed. by Roger Sharrock (Oxford: Clarendon Press, 1962), The Holy War, ed. by Roger Sharrock and James F. Forrest (Oxford: Clarendon Press, 1980), and The Life and Death of Mr. Badman, ed. by James F. Forrest and Roger Sharrock (Oxford: Clarendon Press, 1988).

Where Bunyan's non-narrative tracts and treatises are referred to, The Miscellaneous Works of John Bunyan, 13 vols, General Editor: Roger Sharrock (Oxford: Clarendon Press, 1976-1994) have been used wherever possible. Where relevant volumes of the Oxford Miscellaneous Works have not been readily accessible, The Works of John Bunyan, ed. by George Offor, 3 vols (Glasgow: W. G. Blackie and Son, 1854; repr. by The Banner of Truth Trust, 1991) have been cited. Offor's edition of Bunyan's Works is still both widely available and very often referred to by literary commentators. Offor's Works also usefully includes Reprobation Asserted (1674), which was once attributed to Bunyan.

Both original and twentieth-century editions of other seventeenth-century texts have been cited in this study and no attempts have been made to modernise spelling or grammar when quoting from Bunyan's or any other author's works.

The only abbreviations used in this thesis are for the titles of the following academic journals:

$\begin{array}{lll}E L H & - & \text { A Journal of English Literary History } \\ E L R & - & \text { English Literary Renaissance } \\ M L N & - & \text { Modern Language Notes } \\ N L H & - & \text { New Literary History } \\ P M L A & - & \text { Publications of the Modern Language Association of America } \\ R E S & - & \text { Review of English Studies } \\ S E L & - & \text { Studies in English Literature }\end{array}$




\section{Introduction}

This is the sweetest study that a man can devote himself unto; because 'tis the study of the love of God and of Christ to man. Studies that yield far less profit than this, how close are they pursued, by some who have adapted themselves thereto?

This thesis presents a reassessment of one of the most problematic issues in the literary study of John Bunyan's writings: how narrative works like Grace Abounding to the Chief of Sinners and The Pilgrim's Progress are to be read and understood in relation to Bunyan's Calvinist theological convictions. As such, this is a study which, given the critical reception of Bunyan (over the last century, at least) could seem to be far from 'the sweetest' that anyone would 'devote himself unto'. Indeed, much criticism of Bunyan's writings seems to offer a sentiment exactly opposite to this, finding the theological aspect of Bunyan's imaginative and narrative works both difficult to accept in itself and, moreover, hard to assimilate into a concept of 'literature' that has developed according to the positive and humane precepts of what might be termed 'liberal humanism'. ${ }^{2}$ Consequently, literary studies have tended, on the one hand, to encourage readers to read texts like The Pilgrim's Progress in more general, moral, or universally 'religious' terms, thereby ignoring the tougher aspects of Bunyan's Nonconformist doctrinal stance completely. On the other hand, however, those critics who have addressed the specifics of Bunyan's faith have often done so simply to condemn it as unacceptable in any case - that is, as an abhorrent doctrine of predestinarian Calvinism that gladly sees the majority of mankind damned to eternal perdition. ${ }^{3}$

\footnotetext{
' John Bunyan, The Saints Knowledge of Christ's Love (1692), in The Miscellaneous Works of John Bunyan XIII, ed. by W. R. Owens (Oxford: Clarendon Press, 1994), p. 407.

${ }^{2}$ According to Tamsin Spargo 'liberal humanism' embodies 'many values now assumed to be self-evident truths about the nature of language, power and subjectivity' and which arose from 'the struggles and discontinuities of the contest for meaning in the seventeenth century'. It is in this tradition that 'the notion of the author as individual subject and source of meaning, and of critic as individual subject in confident possession of the objects of knowledge' seems to have its roots (The Writing of John Bunyan [Aldershot: Ashgate, 1997]), pp. 78.

${ }^{3}$ These critical viewpoints and the works in which they are demonstrated will be discussed in detail in the first chapter of this thesis.
} 
In these terms, the segregation of Bunyan the 'Parnassian' creative writer and protonovelist from Bunyan the harsh conventicling theologian seems to have become the necessary function of a literary appropriation of Bunyan that seeks to redeem him from his own doctrine in order for him to remain readable as 'literature'. It is the purpose of this thesis, however, to suggest a different and more constructive way of reading Bunyan's narrative and doctrinal works, one which integrates a literary understanding of Bunyan's texts with (rather than separating it from) the theology that so obviously and wholly informs them. This study will show how Bunyan's texts can and should be read as works seriously engaged with complex literary issues of narrative practice and textual manipulation, metaphor and interpretation, but precisely in (and not in spite of) the tenets of a theology that is so often amputated from them.

In order to achieve such an explicit renegotiation of our understanding of Bunyan's narrative art, this thesis begins by instating a reassessment of Bunyan's theology itself in relation to the terms often used to describe it by literary commentators (whose 'critical controversies', it is being assumed here, are largely 'disguised reports of what readers uniformly do' when reading Bunyan's writings). ${ }^{4}$ What this thesis proposes is that the common perception of Bunyan's theology as harsh, predestinarian, and essentially Calvinist is largely inadequate (if not wholly misleading) in the face of a more detailed exploration of Bunyan's writings and beliefs. Indeed, such a mistaken view of Bunyan's theological convictions is not only detrimental to a more precise understanding of Bunyan's narrative works but has been used frequently to justify an ignoring of the doctrinal in Bunyan's works altogether.

Consequently, and before anything else, this thesis will establish a comprehension of Bunyan's theology as far from harsh and inhumane but, rather, as accommodating and

\footnotetext{
'Such a defence of the conflation of the practice of literary criticism with a more general process of 'reading' Bunyan's texts takes its precedent from Stanley Fish, 'Interpreting "Interpreting the Variorum" ', Critical Inquiry, 3 (1976-1977), 191-196 (p. 194), and reprinted in Is There A Text in This Class: The Authority of Interpretive Communities (Cambridge, Massachusetts and London: Harvard University Press, 1980), pp. 174180. Fish argues that while the interpretations of a text among critics and their debates vary, the 'problems and controversies' which are the focus and source of these debates 'do not and therefore point to something all readers share' (p. 193). However, unlike Fish (who claims not to be interested in critical controversies in the literary study of an author), this thesis specifically addresses how Bunyan has been read specifically in literary studies in any case, literary criticism being assumed, here, to reflect ways of reading that have developed over time and which often signals broader cultural implications in terms of how an author and his works are perceived and received.
} 
comforting. It will be shown that what is central to the doctrine of grace that informs each of Bunyan's writings is a covenant theology that is far from obsessed with any Calvinist introspection and predestination but which, in fact, accords the human will a particularly positive role in salvation and which, moreover, warns against any preoccupation with the issues of predestined election and reprobation in any case. In this way, a detailed revaluation of the central tenets of Bunyan's soteriology will be presented, here, with specific reference to many of Bunyan's tracts and treatises as well as to a large body of scholarship on Nonconformist theology and ecclesiology which, having long viewed Bunyan's as a comfortable doctrine indeed, seems to have been ignored by most literary criticism on the subject so far.

On one level, therefore, the 'grace-ful reading' of Bunyan's works that this thesis proposes will involve an explicit analysis of texts ranging from A Mapp Shewing the Order and Causes of Damnation to The Holy War in terms of a revised understanding of Bunyan's faith. Each of Bunyan's major narrative works will be explored as promoting Bunyan's doctrines of Law and grace and justification by faith rather than any concern over predestination. In turn, it will be shown how problematic textual, narrative, and critical issues in the reading of Bunyan's texts (such as matters of structure, form, and closure) can be illuminated and resolved through such a theologically-centred approach. But a reading of Bunyan's texts according to doctrine alone is not the sole point of this study. Indeed, the 'grace-ful reading' of this thesis's title involves not only a revision of our reading of Bunyan's texts according to a more accommodating concept of his doctrine but implies something quite specific about the way that the texts themselves need to be read.

What is suggested in this study, in fact, is that Bunyan's theology not only imbues his narratives with a doctrinal language that needs to be decoded more accurately by the contemporary reader and critic but which informs the very organisation of those narratives according to a particularly 'spiritual' concept of hermeneutics. Consequently, narratives like Grace Abounding and The Pilgrim's Progress reveal a textual practice at the heart of which lies a distinct (albeit obvious) intention: to encourage the reader to read him- or herself in terms of Bunyan's theology of grace. As such, Bunyan's works demand to be read according to the 
tenets of Bunyan's particular type of salvation but, at the same time, they encourage also a 'grace-ful reading' of the reader's self in relation to his or her own soterial concerns (or lack of them). ${ }^{5}$ Central to the concept of 'grace-ful reading', therefore, lies the need to recognise that Bunyan's texts not only bear a salvatory imperative in urging the reader to have faith but that they encourage the reader to approach the issues of coming, believing, and interpreting according to a 'rule of faith' which reflects the spiritually (if not radically) experiential nature of Bunyan's theology as a whole.

In order to read one's self and the Word grace-fully, for instance, Bunyan primarily asserts that a far different hierarchy of understanding must be invoked by the believer, one involving not a worldly carnal reason or a merely intellectual comprehension of salvation but one that is largely irrational, unworldly, and illogical - a reading of 'things unseen' via the light of the Spirit, not of the mind. It is this need to read the self in terms of an unworldly faith that Bunyan's narratives always encourage in the reader. Consequently, Bunyan's works, on one level, teach the reader in a straightforwardly didactic way about the right way to apply the promises of salvation to the soul. With more complexity, however, Bunyan's narrative practice itself also provides the reader with lessons in a grace-ful hermeneutics through strategies intended to frustrate any reader who brings a conventional or faithless mode of interpretation to them. Bunyan's narratives will thus be shown to urge the reader to read the self and the Word 'grace-fully' first by refusing to be read themselves according to any thisworldly precedent of narrative logic, causality, and sequentiality, nor any earthly notions of knowledge and reason. As a result, Bunyan's works can be said to demand a hermeneutic approach according to the more strict meaning that the term 'hermeneutics' postulates: 'a transcendental function' of reading which raises, 'questions about the extralinguistic truth value of literary texts', and the 'ultimate aim' of which, 'is to do away with reading altogether.'

\footnotetext{
' While the terms 'soterial' and 'soteriological' may be (and often are) taken synonymously in referring to matters of salvation (and damnation), in this thesis a subtle distinction is to be maintained between them. Whereas 'soteriological' pertains to a doctrine of salvation (and, subsequently, to the knowledge of that doctrine as a 'soteriology'), 'soterial' pertains more directly to the matter of salvation in itself. See the definitions of these terms given in, for instance, the Oxford English Dictionary, 2nd edn (Oxford: Clarendon Press, 1989).

" Hans Robert Jauss, Toward an Aesthetic of Reception, transl. by Timothy Bahti, intro. by Paul de Man (Brighton: Harvester Press, 1982), p. ix. For a critical approach which regards Bunyan's works as emphasising that 'the only point of reading is to stop reading', see Thomas H. Luxon, Literal Figures: Puritan Allegory and the Reformation Crisis in Representation (Chicago and London: The University of Chicago Press, 1995), pp.
} 
Reading Bunyan's narratives as eliciting a specific interpretive response from the reader is thus a central issue in this thesis, with the critical discourse of reader-response analysis (in which an understanding of the role the reader plays in determining the meaning of any given text is given precedence) having an obvious relevance for Bunyan's writing as a whole.? 'Greace-ful Reading' will show, for example, that it is always the reader who is the central focus of Bunyan's texts and who is deliberately and self-consciously made 'an actively mediating presence' in their meaningful interpretation (or misinterpretation, as the case may be) ${ }^{8}$ Indeed, what can hardly be ignored in any of Bunyan's narratives is the fact that they demand a response from the reader in absolute terms: in urging a serious consideration of whether one's faith is saving or damning (and, moreover, to do something about it), Bunyan's texts can hardly be considered as attempting to provoke the reader into anything other than direct faithful action.

However, such a reader-response approach to Bunyan demands some qualification. What this thesis does not attempt to do, for instance, is construct an ideal concept of Bunyan's seventeenth-century reader, largely because such a project would result not only in misleading generalisations but, as one commentator politely puts it, because it may not result in 'the best possible reading' of any book or author in any case. ${ }^{9}$ Rather, this thesis takes its analytical

162-185 (p. 164). Luxon, however, describes Bunyan's as an 'anti-hermeneutic theology', which is confusing given the nature of theological hermeneutics as it is described above (pp. 167-168).

7 There are, obviously, many different varieties of reader-response, reception, and audience-oriented approaches to reading, all of which nevertheless share an emphasis on the importance of the role of the reader. For useful introductions to this field of literary theory see The Reader in the Text: Essays on Audience and Interpretation, ed. by Susan Suleiman and Inge Crosman (Princeton: Princeton University Press, 1980), especially Susan Suleiman, 'Introduction: Varieties of Audience-Oriented Criticism', pp. 3-45; Wolfgang Iser, The Act of Reading: A Theory of Aesthetic Response (Baltimore: John Hopkins University Press, 1978; repr. 1980), pp. 20-50; Elizabeth Freund, The Return of the Reader: Reader-Response Criticism (London and New York: Methuen, 1987). For the most famous (and most influential) essays in this field, see Hans Robert Jauss, 'Literary History as a Challenge to Literary Theory', $N L H, 2$ (1970-1971), 7-37, and reprinted in Toward an Aesthetic of Reception, pp. 3-45; Wolfgang Iser, 'The Reading Process: A Phenomenological Approach', NLH, 3 (1971-1972), 279-299, and The Implied Reader: Patterns of Communication in Prose Fiction from Bunyan to Beckett (Baltimore: John Hopkins University Press, 1974); Stanley Fish, 'Literature in the Reader: Affective Stylistics', NLH, 2 (1970-1971), 123-162, which is reprinted (along with most of Fish's other essays on the subject) in Is there a Text in This Class?, pp. 21-67.

"Fish, 'Literature in the Reader', in $N L H, 2,123$.

' Wallace Martin, Recent Theories of Narrative (Ithaca and London: Cornell University Press, 1986; repr. 1994), pp. 160-161. Barbara A. Johnson's recent account of the reception of Bunyan's works constructs both a generalised and limited concept of the 'Protestant' reader that, while useful in a general sense, is unhelpfully non-specific about either Bunyan's doctrine or his own methods of interpretation. Hence, for 'Protestant readers, texts are instruments rather than objects' viewed in 'salvational rather than recreational terms', for whom '[i]nspiration comes from God, and specifically the Holy Spirit, rather than a literary tradition', and for whom 
lead from the kind of reader-response theory that Stanley Fish famously and persuasively propounds and which, in arguing that the meaning of a text lies in the reader's experience of reading it (rather than in any distanced analysis of it), provocatively re-orders the hierarchy of literary investigation in terms of asking not what a text means but what it does and how it acts upon the reader. ${ }^{10}$ Fish's seminal reading of The Pilgrim's Progress as a 'self-consuming artifact' that draws attention to its own anti-progressive strategies is exemplary of such an approach. Far from being just a clever and theoretically thetorical way of reading Bunyan's allegory as a text that instructs the reader about reading, however, Fish's analysis of The Pilgrim's Progress is so important because it offers a more faithful critical attention to the metaphysical imperative lying behind Bunyan's narrative practice, one that seeks to emphasise the limitations of any 'conventional' or 'literary' interpretive approach to reading as a whole. "

Consequently, the analysis of Bunyan's narrative practice in this thesis in many ways follows in the wake of Stanley Fish's impressive interpretive legacy. However, some differences must be acknowledged here, too. Whereas Fish's reading of The Pilgrim's Progress is largely doctrinally non-specific and rhetorical, this study offers a reading which seeks to align Bunyan's acts of textual subversion more strictly both with Bunyan's theological convictions and with his own doctrine-oriented attitudes to reading, narrative, and Scriptural poetics. Moreover, while Fish is largely and consciously ahistorical in his methodology (he prefers to concentrate on the contemporary meanings a reader brings to a work) this study also seeks to regard the complex construction of Bunyan's texts in relation to the particular social and political culture of Restoration England (from which all of Bunyan's works dissent). In this respect, this thesis is as much contextual and historicist in terms of asking how and why Bunyan's texts demand grace-ful readings from their readers. Indeed, Bunyan's concerns

also 'the stature of authors depends [...] on their function as God's servants.' These are, Johnson writes, 'suppositions shared by all Protestant readers' from the early modern 'period' onwards (Reading Piers Plowman and The Pilgrim's Progress: Reception and the Protestant Reader (Carbondale and Edwardsville: Southem Illinois University Press, 1992), p. 26, see also pp. 184, 185).

10 See Fish, 'Literature in the Reader', in $N L H, 2$, and also 'Interpreting the Variorum', Critical Inquiry, 2 (1975-1976), 465-485, reprinted in Is There a Text in This Class?, pp. 147-173.

"Stanley Fish, Self-Consuming Artifacts: The Experience of Seventeenth Century Literature (Berkeley, L. A. and London: University of California Press, 1972), pp. 224-264, and (for an earlier version of this analysis) 'Progress in The Pilgrim's Progress', ELR, 1 (1971), 261-293. For an excellent analysis of Fish's reading of The Pilgrim's Progress as acknowledging and sharing the text's own metaphysics (albeit in different terms) see Luxon, Literal Figures, pp. 161-169. 
about reading and salvation, it will be shown, are informed as much by the rise of a Latitudinarian doctrine of rational moralism and an increasingly rationalised and empirical late seventeenth-century culture as anything else.

This kind of historical contextualisation of Bunyan's narrative practice is important not only because any understanding of Bunyan's Nonconformist theology is inseparable from it but, moreover, because literary criticism of Bunyan so often seems guilty of embracing attitudes and beliefs with which Bunyan himself chose not to conform, both historically and politically. In this sense, Stanley's Fish's revised opinion that the reading strategies of different interpretive communities provide a variety of equally valid and constructive readings of any given text, along with Wolfgang Iser's assertion that a 'text comes to life' in the reader who redeems it through the 'astonishing process' of reading even when its, 'meaning has become so historical that it is no longer relevant to us', is problematic. ${ }^{12}$ Not only does such an approach discount the fact that Bunyan's works are constructed to elicit a specifically singular (albeit historically situated) doctrinal response from the reader but, moreover, it ignores the fact that some readings are inscribed within the political agenda of 'interpretive communities' that have traditionally and fundamentally held a disapproval of Bunyan's faith and the Nonconformity it embodies. As such, it is the aim of this thesis to reveal grace-less readings of Bunyan's texts not only to be theologically misinformed but, arguably, to be aligned with the very conformism and rational moralism which sought to persecute and marginalise the likes of Bunyan in his own time and which his own works are written against so forcefully.

What this study engages with, therefore, is a practice of reception theory which goes beyond the affective stylistics of Fish's original reader-response methods and into what Steven Mailloux has recently denoted as a 'rhetorical hermeneutics' of Bunyan's critical reception in literary studies. ${ }^{13}$ That is, in order to assert that Bunyan's texts demand an essentially limited and narrow response through grace-ful reading, it becomes necessary to show how and why

\footnotetext{
${ }^{12}$ Fish, 'Interpreting the Variorum', in Critical Inquiry, 2, 482-484, 'Interpreting "Interpreting the Variorum" ', in Critical Inquiry, 3, 194, and, Is there a Text in this Class?, pp. vii, 1-17, 303-321; Iser, The Act of Reading, p. 19.

${ }^{13}$ Steven Mailloux, 'Persuasions Good and Bad: Bunyan, Iser, and Fish on Rhetoric and Hermeneutics in Literature', Studies in the Literary Imagination, 28 (1995), 43-61.
} 
other readings are inappropriate not merely in terms of being, for example, non-doctrinal but in how they reinforce common conceptions of Bunyan as, say, a mentally unstable religious radical or an extreme Calvinist, conceptions which not only have their roots in the Restoration political oppression and disparagement of Nonconformity itself but which essentially defuse the meaning of Bunyan's Nonconformist texts by subjecting them to a distinctly conformist, moralist, and rationalist reading. In this study, therefore, reading Bunyan on a receptiontheory basis does not concentrate on 'the interaction between text and reader' alone but also on 'historical interpreters arguing about and otherwise using texts within specific cultural conversations at particular historical moments'. Such an approach to Bunyan's critical reception 'practices hermeneutic theory by doing rhetorical history' upon Bunyan criticism in order to explore some of the problematics in certain readings of his works. ${ }^{14}$

At the same time, however, it is the purpose of this study not only to interrogate and highlight the misreadings of Bunyan in criticism but to identify a literary mode of analysis which, in fact, would be more appropriate for the task of negotiating Bunyan's narrative practice and the metaphysics that informs it. This thesis reads Bunyan's Nonconformist literary works, therefore, not only in relation to the historical context of Bunyan's faith and Nonconformity but according to the interpretive tenets of a current literary critical interpretive community' which, in Fish's own terms, can more readily take into account the 'meaning experience' of Bunyan's works and the way in which they operate according to the 'progressive decertainizing' and 'disorientation' of the reader's textual and literary expectations. $^{15}$ Given that much literary criticism traditionally seems intent upon settling 'on the meaning' of a text and doing so by 'first stepping back from the text' (a process of reading to which Bunyan's hermeneutics is largely antithetical), it would seem that a more nonconformist critical apparatus is indeed needed for Bunyan. ${ }^{16}$ This thesis, therefore, not only views Bunyan's works from a historically and theologically informed viewpoint but

\footnotetext{
14 Mailloux, 'Persuasions Good and Bad', pp. 55, 59.

${ }^{15}$ Fish, 'Literature in the Reader', in $N L H, 2,129,124-125$.

${ }^{16}$ Fish, 'Interpreting the Variorum', in Critical Inquiry, 2, 469, 473-474. See also Tamsin Spargo's analysis of 'the bid to appropriate Bunyan as author within the broadly humanist project of literary studies (although she proposes a solution different from the one offered in this thesis), The Writing of John Bunyan, pp. 6-10, 110112.
} 
according to a contemporary poetics of postmodernist textual practice. Indeed, as they are understood by commentators like Brian McHale and Patricia Waugh, the strategies and issues of postmodernist fiction and metafictive writing can be adopted both profitably and insightfully (albeit anachronistically) in illuminating how Bunyan's self-referential narratives are both constructed and operate upon the reader and how they resist 'conventional' types of literary categorisation and interpretation. Consequently, this study sometimes reads Bunyan's works as almost ur-postmodernist in their overriding rejection of fixed notions of the rational and the knowable, of the seen in favour of the unseen, and in their exploration of the relationship between fiction and reality, between worldly truths and a transcendent 'Truth'.

Far from being simply a more accurate doctrinal reading of Bunyan's works, therefore, 'Grace-ful Reading' aims to show how Bunyan's narratives are carefully constructed in order to be read in a particular way, a way that much criticism either misunderstands or ignores and which needs to be addressed through a more suitable analytical discourse. In asserting this, however, it needs to be acknowledged that the 'grace-ful reading' of Bunyan's narrative works that this thesis proposes is essentially limiting in terms of what it implies about a literary interpretation of texts like The Pilgrim's Progress. In many ways, in fact, a grace-ful reading of Bunyan's works can only be maintained at the conscious exclusion of other readings and, as such, it is an interpretive approach which would seem to deny the very fact that narratives are both interesting and enduring precisely because they can and should be read in different ways over time. Far from denying that a variety of interpretations of Bunyan's works is possible, this thesis simply argues that non-doctrinal readings are often both inappropriate and frequently pernicious, and usually for certain historical and polemical reasons. This thesis consciously aims to question the validity of those readings of Bunyan's works that effectively ignore Bunyan's own position as a Nonconformist writer whose subject always is the salvation of his reader's soul.

Despite the fact, therefore, that this thesis addresses the particular issue of understanding Bunyan's narrative practice anew, especially in relation to Bunyan's reception in literary studies so far, Bunyan nevertheless emerges here (and quite naturally, given his role as 
preacher and pastor of the Bedford Church) as someone with almost anti-literary (and certainly anti-narrative) intentions. What this thesis presents, in fact, is a Bunyan who is deeply immersed in the literary issues of narrative construction and reader-response, but primarily in terms of containing his reader's interpretive interest in works that are always in danger of becoming merely narrative and imaginative, fictive and 'literary' artefacts. Indeed, because Bunyan's endeavour to persuade his reader to read his or her life according to a grace-ful understanding of the Word is inevitably endangered by the fact that the narrative forms he frequently adopts engender not only other and possibly quite different interpretations but that readers themselves may have just a 'historical' interest in them as narratives, then Bunyan's textual practice consistently reveals a profound concern over his reader reading not for spiritual edification but just for the 'story' or the 'plot'. Hence, Bunyan's narrative strategy, from his spiritual autobiography to his spiritualised allegories, it is argued here, is always geared towards preventing the reader from indulging in his writings in any way other than the doctrinal, a concern that Bunyan is particularly preoccupied with not only in the highly imaginative (if not dangerously romantic) The Pilgrim's Progress but in its very different allegorical sequels. As such, a telos will be apparent in this study, with Bunyan emerging as a writer continually grappling with the problematics of containing an imaginative response to his essentially doctrinal narratives.

This thesis has been organised into six chapters which deal extensively with Bunyan's narrative works in the chronological order of their publication. The first chapter is, of course, an exception to this, dealing with Bunyan's theology with reference to a great number of works published both throughout Bunyan's life and posthumously. This initial chapter also offers an example of 'grace-ful reading' in relation to A Mapp Shewing the Order and Causes of Salvation and Damnation and An Exposition on the Ten First Chapters of Genesis. Chapters two and three, however, deal exclusively with readings of and reading in Grace Abounding to the Chief of Sinners, while chapters four and five offer analyses of the 'Author's Apology' and theology and narrative in The Pilgrim's Progress respectively. Most attention is given in this thesis to Grace Abounding and The Pilgrim's Progress because both still are the most widely 
read and popular of all Bunyan's books and have, naturally, received the most attention in literary critical studies.

The final chapter offers grace-ful readings of Bunyan's other narrative works (The Life and Death of Mr. Badman, The Holy War and The Pilgrim's Progress, Part II), in relation to the methodology and success of Part I as well in terms of the criticisms inherent in Thomas Sherman's Second Part of The Pilgrim's Progress. In turn, the conclusion assesses the broader literary legacy of Bunyan's most famous allegory (and some of its cultural implications) since its initial publication to the present. The 'Appendix' to this study, however, provides an analysis of Bunyan's theological language in relation to the rise of medical discourse in the Restoration period which, though especially relevant to the chapters on Grace Abounding, could not be included in the main text without a great deal of digression. 


\title{
1 \\ A Comfortable Doctrine: John Bunyan's Theology of Grace
}

\begin{abstract}
O Son of God! Grace was in all thy Tears, Grace came bubling out of thy side with the Blood, Grace came forth with every word of thy sweet Mouth [...]. Grace came out where the Whip smote thee, where the Thorns prickt thee, where the Nails and Spear pierced thee: O Blessed Son of God! Here is Grace indeed! Unsearchable Riches of Grace! Unthought of Riches of Grace! Grace to make the Angels wonder, Grace to make Sinners happy, Grace to astonish Devils. ${ }^{1}$
\end{abstract}

At first glance there may not seem much in this passage that we would usually associate with the theology of John Bunyan. With its profound fixation upon the imagery of the crucifixion, of Christ's crucified body, of the blood and the Passion, there appears to be something far more Catholic (even idolatrous) about such intense religious contemplation than we would expect from one of English literature's most famous Protestant (and notably 'Puritan') authors. While such impassioned writing merely typifies, in actual fact, the degree to which Bunyan's distinctly Reformed theology of grace saturates both his life and works (as well as his prose style), the important issue of what we do expect (and often suspect) of Bunyan's doctrinal thinking is usefully brought to the fore here. Bunyan's emphatically Christocentric theology may occasionally leave his writing with some uncomfortably 'Romish' overtones (of which Bunyan's controversialist detractor, the Quaker Edward Burrough, could opportunely abuse him), but it is hardly in these terms that Bunyan's writings and doctrines are usually, if at all, considered. ${ }^{2}$ Rather, the case is quite the opposite: the overwhelming association Bunyan's theology has for many contemporary readers and critics is that of a harsh Calvinism - a strict and strictly Protestant mode of divinity in which, above all else,

\footnotetext{
1 John Bunyan, Saved By Grace (1676), in The Miscellaneous Works of John Bunyan VIII, ed. by Richard L. Greaves (Oxford: Clarendon Press, 1979), p. 191.

2 In The True Faith of the Gospel of Peace (London: 1656), Edward Burrough writes that 'without the revelation of the Christ within, there is no salvation: However, so much may be spoken of him without, as the Pope can doe as well as thou [Bunyan]' (pp. 10, 22). 'Reader, see if this be not near unto Popery', Burrough ironically asserts in Truth (the Strongest of all) (London: 1657), 'or enquire what he [Bunyan] meanes, as if he would have people goe a Pilgrimage' (p. 57).
} 
man's depravity is emphasised and the human will completely effaced before the power of an almighty, sovereign, and austere God.

The problem with bearing such an understanding of Bunyan's theological background, though, is that it rarely leads to any kind of positive response either to Bunyan's works or his faith. This is shown most clearly by the fact that Bunyan's Calvinist heritage (evidence for which could be found quite readily through even the most cursory glance at practically any of his fifty-eight tracts, treatises, and narrative works) has received some ineffably bad press in recent years. As a definitively Calvinist author and minister, Bunyan is often viewed somewhat simplistically as a proponent of a grim and psychologically terrorising divinity at the heart of which lies a wrathful Creator merciless in his administration of damnation and forgiving to but a helpless (and severely limited) few. In these terms alone it is hardly surprising that commentators might find Bunyan's soteriology, to paraphrase Donald Davie's comment, difficult to stomach. ${ }^{3}$ Gordon Campbell, for example, views Bunyan's as 'an apparently abhorrent theology' at the heart of which lies a 'cruel God' at the whim of whom 'most of mankind is condemned to eternal torment' ${ }^{4}$ Nor is Campbell alone in this opinion. A. Richard Dutton, Stuart Sim, and John Stachniewski have all recently published important studies of Bunyan's narrative works in the context of an inherently Calvinist theology, stressing the tortuous paradoxes that need to be negotiated within such a belief-system along with its mentally persecutory nature. Calvinism being made synonymous with anxiety, the phrase 'harsh doctrine of predestination' has become a particularly popular clarion-call (as well as a blanket statement) for commentators attempting to describe the doctrinal landscape of Bunyan's fictive art.5

\footnotetext{
${ }^{3}$ For Donald Davie's comments on Bunyan's theology see A Gathered Church: The Literature of Dissenting Interest 1700-1930 (London: Routledge and Kegan Paul, 1978), p. 10.

4 Gordon Campbell, 'Fishing in Other Men's Waters: Bunyan and the Theologians', in John Bunyan: Conventicle and Parnassus, Tercentenary Essays, ed. by N. H. Keeble (Oxford: Clarendon Press, 1988), pp. 137-151 (150-1). For similar comments see also Gordon Campbell's 'The Theology of The Pilgrim's Progress', in The Pilgrim's Progress: Critical and Historical Views, ed. by Vincent Newey (Liverpool: Liverpool University Press, 1980), pp. 251-262.

5 See A. Richard Dutton, 'Interesting, but tough: Reading The Pilgrim's Progress', SEL, 18 (1978), 439-456; Stuart Sim, ' "Safe For Those For Whom it is to be Safe": Salvation and Damnation in Bunyan's Fiction', in John Bunyan and His England, 1628-88, ed. by Laurence, Owens, and Sim (London: Hambledon Press, 1990), pp. 149-160, and Negotiations With Paradox: Narrative Practice and Narrative Form in Bunyan and Defoe (London: Harvester Wheatsheaf, 1990); John Stachniewski, The Persecutory Imagination: English Puritanism and the Literature of Despair (Oxford: Clarendon Press, 1991).
} 
Such a demonisation of Bunyan's doctrine has not been without effect either, especially in literary terms. The fact that the abhorrent theology seems to obstruct the enjoyment of, say, The Pilgrim's Progress as 'literature' for a reader like F. R. Leavis has led to some notable responses. One way, for instance, in which critics tend to deal with Bunyan's inhuman creed of innate corruption and double predestination (the predetermined salvation or damnation of every soul by God before time began) is to sever Bunyan the imaginative and humane author of The Pilgrim's Progress from Bunyan the harsh doctrinarian, a view long epitomised in Coleridge's discrimination between Bunyan of the conventicle and Bunyan of Parnassus, between 'Bunyan's Christian faith and his imagination' 6 In effecting such a segregation, it would seem that at least Bunyan's fictive and literary genius can be salvaged from the taint of his 'interesting, but tough' theology. For many critics and readers since the Romantic period, then, 'the redeeming literary quality' of works such as The Pilgrim's Progress 'resides in the fact that Bunyan's imagination' so successfully 'transcends his theological convictions'.?

But there are, of course, problems in attempting to exorcise the spectre of an unthinkable Calvinism from our reading of Bunyan. Donald Davie, for example, regarding Bunyan's theology as unambiguously sinister, 'primitive', and to be neither sentimentalised nor forgotten, nevertheless wonders if there is not something unpleasantly duplicitous, 'about applauding Bunyan for the humane feeling that he managed to express inside a framework inimical to it, without at least acknowledging the inhumanity of that frame?'8 While we may only be able to marvel at the desire to recognise the 'inhumanity' of Bunyan's literary art, Davie's reaction is significant. He is, after all, simply registering his dissatisfaction with a reading of Bunyan in which the doctrinal (albeit synonymous with the inhuman and primitive) is being unfeasibly amputated from the literary. The result for Davie is thus a

\footnotetext{
${ }^{6}$ N. H. Keeble, Preface to Conventicle and Parnassus, p. v. Samuel Taylor Coleridge, in Coleridge on the Seventeenth Century, ed. by Roberta Florence Brinkley (Duke University Press, 1955), pp. 475-476, and reprinted in The Pilgrim's Progress: A Casebook, ed. by Roger Sharrock (London: Macmillan, 1976), pp. 5253. For an account of Romantic critics' separation of Bunyan in this way, see also N. H. Keeble, ' "Of him thousands daily Sing and talk": Bunyan and his Reputation', in Conventicle and Parnassus, pp. 241-163 (pp. 252-255).

7 Campbell, 'Fishing in Other Men's Waters', p. 150. See F. R Leavis, 'The Pilgrim's Progress', in Anna Karenina and Other Essays (London: Chatto and Windus, 1967), pp. 33-48, and Leavis's essay 'Literature and Society' in The Common Pursuit (London: Chatto and Windus, 1952), pp. 182-194 (pp. 188-192).

8 Davie, A Gathered Church, pp. 7-15.
} 
hypocrisy in the reader or critic who praises the humanity of, say, The Pilgrim's Progress but will have nothing to do with its perhaps discomforting credal context.

Davie's point here, while giving no concession to Bunyan's humanity as preacher or writer, is that any separation of Bunyan the imaginative author from Bunyan the minister is to be recognised as fundamentally artificial and misleading, if not blatantly ahistorical. Given the fact that Bunyan's entire life and purpose for publishing anything he ever wrote were dedicated to the conversion of sinners and the salvation of the human soul, maintaining such a contrived division between theology and text when reading Bunyan's works would seem to require nothing less than a feat of phenomenal and concerted ignorance. To sidestep the specifics of Bunyan's doctrine in any of his writings is, adopting that most famous metaphor, to stray from the way of Bunyan's literary purpose, if not to miss the path completely. At best, such reading leads to the construction of a Bunyan whose literary relics alone are to be preserved for their importance, say, to the rise of the novel (and only by being decontaminated of their theological content in any case). At worst, it leads to a poor interpretive practice, one which wilfully ignores not only theological context but the very words on the page which, in Bunyan's case, invariably point the reader towards a particular form of salvation.

It seems, then, that if we are to endeavour to read Bunyan in any sense 'correctly', if we are to do justice as readers to his writings at all, it is essential that we re-address this apparently uneasy relationship between Bunyan's theology and narrative practice. First and foremost, we must recognise that they are conceptually and stylistically inseparable. Only by showing how Bunyan's narrative works are finally and entirely informed by the specific ontology of his Nonconformist (and largely Reformed) Christian faith can the notion of a Bunyan divided between the aesthetic and the dogmatic be overcome. If we are to understand and appreciate Bunyan's narrative texts (The Pilgrim's Progress, Parts I and II, The Life and Death of Mr. Badman, and The Holy War) in a way that may be considered plenary and undiminished, we must read them not in the light of their theology or their literariness alone (whatever this may entail) but according to how the one specifically acts upon and affects the other and, in turn, what effect this has upon the reader. Without such an 
approach, a text such as The Pilgrim's Progress can only remain ruefully marginalised as a somewhat minor stepping-stone in the history of English literature or as a book once most popular as a morally instructive fable for Victorian children. ${ }^{9}$

But reversing such a reading (or cultural understanding) of Bunyan must first involve a re-appraisal of the theology which the likes of Davie and Campbell find so insufferable. If, indeed, we are to rescue Bunyan from accusations of inhumanity and his works from literary castigation, the sticking-point of his writings - the theology - should first be un-demonised. This process must begin, therefore, with a thorough (and by now much needed) reassessment of Bunyan's apparently severe doctrinarian stance and, in particular, of the terms in which it has wrongly been couched for far too long - harsh, Calvinist, and predestinarian.

In order to do this we must start with the most basic concepts upon which Bunyan's faith is constructed. As the passage serving as the epigraph of this chapter shows, the cornerstone of Bunyan's whole theology is, above anything else, his notion of grace, 'a concept which permeated the whole of his writings and which was the focal point of his preaching and thinking.' 10 Bunyan's is a distinctly Reformed (or, as Richard Greaves argues, Lutheran) understanding of grace: 'Whereas traditional Catholic thought had conceived of grace as a divine substance bestowed upon or infused in man, Luther [and, consequently, the Reformed tradition of theologians as a whole] reverted to the biblical view of grace as God's favour' bestowed upon believers. In this way, the salvation of the sinner by grace 'is neither his transformation by divine activity, nor his reception of a divine substance infused into him, but instead his forgiveness by God and restoration to divine favour.' "I Such a view consequently leads to a demotion of a concept of salvation through Church sacraments and to a far more individualistic sense of salvation sola scriptura.

\footnotetext{
9 Michael Mullett notes the growth in popularity of The Pilgrim's Progress as a 'children's classic' from the early nineteenth century onwards: John Bunyan in Context (Keele: Keele University Press, 1996), pp. 191-192. It is also one of the aims of Barbara Johnson's Reading Piers Plowman and The Pilgrim's Progress: Reception and the Protestant Reader (Carbondale and Edwardsville: Southern Illinois University Press, 1992) to 'account for the emergence of The Pilgrim's Progress as a children's book among the "more polished classes",' of the Victorian period (p. 8).

10 Richard L. Greaves, John Bunyan (Abingdon: The Sutton Courtenay Press, 1969), p. 159.

11 Richard L. Greaves, 'Luther's Doctrine of Grace', Scottish Journal of Theology, 18 (1965), $385-395$ (p. 387 ).
} 
Bunyan's concept of grace is, it seems, entirely synonymous with such a Reformed view. For Bunyan, grace is defined, alongside more general notions of God's 'favour with men', the 'holy qualification of Saints', and 'the condescension of Christ' in coming amongst men, as 'the free, rich, and unchangeable love of God to man, through Jesus Christ'.12 Whereas Bunyan asserts elsewhere that we are saved by the interdependent grace of the Father, the Son, and the Spirit operating in spiritual unison, the most important aspect of grace for Bunyan is, without doubt, the complete forgiveness of man's sins by God through the sacrifice of Christ's death upon the cross. ${ }^{13}$ It is through this redemptive act alone that man is saved, according to Bunyan, and through which the 'unsearchable riches' of God's love for man are, in Christ, ultimately manifested: 'The word Grace therefore, being understood, doth most properly set forth the true cause of Man's happiness with God', he states, for it is 'by the good Will, free Mercy, and loving Kindness of God, ye are saved'. 14

Any understanding of Bunyan's notion of grace is meaningless, however, without a comprehension of the strictly covenantal nature of his theology as a whole, a full exposition of which comprises Bunyan's early treatise The Doctrine of Law and Grace Unfolded (1659). Essentially, Bunyan's covenant theology delineates a doctrine of salvation and damnation based on the crucial juxtaposition of the covenant of grace against the covenant of works. For Bunyan, only by being within the compass of the former can salvation truly be attained; being under the covenant of works, on the other hand, can lead only to damnation. ${ }^{15}$ The

\footnotetext{
12 John Bunyan, The Doctrine of Law and Grace Unfolded (1659), in The Miscellaneous Works of John Bunyan II, ed. by Richard L. Greaves (Oxford: Clarendon Press, 1976), p. 83.

13 See Bunyan, Saved by Grace, pp. 182-194: 'The Father's Grace is shewed in Heaven and Earth', Bunyan writes, 'the Son's Grace is shewed on the Earth , and on the Cross; and the Spirit's Grace must be shewed in our Souls, and Bodies, before we come to Heaven' (p. 191).

14 Bunyan, Saved by Grace, pp. 183-4.

15 For discussions of sixteenth and seventeenth century covenant theology, the different types of covenant thinking, and Bunyan's position in relation to them, see John von Rohr, The Covenant of Grace in Puritan Thought (Atlanta, Georgia: Scholars Press, 1986), and 'Covenant and Assurance in English Puritanism', Church History, 34 (1965), 195-203; Richard L. Greaves, 'The Origins and Early Development of English Covenant Thought', The Historian, 31 (1968), 21-35, and 'John Bunyan and Covenant Thought in the Seventeenth Century', Church History, 36 (1967), 151-169; Leonard J. Trintenud, 'The Origins of Puritanism', Church History, 20 (1951), 37-57; Jens G. Møller, 'The Beginnings of Puritan Covenant Theology', Journal of Ecclesiastical History, 14 (1963), 46-67; Richard A. Muller, "Covenant and Conscience in English Reformed Theology', Westminster Theological Jourmal, 42 (1980), 308-334; Michael McGiffert, 'Grace and Works: The Rise and Division of Covenant Divinity in Elizabethan Puritanism', Harvard Theological Review, 75 (1982), 463-502, and 'From Moses to Adam: The Making of the Covenant of Works', Sixteenth Century Journal, 19 (1988), 131-155; Kenneth Hagen, 'From Testament to Covenant in the Early Sixteenth Century', Sixteenth Century Journal, 3 (1972), 1-24; Lyle D. Bierma, 'Federal Theology in the Sixteenth Century: Two Traditions', Westminster Theological Journal, 45 (1983), 304-321; Everett H. Emerson, 'Calvin and Covenant Theology', Church History, 25 (1956), 136-144; Anthony A. Hoekema, 'The Covenant of Grace in Calvin's Teaching',
} 
theological reasoning behind this soteriological scheme is (despite its somewhat technical vocabulary at times) relatively straightforward. The covenant of works is, quite simply, the moral law every individual is naturally placed under and which has been revealed most significantly in the ten commandments given to Moses on Mount Sinai. For Bunyan, then, the covenant of works is largely synonymous with Mosaic Law and in his writings the two terms are mutually interchangeable.

Being under the covenant of works is, therefore, to attempt to achieve salvation by keeping the Mosaic Law alone, by works in other words. In order to do this, one must not sin or err from that Law in any way. Indeed, Bunyan is at pains to emphasise that fulfilling one's obligations within a covenant of works ultimately demands complete obedience to Mosaic Law without any deviance from it whatsoever. However, because Bunyan's doctrine is grounded upon the notion that man is innately corrupt and sinful, the concept of achieving salvation by good works alone is rendered absolutely impossible. To believe that one can attain righteousness by works is supreme folly for Bunyan as the ability to fulfil the Law was forfeited for everyone by Adam (mankind's representative, or 'publick person') in his act of disobedience in the Garden of Eden. Because the prelapsarian command given to Adam and Eve not to eat the fruit of the Tree of Knowledge is viewed by Bunyan as the same in 'substance' as the later Mosaic Law, because in essence 'it was all one with that on Sinai', and because that command was broken, any consequent attempt to gain a saving righteousness through an adherence to the Law will fail: God's justice (damnation, eternal death) will be rightfully invoked upon anyone who tries to do so. ${ }^{16}$

The 'Law of Works, otherwise called the Covenant of Works; or the first, or old Covenant' is, then, the ultimate salvationary red-herring according to Bunyan: thinking that one can rely on either an inherent moral righteousness or good deeds in order to be saved can

Calvin Theological Journal, 2 (1967), 133-161; Paul Helm, 'Calvin and the Covenant: Unity and Continuity', Evangelical Quarterly, 54 (1982), 65-81; Francis Lyall, 'Of Metaphors and Analogies: Legal Language and Covenant Theology', Scottish Journal of Theology, 32 (1979), 1-17; Perry Miller, 'The Marrow of Puritan Divinity', in Errand Into the Wilderness (Cambridge, Massachusetts: Harvard University Press, 1956; repr. 1970), pp. 48-98, and chapters XII-XV in The New England Mind: The Seventeenth Century (Cambridge, Massachusetts and London: Harvard University Press, 1939; repr. 1982).

16 Bunyan, Law and Grace, pp. 23-29. The Mosaic Law was given, Bunyan asserts, 'for the more clear discovery of those sins that was before committed against it', and so that sin 'might the more clearly be made manifest, and appear' (Law and Grace, p. 29). 
lead only to damnation. Moreover, the fact that no man can fulfil the terms of the covenant of works lends it a distinctly terrifying aspect. No matter how perfect a life one may lead, no matter how one has lived up to the Ten Commandments, 'even all of it, for a long time, ten, twenty, forty, fifty, or threescore years, yet if thou do chance to slip, and break one of them', Bunyan warns, 'before thou die, thou art also gone and lost by that Covenant': 'though a man do walk up to the Law all his life time', Bunyan insists, 'but onely at the very last sin one time before he die, he is sure to perish for ever'. As the 'administration of death', therefore, the covenant of works can only 'set open all the flood-gates of Gods wrath against thee, and irrecoverably by that Covenant, it doth bring eternal vengeance upon thee.' 17

Bunyan is also keen, however, to emphasise the dire effects the Law can bring upon anyone on this side of Judgement Day who attempts to live up to it. Bunyan thus describes the Law as nothing less than tyrannically totalitarian in terms of the psychological abuse it induces in anyone attempting to gain righteousness thereby. Because he "that is under the Law, as it is a Covenant of Works, is like the man that is bound by the Law of his King upon pain of banishment, or of being Hanged, Drawn, or Quartered not to transgress any of the Commandments of the King', it is hardly surprising that such a person is to be found in a 'sad condition'. Because the Law, Bunyan states, 'doth always finde fault with the sinners obedience, as well as his disobedience', consequently,

it doth controll them, saying, This was not well done; this was done by the halves: this was not done freely, and that was not done perfectly, and out of love to God: and hence it is that some men, notwithstanding they labour to live as holy as ever they can, according to the Law; yet they do not live a peaceable life, but are full of condemnings, full of guilt and torment of Conscience; finding themselves to fail here, and to fall short there, omitting this good which the Law commands, and doing that evil which the Law forbids; but never giveth them one good word for all their pains. ${ }^{18}$

Any reader of Grace Abounding to the Chief of Sinners will recognise that Bunyan's discourse here sounds deeply from personal experience: Bunyan is fully aware of the terrors involved in foolishly subjecting the conscience to the uncompromising and unforgiving bondage of works-righteousness. Bunyan's primary aim in publishing works like The Doctrine of Law and Grace Unfolded is, therefore, to dispel any ignorance in his reader

\footnotetext{
17 Bunyan, Law and Grace, pp. 30-35.

18 Bunyan, Law and Grace, pp. 31, 44.
} 
about the Law, especially anyone remaining 'unacquainted with the natures of these two Covenants, or either of them', and who otherwise 'will never be able neither to know what they are by Nature, nor what they lie under.' It is ignorance more than anything else that, in a way which explains much about the damnation of the character of the same name in The Pilgrim's Progress, keeps '[p]oor souls' unaware 'of the nature of that Covenant of Works, the Law, that they are under', so that consequently they 'do not think their state to be half so bad as it is: when alas there is none in the world in such a sad condition again besides themselves; for indeed they do not understand these things.' 19

Because being under the Law posits an unbearable and impossible burden of soterial responsibility on man, demanding a holy perfection unattainable since the Fall, salvation for Bunyan can only be achieved for (and not by) man through God's saving grace. This grace, the promise of God's forgiveness, mercy, and eternal life, is both embodied and accomplished in Christ's ministry upon the earth and, most importantly, in his death upon the cross. The reason for this is, again, relatively clear. Given the fact that man cannot maintain his contractual obligation to God in fulfilling the covenant of works, living a sinless life according to the Law, and given the fact that, according to Bunyan, God's justice must be exacted upon man's sins and sinfulness in any case, it is necessary for man to have the Law fulfilled for him (and thereby have God's justice appeased) by someone else - Christ. Christ, as both man and God, is the only 'publick' figure who can attain the perfection that Adam lost in the Fall and satisfy God's wrath over man's sins through the sacrifice of his own blood. ${ }^{20}$ In this way, Bunyan can assert that man's salvation is doubly ensured for the believer: Christ has achieved righteousness for man through 'both active and passive' obedience, through both the fulfilling of the Law as well as through his death, so that 'justice cannot object anything, holiness now can finde faulte with nothing' ${ }^{21}$

As is shown in the epigraph to this chapter, then, Christ's role in Bunyan's theology is central. As the supreme mediator of God's justice and mercy for mankind 'all is made up by our middle man Jesus Christ'. ${ }^{22}$ What this involves, however, is not simply the fulfilling

\footnotetext{
19 Bunyan, Law and Grace, pp. 11, 31.

20 Bunyan, Law and Grace, p. 94.

21 Bunyan, Law and Grace, p. 169.

22 Bunyan, Law and Grace, p. 169.
} 
of the old covenant by Christ for man but, rather, the establishing of a 'New Covenant' that does away with the old one altogether. The covenant of grace thus emerges in Bunyan's doctrine as the sole source of man's salvation because it is a 'Covenant, Bargain, or Contract' made not between God and man (as in the covenant of works) but between God and the Son. In a pactum salutis made before time itself, a 'Covenant or Bargain' made 'in truth before man was in being', the terms of man's sole means of redemption were agreed between the divine Father and the Son: 'for the everlasting deliverance of many', a covenant 'by blood' was made wherein 'the price that was paid for sinners' (and that 'was agreed upon before the world began') was to be 'The Precious Blood of Christ'. In other words, the Son offered himself as payment for man's sins. ${ }^{23}$

That a 'New Covenant' has been both established by God for all eternity and fulfilled by Christ for man on the cross marks the fundamental basis of Bunyan's concept of grace. Herein lies the source, for Bunyan, of the true believer's hope and faith in man's ultimate redemption. With Christ as 'Mediator' in the covenant of grace, man is given the opportunity of salvation by being effectively freed from the terrors, the bondage, and the inevitable justice that accompany any attempt to fulfil the Law, as well as any guilt over sin. Hence,

The word [GRACE] is to be understood of the free love of God in Christ to sinners, by vertue of the new Covenant, in delivering them from the power of sin, and from the curse and condemning power of the Old Covenant, from the destroying nature of sin, by its continual workings. ${ }^{24}$

Though 'you have transgressed against the Covenant of works (the Law)', Bunyan writes, 'which accuseth, chargeth, condemneth, and brings execution on the soul for sin', it is grace,

which frees you, forgives you, keeps you, and justifies you from all your sins, adversaries, or whatsoever may come in to lay any thing to your charge, to damn you. For that is truly called grace in this sense, that doth set a man free from all his sins, deliver him from all the curses of the Law [...]: and also that doth keep the soul by the same power through faith (which is also his own proper gift) unto eternal glory. ${ }^{25}$

The terms of this grace for man are thus joyously simple. The grace available through the new covenant is unquestionably 'free and unchangeable'. ${ }^{26}$ It is free (that is,

23 Bunyan, Law and Grace, pp. 88-91.

24 Bunyan, Law and Grace, p. 84.

25 Bunyan, Law and Grace, p. 84.

26 Bunyan, Law and Grace, p. 88. 
totally unconditional) because man, being delivered thereby from both the burden and the curse of the covenant of works, has only to accept and believe that he is truly saved by grace in order to be redeemed. The Law or works (as a means of righteousness in itself) has no saving efficacy in this process: there are no conditions that man is obliged to fulfil now, no perfection to attain. Any act made by the sinner in an attempt to further his or her salvation can only be considered as a 'filthy' product of works-righteousness. It is unchangeable grace, moreover, because the new covenant, unlike the old, is forged in eternity by the divine Godhead itself and, having been kept by Christ, can never be broken by man. For this reason, it is through faith and grace (or rather faith through grace) that one's salvation can be and should be relied upon as eternal indeed.

It seems clear, even from such a brief exposition as this, that Bunyan's theology needs to be understood more specifically by readers and critics beyond generalisations about Calvinism and predestination. Indeed, it is only in these covenant terms that Bunyan's concept of salvation can be technically described and more fully understood at all. In relation to his covenant theology, for example, it is important to recognise that Bunyan's is, quite explicitly, a doctrine of imputed righteousness at the heart of which lies assurance for the sinner. Because man can at best achieve a 'silly Cobweb-righteousness' in which even 'the best of our Gospel-performances' are but full of 'faults and sins', we must rely upon the fact that righteousness can be ours 'onely by Imputation'. 27 Just as it is 'improper to say, Adam's eating of the Forbidden Fruit, was personally and inherently an Act of mine: 'Twas personally his, and imputatively mine', so too must the righteousness of Christ be considered ours. Just as the 'Sin' of Adam is 'imputed to his posterity', the righteousness of Christ 'is Reckoned the Righteousness of those that are his' by imputation alone. ${ }^{28}$ By maintaining a doctrine of imputed righteousness, Bunyan thus upholds the absolute unconditionality of

27 John Bunyan, A Discourse Upon The Pharisee and the Publicane (1685), in The Miscellaneous Works of John Bunyan X, ed. by Owen C. Watkins (Oxford: Clarendon Press, 1988), p. 191; Of Justification by an Imputed Righteousness (1692), in The Miscellaneous Works of John Bunyan XII, ed. by W. R. Owens (Oxford: Clarendon Press, 1994), pp. 330-331.

28 Bunyan, Of Justification by an Imputed Righteousness, pp. 330-331. 
grace above all else: whatever right we have to salvation has nothing to do with our works or deeds but through Christ's merits alone. ${ }^{29}$

But while Bunyan's is pre-eminently a doctrine of free grace, free from the taint of works-righteousness and the Law, it is also upheld as one of justification by faith alone. While our righteousness lies in Christ's being imputed to us, we are nevertheless justified (made righteous before God) only through our faith in the saving efficacy of Christ as redeemer: 'There is a Justification, by Faith', Bunyan writes, 'by Faiths applying of that righteousness to the Understanding and Conscience, which God hath afore of his Grace imputed for righteousness to the Soul for Justification in his sight. And this is that by which we, as to sense and feeling, have peace with God.' 30 We are, then, undoubtedly saved by grace alone (sola gratia) from a 'divine perspective', as Greaves puts it, but from the human side it is by faith alone (sola fide) that man is revealed as justified. ${ }^{31}$ In these terms, therefore, Bunyan's covenant theology offers assurance for the believer who has nothing to do but believe in order to be saved. But there are complications to this doctrine nevertheless.

The problematic implication of being justified by faith, for instance, is that faith itself may be in danger of becoming a condition or requirement of salvation, thus negating Bunyan's notion of free and unconditional grace. In such a case, faith would simply become synonymous with the Law as something to be fulfilled by man for justification. Bunyan is, consequently, at pains to clarify such a paradox in his doctrine of faith. Justifying faith is indeed discussed by Bunyan as a prerequisite condition for salvation: 'lest thou shouldest split thy soul upon the conditions laid down in the Gospel', Bunyan implores of his reader, 'see if thou canst fulfill the first condition; that is, to believe that all thy sins are forgiven thee'. Bunyan can maintain in the same breath, however, that 'Grace is Grace' indeed (in that it actually requires nothing of man) principally because the condition of faith is a gift of God in any case: 'Though there be a condition commanded in the Gospel', Bunyan writes, 'yet he that commands the condition, doth not leave his children to their natural abilities, that in their own strength they should fulfill them'. This would be to make of faith, Bunyan

\footnotetext{
29 For a general account of the assurance such covenant certainty brings to the believer in the seventeenth century, see von Rohr, The Covenant of Grace in Puritan Thought, pp. 12-13, 178-191.

${ }^{30}$ Bunyan, A Discourse Upon The Pharisee and the Publicane, p. 195.

31 Greaves, John Bunyan, pp. 78-79, 166.
} 
asserts, a legal righteousness. Rather, 'the same God that doth command that the condition be fulfilled, even he, doth help his children by his holy Spirit to fulfil the same condition', so that when the condition 'be fulfilled, it is not done in the ability of the creature.' 32

Faith for Bunyan is thus both a condition and a non-condition as it is ultimately fulfilled for us by God in any case: 'faith as it is a gift of God, or an act of ours, take it which way you will [...] layeth hold of, and applieth to us that which saveth us, which is the love of God, through the merits of Jesus Christ, which are the two main causes of our salvation'. That God 'hath saved us by Grace, that is, of his own voluntary love and good will', is thus evidenced in the fact that 'he gave us faith to believe in Christ' in the first place. Despite discussing the (albeit paradoxical) conditionality of faith, however, Bunyan is careful in any case to maintain a crucial distance from positing too much emphasis upon faith as the means of our salvation in itself: 'Faith as the gift of God is not the Saviour', Bunyan warns, 'as our act doth merit nothing. Faith was not the cause that God gave Christ at the first, neither is it the cause why God converts men to Christ: but faith is a gift bestowed upon us, by the gracious God [...] to lay hold on Christ'. Faith in itself is not meritorious, Bunyan asserts, but a means to an end: in no sense is it a cause of our salvation, "but is onely the instrument, or hand, that receiveth the benefits that God hath prepared for thee before thou hadst any faith' 33

Ultimately, what lies behind such apparently paradoxical doctrinal thinking is not a confused and confusing Calvinistic creed but a need for Bunyan to eradicate anything that may be considered legalistic or meritorious from his soteriological scheme. Because the single most important tenet in Bunyan's entire doctrine is that we are saved by the free and unconditional grace of God alone, and not in any way by anything we may do, that doctrine does, however, seem to take some tautological turns at times. Hence, faith is obviously a condition of salvation for Bunyan but, lest it become a mere 'act' of merit, it is also considered both a gift from God and, finally, no cause of our salvation at all. What we must always remember in approaching Bunyan's doctrine, therefore, is that everything in his

\footnotetext{
32 Bunyan, Law and Grace, pp. 77-81.

33 Bunyan, Law and Grace, pp. 81-2. See also Of Justification by an Imputed Righteousness, p. 334. For a discussion of the different attitudes of Puritans towards faith as a condition of salvation in covenant theology, see John von Rohr, The Covenant of Grace in Puritan Thought, pp. 53-55, 63-72.
} 
thinking reflects his covenantal scheme of salvation. For this reason, when Bunyan discusses justifying faith it is often strictly in opposition to being justified by works: saving faith, Bunyan writes, respects 'not any good work done by us, but the righteousness that resideth in the person of Christ; and is made ours by the imputation of grace.' This faith simply 'accounteth him in whom it is, now a sinner, and without works; yea, if he have any that in his own eyes are such, this faith rejects them, and throweth them away; for it seeth a righteousness in the person of Christ sufficient; even as such is verily the righteousness of God.' 34

Unfortunately, however, Bunyan's emphasis upon salvation by free and unconditional grace also lends his theological stance something of an antinomian hue: in seeming to advocate no adherence to the Law at all Bunyan's doctrine could be accused of wilfully allowing sin to abound as much as grace. ${ }^{35}$ Such a tendency towards the doctrinally disreputable is shown, moreover, in Bunyan's approach to faith itself. In order to maintain that faith is not a meritorious act of salvation, Bunyan asserts that the saved are ostensibly justified before they even have faith. That 'long Life is granted to the Elect before conversion' (and, therefore, one's experience of conversion merely confirms that one has been elect all along) is taken as evidence by Bunyan of the fact that 'the Elect are saved before they are called.' 36 While the idea that we may be justified before faith, saved before being justified, may seem once again tautological (as well as theologically improper), we should consider again Bunyan's doctrinal logic here. The sole purpose of such a system of salvation is to ensure that man bears no responsibility for his redemption at all and that God's grace reigns supreme: hence, 'Bunyan let being clothed with the righteousness of Christ logically precede receiving the Spirit of faith', Pieter de Vries asserts, 'to make clear in that

\footnotetext{
34 John Bunyan, A Defence of the Doctrine of Justification by Faith (1672), in The Works of John Bunyan, ed. by George Offor, 3 vols (Glasgow: W. G. Blackie \& Son, 1854; repr. by The Banner of Truth Trust, 1991), II, 314.

35 Antinomianism: "The term derives from the Greek words anti, "against", and nomos, "law". It properly refers to those who asserted that the Mosaic law was abrogated for Christians living under the covenant of grace' (Greaves, John Bunyan, p. 163). The term is, though, mainly used pejoratively both by seventeenthcentury theologians and current commentators. See R. T. Kendall, Calvin and English Calvinism to 1649 (Oxford: Oxford University Press, 1979), fn 3, p. 169.

36 Bunyan, Saved By Grace, pp. 172-173.
} 
way that faith takes hold of Christ's righteousness but that it does not in some way or other bring about this righteousness. 37

A more straightforward issue, perhaps, is Bunyan's apparent antinomianism in terms of what appears to be a complete negation of the moral law. In advocating grace over works so strenuously, isn't Bunyan's doctrine bordering dangerously on something licentious? Although it is tempting to consider it so, as did moderate Nonconformists such as Richard Baxter, part of the problem here lies in our understanding of the term 'antinomian' itself. ${ }^{38}$ As Dewey D. Wallace has so importantly indicated, 'antinomianism' as a concept is prone to exaggeration and misunderstanding (evidence for which can be found in many studies of Puritanism), having been appropriated through the years by commentators who understand it merely in terms of licentiousness and doctrinal fallacy, a theological stance synonymous with the more outrageous proponents of seventeenth century radical religion, such as Ranters. ${ }^{39}$

For this reason, then, Bunyan may or may not be considered an antinomian according to how one views the term. In its least pejorative sense, for instance, Bunyan's could indeed be considered an antinomian doctrine: Bunyan's emphasis upon the inadequacy of all man's efforts to achieve righteousness through works leads to a rejection of the Law as a means to salvation, as we have seen, in absolute terms. For this reason alone, Bunyan's is, in its most literal sense, an 'antinomian' (against the law) stance. Moreover, in comparison to other

\footnotetext{
${ }^{37}$ Pieter de Vries, John Bunyan On the Order of Salvation, transl. by C. van Haaften (New York: Peter Lang, 1994), pp. 151-155 (p. 154).

${ }^{38}$ Baxter includes Bunyan amongst antinomians in the preface to his, The Scripture Gospel Defended (London: 1690): Baxter includes 'Bunyan on the Covenants' alongside books by those 'such as Paul Hobsons' and, 'Mr. Saltmarshes [...] which ignorantly subverted the Gospel of Christ' (p. i). But on not being under Mosaic law, Baxter is, it seems, in general agreement with Bunyan: 'If this be Antinomianism', he writes, 'I am an Antinomian that have written so much against them' (p. 70). Less reasonably, however, the author of Dirt Wipt Off (London: 1672), a response to Bunyan's A Defence of the Doctrine of Justification By Faith (1672) and once thought to have been written by Edward Fowler, speaks of 'that filthy doctrine of Antinomianism' with which Bunyan 'has stuffed his sad Scrible; and it appears not only by that but by his other lamentable writings, that he is as rank and Ranting an Antinomian as ever foul'd paper' (p. 17). For discussions of Bunyan's affinity to antinomian doctrines, see Greaves, John Bunyan, pp. 97-118, and Law and Grace, pp. xxix-xxxii.

39 Dewey D. Wallace, Puritans and Predestination: Grace in English Protestant Theology, 1525-1695 (Chapel Hill: University of North Carolina Press, 1982), pp. 113-120. For an example of the less moderate (and informed) view of antinomianism, Perry Miller writes that it 'was a crude grasping at the tenets of sin and irresistible grace and of the union of believers to the Godhead, apart from any logical understanding of the terms, with no comprehension of the nature of cause and effect, with no instruction in the faculties of the soul or in the method of conversion through means.' It is, according to Miller, 'an uncontrolled piety without the indispensable ballast of reason' practised by 'Ignorant zealots' (New England Mind, pp. 372-373). For an account of the doctrines of Ranters and other radical sects (and their sexual licentiousness), see Christopher Hill, The World Turned Upside Down: Radical Ideas During the English Revolution (Harmondsworth: Penguin, 1972; repr. 1991), pp. 184-230, 314-320. See also, A Collection of Ranter Writings from the 17th Century, ed. with an intro. by Nigel Smith (London: Junction Books, 1983).
} 
interpretations of covenant theology by seventeenth century divines, Bunyan's covenantal scheme as a whole may be deemed distinctly rooted in antinomianism. For example, Bunyan's theology is based strictly upon the covenant model of a promise (promissio) or a testament (as in a deed of covenant or will) through which salvation is to be received by the sinner as something ensured as a promise or as a right of inheritance. ${ }^{40}$ In this way, Bunyan can emphasise the essentially free and unconditional nature of salvation through such a covenant: all that is required is to accept one's righteousness (as promised and bequeathed to man by Christ) through faith.

This redemptive scheme is in direct contrast, however, with an understanding of the covenant as essentially a bargain (pactum) made between God and man (as opposed to Bunyan's in which the pact salutis is made between the Father and the Son only) in which man's salvation is, on the surface at least, guaranteed through man's fulfilling certain conditions. The model or example cited for this kind of covenant is usually Abrahamic God's promise to Abraham that his seed will be guaranteed salvation according to the terms of the agreement made between God and the Old Testament Patriarch alone. ${ }^{41}$ It is upon this covenant model, it would seem, that many orthodox and moderate divines of the early and later seventeenth century focus their soteriological attention. Through such a mutual covenant scheme, the believer's salvation can be anchored in a maintaining of faith and good works as well as in a full participation of Church life (principally through the sacraments), all of which could be interpreted as keeping man's side of the bargain with God. ${ }^{42}$ Bunyan's covenant theology, of course, is radically different from this scheme. Because man's ability to fulfil any salvatory contract with God was lost in the Fall, God's subsequent covenant with

\footnotetext{
40 See John Bunyan, The Advocateship of Jesus Christ (1688), in The Miscellaneous Works of John Bunyan XI, ed. by Richard Greaves (Oxford: Clarendon Press, 1985), pp. 184-185; The Strait Gate (1676), in The Miscellaneous Works of John Bunyan V, ed. by Graham Midgely (Oxford: Clarendon Press, 1986), p. 100; Come, \& Welcome, to Jesus Christ (1678), in Miscellaneous Works VIII, p. 250. von Rohr cites other divines who consider the covenant in terms of an inheritance: The Covenant of Grace in Puritan Thought, p. 78.

41 The Biblical reference for this berith (Hebrew for agreement or pact) between God and Abraham is Genesis 17. 1-22. For an excellent discussion of the various uses and meanings of the word 'covenant' (along with 'testament') in Puritan writings, see Charles Lloyd Cohen, God's Caress: The Psychology of Puritan Religious Experience (New York and Oxford: Oxford University Press, 1986), pp. 47-55.

42 For the Abrahamic understanding of covenant theology see Norman Pettit, The Heart Prepared: Grace and Conversion in Puritan Spiritual Life (New Haven and London: Yale University Press, 1966), pp. 11-13; John S. Coolidge, The Pauline Renaissance in England: Puritanism and the Bible (Oxford: Clarendon Press, 1970), pp. 81-89, 101-110; Miller, New England Mind, pp. 377-378. For an account of Bunyan's non-Abrahamic covenant stance see Richard A. Muller, 'Covenant and Conscience', p. 327.
} 
Abraham is understood by Bunyan simply as a confirming promise of salvation (as opposed to a pact of any kind), the only bargain that having any relevance to man's salvation having been struck between Christ and God before time itself. ${ }^{43}$ In this sense, Bunyan's is hardly a 'federal' covenant theology at all.44

It is important to outline, even as broadly as this, such differences between Bunyan's and other divines' concepts of covenant theology largely because such distinctions often go unrecognised in approaches to Bunyan's doctrine. ${ }^{45}$ Bunyan's covenant model is not synonymous with that of most other English divines (indeed, seventeenth-century covenant theology is hardly homogeneous at all) but is, as John von Rohr so often illustrates, at the more extreme and 'antinomian' end of the seventeenth century's theological spectrum. ${ }^{46}$ Bunyan's covenant theology, therefore, cannot merely be said to follow Calvin's sense of covenant as the promise of, not a contract with, God (as opposed to Zwingli's and Bucer's interpretation, for instance) which has been the predominant approach to the origins of Bunyan's covenant theology so far. ${ }^{47}$ Rather, being a double covenant doctrine, in which works righteousness is most distinctly segregated from grace, Bunyan is following a strictly English tradition of covenant thinking developed, according to Michael McGiffert, in the early seventeenth century in order to prevent the doctrine of grace from becoming tainted with legalism (the upshot, perhaps, of the Abrahamic and Church covenant models). Bunyan's whole salvatory scheme must more accurately be considered, therefore, as having arisen from an English tradition of covenant theology the impulse for which was, it seems, inherently antinomian. ${ }^{48}$

\footnotetext{
43 Bunyan, Law and Grace, pp. 89-92. For Bunyan's similar understanding of God's covenant with Noah after the Flood, see An Exposition on the Ten First Chapters of Genesis, in The Miscellaneous Works XII, pp. 252258.

44 The term federal comes from the Latin foedus, meaning 'pact'. Muller's definitions of all covenants being either 'foedus monopleuron' (one-sided pact) or 'foedus dipleuron' (two-sided agreement) do not really apply to Bunyan who conceives of the covenant as no pact between God and man at all ('Covenant and Conscience', pp. 309-310). See also Francis Lyall, 'Of Metaphors and Analogies' on the language of covenant theology.

45 Christopher Hill, for example, does not seem to recognise the broad range of differences between covenant theologians on matters of grace when discussing Bunyan's doctrinal background: A Turbulent, Seditious, and Factious People: John Bunyan and his Church 1628-1688 (Oxford: Oxford University Press, 1988; repr. 1989), pp. 170-174.

46 von Rohr, The Covenant of Grace in Puritan Thought, pp. 10-11, 44-45, 50, 54, 64, 92-100, 107-110. Muller also confirms such an approach in 'Covenant and Conscience', p. 327.

47 Trinterud, Møller, and Greaves have long proposed a 'two traditions' approach to the development of covenant theology in the sixteenth and seventeenth centuries. This approach has been challenged, however, by the likes of Bierma and McGiffert (see fn 15 of this chapter).

48 See McGiffert, 'From Moses to Adam', pp. 152-153.
} 
Bunyan's 'antinomianism' is, therefore, clearly grounded in a theological need to preserve a concept of salvation by grace alone from any legalistic obligations. Moreover, again as Dewey D. Wallace observes, such a stance was rarely centred in anything radical or licentious, being born instead out of a deep need for spiritual assurance that salvation is ours without, ultimately, anything being required of us. ${ }^{49}$ If we were even to attempt to consider Bunyan as an antinomian in its far more pejorative sense (that is, as a proponent of a doctrine which encourages sin in the light of being elect in any case), such a denomination simply would not tally with what Bunyan's theology finally and continually points us towards - not only assurance of salvation but holiness of life. Bunyan states throughout his tracts and treatises that righteousness through the Law is worthy of damnation alone and that the means of man's salvation are finally beyond him, but he is also careful always to countenance any possible accusation of this doctrine being but an excuse for licentiousness: 'Let no Man turn this Grace of God into Wantonness' is a call frequently emphasised by Bunyan. ${ }^{50}$ For this reason, then, Bunyan is adamant about the Law's inefficacy in procuring man's salvation, but this is not to say that it has no place at all in his doctrine of grace.

The Law has, in fact, two important roles to perform in Bunyan's theology. Firstly, and in what may appear an ironic fashion, it is only through the Law that one can begin one's conversion towards saving grace in the first place. This is not because good deeds or an adherence to the Law leads to a holy righteousness, of course, but quite the opposite. For Bunyan, it is only through a realisation that under the Law we are condemned by God's eternal justice to damnation that a sinner can begin to turn to Christ as the sole means of salvation. The Law, then, has a most significant role preparatory to effectual calling (the realisation that we are indeed saved and by Christ alone) because it is only through the Law that any sinner can become aware of his own sinfulness (have a conviction of sin) and recognise his (or her) own soterial helplessness. Because the case is such that 'without this Sense of a lost condition' there can be 'no moving of the mind' towards Christ, 'from a Sound Sense of the absolute want that a man hath of him for his Justification and Salvation', the Law provides the first step (from man's perspective, at any rate) in Bunyan's ordo

\footnotetext{
49 Wallace, Puritans and Predestination, p. 114.

50 Bunyan, Come \& Welcome, p. 270.
} 
salutis: 'When God brings sinners into the Covenant of Grace,' Bunyan asserts, 'he doth first kill them with the Covenant of Works, which is the Morall Law, or Ten Commandments', according to both 'Pauls doctrine, and also Pauls experience.'51 Because it is essential to come to Christ 'as the basest in the world, more fitter to be damned, if thou hadst thy right, then to have the least smile, hope, or comfort from him' and 'with the fire of hell in thy conscience', and because only a sinner convinced of his sin can be converted (for, as Bunyan reminds us so often, only the sick can have need of the physician that is Christ), then the Law stands as a 'glass' in which the sinner must see himself both sinful and damned. Consequent to this, the sinful man cannot be contented until he is convinced 'that Jesus Christ standeth open armed to receive thee, to wash away thy sins, to clothe thee with his righteousness'.52

While it may indeed seem ironic that the terrifying preparatory role of the Law is enacted in order to be rejected (salvation being not by works but by grace), it may seem even more paradoxical that, once conversion is completed (effectual calling and justification being simultaneous through the reception or revelation of faith for Bunyan), good works become one of the paramount ideals of the believer in the maintaining of one's grace through a holy life. Indeed, for justification to be truly efficacious it must, according to Bunyan, be supported by the sanctification of the sinner and this, inevitably, demands a certain amount of works righteousness. ' 'Tis true', Bunyan states, 'Faith without works justifies us before God: yet that Faith that is alone [i.e. without sanctification], will be found to leave us sinners in the sight both of God and man': to 'be so careless as to say, what care I for being righteous to profit others' is evidence for Bunyan 'that the love of God is not in thee.' In order to 'walk like a Christian indeed' it is 'requisite' that the believer 'continue in Good Works'.53 This is not to make of Bunyan's theology legalistic, though. Bunyan is, rather, merely setting the covenants in their right places: 'WORKS', he writes, 'do not proceed, but follow after [the receiving of Christ's imputed] Righteousness', as 'the Tree must be good before it bear good fruit, and so must also a Man'. For this reason, it is not the saints' 'continuing in

51 Bunyan, Come, \& Welcome, p. 256; Law and Grace, pp. 137-8. For a more detailed description of the conversion process from profanity to works-righteousness to conviction of sin (and the inefficacy of works righteousness) to effectual calling, see Saved By Grace, pp. 203-206.

52 Bunyan, Law and Grace, pp. 184; 12-14; 17.

53 John Bunyan, Christian Behaviour (1663), in The Miscellaneous Works of John Bunyan III, ed. by J. Sears McGee (Oxford: Clarendon Press, 1987), pp. 51-54. 
the way of God [that] is the cause of the work being right, but the work being right, [which] causeth continuance therein.' 54

For Bunyan, then, good works are indeed essential both to the continuing righteousness of the converted sinner as well as to their perseverance in grace. Bunyan continually maintains that one's grace can and should be improved upon by the saints through the fruits of conversion (good works, repentance, renewing one's faithful understanding through prayer and the Word). Works are essential to the sanctification of the saint, therefore, but only if all is done in a Gospel (as opposed to a legal or works-righteous) spirit: it is important to realise, Bunyan maintains, that even works achieved through faith are not in any way meritorious of salvation.55 Saints are thus to strive to maintain their faith, grace, and sanctity through good works but, at the same time, this would be a natural instinct for visible saints in any case. Indeed, corollary to true conversion comes a desire for holiness inspired by faith itself. In faith 'we forthwith become through a change which the Holy Ghost works in our minds, the Servants of God': 'they that are thus in Jesus Christ', Bunyan asserts, 'are so far off from delighting in sin, that sin is the greatest thing that troubleth them'.56

Bunyan's doctrine can thus be seen as wholly centred in sanctification and perseverance without being legalistic, a fact reflected in tracts as emphatically pastoral (and works-oriented) as Christian Behaviour (1663), The Barren Fig-Tree (1673), and The Holy Life (1683). For the converted sinner, the Law becomes something to be harnessed rather than something which burdens - it is a guidebook for the saint, a rod 'not for the Destruction, but the Correction of the Children', vindicating the 'Holiness' of the 'Father', and which will 'drive them [not] further from, but nearer to their God.' 57 As such, Bunyan can more than adamantly claim that his is a far from 'Ranterish' (that is, pejoratively antinomian) doctrine. For Bunyan, 'the Doctrine of free grace believed, is the most Sin-Killing in the world, and any claim that it 'is a doctrine tending to loosness and lasciviousness' is to be answered by

\footnotetext{
54 John Bunyan, The Desire of the Righteous Granted (1692), in The Miscellaneous Works of John Bunyan XIII, ed. by W. R. Owens (Oxford: Clarendon Press, 1994), p. 110; Christian Behaviour, p. 53.

55 Bunyan, Of Justification by an Imputed Righteousness, pp. 333-334.

56 Bunyan, Desire of the Righteous Granted, p. 111; Law and Grace, p. 171.

57 Bunyan, The Advocateship of Jesus Christ, p. 182.
} 
the natural objection: 'What because Christ is a Saviour, thou wilt be a sinner; because his grace abounds, therefore thou wilt abound in sin. $\mathrm{O}$ wicked wretch!'58 The reason why some do conclude that Bunyan's is a 'licentious Doctrine' is, he asserts, merely 'because they are fools, and such as have not tasted of the Blood of Jesus Christ; neither did they ever feel the nature, and sway that the love of Christ hath in the hearts of his.' 59

Deliberating at length upon the specifics of this covenant theology is a fundamental duty of both the sinner and the believer for Bunyan. After all, it is ignorance alone, of unknowingly being under the Law instead of grace, that presents the greatest and most horrifying danger for Bunyan. 60 As Bunyan's readers today, however, there are reasons other than the soteriological as to why we should consider Bunyan's doctrine in such detail. Only by doing so, for instance, can we begin to realise how grace is the totalising concept in Bunyan's life and writings: that we are saved by grace and not works, by the Gospel and not the Law, is the single most important theological issue for Bunyan and, as such, it informs practically every treatise and narrative work he ever published, from early tracts such as The Doctrine of Law and Grace Unfolded to his last and even posthumous works, such as A Discourse Upon The Pharisee and the Publicane (1685), The Water of Life (1688), and Of Justification by an Imputed Righteousness (1692). If we are to approach and understand Bunyan doctrinally, it must not be in terms of a general and somewhat prejudicial 'Calvinism' (whatever this may mean) but in the very terms of Bunyan's theology itself - Law and grace.

The reasons for doing so are, moreover, obvious. For instance, it is only with a more complete understanding of Bunyan's covenant doctrine that we can begin to appreciate the difficulty of categorising or denominating Bunyan's religious stance as a whole. Historically (or, rather, politically), Bunyan is clearly a Nonconformist: his adherence to a profession of Christianity within a Church separate from that of the Church of England and with its own rules of worship, fellowship, and membership (including a rejection of the Common Book of

\footnotetext{
58 Bunyan, Saved By Grace, p. 221; Law and Grace, p. 170.

59 Bunyan, Law and Grace, p. 200.

60 See, for example, Law and Grace, pp. 12-13, 31, 63, 178, 181-184.
} 
Prayer) makes this apparent. ${ }^{61}$ However, Bunyan's strict faith in and emphasis upon a doctrine of salvation by grace alone makes him far more difficult to pigeon-hole denominationally. As we have seen, Bunyan could be considered either an antinomian or not, depending upon how we view the term. Equally, Bunyan is frequently referred to as a Particular (as opposed to a General) Baptist, a title synonymous with being a strict or high (as opposed to moderate) Calvinist.62 But such denominations are not without their problems either. Particular Baptists, for example, are often delineated as Calvinist 'ultrapredestinarians' whose emphatic zeal concerning the salvation of the individually predestined elect (both as Michael Mullett points out and as shall be illustrated more fully in this chapter) fits somewhat uneasily with the almost voluntaristic evangelism of Bunyan's soteriology, one that softened 'the rigours of hyper-determinist predestinarianism' as it 'responded to the possibilities of decision making' on the part of Bunyan's 'auditors'.$^{63}$

Moreover, the (Particular) Baptist issue of insisting upon the baptism of adults (usually by full bodily immersion) prior to a believer's full Church membership is especially problematic in Bunyan's case. For Bunyan, in fact, the notion that for want of a sacrament, a mere outward sign of faith, a believer should be barred from communion with a Church of saints was simply anathema and, consequently, he engaged in heated controversy with more strict, closed-communion Baptists to say so. ${ }^{64}$ In order for Bunyan to settle this issue, he

61 See John Bunyan, I Will Pray With the Spirit (1662?), in The Miscellaneous Works II, and A Relation of My Imprisonment (1765), in Grace Abounding to the Chief of Sinners, ed. by Roger Sharrock (Oxford: Clarendon Press, 1962).

62 The principal difference between Particular and General Baptists of the seventeenth century is essentially soteriological, the former adhering to the more strict Calvinist doctrine of limited atonement while the latter advocated a belief in general atonement. As B. R. White puts it, General Baptists 'believed, with the followers of Jacobus Arminius, that Christ died for all men', while Particular (or 'Calvinistic') Baptists 'believed that Christ died only for the elect'. According to White, both General and Particular Baptists 'believed that the visible church of Christ was composed of believing men and women and they believed in and practised (at least from 1642) believer's baptism by immersion' (The English Baptists of the Seventeenth Century [London: The Baptist Historical Society, 1983], p. 7). For further doctrinal and ecclesiological similarities and differences between these two denominations see White, The English Baptists of the Seventeenth Century, pp. 7-12, as well as A. C. Underwood's A History of the English Baptists, with a foreword by J. H. Rushbrooke (London: The Carey Kingsgate Press, 1947; repr. 1956). For a useful introduction to Baptists (and their differences) in seventeenth-century England see also J. F. McGregor, 'The Baptists: Fount of All Heresy', in Radical Religion in the English Revolution, ed. by J. F. McGregor and B. Reay (Oxford: Oxford University Press, 1984), pp. 2363 (esp. p. 28).

${ }^{63}$ Mullett, John Bunyan in Context, p. 47 (and see also pp. 180-181).

64 See Bunyan, A Confession of My Faith (1672), Differences in Judgment About Water Baptism (1673), and Peaceable Principles and True (1674), in The Works of John Bunyan, ed. by Offor, II. For a good account of Bunyan's role in such controversies see T. L. Underwood, " "It pleased me much to contend": John Bunyan as Controversialist', Church History, 57 (1988), 456-469, Michael Mullett, John Bunyan in Context, pp. 176-181, and John Brown, John Bunyan: His Life, Times, and Work (London: The Hulbert Publishing Co., 1885; Tercentenary Edition, rev. by Frank Mott Harrison, 1928), pp. 219-225, 234-238. 
pointed authoritatively towards an understanding of the ordinances as merely shadowish

forms of true faith, simply representations of grace without being soterially efficacious in themselves. In other words, when it came to the problematic issue of baptism, Bunyan simply asserted his overriding theological stance in terms of salvation by grace: true faith and grace come through Christ and the Word alone, the only true baptism (or circumcision) being that of the heart by the Spirit in conversion.65 For this reason, Bunyan could hardly be said to be a Particular Baptist at all but, as Joseph D. Ban (among others) has more accurately noted, an open-communion Congregationalist, the Bedford Church being an 'open-communion congregation', the open-membership of which allowed 'all who had experienced the saving knowledge of being in Christ to join the solemn communion table.'66 Bunyan's emphatic preaching of faith through grace thus left the Bedford Church open for the fellowship of those baptised in the Spirit, with all outward ordinances being down-graded, effectively, as spiritually impotent in the face of the experience of grace alone (although Bunyan didn't object to ordinances as a part of Church life per se). ${ }^{67}$ The consequence of this debate for

\footnotetext{
65 Bunyan, A Confession of My Faith, pp. 604-611.

66 Joseph D. Ban, 'Was John Bunyan a Baptist?', Baptist Quarterly, 30 (1984), $367-76$ (p. 373). White notes, however, that as most Particular and General churches were of the closed-communion and membership variety, the Bedford open-membership church was, in fact, among the minority at this time (The English Baptists of the Seventeenth Century, pp. 9-10). On the issue of Bunyan-as-Congregationalist, see also Hill, $A$ Turbulent, Seditious, and Factious People, pp. 293-294, and Geoffrey F. Nuttall who includes Bunyan among 'the Congregational men' of his study, Visible Saints: The Congregational Way, 1640-1660 (Oxford: Basil Blackwell, 1957), p. 125. While Nuttall is careful not to make the 'Congregational way' simply synonymous with 'Congregationalism' (pp. vii-viii), N. H. Keeble describes Congregationalists (or Independents, as they can also be known) as essentially propounding the belief that 'the visible and invisible churches could and should be more closely approximated by "gathering" churches composed of members who testified publicly to their conversion and faith and who covenanted to join in fellowship together' (The Literary Culture of Nonconformity in Later Seventeenth Century England (Leicester: Leicester University Press, 1987), pp. 9-10). But while Bunyan's ecclesiology is clearly one of 'open-membership', the issue of his Congregationalism is more complicated. Because, as McGregor points out, the necessary qualification for Baptist membership was also a declaration of an experiential work of the Spirit on the heart', then Bunyan can still be referred to (by A. C. Underwood, for example) as 'an open-membership Baptist' (McGregor, 'The Baptists: Fount of All Heresy', p. 57, and Underwood, $A$ History of the English Baptists, p. 98). In fact, Underwood cites the intriguing fact that Bunyan styles himself 'as a Congregationalist' when applying for licences to preach and worship under the Act of Indulgence of 1672 in terms of Bunyan's need to assert his neutrality on the controversial question of baptism and closed (or mixed) membership in the Bedford Church. This explains, Underwood suggests, why 'Bunyan is claimed by both Congregationalists and Baptists' and also why 'the man whom all the world knows, had so little influence upon his fellow Baptists in his own lifetime' (A History of the English Baptists, pp. 102104). Equally, John Brown (who usefully publishes details and facsimiles of Bunyan's application for these licences in 1672, wherein Bunyan is referred to as 'a congregationall person'), argues that the term 'congregationall' itself is of no definitive significance in any case, it being in general 'a term which appears to have been used in describing Independents and Baptists; in fact, to such as disclaimed to be either Episcopalian or Presbyterian' (John Bunyan: His Life, Times, and Work, pp. 234-237).

67 Although they are considered but 'shadowish or figurative ordinances', 'Water baptism and the supper of the Lord', Bunyan asserts, 'are of excellent use to the church in this world; they being to us representations of the death and resurrection of Christ; and are, as God shall make them, helps to our faith therein' (A Confession of
} 
Bunyan was, therefore, that even as a 'Baptist' he refused to uphold any denomination above grace. Indeed, Bunyan was not interested in specifics of denomination at all (particularly as it seemed to be a source of nothing but faction within his Church):

since you would know by what name I would be distinguished from others; I tell you, I would be, and hope I am, a CHRISTIAN; and choose, if God should count me worthy, to be called a Christian, a Believer, or other such name which is approved, by the Holy Ghost. Ac. xi. 26. And as for those factious titles of Anabaptists, Independents, Presbyterians, or the like, I conclude, that they come neither from Jerusalem, nor Antioch, but rather from hell and Babylon; for they naturally tend to divisions. 68

For this reason, then, Richard Greaves seems right to conclude his seminal study of Bunyan's theology with a confirmation that '[n]o single theological label without careful qualification will fit Bunyan.' ${ }^{69}$ But some labels have been applied nonetheless. Greaves himself, for example, describes Bunyan's theological position broadly as that of strict or high Calvinism - a stance involving, as already noted, close adherence to Calvinist tenets (such as the depravity of man, the eternal election of specific individuals, and man's passivity in salvation) as well as an understanding of covenant-as-promise and not contract. It is in these terms, therefore, and with his faith being perhaps most similar to that of his contemporary high Calvinist, John Owen, that Bunyan's theological stance is often placed in the context of the beliefs and doctrines of his contemporary divines, ministers, and preachers - such as moderate Calvinists (who emphasised more the role of man's will in salvation and evinced a contractual sense of covenant with God) and antinomians unrestrained by the moral law, as well as Arminians and Latitudinarians who propagated a doctrine of free will and moral righteousness. ${ }^{70}$

My Faith, p. 604).

68 Bunyan, Peaceable Principles and True (1674), in The Works of John Bunyan, ed. by Offor, II, 648-649. Given this, however, in The Heavenly Footman (1698), Bunyan gives another clue as to his denominational identity: 'do not have much Company with some Anabaptists', he warns his reader, 'though I go under that name myself (Miscellaneous Works V, p. 153). The Heavenly Footman, we must assume, is an early work written before Bunyan's controversies over baptism and communion. Important and useful articles on Bunyan's denomination as 'Baptist' include: J. Hobson Thomas, 'Bunyan the Baptist', Baptist Quarterly, 4 (1928), 97-103; Joseph D. Ban, 'Was John Bunyan a Baptist?'. These articles also touch upon possible explanations as to why Bunyan, as a strict antipaedobaptist, apparently had his own children baptised. Mullett suggests that this may be indicative of Bunyan's 'relative openness to the Church of England', the baptism of his children amounting 'to little more than the registration of a birth' in any case (John Bunyan in Context, p. 101).

${ }^{69}$ Greaves, John Bunyan, p. 159.

${ }^{70}$ For discussions of such differences see The Miscellaneous Works II, ed. by Greaves, pp. xxiv-xxvi; Greaves, John Bunyan, pp. 97-99, 163-4; and Wallace, Puritans and Predestination, pp. 112-157. 
It is undoubtedly useful to categorise Bunyan in this way in order to place him in the context of the wide and subtle varieties of faith prevalent in late seventeenth-century England, but it is equally important not to become blind to the actual nature of Bunyan's doctrines because of the labels alone. Bunyan's has been a theology, for instance, which the likes of Greaves (among others) have attempted to rescue from being condemned simply as 'Calvinist' (with all this term's negative baggage) by stressing the Lutheran influences it reveals - such as its emphasis upon and Law and grace, as well as justification by faith. However, Bunyan's is no more an overtly Lutheran theology (despite his reading of Luther's Commentary on Galatians) than it is Calvinist. As we have seen, Bunyan's covenant theology (while undoubtedly sharing basic similarities with both Luther's and Calvin's doctrines of salvation as well as their discussions of Law and grace) is of a distinctly English Calvinist tradition. For this reason, it would perhaps be more useful for any reader of Bunyan to understand his theology not in terms strictly of Lutheranism or Calvinism but, more broadly and simply, as of the Protestant Reformed tradition in general (although the purism of Bunyan's theology of grace would seem to excel even that of the Protestant Reformers themselves at times). ${ }^{71}$

By suggesting that we accept Bunyan's theology more broadly as part of the Reformed tradition is not an attempt to deny that Bunyan has inherited some fundamentally Calvinist doctrines, though. Indeed, inherent corruption, election and predestination, and the effacement of the will (all focal in a Calvinist faith) are central to Bunyan's thinking. But it is nevertheless crucial to understand such tenets in the context of Bunyan's theology of grace as a whole and not isolated from that context. Indeed, part of the problem with studies of Bunyan's literary works in terms of their inherently Calvinist theology (such as Sim's and Stachniewski's) has been that, while emphasising the more unacceptable and inhumane aspects of Bunyan's Calvinism, the soteriological analysis of such work is largely divorced from the specifics of Bunyan's covenant theology. What emerges in such studies is,

\footnotetext{
71 I adopt this use of the term 'Reformed' theology from Wallace, Puritans and Predestination, pp. $x-x i, 3-4$. For a distinctly Luther-centred approach to Bunyan, see Vera Camden, " "Most Fit for a Wounded Conscience": The Place of Luther's "Commentary on Galatians' in Grace Abounding', Renaissance Quarterly, 50 (1997), 819-849. Camden views Bunyan's theology as wholly informed by 'Luther's doctrine of law and grace' (p. 823), ignoring altogether both the development of English Calvinist covenant theology and the fact that Luther's was not even a covenantal doctrine of salvation at all.
} 
therefore, an abhorrent and terrifying Calvinist theology indeed. However, if we attempt to understanding Bunyan's theology of grace in its own terms, as related so far for instance, a very different sense of Bunyan's doctrines emerges from the harsh and dogmatic Calvinism with which it is most often associated.

For example, when understood within the context of Bunyan's doctrine of Law and grace, the Calvinist notion of man's inherent depravity takes on quite a different hue from that of the anti-humanist and anti-humanitarian doctrine as it is understood by literary commentators such as F. R. Leavis. For Bunyan, the innate sinfulness of man is simply to be accepted as central to the human condition: no one but Christ since the fall of Adam has been or can be morally perfect. Moreover, as we have seen, only by realising that one is sinful can the believer begin to take those steps which will alleviate him both from the burden of guilt caused by sin and the responsibility of meeting God's justice for that sin. Because Bunyan posits righteousness in Christ and not in the perfect obedience of the sinner to the moral law, Bunyan's thus emerges as an inherently accommodating, comforting, and reassuring doctrine for anyone convinced they are sinful. Because 'the righteousness of the Law is become too weak through this our flesh' that 'notwithstanding all our obedience to the Law, we are yet through our weakness under the Curse of the Law', and because, at the same time, 'the Law is so holy, so just, and so good, that it cannot allow that any failing or slip should be done by them that look for life by the same', Bunyan proposes his doctrine of salvation by grace as essentially liberating and spiritually vivifying. ${ }^{72}$ In opposition to the tyranny of the Law, under grace the believer can come to terms with his or her inability to maintain perfection to the Law. The covenant of grace 'doth allow of repentance, in case thou chance to slip or fall, by sudden temptation', Bunyan asserts, 'but the Law allows of none'. ${ }^{73}$

In this way, Bunyan's doctrine of grace and innate corruption is far from inhumane but grounded in accommodating the sinfulness that Bunyan feels is inherent in humanity. Because Bunyan's is indeed a theology for the chief of sinners, he can rightly propound what is rarely ever considered by commentators in terms of his 'Calvinism' - that 'this glorious Doctrine of the New Covenant, and the Mediator thereof, will serve for the comforting, and

\footnotetext{
72 Bunyan, Law and Grace, p. 57.

73 Bunyan, Law and Grace, p. 186.
} 
the maintaining of the comfort of the children of the New Covenant'. ${ }^{74}$ Thus, the condition of the believer under grace is undoubtedly one of striving for sanctification amid a continual battle against temptation but, should (or when) sin occur, it can be accommodated by grace nonetheless: 'Here is Grace!', Bunyan can exclaim: 'So many times as the soul backslides, so many times God brings him again [...], he renews his pardons and multiplies them'. Because of the 'Heart-wandrings', 'daily Miscarriages', and 'common Infirmities that are incident to the best of saints, and attend them in their best Performances', such as 'worldly Thoughts, unclean Thoughts, too low thoughts of God, of Christ, of the Spirit', grace simply provides 'Millions of pardons from God for these'. All that is required of the saint is faith in the fact that our transgressions are forgiven 'through the Redemption that is in Christ's blood.'75

For this reason, Bunyan can assert that 'the great Cause now of Man's Condemnation, is not because of his inherent Pollution, but because he accepteth not [...] of the Satisfaction made by Christ' ${ }^{76}$ Indeed, it is through weakness of faith alone, through doubt in the everlasting nature of redemption and a forgetting of the promises in Scripture, that 'the very Saints of God have so many ups and downs' in their spiritual life: 'they think that if they fail in this or that particular performance [...] therefore now God is angry [...] now the new Covenant is broken'.7 In the face of such legalistic lapses, Bunyan merely advocates a return to grace itself through meditation on Christ's redemption as revealed in Scripture: 'I know that thou wilt be afflicted with a thousand temptations', Bunyan writes,

to drive thee to despair, that thy Faith may be faint, etc. but against all them set thou the Word of God, the Promise of Grace, the Blood of Christ, and the Examples of God's Goodness to the great Backsliders, that are for thy encouragement, recorded in the Scriptures of Truth; and remember that turning to God after back-sliding, is the greatest piece of service thou canst do for him, and the greatest honour thou canst bring to the Blood of Christ. ${ }^{78}$

In emphasising comfort for the sinful, and recognising the imperfection of all saints' endeavours to a holy life, Bunyan's doctrine of grace finally becomes the bottom line not of a

\footnotetext{
74 Bunyan, Law and Grace, p. 194.

75 Bunyan, Saved By Grace, p. 208.

76 Bunyan, An Exposition on the Ten First Chapters of Genesis, p. 245.

77 Bunyan, Law and Grace, p. 167.

78 Bunyan, Christian Behaviour, p. 61.
} 
harsh and terrorising theology that merely degrades mankind as hopelessly depraved but which accepts human imperfection and offers a reassuring solution.

Of course, such an assertion of Bunyan's being a theology of comfort and accommodation could easily be objected to, one would suppose, by simple reference to the Calvinist doctrine of predestination, whereby those who have faith and are saved are simply so because it is God's will as decided before time itself. How can Bunyan's doctrine be comforting in the face of such an overtly anxiety-generating doctrine? If, as Stuart Sim and John Stachniewski have so emphatically pointed out, the Calvinist sinner can only remain finally uncertain as to whether he is elect or reprobate, and if the true sign of the elect is not presumption but anxiety over such matters anyway, how can Bunyan, who most certainly adhered to a doctrine of double predestination, be considered humane? The answer here, of course, lies in both understanding Bunyan's theology of grace more fully and in a much needed re-orientation as to how we view the doctrine of predestination operating for seventeenth-century divines in general.

Bunyan's is undoubtedly a theology, for instance, that frequently adopts the language of predestination and election. The saved are, according to Bunyan, the 'Elect' given by God to Christ and whose salvation depends upon a divine 'Act of electing Love': 'They that are saved', Bunyan asserts, 'are predestinated to the adoption of Children by Jesus Christ to himself, according to the good pleasure of his Will, to the praise of the Glory of his Grace, Ephes. 1. 5,6.'79 That Bunyan adheres to a doctrine of predestination is, then, unequivocal. However, the centrality of this doctrine in Bunyan's overall theology is more questionable. While commentators have often stressed how predestined election and the inefficacy of the will are the most important factors in Bunyan's harsh Calvinist thinking, his covenantal scheme actually reveals quite a different emphasis. As we have seen so far, Bunyan's theology may have been obsessed with the opposition of grace and works in the salvation of the sinner, but it most certainly is not preoccupied with double predestination. Indeed, in his

\footnotetext{
79 Bunyan, Come, \& Welcome, p. 254; The Advocateship of Jesus Christ, pp. 130-131; Saved By Grace, p. 213. See also the importance of the doctrine of election in Bunyan's faith in A Confession of My Faith (1672), in The Works of John Bunyan, ed. by Offor, II, 598-599.
} 
endeavour to convert the sinner according to a doctrine of Law and grace, predestination (it is to be argued here) is finally not that important for Bunyan at all..$^{80}$

Whenever Bunyan does refer to predestination and election, for example, it is strictly in covenant terms. Election, though distinctly pertaining to the choosing of the saved before time began, is far from a source of anxiety or evidence of a terrifying Calvinist God for Bunyan. Rather, election and predestination in general operate for Bunyan only in the context of maintaining the sovereignty of God's will over any attempt by man to achieve salvation for himself. In this sense, predestined election is important for Bunyan only to the extent that he can assert his doctrine of grace over the works-righteousness of the Law thereby, thus maintaining unconditional salvation above all. This is made clear in a number of Bunyan's tracts. In A Confession of My Faith (1672), for instance, Bunyan discusses election specifically in terms of 'having been founded in grace, and the unchangeable will of God'. As such, the role 'the decree of election' plays in Bunyan's doctrine is primarily one of preventing the 'making of works [...] the ground or cause of the choice' of the elect by God while, at the same time, "it containeth in the bowels of it, not only the persons, but the graces that accompany their salvation.' 81

In placing his doctrine of election strictly in the context of an on-going anti-works campaign, Bunyan can, moreover, assert that the doctrines of predestination and election are but another expression of the assurance of salvation guaranteed to the believing sinner through imputed righteousness. As Jesus Christ is considered our 'publick Man, our Head, and so one in whom is concluded all the Elect of God', Bunyan states that, '[w]e then are by him already in Heaven'. 'Hence the Apostle', Bunyan concludes, 'saith, That as we are predestinate, we are called, justified, and glorified: Called, Justified, Glorified; all is done, already done, as thus considered in Christ, Rom. 8. 30.'82 Predestination for Bunyan, therefore, is simply synonymous with salvation by grace itself: it is not to be a source of

\footnotetext{
80 Very few commentators recognise that this is the case. Pieter de Vries certainly thinks so: John Bunyan On the Order of Salvation, pp. 117-119. Michael Mullett, on the other hand, concedes that the 'stress on the determinants of predestination is diminished' in Bunyan's theology but he seems confused by an emphasis on 'choice' in Bunyan's doctrine of salvation that 'ought not, according to the logic of his determinist soteriology, to exist' (John Bunyan in Context, pp. 149, 145-146: see also pp. 46-47, 160, 165-166, 185).

81 Bunyan, A Confession of My Faith, p. 598.

82 Bunyan, Of Justification by an Imputed Righteousness, p. 292.
} 
soteriological anxiety but, rather, of comfort in the knowledge that eternal life is the convert's from and for all eternity through Christ alone. For this reason Bunyan can also state, '[n]or doth this Doctrine hinder or forestall the Doctrine of Regeneration or Conversion: Nay', he says, 'it lays a Foundation for it; for by this Doctrine we gather assurance, that Christ will have his own; For if already they live in their Head, what is that but a Pledge that they shall live in their Persons with him?'83

Bunyan also has, however, a high Scriptural authority for asserting a sense of predestination as little more than a source of assurance against works-righteousness. 'The apostle [Paul]', he writes, 'when he speaks of God's saving election', which 'hangeth' upon the 'hinge [...] of justification' by faith, does so principally because he 'opposeth it to works'. In saying this, Bunyan intends to counter the accusations by the likes of the Latitudinarian Edward Fowler (as well as more contemporary commentators) who try to turn Bunyan's 'reasonable conclusions [...], drawn from the forementioned mercy of God, viz., from predestination, calling, adoption, and justification by Christ's blood, while we in ourselves are sinners', into 'the very radicals of Christianity'. For Bunyan, these are simply 'the things which Paul endeavoured to provoke the Romans, Philippians, and Colossians, to an holy conversation by.'84 Bunyan evidently feels it necessary, therefore, to clear his adherence to a doctrine of predestination of any radical mis-associations: the end of election is thus upheld by him as little more than non-legalism, assurance of salvation, and a holy life as propounded by Protestantism's greatest evangelist, Paul.

It becomes clear, then, that Bunyan's doctrine of predestination can only remain misunderstood when taken out of the context of his covenantal doctrine of grace as a whole. The simple fact prevails that, as even the briefest outline of Bunyan's theology shows, the doctrine of election is always subordinate to those of free grace and justification by faith in Bunyan's thinking. ${ }^{85}$ Indeed, for Bunyan, the most important issue for any sinner to address

\footnotetext{
83 Bunyan, Of Justification by an Imputed Righteousness, p. 292; see also Law and Grace, p. 199.

84 Bunyan, A Defence of the Doctrine of Justification, pp. 314-315, 284-285.

85 Pieter de Vries is one of the few commentators who recognises this fact when it comes to the discussion of Bunyan and predestination. For de Vries, that justification is placed before election in Bunyan's $A$ Confession of My Faith is alone enough to signal the importance of faith over and above matters of predestination. Moreover, 'Election precedes calling, but knowledge of election follows only after knowledge of calling. First we must believe in Christ before we are capable of knowing that we are amongst the elect. From faith in God's promises, which in Christ are yea and amen, the Christian proceeds to his eternal election': de Vries, John
} 
is not whether he or she is elect but, more simply, if he or she has faith that Christ died for us. Thus, in addressing the sinner who queries his salvation on the grounds that if I should not be elected, all is in vain', Bunyan merely asserts that 'before thou canst know whether thou art elected, thou must believe in Jesus Christ so really, that [...] there shall be life begotten in thy soul by the same.' 86 Because 'no man can know his election, but by his calling', and as the 'end of effectual calling' is 'faith in Jesus Christ', it is through faith alone that such matters should be approached. ${ }^{87}$ Beyond this, moreover, Bunyan is keen to ward any sinner from searching for knowledge of one's election in any case: as a divine decree, election is finally unknowable by any man and, consequently, it is fruitless to pursue it for soterial assurance. Because God's grace is simply 'unsearchable', 'and by unsearchable grace, God oft puzzles, and confounds our reason', then 'prying overmuch into Gods Secret Decrees' can only lead the sinner to 'stumble and fall, as many Hundreds in England have done, both in Ranting and Quakery, much to their own eternal overthrow'. Questioning one's election is even viewed by Bunyan as pernicious to the point of giving way to impulses of a Satanic nature: doubt of election is but a temptation of the devil himself, Bunyan states, the only answer to which is, of course, faith in the promises of the Word.88

With faith and not election, Christ and not predestination, being the soteriological focus of his theology, it becomes evident that the issues which have brought a marked horror to many doctrinal studies of Bunyan's work are largely groundless. The fact that the 'starting point for Bunyan in preaching the Gospel was not predestination, but faith in Christ', and that anyone 'who does not believe is lost and whoever believes is saved', inevitably lends our conception of Bunyan's theology a very different perspective from what we may expect of it as distinctly and narrowly Calvinist. As de Vries rightly notes, '[w]ith Bunyan it is the contrast between believers and unbelievers which is the foreground, and not that between the elect and reprobate. ${ }^{\prime 89}$ Our comprehension of predestination must finally give way, it seems,

\footnotetext{
Bunyan On the Order of Salvation, pp. 109-112 (p. 109).

86 Bunyan, Law and Grace, pp. 214-215.

${ }^{87}$ Bunyan, A Confession of My Faith, pp. 598-599.

88 Bunyan, Saved By Grace, p. 184; The Heavenly Footman, p. 156; Come, \& Welcome, pp. 352-353. For similar statements about the problems of discerning one's soterial fate, see The Strait Gate, pp. 118-119; Of Justification by an Imputed Righteousness, pp. 287-288.

89 de Vries, John Bunyan On the Order of Salvation, p. 112.
} 
to the far more humane doctrines of grace and faith. But such a re-positioning is not, of course, without its complications, particularly when it comes to the matter of faith. If we must look only to Christ and our own faith (as opposed to election) for assurance of salvation, how can we reconcile such a tempering of the predestinarian impulse with the paradoxical fact that only the elect receive the gift of faith from God in the first place? What comfort can Bunyan's doctrine bring to the uncertain sinner when faith itself is given only to the saved anyway?

The answer to this puzzle lies largely in Bunyan's dialectical attitude towards the role that human will plays in both conversion and the holy life. Whereas it is, once more, something of a commonplace to assume that for Bunyan, through his predestinarian doctrine alone, the human will is completely effaced, Bunyan himself actually discusses the will in terms quite divorced from election or reprobation. The issue of the will is, in fact, grounded not in a discourse of predestination per se for Bunyan but, rather, in the doctrine of free grace. Indeed, it is only because it is crucial for Bunyan to keep his theology free from any taint of legalism, conditionality, or works righteousness that he disabuses anyone propounding a doctrine of free will. The desires of 'Carnal Men' to go to heaven, Bunyan states in his Last Sermon (1689), are natural but 'they are not an argument to prove a Man shall go to Heaven when he dies; I am not a Free-willer, I do abhor it, yet there is not the wickedest Man, but he desires sometime or other to be saved'. Bunyan is careful not to overstep the antinomian line here, though. This is not, he asserts, to deny 'a Vertuous Course of Life to be the way to Heaven', but that 'a Man without Grace, though he have Natural Gifts, yet he shall not obtain Privilege to go to Heaven':

Though a Man without Grace may have a Will to be Saved, yet he cannot have that Will Gods way; Nature, it cannot know any thing but the things of Nature; the things of God knows no man, but by the Spirit of God; unless the Spirit of God be in you, it will leave you on this side the Gates of Heaven. ${ }^{90}$

Bunyan's abhorrence of free-will, then, must clearly be taken in the context of his approach to salvation by grace and not merely as evidence for a harsh predestinarian Calvinism. But saying this does not necessarily detract from the fact that conversion and

\footnotetext{
90 John Bunyan, Last Sermon, in The Miscellaneous Works XII, pp. 88-89. For a similar disavowal of free-will as synonymous with works-righteousness, see The Strait Gate, pp. 126-127.
} 
faith can come only, as Bunyan states above, by 'the Spirit of God'. This in itself may seem to imply something harsh: no matter how virtuous a life someone may live, unless it is done in a Gospel spirit (i.e. with faith) then damnation will follow (a stance which is, after all, the entire basis of Bunyan's doctrine of works). In case we should be overly concerned about achieving this faith, however, Bunyan nevertheless gives the human will a role to play in conversion that is often overlooked by commentators. 'I tell you the Will is all, Bunyan states in The Heavenly Footman (1698), urging the sinner to '[g]et thy Will tipt with the Heavenly Grace, and resolution against all discouragements, and then thou goest full speed for Heaven; but if thou faulter in thy Will and be not sound there [...] thou wilt fall short at last.'91 For Bunyan, then, to will one's own salvation is simply (albeit paradoxically) essential. Consequently, and because 'coming and believing is all one' for Bunyan, it is hardly surprising that he continually exhorts his reader to turn to Christ voluntarily (no matter what he says about abhorring free-will elsewhere).${ }^{92}$

The reason for such a puzzlingly voluntarist elevation of the will lies, of course, in Bunyan's pastoral sensitivity when it comes to encouraging sinners to convert: even the smallest movement towards a desire for salvation through the grace of Christ, Bunyan asserts, is evidence enough that the sinner has the electing love of God and the gift of faith itself. In other words, one's will to convert, no matter how slight, is actual evidence of God's spirit working within us in any case. This (paradoxical) stance is most clearly delineated in a text like Come, \& Welcome, to Jesus Christ (1678). Here, Bunyan can unequivocally state that those who are saved by a life in Christ are simply '[s]uch as are willing to have it' and that coming to Christ is most certainly achieved 'through the inclining of the will' as 'an act of the Mind or will'.93 At the same time, though, Bunyan is also unequivocal in stressing that the source of this inclination is not self-meritorious but wholly divine: as 'no man by his own power can come to Jesus Christ', he writes, 'we are said to be made willing to come, by the power of God; and to believe, that is, to come, through the exceeding working of his mighty power'. For this reason, the coming believer, no matter how slight his or her faith, can feel

\footnotetext{
91 Bunyan, The Heavenly Footman, p. 165.

92 Bunyan, Come, \& Welcome, p. 283.

93 Bunyan, Come, \& Welcome, pp. 372, 255.
} 
assured that their 'coming to Jesus Christ aright, is an effect of their being (of God) given to Christ before' (i.e. in the decree of election):

Now this is indeed a Singular comfort to them that are coming in truth to Christ, to think that the reason why they come, is because they were given of the Father before to him. Thus may the coming Soul reason with himself as he comes. Am I coming indeed to Jesus Christ? this coming of mine is not to be attributed to me, or my goodness, but to the grace and gift of God to Christ: God gave first my Person to him, and therefore hath now given me a heart to come to him. ${ }^{94}$

By reverting to this paradox over the will-to-salvation, Bunyan achieves a variety of doctrinal and pastoral aims. He can once more reverse the conventional assumption that election predominates over justification. Here, faith merely confirms election, election itself being invoked as but a source of comfort for the believer: any faith, any coming and believing at all, merely verifies that our salvation has been guaranteed throughout all time. Bunyan thus continually exhorts and pleads with the sinner to turn to Christ, to "come then, come and try, come tast, and see how good the Lord is to an Undeserving Worthless Sinner', principally because even the slightest desire for salvation can be soterially crucial.95 At the same time, however, Bunyan can also maintain that grace is still wholly unconditional by making coming and believing gifts of God's spirit. In answering the objection that coming to Christ in itself marks a 'Conditionality of this Promise' ('And him that cometh to Me, I will in no wise cast out'), Bunyan simply resorts to the tautology of his faith: 'the Coming in these Words mentioned, as a Condition of being Received to Life, is that which is promised, yea, concluded to be effected in us by the Promise going before.' In this way, 'Coming to Christ is implicitly required of us', but it is not to be considered a condition because 'that Grace that can make us come is positively promised us. 96

Bunyan thus kills two problematic birds with one dialectical stone: on the one hand, he can encourage the sinner to convert autonomously while simultaneously ensuring the freedom of grace from works-righteousness and one's free-will on the other. It is faith that once more becomes the sole focus of Bunyan's soteriological scheme here (at least from a human perspective). Bunyan's overwhelming doctrinal message is unequivocally 'Be not

94 Bunyan, Come, \& Welcome, pp. 329, 273.

95 Bunyan, Come, \& Welcome, p. 271.

96 Bunyan, Come, \& Welcome, p. 291-292. 
afraid Sinner, only Believe', corollary to which is an acceptance of the fact that faith itself 'hath no dependence upon our will, or power, or goodness'.97 For Bunyan, despite the apparent contradiction, it is simply outrageous to suggest that a sinner cannot come to Christ willingly: 'If thou meanest thou hast no will', he writes, 'then thou art out also, for every Christian (in his right mind) is a willing Man' (even if only because 'the day of God's Power hath made him so'). ${ }^{98}$ In this way, Bunyan's is a theology which simultaneously asserts the freeness of grace as well as the importance of the believer's will: it emphasises that few will be saved (and that the gate is indeed strait) but that all sinners should nevertheless 'run for heaven, fight for heaven, labour for heaven, wrestle for heaven, or you are like to go without.' 99

Bunyan's theology, then, cries out not to the elect but to the sinful, which is perhaps why his soteriology often seems to imply a general as opposed to a limited atonement (that Christ died for all and not just the elect), despite the fact that Bunyan is of a tradition which asserts that only a few will be saved.100 Despite the terms of election and predestination which Bunyan uses, therefore, his doctrine finally encourages all sinners to discover themselves as elect through faith in any case. There is no discouragement from Bunyan as his is a doctrine which will in no wise cast out the willing believer, no matter how sinful. For Bunyan, the reprobate is simply the person who refuses to believe, who ignores the possibility of his own salvation, while the saved sinner is he or she willing to believe and to accept that such willingness itself is a measure of God's grace. ${ }^{101}$ Any paradox over the

\footnotetext{
97 Bunyan, Come, \& Welcome, pp. 345, 274-275.

98 Bunyan, Saved by Grace, p. 227.

99 Bunyan, Strait Gate, pp. 81, 123-124.

100 For a discussion of the impact of the doctrine of limited atonement on English Calvinism see R. T. Kendall, Calvin and English Calvinism to 1649. The issue of general and limited atonement in Bunyan's theology in particular is an issue in the debate over Bunyan's authorship of Reprobation Asserted, a tract for many years believed to have been written by Bunyan. See Richard Greaves, 'The Authorship of Reprobation Asserted', Baptist Quarterly, 21 (1965), 126-31, reprinted in John Bunyan and English Nonconformity (London: Hambledon Press, 1992), pp. 185-191, and Paul Helm, 'John Bunyan and "Reprobation Asserted" ', Baptist Quarterly, 28 (1979), 87-93. Richard Greaves notes elsewhere that Bunyan 'did not devote any of his literary efforts to a discussion of the extent of the atonement', and that what he did say on the subject 'was fragmentary and slightly contradictory' in any case. On the whole, Greaves concludes, in terms of the question of atonement in general, that 'Bunyan's doctrine was quite compatible with the strict Calvinism of the period' (John Bunyan, pp. 43-44).

101 It would seem that the lack of will to believe in salvation by grace ultimately manifests itself, for Bunyan, in the sin against the Holy Ghost or the unpardonable sin, the final sign of reprobate apostasy. See Law and Grace, pp. 201-210. Bunyan's advice as to this sin is simply, 'never trouble thy Head, or Heart, about this Matter: He that cometh to Jesus Christ, cannot have sinned against the Holy Ghost' (Come, \& Welcome, pp.
} 
divine and human will is solved by the experience of faith itself: these are things that reason simply cannot encompass, Bunyan frequently tells us, for they 'must be understood spiritually, not carnally'. ${ }^{102}$

The fact that such soteriology ultimately demands something of a turn-around in the sinner's (and the reader's) metaphysical conception of the world (grace and salvation being comprehensible only in spiritual and not worldly or rational terms) perhaps represents a final stumbling block for many of Bunyan's readers today. As Dewey D. Wallace puts it, the 'experience of grace, which entailed predestination, was so powerful, it had a logic, order, and beauty of its own that was difficult to grasp by an outsider, and, apparently, by modern persons.' What seems essential in approaching the works of Bunyan is, therefore, 'an [...] empathetic reconstruction of the past' whereby 'the modern student [...] can grant to predestinarian theology a plausibility for its time and place'. ${ }^{103}$ Hence, Bunyan's theology, as a case in point, can be seen as far different from the detestable Calvinist doctrine that commentators have long perceived it to be only when it is finally considered in its own terms. It is not a theology of anxiety-inducing paradox (as Stuart Sim asserts) nor is it framed wholly in terms of the elect and reprobate paradigms which, according to John Stachniewski, plagued Bunyan's Puritan imagination to a horribly persecutory degree.

Rather, as other (more specifically theological) commentators have indicated, the role predestination plays in the theology of many 'Calvinist' seventeenth century divines, and for Bunyan in particular, is one of comfort and assurance: rooted in grace and not in any 'fixation upon the attributes of absolute divine sovereignty' (and its 'implacable consequences'), predestination can be said to have married the reliability of God's will to a life of piety, reassuring the believer 'that the awesome divine power that ruled over all rescued the sick soul from its pain'. From such a perspective 'the claim to free will would have taken away all comfort by driving persons to despair of a salvation they were too weak to work out for themselves.' It would be more accurate, therefore, to consider predestination,

353-354). For a discussion of this sin, see Baird Tipson, 'A Dark Side of Seventeenth-Century English Protestantism: The Sin Against the Holy Spirit', Harvard Theological Review, 77 (1984), 301-30.

102 Bunyan, Come, \& Welcome, p. 254.

103 Wallace, Puritans and Predestination, pp. 194, 191. 
the effacement of the will, and innate depravity not as abhorrent and inhumane perceptions of the world but as 'sources of comfort and assurance' for seventeenth century preachers and their congregations alike,

predestination being [...] a "sweet" and "consoling" doctrine for the saints of God, an assurance that their salvation was built upon a rock that could not fail and that the elect ought to be both comforted and encouraged to good works by the recognition that their salvation was indefectible. ${ }^{104}$

It must be remembered, however, that it is not just the modern commentator who has found Bunyan's doctrines of grace, predestination, and justification by faith problematic. Of Bunyan's contemporaries, neither Quakers (such as Edward Burrough) nor Latitudinarians (such as Edward Fowler) considered anything in Bunyan's theology that could provide comfort or assurance for the sinner. While the Quakers attacked Bunyan for Papistically directing the sinner to what they considered a merely external Christ (as opposed to the Light dwelling within), Latitudinarians, within their own enlightened rational moralism, considered Bunyan's doctrines nothing less than uncivil and unbridled 'Enthusiasm' at a time when Nonconformity clearly implied sedition. ${ }^{105}$ Moreover, Quakers and Latitudinarians, though at opposite ends of the theological spectrum, could join together in disparaging Bunyan's antinomian attitude to the Law: both considered Bunyan's a grossly licentious doctrine and, in turn, were countered by Bunyan who then accused them both of being damningly legalistic. 106

It is perhaps not surprising, then, that throughout his life and works Bunyan is to be found vigorously defending his faith against the slanders that members of other

\footnotetext{
104 Wallace, Puritans and Predestinatiom pp. 194-195, 6-11. For other accounts of the reassurance that typically 'abhorrent' Calvinist doctrines (such as double predestination) brought to the seventeenth century believer, see von Rohr, The Covenant of Grace in Puritan Thought, pp. 12-13, 80, 114-115, 123; John S. Coolidge, The Pauline Renaissance in England, pp. 115-124; Charles Lloyd Cohen, God's Caress, pp. 115-117, 159-161, 221; Perry Miller, New England Mind, pp. 380-381, 385-386; Pieter de Vries, John Bunyan On the Order of Salvation, pp. 118-119, 199; Greaves, John Bunyan, p. 97.

105 For an understanding of Dissent and Nonconformity in a political context, see Richard Greaves, John Bunyan and English Nonconformity, especially 'The Sword and the Spirit: John Bunyan and the Stuart State', pp. 101-126. For an example of an extreme reactionary response to Nonconformity, see Samuel Parker, $A$ Discourse of Ecclesiastical Politie (London: 1670). Here Parker refers to the adherents of 'Schismatical Nonconformity' as the 'worst and most dangerous Enemies' to the 'Security of Government' who, as 'the rudest and most barbarous people in the world', threaten to 'blow up the very foundations of Government' ('Preface', pp. . xii-xxii).

106 See Bunyan's tracts against Edward Burrough's The True Faith of the Gospel of Peace (London: 1656) and Truth (the Strongest of all) (London: 1657), Some Gospel Truths Opened (1656) and A Vindication of Gospel Truths Opened (1657), in The Works of John Bunyan, ed. by Offor, II. In response to the Bedfordshire Latitudinarian Edward Fowler's. The Design of Christianity (London: 1671), Bunyan wrote A Defence of the Doctrine of Justification by Faith (1672), also in The Works of John Bunyan, ed. by Offor, II.
} 
denominations (not unlike recent commentators) level against it. Even less surprising, therefore, is the fact that in the face of such opposition Bunyan's need to promote grace as comforting and assuring has a distinct effect upon the very textuality of his writing, especially when urging the sinner to contemplate his or her own salvation. When Bunyan discusses grace, for instance, he often does so in terms which clearly attempt to invoke in the reader a sense of revolutionary wonder at the promise of man's forgiveness by God. Hence, a predominant image for God's grace in Bunyan's writings is that of a wondrous inversion of worldly, socio-political hierarchies, with God as a spiritual King tendering unheard of mercy to his undeserving or rebellious subjects. Bunyan thus encourages the reader to marvel at the incredible topsy-turviness of grace from a God who, unlike worldly monarchs (or the austere Calvinist God with which Bunyan is most often associated), actually begs his subjects to accept salvation from him : 'O grace!', Bunyan exclaims,

O amazing grace! To see a Prince entreat a Beggar to receive an Alms, would be a strange sight; to see a King entreat the Traitor to accept of Mercy, would be a stranger sight than that; but to see God entreat a sinner to hear Christ say, $I$ stand at the door and Knock, with an heart-ful, and an heaven-full of grace, to bestow upon him that opens; this is such a sight that dazles the eyes of Angels. ${ }^{107}$

Here, Bunyan effectively manages to convey both the voluntarism implicit in his doctrine of grace as well as the willingness of God to accept the sinner within a parabolic frame wholly inconceivable in earthly terms - a monarch begging a rebel to accept mercy. It would be tempting, perhaps, to read into such an analogy a conscious manipulation by Bunyan of the politico-spiritual doublespeak the language of salvation naturally offers: through such language Bunyan could, it seems, covertly criticise Restoration political structures by implying, for example, that the only authority worth heeding is that of the Nonconformist God's grace. But while Bunyan frequently describes grace through the language of poverty and sovereignty, through imagery that operates on a variety of semantic and cultural planes with little to separate the political from the spiritual, it is nevertheless faithful and not social revolution that Bunyan is always intent upon inspiring in his reader. ${ }^{108}$

107 Bunyan, Saved by Grace, p. 202. For similar passages see Law and Grace, pp. 31-32, 37-39; Israel's Hope Encouraged (1692), in The Miscellaneous Works XIII, pp. 7-8.

108 Much has been written about the potential radicalism of Bunyan's political stance, especially in the light of millenarian tracts such as Of Antichrist and his Ruine (1692), by Christopher Hill (A Turbulent, Seditious, and Factious People, pp. 310-334), and William York Tindall, John Bunyan Mechanick Preacher (New York: 
This is not, of course, to say that Bunyan was unaware of or uninterested in the politics of his faith and its language, or that he must have been insensitive to the radical implications his spiritualised phraseology holds at times. ${ }^{109}$ As his imprisonment shows, and as shall be explored throughout this thesis, Bunyan is deeply concerned with the language of grace and the issue of expressing his Nonconformist faith in the context of the Restoration. But, as the above example illustrates with its final emphasis upon a grace that would dazzle even angels, Bunyan is always keen to point any metaphor or analogy explicitly towards the spiritual and away from the political when discussing salvation. When Bunyan describes grace as setting 'open the prison doors' and letting 'the prisoners go free', liberating man from 'misery and thraldom', it is in no sense a politicised experience Bunyan is advocating. Rather, he is simply discussing grace as offering the only possible liberty from a range of spiritually perilous factors: the chains of Satan, the guilt of sin, the bondage of the Law, and the eternal and damning justice of God. ${ }^{110}$

Behind Bunyan's doctrine of grace, then, lies a language that, despite its surface radicalism, is centred in a desire to assure and comfort the burdened sinner and which has its roots firmly planted in the promises of Scripture. Crucial to the way Bunyan depicts grace, therefore, is a breadth of Biblical references not only to liberation but to offers of rest, clothing, and comfort for the spiritually burdened, lost, and homeless. ${ }^{111}$ Bunyan thus presents the promise of his New Covenant with a constant iteration of it providing 'rest for your soul' and placing the garments of Christ's 'righteousness' upon you, with the sinner

Columbia University Press, 1934; repr. 1964). However, the radical associations of Bunyan's politics have been qualified in recent years: Bunyan's political position appears to have been largely pacifist and conservative. See, for example, Richard Greaves, 'The Sword and the Spirit: Bunyan and the Stuart State', 'Amid The Holy War: Bunyan and the Ethic of Suffering', and 'The State of Historical Scholarship', in John Bunyan and English Nonconformity, pp. 101-126, 169-183, and 37-50. See also Aileen M. Ross, 'Paradise Regained: The Development of John Bunyan's Millenarianism', in Bunyan in England and Abroad, ed. by M. van Os and G. J. Schutte (Amsterdam: V. U. University Press, 1990), pp. 73-89, and 'Millenarianism in the Works of John Bunyan' (unpublished doctoral thesis, University of Alberta, 1986). For a good example of Bunyan's wish to preserve social hierarchies in general see Christian Behaviour, pp. 10, 23, 36, 40-41.

109 A good example is Bunyan's frequent exhortations to his reader to 'Possess the land' (The Heavenly Footman, pp. 140-141; Grace Abounding, p. 4). Of course, this is a spiritual land Bunyan is writing of, with reference to Judges 18.9 it seems, but, nevertheless, the political overtones cannot be mistaken.

110 Bunyan, Saved by Grace, pp. 169, 201; Law and Grace, p. 101. Of course, this is traditional Christian imagery, especially adopted by Luther, for example: see, A Commentarie of Master Doctor Martin Luther Upon the Epistle of S. Paul to the Galathians (London: 1644), Fols $167^{\circ}-168$.

111 Highlighting these metaphors for grace in Bunyan's writings offers an alternative to Hill's which merely emphasises the 'commercial metaphors' of Bunyan's covenant theology: see A Turbulent, Seditious, and Factious People, pp. 180-182. 
being 'served' by the 'comforting' grace of God. It is an unambiguously 'soul-refreshing and sin-pardoning' doctrine Bunyan offers the sinner. ${ }^{112}$ It is precisely along these lines, moreover, that Bunyan also offers grace as a most effective 'remedy' against the spiritual sickness induced by sin, guilt, and works-righteousness. ${ }^{113}$ The 'sweet Doctrine of the grace of God, by which alone Conscience getteth health and Cure' is indeed, according to Bunyan, a 'Medicine' for the sinner's 'Disease': 'STUDY therefore this Doctrine', Bunyan exhorts, as 'the first step to the Cure of a wounded Conscience is to know the grace of God'.114

In taking Bunyan's theology as one centred in a comfortable doctrine we should become sensitive, however, not only to Bunyan's metaphors for grace but, more importantly, how his doctrinal narratives operate as a whole. By understanding Bunyan's doctrine of grace as centred in comfort and assurance for the sinner, we should indeed be encouraged to approach his works from a more accommodating (and less horrified) perspective. While this thesis offers readings of Bunyan's major narrative works in the light of his doctrine of Law, grace, and faith (as opposed to election, reprobation, and damnation), it would be useful to begin such a re-reading of Bunyan by interrogating a text long upheld as presenting the clearest evidence yet of his abhorrent predestinarian Calvinist theology - A Mapp Shewing the Order and Causes of Salvation and Damnation (1692). Here, with the stark stages of salvation and damnation figured forth as firmly rooted in the decrees of election and reprobation (and ending with unambiguous representations of heavenly glory and a monstrous hell), there may seem little depicted in this Mapp that could offer any kind of assurance at all to anyone attempting to read it as a document in humane theology. Indeed, it would seem that here the most abominable and inhumane aspects of Bunyan's soteriology are, quite literally, presented to the reader in black and white (these being, of course, the lines on the Mapp that the predestinated reprobate and elect must follow in their journey from this world to the next).

\footnotetext{
112 Bunyan, Law and Grace, pp. 194, 224, 39.

113 Bunyan, Law and Grace, p. 13.

114 Bunyan, Saved by Grace, pp. 218-219. Clearly, Bunyan's use of metaphors of comfort and assurance has a great deal in common with (and is presumably influenced by) Luther's writing: see $A$ Commentarie [...] Upon Galathians, Fols $112^{\circ}-113,140,226^{\circ}, 240$. For a discussion of the broader context and implications of Bunyan's use of medical metaphors, see the Appendix to this thesis: 'Bunyan and Medical Discourse in the Restoration Context'.
} 
As a consequence, it is hardly surprising that commentators have got little to say about this text. Maurice Hussey, for instance, has been as generous as possible in trying to generate scholarly interest in Bunyan's Mapp but even he can barely disguise an antipathy to what it finally signifies: 'with it', he writes, 'one understands how the terrifying doctrines of Calvinism made their initial impact upon the people.' Bunyan's Mapp should thus be seen as little more than a form of theological 'popularisation' which 'tries to present faith in palatable form without casting a sentimental smear over it or in any way softening the impact.' Without such reserve, however, John Stachniewski finds in the Mapp nothing but the horrors of a Calvinist world view which, like William Perkins's soteriological 'Table' before it, merely 'exposes the absurdity of the stern warnings preachers issued against probing "the secret and hidden counsell of God", which began the chain of cause and effect people were taught to examine.'115 Bunyan's Mapp and the theology it represents is thus read by Stachniewski as inducing 'anguish' in people whom it encouraged 'to consider whether they were objects of God's hatred'. Moreover, this distress is evidently as much textual and interpretive as it is soteriological: the 'apparent clarification' of one's eternal destiny offered to the reader by the likes of Perkins's 'Table' and Bunyan's Mapp, Stachniewski asserts, simply 'masks terrifying ambiguities' inherent in all Calvinist thinking. ${ }^{116}$

Of course, it is easy to understand why Bunyan's Mapp has been read as a diagram of anxiety. As Gordon Campbell has pointed out, the Mapp has as its source not only in the great English Calvinist William Perkins's 'Table' but, it would seem, in a long tradition of both Calvinist and Ramist diagrammatic presentations of syllogistic reasoning about salvation and damnation reaching as far back as Beza. 117 The Calvinist (and strictly predestinarian) genealogy of Bunyan's Mapp thus seems clear. At the same time, moreover,

115 Maurice Hussey, 'Bunyan's Map', Baptist Quarterly, 14 (1951-52), 227-231 (p. 231); John Stachniewski, Persecutory Imagination, p. 90 . For another brief discussion of the Mapp in the context of other soteriological tables and diagrams see Gordon Campbell, 'The Source of Bunyan's Mapp of Salvation', Journal of the Warburg and Courtald Institutes, 44 (1981), 240-241.

116 Stachniewski, Persecutory Imagination, pp. 90-91.

117 Both Beza's and Perkins's 'Tables' are reproduced in Richard A. Muller, 'Perkins' A Golden Chaine: Predestinarian System or Schematized Ordo Salutis?’, Sixteenth Century Journal, 9 (1978), 69-81. Perkins's 'Table' is also reprinted in both Stachniewski's Persecutory Imagination, and in The Works of Wiliam Perkins, intro. and ed. by Ian Breward (Abingdon: Sutton Courtenay Press, 1970). For a discussion of the production and mnemonic uses of Protestant 'Godly Tables', see also Tessa Watt, Cheap Print and Popular Piety, 1550 1640 (Cambridge: Cambridge University Press, 1991; repr. 1994), pp. 223-253. 
the Mapp itself seems to harbour certain anxiety-ridden features. In the verse address for the reprobate line, for example, Bunyan somewhat tautologically writes that the damned who 'Oppose [...] most willingly' the promise of 'Eternal Life' do so largely because 'God doth leave' them 'to live and die'. The final words on the reprobate's fate (that they are damned because 'Grace thou didst slight') thus indicate a willingness to damnation that is typically paradoxical of the non-elect: has the reprobate had any choice in the matter? Are the damned finally responsible for their willingness to $\sin ?^{118}$

Equally ambiguous, however, seem the frightening similarities between certain reprobate and elect stages. Following the Calvinist (even if it is not finally Calvin's) assertion of temporary faith in the reprobate, it seems that even those destined to be damned can have 'tasted the good word of God' at some point through a 'Legall conviction for Sin [...] which worketh some desires after life [...] to whom God in mercy gives some tasts of Life'. ${ }^{119}$ If both the elect and reprobate can have a taste of 'Life', as well as the kind of legal conviction essential to true conversion, does this not lead to that stereotypically Calvinist state of anxiety whereby one cries out, 'How can I tell if I am saved?' If this is the case, then, doesn't this Mapp merely generate uncertainty in its reader about discovering oneself to be elect or reprobate? In what sense is this 'comforting'?

Naturally, by reading this text in this way one could hardly avoid the conclusion that Bunyan's doctrine, as it is presented in the Mapp at least, is indeed difficult to digest. But such a reading in itself, as is shown through any proper understanding of Bunyan's theology, would be inadequate in any case. While it is easy to draw conclusions about the doctrinal nature of the text from what appear to be its paradoxes, ambiguities, and hellish illustrations, reading the Mapp in its entirety, however, reveals a quite different theological emphasis than the distress over election and reprobation that is often placed upon it. For example, the

\footnotetext{
118 John Bunyan, A Mapp Shewing the Order \& Causes of Salvation and Damnation (1692), in The Miscellaneous Works XII, pp. 420-423.

119 For an interesting discussion and debate on Calvin's view of temporary faith again see Kendall, Calvin and English Calvinism to 1649. Kendall's assertions about Calvin's teachings on faith and on the atonement have not been without controversy, though. For continuations of discussions of such matters see M. Charles Bell, 'Calvin and the Extent of the Atonement', Evangelical Quarterly, 55 (1983), 115-123; Roger Nicole, 'John Calvin's View of the Extent of the Atonement', Westminster Theological Journal, 47 (1985), 197-225; Stephen Thorson, 'Tensions in Calvin's View of Faith: Unexamined Assumptions in R. T. Kendall's Calvin and English Calvinism to 1649', Joumal of the Evangelical Theological Society, 37 (1994), 413-424.
} 
decrees of election and reprobation themselves are, naturally enough for Bunyan, presented in the Mapp as having only an indirect relation to any sinner's soterial status. They are thus the first stage in the 'order' of salvation and damnation but they are also most definitely beneath the covenants of grace and of works, both pictorially and doctrinally. In the Mapp, therefore (as in Bunyan's theology as a whole), it is grace and works and not election and reprobation that the sinner must examine himself as (again literally in this case) being 'under'.

Because it is Bunyan's covenant theology which dominates this Mapp and not any Calvinist obsession with predestination, the document consequently unfolds in terms which describe the elect and reprobate not in the abstract terms of foreordination and free will but in terms, as ever, of belief and holy living. Bunyan's Mapp, then, is no diagram of Ramian dichotomous thinking but of his double covenant theology which focuses upon conversion, faith, and sanctification as most important. Each circle does not lead to another branch of a syllogistic reasoning or logical deduction, in fact, but to an assertion of the natural stages in the believer's and the unbeliever's spiritual life. Consequently, one need only read the circles in sequence to have a double narrative in which the faithful have the 'righteousness of God' revealed to them 'from Faith to Faith', while the impenitent who will 'in no wise believe' (and whose sins are 'linked together' as 'One doth follow another') lead themselves along a path to eternal damnation.

The ways of mercy and justice are thus centred in the most practical aspects of spiritual thinking and living here: this is a Mapp which asks its reader to 'look/Into thy Heart as in a Book' not in relation to predestined decrees but in terms of faith, a willingness to believe, and a finding in oneself effectual calling with a readiness to maintain grace through sanctification. For Bunyan, proof of election in this Mapp is to be found nowhere other than in one's faith and 'true love to Holinesse'. At the same time, therefore, when reading this Mapp one is not being encouraged to despair over being reprobate either. In fact, it would seem that the reader is encouraged to look to the reprobate line not to find him- or herself damned but to find caution in its warnings about impenitency, iniquity, and an 'Unbeliefe' that can become for the reprobate (if it is not stemmed early on) both an 'Atheisme' and 'a 
Spirit of Persecution'. For any reader concerned enough to seek his spiritual identity in this Mapp, then, it is unlikely that he will read in himself the final stages of reprobation in any case. Indeed, as 'Apostasy' is a most telling sign of reprobation, any earnest interest in salvation can in itself be understood as a marker of 'the Holy Ghost and the Operations of it' available only to the elect. In other words, any serious soterial interest from the reader in the Mapp can be taken as signalling some hope of conversion in grace after all: the reader is thus never encouraged to despair in reading Bunyan's Mapp but always to find him- or herself as potentially elect through faith if he or she is willing.

Bunyan's Mapp should be read not in terms of predestination, therefore, but in terms of a delineation of an ordo salutis within which the reader is encouraged to find (or place) himself and subsequently follow in order to gain eternal life. In this sense, Bunyan's Mapp has more in common with Perkins's Calvinist 'Table' than commentators such as Stachniewski seem to realise. While Stachniewski regards Perkins's A Golden Chaine (in which his 'A Survey, or Table declaring the order of the causes of Salvation and Damnation' can be found) as fundamentally terrorising in its effect upon its reader, it can also be argued that quite a different pastoral effect is actually being aimed at by Perkins here. Richard A. Muller, for example, refuses to read the 'Table' beyond the context of Perkins's doctrinal thinking as a whole, and, in particular, beyond the text of The Golden Chaine itself which, in fact, does not dwell on reprobation at all. In fact, in The Golden Chaine, Muller asserts, Perkins is interested in encouraging the reader to consider only the secondary causes of salvation and damnation, such as sinfulness and faith revealed through the medium of, say, preaching the Word. Because of this, Perkins's The Golden Chaine, like Bunyan's Mapp, has at its centre not any encouragement to seek knowledge of election but a view of all men 'as possibly elect', a claim which naturally 'demands response' from the reader and which, in its Christological emphasis, 'accounts for the broad exposition of the path to salvation and the almost tangential treatment of reprobation in Perkins' treatise despite the perfect parallelism of the diagram.' 120 Bunyan's primary source (potentially at least) for the Mapp thus has at its heart not harsh Calvinist dogma but an aim to assure the sinner of salvation

${ }^{120}$ Muller, 'Perkins' A Golden Chaine', p. 80. 
through encouragement towards faith and sanctification, whereby anyone fearful of reprobation 'should seek the aid of God's word' that 'he might feel the power of Christ in him' in any case. In this way, the 'dread syllogismus practicus of Beza' (culminating in the question of 'how does one know one is saved?') is avoided by both Perkins and Bunyan alike. ${ }^{121}$ The central tenet of Bunyan's Mapp can thus be said to be far from Calvinistically anxiety-inducing: it does not encourage an investigation into knowing whether one is saved but, more usefully, how one can be saved.

This does not mean, though, that the reader's role in interrogating the Mapp can be a complacent one, either doctrinally or critically. Far from it, in fact. Because the Mapp encourages sinners to discover themselves as 'possibly elect', to find the saving grace of faith within him, the text as a whole operates in terms of an emphatic self-reflexiveness the focus of which is always the reader him- or herself. In exhorting the reader of the Mapp to 'look/Into thy Heart, as in a Book' in order to see if he or she is following the path of faith or unbelief, Bunyan is thus establishing an interactive relationship between text and reader of crucial significance in terms of how we approach his narrative practice as a whole. With the Mapp itself as but an introductory guide to the more important reading of the heart, it is clearly the reader who is to read himself when faced with such a document. As any reader of The Pilgrim's Progress will recognise, moreover, such a turnaround in the prioritising of the reader's focus from the page to the self also has profound effects upon other aspects of our reading, especially in terms of the stylistic nature of the text in question and how we are to respond to it.

In the case of the Mapp, for instance, even the most cursory glance at its overall design would not fail to draw the reader's attention to the textual complexity of the work. While the fundamental theological issues of the reader's salvation or damnation are addressed in the elaborately enclosed verses marking the elect and reprobate paths, the rest of the text is obviously designed to prevent any consideration other than one's faith, sinful life, and potential salvation from entering the mind. Because the doctrinal aim of this text is to

\footnotetext{
121 Muller, 'Perkins' A Golden Chaine', p. 80. See, for example, chapters LII-LVII (on reprobation) and chapter LVIII, 'Of the application of predestination', in Perkins's A Golden Chaine (London: 1591, an edited version of which is included in The Works of Wiliam Perkins, ed. by Breward).
} 
encourage an examination of the reader's heart as if it were a book, stylistically the text itself mirrors such spiritual self-consciousness by inculcating a pre-eminent self-awareness in the reader of the importance of reading in itself. Indeed, if the reader is to read his own heart, it is the purpose of the Mapp to provide a lesson in reading from the outset. It thus becomes impossible to read this text with anything like carelessness or ease, therefore, not simply because it is soteriological in topic but because it continually draws the reader's attention to the very fact that reading Bunyan's doctrine of salvation by grace is a most serious and difficult process in the first place. Hence, this Mapp conspicuously raises a series of issues about interpretation from the very start. Where does one begin reading Bunyan's Mapp, for example? At the triangle embracing the inverted trinity of the eternal Godhead, or the boxed verses?122 How should one read the text? From left to right, comparing each stage of the 'Line of Grace' with the 'Line of Justice' in turn, or downwards dealing with both of them separately?

When one has finally decided upon one's starting point, however, the complexity does not abate. The author's elect-side note, for example, suggests that reading this Mapp will be simple: in order to 'understand what you read' one should simply 'Follow the Line by the figures over each Circle'. Reading-by-numbers, though, turns out not to be so straightforward. Each inscription in the circles, for example, should be read in sequence to form a description of the order of the stages leading the sinner to heaven or to hell. We are thus given a comprehensively dual narrative in the Mapp as to the paths of the saved and the damned which would seem quite undeviating. However, as if in order to prevent the reader from merely rushing through the spiritual story of each line, Bunyan inserts a variety of interruptive and distracting devices. Each circle not only bears a qualifying Biblical reference for the reader to take note of but a boxed tag containing a brief elucidation of an important doctrinal point. Before the reader can complete the sequence of the circles, then, he or she must take into account the theological point that comes with it: with the eye continually being pulled away from the narrative schematisation and towards its doctrinal significance, Bunyan's simultaneous text-with-running-commentary encourages nothing less

122 Gordon Campbell comments on the doctrinal significance of Bunyan's unorthodox representation of the trinity in 'The Source of Bunyan's Mapp', p. 241, and in 'Fishing in Other Men's Waters', pp. 141, 145-146. 
than a concerted meditation by the reader on the meaning of each stage of salvation or damnation, a strategy Bunyan similarly adopts (as we shall see) through the marginalia of a narrative like The Pilgrim's Progress.

Beyond the attached boxes, moreover, lie other layers of comment conducive to a doctrinal reading of one's own heart. The often rhyming outer marginalia, for instance, function as another authorial guide to each stage of the Mapp. Unlike the boxed tags, though, these seem to be loosely free-floating textual appendages which can be read alongside specific stages in a more casual (and yet more distracting) manner. Indeed, it is difficult to know when to read these comments at all: after or before each circle, following or during one's reading of the sequences as a whole? And beyond such inscriptions there are the many motifs displayed upon the Mapp's scrolls which, though often being narrative in function or simply quotations from Scripture, equally demand the reader's attention amidst all the other textual voices. For this reason, even the most doctrinally informed reader would find Bunyan's Mapp arduous reading and not because of its subject matter either: this is a text that his hard to read not because it is dealing with the tough Calvinist issues of reprobation and election but because it places so many demands upon its reader from the outset. Textually, reading the Mapp is made deliberately strenuous because it continually pulls the reader away from the ordo salutis as just a series of statements about salvation and damnation and forces the reader to pay attention to the doctrinal significance behind that narrative. Soteriologically, moreover, it seeks the most demanding response of all from its reader - the searching of one's heart in terms of Bunyan's doctrine of Law, grace, and faith which will culminate in conversion.

The implications of the textual method evident in Bunyan's Mapp, as an example in miniature of his narrative practice in general, are (as the rest of this thesis will show) far reaching. On the most practical level, the Mapp has been constructed to prevent any reader from reading it too quickly. Because it pulls the reader so effectively into the textual complexity of a page divided multiplicitously into a series of authorial layers, voices, and Biblical texts, it is impossible to read this chart comprehensively without a great deal of careful (if not laborious) study. As such, the Mapp seems indicative of the interpretive 
demand made upon the reader by all of Bunyan's narrative works. At the same time, though, there is clearly more at stake here than just a need for painstaking attention to detail. The fact that it is the reader's soterial status that is the ultimate focus of the Mapp (again as in all Bunyan's writings) points to the fact that interpreting Bunyan's works involves a certain amount of revision in the reader's approach to reading in general. On the one hand, this is, of course, quite obvious from a doctrinal perspective: Bunyan's texts are intent upon inspiring the reader to convert into grace and encourage him towards salvation. Indeed, reading for Bunyan has a distinct spiritual goal: faith. On the other hand, however, it is precisely because Bunyan's writings have this goal in the first place that the reader needs to adopt a very different reading practice altogether if they are finally to be understood in any way properly or comprehensively at all.

It is to encourage a self-consciousness about reading, for instance, that Bunyan's Mapp initially presents itself to the reader as innately unconventional: this chart simply refuses to be read just like any another text as one cannot read it from left to right or even from start to finish. At the same time, because Bunyan's Mapp has as its focus not a reading of itself but a reading of the self, because it is to be read only as a means to the spiritual ends of conviction of sin and faith in salvation, it presents itself as an eminently self-subverting (or at least self-effacing) text. This Mapp, in a way that Stanley Fish would perhaps appreciate, exists not to be read for its own sake but to help the reader read the text of his or her own life doctrinally and faith-fully. So much is perhaps obvious. But in recognising such features it also becomes clear that in its unconventional structure and intention, the Mapp requires another unusual type of reading - one which, in asking the reader to revise his or her own soterial position in relation to faith, demands an overturning of the conventional (even rational) apparatus the reader might usually bring to a text in the first place.

For example, unlike the soteriological charts of Beza and Perkins, which present themselves distinctly as 'Tables', Bunyan's is offered most definitely as a Mapp. This title is intriguing, however, as the term both implies and encourages a great deal of assumptions and expectations about the work as a 'map' which the text itself, in the subversive way characteristic of all Bunyan's narrative works (as we shall see), proceeds to destroy. For 
instance, although there are many types of map and, equally, many ways to map various kinds of information, all of them can, nevertheless, be said to share certain features and suppositions. A map can be thought of as summarising 'salient points' of, say, a landscape 'in a spatial format', whereby it offers a 'representation on a flat surface' of that landscape 'to show physical, or political, or other features, each point on the diagram corresponding to a geographical position according to a definite scale or projection.' A map will consequently embody "certain degrees of generalisation and exaggeration, of selective emphasis and stylised representation' in its endeavour to communicate information. ${ }^{123}$ In these terms, Bunyan's Mapp would, it seem, at least conform to such broad definitions in its presentation of an albeit doctrinal landscape.

But when one considers more broadly what maps do and what they assume, Bunyan's Mapp takes on a far more radical aspect. For instance, in presenting information of any kind, maps function upon a primarily epistemological level: they provide an 'encoded real-world perception', a model of the 'real world' of physical (and most often geographical or topographical) features the adequacy or accuracy of which its reader can test via practical experience of that world. Maps can be said to be chiefly concerned with knowledge, therefore, their significance lying in the fact that 'people make them to tell other people about the places or space they have experienced'. As such, a map seems to offer a framework for any human being 'to communicate to his fellows something of the nature of the real world', no matter how flawed that representation may be. ${ }^{124}$ Bunyan's Mapp, however, does something quite different. Most obviously, it is essentially non-geographical: this is a map that charts and communicates nothing 'worldly' at all (a pun which the reader is being asked to recognise all along) but a spiritual experience that begins beyond time and place in the

123 W. G. Moore, The Penguin Dictionary of Geography, 6th edn (Harmondsworth: Penguin, 1981), p. 140; John Small and Michael Witherick, A Modern Dictionary of Geography, 3rd edn (London: Edward Arnold, 1995), p. 149; Gary S. Dunbar, Modern Geography: An Encyclopedic Survey (Chicago and London: St James Press, 1991), p. 26.

124 The Dictionary of Human Geography, ed. by R. J. Johnston, Derek Gregory, and David M. Smith, 3rd edn (Oxford: Blackwell, 1994), p. 355; J. B. Harley, 'The Map and the Development of the History of Cartography', in The History of Cartography, Volume One: Cartography in Prehistoric, Ancient, and Mediaeval Europe and the Mediterranean, ed. by J. B. Harley and David Woodward (Chicago and London: University of Chicago Press, 1987), pp. 1-42 (p. 2); C. Board, 'Maps as Models', in Models in Geography, ed. by Richard J. Chorley and Peter Haggett (London: Methuen, 1967), pp. 671-725 (pp. 671-672). 
decrees of election and reprobation and which passes through conventional temporality and spatiality unto the end of time itself.

It thus becomes clear that any assumptions and expectations about what maps both are and do are confronted (and have to be discarded) before one can read this text properly. Bunyan's Mapp deals in no earthly epistemology: it presents no knowledge nor communicates any information about the 'real world' other than that of a spiritual realm which transcends time and space. Hence, it is deliberately intent upon upsetting any rational suppositions about mapping (and reading maps) from the outset. Indeed, it offers a progression of spiritual events and 'places' in a spatial form that correlates to nothing spatial or mappable at all. The Mapp only deals with the distinctly unworldly matters of salvation, faith, and a most definite spiritual experience which correlates to another world entirely - that of, as the Mapp denotes at one point, 'things unseen'.

At the same time, though, Bunyan's Mapp nevertheless initially presents itself (and quite deceptively too) as providing the kind of totalising knowledge we may expect of a map but which, upon reading, it finally denies. Unlike the topographical features on a conventional map, for instance, the circles on Bunyan's Mapp merely masquerade as being in any kind of general spatial relationship to each other. Far from being landmarks whereby one can assert one's position according to that of the others given on a map, the circles on Bunyan's chart are not 'places' at all but stages to be assessed not spatially but in narrative and temporal sequence alone. In other words, Bunyan's Mapp is not a map at all but a cleverly presented instructive description of how to proceed (and how not to proceed) in one's spiritual wayfaring. Unlike a conventional map, Bunyan's does not tell one where one is in this journey, either spiritually or spatially, but only where to begin and how to go on. Hence, as Christian discovers in The Pilgrim's Progress (of which Bunyan's Mapp is clearly a visualised version), such a journey is a distinctly step-by-step process plagued by what may seem to be wrong turnings and in which one has very little knowledge of where one is or what comes next. In this sense, Bunyan's Mapp most definitely points the way to heaven and hell, but for the reader who takes the Mapp and reads it non-epistemologically, it presents something other than a geographical map entirely: it is a periplus, in fact, 'that projects the 
stages of a journey as they succeed each other for the traveller [...] as opposed to a map that gives an image from outside and above the terrain of every point on it simultaneously.' As a periplus for spiritual life, then, Bunyan's Mapp is crucially different from other maps as it 'forms a temporal narrative rather than a spatial image' of a world that is empirically unverifiable. ${ }^{125}$

Any reader who tries to read Bunyan's Mapp as a map is, therefore, to be purposefully discomfited from the outset. The Mapp turns out to be a temporal (and an atemporal) dual narrative which replaces the usual epistemological basis of representing the spatial world with a mapping of a spiritual and unseen reality to be navigated not via knowledge, reason, and experience of this world but through a faith and a perseverance in an other-worldly grace. Bunyan's Mapp, then, simply provides a series of stages for the sinful believer to recognise during his or her progress to heaven with no promise of any final or totalising knowledge of election or reprobation. The textual sophistry of Bunyan's Mapp, therefore, belies a series of spiritual imperatives for the reader. On the one hand, reading Bunyan's Mapp involves a reading of oneself and the journey one is making in the light of grace and faith: it is a strictly doctrinal application that Bunyan is urging his reader to indulge in. On the other hand, Bunyan's Mapp also discourages the reader against his or her usual epistemological (or certainly this-worldly) approach to reading as a whole: it teaches about a recognition of something other than the carnal and the rational. Indeed, this is signalled most by the inherent word-play lying behind Bunyan's presentation of his Mapp. Above all, we are required to recognise that Bunyan's Mapp is not a 'faithful' representation of the 'real world' at all (as maps usually attempt to be) but a description of a reality that can be accepted as accurate only in terms of a different kind of 'faithfulness' entirely. ${ }^{126}$

Bunyan's Mapp turns out not to be 'a rigid diagram' of a condensed Calvinist soteriology, then, but (as are all of Bunyan's narrative works) a most sophisticated text which, operating upon the reader in a variety of textual and doctrinal ways, seeks to teach the reader about

125 This definition of the 'periplus' was brought to my attention via Steven Connor's Postmodernist Culture: An Introduction to Theories of the Contemporary (Oxford: Blackwell, 1989; repr. 1991), pp. 119, 227-228.

126 On the fundamental importance of 'faithfulness' in map making and reading see C. Board, 'Maps as Models', pp 706-711. 
reading in terms of a distinct other-worldliness. ${ }^{127}$ Indeed, what the Mapp illustrates most effectively (and which this thesis will address as a central concern in all of Bunyan's narrative works) is that reading for Bunyan, whether it is of his Mapp, one's heart, or the Word, simply cannot be divorced from matters of grace and faith. In this sense, however, it is far from simply a notional or conceptual recognition of doctrine that Bunyan requires of the reader of his texts. Rather, in constantly exhorting the reader to search his or her own heart for faith, Bunyan urges in all his writings a kind of reading that should move the reader towards nothing less than the kind of saving spiritual experience that begins with conversion. Consequently, the characteristic nature of the 'grace-ful reading' of this thesis's title involves not merely a rational and intellectual acceptance of Bunyan's theological tenets about salvation according to Law and grace, but the acceptance of a doctrine that, as is embodied in the form of the Mapp, encourages the reader to consider a spirituality that transcends the limits of carnal reason and conventional concerns about worldly knowledge completely. In exploring the issues of grace-ful reading, therefore, this thesis aims to offer an account of Bunyan's most popular works according to a more accurate understanding of his doctrine of salvation beyond matters such as Calvinist predestination. But, at the same time, this study also seeks both to recognise and to illustrate how central to Bunyan's narrative art lies a conviction to promote an understanding of his doctrine (and a reading of his own texts) that goes beyond the rational, the logical, and the cerebral, and which is to be experienced in the heart rather than in the mind.

Such a reading of Bunyan's narratives, one that recognises that all reading for Bunyan is in itself finally bound-up with metaphysical matters of faith and experience, is not simply being asserted here according to any kind of abstract theory or hermeneutic methodology quite apart from Bunyan's own explicit teachings about belief and interpretation, either. Rather, this thesis is constructed upon the basis that Bunyan himself, in his many narrative works and tracts, continually reveals a profound concern about one's reading of the texts of doctrine and one's life grace-fully, a fact which is illustrated, perhaps most significantly, in Bunyan's distinctly grace-ful practice of interpreting that most important text of all - the

127 James Turner, 'Bunyan's Sense of Place', in The Pilgrim's Progress: Critical and Historical Essays, pp. 91 110 (pp. 105, 108). 
Word. Indeed, the kind of hermeneutic that Bunyan brings to Scripture acts as a kind of blueprint for his reading of all things (and for our reading of his texts) because, in holding the key to the promises of salvation, it demands something deeply unworldly, experiential, and faithful from one's understanding as a whole. Hence, 'nothing of the Gospel can be apprehended', Bunyan frequently asserts, 'but by Faith', for it is only by faith that anyone can lay hold of 'those heighths and depths of Gospel-mysteries' that constitute the foundations of his doctrine of grace. Only with faith as 'the Eye of the Soul' and the 'Spirit' as 'the Searcher of the deep things of God' can the Gospel truths be fully understood by anyone, for it is only when 'the Holy Ghost worketh upon us, and in us', that he 'toucheth our Understanding, that great piece of the Heart, with his Spiritual Illumination.' 128

In such a radically experiential approach to reading, rationality and epistemology are, as a consequence, most definitely secondary in importance: Bunyan discusses doctrines such as the mystery of the Trinity, for example, with an accompanying warning for his reader not to "imagin about them according to thine own carnal and foolish fancy; for no Man can apprehend this Doctrine but in the Light of the Word and Spirit of God.' 'If thou feel thy Thoughts begin to wrestle about this Truth', Bunyan writes, 'take heed of admitting such a Question, How can this thing be? For here is no room for Reason to make it out, here is only room to believe it is a Truth. ${ }^{129}$ Indeed, Bunyan even considers the Fall to be the immediate result of Eve mistakenly 'Seeing' the forbidden fruit 'not by the Word, which ought to be the Touch-stone of all, but by and according to her own natural Reason without it.' 130 It should come as no surprise, therefore, that what Bunyan's narratives often present to the reader are lessons in how to approach the Word in a faithful and non-rationalised way.

Moreover, in allowing 'for Faith to take it up and embrace it', Bunyan himself both advocates and practises an experiential interpretation, a grace-ful reading, not only of the 'Truth' of Gospel Scripture and its doctrine but of the 'Truth' of non-Gospel (that is, Old Testament) texts too. The principal means through which Bunyan enacts this kind of a

128 Bunyan, Of Justification by an Imputed Righteousness, pp. 320, 339; An Exposition on the Ten First Chapters of Genesis, p. 108. For a summary of Puritan approaches to reading the Word see Geoffrey F. Nuttall, The Holy Spirit in Puritan Faith and Experience (Oxford: Basil Blackwell, 1946; 2nd ed. 1947; repr. with an introduction by Peter Lake, Chicago and London: University of Chicago Press, 1992), pp. 20-33, 37-38, 135.

129 Bunyan, An Exposition on the Ten First Chapters of Genesis, p. 104.

130 Bunyan, An Exposition on the Ten First Chapters of Genesis, p. 131. 
spiritual hermeneutic is, of course, through elaborate typological readings of Old Testament passages and events or, in the case of Solomon's Temple Spiritualized (1688), even whole buildings and objects. The importance of this kind of interpretation for Bunyan is clear. By reading in terms of a 'spiritual' (as opposed to a literal or historical) sense, Bunyan can transform Biblical texts which may otherwise have little meaning for a Christian into cogent and significant passages which speak about Law and grace, faith and salvation. Of course, such a grace-ful 'spiritualising' of Biblical texts by Bunyan is not particularly original, it being a reading practice common to seventeenth-century hermeneutics in general: the treating of Old Testament texts as types and shadows for New Testament doctrines. But even given the predominance of typology as a way of reading Scripture in this period it can be shown, nevertheless, that Bunyan's spiritual reading of Scripture sometimes goes beyond any conventional or rudimentary typologising, and with important implications for the reader of his allegories and narrative works too.

In An Exposition on the Ten First Chapters of Genesis (1692), for example, Bunyan offers, on one level, quite a typical example of the kind of allegorical reading achieved through a typological interpretation of Scripture. Hence, as we could expect, the story of Cain and Abel becomes a parable of faith and grace, the fruitless professor and the faithful servant of God, the graceless and the elect. ${ }^{131}$ Similarly, Old Testament locusts and floods become political types for the persecution of Nonconformists and 'our graceless Clergy, that have covered the ground of our Land.' 132 So much is straightforward. But this concerted grace-ful reading of the first ten chapters of Genesis also has another imperative crucial for our understanding of Bunyan's attitude not simply to 'spiritual' interpretation but to the reading of narrative as a whole. Unlike the typological reading of Solomon's Temple, which elaborates on a single feature of Old Testament Scripture in order to reveal its Gospel significance, An Exposition [...] of Genesis shows Bunyan spiritualising the first book of the Bible in the grander terms of it status as historical narrative. In other words, Bunyan is not merely concerned with typologising certain aspects of Old Testament Scripture in order to

131 Bunyan, An Exposition on the Ten First Chapters of Genesis, pp. 155-181 (esp. 157-159).

132 Bunyan, An Exposition on the Ten First Chapters of Genesis, p. 223. 
extract some cogent lessons about Gospel 'Truth' in this work but, more importantly, with a reconstruction of an understanding of Biblical history in general.

The implications of this interpretive practice in terms of Bunyan's (and consequently our own) approach to reading and narrative is crucial because what is most important to recognise in An Exposition is that Bunyan not only discourses on Old Testament characters and events as types and shadows of New Testament doctrine but, in doing so, purposefully and effectively prevents any reading either of them (or of the book of Genesis as a whole) simply in terms of history or story. In An Exposition [...] of Genesis, then, Bunyan distinctly breathes the life of the Spirit into the letter of the Old Testament but, simultaneously, he is able to rewrite Biblical history (of the Fall and of the Flood, for example) no longer as a series of stories about characters with distinct and separate 'plots', but as a painstaking commentary pre-figuring the eternal doctrinal 'Truth' of the Gospel. Subsequently, Bunyan's spiritualisation of history in An Exposition serves to dismantle Biblical story and, in a very literal sense, reconstruct it in the form of doctrinal teaching alone, a process which effectively destroys the book of Genesis as a series of events organised according to 'temporal succession and causality' - that is, as an historical narrative alone. ${ }^{133}$

Even a brief glance at An Exposition [...] of Genesis indicates how Bunyan achieves such an anti-narrative re-presentation of Biblical (hi)story. Throughout this work, for example, Bunyan adopts his usual practice of expounding upon the doctrinal relevance of a Scriptural sentence (a method that begins so many of his sermon-like tracts) but applies it now to whole chapters of Genesis. With Bunyan exploring the Gospel relevance of practically each event and, moreover, each sentence of a Biblical chapter, sometimes elaborating at length upon an understanding of particular words in a sentence, the effect this has upon the narrative dimension of Genesis is essentially disintegrative. Indeed, the kind of glossing of Scripture that is usually confined to the margins of a text's page actually seems to have invaded the page itself in Bunyan's An Exposition, with the narrative of Genesis being sparsely scattered in and around the doctrinal commentary that it serves to excite and yet

133 This definition of narrative ('plot' being the literary term for narrative, apparently) is given by Wallace Martin in Recent Theories of Narrative (Ithaca and London: Cornell University Press, 1986; repr. 1994), pp. 81, 187. 
which finally subsumes it. Hence, Noah's obedience to God's command to build an ark ('Thus did Noah; according to all that God commanded him, so did he', Genesis 6. 22) is not to be read simply in the sequence of the story of the Flood but as an individual textual unit for spiritual and doctrinal exposition which not only breaks that story into segments of Gospel 'Truth' but which in itself is broken down in order to make this possible. ${ }^{134}$ As a consequence, the fall of Adam and Eve, the death of Abel, and the Flood are no longer to be read by Bunyan's reader (nor can they be, in this text) simply as Biblical or historical stories. Rather, they become important sources of doctrinal understanding alone and for nothing less than the reader's present salvation.

Bunyan's reasons for presenting his spiritual reading of Genesis in a way that so ruthlessly foregrounds doctrine at the expense of story are, however, clear. On one level, for instance, An Exposition reflects how Bunyan (along with many other seventeenth century preachers) is deeply and pastorally concerned about the inefficacy of a mere 'historical faith' to save the sinner. Anyone, Bunyan asserts, can have 'an Historicall Faith, that is, such as is begotten merely by the history of the word, not by the operation of the Spirit with the Word.'135 Such a faith can recognise what happens in, say, the book of Genesis but because there is no 'believing that is wrought in the heart by an invisible operation of the Spirit', then the Fall of man and the Flood can only remain dead-lettered stories of what once occurred, mere words (rather than the Word) empty of any spiritual or saving significance. With reading and interpretation so closely connected to spiritual perception in general for Bunyan, An Exposition [...] of Genesis thus offers a distinctly practical lesson in how to read Biblical narrative in terms of grace and faith. In doing so, Bunyan can sermonise freely on grace, here, while simultaneously preventing a reading of the Word as history alone.

Bunyan is anxious about a historical or narrative reading of Scripture, therefore, because the way one reads is so evidently and intimately related to one's approach to faith and salvation in general: advocating against any reading via a historical faith is all a part of bringing sinners to salvation, it seems. Equally, though, Bunyan's eagerness to re-write the meaning of the book of Genesis also bears a cultural and contextual resonance beyond any

134 Bunyan, An Exposition on the Ten First Chapters of Genesis, pp. 208-209.

135 Bunyan, Law and Grace, p. 134. 
basic pastoral concerns. Indeed, Bunyan's evident apprehension over 'historical faith' and the historicity of Scripture can be seen as reflecting changes evident in the broader developments in religious belief in the Restoration period as a whole. Bunyan's controversies with the Quaker Edward Burrough and the Bedfordshire Latitudinarian Edward Fowler, for example, are most important in this respect as the doctrines of both of these men present a threat both to the popularity and the efficacy of Bunyan's Reformed covenant faith, a threat distinctly characterised, on one level at least, by their methods of reading the Word and the world. ${ }^{136}$ Edward Fowler's reading of the Gospel, for instance, seems wholly 'historical' according to the tenets of a doctrine centred in the rational moralism prevailing in the established Church of Restoration England. Because Fowler advocates a doctrine of salvation (albeit abhorrently legalistic for Bunyan) through an adherence to the moral code laid down by Christ in the Gospels, the Word itself becomes little more than an 'admirable example' which men are encouraged to imitate. 137 In this way, the 'Precepts of the Gospel' are 'to perform good Actions [...] after a right manner, with right ends, \&c. or in one word from good Principles' centred in 'our Saviour's whole Conversation' as 'a rare exemplification of all kinds of Vertue and true Goodness.' For Fowler, therefore, the Gospel is to be read as little more than a conduct book in civility and good manners with Christ as an eminent gentleman of feeling: Christ's 'whole Life was', Fowler asserts,

one Continued Lecture of the most Excellent Morals, the most Sublime and exact Vertue. For instance; He was a Person of the Greatest Freedom, Affability, and Courtesie, there was nothing in his Conversation that was at all Austere, Crabbed or Unpleasant. Though he was always serious, yet he was never sowr, sullenly Grave, Morose or Cynical; but of a marvellously conversable, sociable and benign temper. ${ }^{138}$

The fact that Fowler speaks of Christ's work in the past tense indicates a grammar of faith emphasising the importance of the purely historical aspect of Jesus's ministry upon earth. For Fowler, the Gospels should present no radical or unsettling message about the unseen world of spiritual experience that Nonconformist fanatics and enthusiasts speak of.

\footnotetext{
136 For accounts of Bunyan's controversies with Fowler and Burrough, and of Latitudinarianism in general see T. L. Underwood, “"It pleased me much to contend": John Bunyan as Controversialist', Church History, 57 (1988), 456-469; Isabel Rivers, 'Grace, Holiness, and the Pursuit of Happiness: Bunyan and Restoration Latitudinarianism', in Conventicle and Parnassus, pp. 45-69, and Reason, Grace, and Sentiment: Studies in the Language of Religion and Ethics in England, 1660-1780 (Cambridge: Cambridge University Press, 1991).

137 Fowler, Design of Christianity, pp. 53, 63, 68.

138 Fowler, Design of Christianity, pp. 23-24, 68, 39.
} 
Rather, 'our Saviour's most Excellent Life' (which Fowler gives a useful summary of at one point) is to be advocated simply as 'the Pattern of our Lives' and, as such, the Gospel becomes little more than an edifying and exemplary moral biography: "if the History of [Christ's] Life were more perused and minded', Fowler writes, 'the Design of his Gospel' would not be 'by so many so very miserably mistaken, as we see it is.' ${ }^{139}$ In this way, Fowler encourages a purely historical and biographical example of Christ's work which complements his doctrine of imitation and works-centred moralism entirely. At the expense of Bunyan's kind of faith, the New Testament is thus de-spiritualised (and certainly deexperientialised) by Fowler into something reasonable, sociable and civil: it is a reading of Christ's life as holy example and as such (and aside from the fact that it tends to fall apart a little when required to account for the more inexplicable and unreasonable Gospel episodes, such as Jesus's cursing of an 'innocent Vegetable', the barren fig-tree) it is to be condemned by Bunyan as wholly and damnably ignorant. ${ }^{140}$

With the Quakers, however, Bunyan faced a reading of the Word which, though completely opposite to that of the Latitudinarian, was to be just as mistaken and doctrinally perilous. Whereas Fowler's reading of Christ's life betrays an overt foregrounding of history emptied of spiritual importance, according to Bunyan the Quakers offered a reading practice that ignored the historical significance of Christ's life and death altogether. Bunyan perceived the Quaker doctrine of the 'Light within' to be fundamentally pernicious, in fact, because it did not direct the sinner to the one thing that offers mankind hope of salvation Christ's death on the cross: 'he that cries up a Christ within', Bunyan writes, 'in opposition to a Christ without, that man instead of having the Spirit of Christ within him, is possessed with a spirit of delusion'. As 'the Spirit of Christ [...] in truth' lies in a faith in a Jesus who lived and died upon the earth as 'the Son of Mary', Bunyan perceives Quaker faith to hold Christ 'to be but a shadow or type, of something afterward to be revealed'. Hence, for Bunyan, any

\footnotetext{
139 Fowler, Design of Christianity, pp. 296-297.

140 Fowler, Design of Christianity, pp. 73-74. Unlike Bunyan who spiritualises Jesus's cursing of the fig-tree in typological terms, Fowler, in his attempt to explain such behaviour in such an exemplary man of courtesy, turns to a more historically based 'Emblematical explanation of the episode. Christ was simply speaking emblematically, Fowler asserts, 'for no-one [...] would be guilty of such a piece of Impotent revenge, as to wreak his anger on a Senseless tree' (p. 73). For an obvious methodological and doctrinal contrast, see Bunyan's The Barren Fig-Tree (1673) in Miscellaneous Works V.
} 
Christ 'crucified within, dead within, risen again within, and ascended within, in opposition to the Son of Mary, who was crucified without, dead without, risen again without' is merely a 'new and false Christ' indeed. ${ }^{141}$

Bunyan's reaction to the Quakers, as to Fowler's Design of Christianity, is thus telling in many ways. On the one hand, we can begin to see how reactionary and conservative Bunyan's doctrine of salvation really is (despite Fowler's frequent accusations of its fanaticism) in the face of a spiritual experience that does away with all external forms of worship and conventional understandings of Scripture. On the other hand, however, Bunyan's emphatic reiteration of a Christ 'without' reveals just how important Christ's life and death are for Bunyan in terms of the historical factuality of man's salvation in terms of grace. Just as Fowler's doctrine is damningly moral and historical, what Bunyan clearly denounces about the Quaker doctrine is the ahistoricality of a soteriology in which the resurrection is an 'event occurring within men in the present' or in which salvation by Christ 'could be described as past, present, and future.' ${ }^{142}$ For Bunyan, whose faith was built upon the factual importance of Christ's death within a grand historical scheme of salvation beginning before time itself, such a radically dehistoricised reading of redemption is simply unthinkable.

What Bunyan's controversies tell us about how Bunyan reads Scripture, then, is relatively straightforward: Bunyan was evidently zealous in countenancing any reading of the Bible which ignored, through either an overt emphasis upon the historical or the ahistorical, its 'true' Gospel meaning. Hence, while reading in terms of faith should always place any historical or narrative interest as secondary to the doctrine (a lesson Bunyan's own narratives frequently teaches their readers), the reality of our salvation through Christ's death within history is to be recognised as crucial nevertheless. Indeed, we are to read our lives strictly according to the greater soteriological narratives of mercy and justice, the focal point of which for the sinner is Christ's fulfilment of the covenant of grace on the cross. To return to

141 John Bunyan, Some Gospel Truths Opened, in The Works of John Bunyan, ed. by Offor, II, 147, 172, 134135.

142 The Miscellaneous Works of John Bunyan I, ed. by T. L. Underwood, with the Assistance of Roger Sharrock (Oxford: Clarendon Press, 1980), pp. xix-xx. For a good account of Quaker approaches to the Word see also Geoffrey F. Nuttall, The Holy Spirit in Puritan Faith and Experience, pp. 26-28, 52, 157-161. 
the quotation given at the very beginning of this chapter, then, it thus becomes clear why Bunyan devotes so much attention to Christ's crucifixion: without a contemplation of it as the moment of divine justice fulfilled within the narrative of our redemption, salvation is impossible for anyone (no matter what 'Romish' overtones it may lend to his writing).

Bunyan's controversies, then, like his Mapp and the Exposition [...] of Genesis, tell us a great deal about his attitudes to faith and reading and, as a consequence, point to the kind of reading practice his own narratives demand of us. On one level, it seems that we are required to acknowledge that history, story, and narrative are to be secondary to the doctrinal and spiritual concerns of texts like The Pilgrim's Progress and that, as we shall see, they attempt to enforce such an approach through the kind of textual tricks and traps evinced by the Mapp. What this thesis will argue, therefore, is that it is always the doctrine and not the story that Bunyan's narratives continually privilege in their construction. This is not to say that doctrinal reading is the same as grace-ful reading, though. Indeed, the debates with the likes of Fowler and Burrough reveal Bunyan continually warning his reader against any notionalist (that is merely ignorant, rational, and spiritually mistaken) reading of his narratives, the doctrine they hold, the Word, or one's life as a whole. Bunyan can rail not only against the fallacious doctrines of his 'notionalist' controversialists, therefore, but at the same time use them to warn his reader against any merely intellectual assent when reading his own doctrine:

Have a care that when thou art under conviction, thou dost not satisfy thyself with a notion of the free grace of the gospel; my meaning is, do not content thyself with any measure of knowledge that thou canst attain unto, or bottom thy peace upon it, thinking that thou art now well enough, because thou canst speak much of the grace of God. ${ }^{143}$

Once more, what lies at the heart of Bunyan's concept of understanding doctrine is not a concern over knowledge but over experience: one should not simply have 'conviction' but strive for a certainty in faith that does not lie within one's mind, knowledge, or the ability to read and talk of grace alone.

Consequently, it will be argued in this thesis that all of Bunyan's texts finally require such an experiential type of interpretation from the reader. Offering readings of Bunyan's

143 Bunyan, Some Gospel Truths Opened, p. 137. 
texts specifically according to a doctrine of Law and grace, therefore, this study also asserts that Bunyan's narratives demand a reading of one's own heart in terms of a faith in a salvation which goes beyond the notional and into the domain of accepting an other-worldly realm of spirituality. As such, reading a text like The Pilgrim's Progress requires the same procedure as reading the texts of the Word and one's life properly. Hence, on the one hand, one must approach Bunyan's texts in terms of their doctrine of grace and faith, and not in terms of mysteries unfathomable by man, such as reprobation and election. On the other, however, this in itself demands an overturning of one's rational assumptions in approaching matters of salvation: faith and experience are to be accepted as pre-eminently non-rational and non-epistemological. It is this metaphysical shift which Bunyan's texts, it is argued here, attempt to initiate within the reader through the way they are constructed and presented: the Mapp thus reveals an early and useful example of how all Bunyan's narratives operate upon the reader by first upsetting any assumptions about reading as a prelude to the kind of understanding that faith both demands and ultimately provides. It is in the context of such concerns, moreover, that any reading of Bunyan's narratives for the story or the plot, the fiction rather than the 'Truth', emerges as mistaken, if not spiritually pernicious.

It is, then, the combination of these factors that goes towards the particular kind of interpretive practice that I have referred to in this thesis as grace-ful reading. ${ }^{144}$ It is more than a notional recognition of Bunyan's doctrine that Bunyan's texts require as they are specifically devised, I will argue, to point the reader to a salvation which is distinctly of another world. The essential point to grasp about all Bunyan's texts, therefore, is that, like faith itself for Bunyan, they endeavour to 'teach us, not only to reade but to attend in reading, not only to read but to lift our hearts to God in reading', to be 'heedful' with a spiritual 'light and understanding', and to see 'a whole heaven [...] intimated, where it is not at all expressed.' It is only by reading grace-fully in this kind of way that we can 'regard the other

\footnotetext{
144 This thesis does not attempt to construct a concept of a 'Protestant' reader, as Barbara Johnson has done in Reading Piers Plowman and The Pilgrim's Progress, but to assert that Bunyan's texts operate upon the reader in specific ways in order to achieve a specific spiritual response. Johnson's concept of the 'Protestant' reader goes some way to suggest this but, as a historical survey of responses to Bunyan, is finally vague when it comes to the theology of Bunyan's texts. Johnson's 'Protestant' reader is, unfortunately, doctrinally imprecise, a fact that invalidates such a construction from the outset as, without reference to Bunyan's doctrines more specifically, it can only remain largely meaningless. See, for example, pp. 26, 184-191.
} 
World' at all, and it is only when we see things of 'another World' that, Bunyan asserts, we can be inspired to 'Run throw thick and thin to enjoy it.' 145

This is not to say, however, that the emphasis of this thesis is in any way evangelical: it does not suppose that many of Bunyan's readers today will be moved by his writings to the kind of faith that Bunyan would consider as effectually saving. Indeed, this thesis offers an understanding of Bunyan's doctrine that Bunyan himself would undoubtedly consider damnably notionalist: knowledgeable about doctrine, for Bunyan this thesis undoubtedly would be all talk, not enough doing, and unarguably 'historical'. In advocating an understanding of the kind of reading that Bunyan's texts require, then, this study does not expect to convert anyone into Bunyan's theology. However, it does seek to convert any reader of Bunyan's narratives and any student of his narrative practice into a recognition of the spiritual imperatives that lie behind them. The central consideration of this thesis is, in fact, that it is only by recognising the kind of doctrinal and critical reading that Bunyan's texts require of their readers that we can even begin to understand the complex relationship between Bunyan's theology and his textual methods both more comprehensively and more positively. It is only by accepting that texts such as Grace Abounding to the Chief of Sinners finally encourage the reader to regard 'another World' that Bunyan's works as a whole can be read with eyes of understanding and, more importantly, without the prejudice that they are so often met with by many of their current readers and critics.

145 Bunyan, The Strait Gate, pp. 73-74; Heavenly Footman, p. 162. 


\title{
2
}

\section{Bunyan's Exceeding Maze:}

\section{Doctoring and Doctrine in}

\section{Grace Abounding to the Chief of Sinners}

\begin{abstract}
But the same day, as I was in the midst of a game of Cat, and having struck it one blow from the hole; just as I was about to strike it a second time, a voice did suddenly dart from Heaven into my Soul, which said, Wilt thou leave thy sins, and go to Heaven? or have thy sins, and go to Hell? At this I was put into an exceeding maze; wherefore, leaving my Cat upon the ground, I looked up to Heaven, and was as if I had with the eyes of my understanding, seen the Lord Jesus looking down upon me, as being very hotly displeased with me.1
\end{abstract}

As the young Bunyan's first encounter with the supernatural world of spiritual life, the 'game of Cat' episode acts as something of a prelude for the rest of Grace Abounding to the Chief of Sinners. Indeed, it seems to encapsulate in just a few lines the essence of Bunyan's conversion narrative as a whole. Here, as in much of the rest of his account, Bunyan undergoes what appears to be a radical religious experience amidst an otherwise mundane and ordinary context, the very physical nature of his sport, in this instance, providing a dramatic contrast for something profoundly meta-physical and most extra-ordinary. Faced with a vision of God who like a disapproving father is 'hotly displeased' with the Sabbath-breaking boy, here Bunyan is left in a position we are to find him in at various points throughout Grace Abounding: stunned, bewildered, and indeed amazed, the converting Bunyan's progress in understanding things divine is to prove rarely other than slow, painful, and frequently selfreversing. As Vincent Newey has pointed out, the heavenly visitation occurring amidst the game of Cat has nothing but a disturbing effect on the gamesome lad: interpreting his experience at this point as little other than a sign of his damnation rather than salvation, the

\footnotetext{
1 John Bunyan, Grace Abounding to the Chief of Sinners, ed. by Roger Sharrock (Oxford : Clarendon Press,
} 1962), p. 10. 
whole episode effectively becomes self-negating for Bunyan, paradoxically occasioning 'a misreading which defers, indeed challenges, the ends it theoretically promotes.'

Bunyan's first important move towards religious conversion thus becomes a step into the 'exceeding maze' of uncertain spiritual pathfinding and hermeneutic wrong-turns that Grace Abounding both records and presents. But it is not only Bunyan-the-convert who is frequently a-mazed by his experience. For any reader of Grace Abounding, the game of Cat episode must typify something of the problematic nature of reading the text as a whole. It may seem that we are encouraged to consider the game of Cat, for example, as Bunyan's original point of conversion. ${ }^{3}$ As we continue to read the account, however, it becomes clear that Grace Abounding is to offer a series of events any one of which could be understood as the specific conversion moment - Bunyan's meeting with the Bedford women, for example, or the period following his introduction to the pastor, Mr Gifford. ${ }^{4}$ At the same time, Bunyan's relation throughout the narrative of dramatic swings between terrible anxiety and sweet comfort ensures that any final resolution or assurance usually associated with conversion is continually deferred, mistaken, and finally denied in this text for reader and protagonist alike. As a consequence, what the reader of Grace Abounding ostensibly faces is a conversion account in which the conversion itself is uncertainly defined and at the end of which Bunyan, even as a preacher, is to be found suffering still from appalling temptations to blaspheme and sin. Diffuse, repetitious in structure, and ending with a no uncertain amount of dis-closure, it would seem that the figure of an 'exceeding maze' is incisively appropriate in describing the construction of a narrative the reading of which has been likened notably to that of,

travelling in a mighty maze whose plan is far from clear, and where at every turn we meet some new and puzzling psychodrama suggesting not so much providential design as solitary struggle in a spectacular universe of the mind's own making. ${ }^{5}$

\footnotetext{
2 Vincent Newey, “ "With the Eyes of My Understanding”: Bunyan, Experience, and Acts of Interpretation', in John Bunyan: Conventicle and Parnassus, Tercentenary Essays, ed. by N. H. Keeble (Oxford: Clarendon Press, 1988), pp. $189-216$ (p. 194).

3 This is certainly Vera Brittain's view of the episode, along with that of other commentators. See In the Steps of John Bunyan: An Excursion into Puritan England (London: Rich and Cowan, 1950; repr. 1987), p. 10.

${ }^{4}$ For possible alternatives as to the conversion moment, see Grace Abounding, pp. 14-15, 25-26, 37-38, 67, $72-74$.

5 Newey, 'With the Eyes of my Understanding', p. 192.
} 
It is not only in terms of its overall narrative structure, though, that Grace Abounding frequently makes for a-mazing reading. If we return once more to the game of Cat, there is a great deal in Bunyan's specific representation of experience itself that forces an uncertainty or hesitancy in one's interpretation of it. What, for instance, is really happening at this point in the text? Are we to understand that Bunyan physically hears a voice from heaven? If so, do we take the game of Cat episode to be an example of the audibility and physicality of intense religious experience that seems to characterise so much of Grace Abounding? Or should we be more sceptical about the descriptive order of events here? After all, Bunyan does not explicitly state, in a way that George Fox continually does in his Journal, that he 'hears' the voice of God, although this may be the impression given. ${ }^{6}$ Rather, he suggests that 'a voice did suddenly dart from Heaven into my Soul'. But what can this mean? Is it an audible experience or not? Are we to understand the experience as a sophisticated metaphorical construction expressing the machinations of a burdened conscience (hearing God in the soul), or, as someone like Joseph Salmon supposes in recounting a similarly audible ordeal, are we to accept it as a purely metaphysical event transcending conventional sense perceptions? 'I was made as truly sensible of this inwardly', Salmon affirms after hearing 'that voice from the throne of the heavenly Almightiness', 'as the eye is sensible to the light, or the ear of the outward sound."7

Unfortunately for the reader of Grace Abounding, Bunyan offers no statement equivalent to Salmon's to indicate more clearly the nature of what occurs here and elsewhere in the text. Bunyan's vision of Christ 'looking down' upon him (an experience that seems to recur in Grace Abounding) operates in the same way. ${ }^{8}$ One may wonder whether Bunyan is actually seeing God's face in the sky or not, particularly as the experience is mediated by that uncertainty-inducing construction, 'it was as if' (a phrase Bunyan frequently uses in describing his spiritual encounters). ${ }^{9}$ So it was only as if Bunyan was seeing the Lord looking down

\footnotetext{
${ }^{6}$ See, for example, The Journal of George Fox, revised edition by John L. Nickalls, with an epilogue by Henry J. Cadbury and an introduction by Geoffrey F. Nuttall (Cambridge: Cambridge University Press, 1952), pp. 7, $11,13-16,19,22,39,103-104,312,662-663$.

7 Joseph Salmon, Heights in Depths and Depths in Heights (London: 1651), p. 13.

${ }^{8}$ See, for example, Grace Abounding, pp. 65, 72.

${ }^{9}$ See, for example, Grace Abounding, pp. 38, 65, 80-81, 100.
} 
from heaven upon him, then, and with the 'eyes of my understanding' in any case. Again, are we to understand such a relation as a deeply spiritual, almost mystical, event? Or is Bunyan simply adopting the kind of metaphorical way of speaking about convictions of the heart common to late seventeenth century religious discourse, through which converts such as Charles Doe could speak of having the love of Christ revealed to them via 'the Eyes or Understanding of my Soul'?10

Clearly, an odd thing is happening in such passages. As much as we may accept that Bunyan is relating his experience to us metaphorically, nevertheless the presentation of audibility and visibility in this and other episodes is so powerful, so intense, that it conveys the sense that it is far from metaphorical at all but literal and actual, and therefore mystical. The problem that faces the reader here, then, is one of hermeneutic hesitation. The nature of Bunyan's experience is so difficult to fathom throughout Grace Abounding because his descriptive technique frequently leaves the events he relates literally flickering beneath the gaze: for the reader, Bunyan both hears the voice and sees the vision and yet simultaneously - he does not. Upon the page, these events 'happen' and yet they do not. Facing such representational hesitation, the reader is indeed placed in something of an interpretive maze: how does one respond, which way does one turn?

There is, however, a point to such narrative a-mazement, it seems. On the most basic of levels, Bunyan's textual practice artfully ensures that the process of reading Grace Abounding exacts something of a test of faith from its reader. Because the way we understand what Bunyan describes as happening when he hears voices and has visions reflects whether we find his world-view truthful or not, the question Grace Abounding continually asks of its reader is, do we share Bunyan's concept of a spiritual reality, or do we not? Do we embrace his faith in things unseen, or do we reject it? It is the purpose of both this and the following chapters to demonstrate how both the narrative structuring and the descriptive practice of Grace Abounding finally urge a questioning in its reader about faith, grace, and a spiritual order of reality. Because the text foregrounds a self-reflexiveness about the way we read and interpret it, in the same way that Bunyan's Mapp has been seen to operate upon the reader, then the way

10 Charles Doe, A Collection of Experience of the Work of Grace (London: 1700), p. 44. 
we respond to Grace Abounding can be seen as the most central concern of Bunyan's narrative and doctrinal didactic aims. With the reader's spiritual welfare as the ultimate focus of Grace Abounding, it will be argued that Bunyan's spiritual autobiography does more than recount, for the benefit of others, his often harrowing experiences: more importantly, it teaches about Law and grace. In doing so, Grace Abounding also instructs the reader in reading the texts of the Word and one's life grace-fully. In order to substantiate such a claim, however, it is necessary first to show how Bunyan's narrative practice in Grace Abounding has procured some astonishing (as well as arguably pernicious) misreadings amongst its critics, readers, and commentators of recent years.

Within a cultural climate in which Christian faith has, since Bunyan's time at least, moved towards what may be called rational moralism and in which matters of faith in general seem to have given way to a secularisation of much of what was once considered religious, it is hardly surprising that contemporary readers may indeed be put into an exceeding maze by Grace Abounding. In the absence of a faith in a Calvinist God who reveals his sovereign omnipotence both through divine providence and the direct operation of the Spirit, Bunyan's claim that he hears voices and sees visions, even if it is via the eyes of understanding and the ears of the soul, may be difficult, if not impossible, to accept uncritically (if at all). If we no longer believe in things such as direct spiritual revelation, then Bunyan's 'hearing' of unbidden Scriptural texts along with his various envisionings must, it seems, be explained via an alternative, more plausible truth. Unsurprisingly, then, it has become something of a commonplace to interpret much of what occurs in a text like Grace Abounding from a specifically psychological or medical point of view, the conclusion often being, of course, that the Bunyan of Grace Abounding was, for a certain period of his life at least, something akin to insane.

Such a view is not novel, however, having been established by intellectuals like Josiah Royce and William James, for example, since the turn of the twentieth century. These writers can be found exploring and explaining Grace Abounding not in terms of its theological doctrine or as a religious narrative but as a psychological case-book, Bunyan evidently having suffered 
from a variety of delusions and mental perturbations manifesting themselves in what was conceived at the time (by Bunyan, if no-one else) to be a religious crisis. Grace Abounding is considered by Royce, therefore, as 'a fairly typical case of a now often described mental disorder', a 'dramatically systematized' 'malady' consisting of 'morbidly insistent impulses', 'borderland pseudo-hallucinations of speech', and uncontrollable 'motor speech-functions'.11 This is Royce's interpretation of Bunyan's aural and oral experiences, his hearing of Biblical quotations and his compulsive temptation to blaspheme and curse.

William James, however, effectively institutionalises such an analysis. Applying metaphors of illness and delusion within his process of 'mental anatomy' to 'those individuals for whom religion exists not as dull habit, but as an acute fever', James's 'subjects' are considered 'creatures of exalted emotional sensibility', prone to 'all sorts of peculiarities'. While George Fox, according to James, 'was a psychopath or detraqué of the deepest dye', his diagnosis of Bunyan betrays a similar vein of condescension: 'Poor Bunyan's troubles', he writes,

were over the condition of his own personal self. He was a typical case of the psychopathic temperament, sensitive of conscience to a diseased degree, beset by doubts, fears and insistent ideas, and a victim of verbal automatisms, both motor and sensory [...]. Added to this were a fearful melancholy self-contempt and despair.

James's insensitivity to the particular doctrinal context of Bunyan's conversion thus becomes evident: the famous Calvinist cry of ' "What must I do about it?" is the form of question', James asserts, 'a "cranky mind" takes.' 12

It is worth quoting James at length not only because his language seems so astonishingly condemnatory of Bunyan's religious experience (even as it purports to regard it in more human and humane terms), but because such a view has been so influential upon how Grace Abounding has been received in the twentieth century. It is James, for instance, who first articulates the notion of Bunyan as a 'divided self', a term frequently adopted ever since

\footnotetext{
11 Professor Josiah Royce, 'The Case of John Bunyan', Psychological Review, 1 (1894), 22-33, 134-151, 230240 (pp. 23, 240).

12 William James, Varieties of Religious Experience: A Study in Human Nature (London: Longmans, 1902; repr. 1952), pp. 8-9, 23-25, 154. James defines the 'psychopathic temperament' as that which, 'whatever be the intellect with which it finds itself paired, often brings with it ardor and excitability of character. The cranky person has an extraordinary emotional susceptibility. He is liable to fixed ideas and obsessions. His conceptions tend to pass immediately into belief and action' (p. 24).
} 
by critics who view Grace Abounding as illustrative of a 'heterogeneous personality' whose 'psychopathic' (if not schizophrenic) disorders are resolved through the unifying process of conversion. ${ }^{13}$ With the empirical frameworks of psychology and physiology offering a firm explanation of Grace Abounding's apparently incoherent narrative structure and its relation of spiritual revelation, it is hardly surprising that medical interpretations of Bunyan's autobiography have come to abound. Reflecting an 'insobriety of the mind', Grace Abounding can effectively inform us that Bunyan, 'suffered from neurasthenia, phobias, and a wasting disease; his digestion was impaired.' And as if it were not enough that poor Bunyan's troubles are to be explained away as the product of, among other things, indigestion, his 'violent bodily agitations' also indicate that Bunyan was both 'almost epileptic' as well as prone to overdramatisation: 'Calvinists', Margaret Bottrall affirms, 'without conscious exaggeration, describe their psychological experiences in terms that today seem not only archaic but hysterical' ${ }^{14}$

Such an approach ultimately culminates, of course, in a psychoanalysis of Grace Abounding through which, as W. N. Evans's study illustrates, a preoccupation with diagnosing Bunyan's mental problems effectively cripples any humane and imaginative (not to mention doctrinal) response to the text. ${ }^{15}$ But it does not take such extreme readings as Evans's to signal that psychologising Grace Abounding is a problematic business. At a most basic level, such a response reflects a fundamentally poor interpretive practice, a lack of sensitivity to the very words on the page: the reaction of James (and others since) to Grace Abounding reveals a reading of Bunyan's experiences on a purely literal basis, ignoring not

13 James, Varieties of Religious Experience, p. 180.

14 William York Tindall, John Bunyan, Mechanick Preacher (New York: Columbia University Press, 1934; repr. 1964), p. 18. Margaret Bottrall, Every Man A Phoenix: Studies in Seventeenth-Century Autobiography (London: John Murray, 1958), pp. 83, 85; Monica Furlong, Puritan's Progress: A Study of John Bunyan (London: Hodder and Stoughton, 1975), pp. 155-179. For a more positive psychological view, see John N. Morris, Studies in English Autobiography from John Bunyan to John Stuart Mill (New York \& London: Basic Books, 1966), pp. 90-92.

15 W. N. Evans, 'Notes on the Conversion of John Bunyan: A Study in English Puritanism', International Journal of Psycho-Analysis, 24 (1943), 176-185. Evans suggests, for example, that Protestantism 'in essence is preoccupied solely' with the Oedipal 'father-son relationship', and that 'the doctrines of the Reformers direct their main attack against the pregenital manifestations of the libido': 'In Puritanism', he writes, 'the original conflict is enacted on the anal level and only rarely advances to the genital level.' Aside from revealing the suppression of 'instinctual desires' and demanding a similar 'submission' from others, Bunyan's apparently 'homosexual longing to bring all men to the father is made abundantly clear' in Grace Abounding (pp. 181183). 
only theology but the delicate hesitations that constructions like 'it was as if' or 'the eyes of my understanding' impose upon the text. At the same time, such readings do not further our understanding of the text in any real or effective way. As Roger Sharrock has pointed out, studying Grace Abounding as 'a psychiatric case-history' may more easily 'recommend Bunyan for consideration as a cousin of the modern man', with his '[n]agging anxiety and uneasy conscience', but this would be, he admits, 'to approach no nearer to the secret of the book.' Rather, it would 'simply be to translate the psychological terminology of the seventeenth century into that of the twentieth', a process not without detriment: 'Something is lost', Sharrock feels, 'once we exchange Bunyan's beliefs for any translation into purely psychological terms which neglects their devotional context.' 16

Although Sharrock's point about the dangers of merely translating Bunyan's experience into twentieth century psycho-babble is cogent even he, it seems, finds it difficult to escape from such terminology: he suggests, for example, that Grace Abounding depicts a period in which 'some psychological spring snapped' in Bunyan, and wonders incredulously whether this 'neurotic Bunyan [has] anything to do with the resolved and extroverted pastor whose admiring flock called him "Bishop Bunyan"?'.17 But there are clearly other, perhaps more

\footnotetext{
16 Roger Sharrock, John Bunyan (London: Macmillan, 1954; repr. 1968), pp. 57-58, 62. Sharrock is obviously not alone in voicing such an opinion. While Richard Greaves is sceptical about any 'tendency to treat Grace Abounding as a reliable source of information about Bunyan's life and psyche', asserting that, as a primarily 'pastoral' work, it is 'not a document that can bear the psychological and biographical interpretations often built on it', Peter Carlton views psychoanalytic readings of Bunyan's religious experience as demonstrative of a more insidious cultural hocus-pocus. They are problematic, he suggests, because 'by explaining a religious experience in loosely Freudian terms, they preserve its aura of otherness while omitting the divine other.' Indeed, because Freudian analysis is dominated by a language of subconscious drives and forces within the individual, such explanations effectively 'prove no less magical than Bunyan's own statements - they secularize them, but fail to demythologize them.' Richard Greaves, 'John Bunyan: The Present State of Historical Scholarship', in Bunyan in England and Abroad, ed. by M. van Os and G. J. Schutte (Amsterdam: VU University Press, 1990), pp. 29-43 (p. 29), also in John Bunyan and English Nonconformity (London: Hambledon Press, 1992), pp. 37-50; Peter J. Carlton, 'Bunyan: Language, Convention, Authority', English Literary History, 49 (1982), 17-32 (pp. 18-22). See also Gordon Wakefield's comments on such matters in John Bunyan: The Christian (London: HarperCollins, 1992; repr. 1994), pp. 16-18.

17 Roger Sharrock, 'Personal Vision and Puritan Tradition in Bunyan', Hibbert Journal, 56 (1957-58), 47-60 (pp. 55-57). Peter Carlton seems guilty of this too: Bunyan's 'disclaiming locutions' (the unbidden hearing of Scriptural texts) evidently spare the convert, he writes, 'from an anguish that may have proven too much for his neurotically sensitive temperament to bear' ('Bunyan: Language, Convention, Authority', p. 22, my emphasis). Similarly, Anne Hawkins, who has written so insightfully upon the structure of Grace Abounding as a conversion narrative, finds it 'fascinating in its excited, nervous prose and pathological obsessiveness.' Indeed, her terms lysis and crisis, although undoubtedly useful in describing the dyadic structure of Bunyan's conversion, are nevertheless derived from William James's analysis. See Anne Hawkins, 'The DoubleConversion Narrative in Bunyan's Grace Abounding', Philological Quarterly, 61 (1982), 259-276 (p. 259), and William James, Varieties of Religious Experience, p. 180.
} 
important, concerns to be voiced about Grace Abounding when it comes to its cultural translation through medicalisation. The substitution of terms, for example, from seventeenthcentury religious conversion to twentieth-century psychology may be ineffective in rendering any greater understanding of either the text or the experiences it describes, but such a process should not be concluded upon as being either meaningless or harmless. As Anne Hawkins has noted, it is right to be suspicious of 'the psychologist's tendency [...] to deal with the unsettling ambiguities of heart and mind by labels, classifications, and categories' not merely because it is somewhat unimaginative, however, but because it often belies a pernicious, hidden cultural agenda. ${ }^{18}$ Indeed, it is precisely through such a psychological labelling and categorisation that the likes of Bunyan, even since the seventeenth century (to draw upon Foucauldian terminology), have been medically objectified in order to be marginalised both socially and politically. ${ }^{19}$

Bunyan's conversion being synonymous with mental and nervous disorder, it is easy to see how this could be the case: with religious experience (and especially the kind that has always been considered 'radical') becoming explicable in terms of the operations of nothing but a faulty mind, Bunyan could be categorised safely by any political objector as eccentric, disturbed, or insane. For Bunyan to be considered so in his own time was, moreover, something of necessity, it seems, for those who considered Nonconformists to be a social and political danger. As N. H. Keeble has noted, there is a clear suspicion of 'Enthusiasm' throughout the seventeenth century in the writings of, amongst others, Henry More and Robert Burton. It seems, however, that while the latters' condemnations rest more upon a suspicion of religious charlatanism amongst enthusiasts than sedition and unrest, in the Restoration period the condemnations of Nonconformists and Dissenters as lunatic fanatics by the likes of Latitudinarians such as Samuel Parker and, in Bunyan's case in particular, Edward Fowler, are blatantly political. To these figures, Bunyan is but 'a most Black-mouth'd Calumniator' who, along with other 'Fire-brands, and most impudent malicious Schismaticks' equally

\footnotetext{
18 Hawkins, 'Double-Conversion Narrative', p. 259.

19 For an excellent introduction to Foucauldian thinking on such matters, see The Foucault Reader: An Introduction to Foucault's Thought, ed. by Paul Rabinow (Harmondsworth: Penguin Books, 1991), especially the editor's introduction and useful extracts from Madness and Civilisation (pp. 3-29, 123-167).
} 
undeserving of 'his Majesties Toleration', 'tend to the subversion of all Government' if left 'unpunish't'.20

With Bunyan's Nonconformist (if not sectarian) faith being synonymous with sedition in one of the worst periods of political unease and persecution of English history, Bunyan's distinctly separatist and experiential Calvinism was thus clearly perceived as presenting a very real social and political threat to order in Restoration England.21 This is particularly understandable given that the ecclesiastical polity of uniformity propounded by Parker (and rejected by the likes of Bunyan) was also centred in the pre-eminently rational, moral, and civil doctrines of Latitudinarianism. One self-evident way of denouncing, depopularising, and demonising those who hold a non-rationalist, providentialist, and separatist view of faith is, therefore, to refer to them as insane fanatics who intend to tear the fabric of social order apart: according to Bishop Parker, Nonconformists represent 'a Wild and Fanatique Rabble' of 'Brain-Sick People' who, 'impregnably possest with their own wild and extravagant Fansies', are the 'worst and most dangerous Enemies' to 'Authority'.22 But while Parker's infamous diatribe is an outrageously hysterical reaction to Nonconformity (ingeniously justified, it seems, by his adoption of a supremely rational and civil mode of discourse), by 1700 such a view was nevertheless to be institutionalised by the new empirical philosophy in any case. Indeed, it is John Locke who delivers the 'coup de grace', as Keeble puts it, in the condemnation of enthusiastic religious experience through a discourse of unarguable proof and epistemological certitude that refutes the very essence of Bunyan's kind of experimental faith. Reason having no place in the religious experience of enthusiasts, verification is grounded,

\footnotetext{
${ }^{20}$ Dirt Wipt Off (London: 1672), pp. 2, 3, 70. This is a tract which, as a response to Bunyan's $A$ Defence of The Doctrine of Justification (1672), is often attributed to Edward Fowler but which Fowler probably did not pen: it may have been written by Fowler's clerk. In The Design of Christianity (1671), however, Fowler does speak disparagingly of Nonconformists, suggesting that their doctrines cannot be held in 'the mind of such a one, while he is compos mentis, and not utterly deprived of his Intellectuals' (p. 220). Fowler also asserts that Nonconformists have 'no care to be universally obedient' and considers any refusal 'to comply with our Country-men and Neighbours in their plainly innocent usages and harmless Customes, or with the will of our Governours when they command us such things', the result of 'proud affectation' and 'superstitious scrupulosity' (pp. 243-244).

21 For detailed discussions of the political background of this period see Richard Greaves, John Bunyan and English Nonconformity; Michael R. Watts, The Dissenters: From the Reformation to the French Revolution (Oxford: Clarendon Press, 1978); N. H. Keeble, The Literary Culture of Nonconformity in Later Seventeenth Century England (Leicester: Leicester University Press, 1987), esp. pp. 25-67.

22 Parker, A Discourse of Ecclesiastical Politie (London: 1670), pp. iv, xii-xiii, 57.
} 
according to Locke, in an absurd circular logic of its own: 'It is a Revelation because they firmly believe it', he writes, 'and they believe it because it is a revelation.' ${ }^{23}$

At the same time that Restoration England was experiencing a shift towards rational moralism both in its national religion and its scientific and philosophical developments, another insidious threat to the likes of Bunyan was becoming evident: the rise of the medical profession. ${ }^{24}$ In particular, the medical and psychological treatment of religious experience as synonymous with mental disorder was clearly becoming more predominant in the late seventeenth century and, according to Michael MacDonald at least, for reasons other than that of curative efficacy. Indeed, the practice of medicine professionally was still in its infancy at this point and its growing popularity can hardly be attributed to successful treatments. Rather, it seems more the case that medical theories and explanations provided 'the only kind of explanation for mental disturbance entirely free from controversial religious associations; medical treatments were', MacDonald asserts, 'the only methods of healing insanity that did not meet with the disapprobation of the established clergy.'25

The growth in the authority of medicine and medical psychology to explain madness and religious experience in largely synonymous terms has been seen by MacDonald to have had a devastating effect upon the treatment both of the insane from this period onwards as well as having important resonances for the socially and politically marginalised Dissenting communities of saints. Effectively blurring the distinctions, for instance, between Nonconformist faith and a medically verifiable insanity, the discourse of a new medical psychology lent greater authority to the likes of Parker and Fowler in their condemnation of Dissenters as nothing less than mad enthusiasts. Moreover, by explaining illness in terms of medicine instead of religion, medical discourse and practice helped to eclipse the authority of Nonconformist preachers to minister 'healing' via an experiential or providentialist faith, using an alternative 'truth'. The growth of medical diagnosis in explaining such things as religious

23 N. H. Keeble, The Literary Culture of Nonconformity, p. 180, quoting from John Locke, An Essay Concerming Human Understanding, ed. with a foreword by Peter H. Nidditch (Oxford: Clarendon Press, 1975; repr. 1979), Book IV, Ch. XIX, pp. 697-703.

${ }^{24}$ For a more detailed discussion of this subject, along with Bunyan's use of medical metaphors in his writings, see the Appendix to this thesis: 'Bunyan and Medical Discourse in the Restoration'.

25 Michael MacDonald, Mystical Bedlam: Madness, Anxiety, and Healing in Seventeenth Century England (Cambridge: Cambridge University Press, 1987), p. 226. 
melancholy is thus profoundly related to religious and political concerns in the Restoration, reflecting especially 'the governing elite's reaction against religious zeal': with religious experience and healing carrying the radical associations of Civil War sectarianism, it is not surprising that from the 1660 s onwards medical psychology became 'the sole basis for treatments of insanity sanctioned by the ruling elite. There was no alternative. ${ }^{26}$

With this political context in mind, it is perhaps more understandable why in Grace Abounding Bunyan, unlike other spiritual autobiographers of the time, refuses to provide or even entertain any medical or psychological explanation of his conversion. Such an interpretation could only detract from what is for Bunyan the unquestionable reality of his salvationary experience and the kind of doctrinal 'truth' that Latitudinarians like Parker and Fowler (among other divines) would prefer to view as enthusiastic madness or the product of an empty stomach. While a hypochondriacal sensitivity to bodily illness dominates much of Richard Baxter's more rationalist autobiography, and while the Presbyterian George Trosse continually defers his intense encounters with voices and visions to the realm of mere physical and mental ill-health (the product of a 'crack'd' or 'disturb'd Brain'), Bunyan's account marks his fundamental Nonconformist stance by doing no such thing. ${ }^{27}$ The young Bunyan's early attempt, for instance, to ease his sermon-burdened conscience through bodily means, finding that when 'I had satisfied my nature with my food, I shook the Sermon out of my mind', is shown to fail completely: the game of Cat episode that follows wholly negates the efficacy of such a remedy and Bunyan, now utterly convinced of his damnation, is left to transform his once comforting food of nature into nothing less than a riotous feast of $\sin$, 'that I might taste

\footnotetext{
${ }^{26}$ MacDonald, Mystical Bedlam, pp. 228-229.

27 See Richard Baxter, The Autobiography of Richard Baxter, ed. with an intro. by J. M. Lloyd Thomas (London: Dent, 1931), pp. xvii-iii, 58-59, 75, 216-217, and George Trosse, The Life of the Reverend Mr. George Trosse, ed. by A. W. Brink (Montreal and London: McGill-Queen's University Press, 1974), pp. 87, 99100. Trosse completely rationalises his experience of how, like Bunyan, he was 'full of all manner of Blasphemies and wicked Passions, and was haunted with horrible distracting Temptations to Sef-Murther, \& with a great many terrifying and disquieting Visions and Voices'. Unlike Bunyan, though, Trosse explicitly states that 'tho' (I believe) they had no Reality in themselves, yet they seem'd to be such to me, and had the same Effect upon me, as if they had been really what they appear'd to be. Thus was I disturb'd with silly ridiculous Fancies, and Thousands of unreasonable and non-sensical Delusions' (pp. 89-90). For a similarly medicalised account of spiritual experience (although generally more inclined towards accepting supernatural agency in various forms), see The Journal of Richard Norwood, with introductions by Wesley Frank Craven and Walter B. Hayward (New York: Scholars' Facsimiles \& Reprints, 1945), pp. 26, 91-92, 95-96, 103-104, and Henry Jessey, The Exceeding Riches of Grace Advanced [...] in Mris Sarah Wight (London: 1647).
} 
the sweetness of it' and 'fill my belly with its delicates, lest I should die before I had my desire'.28

Such a reconstitution of the medical ordering of body and mind (or the 'outward man' and conscience) is also evident in Bunyan's relation of his 'inclining to a Consumption', occurring at the end of the narrative. Although he suffers from 'wandrings' of the heart and a sickness of 'my inward man' as a result, there is little sense of the spiritual temptations and Scriptural voicings he experiences being attributable to bodily illness alone. Rather, for Bunyan such physical debility can only intensify rather than explain away any subsequent spiritual infirmity: the feeling of 'some weakness to seiz my outward man', he writes, merely 'made still the other affliction the more heavy and uncomfortable', and on being reassured by Scripture he becomes 'both well in mind and body at once'. ${ }^{29}$ In this way, Bunyan's presentation of spiritual life has far more in common with the more uncompromising (and indeed radical) spiritual autobiographers of the seventeenth century, like Anna Trapnel and George Fox who similarly refuse (unlike Trosse) to internalise their experiences as evidence of anything other than a spiritual truth..$^{30}$ Although often more extreme in their revelationary accounts than Bunyan's, Grace Abounding nevertheless shares with such writings a radicalism in terms of both its representation of experience as well as in its refusal to conform to anything other than a spiritual understanding of it.

With such implications in mind, one may wonder whether twentieth-century readings of Grace Abounding as a document of mental breakdown may not be centred in an equally reactionary association of religious experience with a 'radicalism' often identified as a threat to socio-political order. By approaching Grace Abounding psychoanalytically, are not contemporary commentators and readers simply continuing the process of the objectification, classification, and marginalisation of Bunyan as a fanatical individual, a reading that reflects distinct cultural and political issues in how we understand religious experience in general?

\footnotetext{
28 Bunyan, Grace Abounding, pp. 10-11.

29 Bunyan, Grace Abounding, pp. 79-82.

${ }^{30}$ See, for example, The Journal of George Fox, pp. 700-701, and Anna Trapnel, A Legacy for Saints; Being Several Experiences of the Dealings of God with Anna Trapnel (London: 1654), pp. 7-8, 14. Trapnel, for instance, relates how 'the Glory of God appeared to her' amongst other 'Raptures' and escstasies, voices and visions, 'in a time of sore sickness' (pp. 21-39).
} 
Given that such interpretations have been predominant since Bunyan's own time, moreover, should we not be wary of inheriting an approach that has its roots in the specific and controversial political context of Nonconformity in Restoration England in any case? Clearly, it seems inadequate in itself simply to talk of the failings of Freudian or psychological interpretations when reading Grace Abounding. What is at stake is far more than linguistic substitution or translation. Bunyan, along with many other late seventeenth-century Nonconformists, was clearly sensitive to a growing psychological and medical discourse the rationalism of which not only competed with his own spiritual language and profession but which could also denounce him as insane. We should be wary of approaching Bunyan's writings from a Jamesian perspective, therefore, if only because it seems to be guilty of voicing the kind of accusations Bunyan himself endeavoured to battle against in his own time and which strove to discredit the efficacy and the 'truth' of the very experience Grace Abounding witnesses.

In its attempt to categorise, confine, and contain religious experience and its radical associations, therefore, it would seem imperative for any understanding of Grace Abounding to begin from a perspective quite different from that of the psychological. One important way of doing so is to reconsider the nature and function of conversion narratives in general, particularly as one of the most obvious flaws in psychological interpretations of Grace Abounding lies in a basic malpractice in reading: there is often no distinction recognised between the conversion narrative and the actual conversion event, and so the veracity of the conversion occurring as the narrative depicts is never questioned. ${ }^{31}$ With the conversion and

31 Peter G. Stromberg's article, 'Ideological Language in the Transformation of Identity', American Anthropologist, 92 (1990), 42-57, is most enlightening on this subject. He makes the point that all too often conversion accounts are taken unproblematically to represent the conversion event whereas it simply cannot be assumed 'that the events narrated in the conversion story simply happened the way the narrator claimed' because any conversion narrative comprises not only multiple conversion events but the convert's 'immediate and subsequent reactions to those events'. Stromberg suggests, moreover, that it is through the re-telling of the original experience that the convert can address 'emotional conflicts' that persist beyond the conversion experience and which reveal themselves in the narrative itself, through 'stylistic features' that betray 'the emotional ambivalence that presumably animated the original conversion event.' Such features include those characteristic of Grace Abounding: 'dysfluencies' in the narrative and 'nonintentional' or 'deniable communications' (expressing 'intentions and desires that the speaker may wish to deny'). Stromberg thus provides a cogent explanation of the kind of narrative anomalies many find as evident in Grace Abounding, 
its account being taken as synonymous, however, it is not only medicalised readings of Bunyan's spiritual autobiography that are guilty of misreadings. Indeed, taking the text at face value has lead many critics into accepting Grace Abounding as a reliable source of biographical and psychological truths which, as Greaves puts it, the text simply cannot bear. ${ }^{32}$

This is a particularly apt point to recognise given that the aim of Grace Abounding, as with all of Bunyan's texts, is strictly and wholly pastoral and doctrinal and that, as such, this is where any reading of this text should really begin. As Margaret Thickstun and Rebecca Beal have illustrated, from the 'Preface' (if not the title) onwards Grace Abounding signals itself quite consciously as a text modelled upon the Pauline paradigm not of conversion (it is far from that) but of the doctrine of salvation by faith and grace alone. ${ }^{33}$ Saturated with references to Biblical 'Deliverance', therefore, the Preface offers Grace Abounding as 'a Relation of the work of God upon my Soul' showing how its author 'lay so long at Sinai' (that is, under the Law) and how amidst agonies of legalistic temptation and despair 'out of them all the Lord delivered me' and through 'the great grace that God extended to such a Wretch as I.' While the language of struggle, warfare, and combat here emphasises that Bunyan's conversion was indeed a strenuous spiritual liberation 'from the land of Egypt', the narrative's aim essentially is to comfort and to teach. In a time of great political and possibly spiritual darkness for those of the Bedford Church, the message of Grace Abounding comes in an exhortation both to 'remember 'twas thus with your father', as well as to, 'commune with your heart [...] and leave no comer therein unsearched', so that the 'treasure' of faith 'hid' therein can be

discussing religious conversion in terms of language, identity, and gradual transformation, without making conventional psychological judgements about religious experience.

32 For examples of more strictly psychological studies of religious conversion, see Howard M. Feinstein, 'The Heart Prepared: A Comparative Study of Puritan Theology and Psychoanalysis', American Quarterly, 22 (1970), 166-176; Murray G. Murphey, 'The Psychodynamics of Puritan Conversion', American Quarterly, 31 (1979), 135-147; J. H. Ellens, 'The Psychodynamics of Christian Conversion', Journal of Psychology and Christianity, 3 (1984), 29-36; J. Steve Rhodes, 'Conversion as Crisis and Process: A Comparison of Two Models', Joumal of Psychology and Christianity, 5 (1986), 20-27; Rayman J. Wootton and David F. Allen, 'Dramatic Religious Conversion and Schizophrenic Decompensation', Joumal of Religion and Health, 22 (1983), 212-220. For a useful summary of recent psychological studies on conversion, see Scott Thumma, 'Seeking to be Converted: An Examination of Recent Conversion Studies and Theories', Pastoral Psychology, 39 (1991), $185-194$. Charles Lloyd Cohen offers a detailed criticism of some of these psychological assessments of Puritan conversion in God's Caress: The Psychology of Puritan Religious Experience (New York and Oxford: Oxford University Press, 1986), pp. 14-15, 17-22.

33 Margaret Olofson Thickstun, 'The Preface to Bunyan's Grace Abounding as Pauline Epistle', Notes and Queries, n.s. 32 (1985), 180-182; Rebecca S. Beal, 'Grace Abounding to the Chief of Sinners: John Bunyan's Pauline Epistle', SEL, 21 (1981), 147-160. 
discovered, recovered, or re-discovered, 'even the treasure of your first and second experience of the grace of God toward you.' 34

Despite the somewhat (and perhaps deliberately) obfuscatory Biblical allusions to Law, grace, and experience throughout the 'Preface' (references to be understood by the faithful alone, it seems, for the 'Philistians understand me not', Bunyan asserts), the doctrinal aim of Grace Abounding is clear: it is to provide instruction in the ways of God's grace for anyone who has 'sinned against the light', been 'tempted to blaspheme', or is 'down in despair'. It is the purpose of Grace Abounding to offer assurance and renew the reader's faith at the times when 'you think God fights against you, or if heaven is hid from your eyes.' 35 But while it is easy to recognise that this aim provides the underlying pastoral scheme of the work, it is more important (as well as more useful) to show how reading the narrative specifically in terms of Bunyan's doctrine of Law and grace can enable us to understand more clearly the nature of Grace Abounding both in terms of its apparently erratic textual construction and the episodes which are often explained away as symptomatic of psychosis.

Structurally, for instance, the diffuse, repetitive, and labyrinthine texture of Grace Abounding often leads to a somewhat confused response from readers and critics when its doctrinal context is ignored. One might conclude that Bunyan's conversion was so psychologically traumatic that it renders Bunyan's narrative control in recounting it largely impotent. In turn, this can lead to the rather negative conclusion that in Grace Abounding the integrity of Bunyan's storytelling gives way to the over-riding and unshakeable intensity of experiences he has yet to recover from fully. ${ }^{36}$ How else can one account for the fact that there is little sense of grace abounding in Grace Abounding, that Bunyan's conversion seems to provide no final transformation, no release from the recurring doubts and temptations that assail him even as a minister preaching from the pulpit? Indeed, it would seem that only from a doctrinal perspective can such a question be answered adequately and, not surprisingly, the more theologically-oriented readings of Bunyan's text have been keen to show this.

\footnotetext{
34 Bunyan, Grace Abounding, p. 3.

35 Bunyan, Grace Abounding, pp. 1, 3.

36 Roger Sharrock, for example, suggests that when Bunyan wrote Grace Abounding 'he was still too near to the terrors, too respectful of every detail of the religious experience, to mould them with greater freedom': 'Spiritual Autobiography in The Pilgrim's Progress', RES, 24 (1948), 102-120 (p. 113).
} 
Grace Abounding's uncertain closure and repetitive structure is, for instance, commonly explained in terms of seventeenth-century Calvinism's will-to-uncertainty. Assurance of salvation is not experienced in Bunyan's account, many argue, because this can never be achieved by any believer this side of Judgement, conversion for a Calvinist being a 'progress' which 'has no end on earth.' ${ }^{37}$ Thus, the irresolution that characterises so much of Grace Abounding can be seen as reflecting the fact that for Bunyan 'the proper condition of the believer is one of confiding uncertainty', for whom periods of doubt and temptation will inevitably recur. ${ }^{38}$ As a consequence, there are undoubtedly 'configurations of spiritual progress in Grace Abounding', as Vincent Newey has noted, 'but no such closure in "liberation" or "certitude".' Nor could there be, realistically, if we regard Grace Abounding as following a recognised pattern of justification, sanctification, and perseverance in which the elect's recurring lapses and periods of doubt merely underscore 'the fact that sanctification, unlike justification, was a life-long process that was never completed in this life.' 39

While such a general understanding of the doctrinal structure of conversion for seventeenth-century Calvinists goes some way in explaining, at least in the broadest terms, some of the textual and narrative complexities of Grace Abounding, it must be noted that there are certain limitations in viewing Bunyan's text through such a large 'theological lens'. It is because of this kind of reading, for example, that Grace Abounding seems to have become categorised as hardly distinguishable from the plethora of spiritual autobiographies published in the seventeenth century when, in many ways, it is clearly unique: although many spiritual autobiographies reveal Bunyan's raisings up and castings down to be typical of Calvinist conversion narratives, there are few (if any) that can compare with either Grace Abounding's intensity, detail, and narrative virtuosity or its explicit and overriding doctrinal and pastoral

${ }^{37}$ Henri Talon, John Bunyan: The Man and his Works, trans. by Barbara Wall (London: Rockliff Publishing, 1951; originally pub. in French, 1948), p. 30.

${ }^{38}$ Felicity A. Nussbaum, “ "By These Words I was Sustained": Bunyan's Grace Abounding', ELH, 49 (1982), 18-34 (p. 21). For similar comments on the condition of uncertainty of salvation for Bunyan see Dean Ebner, Autobiography in Seventeenth Century England: Theology and the Self (The Hague: Mouton Press, 1971), p. 46; Hawkins, 'Double Conversion Narrative', p. 273.

39 Newey, 'With The Eyes of My Understanding', pp. 197-198; Richard Greaves, 'The Present State of Historical Scholarship', in Bunyan in England and Abroad, p. 31. 
purpose..$^{40}$ More importantly, such broad theological understandings of the text frequently miss the crucial and specific doctrinal point which Bunyan is at pains to make within Grace Abounding: that salvation must be through grace and faith alone. Indeed, in many 'doctrinal' readings there is often little sense of any understanding of Bunyan's concept of grace at all.

Examples of this, for instance, lie even in the writings of commentators as notable and erudite as Henri Talon. While rightly commenting that through perseverance the convert must fight the temptations and doubts that prevail after conversion, there seems to be a residual disappointment in the fact that transformation is not effected completely. Talon thus views the continuing temptations in Grace Abounding as symptomatic of the fact that 'Bunyan, searching for an impossible perfection, was always dissatisfied.' ${ }^{1}$ Similarly, although more elaborately, Felicity Nussbaum has suggested that the 'autobiographical process' of Grace Abounding as a whole centres upon 'the action of the protagonist's straining toward an ideal state', a 'hopedfor' self which Bunyan the protagonist (as opposed to Bunyan the narrator) attempts to become but is unable to achieve: 'He enters the space of conversion and claims his property', she writes, 'but he is unable to affect its permanence.' 42

For anyone acquainted with the nature of Bunyan's theology of grace, however, such conclusions are significantly mistaken. The concept of a transformation to saintly perfection through conversion into grace is, as we have seen in the last chapter, clearly anathema to Bunyan's theological thinking as a whole. Because grace for Bunyan is no divine endowment or supernatural gift that will protect the believer from sin, the whole concept of sanctification as synonymous with moral perfection is simply too legalistic to be compatible with Bunyan's doctrine of faith at all. For Bunyan, conversion into grace involves an understanding and

\footnotetext{
${ }^{40}$ Compare Grace Abounding, for example, with the narratives of conversion and experience collected in Charles Doe's, A Collection of Experience of the Work of Grace (London: 1700), or Vavasor Powell's Spiritual Experiences of Sundry Beleevers (London: 1653) which, in their brevity alone, reveal that Bunyan's narrative is far more than just a lengthened version of the kind of confession of faith required for entry into a Church of visible saints, as some commentators suggest. See, for example, Michael A. Mullett, John Bunyan in Context (Keele: Keele University Press, 1996), p. 45. For a more complex account of such matters, see Roger Pooley, 'Spiritual Experience and Spiritual Autobiography: Some Contexts for Grace Abounding', Baptist Quarterly, 32 (1988), 393-402. Moreover, one need only compare Grace Abounding with the more lengthy and detailed spiritual autobiographies, such as those by George Fox or Richard Baxter, to realise that it is the doctrinal and spiritual rather than the autobiographical aspect which governs the composition of Bunyan's text.

41 Talon, John Bunyan: The Man and his Works, p. 21.

${ }^{42}$ Nussbaum, 'By These Words I was Sustained', pp. 28, 32.
} 
acceptance of the fact that moral righteousness for carnal man is impossible, a comprehension gained only through the kind of experiential struggle with the Law, conviction of sin, and faith in Christ as the sole mediator between man and divine justice that Grace Abounding both describes and prescribes. Such grace, far from rendering any perfection to the convert, quite simply offers comfort to the believer who, in the knowledge that his own righteousness is essentially corrupt and worthy only of damnation, can find himself saved nonetheless. Hence, the most crucial passages in Bunyan's spiritual progress throughout Grace Abounding are, quite obviously, those in which he grows in his understanding of salvation by grace alone: 'I saw that I wanted a perfect righteousness to present me without fault before God', he writes after a long period of ignorance, 'and that this righteousness was nowhere to be found but in the person of Jesus Christ.' 43

The import of bringing the details of Bunyan's theology to his own conversion narrative cannot be underestimated. It is only through a more full understanding of Bunyan's theology that we can begin to recognise Grace Abounding as representing a journey not of moral perfection towards an 'idealized state' but of self-acceptance and the accommodation of one's sinfulness through faith in Christ as sole source of redemption: conversion for Bunyan is the long sought-after heart-felt experience that 'the right way' for the 'guilt of conscience' to be 'taken off' is by the 'Blood of Christ' alone. ${ }^{44}$ Consequently, Bunyan's continuing sufferance of temptations, doubts, and blasphemies attests to the fact that conversion for him does not, cannot banish sin within him (although it is only through the doctrine of perseverance, the believer's continuing renewal of grace and faith, that sanctification can progress at all). In turn, such understanding enables him to come to terms with innate sinfulness by accepting that his righteousness lies not within himself but in Christ. Hence, after the devastating period of backsliding that follows Bunyan's conversion in Grace Abounding (his conviction that he has sold Christ and 'let him go' taking up more than half the narrative), Bunyan enjoys his second experience of grace only when finally he sees 'that it was not my good frame of heart that made

\footnotetext{
43 Bunyan, Grace Abounding, p. 27.

44 Bunyan, Grace Abounding, pp. 28, 39-40.
} 
my Righteousness better, nor my bad frame that made my Righteousness worse: for my Righteousness was Jesus Christ himself' ${ }^{45}$

Far from being a moral guidebook about an idealised sanctification or, as Nussbaum asserts, a text about a self being united to the self through 'grace abounding' (whatever this might mean), Bunyan's account is, rather, a carefully constructed narrative delineating the particular process of spiritual conversion in faith from Law to grace. ${ }^{46}$ Indeed, one need only compare Grace Abounding with Bunyan's tract Saved By Grace (1676), in which he describes 'the Carriage' of 'sinners to God', to see just how doctrinally absorbed Bunyan's conversion narrative is. Grace Abounding clearly follows a strict pattern of how, in converting into the true faith, the believer must first experience a period of legal righteousness followed by a conviction of sin, with more doubts and misgivings which are in turn followed by a "spirit of Adoption'. With even more temptations to follow, the kind of raisings up and castings down that Bunyan describes in Grace Abounding would seem to be par for the doctrinal course, according to Saved By Grace, if lasting faith in Christ's righteousness is to be achieved by any believer. Only 'after all these Provocations', Bunyan writes, does God bring 'sealing grace and pardon to the Conscience': 'Now the Soul knows that it is to eat Promises', Bunyan asserts, '[n]ow it hath a Calm and Sunshine'. ${ }^{47}$

With such a scheme in mind, therefore, episodes such as Bunyan's early outward 'Conversion' (occurring soon after his first marriage) can be read as implicitly representative of a period of legal righteousness after what has been a brief and largely idolatrous love of Church religion. ${ }^{48}$ Hence, Bunyan confesses not only to how the 'Name', 'Garb', and 'Work' of 'Ministers of God' 'intoxicate' and 'bewitch' him at one point but, more importantly, to his ignorance in setting morality and religious sociability before saving faith: 'I loved to be talked of as one that was truly Godly', he admits. It is precisely from such a damning legalism ('I

\footnotetext{
45 Bunyan, Grace Abounding, p. 72.

46 Nussbaum, 'By These Words I was Sustained', pp. 20-21, 28-29, $31-32$ (p. 32). The extent of Nussbaum's doctrinally mistaken reading of Grace Abounding can be gauged, moreover, by her assertion that Bunyan's is a 'private individual account of conversion which competes with the Bible as a substitute text', and which aims 'to replace the Scriptures as a devotional guide' (p. 22).

47 John Bunyan, Saved By Grace (1676), in The Miscellaneous Works of John Bunyan VIII, ed. by Richard L. Greaves (Oxford: Clarendon Press, 1979), pp. 202-205, 206.

48 Bunyan, Grace Abounding, pp. 9, 12-13.
} 
was nothing but a poor painted Hypocrite', he writes) that Bunyan is saved by his conversion into grace, a process which begins with his meeting the Bedford women and which does not conclude until, having suffered doubts, conviction of sin, despair, and various other temptations and delusions, Bunyan at last achieves an effectual comprehension of redemption: though 'sometimes I should lie under great guilt for sin, even crushed to the ground therewith', Bunyan asserts,

then the Lord would shew me the death of Christ, yea and so sprinkle my Conscience with his Blood, that I should find, and that before I was aware, that in that Conscience where but just now did reign and rage the Law, even there would rest and abide the Peace and Love of God thorow. ${ }^{49}$

Bunyan's language here, at the moment of his confirmation of saving faith in Christ, seems to approach something intensely mystical, especially when he refers to such conviction subsequently as 'evidence, as I thought, of my salvation from Heaven, with many golden Seals thereon, all hanging in my sight'. But while this experience certainly prompts a desire for intense mystical union (Bunyan says that, at this point, he longed for the time 'that I might for ever be inflamed with the sight, and joy, and communion' of Christ), we should not let his rhapsodic, ecstatic prose cloud our understanding of the doctrinal point here. In clear, covenant terms Bunyan's conversion has been effected as a shift to grace from the Law, a fact confirmed in his subsequent reading of Luther's 'comment on the Galathians' which shows to Bunyan that 'the law of Moses, as well as the Devil, Death, and Hell' has 'a very great hand' in afflicting converts with doubt and temptation. ${ }^{50}$

Although we might assume that Bunyan would be freed effectively from the bondage of the Law from this point onwards, the rest of the text illustrates that legalistic doubt is always to present an ongoing struggle for any convert. Bunyan's backsliding, his temptation to sell Christ and fear of having committed the unpardonable sin, is thus frequently characterised by a legalism the desperation of which is often reinforced through the imaging forth of Bunyan being subsumed by the symbolism of divine justice: haunted by the Scriptural reference to Esau, Bunyan comes to feel that his 'soul did hang as in a pair of Scales again, sometimes up,

49 Bunyan, Grace Abounding, p. 40.

50 Bunyan, Grace Abounding, pp. 40-41. 
and sometimes down, now in peace, and anon again in terror.' 51 It is hardly surprising, then, that Bunyan is to be found tortured by the ratiocinations of his 'Tempter' in a way that exploits any weakness towards a predominating legalism: 'because I did not obey a temptation of the Devil', he writes, it was 'as if I had broken the Law of God indeed.'52 As a consequence, the most dramatic of all of Bunyan's struggles in Grace Abounding, over his conviction that he has 'Let him go if he will!', becomes nothing less than an epic struggle specifically between the Word of Law and of grace in Bunyan's soul. When Bunyan's conviction that, like Esau, he has sold his spiritual birthright and disinherited himself from salvation finally gives way with 'peace and joy' to a faith that grace is indeed 'sufficient', the result is not only a jubilant spiritual liberation from terror and despair but an instant reappraisal of the entire story of his backsliding as a parable of covenant theology: 'This was a wonderment to me', he confesses,

yet truly I am apt to think it was of God, for the Word of the Law and Wrath must give place to the Word of Life and Grace; because, though the Word of Condemnation be glorious, yet the Word of Life and Salvation, doth far exceed in glory. ${ }^{53}$

Bunyan's period of backsliding thus effects two doctrinal points central to the theological scheme of Grace Abounding. One is of the basic comfort and accommodation grace provides for the believing sinner: 'Here is grace!', he exclaims in Saved By Grace, 'So many times as the soul backslides, so many times God brings him again [...], he renews his Pardons, and multiplies them.' While great sins procure great grace, backsliding will procure greater grace for anyone willing to accept it. ${ }^{54}$ Central to this, however, lies the broader issue

\footnotetext{
51 Bunyan, Grace Abounding, p. 65.

52 Bunyan, Grace Abounding, p. 43.

53 Bunyan, Grace Abounding, p. 67.

54 Bunyan, Saved By Grace, p. 208. For further discussions of backsliding by Bunyan, see Come, \& Welcome, to Jesus Christ (1678), in Miscellaneous Works VIII, pp. 304-309, and Christ a Compleat Saviour (1692), in The Miscellaneous Works of John Bunyan XIII, ed. by W. R. Owens (Oxford: Clarendon Press, 1994), pp. 299. 303. To recognise Bunyan's experience as one of backsliding is important, moreover, because it helps solve a particular disagreement over the doctrinal structure of Grace Abounding. Noting that attempts to pin-point the conversion moment in Grace Abounding are futile, as 'there is no such definitive turning point', Anne Hawkins suggests that Bunyan's conversion is actually 'dyadic' in structure: 'there are two conversion events', she asserts, Bunyan's experience being one of crisis and lysis, both sudden and gradual change ('The DoubleConversion Narrative in Bunyan's Grace Abounding', pp. 263-264). However, Richard Greaves has objected to this 'pattern of conversion, relapse, and conversion' because ' $[t]$ heologically, the doctrines of election and perseverance to which Bunyan subscribed, as a strict Calvinist, rendered the notion of reconversion impossible' ('John Bunyan: The Present State of Historical Scholarship', in Bunyan in England and Abroad, p. 31). What Hawkins and Greaves both fail to note, however, is that Grace Abounding records both Bunyan's conversion and backsliding. With this in mind, Hawkins is absolutely right to note the dyadic structure of the text but mistakenly considers the backsliding part as Bunyan's gradual (as opposed to crisis) conversion. Equally, while
} 
of Law and grace as a whole: the transfiguration of Bunyan's faith after backsliding is only effected by a realisation that, with a clever covenantal typologising of the Biblical transfiguration itself, 'Moses and Elias must both vanish, and leave Christ and his Saints alone.' 55 Along with such a seeing with new eyes of understanding, moreover, the converting Bunyan has his renewed faith confirmed further with a consideration of the Scriptural texts that provide the foundations for a doctrine of grace at the heart of which lie comfort and assurance. The emphasis from this point onwards is not upon Scripture that locks Bunyan out of the 'Promises' but that welcomes and heartens the sinner. It is only now that the Scripture John 6 . 37, 'And him that cometh to me I will no wise cast out' (a text, as we have seen in Come, \& Welcome, so central to Bunyan's entire theological thinking), did 'most sweetly visit my soul' and with lasting 'sweetness'. In the same way, the 'chains' of despair 'fall of my Legs indeed', Bunyan asserts, when the 'sentence' 'Thy righteousness is in Heaven' experientially falls upon his soul. 56

It becomes clear, then, that Grace Abounding is nothing less than an ordo salutis not merely considered but actually lived, a record charting the painful progress of Bunyan towards his understanding of grace. Consequently, it is only at the end of the narrative, amidst further afflictions of the conscience, that Bunyan is 'made to understand' not only that 'great sins do draw out great grace' but that 'God could justifie a sinner at any time; it was but looking upon Christ', he writes, 'and imputing of his benefits to us, and the work was forthwith done.'57 By revealing that Bunyan has learned about the most fundamental doctrines of his theology (justification by imputed righteousness, innate corruption, salvation by grace and not the Law, and looking to Christ alone) through torturous, painful struggle, Bunyan's qualifications both

\footnotetext{
Greaves is undoubtedly correct in his doctrinal point about double-conversion, what Bunyan says about backsliding reveals that these commentators are simultaneously both right and wrong in their suppositions about Grace Abounding. The backsliding man who has had for a second time 'a Proof of God's goodness in his Christ unto him' has, Bunyan notes, 'been Converted twice, fetcht from the World and from the Devil, and from himself twice. Oh Grace! and has been made to know the stability of God's Covenant, the unchangeableness of God's Mind, the sure and lasting Truth of his Promise in Christ, and the sufficiency of the Merits of Christ, over and over' (Christ a Compleat Saviour, pp. 301-302).

55 Bunyan, Grace Abounding, p. 67.

56 Bunyan, Grace Abounding, pp. 67, 72.

57 Bunyan, Grace Abounding, pp. 78, 80.
} 
to preach and minister doctrine to his Church are thus established as unquestionable. 58 Moreover, while showing that conversion can be a circuitous and arduous path full of wrong turns and self-encirclements (with a lack of linearity that betrays the apparent teleology of Bunyan's Mapp, for instance), Grace Abounding is a text that, saturated entirely by Bunyan's covenant theology, has both an explicit doctrinal structure and a most definite pastoral aim. As Bunyan announces in the 'Preface', the recounting of his experiences is to be read 'for the further edifying and building up in Faith and Holiness' of his Church while he, as an imprisoned preacher, is unable in person 'to perform that duty that doth from God' lie upon him. As a relation of Bunyan's 'Dealings with God', Grace Abounding is (quite literally), then, framed by the explicit desire to 'maintain the house of God' using 'the spoils won' in his spiritual 'Battel'.59

Reading the text as a doctrinal exposition of Law and grace (and of the dangers of mistaking the one source of righteousness for the other) can, however, do more than clarify the general structure of Grace Abounding. Certain episodes in Bunyan's experience in particular insist upon a doctrinal, and specifically covenantal, interpretation without which they can be understood only as meaningless, absurd, or (even worse) indicative of a predominating psychosis. The infamous bell-ringing episode of Grace Abounding, in which Bunyan's desire to resume his delight in bell-ringing is thwarted by what seems to be a deeply irrational fear that 'one of the Bells' (and then the entire 'Steeple') should fall upon him, is a case in point. Dealt with in strict psychological terms by most commentators, this episode confirms for many readers Bunyan's unstable and obsessive mental state as a convert-to-be: Bunyan's 'morbid terror of bell-ringing' initiates 'a neurotic condition' which brings the reader very close 'to the vagaries of the human mind and the psychological eccentricities of individual experience', the 'oddness' of which can at least offer the reader 'the best guarantee of their authenticity' ${ }^{60}$

\footnotetext{
58 'The returning backslider', Bunyan notes, 'is a rare Man, a Man of worth and intelligence, a Man to whom the Men of the World should flock, and of whom they should learn to fear the Lord God. He is also a Man of whom the Saints should receive both caution, counsel and strength in their present standing; and that should, by his harms, learn to serve the Lord with fear, and to rejoyce with trembling': he 'can tell strange Stories, and yet such as are very true' (Christ a Compleat Saviour, pp. 301-303).

59 Bunyan, Grace Abounding, pp. 1, 101.

60 Sharrock, John Bunyan, pp. 60-61; Monica Furlong, Puritan's Progress, p. 37; James Sutherland, Restoration Literature 1660-1700: Dryden, Bunyan, Pepys (Oxford: Clarendon Press, 1969; repr. 1990), pp. 325-326. For a more outrageous psychologising of this episode see Jack Lindsay, John Bunyan: Maker of
} 
Such uncharitable, medicalised readings of Bunyan's terror of bell-ringing can (and should) be avoided, however, if we view the episode within the context of the doctrinal structure of Grace Abounding as a whole. This episode occurs, for example, at the time when, prior to any initiation into the language or concept of grace, Bunyan thought he 'pleased God as well as any man in England'. In other words, Bunyan's obsessive fear of bell-ringing occurs at a time of spiritual ignorance during which he effected 'some outward Reformation', his 'Conversion' into which being little more than an attempt to achieve righteousness through adherence to the Law: he confesses to having 'set the Commandments before me for my way to Heaven: which Commandments I also did strive to keep'. Bunyan's fears over bell-ringing are thus wholly motivated not by any innate psychological neurosis but by a legalism which, Bunyan is at pains to emphasise, can only lead to such obsessiveness and terror in its demands for perfection from the sinner. ${ }^{61}$ Bunyan is keen to impress upon the reader the ridiculousness of his fears at this point precisely because living under the Law, as he illustrates throughout tracts like The Doctrine of Law and Grace Unfolded, can only lead to terrible and painful distress. Indeed, activities such as bell-ringing and dancing, for anyone whose conscience is afflicted by the tyranny of a legalistic belief, become temptations of unimaginable and obscene proportions. ${ }^{62}$

Bunyan's point in relating this episode (which was not added until the second or at least third edition of Grace Abounding) is thus apparent: it represents as clearly as possible a warning about the very real dangers legalism presents to the ignorant not only within Bunyan's theological scheme of damnation and salvation but to the very well-being of any sinner tender of conscience. Bunyan makes his point more effective, however, by having his prose at this

Myths (London: Methuen, 1937; repr. 1969), p. 55. Michael Mullett, on the other hand, views this experience as indicative of a 'religious melancholia' compounded by Bunyan's 'abandonment of a set of taxing and gregarious exercises': 'A big and active man', Mullett writes, 'Bunyan was used to regular outdoor exercise, and probably needed the release afforded by strenuous physical activity' (such as bell-ringing) to help keep him healthy in mind and body (John Bunyan In Context, p. 27). For similar conclusions see Furlong, Puritan's Progress, p. 158.

61 Cohen notes that being under the Law inculcates such a crisis because it presents a 'double-bind communication' in which the sinner is commanded to obey the Law while simultaneously being told that this is in itself impossible: 'Repeated double-bind communications', he states, 'can elicit neurotic and psychotic behaviour' (God's Caress, p. 62).

62 For a useful discussion of sin and legalism in Grace Abounding, see Dayton Haskin, 'Bunyan, Luther, and the Struggle with Belatedness in Grace Abounding', University of Toronto Quarterly, 50 (1980-81), $300-313$ (p. 306). 
moment enact for the reader the psychological effect of being seduced by the idea of living up to the Law. Bunyan begins, for instance, by saying that before his 'outward Reformation' he 'had taken much delight in ringing' but that because, as someone 'proud of my Godliness' and 'Conscience', 'I thought that such a practice was but vain, and therefore forced myself to leave it'. Before the declaration of this renunciation is even completed, however, the sentence sways to a contrary desire to give in to the temptation - 'yet my mind hanckered'. Compromising his 'Godliness' with the prospect of only spectating ('though I durst not ring', he says) simply initiates a further cascade of clauses, counter clauses, and dramatic swings which, through an absurd, super-rationalist logic, drive Bunyan further and further from the Church tower. Forcing himself initially to stay and 'look on still', he quickly suffers a paranoiac uneasiness about one of the bells falling on him. Rationally considering this, he nevertheless calculates the trajectory of the bell and concludes that he will be safe beneath a 'Beam' until, fearful still, he shifts again to the door. With each step to safety ironically causing Bunyan's terror to escalate further, even standing by the door of the Steeple provides no escape: he 'was forced to fly, for fear it should fall upon my head.' Consequently, the whole episode operates upon a principle of reversed reasoning: with the prose itself progressing only in tentative movements forward, Bunyan's super-rational desire for security takes him nowhere but into further panic and fear. Here, with every step to safety branching into further alternatives of danger and anxiety, and with a damning and remorseless logic of its own too, there seems no escape for Bunyan who, under the tyranny of the Law, begins to feel that the world is conspiratorially collapsing around him.

Clearly, the bell-ringing episode should be recognised as something of a tour de force in Bunyan's narrative style. As a literary rendering of legalistic terror it is nothing less than a supremely effective (and affective) piece of prose, an interior monologue which communicates through its very construction the circuitous and torturous syllogisms that the tender conscience is subject to under the Law. As an unacknowledged parable of the dangers of legalistic moralism for the soul, therefore, Bunyan's doctrinal point aptly strikes home: there is, quite conspicuously, no spiritual progress in this episode at all. Indeed, as a distinct experience of non-progression (the further Bunyan asserts his safety the more terrified he becomes), this is a 
signal lesson for the reader about the folly of seeking soterial assurance and security in an impossible legal righteousness. Bunyan's phobia of the Church steeple is thus but a carefully dramatised example of how the conscience can so easily become 'entangled by the Law', especially because '[r]easoning suiteth much with the Law': 'Oh, the Holiness of the Law!', Bunyan exclaims, 'It mightily swayeth with Reason, when Man addicteth himself to Religion', and it 'strengthneth our Blindness, and bindeth the Vail more fast about the Face of our Souls.' 63

It thus becomes clear why Bunyan chooses to tell this important (and far from psychotic) lesson again in the allegorical form of The Pilgrim's Progress (Christian experiencing similar terrors beneath that most awesome symbol of legalism, Mount Sinai). However, a doctrinal understanding of Grace Abounding according to Law and grace not only helps us appreciate the nature of Bunyan's experience as different from a merely medical condition but, importantly, directs us away from theological readings which are both misleading and inaccurate. It is a commonplace, for example, to speak of Grace Abounding as being of a tradition of spiritual autobiography explicitly concerned with Calvinist issues of election and predestination. Despite the text focusing specifically on the doctrine of Law and grace, therefore, Grace Abounding is often read as a text exemplary of the kind of dangerous and fanatical introspection that the infamous Calvinist cry, 'How do I know I am saved?', inculcates in the believer. With the keynote of Grace Abounding being for many readers one of overt soteriological anxiety ('One has only to look at Grace Abounding', Stuart Sim asserts, 'to see the degree of psychological confusion belief in election and predestination could create within a sensitive individual'), it is hardly surprising that such doctrine appears unmistakably abhorrent. ${ }^{64}$ Calvinist introspection is, for instance, often viewed as inducing nothing less than schizophrenia in its subjects, Grace Abounding in particular depicting a divided self 'morally split and bifurcated', with 'the alternation of elect and reprobate selves, the unbearable split

63 John Bunyan, Of Justification by an Imputed Righteousness (1692), in The Miscellaneous Works of John Bunyan XII, ed. by W. R. Owens (Oxford: Clarendon Press, 1994), pp. 323-324.

${ }^{64}$ Stuart Sim, Negotiations With Paradox: Narrative Practice and Narrative Form in Bunyan and Defoe (London: Harvester Wheatsheaf, 1990), p. 24. 
between exclusive identities' becoming 'the theme of the narration and the source of its tension.' 65

Grace Abounding has thus come to exemplify par excellence a Calvinist theology that exacts a telling but all too stereotypical response from its convert. Forced to embrace 'the struggle of conflicting mental forces', the agonies Bunyan undergoes in Grace Abounding are attributable to a Calvinism that procures nothing less than an 'obsession with the enemy within': 'Convinced that he was possessed by evil', Paul Delany writes, the 'Calvinist' spiritual autobiographer

naturally clutched at some kind of reassurance within himself, since no external observances - such as good works or sacraments - could avail a whit towards his salvation. His normal reaction was to embark on a complicated, even devious process of rationalization which always seemed to culminate in a semimystical assurance that $h e$, at least, was enrolled among the elect. ${ }^{66}$

Unfortunately, however, and as we have seen extensively in both this and the previous chapter, the doctrinal focus of Grace Abounding is, as with Bunyan's theology as a whole, far from explicitly concerned with matters of election and predestination (particularly when it comes to any devious rationalisation). In fact, with its focus on faith and not election, Grace Abounding is hardly concerned with the issue of predestination at all. Rather than introspective, syllogistic reasoning, what Bunyan is intent upon teaching the reader of Grace Abounding concerns not eternal decrees but, from a far more practical point of view, the dangers of spiritual ignorance in being under the Law and attempting to attain salvation through legalistic righteousness. It is to faith in Christ as the source of salvation that Grace Abounding repeatedly points its reader and yet, surprisingly, few readers and commentators seem to have recognised this basic doctrinal point. ${ }^{67}$

\footnotetext{
65 Evans, 'Notes on the Conversion of John Bunyan', pp. 177-178; John Stachniewski, The Persecutory Imagination: English Puritanism and the Literature of Despair (Oxford: Clarendon Press, 1991), p.132; Furlong, Puritan's Progress, pp. 37-38; Mullett, John Bunyan in Context, pp. 17, 20, 24. See also William James, Varieties of Religious Experience, pp. 183-185.

66 Paul Delany, British Autobiography in the Seventeenth Century (London: Routledge and Kegan Paul, 1969), p. 36.

${ }^{67}$ Michael Mullett, for example, seems surprised by the lack of predestinarian emphasis in Bunyan's conversion account: 'In Bunyan's discourse of the work and person of Christ during his recapitulation in Grace Abounding of his first crisis phase', Mullett writes, 'there is no explicit mention of election', the 'logical rigours of predestination' being 'supplanted by emotive perceptions of the life and death of Jesus' (John Bunyan in Context, p. 35).
} 
In terms of self-examination, moreover, it is pertinent to note that Bunyan is far from exhorting his reader to rationalise over whether he or she is elect or not. This stance is obvious from Bunyan's frequent discussions of the kind of self-examination he urges throughout his many tracts and sermons. Far from exhorting any interrogation of the self in terms of election or reprobation, Bunyan asserts more simply that 'Thou must believe unto Justification' and 'direct thy Soul to the Lord Jesus Christ': 'Get good acquaintance with the Covenant of Grace', he urges, 'consider thy own Perfections; I say, study how polluted thou art, even from the heart throughout: No Man hath an high esteem of the Lord Jesus, that is a stranger to his own sore.'68 While such self-assessment in terms of one's own insufficient righteousness without Christ encourages the believer to look to grace alone for salvation, Bunyan undoubtedly views any over-emphatic interest in election and predestination as obstructive in itself to the more important matters of faith, salvation, and conviction of $\sin$ in any case. 'Now men will tattle and prattle at a mad rate, about election and reprobation', Bunyan notes, 'and conclude, that because all are not elected, therefore God is to blame that any are damned'. However, it is simply more important, Bunyan states pragmatically, for sinners to see, 'that they are not damned because they were not elected, but because they sinned, and [...] gave way, and that willfully, knowingly, and desperately to Satan and his suggestions.' 69

With Bunyan's emphasis being upon justification by faith rather than election or reprobation, it is clear why many commentators since Coleridge have attempted to rescue Bunyan from the detrimental charge of Calvinism (so often associated with both radicalism and psychological terrorism) by re-nominating him as more Lutheran in doctrine. ${ }^{70}$ Such a realignment of Bunyan's doctrinal pedigree can be misleading, however, if only because

\footnotetext{
68 John Bunyan, The Advocateship of Jesus Christ (1688), in The Miscellaneous Works of John Bunyan XI, ed. by Richard L. Greaves (Oxford: Clarendon Press, 1985), pp. 188-189; Of Justification, pp. 335-336.

69 John Bunyan, The Resurrection of the Dead (1665) in The Miscellaneous Works of John Bunyan III, ed. by J. Sears McGee (Oxford: Clarendon Press, 1987), p. 282.

70 Coleridge, in response to Southey's denominating Bunyan as a Calvinist, writes: 'I have met with nothing in his writings [...] that is not much more characteristically Lutheran' (The Literary Remains of Samuel Taylor Coleridge, ed. by H. N. Coleridge (1836-39), III, 398, quoted in Richard Greaves, John Bunyan (Abingdon: The Sutton Courtenay Press, 1969), pp. 153-4). Greaves's excellent discussion of this matter concludes that on a 'Lutheran foundation Bunyan built an essentially Calvinist superstructure' (John Bunyan, p. 156). For similar remarks, see Talon, John Bunyan: The Man and his Works, p. 272; Mullett, John Bunyan in Context, p. 48; and especially Vera Camden, "Most Fit for a Wounded Conscience": The Place of Luther's "Commentary on Galatians' in Grace Abounding', Renaissance Quarterly, 50 (1997), 819-849.
} 
Bunyan's concerns over predestination, introspection, and knowledge of one's own election unmistakably and exactly mirror Calvin's own teachings in such matters. Indeed, understanding Calvin's own approach to such things can be more than useful in dispelling much of the myth about the apparent 'Calvinism' of Grace Abounding. While it is common, for example, for commentators to cite Calvin as encouraging a new sense of self through intense introspection, particularly as the opening pages of Institutes of Christian Religion present a notable exhortation to self-knowledge, Calvin's consideration of election, faith, and salvation often seems to have been misrepresented. ${ }^{71}$ As R. T. Kendall notes, Calvin abhorred and actively warned against the notion of introspection as to one's soterial status: 'For even if the reprobate experience "almost the same feelings as the elect",' Kendall asserts, 'Calvin warns against looking to one's feelings in any case. Indeed, the one thing above all else which Calvin emphasises is that we must never look to ourselves for assurance. 72

The reason for such an apparently un-Calvinist stance from Calvin is obvious. For Calvin, as for Bunyan, faith alone was assurance enough of salvation. According to him, Christ died for all men leaving the distinguishing mark between the elect and reprobate to be faith. ${ }^{73}$ This faith, as Kendall summarises, Calvin describes as knowledge, particular knowledge in the form of a 'given, intellectual, passive' assurance. ${ }^{74}$ Self-knowledge for Calvin is useful, therefore, only as a first step in the soteriological process, a means of knowing our carnal and corrupt nature through which Christ's role as saviour can be truly understood: it is only 'from the feeling of our own ignorance, vanity, poverty, infirmity, and [...] depravity and corruption', Calvin asserts, that 'we recognise that the true light of wisdom

\footnotetext{
${ }^{71}$ Roger Pooley, for example, cites the opening of Calvin's Institutes as inculcating the new sense of self that introspective Calvinist spiritual autobiographies (like Grace Abounding, according to many) illustrate. See 'Grace Abounding and the New Sense of Self', in John Bunyan and his England, 1628-1688, ed. by Laurence, Owens, and Sim (London: Hambledon Press, 1990), pp. 105-114 (pp. 105-106).

72 R. T. Kendall, Calvin and English Calvinism to 1649 (Oxford: Clarendon Press, 1979), p. 24.

${ }^{73}$ Such a claim, which is the basis of Kendall's thesis, is somewhat contentious and has been the subject of some debate. Stachniewski, for example, refutes Kendall's thesis (while referring to Kendall himself as 'a timewarped Calvinist'), Persecutory Imagination, pp. 24-25, 89-90, as does John von Rohr, The Covenant of Grace In Puritan Thought (Atlanta, Georgia: Scholars Press, 1986), pp. 26, 31. For a continuation of the debate over Calvin, faith, and the atonement, see M. Charles Bell, 'Calvin and the Extent of the Atonement', Evangelical Quarterly, 55 (1983), 115-123; Roger Nicole, 'John Calvin's View of the Extent of the Atonement', Westminster Theological Journal, 47 (1985), 197-225; Stephen Thorson, 'Tensions in Calvin's View of Faith: Unexamined Assumptions in R. T. Kendall's Calvin and English Calvinism to 1649', Journal of the Evangelical Theological Society, 37 (1994), 413-424.

${ }^{74}$ Kendall, Calvin and English Calvinism, p. 19.
} 
[...] and purity of righteousness rest in the Lord alone.' Consequently, 'knowledge of ourselves', according to Calvin, 'not only arouses us to seek God, but also as it were, leads us by the hand to find him.'75 Because this knowledge involves no introspection per se for Calvin, especially in terms of one's election or reprobation, it seems that a revision of our understanding of Calvin's position in relation to spiritual autobiography and Puritan selfanalysis as a whole is long over due.

While, of course, we may not be able to account for 'Calvinism' in the same way, nevertheless what Calvin says about introspection and asking the famous Calvinist question, 'How do I know I am saved?', is intriguing. For Calvin (as for Luther before him), man is incapable of reasoning with spiritual matters using the usual epistemological apparatus. Because issues of faith and salvation are conveyed via the illumination of the Spirit, which alone can open 'mysteries deeply hidden from human insight', then human rationality can avail nothing in matters of spiritual revelation: in relation to such concerns 'the greatest geniuses', Calvin asserts, 'are blinder than moles!'76 Consequently, what is most important for the believer is the implicit, reassuring knowledge of faith above all else. Attempting to assess one's spiritual standing in rational terms is not merely foolish according Calvin, though, but pre-eminently dangerous for the self: 'The election of God', he writes,

is itself hidden and secret, and the Lord manifests it when he bestows it upon us by calling. They are madmen who seek their own salvation or that of others in the labyrinth of predestination, not keeping the way of faith which is exhibited to them.77

Significantly, Calvin's fear for those who seek knowledge of election and predestination reveals itself in the metaphor of the labyrinth or maze, a 'pictorial figure [...] frequently employed [by Calvin] as a symbol of human frustration and confusion.'78 Fully aware of the power of the mind in religious matters, Calvin realises that 'when consciences

\footnotetext{
75 John Calvin, Institutes of Christian Religion, ed. by John T. McNeill, trans. by Ford Lewis Battles, 2 vols (Philadelphia: Westminster Press, 1960), I, 36-37.

76 Calvin, Institutes, I, 279-280, 277. For expressions of Luther's anti-rationalist faith see $A$ Commentarie of Master Doctor Martin Luther Upon the Epistle of S. Paul to the Galathians (London: 1644), Fols 110-110', $112,233$.

77 John Calvin, Calvini Opera, XLVII, 147, trans. by Edward A. Dowey, Jr., The Knowledge of God in Calvin's Theology (New York: Columbia University Press, 1952), p. 187. Cited in Dean Ebner, Autobiography in Seventeenth Century England, p. 34.

78 Calvin, Institutes of Christian Religion, I, editor's note 36, 64-65.
} 
once ensnare themselves, they enter a long and inextricable maze, not easy to get out of'. This ensnaring can occur, he asserts, in the contemplation of what some may call 'vain frivolities', such as, 'the unrestricted eating of meat, use of holidays and vestments', all of which can cast a man, 'into a pit of confusion'. ${ }^{79}$ Though generally keen to warn of how speculating on such 'superfluous' issues as the divinity of God, the Trinity, and the nature of heaven can lead, 'men's minds, when they indulge their curiosity, [to] enter into a labyrinth', Calvin, aware of the doctrine's potential for anxiety, is particularly concerned with the concept of predestination.

'Human curiosity,' he writes, 'renders the discussion of predestination, already difficult of itself, very confusing and even dangerous.' It is, moreover, the duty of believers to restrain any anxiety about it:

let them remember that when they inquire into predestination they are penetrating the sacred precincts of divine wisdom. If anyone with carefree assurance breaks into this place, he will not succeed in satisfying his curiosity and he will enter a labyrinth from which he can find no exit. For it is not right for man unrestrainedly to search out things that the Lord has willed to be hid in himself. ${ }^{80}$

What is to be understood of the secrets of God's will, Calvin suggests, is set down in the Word. The Word 'is the sole light to illumine our vision of all that we should see' of the Lord and his will, and as such it 'will readily keep and restrain us from all rashness.' ${ }^{1}$ Calvin thus describes the Word as the straight path necessary to follow 'if we seriously aspire to the pure contemplation of God.' '[T]he splendor of the divine countenance, which even the apostle calls "unapproachable" (I Tim. 6:16), is for us like an inexplicable labyrinth unless we are conducted into it by the thread of the Word.'82 Beyond the pathway of the Word 'we must repeatedly wander, slip, and stumble':

to seek any other knowledge of predestination than what the Word of God discloses is not less insane than if one should purpose to walk in a pathless waste. [...] And let us not be ashamed to be ignorant of something in this matter, wherein there is a certain learned ignorance. Rather, let us willingly refrain from inquiring into a kind of knowledge, the ardent desire for which is both foolish and dangerous, nay, even deadly. ${ }^{83}$

\footnotetext{
79 Calvin, Institutes, 1, 838-839.

80 Calvin, Institutes, II, 922-923.

81 Calvin, Institutes, II, 923.

82 Calvin, Institutes, I, 73.

83 Calvin, Institutes, II, 923.
} 
The relevance of Calvin's teachings, indeed of the very tropes he adopts, cannot be underestimated in terms of how we should understand Grace Abounding. What Bunyan's text ostensibly represents is the account of a man who has entered Calvin's labyrinth - doctrinally, rhetorically, and textually. If Grace Abounding operates in any kind of a didactic or edifying way, therefore, Bunyan's mistakes and confusions teach the reader precisely not to ask the question 'how do I know I am saved?' In this sense, Bunyan's text is indeed not so much a guidebook for the soul as a map of misreadings. What Bunyan urges in the Preface of Grace Abounding is, after all, not a self-introspection in terms of election or reprobation but, more simply, a remembering of God's mercies and grace. With this in mind, Delany's assertion that spiritual autobiography (as a genre of introspection), embraces the 'complicated, even devious process of rationalization', culminating in a 'semi-mystical assurance', could not be more inappropriate when applied to Bunyan's Grace Abounding, a text which reveals any sense of rationalising the spiritual to be treacherously mistaken. ${ }^{84}$

It is for this reason, then, that we are not only denied a lasting sense of assurance in Grace Abounding, semi-mystical or not, but that Bunyan's text displays explicitly how devious reasonings lead him into a labyrinth of doubts and epistemologically determined forking paths. After meeting the women of Bedford, for instance, the narrative of Grace Abounding becomes a recounting of the many painful (and often absurd) mistakes Bunyan's purely rational assessment of matters of faith and salvation lead him into. Hence, on encountering a Scriptural text which, in retrospect, Bunyan admits to misunderstanding, this convert-to-be foolishly embarks on a quest to discover 'whether I had any Faith or no' ${ }^{85}$ After having attempted 'to work some miracle' to settle the issue (as well as experiencing 'a kind of Vision'), Bunyan confesses that not only did he fail to 'attain to any comfortable perswasion that I had Faith in

\footnotetext{
84 Dayton Haskin also notes that Calvin 'warned against introspection, which, he said, causes anxiety and leads even to damnation', and yet considers Grace Abounding to be obsessively informed by an 'intense introspection' (see 'The Burden of Interpretation in The Pilgrim's Progress', Studies in Philology, 79 (1982), 256-278, p. 270). Haskin believes that Bunyan follows the English Calvinist tradition of introspection established by William Perkins and, especially in Bunyan's case, gaining transmission through texts such as Arthur Dent's Plaine-Man's Path-Way to Heaven and Lewis Bayly's Practise of Piety (pp. 261-269). However, Rebecca S. Beal radically counters the efficacy of such texts in Bunyan's conversion (and hence his theology), suggesting that in Grace Abounding these books are, in fact, 'spiritually soporific! [...] incapable of inculcating an awareness of [Bunyan's] true need for grace, or even of his true spiritual state' (see 'John Bunyan's Pauline Epistle', p. 154).

85 Bunyan, Grace Abounding, pp. 17-18.
} 
Christ', but that 'instead of having satisfaction, here I began to find my Soul to be assaulted with fresh doubts about my future happiness', especially 'Whether I was elected' and 'how if the day of grace should be past and gone?'86

While the question about having faith (a concept which for the converted Bunyan, as for Calvin, is the clearest indication possible that one does not have faith at all) breeds hydralike into a further double-doubt over election and the day of grace, in turn these become resolved only to find new life in a profound 'fearing' that 'I was not called'. While Bunyan describes himself typically as 'at a very great stand, not knowing what to do' at this point (a state of a-mazement that recurs throughout Grace Abounding in various images), it becomes clear that were it not for the assistance of an encouraging community of saints, the "poor people in Bedford' along with their pastor, Mr. Gifford, Bunyan could have continued in such a maze of spiritual misunderstandings and uncertainties endlessly. ${ }^{87}$ As such, the lesson that Grace Abounding is intent upon teaching its reader here is precisely that,

Though election is, in order, before calling, as to God, yet the knowledge of Calling must go before the belief of my Election, as to my self. Wherefore souls that doubt of the truth of their Effectual Calling, do but plunge themselves into a deeper labyrinth of confusion that concern themselves with their election; I mean, while they labour to know it before they prove their Calling. ${ }^{88}$

In this way, Grace Abounding is clearly Bunyan's response by personal testimony to the pastoral issue of the sinner who doubts whether he or she is 'elect, or chosen in salvation': 'lay the thoughts of thy Election by, and ask thyself these questions; Do I see my lost condition? Do I see salvation is no where but in Christ? Would I share in this salvation by Faith of him? [...] Do I love Christ, his Father, his Saints, his Word and Ways? This', Bunyan affirms unequivocally, 'is the way to prove we are Elect.' 89 This is the way to avoid such a 'labyrinth of confusion'.

At the same time, Grace Abounding also represents an account of conversion experience in terms of learning to follow the thread of the Word through a maze of

\footnotetext{
${ }^{86}$ Bunyan, Grace Abounding, pp. 18, 19-20.

87 Bunyan, Grace Abounding, pp. 24-25.

88 John Bunyan, Good News for the Vilest of Men (1688), ed. by Richard L. Greaves (Oxford: Clarendon Press, 1985), p. 88.

${ }^{89}$ Bunyan, Good News for the Vilest of Men, pp. 88-89. For further examples and a discussion of the image of the labyrinth in relation to the doctrines of election and assurance in the writings of Puritan divines, see von Rohr, The Covenant of Grace in Puritan Thought, pp. 131-133, 156-158, 167, 176.
} 
misunderstandings. This is particularly important for Bunyan who not only knows experimentally of the necessity of wrestling with an interpretation of the Word but who can warn, with Calvin, of 'prying to[o] far' in spiritual matters; 'take heed', he writes in The Saints Privilege and Profit (1692), 'for in Mysteries Men soon lose their way', (a caution memorably reiterated in The Holy War's verse address to The Reader).90 In The Saints Privilege and Profit, then, Bunyan asserts that the 'breadths, and lengths, and depths, and heighths' of Christ's love as set down in the Word are the kind of mysteries rarely understood 'save by those that are very well skilled in those mysterious methods of God'. As 'they are very mysterious in their workings,' Bunyan writes, 'For they work by, upon, and against oppositions', the role of the preacher-pastor becomes instrumental in negotiating such enigmas for the spiritual well-being of his congregation. Difficult but ultimately comforting Scriptural sentences 'are easily played with by a preacher, when in the pulpit', writes Bunyan, 'specially if he has a little of the notion of things, but of the difficulty, and strait, that those are brought into [...] by reason of the force of the Labyrinths they are fallen into: of those [comforts] they experience nothing, wherefore to those they are utterly strangers.' 91 Bunyan's labyrinths here may not only be those of the world and sin and an entangled conscience. Bunyan implies here what Grace Abounding many times records: that the Word itself may need mediating for the sinner by one skilled in the mysteries of God, that the enigmatic Word itself may lock the sinner out of the comforts offered should there not be a hand proffering assurance and guidance, particularly as 'those that the Scriptures favour they must inherit bliss; but those that they oppose and condemn, must perish for ever.' 92

The implications of Calvin's labyrinth of predestination clearly go far. What was most important about conversion for Calvin himself was that through his experience 'God subdued my heart to teachableness', stressing in Institutes that believers should apply themselves to spiritual questions 'with teachableness than with subtlety.'93 Grace Abounding can be seen to be operating with this edifying intention also: the reader who reads the 'exceeding maze' of

\footnotetext{
90 John Bunyan, The Saints Privilege and Profit (1692), in Miscellaneous Works XIII, p. 225.

91 John Bunyan, The Saints Knowledge of Christ's Love (1692) in Miscellaneous Works XIII, pp. 356-357.

92 Bunyan, Grace Abounding, pp. 76, 58.

93 Calvin, Preface to the Commentary on the Psalms, CR XXXI, 21, quoted in the introduction to Institutes, p. li, and Institutes, I, 146.
} 
Grace Abounding 'aright' must learn to be teachable in matters of faith and salvation. In order to achieve this didactic aim Bunyan presents a narrative which, in its maze-like structure of continuous spiritual progression and negation, in its ultimately unresolved resolution, becomes impossible to read just for the 'story'. Grace Abounding thus becomes unapproachable even as autobiography or a life-story, denying the most basic of narrative conventions, that of plot or fable, in order to foreground the ongoing struggles of the convert and the nature of grace. The labyrinth Bunyan describes having entered during the game of Cat discussed at the very beginning of this chapter can thus be seen to teach its reader experientially about both reading in doctrine and the doctrine in reading. 


\title{
Of Things Seen and Unseen: \\ Grace-ful Reading and Narrative Practice in Bunyan's Grace Abounding
}

\begin{abstract}
Yea, and I am fully convinced of it, that it is possible for a Soul that can scarce give man an answer, but with great confusion as to method, I say it is possible for them to have a thousand times more Grace, and so to be more in the love and favour of the Lord, then some who by vertue of the Gift of Knowledge, can deliver themselves like Angels.'
\end{abstract}

Bunyan's comment here (made almost at the very close of Grace Abounding) may appear to indicate some defensiveness about both the style and un-scholarliness of his spiritual autobiography. After all, as a repetitive, diffuse, and labyrinthine account of a soul attempting to 'give man an answer' to some un-worldly questions, Grace Abounding may indeed appear to have been composed with little other than 'great confusion as to method'. Bunyan's justification for this, it might seem, is simply that the visible saint can, despite being quite graceless stylistically (as well as socially), have more grace yet than any who are able to discourse like eloquent 'Angels' (especially as 'the Lord looketh not at the outward appearance, but on the Heart, neither regardeth high swelling words of vanity, but pure and naked Truth'). ${ }^{2}$ Aside from an obvious punning on notions of style, grace, and civility, though, such a statement is neither a defence of any confused mode of narration in Grace Abounding nor, as we get elsewhere in Bunyan's writings, an outright dismissal of human learning. ${ }^{3}$ Rather,

\footnotetext{
1 John Bunyan, Grace Abounding To the Chief of Sinners, ed. by Roger Sharrock (Oxford: Clarendon Press, 1962), pp. 91-92.

${ }^{2}$ John Bunyan, The Holy City (1665), in The Miscellaneous Works of John Bunyan III, ed. by J. Sears McGee (Oxford: Clarendon Press, 1987), p. 71.

${ }^{3}$ Bunyan frequently disavows learning in favour both of the Spirit and the Word alone, counting himself 'better furnished' with the Bible 'than if I had without it all the Libraries of the two Universities': 'I do find in most', he writes, 'such a Spirit of Whoredom and Idolatry concerning the Learning of this World, and Wisdom of the Flesh, and GOD'S Glory so much stained and diminished thereby' (The Holy City, pp. 71-72). For similar comments, see The Doctrine of Law and Grace Unfolded (1659), in The Miscellaneous Works of John Bunyan II, ed. by Richard L. Greaves (Oxford: Clarendon Press, 1976), p. 16, and Solomon's Temple Spiritualized (1688), in The Works of John Bunyan, ed. by George Offor, 3 vols (Glasgow: W. G. Blackie and Son, 1854; repr. by The Banner of Truth Trust, 1991), III, 464.
} 
Bunyan's words here reinforce an aspect of spiritual experience central to his theology of grace as a whole: that the 'vertue' often perceived to be inherent in 'the Gift of Knowledge' has little role to play (if any at all) in the strictly spiritual matters of faith and salvation.

That Bunyan makes such a point about knowledge and grace in Grace Abounding is hardly surprising. Although the last chapter aimed at emphasising how important it is for the reader to read Grace Abounding primarily in terms of Law and grace, innate corruption, and justification by imputed righteousness, Bunyan's concern (as demonstrated by his declaration above) also focuses on the fact that 'knowledge' of doctrine alone does not render a saving faith, no matter how angelic the delivery. As Bunyan is aware, the consequence of being mistaken in such soteriological matters can be dire. Too many Christians, he warns, fall into the trap of failing to discern 'the difference between gifts and ignorance, and very foolishness', having 'naught but wits and gifts' to rely upon: 'they are but words', he asserts, 'all their religion lyeth in their tongues and heads. ${ }^{4}$ Bunyan's punning here is no frivolous word-play, either. He is stating as clearly as possible that without a more profound and experimental understanding of doctrine, a seeing through the eyes of the understanding effected by the kind of experience Bunyan undergoes in Grace Abounding, one can never confess to true faith but only to a knowledgeable lie that reduces the self-deluding professor from Logos to lexis: he or she becomes just words and no Word, all letter and no spirit.

The problem here, though, is not simply one of hypocrisy amongst Christians; a difference between outward show and inward deceit. Rather, it concerns spiritual, as opposed to worldly, perception. As Calvin asserts in Institutes of Christian Religion, clearly following Paul on such matters, faith in salvation involves a knowledge that transcends the epistemological and rational limits of the human mind: such knowledge comes via the Spirit alone, the 'revelation' of which sheds light on mysteries 'deeply hidden from the human insight'. Hence, for Calvin (as for many Divines of the Reformed tradition, including Bunyan), the higher knowledge of faith goes beyond the capacity of human rationality entirely:

When we call faith "knowledge" we do not mean comprehension of the sort that is commonly concerned with those things which fall under human sense perception. For faith is so far above sense that man's mind has to go beyond

\footnotetext{
${ }^{4}$ John Bunyan, The Resurrection of the Dead (1665), in Miscellaneous Works III, p. 281.
} 
and rise above itself in order to attain it. Even where the mind has attained, it does not comprehend what it feels. But while it is persuaded of what it does not grasp, by the very certainty of its persuasion it understands more than if it perceived anything human by its own capacity. ${ }^{5}$

Incomparable, inexpressible, and distinctly spiritual, 'this kind of knowledge is far more lofty than all understanding', Calvin asserts, faith thus consisting 'in assurance rather than comprehension' and frequently being referred to in Institutes as recognition. ${ }^{6}$

With Calvin's comments in mind, what this chapter will explore is how Grace Abounding, both in content and construction, seeks to teach the reader that the grace-ful reading of one's life and the Word must encompass far more than any mere intellectual knowledge of Bunyan's doctrine of redemption. Indeed, Grace Abounding illustrates that understanding the 'Gospel mysteries' calls for a reliance upon a spiritual apprehension (over and above any worldly knowledge) which the man 'destitute of Faith' cannot 'once think of'.? Grace-ful perception, wherein one begins to 'have access into the Grace of God' through faith ('the eye of the soul', as Bunyan puts it), thus encompasses a radically different ordering of what is knowable and rational for the believer from the outset. ${ }^{8}$ Faith puts into the soul an understanding enlightened on purpose to know the things of God', only when 'carnal Reason' is 'avoided, opposed, and mortified: and the Word of Faith the more carefully submitted to'. Because 'trusting in the Lord, and leaning to our own understanding are opposites', then, Bunyan states that ' $[$ ' $t]$ is a great thing for a Man, when the Word, \& his reason clashes, [...] to

\footnotetext{
${ }^{5}$ John Calvin, Institutes of Christian Religion, ed. by John T. McNeill, trans. by Ford Lewis Battles, 2 vols (Philadelphia: Westminster Press, 1960), I, 279-280, 559.

' Calvin, Institutes, I, 560. In Institutes, the various Latin words for knowledge are often used interchangeably by Calvin. As such, "knowledge, whatever the word employed, is for Calvin never "mere" or "simple" or purely objective knowledge.' However, Calvin does distinguish between the different types of knowledge that man is capable of attaining: 'agnitio, recognition or acknowledgement; intelligentia, primarily meaning perception; and scientia, primarily expert knowledge' (Institutes, I, fn 1, 35-36). For an account of attitudes to reason and knowledge amongst the broad spectrum of Puritan divines and ministers, see Geoffrey F. Nuttall, The Holy Spirit in Puritan Faith and Experience (Oxford: Basil Blackwell, 1946; 2nd edn 1947; repr. with a new introduction by Peter Lake, Chicago and London: University of Chicago Press, 1992), pp. 35-47, and John Morgan, Godly Learning: Puritan Attitudes Towards Reason, Learning, and Education, 1560-1640 (Cambridge: Cambridge University Press, 1986), pp. 4, 33, 40, and esp. pp. 41-78, 305-309.

${ }^{7}$ Consequently, Richard L. Greaves follows Nuttall's assertions on the place of reason in the theology of 'radical Puritans' (see The Holy Spirit in Puritan Faith and Experience, p. 38), noting that 'Bunyan's religious epistemology was in the sectarian tradition, which embraced the fundamental principle that religious knowledge was derived from the Holy Spirit, not the use of human reason' (in Law and Grace, p. 295, note to p. 149).

${ }^{8}$ Bunyan, Of Justification by an Imputed Righteousness (1692), in The Miscellaneous Works of John Bunyan XII, ed. by W. R. Owens (Oxford: Clarendon Press, 1994), p. 339.
} 
adhere to the Word, and let his Reason fall to the ground.' It is just such a clash, resulting in a 'faithful knowledge' of the Spirit and the Word, couched within a 'spiritual empiricism' in which the evidence of things unseen 'is exchanged for a mundane empiricism of things seen', that Bunyan achieves in Grace Abounding. ${ }^{10}$ For Bunyan, gaining such spiritual knowledge 'indeed is Christianity in the practic part', with '[t]he Spirit of Christ in the Word' being 'hearkned unto, above all things'. It is towards this 'practic part', therefore, that Grace Abounding points the reader earnestly seeking salvation. ${ }^{11}$

To illustrate how Grace Abounding is structured both around and upon this didactic aim, it is perhaps most useful to begin at the very end of the narrative. Here, faced with imprisonment for refusing to cease his preaching, Bunyan discourses at one point upon how he gained comfort by discovering through the Word that 'The way not to faint, is to look not at the things that are seen, but at the things that are not seen; for the things that are seen are temporal; but the things that are not seen, they are eternal, 2 Cor. 4. 18.' Bunyan thus adopts a tenet of Pauline spirituality to come to terms with his most Pauline position. Faced with potential exile or execution, the gaoled Bunyan leans upon the Word to help him endure separation from his wife and children (to 'pass a sentence of death upon everything that can properly be called a thing of this life') and to consider death and banishment as their literal replacements ('to familiarize these things to me'). ${ }^{12}$ That Bunyan has achieved a certain amount of spiritual wisdom by this point is signalled not only by the measured recounting of his fear and anxiety over suffering for his faith (nor by his habitual punning) but by his controlled appropriation of the Word to provide comfort for him when he needs it most. Paul's complex and paradoxical teaching on things seen and unseen is understood unproblematically by Bunyan here as implicitly relevant to his situation: through faith, the Word leads him to the conviction that he must both trust in and 'live upon the God that is invisible', no matter what may befall him.

\footnotetext{
'Bunyan, Law and Grace, p. 149; Israel's Hope Encouraged (1692), in The Miscellaneous Works of John Bunyan XIII, ed. by W. R. Owens (Oxford: Clarendon Press, 1994), p. 92.

10 Thomas H. Luxon, Literal Figures: Puritan Allegory and the Reformation Crisis in Representation (Chicago \& London: The University of Chicago Press, 1995), pp. 160, 175.

"Bunyan, Israel's Hope Encouraged, p. 92.

12 Bunyan, Grace Abounding, pp. 97-98.
} 
Achieving such an ease with the Word, in which understanding Scripture comes as effortlessly to Bunyan as his previous automatic 'hearing' of Biblical texts, is the progress that Bunyan principally records in Grace Abounding. Grace Abounding, as many commentators have already noted, is Bunyan's account of how he becomes a reader both of his life and Scripture. ${ }^{13}$ This is, however, a process that Bunyan hardly romanticises about. Because gaining the ability to read and understand the Word through the eye of the soul, 'to learn Christ, as we find him revealed in the Gospel', is for Bunyan the 'utmost lesson set us' as 'to the perfecting of our Understanding in the Mysteries of God', he presents it, unsurprisingly, as something not to be undertaken lightly. ${ }^{14}$ Indeed, learning to read and understand is presented as a particularly serious, arduous, and traumatic ordeal for Bunyan, Grace Abounding comprising a series of experiences in interpretation and misinterpretation which the reader should both note and learn from.

It is because Bunyan's growth in understanding in Grace Abounding acts as an index for his faith in salvation as a whole, moreover, that the analysis of Bunyan's conversion in this chapter first concentrates specifically upon his learning to read, a development which both frames and pervades the entire text. Bunyan's narrative may end with him being able to face his imprisonment armed with the shield of his faith, but his journey in such matters begins, we must not forget, with the admission that, as an unregenerate youth whose soul is laden with 'the lusts and fruits of the flesh', the Word itself once inspired little more than an incarcerating dread: 'In these days, the thoughts of Religion was very grievous to me', Bunyan writes, 'so that when I have but seen some read those books that concerned Christian piety, it would be as it were a prison to me. ${ }^{15}$ Grace Abounding is, therefore, Bunyan's relation of how conversion

\footnotetext{
${ }^{13}$ Roger Sharrock, for example, views Grace Abounding as 'both the story of Bunyan's own reading of Scripture and his commentary or marginalia upon that': 'Temptation and Understanding in Grace Abounding', Bunyan Studies: John Bunyan and his Times, 1 (1988), 5-14 (p. 5). For other studies of Bunyan's reading in Grace Abounding, see Vincent Newey, " "With the eyes of my understanding": Bunyan, Experience, and Acts of Interpretation', in John Bunyan: Conventicle and Parnassus, Tercentenary Essays, ed. by N. H. Keeble (Oxford: Clarendon Press, 1988), pp. 189-216; John R. Knott, Jr., The Sword of the Spirit: Puritan Responses to the Bible (Chicago and London: University of Chicago Press, 1980), pp. 131-137; Peter J. Carlton, 'Bunyan: Language, Convention, Authority', ELH, 49 (1982), 17-32; Graham Ward, 'To Be a Reader: Bunyan's Struggle with the Language of Scripture in Grace Abounding to the Chief of Sinners', Joumal of Literature and Theology, 4 (1990), 29-49; Maxine Hancock, 'Bunyan as Reader: The Record of Grace Abounding', Bunyan Studies: John Bunyan and his Times, 5 (1994), 68-82.

${ }_{14}$ John Bunyan, The Saints Privilege and Profit (1692), in Miscellaneous Works XIII, p. 225.

${ }^{15}$ Bunyan, Grace Abounding, p. 7.
} 
liberates him from the interpretive imprisonment of ignorance and enables him to enter into a spirituality through which imprisonment itself can be interpreted as a victory for the Word. As such, it is Bunyan's reading, both regenerate and unregenerate, that requires the most scrutiny here.

Aside from the spiritual claustrophobia that books of Christian piety induce in his youthful self, Bunyan begins teaching the reader about reading in Grace Abounding by illustrating how his own engagements with religious matters prior to conversion into faith were conspicuously unregenerate, reflecting little more than the perilous legalism of his initial devotional practice. Bunyan's acceptance of his first wife's godly books ('The Plain Mans Path-way to Heaven, and The Practice of Piety, which her Father had left her when he died') illustrates this well: they did 'beget within me some desires to Religion', he admits, but 'they did not reach my heart to awaken it about my sad and sinful state' ${ }^{16}$ The problem, of course, is not with the books themselves but with Bunyan's reading of them. They neither inspire anything truly faithful nor awaken Bunyan to his own sinfulness because he mistakes the knowledge of God's ways at this point for the kind of outward piety (as Bunyan perceives it) that his first wife's father embodies as a 'godly man' and which subsequently leads him into an empty idolising of Church ritual. ${ }^{17}$ As such, it is Bunyan's depiction of an unregenerate hermeneutic practice early on in Grace Abounding that serves him most effectively in warning the reader against the kind of spiritual naiveté that nestles complacently in a moral and a social religious conformity.

Even more exemplary of such spiritual folly, however, is Bunyan's first and more specific exploration into Scripture itself. Again, it is his reading here which most of all betrays Bunyan's legalism, his understanding of the Word at this point effecting nothing but a sanctioning of the right to ignore any Biblical text that Bunyan finds soteriologically difficult or uneasy. Seduced by a sociable and theologically unproblematic notion of religion, therefore, Bunyan describes being most impressed by one who 'did talk pleasantly of the Scriptures, and

\footnotetext{
${ }^{16}$ Bunyan, Grace Abounding, p. 8.

${ }^{17}$ Bunyan, Grace Abounding, pp. 8-9.
} 
of the matters of Religion', and decides to read according to this example: 'I betook me to my Bible', he explains,

and began to take great pleasure in reading, but especially with the historical part thereof: for, as for Pauls Epistles, and Scriptures of that nature, I could not away with them, being as yet but ignorant either of the corruptions of my nature, or of the want and worth of Jesus Christ to save me. ${ }^{18}$

While it is Bunyan the converted and knowing narrator who correctionally comments on his former state of ignorance (and with a doctrinal heavy handedness too), Bunyan's early knowledge of the Word is signalled as false not only because he reads the Bible with the selfindulgence usually associated with fiction or romance (that is, for pleasure), but because it ignores the very texts so crucial to Bunyan's doctrine of salvation - the letters of Paul. Bunyan's mistake here is due to a distinct literalism (an adherence to the letter alone) in his interpretive procedure, making the reading of Scripture a complacently aesthetic experience. Indeed, this kind of reading is, quite conspicuously, hardly a form of interpretation at all. ${ }^{19}$

Both reflecting and compounding a self-contented doctrine, then, Bunyan's reading for 'the historical part' of the Bible prior to conversion is important to note as it so clearly signifies a 'faith' that is in itself purely letter-al and 'historical': it is an unregenerate reading of the Gospel in the most basic (and for Bunyan the worst) of senses - for the stories, for the words on the page. As such, this reading is but the interpretive counterpart to mere moralism, a legalistic ignorance both of doctrine and perception that leads only to damnation. Bunyan's warning is clear in this matter. What Grace Abounding goes on to delineate, therefore, is that only through an ability to conceive of salvation in terms of grace (as Bunyan understands it) can the sinner be free of the bondage of such Law-centred righteousness, its carnal habits, and the divine justice it demands. Bunyan's conversion is thus presented as a step-by-step release from such ignorance, a progress towards a grace-ful understanding that, effecting a drastic re-

\footnotetext{
${ }^{18}$ Bunyan, Grace Abounding, p. 12.

${ }^{19}$ Reading for the historical part is not uncommon in seventeenth-century conversion narratives as a sign of unregeneracy. Spiritual autobiographers as devotionally different as Laurence Clarkson and George Trosse make reference to it. See Laurence Clarkson, Lost Sheep Found (London: 1660), pp. 32, 38; George Trosse, The Life of the Reverend Mr. George Trosse, ed. by A. W. Brink (Montreal and London: McGill-Queen's University Press, 1974; originally pub. 1714), p. 100; Arise Evans, An Eccho to the Voice from Heaven (London: 1652), p. 17.
} 
orientation of his thinking about salvation, begins somewhat inadvertently for him in his meeting with the women of Bedford.

This is such a crucial episode in Grace Abounding principally because it is the grace-ful discourse of these women that finally and effectively challenges Bunyan's legalistic knowledge of God's ways, Bunyan thereby becoming able to perceive the possibility of a spiritual reality beyond his rationalist and literalist faith. Consequently, Bunyan undergoes an epiphany here which is signalled most of all by his inability to comprehend the language the women use. Though a 'brisk talker [...] in the matters of religion', the women's conversation 'about a new birth', about how 'God had visited their souls with his love in the Lord Jesus', and 'of their own wretchedness of heart, of their unbelief', Bunyan tells us, 'were far out above my reach'. Though speaking of things religious in a tongue he clearly recognises, it is the spiritual as opposed to lexical meaning that Bunyan finds impossible to fathom here. Able to register the words but not comprehend the faith behind them, 'I heard', he confesses, 'but I understood not'. Finally confronted, therefore, not only with his inherent legalism but with the recondite limitations of a literal, rationalising, and self-satisfying approach to spiritual things, this experience is for Bunyan like discovering an alternative and alien reality, 'a new world' as he puts it. Now, Bunyan must not only negotiate the concept of grace and faith the women speak of but a mode of being which enables them to discourse of their own 'filthy' and 'insufficient' righteousness paradoxically 'as if joy did make them speak'. ${ }^{20}$

For the Bunyan who has only adhered to the Law for salvation, such conviction is no less than amazing. Indeed, what is remarkable about this episode is the profound sense of estrangement and disorientation that Bunyan, with great subtlety, manages to convey here. As casual as the self-satisfied Bunyan himself, the prose draws us unassumingly into a world of domestic peace and comfort, some 'poor women sitting at a door in the Sun, and talking about the things of God'. However, the women's joyful talk of depravity and innate corruption, the very terminology of their discourse, deconstructs this scene before our very eyes, its unparalleled homeliness, tranquillity, and happiness being revealed suddenly as built not upon an easy moralism but on a harsh and oxymoronic vocabulary of Calvinist self-abhorrence.

\footnotetext{
${ }^{20}$ Bunyan, Grace Abounding, pp. 14-15.
} 
Presenting a step into a realm of faith and not works, this encounter deliberately discomforts any initial (and, in Bunyan's case, complacent) assumptions about pious Christian discourse that both the reader and protagonist may hold. Bunyan is thus confronted (and is confronting his reader) not only with the insufficiency of legalism but with a mode of believing and discoursing which, beyond any learnedness or religious briskness, demands a revolution in one's consideration of things seen and unseen. ${ }^{21}$

This experience is so important in Grace Abounding, then, because it is from this point onwards that Bunyan begins to learn, to become (as Calvin puts it) teachable in spiritual things: 'I felt my own heart began to shake', he writes, and now mistrusts his 'condition to be naught'. Bunyan's initial conviction is thus profoundly of his own lack of understanding and knowledge of salvation: he comes to see that he has known neither 'the comfort of the Word and Promise, nor the deceitfulness and treachery of my own wicked heart'. Of equal significance, however, is the fact that this meeting procures not only 'a very great softness and tenderness of heart' but 'a continual meditating' on Scripture that culminates in a complete conversion in Bunyan's approach to the Word: 'I began to look into the Bible with new eyes', Bunyan writes, 'and read as I never did before; and especially the Epistles of the Apostle S. Paul were sweet and pleasant to me'. Thus, shifting literally from the Word of the Law to that of grace in his acceptance of the very texts he once complacently ignored (the letters of Paul), Bunyan's conversion begins with him becoming notably immersed in the Word: 'I was then never out of the Bible, either by reading or meditation, still crying out to God', he states, 'that I might know the truth, and way to Heaven and Glory. ${ }^{22}$

Despite Bunyan's new-found enthusiasm for reading Scripture, though, his encounter with the Bedford women does not lead him instantly nor unproblematically into the kind of understanding that is indicative of true faith. We should be sensitive, for instance, to the terms of Bunyan's new-found conviction here: his desire to 'know the truth' implies a precariously carnal attitude to faith and salvation, that they can be discovered and known through

\footnotetext{
${ }^{21}$ Bunyan, Grace Abounding, pp. 14-15.

${ }^{22}$ Bunyan, Grace Abounding, p. 17. Rebecca S. Beal also makes the point that Bunyan's reading enacts a shift literally from Law to grace here: 'Grace Abounding to the Chief of Sinners: John Bunyan's Pauline Epistle', SEL, 21 (1981), 147-160 (p. 155).
} 
conventional, perhaps rational means. We have already seen in the last chapter the labyrinthine dangers that Bunyan's questing for certain knowledge of faith, election, calling, and belatedness lead him into from this point onwards. In a similar way, then, it is because Bunyan's total dedication to the Word is complicated by his lack of a full comprehension of grace that Scripture itself becomes something of a net of confusion into which Bunyan repeatedly falls. It is, for instance, Bunyan's misunderstanding of Scriptural texts about 'the word of knowledge' and that of 'Faith' that leads him into a maze of epistemological forking paths in which, without having faith to guide him, such texts as 'It is neither in him that willeth, nor in him that runneth, but in God that sheweth mercy' come to 'trample upon' all his 'desires'. Consequently, Bunyan's need to know of faith and election, and his attempts to read the Word rationally, merely compound his sense of a-mazement further: 'By these things I was driven to my wits end, not knowing what to say, or how to answer these temptations', Bunyan writes, for 'there lay all the question. ${ }^{23}$

Bunyan's understanding at this stage in his conversion is both problematic and distressing because it is primarily transitional and hesitant. Having plunged himself so deeply in the Word, and yet having no sure faith in its promises, Bunyan is forced to inhabit an intermediary realm of interpretation in which he simultaneously receives comfort and pain from Scriptures which seem to act physically and metaphysically upon him. Consequently, he describes experiencing a spectacular whirlwind of spiritual doubt at this point in his conversion. Continually caught between uncertainty and hope as to his own salvation, Bunyan oscillates from having the Word 'trample' and 'fall' violently upon him to it refreshing his spirit intimately with 'such strength and comfort' that 'I was as if it talked with me.' In this state of soterial uncertainty, the Word seems both to persecute and shelter a Bunyan 'greatly assaulted and perplexed' by doubts and fears of salvation and damnation. ${ }^{24}$ The converting Bunyan's early relationship to the Word is thus fraught with a complexity and ambivalence that often threatens to overwhelm him. Scripture makes him 'sick', 'faint and fear' even as it 'kindled fire in my Soul', the unseeing Bunyan's doubts about the Word often being resolved by the

\footnotetext{
${ }^{23}$ Bunyan, Grace Abounding, pp. 17-18, $20-21$.

${ }^{24}$ Bunyan, Grace Abounding, p. 21.
} 
Word itself but, paradoxically, only when it acts upon him in the most irrational, illogical, and aggressively intrusive ways. As a result, Bunyan is often comforted by Scripture but only when it acts violently upon him, when 'words broke in upon my soul'. ${ }^{25}$

What Grace Abounding is cautioning against at this point, however, is an approach to matters of faith and salvation that mistakes the unseen for the seen and which tries to know and prove them rationally. Indeed, doubt and despair are most terrifying for the converting Bunyan in this state precisely because they seem so safely couched in reason. Bunyan's worst periods of despair are thus characterised by this kind of questioning: 'How can you tell but that the Turks had as good a Scriptures to prove their Mohamet the Saviour, as we have to prove our Jesus is', and how could it be that 'we onely, who live but in a corner of the Earth' should alone be blessed with 'the knowledge of the right way to Heaven (if there were indeed a Heaven)'. While Bunyan externalises these innately logical doubts in the form of assaults by his 'Tempter', such reasoning nevertheless can all too easily seem like a painful, paranoiac, and often absurdist super-rationalism in Bunyan's thinking. In attempting to combat his doubts by applying 'the Sentences of blessed Paul against them', Bunyan even begins to question whether Paul himself is plotting against him, 'to deceive with strong delusions' and 'to undo and destroy his fellows?'26

Equally and patently preposterous, however, is Bunyan's need 'to try if I had Faith by doing some miracle' which, subsequently, represents something of a parable about mistaking faith for something externally and physically verifiable. Hence, 'tossed betwixt the Devil and my own ignorance', Bunyan memorably attempts to transform 'the puddles that were in the horse pads' to be alternately 'dry and full'. An excruciating parody both of Christ's temptations in the desert and, more importantly, Gideon's tempting of God 'with his Fleece, both wet and dry', Bunyan's need for spectacular and miraculous proof of faith is merely selfdefeating, leaving him only more desperate, convinced indeed that he is 'a Cast-away and lost'. As Bunyan asserts later in the text, such a temptation is indicative only of a lack of faith: just as Gideon 'should have believed and ventured' upon God's word alone, so too does Bunyan see

\footnotetext{
${ }^{25}$ Bunyan, Grace Abounding, pp. 22-25.

${ }^{26}$ Bunyan, Grace Abounding, p. 31.
} 
God serving him so in the very moments when 'I should have believed his Word, and not put an if upon the all seeingness of God. ${ }^{27}$

While it would seem that Grace Abounding teaches about reading and understanding principally as a collection of painful errors and mistakes in interpretation, Bunyan's hermeneutic experiences are not all negative. His early typological understanding of 'the Beasts that Moses counted clean, and unclean' and his allegorical exposition of his own envisioning of the Bedford congregation on a mountain in sunlight show that he was capable of spiritualising texts and events even before he had received any firm assurance of his faith. But despite these apparent signs of progress, Bunyan's final release from his almost unbearable interpretive raisings up and castings down is not effected properly until he is led into a perceptual revelation effected through the pastoral aid of the Bedford Church's minister, Mr. Gifford. The significance of Gifford's role prior to Bunyan's conversion, although surprisingly understated in the text, should not be underestimated. Indeed, Gifford's 'Doctrine' is most significant precisely because it gives Bunyan 'stability' amidst the 'sad experience' of spiritual and interpretive turbulence by pointing him towards an understanding of spiritual things that aligns itself with a mistrust of anything worldly or conventionally rational. Indeed, it is the Bedford minister's vocation, Bunyan tells us, 'to deliver the People of God from all those unsound rests that by Nature we are prone to take and make to our Souls'. Gifford's role is so crucial, then, because he urges the likes of Bunyan to pay attention only to the unseen nature of the doctrine of grace: 'he pressed us to take special heed', Bunyan recalls, 'that we took not up any truth upon trust, as from this or that or another man or men, but to cry mightily to God, that he would convince us of the reality thereof, and set us down therein, by his own Spirit in the holy Word'. ${ }^{28}$

As the counterpart to Bunyan's experience with the women of Bedford, Gifford's ministry is so central to Bunyan's growth in understanding because it affirms that, without such an approach to faith and salvation, any convert will be found wanting 'that help and strength' to resist 'temptations', having not 'received them with evidence from Heaven'. This

\footnotetext{
${ }^{27}$ Bunyan, Grace Abounding, pp. 18-19, 76.

${ }^{28}$ Bunyan, Grace Abounding, p. 37.
} 
teaching consequently provides the impetus for the final turning-point in Bunyan's faithful perception. Bunyan not only feels 'the truth of these his words' according to his recent struggles but now begins to understand something 'of the reality' of God's ways as originally discoursed by the women of Bedford. What Bunyan is convinced of now is the need to understand matters of doctrine and the 'Promises' wholly in spiritual terms - not by what 'this or that or another man' speaks of but by God's 'own Spirit in the holy Word'. Bunyan's conviction thus becomes transcendent: 'For I had felt', he states, 'no man can say, especially when tempted of the Devil, that Jesus Christ is Lord, but by the holy Ghost.' Having now been shown the error of his own ways, as in his encounter with the Bedford women, Bunyan's reading of the Word subsequently undergoes an almost mystical transformation at this point. No longer haunted by isolated fragments of Scripture that refuse to be decoded by reason and logic, Bunyan now finds himself able to read the Word in a way which, through faith, is both rapturous and totalising in its acceptance of the Gospel message. Now Bunyan is 'led from truth to truth by God!', he exclaims, 'even from the birth and cradle of the Son of God, to his ascention and second coming from Heaven to judge the World. ${ }^{29}$

At this point, Bunyan's reading becomes what Thomas Luxon would describe as a form of 'anti-hermeneutics', yielding insight 'in spite of, rather than as a result of, the various acts of interpretation one performs in reading', and which 'insists that understanding comes, not by acts of interpretation, but by believing without knowledge or understanding. ${ }^{30}$ In this case, through an adherence to the Spirit rather than the letter, interpretation gives way at last to a visionary revelation of the whole meaning of the Gospel: for Bunyan 'there was not any thing that I then cried unto God to make known and reveal unto me but he was pleased to do it for me', Bunyan remembers, 'I mean not one part of the Gospel of the Lord Jesus, but I was orderly led into it'. What is remarkable about Bunyan's relation of this experience, moreover, is the new-found intensity of his relationship to the Word: in seeing 'with great evidence [...] the wonderful work of God in giving Jesus Christ to save us', Bunyan writes, 'me thought I was as if I had seen him born, as if I had seen him grow up, as if I had seen him walk thorow

\footnotetext{
${ }^{29}$ Bunyan, Grace Abounding, p. 37.

${ }^{301}$ Luxon, Literal Figures, pp. 167-168, 175.
} 
this world, from the Cradle to his Cross'. No longer reading Scripture for the historical part alone or for evidence of election, Bunyan's reading transcends both his historical faith as well as any desire to know the unknowable, closing with the Word and the Spirit in a faithful understanding of Christ's life, ministry and death that fuses the historical with the doctrinal, the actual with the timeless and covenantal. Relating how 'God did set me down in all the things of Christ, and how he did, that he might do so, lead me into his words', Grace Abounding thus becomes an explicit record of how conversion manifests itself as a grace-ful reading of the Gospel, a profound meditation on the crucified Christ. With such understanding being both synonymous and synchronous with assuring faith, Bunyan can now say indeed that he had 'evidence, as I thought, of my salvation from Heaven'. ${ }^{31}$

Faith becoming analogous with understanding, believing with reading, and conversion as a spiritual conjunction of the two, it becomes clear that Bunyan's aim in relating his interpretive experiences in Grace Abounding is to instil in his reader the very convictions that he describes Mr. Gifford having inspired in him. What is most important for the reader seeking salvation by grace to remember is that only by the 'Spirit in the holy Word' and a crying 'mightily to God' can we achieve a faithful apprehension of the 'Promises'. Despite the fact that such apprehension is finally beyond communication, beyond words ('It would be too long for me here to stay, to tell you in particular how God did set me down in all the things of Christ',

\footnotetext{
${ }^{31}$ Bunyan, Grace Abounding, pp. 39-40. Other spiritual autobiographies also stress the importance of reading in conversion. For more rationalising (or learned) Puritans and Nonconformists like Richard Baxter and Richard Norwood, reading a certain book in particular brings about a transformation - see The Autobiography of Richard Baxter, ed. with an intro. by J. M. Lloyd Thomas (London: J. M Dent, 1931), p. 7, and The Journal of Richard Norwood, Surveyor of Bermuda, with intros. by Wesley Frank Craven, and Walter B. Hayward (New York: Scholars' Facsimiles \& Reprints, 1945), p. 71. Alternatively, Laurence Clarkson's Lost Sheep Found is an account 'of the various leadings forth' of his 'spirit' not only through England but through various faiths and their books on doctrine, from State religion through to antinomianism and Quakerism. On a more mystical level, George Fox's conversion is accompanied (or demonstrated) by an ability to read Scripture through an apprehension of the 'Light' and its 'openings-up' (The Journal of George Fox, ed. by John L. Nickalls, with an epilogue by Henry J. Cadbury and an intro. by Geoffrey F. Nuttall (Cambridge: Cambridge University Press, 1952), p. 14). Most similar to Bunyan's, however, is Anna Trapnel's ability to see the Law 'with an Evangelicall eye' after conversion, 'whereas before the light of the spirit came', she writes, 'I turned Gospel into Law, but now appeared a harmony between both', thus seeing 'morall precepts in Evangelicall arms, Sinai's voice in Sion's breast' (A Legacy For Saints; Being Several Experiences of the Dealings of God with Anna Trapnel (London: 1654), pp. 14-15). None of these accounts, however, (even George Fox's Journal) offer their reading and understanding within an explicitly doctrinal and didactic frame as is clearly the case in Grace Abounding: they are not accounts that either seek to recount or teach about learning to read and understand.
} 
Bunyan writes), Grace Abounding is nevertheless written to demonstrate how faith can indeed 'put into the soul an understanding enlightened on purpose to know the things of God, which is Christ and his imputed righteousness (I John 5. 20), which it never thought of nor understood before' ${ }^{32}$ But while the attainment of such understanding is communicated as an almost mystical experience in Grace Abounding, it is important not to mistake Bunyan's emphasis upon spiritual reading (in which he is led into words) as sanctioning any interpretive passivity or complacency in the convert. Thomas Luxon's point that Bunyan's is an 'antihermeneutic theology' yielding insight and meaning 'in spite of, rather than a result of, the various acts of interpretation one performs in reading' can (if overstated) be misleading in this respect. By suggesting that 'the only point of reading is to be reminded to stop reading', Luxon seems in danger of suggesting that the convert has no role to play in his own conversion or that one need not read at all to achieve understanding. ${ }^{33}$

Clearly, the message of Grace Abounding is not that the Spirit should be relied upon to do all the interpretive work for the believer. While a reliance on the Spirit for the illumination of things unseen does indeed represent a remarkable anti-hermeneutic in his theological thinking, Bunyan is always at pains to emphasise the convert's need to strive for a saving knowledge of the Word nevertheless. Conversion is thus characteristically presented in Grace Abounding as a strenuous battle, an almost physical wrestling with the Word for the promises, through which the very effort to read and understand becomes one of the principal qualifications in achieving a grace-ful acceptance of salvation. It is hardly surprising, therefore, that when it comes to understanding the Word spiritually Bunyan exhorts the believer simply to 'read and read again':

and do not despair of help to understand something of the Will and Mind of God therein, though you think they are fast lockt up from you. Neither trouble your heads though you have not Commentaries and Expositions, pray and read, read and pray. For a little from God is better than a great deal from men. ${ }^{34}$

\footnotetext{
32 Bunyan, Law and Grace, p. 149.

${ }^{33}$ Luxon, Literal Figures, pp. 167-168, 162. Luxon is, of course, referring to interpretive procedures, here, but the sense of passivity is nevertheless evident when he states: 'Once the pilgrim reader is cajoled into stopping the effort to "make sense", the Spirit, believes Bunyan, is free to do its work' (pp. 162, 185).

34 John Bunyan, Christ a Compleat Saviour (1692), in Miscellaneous Works XIII, pp. 331-332.
} 
Importantly, Bunyan aligns the strenuous effort to read here as synonymous with the work of the Spirit in rendering understanding. With reading and praying as practically the same for Bunyan, Christians are often 'at such a loss' in matters of faith and assurance, he notes, primarily because they refuse to engage with the Word devotionally themselves, becoming complacently 'content with what comes from men's mouths, without searching, and kneeling before God, to know of him the truth of things. ${ }^{35}$

Such teaching is most pertinent to Bunyan's experiences in Grace Abounding not because his conversion reveals any lack of a zealous searching for truth (this is far from the case, despite Bunyan's questing being mistaken at times) but because his point in writing Grace Abounding is also to emphasise that such searching must go on after conversion if faith and understanding are both to be maintained and developed in the believer. Although one of the principal effects of receiving an enlightened understanding through faith is an ability to read Scripture with new eyes of understanding, the soul receiving 'some blessed experience of the things of God, even of the glorious mysteries of the Gospel', if the convert does not persevere in his searching for truth after conversion then both faith and understanding will become nothing. ${ }^{36}$ Anyone who is willing to 'retain and hold fast the Doctrin of Redemption [...] must not deal in God's matters with a slack hand', Bunyan asserts, for

'Tis not enough for them that would do so, to be content with Sermons,
Familie-Duties, and other publick Assemblies for worship; but there must be a
continual exercise of the mind about these matters, and a labour of the Soul to
retain them in their glory and sweetness; else they will first enter their
excellency, then as to the very notion of them, slip from the heart and be gon. ${ }^{37}$

The need to maintain a distinction between outward duty and inward knowledge of salvation thus applies as much to the converted saint as to the converting sinner, a crucial fact that Bunyan evidently forgets in Grace Abounding. Hence, Bunyan's new-found understanding is followed by a backsliding which, characterised by the distinct absence of any continual exercising of his mind about the doctrine of redemption, comprises almost half of the entire narrative. What this backsliding represents, in fact, is a total interpretive collapse. With Bunyan failing to maintain the faithful understanding of Scripture originally achieved in

\footnotetext{
${ }^{35}$ Bunyan, Christ a Compleat Saviour, p. 332.

${ }^{36}$ Bunyan, Law and Grace, pp. 154-156 (p. 154).

${ }^{37}$ Bunyan, Israel's Hope Encouraged, p. 91.
} 
conversion, his fear of having committed the unpardonable sin and his escalating state of hopelessness are both signalled and compounded by an inability to apply the 'Promises' of the Word to his spiritual situation. In despair, Bunyan can only contrive to turn the Word against him: every sentence he discovers merely confirms for him his unpardonable status, particularly that of 'Esau, who for one morsel of meat sold his Birth-right', the condemnations of the Word thus becoming irreconcilable with its promises. ${ }^{38}$ Consequently, Bunyan's neglecting to sustain his faith through reading simultaneously renders him unable to read the Word in faith, despair forming a vicious circle that spirals Bunyan into a perilous spiritual deterioration and disorientation figured forth continually in the text through images of entrapment, oppression, and drowning. ${ }^{39}$ Instead of applying the Gospel to his soul, now Bunyan can only persist in an over-identification with both popular and Biblical types of unpardonable sinners (Francis Spira, Judas, and 'the man that hath his dwelling among the Tombs with the dead'), with the Word, as he puts it, having 'shut him out." ${ }^{40}$

For this reason, Bunyan's backsliding culminates in what is for many readers and commentators the most spectacular interpretive struggle of all in Grace Abounding, with the Word of the Law (on Esau's birthright) and that of grace ('My grace is sufficient for thee') becoming engaged in a metaphysical conflict that takes place both in Bunyan's conscience and yet, it seems, beyond his conscious control. It should be noted, however, that despite the innate drama this almost epic Scriptural contest conveys in Grace Abounding, it is not the momentous meeting of these two texts alone that represents the most important point of Bunyan's recovery from backsliding. Bunyan's true triumph over despair comes not merely with the vanquishing of 'those most fearful and terrible Scriptures' but with their subsequent appropriation into a scheme of covenantal salvation - that is, by being read grace-fully. The moment that the text 'about Esaus birthright began to wax weak, and withdraw, and vanish; and this about the sufficiency of Grace prevailed, with peace and joy' undoubtedly offers immediate release for Bunyan, but its more important consequence lies in the fact that it encourages him to read Scripture with the eyes of understanding again. Bunyan is thus given

\footnotetext{
${ }^{38}$ Bunyan, Grace Abounding, p. 43.

${ }^{39}$ Bunyan, Grace Abounding, pp. 47, 50, 62.

${ }^{40}$ Bunyan, Grace Abounding, pp. 58, 76.
} 
renewed confidence in the Word at this moment and subsequently regains a timid but almost tactile intimacy with the texts that have haunted him so desperately: 'I began to take some measure of incouragement', he writes, 'to come close to them, to read them, and consider them, and to weigh their scope and tendence. ${ }^{41}$

Only through such a gradually re-emerging confidence in faithful interpretation can the Esau text be de-fused of its desperate significance by Bunyan through being read, reconsidered, and finally illuminated by the light of his doctrine of grace. In this way, Bunyan eventually concludes that 'the Birthright signified Regeneration, and the Blessing the Eternal Inheritance', both being recognised as permanently fixed for the faithful. In this way, Bunyan re-establishes the kind of totalising comprehension of Scripture originally achieved in conversion. Bunyan's renewed assurance thus comes not through just the banishment of hard texts, therefore, but through a confident reading of them via the doctrine of grace. Only as a consequence of such grace-ful reading is Bunyan released from his interpretive a-mazement. Able to see more fully 'that thus to understand them was not against but according to other Scriptures', Bunyan now succeeds in finding 'a concurrence and agreement in the Scriptures' by creating (or perhaps having revealed to him) a semantic space in the Word in which forgiveness and hope take precedence rather than condemnation and justice. True understanding (which not all believers can achieve, Bunyan admits) is just such an ability to 'reconcile the seeming contradictions that are in these texts. ${ }^{42}$

Bunyan's final release from an interpretive imprisonment which paradoxically locks him out of the 'Promises' that can liberate him is duly followed by a re-enactment of the kind of glorious mystical understanding and glorifying spiritual revelation he experiences originally through conversion: Bunyan is led once more 'into the mystery of Union with this Son of God', seeing himself almost ecstatically as 'flesh of his flesh, bone of his bone' and 'in Heaven and Earth at once'. But despite the descriptive pyrotechnics, here, the most important spiritual wisdom that Bunyan gains from his backsliding experience is articulated more profoundly (and less dramatically) in his subsequent reflections on the matter. For Bunyan,

\footnotetext{
${ }^{41}$ Bunyan, Grace Abounding, p. 70.

${ }^{42}$ Bunyan, Grace Abounding, pp. 66-67, 70-71, 61; The Saints Privilege and Profit, p. 224.
} 
such 'Temptation' has taught him beyond all else to avoid his 'former foolish practice, of putting by the Word of the Promise when it came into my mind'. Whereas 'formerly', Bunyan admits, 'I thought I might not meddle with the Promise, unless I felt its comfort', now he states: 'I should labour to take the word as God had laid it down, without restraining the natural force of one syllable thereof'. Bunyan reads now 'with careful heart and watchful eye, with great seriousness to turn over every leaf, and with much diligence mixed with trembling, to consider every sentence, together with its natural force and latitude. ${ }^{, 43}$

The point that Bunyan communicates here is that the believing Christian needs to be most diligent and watchful in his or her understanding of the Word not only because perseverance demands the continual application of the 'Promises' to the soul but because the kind of reading that faith leads the believer into is always in danger of slipping into a rational and logical, as opposed to a grace-ful, hermeneutic. Spiritualising the Word in a Gospel-sense, as Bunyan does with Esau's birthright, is, for example, clearly presented in Grace Abounding as an act of faith marking both a release from despair and an advance in the spiritual comprehension of Biblical texts. But, at the same time, this reading is also outwardly indistinguishable from a merely cerebral acceptance of Scripture as metaphorical, parabolic, or allegorical. Bunyan is always at pains to stress, therefore, that the one factor that prevents a spiritual understanding of Scripture from becoming just clever interpretation is a faith that, without an intimate and dutiful reading of the Word, will fade. It becomes apparent, therefore, that it is the convert him- or herself who is the final focus of Bunyan's teaching about mistaking knowledge for understanding in Grace Abounding. Without a diligent faith, any Christian's ability to read Old Testament texts through New Testament doctrine simply makes them the most ignorant and deluded of all: a 'tinkling Cymbal' that 'hath not life'. ${ }^{44}$ Bunyan's discourse about distinguishing between the gift of knowledge and that of grace, between interpreting and understanding, must be applied with most urgency of all, therefore, not to the ignorant reading practices of the unregenerate but to the kind of reading that Bunyan describes

\footnotetext{
${ }^{43}$ Bunyan, Grace Abounding, pp. 72-74, 77.

44 Bunyan, Grace Abounding, p. 91.
} 
himself achieving as a believer in Grace Abounding and which, as the minister of the Bedford Church, prevents him from becoming but 'a sounding Brass'.

Bunyan's teaching about interpretation and understanding, faith and knowledge, throughout Grace Abounding is thus simultaneously simple and complex. On one level, Bunyan's progress in reading continually emphasises that the convert must become sensitive to any carnal reasoning in one's pursuit of faith not only because it can turn understanding into mere knowledge but because it can turn faith into despair. Bunyan's worst 'flouds of Blasphemies' 'against the very being of God, and of his onely beloved Son' thus take the conspicuous form of logical and rational scepticism over 'whether there were in truth a God or Christ, or no? and whether the holy Scriptures were not rather a Fable and cunning Story, then the holy and pure Word of God?' Uncertain as to whether his own knowledge of 'Faith, and Christ, and Scripture' is but 'a think-so too', it is the interrogative mark which plagues Bunyan's narrative at such times, with despair arriving in 'sudden thoughts to question all I read' and obliterating his ability to understand or retain anything of the Word: 'my mind would be so strangely snatched away', Bunyan writes of such times, 'that I have neither known, nor regarded, nor remembred so much as the sentence that but now I have read." 45 To "question the being of God, and the truth of his Gospel', Bunyan writes in Grace Abounding's conclusion, is the 'worst' temptation of all because it 'removeth the foundations from under me' ${ }^{46}$

Reading Grace Abounding as an account of Bunyan's learning to understand through faith rather than reason is important, moreover, because it goes some way also in revising the conventional assumption that Grace Abounding represents little more than the individual's struggle to interpret the Word in the wake of a Reformation emphasis on salvation sola scriptura. Any overt emphasis on Grace Abounding being an account of how 'without an agreed methodology and the authority for such a methodology, Scripture became a "nose of wax" able to be shaped according to any individual's wishes' seems to miss the more crucial point of Bunyan's interpretive education, which is to distinguish between the seen and the

\footnotetext{
${ }^{45}$ Bunyan, Grace Abounding, pp. 31, 34.

${ }^{46}$ Bunyan, Grace Abounding, p. 102.
} 
unseen. Bunyan's reading in Grace Abounding reveals not so much a struggle 'to distinguish between the written and the verbalised' Word, therefore, with Bunyan being incapable of appreciating 'the text historically' or seeing 'the Word as part of a context that is other than the context of his own life', as much as it shows him learning that interpretation alone 'yields knowledge of things', while only 'believing yields experience of the promises' ${ }^{47}$ In this way, Grace Abounding is not so much the triumph of Bunyan becoming 'a reader' only when he manages to maintain 'a mind independent of the Scriptural text' as it is an account of how Bunyan comes to read only when he becomes a believer and comes to believe only when he becomes a reader. ${ }^{48}$

In this way, Grace Abounding can be said to encourage a reading which is antihermeneutic in its emphasis on spiritual understanding but which nevertheless requires the convert's whole-hearted effort, attention, and perseverance as a reader. Hence, Bunyan's grace-ful understanding is not just an individualistic struggle with the Bible but a being led into God's words and into the Gospel mysteries of the Word. ' 'Tis eternal life to know' Christ 'by the Scriptures', Bunyan asserts, believers being encouraged thereby to keep 'close to the Scriptures, and let thy Faith obey the Authority of them', more than anything else. ${ }^{49}$ This is an anti-hermeneutic not because it requires nothing from the believer but because, as Bunyan says most crucially at the end of Grace Abounding, experience of such things, 'hath more interest in that text of Scripture, Gal. I. 11, 12 than many amongst men are aware: 'the Good News I preached', this Pauline text reads, 'is not a human message that I was given by men, it is something I learned only through a revelation of Jesus Christ.' 50

Reading into Bunyan's reading in this way reveals a spiritual agenda in Grace Abounding at the heart of which lies the need to recognise a difference between the seen and the invisible, the 'ordinary' and the 'extraordinary', as Bunyan puts it at one point. ${ }^{51}$ But while the message Bunyan promotes in Grace Abounding is intended to teach the reader about such matters via the 'Brief Relation' of his own experience, his conviction that unseen things

\footnotetext{
${ }^{47}$ Ward, 'To Be a Reader', pp. 29-30, 32; Thomas Luxon, Literal Figures, p. 175.

${ }^{48}$ Ward, 'To Be a Reader', p. 29.

${ }^{49}$ Bunyan, The Saints Privilege and Profit, p. 225.

${ }^{50}$ Bunyan, Grace Abounding, pp. 87-88.

${ }^{51}$ Bunyan, Grace Abounding, p. 17.
} 
can be learned through a faithful experience of 'the Word and Spirit of Christ' alone also places the reader of Grace Abounding in a somewhat paradoxical position. Bunyan cites the above quoted Scriptural reference (Galatians I. 11, 12), for instance, not only to reinforce his point that reason and knowledge have little role to play in understanding the doctrine of salvation by grace but, moreover, to refute any suggestion that he makes use of 'other men's lines' in establishing his own faith..$^{52}$ In saying this, Bunyan is affirming neither the originality nor the veracity of his experience but stating that grace-ful understanding comes only through the 'revelation of Jesus Christ' via the Word and the Spirit and not through any knowledge 'given by men'. If this is the case, however, then how can Grace Abounding, a text so distinctly another man's 'lines', teach the reader anything at all about the experience of faith?

As a consequence of this dilemma, Bunyan's record of hermeneutic trials may represent both the kind of faithful perception finally required of the believer as well as the mistakes to avoid along the way but it is also aware that it cannot in itself finally bring forth saving faith in the reader: this is the remit of the Word and the Spirit, not another man's (even Bunyan's) lines. What Grace Abounding can do as an example of conversion, however, (as is so effectively communicated in the Preface, for instance) is provide comfort in the shared experience of hard times ('remember 'twas thus with your father') and act as a stimulus for the reader to meditate on his or her own faith, salvation, and experience of grace: 'Remember, I say, the Word that first laid hold upon you; remember your terrours of conscience, and fear of death and hell: remember also your tears and prayers to God; yea, how you sighed under every hedge for mercy. ${ }^{53}$ In this way, the text advances itself from the outset as a somewhat selfeffacing account of conversion, one which, in the end, is to be disregarded by the reader in favour of his or her own experience, to be read not for its own sake but to encourage the reader to look beyond its pages to within him or herself for faith and true understanding. The ultimate focus of Grace Abounding is never itself, therefore, but the reader reading it whom Bunyan continually exhorts to remember grace and, by his own example, hopes to remind about the dangers of reason, knowledge, and despair as well as the need for perseverance in faith.

\footnotetext{
${ }^{52}$ Bunyan, Grace Abounding, pp. 87-88.

${ }^{53}$ Bunyan, Grace Abounding, p. 3.
} 
In encouraging the reader to consider the nature of things unseen by turning back to their own experience, Grace Abounding would seem, then, to avoid the problem voiced in Bunyan's anxiety over 'other men's lines'. Indeed, in this sense, Bunyan could be seen as wanting Grace Abounding to emulate the role Luther's 'comment on the Galathians' played in his own experience, his text being relied upon by others as similarly offering a 'Godly man's Experience' when other accounts may seem to evince but 'Wits and Parts' rather than anything of 'going down themselves into the deep.' 54 Yet, for all the rhetoric of self-effacement and servitude in the professed (and prefaced) aim of Grace Abounding, the text manages to teach the reader about grace-ful reading nevertheless. In fact, it is precisely because the reader is the central focus of the text that Bunyan can ensure that his point about grace-ful understanding is not just communicated as a series of exemplary tales to follow and learn from historically but, moreover, that it is embedded in the very experience of reading the narrative, within its textual strategies, its generic complexities, and the way the reader responds to them. What is to be stressed here, then, is that Grace Abounding teaches the reader about reading and understanding not merely by being another man's lines and illustrating another man's deeds but by having the text itself demand a turn around in the perceptual habits of its reader - that is, Grace Abounding too must be read by faith rather than reason.

What such a view posits, and perhaps rather simplistically, is that Grace Abounding exacts something of a test of faith from its reader, being constructed to elicit either proper or improper responses to the experiences it relates. Hence, just as Bunyan's narrative depicts him learning to approach doctrine in terms of the unseen rather the seen, and the Word in terms of its 'extraordinary' rather than 'ordinary' significance, then so too does Grace Abounding demand of the reader a reading according to a spiritual as opposed to a rational hermeneutic. To appropriate Brian McHale's more contemporary vocabulary, what is being asserted here is that Grace Abounding demands a reading which is centred in 'ontological' as opposed to 'epistemological' concerns, that Bunyan chooses to adopt textual strategies which engage and

\footnotetext{
${ }^{54}$ Bunyan, Grace Abounding, p. 40. Vera Camden similarly stresses the importance of Luther's Commentary in fostering Bunyan's 'embrace of a more authentic - because more original - testimony' in Grace Abounding, making Bunyan's account 'unmatched by his contemporaries' in intensity and vividness: ' $M o s t$ Fit for a Wounded Conscience": The Place of Luther's "Commentary on Galatians' in Grace Abounding', Renaissance Quarterly, 50 (1997), 819-849 (pp. 821-822).
} 
foreground 'post-cognitive' questions about an alternative (that is, spiritual) reality like 'Which world is this? What is to be done in it?' and 'What happens when different kinds of world are placed in confrontation, or when boundaries between worlds are violated?', as opposed to questions such as 'What is there to be known? Who knows it? How do they know it, and with what degree of certainty? How is knowledge transmitted from one knower to another, and with what degree of reliability?'5s In other words, and in a way greatly similar to how McHale views postmodernist fiction operating, Grace Abounding urges the reader to view the text not in terms of knowing but, as we have seen, in terms of being and believing.

Although McHale adopts 'epistemological' and 'ontological' to differentiate between how modernist and postmodernist works of fiction can be read, the terms of his analysis apply nevertheless (albeit somewhat anachronistically) to what lies at the heart of Bunyan's narrative practice in Grace Abounding. In brief, McHale views the literary 'dominant' of modernist fiction as centred in 'epistemological themes' such as the 'accessibility and circulation of knowledge' and 'the problems of "unknowability" or the limits of knowledge', whereas in postmodernist fiction, he argues, the dominant shifts in emphasis away from 'problems of knowing to problems of modes of being - from an epistemological dominant to an ontological one. ${ }^{56}$ Such a shift is, moreover, both effected and made evident through stylistic differences too. The epistemological themes of modernist fiction are thus foregrounded by the use of 'characteristically modernist (epistemological) devices' such as 'the multiplication and juxtaposition of perspectives' and 'strategies of an "impeded form" (dislocated chronology, withheld or indirectly-presented information, difficult "mind styles")', all of which help to transfer 'the epsitemological difficulties of its characters to its readers', simulating for the reader the 'problems of accessibility, reliability, and limitation of knowledge' facing the

\footnotetext{
${ }^{55}$ Brian McHale, Postmodernist Fiction (New York and London: Methuen, 1987; repr. 1993), pp. 9-10.

${ }^{56}$ The literary dominant, McHale explains, is a Russian formalist term and 'a conceptual tool' with which it is possible to elicit a literary system's 'underlying heterogeneous catalogues, and begin to account for historical change. For to describe change of dominant', McHale asserts, 'is in effect to describe the process of literaryhistorical change.' The dominant, moreover, simply 'specifies the order in which different aspects are to be attended to [in a text], so that', McHale notes, 'although it would be perfectly possible to interrogate a postmodernist text about it epistemological implications, it is more urgent to interrogate it about its ontological implications. In postmodernist texts, in other words, epistemology is backgrounded, as the [price for] foregrounding ontology' (Postmodernist Fiction, pp. 7, 11).
} 
narratives' protagonists. ${ }^{57}$ Postmodernist fiction, alternatively, abandons 'the intractable problems of attaining reliable knowledge of our world' and, instead, aims to project another possible world (or even worlds), thus raising questions that 'bear either on the ontology of the literary text itself or on the ontology of the world it projects.' As a consequence, postmodernist fiction 'deploys strategies which engage and foreground' issues centred not in knowledge but being, and which simulate for (and transfer to) the reader concerns of an ontological nature. $^{58}$

Perhaps the most important point in McHale's analysis, therefore, is that postmodernist fiction projects a possible world. With 'an ontology' being accepted by McHale (according to Thomas Pavel's definition) as 'a theoretical description of the universe', then 'to "do" ontology is not necessarily to seek some grounding for our universe; it might just as appropriately involve describing other universes, including "possible" or even "impossible" universes', the narrative implications of which are obvious but nevertheless crucial to note. In presenting the reader with an ontology other than his or her own, a writer can confront the reader with a world that does not conform to conventional epistemological certainties, offering an 'ontological instability or indeterminacy, the loss of a world that could be accepted [...] as a given of experience. 59 Presenting a space in which to critique the reader's this-worldly experience, then, depicting a possible world may be useful because it allows the limitations of what is known to be explored and propositions of classical logic to be defied. Because the world of a postmodernist fiction need obey no laws of reason, it becomes possible to explore concepts that are not simply either true or false but perhaps both true and false simultaneously, presenting experiences 'which violate the law of the excluded middle'. Consequently, such 'selfcontradictory constructs' have great potential in becoming 'subversive critiques of worlds and world-building', Umberto Eco arguing that 'the proper effect of such narrative constructions (be they sci-fi novels or avant-garde texts in which the very notion of self-identity is challenged) is just that of producing a sense of logical uneasiness and of narrative discomfort.'

\footnotetext{
${ }^{57}$ McHale, Postmodernist Fiction, pp. 9-10.

${ }^{58}$ McHale, Postmodernist Fiction, p. 10.

${ }^{59}$ McHale, Postmodernist Fiction, pp. 26-27, quoting Thomas Pavel, 'Tragedy and the sacred: notes towards a semantic characterization of a fictional genre', Poetics 10: 2-3 (1981), 231-242 (p. 234). This essay also forms part of Thomas Pavel's Fictional Worlds (Cambridge, Massachusetts: Harvard University Press, 1986).
} 
They 'arouse a sense of suspicion in respect to our common beliefs and affect our disposition to trust the most credited laws of the world of our encyclopaedia. ${ }^{90}$

In these terms alone, it would seem that such postmodernist poetics lend themselves easily to illustrating how Grace Abounding functions as a text both thematically and narratively. In Grace Abounding, Bunyan is clearly projecting a world which involves a reality offering an alternative to what is knowable and provable in this world, presenting experiences (the hearing of voices, the seeing of visions) which emphasise the invisible dimension of conversion, faith, and salvation over and above the visible 'world of our encyclopaedia'. As the world Bunyan depicts in Grace Abounding is ontological and spiritual, moreover, it foregrounds the inadequacy of any conventional epistemology in interpreting it. Consequently, Bunyan is at pains to emphasise throughout the story of his own hermeneutic ups and downs the fact that spiritual understanding demands a suspension of conventional logic and reasoning, his doctrine of grace violating the law of the excluded middle according to the basic tenets of a Christian (and specifically Pauline) dialectic. Grace-ful understanding is an ability to see the unseen, the extraordinary within the ordinary, and accept not only Christ as the ultimate excluded middle (both God and man simultaneously) but that salvation by grace defies all logic in itself: Bunyan's conversion is complete when he understands that 'the justice of God and my sinful Soul, could imbrace and kiss each other' through the blood of the cross, despite the fact that man deserves nothing but damnation for his sins. ${ }^{61}$

In presenting a narrative which focuses on the need to look at unseen things, Bunyan (to echo Eco's words on the matter) projects a world that destabilises the reader's assumptions not only about faith, knowledge, and reason but about narrative: there is a marked 'logical uneasiness' and a 'narrative discomfort' in reading Grace Abounding precisely because both the world and the doctrine it relates transgress certainties about what is knowable. However, Bunyan's projection of a spiritual reality in Grace Abounding is also more complex than this. Bunyan's conversion account does not manifest, for example, a world which is either purely or

\footnotetext{
(*) McHale, Postmodernist Fiction, p. 33, quoting Umberto Eco, "Lector in Fabula : pragmatic strategy in a metanarrative text," in The Role of the Reader : Explorations in the Semiotics of Texts (Bloomington and London, Indiana University Press, 1979), p. 234.

${ }^{61}$ Bunyan, Grace Abounding, pp. 9, 38, 36.
} 
obviously 'spiritual': Grace Abounding is not a narrative which deals in an abstract or transcendental mysticism but offers a very concrete world largely devoid of any ecstatic or prophetic experience. As such, and along with many other seventeenth-century spiritual autobiographies, it presents the unseen as being very much a part of everyday life with Bunyan's most profound and harrowing experiences in Grace Abounding occurring not when he is transported mystically into another realm but when he is unmistakably anchored in the real world - when he is walking down a lane, playing in a field, perusing in a shop. ${ }^{62}$ In the same way, moreover, he urges his reader to remember his or her experience of grace not in terms of any extravagant mystical histrionics but as very much a part of their ordinary working and domestic lives: 'Have you forgot the Close', Bunyan asks of his reader, 'the Milk-house, the Stable, the Barn, and the like, where God did visit your Soul? ${ }^{63}$

Far from simply projecting a spiritual ontology per se, therefore, the aesthetic of Grace Abounding focuses upon presenting a collision of worlds, with the realm of spiritual experience intruding continually and often violently upon Bunyan's carnal and everyday life. In Grace Abounding, Bunyan thus depicts 'a dual ontology, on one side our world of the normal and the everyday, on the other side the next-door world of the paranormal or supernatural' ${ }^{64}$ The reasons why Bunyan does this are two-fold. Firstly, Bunyan's theology as a whole is based upon a fundamental concept of faith as providing a bridge between this world and the next: grace-ful understanding is nothing less than an ability to negotiate and comprehend the collision of the seen with the unseen, 'to see things of another World', as Bunyan puts it, through 'enlightning Grace' ${ }^{65}$ Secondly, in offering his own experience as a conflict between realities, Bunyan is able to give more emphasis to his point about a need for

\footnotetext{
62 A useful comparison to Bunyan's 'everyday' experience can be found, for instance, in Anna Trapnel's $A$ Legacy for Saints, in which she states, at one point, how 'sometimes as I have been going along the streets, I have looked behind me, thinking I had heard some locall voice, a voice without me, but sure it was because I was unacquainted with the voice of the Spirit speaking in, or to the soul' (pp. 7-8). While Trapnel's experiences develop into something more visionary and mystical, John Sturrock notes that the 'evoking of mundane details' in spiritual autobiography serves to anchor the experiences 'in time and place and to heighten drama, as a moment when the divine order of things supervenes on the human order, portrayed at its most ordinary' (The Language of Autobiography: Studies in the First Person Singular (Cambridge: Cambridge University Press, 1993), p. 42).

${ }^{63}$ Bunyan, Grace Abounding, p. 3.

${ }^{64}$ McHale, Postmodernist Fiction, p. 73.

${ }^{65}$ John Bunyan, Heavenly Foot-Man (1698), in The Miscellaneous Works of John Bunyan V, ed. by Graham Midgley (Oxford: Clarendon Press, 1986), pp. 162-164.
} 
change in one's spiritual perceptions. In demonstrating 'a confrontation between real-world norms (the laws of nature) and other-worldly, supernatural norms' (with such confrontation being either 'understated to the point of [...] unfantastic banality', as in Bunyan's meeting with the Bedford women, or 'strenuously agonistic', as in his period of backsliding), Bunyan is able to establish the world of his experience as epistemologically problematic and consequently one in which 'ontological propositions' about faith and salvation can be opened and explored. ${ }^{66}$ Bunyan's experiencing of profound spiritual phenomena (his apparently irrational impulses or his being tempted by Satan, for instance) within a this-worldly and otherwise everyday context thus challenges the reader continually with a distinct sense of epistemological estrangement, 'confronting the empirical givens of our world with something not given, something from outside or beyond it, "a strange newness, a novum".,67

Bunyan's depiction of spiritual and carnal realms clashing and intruding upon one another is so important in Grace Abounding, therefore, because it opens up a 'zone of hesitation' between 'this world and the one next door' which, in turn, induces an uncertainty in terms of how we are to interpret Bunyan's experience as a whole. Do we accept Bunyan's encounters with voices and texts ontologically, as spiritually 'real', or is there an epistemological and logical explanation behind it all? As it is often difficult to know which way his experiences should be interpreted, the key term to describe Bunyan's narrative strategy throughout Grace Abounding is clearly that of hesitation, with the text itself frequently figuring forth such interpretive uncertainty before the reader's eyes. For instance, when faced with hermeneutic hesitancy Bunyan's experiences teach him that, if doubt and despair are to be avoided, uncertainty in one's reading should be countered by turning through faith to the Word's promises of salvation alone. In other words, the text teaches the reader to foreground the doctrinal and the ontological when reading, Bunyan's worst periods of hopelessness afflicting him when he refuses to do this himself. Unsurprisingly, then, the text's dominant cautionary image is that of stasis, indecision, and floundering, Bunyan frequently being 'at a

\footnotetext{
${ }^{66}$ McHale, Postmodernist Fiction, pp. 75, 44.

${ }^{67}$ McHale, Postmodernist Fiction, p. 59, quoting Darko Suvin, Metamorphoses of Science Fiction: On the Poetics and History of a Literary Genre (New Haven and London: Yale University Press, 1979), p. 4.
} 
stand' or 'as on a miry bog, that shook if I did but stir' until the Word of faith rescues him. ${ }^{68}$ The way the reader of Grace Abounding should avoid interpretive distress (that is, by reading faithfully) seems clear, then. But, equally, because Grace Abounding bears the veracity of autobiography (along with a naturalistic realism), it seems to encourage an epistemological and this-worldly reading at times nevertheless. After all, Grace Abounding does share many of the concerns that McHale identifies with modernist fiction. This text seems profoundly bound-up with the epistemological issues of "the problems of "unknowability" or the limits of knowledge', and like modernist fiction it offers a 'focalization of all the evidence through a single center of consciousness', the private 'I' of Bunyan's account simulating for the reader 'problems of accessibility, reliability and limitations of knowledge.' 69

Consequently, although it is undoubtedly crucial to read ontology over epistemology in order to understand Bunyan's conversion into faith and the doctrine it propounds, and while this is what the text continually teaches the reader, it is also pre-eminently possible to read (or rather misread) the text in epistemological terms alone. The best example of this has already been explored in the last chapter, with the medicalisation of Bunyan's experiences categorising his concept of spiritual reality within the realm of scientific and rational discourse as an enthusiastic madness or nervous disorder. That Grace Abounding can be (mis)read in this way is, furthermore, no accident but is central to Bunyan's narrative purpose. In stating in the Preface that the 'Philistians understand me not', Bunyan makes it clear that there are indeed correct and incorrect ways to understand his text, that there are to be right and wrong readers. In placing the onus of interpretation so conspicuously upon the reader, by making him or her decide how to understand the text, Bunyan's point is that it is the reader's metaphysics, the reader's faith, that any interpretation of Grace Abounding will reflect most of all. The aim of the text is, in fact, to force the reader to read his or her own self for faith, understanding, and salvation (as Bunyan sees them). Without doubt, moreover, one of the principal means of doing this lies in Bunyan's use of metaphor.

${ }^{68}$ Bunyan, Grace Abounding, p. 27.

(9) McHale, Postmodernist Fiction, pp. 9-10. 
That Bunyan's manipulation of metaphor provides a subtle and sophisticated way of separating the Philistines from the believers may seem surprising given that critics and commentators find metaphor in Grace Abounding largely unremarkable, merely reflecting a style that, far from 'playing' with the reader in any way, is in fact self-consciously 'plain and simple', with Bunyan laying down 'the thing as it was'.$^{70}$ Consequently, many readers of Bunyan's conversion account find that in terms of literary style, Grace Abounding reveals not any $u r$-postmodernist angst over representation and interpretation but, rather, a basic and even rustic simplicity, Bunyan's descriptive talents offering little more than 'the rural wisdom that mellows his piety' and a tendency to portray 'psychological struggle' through 'simple metaphors of home, lane and field', thus giving 'to the psychological realities of his conversion a convincing sensuous existence'. ${ }^{71}$ Given Bunyan's penchant to relate his experience in strikingly physical and often colloquial-sounding similes, it is hard to refute such a critique. Bunyan's descriptions of his yearning being 'like a Horseleach at the vein', of his soul being burdened 'as a clog on the leg of a Bird to hinder her from flying', or of being like a 'Child' in the face of a temptation that threatens to carry him away like 'some Gypsie' all illustrate this fact well, such metaphors leading commentators often to note that the 'dominant quality of Bunyan's spiritual vision is the concrete particularity of his struggle. ${ }^{72}$

But this is not even half of the story. Although critics seem assured of Bunyan's simple and domestic style in Grace Abounding, the fact that his use of metaphor is actually more complex than this is often acknowledged more unconsciously in the very terms of their analysis. To describe Bunyan's style, for instance, commentators are often forced to adopt paradoxical or oxymoronic terms, suggesting that Grace Abounding is the work of a 'powerfully concrete imagination'. ${ }^{73}$ Such a phrase, though communicating the obvious physical emphasis in Bunyan's relation of spiritual experience, largely confirms the interpretive hesitation that Bunyan's mode of narration often confers upon the reader. How can an imagination or a metaphor really be 'concrete'? In which case, does this really mean anything?

\footnotetext{
${ }^{70}$ Bunyan, Grace Abounding, pp. 3-4.

"Sharrock, John Bunyan (London: Macmillan, 1954; repr. 1968), p. 65; Dean Ebner, Autobiography in Seventeenth Century England: Theology and the Self (The Hague: Mouton Press, 1971), pp. 67-70.

${ }^{72}$ Robert Bell, 'Metamorphoses of Spiritual Autobiography', ELH, 44 (1977), 108-126 (p. 116).

${ }^{73}$ Sharrock, John Bunyan, p. 64.
} 
Roger Sharrock seems particularly confusing on such matters. Regarding Bunyan's use of 'concrete' detail as providing the only way for the 'total inwardness' of his experience to find 'a way out into objectified expression', and thereby be 'cured [?] and recorded for others', Sharrock's analysis is, nevertheless, riddled with hesitations. On the one hand, Bunyan's 'religious psychology draws a dividing line of Cartesian strictness between inner and outer, the knowledge based on sense perception and that belonging to the spiritual life', Sharrock asserts, while on the other it is through Bunyan's 'concrete strength of imagery' that just such a 'distinction between inner and outer worlds [...] breaks down'. Consequently, Sharrock does not seem to know how to respond to Bunyan's style: 'the physical sensation of straining and pushing' and of 'auditory and tactile sensations' are introduced, he suggests, as either 'powerful illusions or simply as metaphors.' 74

Sharrock's mistake here lies in the fact that, aside from the kind of similes already cited, there is very little in Grace Abounding that can be taken 'simply as metaphor'. Indeed, accepting Bunyan at his word on the matter of his 'plain and simple' style can be particularly problematic given that, in creating a 'zone of hesitation', the kind of a collision of worlds that Grace Abounding projects actually (and deliberately) makes the matter of laying down experience 'as it was' quite complex: this method of world-construction 'pluralizes the "real" and thus problematizes representation', consequently forcing the reader to question how he or she should respond to it. ${ }^{75}$ Metaphor is crucial to this process. Bunyan's experience in the 'game of Cat' episode, to return to a good example, is so difficult to fathom not because it is easy to identify such auditory and visual phenomena as either 'powerful illusions or simply as metaphors' but because it becomes almost impossible to decide how we should accept them at all. When Bunyan describes how 'a voice did suddenly dart from Heaven into my soul', and how 'I [...] was as if I had with the eyes of my understanding, seen the Lord Jesus looking down upon me', how do we interpret these events? Do we accept them epistemologically as the signs of an incipient neurosis in the young Bunyan, or ontologically as the actual

\footnotetext{
74 Roger Sharrock, 'Temptation and Understanding', pp. 10, 7; 'Spiritual Autobiography: Bunyan's Grace Abounding', in John Bunyan and his England, 1628-1688, ed. by Laurence, Owens, and Sim (London: Hambledon Press, 1990), pp. 97-104 (pp. 99-100, 103).

${ }^{75}$ McHale, Postmodernist Fiction, p. 75.
} 
intervention of the divine within the natural world? Did these events really happen, or is Bunyan only saying that it was 'as if' they happened? Does he physically hear a 'voice', or is such experience merely a metaphorical 'darting' within his 'soul'?

Clearly, a textual sleight of hand occurs in such episodes. With the description of Bunyan's experience ensuring that the literal and the metaphorical conspicuously share the same semantic space, it becomes almost impossible to decide whether we should accept Bunyan's experience as 'real' or only 'as if'. As McHale puts it, 'there is no way of processing' such expressions 'without registering the two possibilities and the tug-of-war between them - without, in other words, hesitating between the literal and the metaphorical. ${ }^{, 76}$ Metaphor is so central to the ontological poetics of Grace Abounding, therefore, because inherently it procures interpretive hesitation and demands a recognition of excluded middles: arising 'from the tension between a presence and an absence, an "existent" and a "nonexistent",' metaphor 'by its very nature foregrounds the ontological nature' of a text for the reader. Because, moreover, '[a]ll metaphor hesitates between a literal function (in a secondary frame of reference) and a metaphorical function (in a "real" frame of reference)', what Bunyan does in relating his experience in this way is 'prolong this hesitation as a means of foregrounding ontological structure.' Bunyan's style thus seeks continually to foreground the 'ontological duality of metaphor, its participation in two frames of reference with different ontological statuses' by 'aggravating metaphor's inherent ontological tensions, thereby slowing still further the already slow flicker between presence and absence. ${ }^{77}$

\footnotetext{
${ }^{76}$ McHale, Postmodernist Fiction, p. 135.

7 McHale, Postmodernist Fiction, pp. 133-134. This complexity of representation and interpretation in Bunyan's recounting of 'hearing voices' and texts from Scripture seems, moreover, largely particular to Grace Abounding alone. Other seventeenth-century spiritual autobiographies tend to stress that such experience is either wholly spiritual (a literal hearing of the voice of God, as with George Fox and Arise Evans) or as the consequence of either dreaming or mental disturbance, like melancholy or brain-sickness (as with George Trosse). Those accounts that do share Bunyan's style of stating how 'these words came in' are, on the whole, much less difficult hermeneutically than Grace Abounding, such constructions often simply suggesting memory recall more than anything else: some words 'presently came into my mind', writes Charles Doe at one point, 'as if spoken or intended to me' (Charles Doe, $A$ Collection of the Experience of the Work of Grace (London: 1700), pp. 17, 31). For other examples see Evans, An Eccho to The Voice from Heaven, p. 53; Joseph Salmon, Heights in Depths and Depths in Heights (London: 1651), p. 13; Vavasor Powell, Spiritual Experiences of Sundry Believers (London: 1653), pp. 46, 80, 280; The Journal of George Fox, pp. 7, 11, 13, $14-16,19,22,39,662-663,700-701$.
} 
The reason for doing all this is clear. By deliberately making it difficult to separate literal and metaphorical frames of reference in his relation of experience, Bunyan can place the burden of interpretive responsibility most forcefully upon the reader who must now negotiate such hesitation according to his or her own metaphysics alone. Should the reader accept such events spiritually or medically, ontologically or epistemologically, faithfully or faithlessly? Which frame of reference is Bunyan's metaphors rooted in, the real world of physical event or the alternative reality of things unseen? Bunyan's use of metaphorical expression, especially that most ambiguous construction 'I was if', is far from 'plain and simple', then, but embodies the core of his text's ability to destabilise complacent interpretive practice, to force the reader to consider what is being described and, ultimately, to look within and read him or her self for faith. ${ }^{78}$ Reading Grace Abounding in terms of an aesthetic practice which aims to problematise and foreground its own methods of representation has a distinct agenda for Bunyan, therefore: because the way we understand Bunyan's experiences becomes a matter of belief, reading the text thus becomes a most self-reflexive process indeed. Metaphor is so important in all this, moreover, as conversion into grace-ful understanding manifests itself for Bunyan preeminently in an ability to read hard Scriptural texts as both metaphorical and yet 'true': that is, not according to either a literal or a metaphorical understanding of the Word but a comprehension that can accept the Word as both figurative and literal, as typological but 'truthful'.79

Understanding Bunyan's use of metaphor in this way explains why many critics have, either consciously or unconsciously, been confused by Grace Abounding. Textually, for instance, one of the principal effects of prolonging the hesitations inherent in metaphor is that a blurring occurs between what is physically (or spiritually) real and what is figurative, metaphor

\footnotetext{
${ }^{78}$ On Bunyan's frequently used construction 'I was as if', Thomas H. Luxon suggests that by adapting a similitude for the self Bunyan offers himself as a 'crier thoroughly displaced, objected', through which the 'I becomes an as if I, a ghostly I, an I from the grave': “ "Other Men's Words" and "New Birth": Bunyan's Antihermeneutics of Experience', Texas Studies in Literature and Language, 36 (1994), 259-290 (p. 274); this essay is also reprinted in Literal Figures, pp. 130-158.

${ }^{79}$ For a useful illustration of both 'conservative' and 'radical' Puritan attitudes towards metaphor, Scriptural interpretation, and the representation of spiritual experience see Nuttall, The Holy Spirit in Puritan Faith and Experience, pp. 49, 50, 52-55, 138-140, 146-149, and (to contrast Bunyan's with radical seventeenth-century sectarians' attitudes towards such matters) see Nigel Smith, Perfection Proclaimed: Language and Literature in English Radical Religion 1640-1660 (Oxford: Clarendon Press, 1989), pp. 268-307.
} 
thus often becoming 'realised' and 'concretised', with 'events, objects, situations' apparently developing 'into realities' which would otherwise be taken as metaphorical. ${ }^{80}$ This is certainly the case when Bunyan describes Scriptural texts falling and trampling upon him or speaking to him as if 'some man had behind me called to me'. 81 It is the physical immediacy of Bunyan's language that serves to elide the all important 'as it were' in such cases and contrives to turn the figurative relation of spiritual experience into something that seems pre-eminently literal and often bodily. It is not surprising, therefore, that critics use phrases like 'concrete imagination' when discussing Bunyan's style as the text forces the reader into such paradoxes continually. Is it possible for the reader to respond otherwise? $?^{82}$

When Bunyan's spiritual events occur 'as it were' physically, moreover, it is not just that the reader is being asked to register Bunyan's clever manipulation of metaphor, either. Rather, a more immediate textual manoeuvre is being presented. In describing the 'hearing' of voices and the 'seeing' of visions, the 'as it were' combines with the powerfully 'physical' aspect of Bunyan's testimony to cause an iridescence or flickering in the text. Through prolonged metaphorical hesitation, events seem both to happen and not happen simultaneously in Grace Abounding: Bunyan 'hears' the voice of the Word and yet, simultaneously, he does not - it is only 'as if' he does. It is just such flickering that characterises not only Bunyan's use of metaphor in Grace Abounding, however, but his narrative structuring of the text as a whole. Not only is the reader often hesitant about whether to accept certain descriptions as

\footnotetext{
${ }^{81}$ McHale, Postmodernist Fiction, p. 134.

${ }^{81}$ Bunyan, Grace Abounding, p. 30.

${ }^{82}$ Modern readers may, of course, explain their readings (or misreadings) of Bunyan's experiences in Grace Abounding according to the social and cultural shifts in ontological perception effected since Bunyan's own time. McHale is keen to stress, for example, how different cultures at different points in time may 'distinguish sacred and profane levels of reality', and how entities 'can change their ontological status in the course of history, in effect migrating from one ontological realm to another'. Hence, through time, 'real world entities and happenings can undergo "mythification," moving from the profane realm to the realm of the sacred. Or mythological entities can, with the erosion of the belief-system that sustains them, lose their status of superior reality, "realer" than the real world, and deteriorate to the status of "mere" fictions' (Postmodernist Fiction, pp. 37, 36). The 'erosion' of a Calvinist-providentialist belief-system and its gradual replacement by rational moralism and ultimately by a broader secularisation of society since the seventeenth century would certainly help to explain why poor Bunyan's troubles are often re-mythified as signs of psychosis. As such, it would be quite conceivable that a seventeenth-century reader would not experience any sense of estrangement or interpretive difficulty in accepting Grace Abounding's recounting of spiritual events and temptations as 'real'. Clearly, however, it is not enough to rely alone upon temporal changes in belief to explain how or why Grace Abounding operates so consistently in terms of representational hesitation. Indeed, such a view ignores the fact that there are constructions innate to the text itself, regardless of historical shifts in ontology, that make reading Grace Abounding problematic for any reader of either the twentieth or the seventeenth century.
} 
real, illusory, or figurative but, moreover, whole episodes within the text seem to opalesce, to happen and not happen (or to happen and then un-happen) simultaneously. Bunyan's swift shifting from assurance to despair is, for example, perhaps the most characteristic feature of the account as a whole, and is often seen as indicative of a Calvinist uncertainty about salvation, Bunyan's text thus simply following the conventional pattern of Puritan spiritual autobiography. However, as a conscious strategy adopted by Bunyan, such structural iridescence can be identified as a form of narrative 'self-erasure' whereby, on the one hand, '[e]vents may be narrated and then explicitly recalled or rescinded', while on the other, 'two or more [...] mutually exclusive states of affairs' can be 'projected by the same text' ${ }^{83}$

That Bunyan's text operates in these terms is clear. Indeed, what makes the narrative style of Grace Abounding so remarkable is the intensity not only of the experiences but of the drama in Bunyan's raisings up and castings down which, so repetitive, even threatens to undermine the reader's confidence that Bunyan is progressing at all in his journey towards faith and salvation. Typical of Grace Abounding, therefore, is the relating of numerous events and experiences which lead to comfort and assurance only for such feelings subsequently to be erased - to be un-narrated. Hence, Bunyan, after having experienced the Word 'as an eccho doth answer a voice, This sin is not unto death', unmistakably feels assured at one point that 'my sin was not unpardonable', and reinforces such certitude with particularly solid and reassuring simile: 'for this sentence stood like a Mill-post at my back'. But, as any reader of Grace Abounding knows, such assurance is rarely long-lasting, Bunyan's new-found confidence quickly giving way to a characteristic timidity and uncertainty: 'Yet towards the evening of the next day', Bunyan confesses, 'I felt this word begin to leave me, and to withdraw its supportation from me', Bunyan thus returning 'to his old fears again' ${ }^{84}$ This pattern presents the structural core of Bunyan's narrative and, although such spiritual ups and downs are common to conversion accounts of the seventeenth century, there are few which offer such intense raisings up and castings down over a narrative as sustained and as detailed

\footnotetext{
${ }^{83}$ McHale, Postmodernist Fiction, p. 335.

${ }^{84}$ Bunyan, Grace Abounding, pp. 59-60.
} 
as Bunyan's. ${ }^{85}$ Indeed, halfway through Grace Abounding Bunyan's conversion itself seems to become erased, his backsliding apparently leaving him worse than he ever was: 'the Tempter came upon me again', Bunyan writes, 'and that with a more grievous and dreadful temptation than before. ${ }^{86}$

Undoubtedly, it is through the self-erasing nature of Bunyan's experiences in Grace Abounding that the text gains its complex, labyrinthine structure and has led many critics to comment upon how such diffuseness and circularity can indeed raise uncomfortable doubts as to whether Bunyan has benefited all that much from his experiences. ${ }^{87}$ After all, even in the final paragraphs of the narrative, in which Bunyan offers accounts of his ministry and imprisonment, Bunyan is still suffering from the painful and almost overwhelming temptations to sin and blaspheme that will continue, we can only suppose, well beyond the bounds of the narrative. Such uncertainty, such a tendency to have one's assurance erased from the soul, can be explained as either the result of poor narrative style (Bunyan's plain and simple art failing to command the basics of good story-telling) or, alternatively, as a result of Bunyan's Calvinist doctrine, a will-to-uncertainty that denies the believer any final assurance of salvation. John Stachniewski's analysis is particularly emphatic in this matter. For him, the fact that Bunyan's 'assurance of salvation [...] can be displaced instantaneously by despair' merely reflects Bunyan's struggle with alternating elect and reprobate frames of mind: 'Experientially', Stachniewski writes, 'the reprobate paradigm kept tangling with or effacing the elect' in Grace

\footnotetext{
${ }^{85}$ Most spiritual accounts describe, usually through the nautical imagery of ship-wrecks and tempests, the extremities of spiritual ups and downs - 'the flouds of temptation' which 'over-flowe, and over-whelme the poore distressed, doubting, despairing and drowning soule', as Vavasor Powell puts it in the prefatory 'Epistle' to Spiritual Experiences (p. ii). But most conversion accounts are extremely brief, especially in comparison to Grace Abounding, and even the more lengthy ones, such as Anna Trapnel's and Richard Norwood's, do not present struggles as intense and prolonged as Bunyan's (nor do any have a doctrinal framework as explicit as Bunyan's). See Anna Trapnel, A Legacy for Saints, pp. 7-8, 17-18; The Joumal of Richard Norwood, pp. 96100; Doe, A Collection of Experience, pp. 9-28, 52-53; Powell, Spiritual Experiences (esp. the experiences of 'M. K.', pp. 160-191). An alternative kind of raisings up and castings down can be found, however, in those accounts involving literal sea-journeys. See the 'Experiences of T. R.' in Powell, Spiritual Experiences, pp. 385-394, and the autobiography of Thomas Shepherd who, fleeing to New England in 1635, also undergoes spiritual trials and tribulations brought about by actual (and not just metaphorical) sea-troubles: see God's Plot: The Paradoxes of Puritan Piety, Being the Autobiography and Joumal of Thomas Shepherd, ed. with an intro. by Michael McGiffert (Massachusetts: University of Massachusetts Press, 1972), pp. 58-61.

${ }^{86}$ Bunyan, Grace Abounding, pp. 40-41.

${ }^{87}$ Christopher Hill notes, for example, that by the end of Grace Abounding, there 'have been so many ups and downs in the story that we are left with less certain conviction than Bunyan seems to feel that his doubts and temptations are all behind him' (A Turbulent, Seditious, and Factious People: John Bunyan and his Church, 1628-1688 (Oxford: Oxford University Press, 1988; repr. 1989), p. 74.
} 
Abounding, leaving us with a Bunyan who 'has not, even by the end of the narrative, graduated from his reprobate fears', and who attempts 'to banish the persisting reprobate spectre by wrestling with narrative material that flickers under the gaze. ${ }^{88}$

Of course, Grace Abounding evinces neither artless tale-telling nor is it, as we have seen in the last chapter, plagued by any persecutory complex about reprobation. Rather, Bunyan's self-erasing, maze-like narrative has a more basic (and more important) doctrinal reasoning behind it. As we have already seen, Bunyan's experiences are painfully repetitive not because he is mistaking himself as reprobate instead of elect but because at the heart of Bunyan's doctrine of grace lies a fundamental dialectic: great grace undoubtedly brings great temptation and so, Bunyan exclaims, 'Alas! The more grace [...], the greater Trials. ${ }^{89}$ Far from being a cause to doubt, therefore, Bunyan's continued sufferance of temptation and spiritual affliction in Grace Abounding is to be accepted by the convert whose duty it is to grow in faith and grace through a continual application of the promises of the Word to the soul. In these terms, then, it becomes possible to make sense both of the structure of the text as well as its blatant sense of disclosure through a quite alternative doctrinal reading. What Grace Abounding shows the reader is that conversion into faith offers an escape neither from sin nor temptation: rather, it presents their accommodation within a doctrine of grace and forgiveness. Grace Abounding is not and could not be any straightforward narrative of religious conversion, then, principally because its doctrine is centred in the paradox that, as an ultimate excluded middle, grace abounds only to the sinful man. Grace Abounding is not a text that offers progress away from sin or sinfulness, therefore, but towards its accommodation with God's justice through grace. For this reason, the visible saint that Bunyan progresses towards is not one perfected or freed from sin and temptation but, through grace, is himself preeminently both saint and chief of sinners. ${ }^{90}$

\footnotetext{
${ }^{88}$ John Stachniewski, The Persecutory Imagination: English Puritanism and the Literature of Religious Despair (Oxford: Clarendon Press, 1991), pp. 132, 167, 138.

${ }^{89}$ John Bunyan, The Desire of the Righteous Granted (1692), in Miscellaneous Works XIII, p. 158.

*) Compare with Luther's similar teaching on the matter: 'Thus a Christian man is both righteous and a sinner, holy and prophane, an enemy of God and yet a child of God. These contraries no Sophister will admit, for they know not the true manner of justification' (A Commentarie [...] Upon the Epistle of S. Paul to the Galathians (London: 1644), Fol. 112 ).
} 
Grace Abounding is self-erasing and narratively unorthodox, then, because it realises what would seem to be 'two mutually-exclusive lines of development' simultaneously according to the dialectic of Bunyan's doctrine. Bunyan's story of conversion is not one that reconciles the reprobate paradigm with that of the elect or the sinner to moral perfection but, more simply, the sinful man and his sins with salvation by grace. As such, the uncertain ending of Grace Abounding, which leaves the converted Bunyan both imprisoned and still suffering from dreadful temptations, is particularly important to note as it conveys a sense both of ongoing struggle with sin alongside progress in grace while simultaneously challenging the reader's concept of how narratives should end in general. If 'conventionally', for example, 'one distinguishes between endings that are closed, as in Victorian novels with their compulsory tying-up of loose ends in death and marriage, and those that are open, as in many modernist novels', then a 'forking-path' narrative such as Grace Abounding, 'in which mutuallyexclusive possibilities have been jointly realised', forces the reader to side-step such 'conventional' judgements by offering an ending that seems 'both open and closed, somehow poised between the two', one which is 'multiple or circular'. 91 In encouraging the reader to consider why Bunyan's conversion narrative ends so unsatisfactorily in such disclosure, therefore, Bunyan's doctrinal point seems to have been made: it becomes impossible either to make sense of or be satisfied with the ending without accepting it in terms of Bunyan's doctrine of grace alone. Bunyan's final urges to blaspheme and submit to temptation even as a minister are narratively unsettling, therefore, because they re-emphasise the doctrinal excluded middle offered by grace: the converted undergo no phenomenal transformation into holiness but must bear their imperfections still and persevere in their faith unto death.

Narratively, then, the story of Bunyan's faith will continue beyond the text's 'ending' and, in terms of facing the trials of temptation and sin, will never end in any this-worldly sense. Grace Abounding does not foreground a sense of (non-) ending, therefore, as much as it does the (non-) sense of an ending. ${ }^{92}$ Moreover, in viewing Bunyan's narrative as being constructed upon an aesthetic governed wholly by doctrinal and ontological concerns, reading

\footnotetext{
${ }^{91}$ McHale, Postmodernist Fiction, p. 109.

${ }^{92}$ See McHale on the construction, 'a sense of a (non-) ending', Postmodernist Fiction, pp. 108-109.
} 
the ending of Grace Abounding in this way helps us to acknowledge some of the broader manipulations at work within Bunyan's textual practice. On the one hand, as has been concentrated upon so far, Bunyan's use of metaphor and narrative self-erasure has a distinct ontological agenda: in offering a 'world of fixed and discrete objects' which is 'given and then taken away', Bunyan effects a 'destabilizing' of the ontology of his projected everyday world, confronting the reader with the limitations of any epistemology which cannot recognise his experience as other-worldly. On the other hand, however, and obviously related to the latter procedure, adopting a method of narrative self-erasure affords Bunyan the opportunity of 'laying bare the process of world construction', thus making the business of reading the text a most self-conscious affair indeed.

Whereas in postmodernist fiction, though, narrative erasure presents a strategy 'of laying bare the processes by which readers, in collaboration with texts, construct fictional objects and worlds', Grace Abounding offers something more complex than this. Ostensibly, Bunyan 'lays bare' and makes obvious the process of projecting worlds in collision precisely because, as an autobiography about spiritual things, it is most important for the reader not to read the text as any kind of fictional construct or fable. As such, Bunyan's narrative style, encompassing so much complexity, difficulty, and conspicuous non-linearity, also operates to frustrate any reader who tries to collaborate with the text as if to 'construct fictional objects and worlds.' In simpler terms, Bunyan's narrative practice in Grace Abounding is intent not only upon registering to the reader the limitations of his or her own carnal perceptual habits but also upon making his conversion account impossible to read as if it were simply a fiction - that is, just for the story.

The reason why it is important for Bunyan to do this is, moreover, clear. As Bunyan's own progress in reading illustrates, the danger that faces any professing Christian is that their faith might be 'historical', being a reading of the Gospel in the most basic of senses - for the words on the page or, as Bunyan puts it, for the 'historical part' alone, for the 'story' of redemption rather than its soterial meaning. Grace Abounding itself is "composed with great confusion as to method', therefore, not because Bunyan's plain and simple style of storytelling is artless and naive but because, in encouraging the reader to look beyond 'historical 
parts' to the doctrine of salvation lying behind the mere 'story', Bunyan's conversion account must adopt an aesthetic which is, in practice, anti-narrative. Although such a view may appear simplistic and presumptuous about what readers expect from narratives 'conventionally', it seems nevertheless that Grace Abounding does offer some basic structural features unconventional both to story-telling in general and autobiography and spiritual autobiography in particular. Bunyan's presentation of Grace Abounding is thus intended, it is argued here, to disappoint any reader with a merely 'historical' interest in its experiences.

We have already seen how Bunyan's doctrine of grace and the illogical dialectic it embraces makes a nonsense of the concept of narrative closure. Only by foregrounding the ontological and the doctrinal can the 'ending' of Grace Abounding be rendered satisfactory to the reader. In the same way, the whole text seems structured upon this principle. In terms of linearity and sequentiality in particular, as we have seen throughout this chapter, Bunyan's relation of experience continually calls into question 'narrative logic, that one thing leads to one and only one other, the second to a third and so on to the finale.' In being a labyrinth of mistaking, Grace Abounding is anti-narrative, then, in the sense that its plot moves towards 'revelation' rather than 'resolution': there is no 'sense of problem-solving, of things being worked out in some way, of a kind of ratiocinative or emotional teleology' in Grace Abounding because its intention is not to encourage the reader to ask the question 'What will happen next?' but, rather, to reveal ' a state of affairs'. ${ }^{93}$ Far from presenting a narrative with an essential or even straightforward telos, Bunyan moves, as Vincent Newey notes, towards neither 'liberation' nor 'certitude' in Grace Abounding. ${ }^{94}$ As such, Grace Abounding is no 'story' at all in any conventional sense but a narrative elaboration of Bunyan's doctrinal thinking: it is only a 'story', and a diffuse one at that, in the sense that it illustrates 'That Converted Men are not every way, or in every sense free from the being of sin. For', Bunyan writes, "when it saith there is grace, it inferreth that there is sin in the godly. 95

\footnotetext{
${ }^{93}$ Seymour Chatman, Story and Discourse: Narrative Structure in Fiction and Film (Ithaca and London: Cornell University Press, 1978), from extracts included in Literature in the Modem World: Critical Essays and Documents, ed. by Dennis Walder (Oxford: Oxford University Press, 1990), pp. 115, 112.

${ }^{94}$ Newey, 'With the eyes of my understanding', p. 202.

${ }^{95}$ Bunyan, The Saints Privilege and Profit, p. 171.
} 
In continually foregrounding doctrinal issues, Bunyan consequently structures his narrative in such a way that the reader cannot collaborate with the text for its 'story' alone. Indeed, aside from the continual hesitation inherent in Bunyan's vacillating sense of assurance and despair, the text also violates linear sequentiality by offering the reader many and various narrative blind-alleys. Bunyan's memorable envisioning of the people of the Bedford Church on a mountain in sunlight, for example, operates in just this way, thus discomforting any perceptual and narrative complacency in the reader. Hence, the dream and its subsequent exposition present, on one level, a 'radical ambiguity' which forces the reader into the kind of interpretive dilemma that, as we have seen, is characteristic of the text as a whole. Although seemingly straightforward enough (and even progressive) at first, this episode actually turns out to be imbued with great ontological strangeness: not only is the nature of this 'vision' uncertain in itself (is it supernatural, or just a day-dream?) but if in conversion Bunyan eventually succeeds 'as he dreams his soul succeeds, in getting inside the vision, vision and reality, dream and waking, allegorical and literal, will have exchanged places. This means', Thomas Luxon asserts, 'that the allegorical version of the encounter' with the people of Bedford that Bunyan offers in his exposition of his dream 'will turn out to be reality, and the encounter itself will turn out to have been a mystifying allegory of that reality. ${ }^{96}$

As if such head-spinning ontological implications were not enough of a distraction from Bunyan's story, this episode marks itself as 'a disruptive hole in Bunyan's narrative world' not merely because of its radical hermeneutic ambivalence but because it conspicuously offers the young Bunyan little help or comfort amidst his immediate spiritual distress. ${ }^{97}$ Lying at the heart of Bunyan's mistaken questing to know if he has faith or not, this vision serves the purpose of illustrating 'the difference between the condition of the man trying to justify himself and that of believers relying on the grace of God for justification', and, consequently, figures forth only the naive Bunyan's mistaken conception of spiritual rebirth as an actual and distinct (if not wholly self-willed) birthing experience (as represented in his struggle through the wall in the dream). ${ }^{98}$ As such, the vision offers little more than wish-fulfilment for a Bunyan

\footnotetext{
${ }^{4}$ Luxon, 'Other Men's Words', in Texas Studies in Literature and Language, pp. 280-281.

${ }^{97}$ Luxon, 'Other Men's Words', in Texas Studies in Literature and Language, p. 281.

${ }^{98}$ Beal, ‘John Bunyan's Pauline Epistle', p. 159.
} 
whose doubts about salvation are not led towards any resolution by it or its explanation: 'This resemblence abode upon my spirit many dayes, all which time I saw myself in a forlorn and sad condition', Bunyan admits, the dream merely confirming that 'as yet I knew not where I was. ${ }^{99}$

The fact that the vision is to offer no final resolution or satisfactory narrative development, leaving Bunyan only as 'vehement' in his 'hunger' as ever, is signalled, moreover, by hesitations foregrounded in this episode from the outset. As Sharrock notes, 'Bunyan's hallucination is characterised in the first edition [of Grace Abounding] as "a dream or vision", as if hesitating between the two. In the version in the third edition, "a kind of Vision", he had dropped the idea of an ordinary dream but is vague about what sort of dream it is. ${ }^{100}$ Even the revised terms of recounting the experience are ambivalent in this sense, the first edition dream or vision being 'represented' to Bunyan while in the third it is simply 'presented' to him. ${ }^{101}$ The narrative effect of such hesitations is, of course, that of destabilising the reader's confidence in the text as a coherent 'story' or bearing an obvious narrative logic. The text is patently 'difficult' in this sense. But Bunyan's point in structuring his text like this also offers another important way of constraining unwanted (that is, nondoctrinal) reading interests. In relating his experiences of dreams and visions, voices and assaults, Bunyan is also keen to disturb any reader reading for the supernatural or mystical aspects of his narrative alone. Bunyan's envisioning of the people of Bedford, for instance, turns out to be a particularly dissatisfying 'supernatural' event: it achieves very little while being very much uncertain about asserting itself as anything mystical in any case.

Even more pronounced than this, however, are those occasions when Bunyan himself disclaims any interest in the purely metaphysical aspect his own experience. We should recall, for example, how Bunyan, in a typical state of spatio-spiritual hesitation, describes 'walking to

\footnotetext{
"9 Bunyan, Grace Abounding, pp. 19-20. For other interpretations and comments on Bunyan's 'kind of vision', see Newey, 'With the eyes of my understanding', p. 195; Ward, 'To Be a Reader', p. 38; John R. Knott, Jr., The Sword of the Spirit, p. 135. Professor Josiah Royce interprets this vision ludicrously as 'a fine instance of the automatic visualising process' like that experienced by Bunyan during his 'game of Cat', the 'automatic internal vision' thus becoming 'a frequent incident in Bunyan's life, and [which] later becomes, of course, the main source of his artistic power': 'The Case of John Bunyan', The Psychological Review, 1 (1894), 22-33, 134-151, 230-240 (pp. 32, 137).

${ }^{1(x)}$ Sharrock, 'Spiritual Autobiography: Bunyan's Grace Abounding', pp. 102-103.

${ }^{101}$ See Sharrock's noting of textual variations for this episode, Grace Abounding, p. 19.
} 
and fro [...] bemoaning to myself in my sad and doleful state' in 'a good-man's shop' when 'suddenly there was as if there had rushed in at the window, the noise of Wind upon me, but very pleasant, and as if I had heard a Voice speaking'. Clearly this has all the trappings of a physical-spiritual event typical to Grace Abounding's mode of representation: is there really a 'Voice' and a 'Wind' or is it only 'as if' there was? Moreover, the effect this occurrence has on both Bunyan and the text is remarkable, producing a cascade of further metaphors and hesitations: the experience brings 'light', which both silences the 'masterless hell-hounds' of Bunyan's 'tumultuous thoughts' and operates upon his spirit 'as if an Angel.' 102 Any initial problem of interpretive uncertainty in this episode is thus deferred along a growing chain of metaphors and further hesitations. But Bunyan's more important point here is, more simply, that it is futile to have any curiosity in this experience beyond accepting it as evidence of the fact 'that Jesus Christ had yet a work of Grace and Mercy for me'. Indeed, what Bunyan is at pains to emphasise here is that as a spiritual happening he himself does not know (nor is he concerned to know) what to make of it: 'as to my determining about this strange dispensation', he admits, 'what it was, I knew not; from whence it came, I knew not. I have not in twenty years time been able to make Judgment of it.'

Bunyan's uncertainty in this matter is highlighted not only in his exclamation 'I say [...] I know not what to say' but in his profound awareness of the inadequacy of his own words to convey this experience as a whole: in 'unfolding of my secret things', Bunyan admits that, 'I cannot now relate the matter as there I did experience it.' The point, of course, is that such experiences should neither be relied upon by any convert-to-be as markers of spiritual progress nor taken by readers with an interest in the supernatural alone. For Bunyan, the episode is important only in that it reveals 'as I thought, what sin unpardonable was, and that my Soul had yet the blessed priviledge to flie to Jesus Christ for Mercy.' Bunyan's point in relating this event thus has a purely doctrinal issue behind it: ' $I$ lay not the stress of my Salvation' upon such spiritual occurrences, he asserts, 'but upon the Lord Jesus, in the Promise' alone. ${ }^{103}$

\footnotetext{
102 Bunyan, Grace Abounding, p. 53.

${ }^{103}$ Bunyan, Grace Abounding, p. 53.
} 
Reading for the vicarious pleasure or out of wonder for a man who suffers voices and spiritual winds is thus blatantly discouraged in Grace Abounding. Hence, the outcome of this episode is not only typically non-progressive narratively - after 'three or four dayes', Bunyan writes, 'I began to mistrust and to despair again' - but that Bunyan's reader is prevented from becoming too enthralled by the more mystical elements of his conversion alone with the doctrinal issue about salvation in Christ through the 'Promise' being kept to the fore above all other interpretive concerns. ${ }^{104}$ In this sense, Grace Abounding seems intent not only upon being difficult to read just for the story but as especially hard to accept as just another conversion account or a 'true relation' involving strange visions and frightening apparitions. In fact, great disappointment awaits any reader expecting such a narrative, Ola Elizabeth Winslow suggesting that Grace Abounding was 'not greatly popular in its own day' largely because it does not conform to the formula of 'the greater number of itinerant accounts'. Conspicuously, she notes, there are 'no trances, no contortions, no forty-day fastings, no prophecies in rhyme, no revelations as to current personages in high places, or to events to come [...]. There is not a news item worthy a broadside issue in the whole book., ${ }^{105}$

That Grace Abounding is somewhat unconventional as a spiritual autobiography is an important point to acknowledge, though, not only because critics and commentators too often view it simply as 'not unique' in an age when so 'many such autobiographies were published'

\footnotetext{
${ }^{1144}$ Bunyan, Grace Abounding, pp. 53-54.

${ }^{105}$ Ola Elizabeth Winslow John Bunyan (New York: Macmillan, 1961), p. 126. Compare Grace Abounding with the mystical and prophetic extravagances of, for example, Anna Trapnel's A Legacy for Saints, in which she sees 'an Angell' ('oh how sweet are true visions!', she cries) and undergoes a variety of 'Raptures', ecstasies, voices and visions, and prophetic moments (pp. 14, 21, 25-26, 36-39, 43-47). Similarly, Arise Evans has 'Visions upon Visions' some of which portend 'that the King and Kingdom must speedily be destroyed' (in An Eccho to the Voice from Heaven, pp. 8-9, 18, 27). Bunyan's account is conspicuously devoid not only of prophecy but even of political comment (remarkable given that Grace Abounding was published in the portentous year 1666 and while Bunyan was still imprisoned over freedom of conscience). This is particularly astonishing, moreover, given that the Preface to Grace Abounding seems to prepare the reader for an explicitly prophetic and politically revolutionary text, his allusions to Moses and the bondage of Egypt, David and Goliath, Samson and Paul, his description of being 'between the Teeth of the Lions in the Wilderness', and his encouragement to 'possess the land' seeming overtly seditious (compare the similarity of language and Scriptural referencing here with the radical sectarian Abiezer Coppe's Some Sweet Sips, of Some Spirituall Wine (1649), in A Collection of Ranter Writings from the 17th Century, ed. with an intro. by Nigel Smith (London: Junction Books, 1983), pp. 69-71). But the body of Bunyan's account itself, of course, turns out to be non-prophetic and non-explicit even about the persecution of Nonconformists. If this is disappointing for the reader expecting something more spectacular from the text, Grace Abounding is also plainly devoid of the kind of extraordinary (but apolitical) dreams and visions that conversion accounts often relate. See, for example, Doe, A Collection of Experience, p. 35; Powell, Spiritual Experiences, pp. 81-83, 364-365, 370-373.
} 
but because central to its construction lies an innate resistance to it being read just like any other conversion narrative in any case. ${ }^{106}$ Undoubtedly, Bunyan's pattern of experience, that of raisings up and castings down, is quite typical of the general 'morphology' of Puritan confessions of experience, and Grace Abounding clearly does conform to the broad observation that Patricia Caldwell (among many others) makes about how hard it is 'to write Finis to any Puritan version of life on earth' as the concept of a 'literary standard of completeness' is undermined by the conviction that the believer's life is 'an endless process of wayfaring and warfaring'. ${ }^{107}$ But for all this (and aside from being largely devoid of the spectacularly prophetic or supernatural), Grace Abounding is difficult to read as a spiritual autobiography nevertheless. Even though we may accept that Puritan conversion in general has a telos that extends beyond the text itself, there are other expectations a reader will bring to a spiritual autobiography that Grace Abounding deliberately baffles.

The issue of the conversion effecting a clear transformation in the convert, for example, is obviously problematised in Grace Abounding. If, as James Olney has suggested, 'conversion narratives achieve a kind of completeness by recording the death of the old individual [...] and laying that individual to rest within the confines of the conversion narrative', then spiritual autobiography, as Michael McKeon has observed, can maintain a 'basic biographical dynamic between individual life and overarching pattern through a more subtle narrative balance between present action and retrospective narration. The balance is registered', McKeon asserts, 'as a structural interplay between the sinful present of the Character and the repentant retrospection of the Narrator, who, incorporating God's omniscience, knows how the story will end. ${ }^{108}$ While such a narrative structure may apply to many conversion narratives, it certainly does not apply to Grace Abounding in which the self

\footnotetext{
${ }^{1116}$ Pieter de Vries, John Bunyan On the Order of Salvation, transl. by C. Van Haaften (New York: Peter Lang, 1994), p. 55.

${ }^{107}$ Patricia Caldwell, The Puritan Conversion Narrative: The Beginnings of American Expression (Cambridge: Cambridge University Press, 1983), p. 16. The concept of a 'morphology of conversion' (which Caldwell and other commentators often refer to) is originally discussed by Edmund S. Morgan, Visible Saints: The History of a Puritan Idea (New York: New York University Press, 1963), pp. 67-73.

${ }^{108}$ James Olney, 'Autobiography and the Cultural Moment: A Thematic, Historical, and Bibliographical Introduction', in Autobiography: Essays Theoretical and Critical, ed. by James Olney (Princeton: Princeton University Press, 1980), pp. 3-27 (p. 25); Michael McKeon, Origins of the Novel, 1600-1740 (Baltimore: John Hopkins University Press, 1987; repr. 1991), p. 95.
} 
of the narrator and the self of the protagonist are inseparable, with the torments and temptations Bunyan suffers prior to conversion still continuing, albeit in different ways, until the close of the text and beyond. Indeed, the point of Grace Abounding is precisely that the narrator does not and cannot know 'how the story will end' (or even how to end the story): he can only hope and persevere in faith.

In this sense, if we take a view of spiritual autobiography based essentially on an Augustinian model positing 'a crucial disparity between the narrator and protagonist, which involves more than the usual autobiographical time lag', then, faced with a process of redemption which is 'a continuous ongoing struggle', any reading of Grace Abounding in these terms becomes both problematic and potentially frustrating for the reader. ${ }^{109}$ Not only does Bunyan apparently fail to progress from his fears and temptations in Grace Abounding but we are even denied any resounding conversion moment. Instead, Bunyan offers a series of potential climaxes without any one in particular being absolute or definitive: does Bunyan's conversion occur during his 'game of Cat', or during his meeting with the women of Bedford, after his conversations with Mr Gifford, or following his long period of despair? Any reader expecting such a conventional narrative pivot will be sorely disappointed, then, as Grace Abounding 'notoriously does not present a single moment of conversion on which everyone can agree."110 Indeed, as Sharrock notes: 'To speak of a climactic passage in Grace Abounding is in some sense to beg the question posed by the whole work. For the urgency of the personal experience at work is a continual urgency and if some crisis or revelation seems to bring a climax another is always waiting in the wings'.11

\footnotetext{
${ }^{\text {I(t) }}$ Robert Bell, 'Metamorphoses of Spiritual Autobiography', p. 114. For other useful comments on this matter, see Roger Pooley, 'Grace Abounding and the New Sense of Self', in John Bunyan and his England, pp. 106-114 (p. 109), and Newey, 'With the eyes of my understanding', pp. 203, 207. Again, for a view of conversion and conversion narratives that emphasises transformation as a gradual and ongoing process, see Peter G. Stromberg, 'Ideological Language in the Transformation of Identity', American Anthropologist, 92 (1990), 42-57.

${ }^{110}$ Pooley, 'Grace Abounding and the New Sense of Self', p. 109.

11 Sharrock, 'Temptation and Understanding', p. 8. Most spiritual autobiographies seem to have a defining conversion moment eliciting efficacious transformation (into faith if not holiness) in the Pauline or Augustinian mode. See, for example, Doe, A Collection of Experience, p. 45; Powell, Spiritual Experiences, esp. the 'Experiences of M. W.', pp. 140-153 (pp. 148-149), and the 'Experiences of H. C.', pp. 153-160 (p. 160); God's Plot: The Paradoxes of Puritan Piety, p. 44. In a way different from Bunyan, however, it seems that the more rationalising divines deliberately understate any definitive turning point simply by being vague about conversion as a whole. George Trosse, for example, states at one point, 'For tho' I can tell neither the Minister, nor the Sermon whereby, nor the very Time wherein, I was converted, yet, I bless God! I can say, I
} 
This kind of anti-structuring in Grace Abounding is centred in an aesthetic that makes any reading of the text bewildering unless the reader views conversion itself as a gradual and organic process of inseparable stages and which focuses not on outward change as much as inward progress in understanding and faith - on the unseen rather than the seen. In fact, it is precisely this kind of a re-orientation of the reader's generic expectations, reading habits, and ways of perceiving, that is demanded from the outset, beginning with the text's title - Grace Abounding to the Chief of Sinners. Readers may be bemused, for instance, as to when, where, and how grace abounds for a Bunyan who, by the end of the text, seems no more assured of salvation than at any other point. It is even more reasonable, however, to question the degree to which Bunyan is really a 'chief of sinners', a title adopted by so many spiritual autobiographers and which hardly seems applicable to a narrator who so strenuously and moralistically denies the kind of scandalous sexual allegations which would, presumably, qualify him for the part exactly. ${ }^{112}$ The point is, of course, that both the concept of sin and of grace embraced by Bunyan's title require an understanding far different from that any conventional or moralistic reading can offer: sin and grace are neither rationally nor morally centred in this case but reflect a doctrine of salvation that transcends any ethical, carnal, and narrative logic. ${ }^{113}$ As such, both the testing and the teaching of the reader about faith,

am what I was not' (The Life of the Reverend Mr. George Trosse, p. 112). Richard Baxter (so sceptical about extravagant mystical experience in general, as Nuttall shows in The Holy Spirit in Puritan Faith and Experience, pp. 56-57) also recounts, and with a similar lack of spectacle or drama, his change of heart after reading a book entitled 'Bunny's Resolution': 'Yet whether sincere conversion began now, or before, or after', he states, 'I was never able to this day to know' (The Autobiography of Richard Baxter, p. 7).

112 See Grace Abounding, pp. 93-95. Vera Camden points out how delicate Bunyan's position is in this respect, as Bunyan must 'make the extent of his sin extreme enough to cover the worst sinner, while broad and indistinct enough to protect his reputation from the kind of character assault he will later experience in life': 'Blasphemy and the Problem of the Self', Bunyan Studies: John Bunyan and his Times, 1 (1989), 5-21 (p. 14). While Macaulay understands the title 'chief of sinners' in its 'theological' rather than its 'popular sense' (Thomas Babington Macaulay, 'John Bunyan', in Critical and Historical Essays, 2 vols, ed. by A. J. Grieve (London: J. M. Dent, 1907), II, 399-410 (pp. 405-406), many other commentators find Bunyan's self-nomination simply an incredible exaggeration and an unoriginal one at that. See Margaret Bottrall, Every Man a Phoenix: Studies in Seventeenth Century Autobiography (London: John Murray, 1958), p. 85; Henri Talon, John Bunyan: The Man and his Works, transl. by Barbara Wall (London: Rockliff Publishing, 1951; first pub. in French, 1948), p. 20; Barrett John Mandel, 'Bunyan and the Autobiographer's Artistic Purpose', Criticism, 10 (1968), 225-243 (p. 237). Alternative self-confessed 'chiefs of sinners' include Oliver Cromwell, the Ranters Abiezer Coppe and Laurence Clarkson, Richard Norwood, Anna Trapnel, and Mris Sarah Wight. For others, see Mandel, 'Bunyan and the Autobiographer's Artistic Purpose', p. 237, fn 34.

${ }^{113}$ For useful insights into how Bunyan's sense of sin and conventional reason are incompatible, see Beal, 'John Bunyan's Pauline Epistle', p. 149, and Dayton Haskin, 'Bunyan, Luther, and the Struggle with Belatedness in Grace Abounding', University of Toronto Quarterly, 50 (1980-81), 300-313 (p. 306). 
understanding, and reading for the 'historical part' begins no less than in the first words of Grace Abounding's frontispiece which in itself requires as much grace-ful negotiation as the rest of the text. Indeed, the reader is required to see how grace abounds to a chief of sinners despite the fact that the narrative in many ways seems to present neither.

While Bunyan's conversion account denies many of the basic generic conventions associated with spiritual autobiography, this strategy is even more pronounced when it comes to trying to read the text as just autobiography. As many commentators have recognised, the lack of personal details, precise chronology or dating, and the numerous autobiographical holes within Grace Abounding (Bunyan infamously leaving his first wife nameless, for instance) make it far from 'a reliable source of Bunyan's life and psyche' or, as Greaves puts it, 'a document that can bear the psychological and biographical interpretations often built on it." ${ }^{114}$ Consequently, as another observer states, it becomes possible to 'know minutely what the protagonist of Grace Abounding thought and felt and suffered, but one can barely have an inkling of what he looked like. ${ }^{115}$ The reason for this strangely anti-autobiographical aspect of the text can, of course, be explained quite generally in terms of the fact that 'Grace Abounding is an example of a literary genre with specifically pastoral intentions'."16 Consequently, adopting E. D. Hirsch's distinction between 'intrinsic' and 'extrinsic' genre-status ('intrinsic genre' being that 'sense of the whole by which an interpreter can correctly understand any part of its determinacy', whereas 'extrinsic genre signifies an incorrect determination of the whole' and can 'be used to codetermine meanings, some of which would be necessarily incorrect'), Rebecca S. Beal notes that 'autobiography' is extrinsic to Grace Abounding generically as it is 'inadequate to explain the meaning of the work in its entirety.' As a text which 'reflects a major emphasis of Pauline epistles' (salvation by grace), it is simply more proper to read Grace Abounding, Beal suggests, 'as a seventeenth century version of the Pauline epistle' bearing theological and epistolary rather than 'psychological, autobiographical significance'. As such,

\footnotetext{
${ }^{114}$ Richard L. Greaves, 'John Bunyan: The Present State of Historical Scholarship', in Bunyan in England and Abroad, ed. by M. van Os and G. J. Schutte (Amsterdam: V. U. University Press, 1990), pp. 29-43 (p. 29), and reprinted in John Bunyan and English Nonconformity (London: Hambledon Press, 1992), pp. 37-50.

${ }^{115}$ Mandel, 'Bunyan and the Autobiographer's Artistic Purpose', p. 240.

${ }^{116}$ Greaves, 'John Bunyan: The State of Historical Scholarship', in Bunyan in England and Abroad, p. 29.
} 
biography merely 'becomes the element which motivates the reader to make use of the doctrines'.117

Such a reading certainly explains why Grace Abounding focuses on Bunyan's autos (self) rather than his bios (life, or life-story). Indeed, because it is an account that seeks to teach about things unseen, life-story is conspicuously sacrificed in Grace Abounding to ensure that it is the self of the reader that is made more important than either the autos or bios of Bunyan. $^{118}$ But although many critics of Grace Abounding commonly make note of the difficulties it raises as an autobiography, few recognise the full narrative and generic complexity of Bunyan's account as autobiographical. For instance, if we view autobiography as 'a species of history - a narrative of events occurring in time' which, at its simplest, presents 'a straight-forward chronicle that begins at the beginning and proceeds, more or less mechanically, toward the present or whatever moment of termination the author has chosen', Grace Abounding is most obviously anti-autobiographical. ${ }^{119}$ Not only is Bunyan's account non-linear and devoid of any straightforward chronology but, in being so, it seeks to undermine any reader's attempt to construct Bunyan's life from its pages or to gain from it any conventional 'story'. Equally, though, such a view could be challenged simply by adopting a different consideration of how autobiography operates textually. Elizabeth Bruss, for example, has studied autobiography as a literary form in which the above generic trait of straightforward chronicling hardly exists at all. For her, one of the few 'certain common tendencies' of all autobiographies is precisely the dysfunctional, anti-narrative features that Grace Abounding evinces - a 'leaning toward discontinuous structures' with 'disrupted narrative sequences and competing foci of attention.' The 'story' that 'an autobiography tells

\footnotetext{
117 Beal, 'John Bunyan's Pauline Epistle', p. 148 n.4, quoting from E. D. Hirsch, Validity in Interpretation (New Haven and London: Yale University Press, 1967; repr. 1976), pp. 86, 88), 148-149, 152-154.

${ }_{118} \mathrm{James}$ Olney usefully distinguishes between these two aspects of autobiography in, 'Autobiography and the Cultural Moment', p. 25.

119 John N. Morris, Studies in English Autobiography from John Bunyan to John Stuart Mill (New York: Basic Books, 1966), pp. 10-11. Morris notes that this view of autobiography has its roots in Victorian autobiographical practice which often seeks to impose a 'formal continuity' upon the genre as 'a principle of philosophic, not merely narrative coherence. It is in some sense the emblem of the real subject of the work, the gradual evolution of an always identifiable self' (p. 12).
} 
is never seamless', she suggests, 'and often it is not a story at all but a string of meditations and vignettes - fractional events. 120

It is important to recognise, then, that for both reader and author 'the original sin of autobiography is first one of logical coherence and rationalization' but that, as such, this leaves Grace Abounding in some generic hesitation: it could be considered as either autobiography, anti-autobiography, or even both. But there is, nevertheless, a more fundamental way that Grace Abounding undermines the reader's confidence in it as life-story beyond the narrative discontinuities and lack of biographical detail already considered. Far more radically, in fact, it seems that in making sure his text is to be read for its doctrine and its doctrine alone, Bunyan is even intent upon sacrificing a concept of autobiographical and historical 'truth' (that the events happened as he tells them) in favour of the more important Gospel 'Truth'. Such a claim is supported not only by the fact that events as Bunyan describes them continually opalesce or flicker, it becoming difficult to know whether his experiences were actual or only 'as if', but also by the fact that his account of conversion in Grace Abounding reveals some basic discontinuities and differences when compared with his recounting of the same experiences elsewhere.

In The Doctrine of Law and Grace Unfolded (1659), for example, Bunyan illustrates his covenant theology specifically, at one point, with 'Something of the Authors experience', offering an account of conversion which at first seems wholly synonymous with the later, fulllength version of Grace Abounding. In this early tract, in fact, we have the basic raw material for the whole of Grace Abounding compressed within just a few pages: 'Reader, when it pleased the Lord to begin to instruct my soul', Bunyan writes,

he found me one of the black sinners of the world; he found me making sport of oaths, and also of lies, and many a soul-poysoning meal did I make out of divers lusts, as drinking, dancing, playing, pleasure with the wicked ones of the world. The Lord finding me in this condition, did open the glass of his Law unto me, wherein he showed me so clearly my sins, both the greatnesse of them, and also how abominable they were in his sight, that I thought the very clouds were charged with the wrath of God, and ready to let fall the very fire of his jealousie upon me: yet for all this I was so wedded to my sins, that thought I with myself, I will have them, though I lose my soul [...] but God, the great,

${ }^{120}$ Elizabeth W. Bruss, Autobiographical Acts: The Changing Situation of a Literary Genre (Baltimore and London: John Hopkins University Press, 1976), p. 164. 

the rich, the infinite merciful God, did not take this advantage of my soul, to
cast me away.

The connections to be made are clear. Pre-echoing Bunyan's experience in Grace Abounding, this passage contains the seeds of metaphors which are to be fleshed-out more substantially in the 'game of Cat' episode: here, the unconverted Bunyan is found 'making sport of oaths', enjoying a 'soul-poysoning meal', and being shown the 'glass of the Law', so that rather than a face of the Lord looking down upon him from the sky Bunyan writes, more simply, 'I thought the very clouds were charged with the wrath of God'. It is, moreover, left only to a marginal note to inform us that this 'conviction seized on my soul, one Sabbath day when I was at play'. Although the story is largely the same as in Grace Abounding, then, in Law and Grace there is nevertheless a more explicit emphasis upon the covenant theology that informs Bunyan's experiences (a direct reference to the Law) as well as a more simplistic (albeit condensed) rendering of events: there is no 'game of Cat', no face of God.

This is only a minor level of discrepancy, however, as Bunyan's version of conversion in Law and Grace does, after all, bear all the obvious traits of the later Grace Abounding: it contains its domestic vocabulary, its ups and downs and, most importantly, a dense organicism of style which emphasises spiritual change as process rather than crisis, the narrative of experience in Law and Grace comprising over two pages of unparagraphed text consisting of a mere five sentences. More problematic, though, is the fact that certain details and events are included, excluded, or emphasised differently in Law and Grace which clearly are not in Grace Abounding. Assurance of grace, for instance, is far more certain and less hesitant or selferasing in this early account. When in doubt 'God through grace hath', Bunyan declares, 'all on a sudden, so effectually applied the blood that was spilt at Mount Calvary', this conversion account consequently bearing a sense of comforting and explicitly doctrinal finality missing from Grace Abounding: 'O! methinks it [Christ's blood] hath come with such life, such power, with such irresistible and marvellous glory', Bunyan exclaims, 'that it [...] quenches all the fiery darts, and all the flames of hell-fire, that are begotten by the charges of the Law, Satan, and doubtful remembrances of my sinful life.'122 Though Bunyan's experiences vacillate,

\footnotetext{
${ }^{121}$ Bunyan, Law and Grace, pp. 156-57.

122 Bunyan, Law and Grace, pp. 159, 160.
} 
moreover, there is no recollection of any long period of backsliding in Law and Grace nor any concern over the unpardonable sin, matters which take such a prominent role in Grace Abounding. It is left to a marginal note, once more, for Bunyan to remark: 'I cannot stand here to tell thee of particular temptations. ${ }^{, 23}$

In terms of 'doubtful remembrances', however, the most significant difference between the accounts lies in the fact that Bunyan's conversion in Law and Grace has a specific and teleological frame that is missing (or is at least different) from Grace Abounding. In Law and Grace, Bunyan's account seems to have what Grace Abounding conspicuously lacks - one specific point of conversion, occurring 'just before the men called the Quakers came into the Countrey'. Prior to this, Bunyan had gone 'about a year and upwards, without any sound evidence as from God to my soul, touching the salvation as comes by Jesus Christ.' However, with the advent of the Quakers settling in Bedfordshire, Bunyan is suddenly set down 'so blessedly in the truth of the Doctrine of Jesus Christ' that it is as if he hears a voice directing his actions: 'as I was musing what these things should mean, methought $I$ heard such a word in my heart as this; I have set thee down on purpose; for I have something more than ordinary for thee to do.' It is following this experience that Bunyan finally undergoes a revelation in understanding salvation and sees '(through grace) that it was the blood shed on Mount Calvary that did save and redeem sinners, as clearly, and as really with the eyes of my soul (methoughts) I had seen a penny-loaf bought with a penny'. ${ }^{124}$

While Bunyan's style is essentially the same here in its use of hesitant constructions (all this happens only as 'methoughts') as well as in its vocabulary ('the eyes of my soul' and the homely, solid 'penny-loaf' image), we are nevertheless left to wonder why, if this is a definitive conversion moment, is it not replicated word-for-word in the later Grace Abounding? Why does the (divinely?) dictated text here find no voice in the later conversion narrative, particularly one which unmistakably stresses Bunyan's calling as being other than that of a tinker but something 'more than ordinary'? Indeed, in this account, Bunyan's conversion is evidence of a great and momentous decree: 'I have set the down on purpose'. Moreover, there

\footnotetext{
${ }^{123}$ Bunyan, Law and Grace, p. 159.

${ }^{124}$ Bunyan, Law and Grace, pp. 157-158.
} 
seems to be a shift in the chronology between the two accounts, too. In Grace Abounding, Bunyan's first experience of receiving spiritual understanding of salvation occurs before any mention of the Quakers whose 'errors' merely confirm his new-found faith in the 'teachings of God in his Word'. ${ }^{12}$ In Law and Grace, however, Bunyan's conversion is effected only after the Quakers have appeared in the 'Countrey'. Although this may seem only a minor discrepancy in narrative timing, its greater relevance lies in the fact that in Law and Grace Bunyan's conversion is being explicitly aligned with the advent of the Quakers in a way not evident in Grace Abounding. Indeed, in implying that his faith in a doctrine of Law and grace was forged in the fire of incipient theological controversy with them, Bunyan's conversion in Law and Grace is given a distinct anti-Quaker polemical agenda: conversion occurs, it would seem, to illustrate that Bunyan was called to defend and promote his doctrine of Law and grace at a time when it was (and still is for Bunyan, apparently) needed most.

Such discrepancies between Law and Grace and Grace Abounding undoubtedly leave us with some unsettling questions. How are we to accept either account as historically 'true' given the differences in emphasis and detail between them? Which of the two is more valid or authoritative? Are we to believe that Bunyan can manipulate the relation of his spiritual dealings to suit his polemical needs at any given time? Is his conversion narrative to be adapted and altered by Bunyan when, as in Law and Grace (albeit rather punningly), there is literally a calling for it? In raising such questions of authorial mistrust, it becomes clear that there are greater difficulties in accepting Bunyan at his word when it comes to the historical part of his conversion than previously imagined. Far more radical than a non-linear narrative or a lack of bios, it is the reader's faith in the events happening the way that Bunyan relates them (or in them having happened at all) that is being undermined by Bunyan here. In doing so, Bunyan's final anti-narrative point is made with some ur-postmodernist flourish. In unstitching the reader's confidence in the validity of historical knowledge alone, in events happening even as he tells them, he points the reader towards the conclusion that narrative veracity and consistency are to be discarded in the face of a greater 'Truth'. Bunyan's method of storytelling thus directs the reader towards a concept of truth and knowledge far from historical but

${ }^{125}$ Bunyan, Grace Abounding, pp. 38-39. 
trans-historical, far from untrustworthy and this-worldly but wholly faithful and other-worldly: 'for my Righteousness was Jesus Christ himself', Bunyan asserts, 'the same yesterday, and to-day, and for ever, Heb. 13. 8.'126

The extent to which Bunyan manipulates both his text and the reader's expectations of it in order to encourage a grace-ful reading, a reading which encompasses (more than anything else) the recognition of doctrine and the need to understand it in spiritual terms alone, is thus clear. But there is still, however, one other factor that informs Bunyan's deliberate antinarrative and anti-autobiographical practice in Grace Abounding, one which again is first raised in Law and Grace. In this early tract, the reason why Bunyan offers his own personal experience to the reader is not only to present a concrete example of how his doctrine works in practice but 'so that thou mayest not think these things [his points of doctrine] are fables.' Bunyan's account of conversion, then, is established in order to verify doctrine and doctrine alone: as in Grace Abounding, the 'story' is thus subsumed by a greater purpose than mere tale-telling - that of illustrating the practical efficacy of his theology. However, there is an ironic twist inherent to Bunyan's method here. In adopting an autobiographical mode to confirm the reality of his 'Truth', Bunyan's confidence in his ability to do just this is simultaneously undermined by a persistent doubt in the reader's willingness to believe in Bunyan's 'story' itself, as reflected in the fact that his account in Law and Grace is continually disturbed by appeals to the veracity of his experience: 'I lye not', Bunyan is at pains to emphasise, imploring the reader to believe that 'these things be not fancies' and that he has not preached 'cunningly devised fables, in telling you of the blood of Christ'. ${ }^{127}$

In turning to personal experience in order to authorise his doctrine of salvation, then, Bunyan subsequently faces a different representational crisis, one that now concerns the credibility not only of his theology but of the relation of the experience in which it is anchored. By contriving to offer proof that his doctrine is neither fable nor mere notion, Bunyan's very means of doing so (his account of conversion) in itself threatens to become indistinct from mere 'fable'. The danger Bunyan faces in adopting autobiography in order to illustrate and validate

\footnotetext{
${ }^{126}$ Bunyan, Grace Abounding, p. 72.

${ }^{127}$ Bunyan, Law and Grace, pp. 156-160.
} 
his doctrine, in turning his theology into narrative, is thus clear: the reader may indeed be inclined to read it simply as a story and not as a message of salvation, in which case Bunyan's sole purpose for offering any account at all will have been self-defeating. Bunyan's problem in presenting Grace Abounding, therefore, is largely to do with the very autobiographical form he relies upon to demonstrate his doctrine as truthful. Indeed, because the difficulty with autobiography is that it is largely indistinguishable from first-person narrative prose fiction (both share a basic congruity in style and form, for instance), it is only the reader's faith in the text being what it says it is (either autobiographical or fictive) that allows the distinction to be made at all. Hence, fiction so readily and so often 'mimics' autobiography just as, as one commentator notes, 'in selecting, ordering, and integrating the writer's lived experience according to its own teleological demands, the autobiographical narrative is beholden to certain imperatives of imaginative discourse. Autobiography, in short, transforms empirical facts into artifacts', Louis A. Renza asserts, and as such, 'is definable as a form of "prose fiction"., 128

Because autobiography 'may be fictional and yet at the same time "look" factual', plausibly presenting a sequence of events that is no different from one which did in fact happen', then as a mode of discourse it poses some obvious formal and conceptual problems to the confessing writer who does not want his text to be read simply for the life-story but who, at the same time, needs to maintain the veracity and authenticity of his experience as autobiographically represented. ${ }^{129}$ The teleology conventionally demanded of autobiography and the very act of inscribing one's experience into narrative discourse places such aims in jeopardy. Hence, Paul de Man draws upon Genette's term of the revolving-door or whirligig (tourniquet) in describing how 'the distinction between fiction and autobiography is not an either/or polarity but that it is undecidable.'130 And because, as Bruss asserts, '[a]utobiography as we know it is dependent on distinctions between fiction and non-fiction, between rhetorical and empirical first-person narration', then '[p]erhaps more than any other literary concept, autobiography traps us into circular explanations of its being. Is it an

\footnotetext{
${ }^{128}$ Louis A. Renza, 'The Veto of the Imagination: A Theory of Autobiography', in Autobiography: Essays Theoretical and Critical, pp. 268-295 (p. 269). This essay was originally published in NLH, 9 (1977), 1-26.

${ }^{129}$ Robert Elbaz, 'Autobiography, Ideology, and Genre Theory', Orbis Litterarum: International Review of Literary Studies, 38 (1983), 187-204 (pp. 196-197).

130) Paul de Man, 'Autobiography as De-facement', Modern Language Notes, 94 (1979), 919-30 (p.921).
} 
indeterminate mixture of truth and fiction? Is it based essentially in fact rather than selfinvention? ${ }^{131}$

If autobiographical narrative is as implicitly bound to fictional forms as is suggested here, then Bunyan's task in presenting the truth both of his doctrine and of the spiritual experience that corroborates it is to be doubly hard. Because relying upon an autobiographical mode alone does not guarantee a distinction between truth and fiction, subsequently it becomes imperative for Bunyan to present an account truthful to his spiritual experience which is not autobiography as much as it is not fable. Stylistically, then, Bunyan's text is self-consciously imbued with a plainness of language and simplicity of expression, at times, which conforms to the requirements Jean Starobinski suggests are necessary in providing authenticity in autobiographical narrative. The literary perfection of autobiographical style, according to Starobinski, merely renders suspect 'the content of the narrative, setting up a screen between the truth of the narrated past and the present narrative situation. Every original aspect of style,' he writes, "implies a redundancy that may disturb the message itself., 132

In this way, moreover, Bunyan's adoption of a plethora of textually anti-narrative and anti-autobiographical strategies can also be seen as geared to side-step the tourniquet situation between the fabulous and the autobiographical. While autobiography enables Bunyan to project a world with 'a different ontological status from "pure" fiction, and a stronger one' in many respects, it nevertheless becomes clear why Grace Abounding is bereft of personal particulars or even any identifiably chronologous time-sequence, and why, as a narrative, it is self-erasing, iridescent, and lacking any conventional teleology and closure. ${ }^{133}$ All such strategies operate to prevent the reader engaging with Grace Abounding simply for the story, especially if that story, even as autobiography, threatens to become indistinguishable from a

\footnotetext{
131 Bruss, Autobiographical Acts, p. 8; Renza, 'The Veto of the Imagination', in Autobiography: Essays Theoretical and Critical, p. 268. The problem with studying autobiography for Paul de Man is that it is a selfnegating form : 'The interest of autobiography,' he writes, 'is not that it reveals reliable self-knowledge - it does not - but that it demonstrates in a striking way the impossibility of closure and totalization (that is the impossibility of coming into being) of all textual systems made up of tropological substitutions' ('Autobiography as De-facement', p. 922).

132 Jean Starobinski, 'The Style of Autobiography', in Autobiography: Essays Theoretical and Critical, pp. 7383 (p. 74).

${ }^{133}$ McHale, Postmodernist Fiction, p. 202.
} 
fable which, in turn, could threaten to distract the reader from the all-important doctrinal message of Bunyan's text. ${ }^{134}$

With both autobiography and narrative being deliberately backgrounded in relation to the more important issue of salvation, Grace Abounding can indeed be seen as anti-narrative in that it aims to convey something of the truthfulness of Bunyan's doctrine but, in doing so, simultaneously requires the reader to set aside (or discard completely) the narrative vehicle, the 'story', by which Bunyan's 'Gospel-truth' is carried. Such an extremely anti-literary reading of Grace Abounding as a narrative (or anti-narrative) which demands to be read for doctrine alone will be shown to have clear implications for Bunyan's textual practice both in his most famous allegory, The Pilgrim's Progress, and in his subsequent narrative works. As such, the idea that it is the reader who is the focus of Bunyan's texts, that the way the reader reads them reflects his or her metaphysics, and that Bunyan's narrative practice deliberately frustrates any attempt to read them just for the story, will be shown to lie at the heart even of Bunyan's most popular works.

Moreover, while this chapter has adopted the vocabulary of a postmodernist poetics in order to offer an understanding of Bunyan's narrative methodology, it is worth while noting that Bunyan himself considers spiritual discourse (of which all his narrative works are an inherent part) as necessarily engaged in the kind of ontological foregrounding, textual selferasure, and self-consumption that has been emphasised so far via the analytical terminology of Brian McHale. Bunyan's admiration for Paul's evangelising use of 'words' in particular provides a profoundly significant insight into his own approach to style and writing narrative, confirming how Bunyan's didactic textual practice is firmly rooted within an ontological, spiritual, and pre-eminently Scriptural poetics. As 'both ambiguous and to wonderment', Bunyan notes Paul's words at one point as being,

\footnotetext{
134 In this way, Bunyan's Grace Abounding certainly does not conform to John Sturrock's concept of autobiography effecting a 'conversion' of past 'brute experience' into a coherent and 'improving tale', or that a 'human life can be brought to display meaning' only when 'turned into a story' of which the autobiographer is the central 'character'. Sturrock thus views autobiography in terms of a narratively 'heartening logic' which, as we have seen, Grace Abounding defies as much as it resists being a 'story' at all. Indeed, in contrast to Sturrock's thesis, there is little urgency in Bunyan's account to present a significantly 'historical being' or to offer a 'consciously literary process of integration' (The Language of Autobiography, pp. 20, 8-9, 24).
} 
ambiguous, because unexplained, and to wonderment, because they carry in them an unexpressible something; and that something that which far out-goes all those things that can be found in this World. The Apostle here was under a Spiritual Surprize, for while meditating and writing, he was caught: the strength and glory of the truths that he was endeavouring to fasten upon the People to whom he wrote, took him away into their glory, beyond what could to the full be uttered. Besides, many times things thus expressed, on purpose to command Attention, a stop and pause in the Mind about them; and to divert, by their greatness, the Heart from the World, unto which they naturally are so inclined. Also, Truths are often delivered to us, like Wheat in full Ears, to the end we should rub them out before we eat them, and take pains about them, before we have comfort of them. ${ }^{135}$

Delineating a Pauline aesthetic principle in which the ontology of 'Spiritual Surprize' is foregrounded, with the reader being required to stop and consider 'Truths' that need to be erased (rubbed out) before they can yield any comfortable meaning, the comparison is obvious. With this passage in mind, moreover, and with its echoes of the 'Author's Apology' so clear, The Pilgrim's Progress needs to be seen as both a continuation and a defence of just such a poetics.

${ }^{135}$ John Bunyan, The Saints Knowledge of Christ's Love (1692), in Miscellaneous Works XIII, p. 340. 


\section{4 \\ Into an Allegory: \\ Method, Metaphor, and the Apology of \\ The Pilgrim's Progress}

I did not see him with my bodily eyes, but with the eyes of my understanding; and thus it was. One day I was very sad, I think sader then at any one time in my life; and this sadness was through a fresh sight of the greatness and vileness of my sins: And as I was then looking for nothing but Hell, and the everlasting damnation of my Soul, suddenly, as I thought, I saw the Lord Jesus look down from Heaven upon me, and saying, Believe on the Lord Jesus Christ, and thou shalt be saved.

But I replyed, Lord, I am a great, a very great sinner; and he answered, $M y$ grace is sufficient for thee. Then I said But Lord, what is believing? And then I saw from that saying, [He that cometh to me shall never hunger, and he that believeth on me shall never thirst] That believing and coming was all one, and that he that came, that is, run out in his heart and affections after Salvation by Christ, he indeed believed in Christ. ${ }^{1}$

It is not surprising that, following this account of Hopeful's conversion found towards the end of The Pilgrim's Progress, we recognise in it so clearly Bunyan's own conversion narrative, Grace Abounding to the Chief of Sinners. Along with the memorable phrasing of Bunyan's seeing 'with the eyes of my understanding' and experiencing the assuring answer 'My grace is sufficient for thee', the very style and structuring of Hopeful's narrative seem to replicate those of Bunyan's former account. Hopeful's relation of grace, though a greatly compressed conversion narrative, possesses both the organicism and the suspense of Grace Abounding with great multiclausal sweeps urged on by the insistent and literally momentous repetition of 'I was then', 'Then I said', 'Then I saw'. Like Bunyan, Hopeful hears the voice of Scripture answering his spiritual needs and envisions the face of Christ looking down upon him, his discourse relating how he too has been moved from a state of delight in 'Rioting, Revelling, Drinking, Swearing, Lying', to 'Religious Duties, as Praying, Reading, weeping for Sin', to a conviction of the Law's ineffectuality in salvation, to a long and hard struggle

\footnotetext{
1 John Bunyan, The Pilgrim's Progress, ed. by James Blanton Wharey, 2nd edn, rev. by Roger Sharrock (Oxford: Clarendon Press, 1960), pp. 142-143.
} 
for the revelation of grace. ${ }^{2}$ Moreover, in Hopeful's account lie all the hesitations and uncertainties facing the reader of Grace Abounding. Like Bunyan's representation of such experience, Hopeful both sees and does not see 'the Lord Jesus looking down from Heaven', he both hears and does not hear the Spirit answering him directly. Like Bunyan's, Hopeful's account destabilises our understanding of represented events not only by undermining our confidence in what is metaphorical and what is literal but through the inherent uncertainties in his version of events: he sees only with eyes of understanding and even then, in a typically Bunyanesque manner, it is only 'as I thought'. Consequently, as U. Milo Kaufmann has observed, Hopeful's account does indeed seem little more than a 'Grace Abounding in miniature.' 3

In view of Hopeful's discourse in particular, it is hardly surprising that commentators often read The Pilgrim's Progress as a whole as but an imaginative refashioning of Bunyan's earlier conversion narrative. As Roger Sharrock asserts, 'There is no question of a conscious modelling by Bunyan of the allegory on the autobiography' as 'he was drawing on the same store of personal experience for both' ${ }^{4}$ Over and above such a basic correlation, though, critics and readers also seem to feel that a process of refinement has taken place between the writing of these two texts, Sharrock suggesting (with no uncertainty) that at the time when the autobiography was composed, Bunyan 'was still too near to the terrors, too respectful of every detail of the religious experience, to mould them with greater freedom.' By the time The Pilgrim's Progress was published, however, Bunyan 'was in a position to treat his mental universe with more detachment and to give it in his allegory a shape which makes more concession to literary art.'5 Bunyan's overall fictive 'originality', Sharrock concludes,

\footnotetext{
2 Bunyan, The Pilgrim's Progress, pp. 137-144.

3 U. Milo Kaufmann, The Pilgrim's Progress and Traditions in Puritan Meditation (New Haven and London: Yale University Press, 1966), p. 228.

${ }^{4}$ Roger Sharrock, 'Spiritual Autobiography in The Pilgrim's Progress', RES, 24 (1948), 102-120 (p. 113). Stuart Sim similarly suggests that '[w]hat we witness in Pilgrim's Progress, as we do in Grace Abounding, is the slow, painful, but absolutely inexorable progress to grace, in which conversion marks a critically significant break with the subject's past', and that 'Bunyan's fictions, therefore, fall fairly unproblematically into the conversion narrative genre': Negotiations With Paradox: Narrative Practice and Narrative Form in Bunyan and Defoe (London: Harvester Wheatsheaf, 1990), pp. 8, 10.

5 Roger Sharrock, 'Personal Vision and Puritan Tradition in Bunyan', The Hibbert Journal, 56 (1957-58), 47-60 (p. 57).
} 
thus 'lies in the power which enabled him to project his visions and obsessions on to the objective reality of a work of art: to turn Grace Abounding into Pilgrim's Progress.'6

But there are, quite obviously, some problems in reading these two narratives in terms of either a shared biography or an overarching literary 'progress'. Sharrock's approach, for example, smacks patronisingly of a psychologising of Bunyan's texts in order to promote a sense of Bunyan's personal and artistic development. Thus, Grace Abounding becomes once again a work written without the objectivity afforded by the passage of time, reflecting more than anything else the instability of Bunyan's early religious 'condition'. Not only is it implied that Grace Abounding is without artistry, though, but the work as a whole seems to be being relegated by Sharrock as a somewhat secondary, marginalised text of little value except in shedding light, like some narrative-length biographical gloss, on the more mature, comprehensible, and popular allegory. But such a strict biographical correlation between conversion account and allegory is made problematic, however, given the fact that The Pilgrim's Progress actually seems to frustrate direct comparison with the earlier 'life-story' in any case. While Sharrock would indeed like to impose a systematic, point-by-point structural congruity upon the two texts as telling the same conversion story, such an analysis is often thwarted by the most basic of episodic differences: 'It is not easy', he writes, 'to find an equivalent experience in Grace Abounding which corresponds to Christian's acceptance at the Wicket. ' 7 Nor is it easy to find a counterpart to Christian's experience in Interpreter's House in anything that occurs in Grace Abounding, and likewise his battle with Apollyon, the meeting with the shepherds of the Delectable Mountains, and numerous other significant episodes.

Despite the fact, then, that there seems an almost innate compulsion for the reader to read Christian as but another version of Bunyan himself (especially when it seems that it is 'on to Christian [that] Bunyan projects the terrors and soul-searchings of his own religious awakening as he described it in Grace Abounding'), in actuality both Christian's characterisation and his experience as a whole differ quite markedly from those of the

\footnotetext{
${ }^{6}$ Roger Sharrock, John Bunyan (London: Macmillan, 1954; repr. 1968), p. 157. See also Sharrock's other comments on the relation of Grace Abounding to The Pilgrim's Progress here, pp. 73-74.

7 Sharrock, 'Spiritual Autobiography in The Pilgrim's Progress', p. 114.
} 
protagonist in Grace Abounding. ${ }^{8}$ Indeed, if Sharrock's analysis was absolutely the case, we would be forced to ask why it is Hopeful and not Christian who recounts the conversion that most closely resembles Bunyan's own spiritual autobiography. But, then again, even Hopeful's account is not strictly a Grace Abounding 'in miniature' either. In Hopeful's narrative, in fact, texts are heard and experiences undergone (as in the Law and Grace account) which do not occur in Grace Abounding. Here, the vision of the Lord looking down is not being mistakenly accepted as confirmation of damnation but is, on the contrary, accompanied by a voice of positive assurance with heavenly words conspicuously absent from Bunyan's other accounts. Indeed, for Hopeful, as it never is for the Bunyan of Grace Abounding, such experiences mark an unfaltering confirmation of grace. Moreover, the doctrine offered by each of the various versions of Bunyan's experience is stated more strongly in Hopeful's account than in either Law and Grace or Grace Abounding. The reader cannot but be struck full-on by the explicit message of Law and grace that Hopeful's account acts as a vehicle for in The Pilgrim's Progress, this pilgrim's narrative being accompanied by a forthright teaching on how 'By the works of the Law no man shall be justified', and how 'Christ Jesus came into the World to save sinners' as the 'end of the Law for righteousness to everyone that believes.' ${ }^{9}$ Clearly, Hopeful's discourse is not so much a Grace Abounding miniaturised as it is Grace Abounding completely re-written (and nowhere else is Bunyan more bold in expressing his doctrine so baldly).

But what role does such a reformulation of Bunyan's own conversion narrative perform in The Pilgrim's Progress? On one level, it seems that by re-presenting his own account of experience in this way, Bunyan can at least discourage the reader of The Pilgrim's Progress from complacently engaging with the text on a merely biographical basis. Bunyan thus makes the point that in reading The Pilgrim's Progress one must neither place the most interpretive significance on whether textual details correspond with his own life or not, nor rely upon any comparison between The Pilgrim's Progress and Grace Abounding in order to accept or verify the 'truth' of Hopeful's (or his own) experiences. Indeed, such an approach is problematised by Bunyan from the outset, as Carolyn Van Dyke observes, because the

\footnotetext{
8 Sharrock, John Bunyan, p. 74.

9 Bunyan, The Pilgrim's Progress, pp. 139, 143.
} 
reader is required to read Hopeful's account of conversion 'as both the same and different' (and yet just as truthful) as both Christian's and, in turn, Bunyan's conversion experiences. ${ }^{10}$ As such, and even more so than in Grace Abounding and Law and Grace, Hopeful's account in The Pilgrim's Progress exists to promote little more than a clear, specific, and solely doctrinal understanding of grace and the process of conversion. Any correlation with Bunyan's Grace Abounding (indeed, any emphasis on story at all), once more becomes secondary to doctrine here, especially for the reader trying to read The Pilgrim's Progress in terms either of Bunyan's life-story or, even worse, as but a better formulation of an earlier but evidently less readable tale.

That this is the case is made clear, moreover, if we examine the specific textual positioning of Hopeful's discourse within The Pilgrim's Progress. It is profoundly significant, for instance, that the two pilgrims 'fall into good discourse', of which Hopeful's conversion narrative is the main part, as a strategy for preventing drowsiness while passing through 'the Inchanted ground'. Although Sharrock suggests that biographically or historically this land 'represents a period of peace and toleration for the faithful when moral and spiritual effort might be relaxed', particularly alluding 'to the time after the Declaration of Indulgence in 1672 when meeting-houses could legally be reopened', Hopeful's drowsiness seems to indicate not a political complacency of relaxed conscience as much as a basic spiritual atrophy. ${ }^{11}$ Hence, the verse that precedes Hopeful's account (pointed to in the margin specifically as 'The Dreamer's Note') re-emphasises that the point of the discourse that follows is primarily to keep open 'drowsie slumbring eyes' of saints. In this respect, both Hopeful's talk of conversion and the Dreamer's verse preface both function in terms greatly similar to the former Grace Abounding, a text which also urges it's reader to reconsider the work of grace upon their souls, to keep one's faith awake through remembrance. Moreover, because Hopeful's account makes the doctrinal import of Bunyan's conversion narrative much clearer, stating in more explicit terms the doctrine of

${ }^{10}$ Carolyn Van Dyke, The Fiction of Truth: Structures of Meaning in Narrative and Dramatic Allegory (Ithaca and London: Cornell University Press, 1985), p. 182. Van Dyke also notes that Hopeful's discourse here (particularly as it concerns apostasy, "the insufficient change of mind that begins with a wilful insensitivity to invisible things'), represents 'a scaled-down, one-dimensional version of The Pilgrim's Progress - a map into and out of Bunyan's metaphoric world of faith' (p.182).

11 The Pilgrim's Progress, p. 336 (Sharrock's note to p. 136, 1. 29). 
Law and grace that remains largely implicit in Grace Abounding, it seems that far from Grace Abounding shedding light on this episode of The Pilgrim's Progress, here the exact reverse is true: Hopeful's account can (and perhaps should) be read as a significant gloss on how we are to understand Grace Abounding, pointing to it as a text conveying a specific doctrinal message and functioning to prevent spiritual drowsiness amongst the Bedford Congregation.

Beyond such an inverse correspondence, though, the timing of Hopeful's spiritual autobiography also makes another important point about how we are to read The Pilgrim's Progress. As the very last obstacle (besides the River of Death) that lies between the pilgrims and the Celestial City, what could be expected at this crucial stage of the journey is, perhaps, something a little more spectacular than the wholly uneventful 'Inchanted ground'. Indeed, if the pilgrims had been captured by Giant Despair at this point in the story, to be then rewarded after their escape by entry into the beautiful land of Beulah, perhaps C. S. Lewis's gentle criticism that the discourse between Christian and Hopeful here 'will not prevent drowsiness on the part of many readers' could have been avoided. Indeed, Lewis identifies this episode as one of those 'long dialogues where we get bogged down in doctrine', surpassed only by Faithful's dialogue with Talkative (which, for Lewis at least, is '[w]orse still'). 12 But as is well evinced by Grace Abounding, discouraging the reader who wishes to engage merely with the story is Bunyan's narrative point here. What Hopeful's explicitly theological account of conversion does, despite Lewis's comment, is awaken the reader to the doctrinal import not only of this episode but the text as a whole: it reminds the spiritually drowsy reader of the purpose of The Pilgrim's Progress beyond its overt romancing (as embodied in the overtly fabulous 'Inchanted ground' itself). Hopeful's discourse thus functions far more significantly than just as 'an accessory to the unfolding of the plot', the means by which the pilgrims simply stay awake. Rather, as Kaufmann more incisively comments, the episode offers a clear example of Bunyan's narrative practice throughout The Pilgrim's Progress in preventing the reader foregrounding fable over doctrinal lesson. Hopeful's discourse exemplifies: 'An earmark of [Bunyan's] narrative 
procedure [as] the arresting of the forward thrust of the action while experience is reviewed not for entertainment but for the edification of the listener.' 13 In this case, as ever, the listener is not merely another allegorical character but the reader himself.

What the episode of the 'Inchanted ground' and Hopeful's accompanying discourse reveal, therefore, is that The Pilgrim's Progress is most certainly bound-up with the former text, Grace Abounding to the Chief of Sinners. But this relationship is not based on shared biographical material or detail, the one text being a reworking of the other, as this implies a restricted interpretation of the text and one dangerously bordering on a reading for the story, or at least for a corroboration between stories. Rather, the texts share the same doctrinal and narrative basis and any connection between the two beyond this distinction can only be made with some caution. Like Grace Abounding, therefore, The Pilgrim's Progress foregrounds doctrine at the expense of fable, faith over rationalisation, and the ontology of spiritual experience over epistemologies which threaten an acceptance of the 'truth' of this experience. As in his autobiography, Bunyan's allegory teaches the reader about reading. Even more so, in fact, does interpretation become the focus of the text's action in The Pilgrim's Progress, with the reader learning and re-learning not only to foreground faith over reason, as Stanley Fish has so remarkably indicated, but to resist the text as mere fable or, more insidiously, romance.

Such an approach obviously proposes a radical reassessment of the way in which Bunyan's narrative texts interrelate. While Vincent Newey admits that in The Pilgrim's Progress ' $[t]$ he materials of the precursor text [Grace Abounding] are at once recapitulated and refashioned', nevertheless he recognises the need to qualify such an approach by suggesting that in Bunyan's allegory there is a 'more certain and deliberate foregrounding of spiritual, as opposed to natural, "seeing" and "doing" ', than is to be found in the earlier spiritual autobiography.' '[T]he reader of The Pilgrim's Progress is manoeuvred into a position', he observes, "where he must himself renounce the interest of this-worldly narrative and truth for

13 Kaufmann, The Pilgrim's Progress and Traditions in Puritan Meditation, pp. 230, 231. 
those of Truth - must read according to a belief in "things that are invisible".'14 This is undoubtedly the case. But on these grounds Newey's distinction between the two texts also indicates wherein they are most importantly related, for, in these terms, The Pilgrim's Progress takes its precedent in foregrounding the unseen, both doctrinally and narratively, from the ontological poetics evinced in Grace Abounding. The difference is that while this precedent is implicit in the narrative structure and strategies of Bunyan's conversion account, in The Pilgrim's Progress it is made explicit from the verse Apology onwards. In this way, The Pilgrim's Progress reveals a Bunyan more overtly self-conscious about his narrative practice, a fact evident both in his choice of form (allegorical dream-vision) as well as in his use of the technology of the printed page through complex marginal notation (an aspect of Bunyan's style explored in the next chapter). Consequently, The Pilgrim's Progress, in form and texture, presents itself from the outset (as this chapter aims to show) as an engagement with doctrine and narrative on a grand and arguably more concerted scale.

The title (and more particularly the title-page of early editions) of The Pilgrim's Progress alone is enough to convince us of such an engagement. As with Grace Abounding to the Chief of Sinners, Bunyan's allegory initiates the reader in a re-orientation of expectations from the first words onwards. Most obviously, for instance, is the notion of progress brought to the reader's attention as a term which, having been pointed out by various commentators, abounds in a polysemous slipperiness upon which even the most wary reader could stumble. Invoking a sense of linearity and positive development, and most dangerously a sense of empirical advancement, 'progress' also invokes, as Christopher Hill has indicated, a tradition of royal progresses (in which no spatial progress is made at all) mischievously inverted by Bunyan in the spiritual travels of an itinerant Christian dressed in rags. While this clearly initiates a re-orientation of values in biblical terms (this text is concerned only, as Christian points out to Pliable, with spiritual riches and crowns of heavenly glory), the idea of progress is something which the reader must also learn to reassess continually as he continues reading. Hill, echoing Stanley Fish's famous analysis of

14 Vincent Newey, 'With the eyes of my understanding: Bunyan, Experience, and Acts of Interpretation', in John Bunyan: Conventicle and Parnassus, Tercentenary Essays, ed. by N. H. Keeble (Oxford: Clarendon Press, 1988), pp. 189-216 (pp. 209, 210). 
Bunyan's allegory, thus indicates the subversive potential of the term for the reader: the ensuing events in the text prove to be neither 'necessarily sequential, nor is there a steady advance across country. [...] The "progress" is psychological, not geographical' ${ }^{15}$ Arguably, though, even Hill is slightly mistaken in his use of terms here. The progress involved is not necessarily 'psychological' (whatever that might mean) but doctrinal and spiritual. Christian's journey is a movement from the guilt of sin to grace, from this world to that which is to come, and as we know from the narrative structuring of Grace Abounding, there is nothing straightforward about such experience for protagonist and reader alike. Rational procedures and progress, even of reading itself, must be realigned to submit to an acceptance of things unseen. As such, Stanley Fish suggests that the crux of reading The Pilgrim's Progress correctly or incorrectly hinges upon these very matters, in which 'the reader's awareness of the problematics of the narrative' is an essential part of Bunyan's intention; 'Christian's initial error,' writes Fish, '(and it is the reader's too) is to take seriously and literally the title of his story.' 16

But even the teleology of this journey seems placed in jeopardy by the title of the text. As Van Dyke suggests: 'If the pilgrim progresses "from this world to that which is to come," his journey must be in neither - that is, in a metaphoric dream born of the inconjunction of both."17 Spatial frameworks are being undermined from the outset of this pilgrimage, then, for Christian's movement is evidently one towards a world which is paradoxically coming to him in any case. The title-page thus encapsulates not only the hope of transcending this world but the threat of something uncomfortably apocalyptic too, the two notions of conversion and judgement proving to be inextricable in The Pilgrim's Progress as a whole: Christian's conviction to fly for eternal life originates in a belief that the end is nigh (or at least inevitable) and, echoing his lessons in the Interpreter's House, there is evidently much in the title of this text alone to put the reader 'in hope and fear' of such matters.

\footnotetext{
15 Christopher Hill, A Turbulent, Seditious, and Factious People: John Bunyan and his Church, 1628-1688 (Oxford: Oxford University Press, 1988; repr. 1989), p. 222. See also Philip Edwards, 'The Journey in The Pilgrim's Progress', in The Pilgrim's Progress: Critical and Historical Views, ed. by Vincent Newey (Liverpool: Liverpool University Press, 1980), pp. 111-117.

16 Stanley Fish, Self-Consuming Artifacts: The Experience of Seventeenth-Century Literature (Berkeley, LA and London: University of California Press, 1972), pp. 225, 227.

17 Van Dyke, The Fiction of Truth, p. 169.
} 
Indeed, the implication here seems to be that if one is at least seeking the kingdom of heaven one need not fear its coming, in which case the reader is being asked to seek and recognise in himself justifiable spiritual hope and dread before the narrative proper has even begun.

Clearly, then, the frontispiece of The Pilgrim's Progress is something to be reckoned with in itself. As one commentator puts it: 'The title-page, like the apologetic poem, complicates as it justifies.' ${ }^{18}$ Of particular interest, however, is the remaining text of the original title - Bunyan's declaration that all will be delivered under the 'similitude of a dream' in which we are to be told of the pilgrim's setting out, traveller's tribulations, and safe arrival. Clearly, there cannot be too much question of what happens in the story nor whether the said pilgrim achieves his aim; we know this even before we start reading. More significant than this, though, is the fact that the word 'dream' by far dominates the original title-page, indicating a self-consciousness (to the point of a self-advertisement) as to the text's contrived status as fictive artifice: Bunyan is offering us a text the pivot of which is most conspicuously a literary convention - that of dream-vision - and the importance of which for Bunyan's narrative procedure is obvious. In one way, for example, the exclamation that this is but a similitudinous dream-narrative corresponds to how the titlepage functions as a whole - upsetting the reader's expectations and conventional responses to texts. Because the title-page presents notoriously equivocal implications about progress and worlds which are both coming and going, likewise, "the dream is a "similitude" for the real subject, namely, "the manner of his setting out" and so forth. We are led,' Van Dyke subsequently observes, "both to discount the story as a dream and to discount the dream as a mere vehicle for the story.' 19 As the beginning of the narrative proper also shows, with the dreamer conjuring a narrative which has as its foremost image a man in rags burdened by both the weight on his back and the book in his hand, dreaming and reading are categories about which the reader can only make hesitant assumptions. Indeed, in The Pilgrim's Progress the two categories are simultaneously 'introduced, intertwined, and destabilized' with dreaming and reading 'not presented as opposites or correctives of one another, nor [...]

\footnotetext{
${ }^{18}$ Robert Kiely, 'Angelic Discourse or Unstable Allegory? The Play of the Literal and Figural in Augustine's Confessions, The Little Flowers of St Francis, and Bunyan's Pilgrim's Progress', Stanford Literature Review, 5 (1988), 105-130 (p. 122).

19 Van Dyke, The Fiction of Truth, p. 169.
} 
as similitudes ("dreaming is like reading" or vice versa).' Rather, 'they are contexts of perception, producers of narrative and interpretation. They generate texts,' Robert Kiely suggests, 'without necessarily assuming responsibility or authority for their destinies.'20

For Bunyan, however, the dream-convention is most definitely an authorising device for the generation of his allegorical narrative and (as the verse Apology shows) he does indeed assume full responsibility as author for its consequences and implications (its 'destiny'). The reason for this is clear too: it is precisely through the similitude of a dream that Bunyan is to effect his ontological textual poetics in The Pilgrim's Progress and in a way both similar to and yet markedly different from Grace Abounding. For instance, in this latter text, its status as an autobiographical account effects a no uncertain amount of tension between the ontology of Bunyan's spiritual experiences and conventional epistemologies which influence our acceptance of them. Such tensions are, as we have seen, inherently grounded in metaphor, the reader becoming uncertain in accepting a given representation of experience as literal or metaphorical. Equally, though, these tensions arise from the fact that Grace Abounding presents two worlds in collision, the spiritual realm intruding most forcefully upon the natural, even banal world of Bunyan's everyday experience. Because this collision is presented in the form of a true relation, it is the reader's metaphysics which are being placed under scrutiny: do we accept that what Bunyan relates is true and real?

In contrast, Bunyan's presentation of spiritual matters under the similitude of a dream enables him to create a whole new set of representational parameters. By presenting the world of The Pilgrim's Progress as a dream-zone, Bunyan is able to offer a realm by nature free from the conventional epistemological and empirical assumptions that interfere with the reader's acceptance of events and their doctrinal import in Grace Abounding. While McHale rightly suggests that autobiography "claims a different ontological status from "pure" fiction, and a stronger one', one which is perhaps potentially more radical in its destabilising effects, in presenting an artificial dream-world Bunyan nevertheless has access to a purer form of ontological poetics. ${ }^{21}$ In the realm of the dream, not only can anything happen (logically and most often illogically) but anything can be represented. As with Christian's spiritual burden

20 Kiely, 'Angelic Discourse or Unstable Allegory?', p. 123.

21 Brian McHale, Postmodernist Fiction (London and New York: Methuen, 1987; repr. 1993), p. 202. 
of guilt becoming substantially concretised into an actual burden upon him (one, curiousły enough, which the Graceless family cannot perceive), the unseen can become most visibly seen in the dream of The Pilgrim's Progress, Bunyan thus constructing an ontological strangeness that the reader can accept more readily according to the inherently surreal nature of dreams themselves. 22

That Bunyan's narrative practice in foregrounding the spiritual over the carnal is developed in his choice of form is, then, clear. As the title indicates, this is most explicitly a matter of worlds not only next door to one another colliding but of worlds inseparable from each other. Christian's journey is thus often mimetic of the natural world (the 'way' has characteristics of an actual road, the characters he meets are like real people) but equally the allegorical dream-world destabilises such mimesis: the hand of God actually (and not with a metaphorical 'as if') reaches down from the sky in The Pilgrim's Progress, Christian magically walks free from a most versimilar imprisonment at Vanity Fair, and Despair becomes a most gruesome and violent enemy. This is most definitely and infinitely a world of excluded middles, and in one's understanding of this lies the interpretive crux of the whole text: 'The crisis that initiates the pilgrimage is, in fact, Christian's discovery that he is in two worlds at once. The intangible realities of Scripture - man's pitiful righteousness, his burdensome sin, the imminent destruction of his earthly home - have become as real to Christian as are his wife and children.' In this way, The Pilgrim's Progress becomes a painful navigation of both the realm of unseen things and of Scriptural metaphor in themselves. ${ }^{23}$

That Christian's journey is indeed a progression 'through paradoxical relationships between two realities', 'over real mountains with conceptual doors in them', helps to explain

\footnotetext{
22 In this way, moreover, Bunyan does not face the problem of the reader reading Christian's experiences as signs of inherent madness: the strange events and occurrences in The Pilgrim's Progress can at least be seen as symptomatic of the illogical dream-world. As such, this strategy actually allows Bunyan to contain and represent medical or psychological appropriations of religious conversion within the narrative itself as ignorant and unregenerate. See, for instance, the responses to Christian's spiritual questing by his family, Mr. WorldlyWiseman, and Ignorance, all of whom consider Bunyan's pilgrim to be mad (Bunyan, The Pilgrim's Progress, pp. 9, 18, 148-149). It must be noted, however, that some contemporary critics also hold this opinion of Christian, regarding The Pilgrim's Progress as merely generalising 'the psychosis of an individual into the crisis of a people': (S. J. Newman, 'Bunyan's Solidness', in The Pilgrim's Progress: Critical and Historical Views, pp. 225-250 (p. 237). For similar views, see David Mills, 'The Dreams of Bunyan and Langland', also in The Pilgrim's Progress: Critical and Historical Views, pp. 154-181 (pp. 159-160, 165, 177).

23 Van Dyke, The Fiction of Truth, p. 170.
} 
the ontological vertigo the reader of The Pilgrim's Progress may often feel while engaging with it. ${ }^{24}$ The reason for this, of course, is that in The Pilgrim's Progress (unlike in Grace Abounding), Bunyan is presenting dual ontological issues to the reader: the ontology of a spiritual reality is offered within the text's own ontological frame as something similitudinous, as a fictional or parabolic realm. Such a narrative method, in which fictive and spiritual worlds are conflated, has obvious benefits for Bunyan, not the least of which is the continual upsetting of the reader's expectations in a medium (allegorical dream-vision) which is inherently suited to foregrounding other-worldly matters. Literal and metaphorical, inner and outer, natural and spiritual, all become blurred to the point of a dizzying representational hesitation or iridescence in The Pilgrim's Progress: Christian's burden is both the burden of guilt and an actual burden, it is both physical and spiritual within the fabulous world Bunyan depicts, with the text continuing along these unsettling representational lines throughout. Allegorical dream-vision is thus, as John Stachniewski comments, peculiarly suited to Bunyan's 'Puritan' imagination precisely because it affords the narrative 'a solvent for physical-psychical-spiritual distinctions which meant little to the puritans', and through which '[p]hysical, psychic, and metaphysical events' can be 'blended [...] in a textual continuum.' Allegorical dream-vision's propensity for blurring distinctions thus makes it the 'ideal literal vehicle' for Bunyan's narrative intentions because it seems to be 'the natural vehicle of puritan perception' in general. ${ }^{25}$

The dream-convention thus authorises Bunyan's ontological narrative procedure as one in which typical relations between reader, text, and narrator can be subverted to ensure that his doctrinal point is driven home. Hence, Bunyan's policy is to disturb the surface of his narrative continually by, as but one example shows, having the dreamer intervene in the dream itself, as in his discourse with Help in which the significance of the Slough of Despond and its hidden steps of Promise is revealed. Like the Slough, then, the framework of dream-narrator-reader in The Pilgrim's Progress proves to be dangerous ground, the tale and its telling becoming not something the journeyman reader can confidently rely upon or

\footnotetext{
24 Van Dyke, The Fiction of Truth, p. 169.

25 John Stachniewski, The Persecutory Imagination: English Puritanism and the Literature of Religious Despair (Oxford: Clarendon Press, 1991), pp. 172-179.
} 
pass over easily, thus helping to keep the reader's mind on doctrinal matters through what has been referred to as a deliberate 'tangle' of narrative frameworks. ${ }^{26}$ In presenting the text in this way, moreover, Bunyan's authority within The Pilgrim's Progress can be deliberately elided from the reader's view. While Bunyan's first-person presence is, naturally, overwhelming throughout the relation of Grace Abounding, in The Pilgrim's Progress Bunyan makes it difficult to pin-point him anywhere in the narrative proper. Strictly, he is neither the narrator nor the subject of narration and, in the careful textual layering of authordreamer-protagonist, Bunyan becomes a hidden author only revealing himself to validate his narrative directly on the page, guiding the reader in the framing verses of the text and its ubiquitous marginal notes. Not simply authored by his experience, as in Grace Abounding, Bunyan has now quite notably become an author.

However, although we may be convinced that Bunyan's choice of literary form is ideally suited, both culturally and textually, to his doctrinal and narrative procedures, the presentation of Christian's journey in the similitude of a dream also carries with it, like the life-story of autobiography, some significant problems for Bunyan. One difficulty with the dream-narrative device, for instance, lies in the very questions it raises in terms of the text's status as authored and artificial. Not experience in itself, this is merely a simulation of experience (and in the form of a dream to boot), the creative and contrived aspect of which Bunyan is consequently at pains to deprecate in the 'Author's Apology'. Far from being a conscious fictional creation, The Pilgrim's Progress is thus emphatically presented as being authored by a more appropriate kind of spiritual inspiration: 'Before I was aware, I this begun', Bunyan writes, his similitudes 'multiplying' as if magically self-generated. Moreover, the validity of the dream as a vehicle for Bunyan's doctrine may be placed in jeopardy if we try to read it as a dream. Stachniewski's analysis shows, for instance, that as 'dream' The Pilgrim's Progress is indeed in some danger of being interpreted simply as 'a piece of wish fulfilment' which 'seeks to transform the negative components of the [theological] vision it expresses so as to produce a desired' (but finally denied) 'outcome.' Despite succeeding 'in vanquishing scepticism and despair by reifying the invisible world', 
Stachniewski thus sees Bunyan's dream-text as being continually prone to the inexorcisable spirit of the persecutory imagination which its wish-fulfilling function simply cannot banish: 'the reprobate frame and the social experience to which it adheres gain admittance' in The Pilgrim's Progress nevertheless, he writes, and in the 'potent form' of Giant Despair and Ignorance's damnation. ${ }^{27}$

But for Bunyan, the notion of a text driven by mere 'wish-fulfilment' conjures forth an even more ghastly spectre (in narrative terms, at least) than Stachniewski's 'reprobate frame'. While in Grace Abounding, the autobiographical form raises the problem of a reading just for the life-story or reading life-story as though it were fiction, in The Pilgrim's Progress, Bunyan is faced with the even more problematic fact that his allegory could be accepted as mere fiction alone and that, as wish-fulfilling similitude, it could indeed be read as little more than romance and fantasy. The profound danger for Bunyan, therefore, is that while any text-as-fable threatens to cancel the doctrinal and soterial message it is intended to carry - indeed, threatens to render even doctrine itself as fabulous - this is even more so with allegorical narrative than with autobiography. For instance, in terms of fable, an episode as important as Ignorance's damnation could be read as but a slightly uncomfortable and perhaps unnecessarily harsh ending to the 'story' of The Pilgrim's Progress (an expurgation of unwanted reprobate residue, even) rather than as a powerful and terrifying doctrinal lesson about the inevitable damnation of the spiritually ignorant (which is Bunyan's point all along). With such misreadings between story and doctrine, fiction and allegory, becoming both all too possible as well as evident in The Pilgrim's Progress, it is hardly surprising at all that Bunyan finds it necessary to preface his highly imaginative narrative with what Barbara A. Johnson calls a 'strenuous defence' of method, a revealing explication of Bunyan's aesthetic practice known as the 'Author's Apology For His Book' ${ }^{28}$

Clearly, what both the verse Apology and the Conclusion of The Pilgrim's Progress offer, as U. Milo Kaufmann puts it, is Bunyan's 'aesthetic brief'. But while Kaufmann (among many

27 John Stachniewski, Persecutory Imagination, pp. 179-185.

28 Barbara A. Johnson, 'Falling into Allegory: The Apology to The Pilgrim's Progress', in Bunyan in Our Time, ed. by Robert Collmer (Ohio and London: Kent State University Press, 1989), pp. 113-137 (pp. 114-115). 
commentators, it seems) views the Apology as bodying forth tensions inherent within The Pilgrim's Progress as a whole, between 'the diverse modes of narration and exposition' nominated by Kaufmann as 'the mythic, the allegorical, and the literal-didactic' (or more broadly as the doctrinal and the imaginative, the discursive and the narrative), the Apology can be viewed (and more comprehensively too) as defending an aesthetic with quite different concerns from these. ${ }^{29}$ Indeed, Bunyan's Apology is undoubtedly a methodological tour de force but, ultimately, it is not one in which he tries to account for conflicts in his own narrative procedure as both imaginative and doctrinal, narrative and didactic. Rather, it is a confirmation of Bunyan's aesthetic practice according to the principles lying behind the construction of Grace Abounding, as the final paragraphs of the Apology attest to most strongly. Here, though more explicitly than in its autobiographical counterpart, The Pilgrim's Progress asks the reader outright to submit to its doctrinal import, to learn to be teachable: this book can only 'make a Travailer of thee', Bunyan states, if one is willing to be ruled by its 'Counsel', from which point alone (as the word 'Travailer' and the other birthing puns of the Apology suggest) can the labour for a new life take effect and in miraculously transformative terms too. The slothful can indeed become active, the blind 'delightful things to see', but only if the reader is willing to lay 'Book', 'Head and Heart together' to 'understand' its 'Directions' ${ }^{30}$

Here, once more, the reader is being foregrounded as the focus of the author's attention in order to stress how the process of reading The Pilgrim's Progress itself must be radically different from that of any other 'Novelty', the last paragraph of the Apology thus becoming a verse abounding in the text's ability to embrace logic-defying excluded middles

29 Kaufmann, The Pilgrim's Progress and Traditions in Puritan Meditation, pp. 5, 6-15. For a similar approach, see Barbara A. Johnson, Reading Piers Plowman and The Pilgrim's Progress: Reception and the Protestant Reader (Carbondale and Edwardsville: Southern Illinois University Press, 1992), pp. 37-54, and Kathleen Swaim, Pilgrim's Progress, Puritan Progress (Urbana and Chicago: University of Illinois Press, 1993), which has two separate chapters on allegory and narrative according to Kaufmann's division of logos and mythos (see, for example, p. 43). Similarly, Thomas Luxon's recent book, Literal Figures: Puritan Allegory and the Reformation Crisis in Representation (Chicago and London: University of Chicago Press, 1995), begins by questioning the very premise that lies behind Bunyan's writing of an Apology to The Pilgrim's Progress in the first place: 'what is a Puritan literalist like Bunyan', Luxon asks, 'doing writing allegory?' (pp. ix-xi). For a view of the Apology as a defence of imaginative literary form, see also John Bunyan, The Pilgrim's Progress, World's Classics Series, ed. by N. H. Keeble (Oxford: Oxford University Press, 1984), 'Explanatory Notes', pp. 263-264, and Roger Sharrock, John Bunyan: The Pilgrim's Progress, Studies in English Literature 27 (London: Edward Arnold, 1966), pp. 14-18.

30 Bunyan, The Pilgrim's Progress, pp. 1-7. All following quotations from the text (unless otherwise stated) will refer to these pages. 
and advertising the 'Truth' it conveys quite reasonably as completely irrational. ${ }^{31}$ Not only will it sound of 'honest Gospel-strains' but promises to place the reader himself in a whole new mode of perception, a labyrinth of hesitations in which one is 'in a Dream, and yet not sleep', may simultaneously 'Laugh and Weep', and in which the maze of the text is something to 'loose thy self in without harm and which requires no romance-device or fictive 'charm' to recover one's self from. This could almost be a prefatory verse to Grace Abounding, stressing as it does Bunyan's emphasis upon the reading of his text and the ontological newness that his doctrine and 'Truth' promises. Moreover, this text also warns of the dangers of over-interpretation and points to itself as providing the only commentary necessary for a true understanding of its matter: one must read the 'Riddles' along with 'their Explanation' or 'else be drownded in thy Contemplation', we are told. As in Grace Abounding, and as Christian and Hopeful later discover, too much speculation on a riddle (be it of one's elect status or of Lot's wife) can lead to being overwhelmed by floods of doubt and mistaking.

Too much musing over allegorical puzzles may also lead to another danger - that of, as Bunyan remarks in the Conclusion, 'playing with the out-side of my Dream.' While Bunyan's explanatory marginal presence may be intended to pre-empt such overcontemplations, the Conclusion reveals that Bunyan does not want his text open for debate: 'Nor let my figure, or similitude,' he writes, 'Put thee into a laughter or a feud. [...] Do thou the substance of my matter see.' Here, then, lies the crux of Bunyan's concern - ensuring not only that his text will provoke neither ridicule nor malice but that its essential matter is not missed over more peripheral issues. Bunyan could not be clearer in his intention, here: we are not to read The Pilgrim's Progress for anything but the Gospel-truth. Bunyan's concluding advice thus becomes a forbidding warning: 'take heed of mis-interpreting', he writes, 'By mis-interpreting evil ensues.' 32 Lying at the very end of the story, such a caution is undoubtedly a pulling of the narrative rug from beneath any complacent reader's feet, an

\footnotetext{
${ }^{31}$ Ellen Cantarow also reads the Apology in this way. For her, '[i]t is in Bunyan's insistence on the effect his book was to have on his reader's life that one finds the seeds of an entirely different attitude towards fiction than any preceding the late seventeenth century': 'A Wilderness of Opinions Confounded: Allegory and Ideology', College English, 34 (1972), 215-252 (pp. 248-249).

32 Bunyan, The Pilgrim's Progress, p. 164.
} 
opening of the trap-door of mis-reading to reveal the potent spiritual danger which lurks beneath. Any reader merely slumbering in Christian's achievements is sharply awoken here and, like Christian himself in the arbour, is encouraged to go back to the text and find the truths that have been left behind. Ominously, however, Bunyan's words here also imply that mis-reading (and not simply missing) the salvatory meaning is all too possible in The Pilgrim's Progress.

The Conclusion is important, then, because it states so clearly what is left unsaid in the Apology. Indeed, unlike the Conclusion, the Apology seems dedicated to the fact that Bunyan's text need not be mis-taken or misunderstood in its method at all, Bunyan using the Apology to brush away any of the unsavoury implications his narrative may bear as fictive, imaginative, or untruthful with both a nonchalant ease and a sophisticated debate. But as Barbara Johnson observes, the Apology does, nevertheless, present itself as 'one of the most puzzling statements ever offered for a work of fiction.' 33 Indeed, for this commentator, the Apology is most puzzling because, far from being any 'conventional introduction' it is rather, as already noted, a 'strenuous defence'. But one should first ask, on this basis, what the Apology is a 'strenuous defence' of, for here is really where the initial puzzle lies. What Bunyan does not defend or explain in this prefatory piece, for instance, is the specific use of the dream-device: why he uses this, its status as a literary convention, even its validity as a medium for allegory are all issues omitted from the Apology. Even though the dream-form carries with it potential problems for Bunyan's narrative purposes, and while the benefits can be clearly recognised (after all, in a dream excluded middles can be most rationally represented), it is not a subject of either contention or note for Bunyan.

Moreover, the whole issue of not reading for the story is dealt with easily and briefly in this Apology, despite this being such an integral part of Bunyan's aesthetic practice as a whole. Indeed, Bunyan waits until the last page of The Pilgrim's Progress to remind the reader not to play too much with the 'out-side' of his dream, while asking quite simply and unapologetically 'Wouldest thou see a Truth within a Fable?'. In the Apology, therefore, Bunyan shows little difficulty or defensiveness at all in reconciling the potentially unsettling

33 Johnson, 'Falling into Allegory', pp. 114-115. 
term 'fable' within his narrative scheme as a whole. Saying this, however, it must be noted that Bunyan's emphasis here is placed not upon fable per se but on the kind of fable that purposefully acts as a vehicle for spiritual teaching. Bunyan's precedent here (following Timothy, he admits) is not, therefore, just 'old Wives Fables' but, rather, that most apt truthbearing form of story - the parable. Consequently, in qualifying his allegory as parable rather than fable, not only is Bunyan able to draw upon Biblical and doctrinal support for his narrative method in The Pilgrim's Progress (even 'grave Paul [...] no where doth forbid/The use of Parables', he states), but can draw fully upon the ontological and existential value of the parable as a kind of story which encapsulates and conveys 'Truth' above all else.

For Bunyan, the usefulness of this exchange of mere fable for parable is obvious. A parable (like a dream-narrative) requires a suspension of all conventional logic within the world it creates and must be accepted on these terms alone for the explanation of its riddle to be fully understood: parables require an acceptance of its conditions without epistemological constraint, and demand a converted frame of perception for it to be finally understood. As such, it is an ideal vehicle for offering an ontological realm which discourages carnal rationality and the point of which lies in its doctrinal message, not the story that carries it, a fact Bunyan realised from a very early stage as preacher and writer ${ }^{34}$ For example, his preface to A Few Sighs From Hell (1658), a tract explicating the parable of Lazarus and Dives, seems particularly relevant for his defence of The Pilgrim's Progress. Here, he notes and clarifies familiar objections:

But it may be thou wilt say, All that hath been spoken to in this discourse is but a parable, and parables are no realities. I could put thee off with this answer, That though it be a parable, yet it is a truth, and not a lie; and thou shalt find it so too, at thy cost, if thou shalt be found a slighter of God, Christ, and the salvation of thy own soul.

As ever, the issue for Bunyan is one of salvation, with parables presenting efficacious spiritual truths and not merely fictive vehicles. But equally significant for him is the

\footnotetext{
34 Janet Martin Soskice notes that recent approaches to parables treat them 'primarily as pure units of meaning. The only world which is of importance is the "world" entered into and shattered by the parable, a pre-eminently existential world': Metaphor and Religious Language (Oxford: Clarendon Press, 1985; repr. 1987), p. 98. For a useful article which both assesses recent accounts of 'the parable' while asserting the 'non-rational' element that lies at the heart of it as a type of narrative, see James Champion, 'The Parable as an Ancient and a Modern Form', Journal of Literature and Theology, 3 (1989), 16-39. For Champion, parables can only be described finally as 'odd stories with double meanings that speak to us in ways not entirely subject to management by our greater and greater hermeneutical competency'(p. 37).
} 
ontological dimension of a parable: it is not just story, or truthful story, for 'the thing signified by parables are wonderful realities' (my italics). For Bunyan, then, parables convey not moral issues but ontologically determined actualities, communicating in earthly terms something of the most unfathomable eschatological aspects of Christian faith - the kingdom of heaven, states of salvation and damnation. Bunyan has, moreover, the utmost authority in presenting The Pilgrim's Progress as a parable for, he writes, 'our Lord Jesus Christ did speak [...] for the most part, if not all, in parables.' 35 Bunyan chooses to qualify his fabulous allegorical method, therefore, by invoking the most grace-ful authority possible.

Equally, though, all this must largely be inferred from Bunyan's Apology and, besides, The Pilgrim's Progress is clearly far more than parable (even as vastly extended parable), as it nominates itself most unequivocally as 'an Allegory'. Yet the Apology does not really address even this most important aspect of the text's construction. Allegory itself (as a literary form that has caused readers and commentators no small amount of hermeneutic concern from its medieval past to its postmodern present) is, in fact, mentioned but in passing by Bunyan as something which, he disclaims, he merely fell suddenly into. Bunyan defends his allegorical 'stile' and 'method' quite simply, therefore, not in any literary or imaginative context but according to the greater pastoral 'end' which he is, of course, always loath to miss - ' thy good'. For this reason 'why may it not be done?', he asks. But in making such a straightforward case for using allegory, it is exactly at this point that the Apology appears to complicate where it justifies the most, for what follows the innocent question 'why may it not be done?' is a series of complex verses apparently defending the use of ingenious traps (of which allegory is one, we might assume) in order to win sinful readers. In this sense, consequently, Bunyan's Apology could indeed be taken as a strenuous defence of methodological sophistry, benefiting the reader by sugaring the doctrinal pill with a fablelike good yarn. ${ }^{36}$ But this, however, is not Bunyan's point at all. While admitting that allegorical 'darkness' is a crucial aspect of his method as a whole, it is nevertheless presented

\footnotetext{
35 John Bunyan, A Few Sighs From Hell, or The Groans of a Damned Soul (1658), in The Works of John Bunyan, ed. by George Offor, 3 vols (Glasgow: Blackie and Son, 1854; repr. by The Banner of Truth Trust, 1991), III, 674.

36 Barbara Johnson, for instance, views the Apology in this way, Bunyan's style adopting various devices specifically to entrap his reader. See, Reading Piers Plowman and The Pilgrim's Progress, pp. 40-41.
} 
in the Apology as something both natural ('Dark Clouds bring Waters', he states) and, to use his other propitious metaphor, bountifully productive ('yielding Crops' and 'Fruit'). Just as the style and method are depicted as self-creating (according to Bunyan, the text conceives itself and is offered in 'the bigness which you see', pregnant with significance as well as contention), so too are they as fertile for the reader as any other, lighter or brighter, methods.

In fact, it is impotant to note that Bunyan's style and method are actually presented as something to be distinguished from anything ingenious in this Apology, being both far more simple and yet more skilful and effective. Bunyan's allegorical narrative technique is thus not at all akin to the 'Engins' a fisherman makes, 'how he ingageth all his Wits;/Also his Snares, Lines, Angles, Hooks and Nets', for as a veritable fisher of men Bunyan knows that there are some fish that such elaborate devices simply cannot catch - they must be subtly poached, 'be grop'd for, and be tickled too'. Poaching the reader unawares is thus the watchword of Bunyan's narrative practice in The Pilgrim's Progress. As such, his art is most certainly to be differentiated from the craft of a 'Fowler', presented here as miserably failing to be 'master of what Fowls he please.' In his description of he who 'creeps, he goes, he stands; yea, who can tell of all his postures?' we can hardly mistake a thinly veiled satirical attack by Bunyan on his contemporary Bedfordshire Latitudinarian, Edward Fowler who, for the preaching tinker at least, was most certainly a religious posturer and (with Bunyan's usual propensity for puns) a befouler of the true faith. ${ }^{37}$ Hence, the fowler-image significantly cancels itself out in the Apology as an effective model for Bunyan to pursue in The Pilgrim's Progress: as the enigmatic phrasing of the final couplet implies, the fowler 'must Pipe, and Whistle to catch this,' Bunyan writes, 'Yet if he does so that Bird he will miss' (but what the un-italicised 'this' and 'that Bird' finally signify remains slightly unclear).

It is from the increasing confusions and paradoxes of these lines, and the further notion that Bunyan's methods, though they 'promise nothing, do contain/What better is then

\footnotetext{
37 Bunyan clearly identifies such wiles as unquestionably satanic in his Book for Boys and Girls (1686), presenting the fowler as an emblem for devil himself, Latitudinarian or not (although we could surmise that the two terms are largely synonymous for Bunyan). See John Bunyan, The Miscellaneous Works of John Bunyan VI, ed. by Graham Midgley (Oxford: Clarendon Press, 1980), poem XXIII 'Upon the Lark and the Fowler', pp. 225-226.
} 
Gold', that Bunyan then moves to a clarification of the matter in hand. The Apology is clearly not a defence of allegory, dream-convention, nor fable either as forms of narrative or as devices of an imaginative literary technique, even though they are of such clear import in any understanding of the text and Bunyan's 'method' in general. Barbara Johnson may indeed find in these verses 'one of the most puzzling statements ever offered for a work of fiction', then, because that is precisely what the Apology is not - a statement offered to excuse a work of fiction. Rather, the Apology is a most 'strenuous defence' of that which lies at the heart of Bunyan's narrative concerns in The Pilgrim's Progress as in Grace Abounding - metaphor and 'Truth'. The Apology defends the use of allegory, therefore, not in terms of Bunyan's indulgence in anything imaginative or romantic but, most of all, because it affords him a special use of figurative, and specifically metaphorical, language.

Maureen Quilligan's recent analysis of allegory is useful in illustrating this matter. According to her, all allegories and allegorical narratives share certain verbal or linguistic traits which serve to define the genre. On the one hand, she asserts, allegories are structured upon wordplay: 'A sensitivity to the polysemy in words,' Quilligan writes, 'is the basic component of the genre of allegory. This sensitivity is structural, for out of a focus on the word as word, allegory generates narrative action.' On the other hand, and more importantly perhaps, allegories 'not only pun, they also show many other shared concerns with the truthfulness of metaphor.' Indeed, Quilligan identifies as central to allegory the very issue of metaphor as a vehicle for truth: 'allegory's final question [is,] is metaphor a thrust at truth or a lie?' Thus:

Having set himself the task of writing an allegory (whether or not he calls it by such a name), that is, of investigating the possible permutations of truth he might be able to detect in his language, the author poses questions - do puns reveal the divine design? are words "true" or do they lie?- which make the reader share in the scrutiny of the verbal medium. ${ }^{38}$

And this is exactly the thrust of Bunyan's argument in the Apology, in which metaphor is most confidently (and eloquently) upheld as a means of communicating 'Truth'.

The most important aspect of the Apology (indeed, what quite literally lies at its centre) is, therefore, the carefully structured debate between an imagined objector to

\footnotetext{
${ }^{38}$ Maureen Quilligan, The Language of Allegory: Defining the Genre (Ithaca and London: Cornell University
} Press, 1979), pp. 33, 46. 
Bunyan's metaphorical methods and the author himself. Evidently, Bunyan has considered the issues at stake with some thoroughness, leaving no point unanswered and, as opposed to presenting himself as the unwitting author upon whom the text has accidentally fallen, Bunyan reveals himself in this fictional fracas to be more than capable of defending metaphor with a sophisticated rhetorical and logical rigor. To some readers, however, Bunyan's arguments in this debate may seem rather belaboured. After all, his initial point seems clear enough: Bunyan is, he says, defending his use of metaphor, and therefore allegorical narrative as a whole, according to the straightforward principle of Scriptural authority ('I find that holy Writ in many places,/ Hath semblance with this method') from which, though often 'dark and cloudy', springs 'those rayes/ of light, that turns our darkest nights to days.' From this stance, however, Bunyan then turns his defence into a potent form of attack, forcing any objector (imaginary or not) to look again to 'that same Book' of Scripture not only to note the uses of figure and similitude therein but to question his or her own understanding of that holy writ as a whole. Indeed, it soon becomes clear that it is not only the 'carper's' objections to metaphor that are at issue (as well as his own 'lines') but, moreover, how he reads and understands the Bible itself. In other words, it is the objector's reading and ultimately the faith which it reveals that is being questioned by Bunyan here.

While this defence of method may seem straightforward enough, the implications behind it are important to note. Bunyan's defence of Scriptural metaphor and figure is, for instance, fundamentally centred in a policy of grace-ful reading. Any problem in adopting 'dark' and 'feigned' material is, on the one hand, brushed aside by a Bunyan confident in the capacity of figurative words to 'Make truth to spangle, and its rayes to shine.' On the other, however, Bunyan is also aware, as his comments on the 'Carper' imply, that darkness is something which lies not simply in words alone but in readers themselves. In urging the reader in the verse Conclusion to 'Put by the Curtains, look within my Vail' and 'Turn up my Metaphors', Bunyan is not simply emphasising a way of reading his allegorical text but, more importantly, is encouraging a re-consideration by the reader of his or her own faith. In order to 'not fail' to see the substance of his text, Bunyan is indeed impelling the reader to turn-up (to convert) not the text's words alone in any merely intellectual sense but his or her 
own life in terms of faith. As such, the metaphor of the veil itself, here, does not allude merely to dark similitudes but, significantly and specifically, to St. Paul's words on Law and grace. 39

Bunyan's point in the Apology and the Conclusion, therefore, is that any overturning of metaphors demands an overturning in oneself first, an issue which has been central to Christian interpretive practice since Paul. Indeed, Gerald L. Bruns makes note of ClassicalChristian defences of dark words in exactly these terms: 'Philo's word for "figurative",' Bruns writes,

derives from the Greek trepein, "to turn," which means not transformation (turning one thing into another) but conversion (turning something around): when confronted with a dark saying, you can make it plain by turning it toward you, because the light it sheds is on its nether side, shining away from you. Frequently, however, what requires turning is not the saying but the one who fails to understand it. If a saying shines its light away from you, you are not standing where you should be; you need to alter your place or condition in order to situate yourself in the light of what is said.

This idea, Bruns informs us, goes back 'at least to Plato's allegory of the cave' and explains why Augustine's Confessions concludes 'with two books of commentary on Genesis.'40 Bunyan, then, is clearly in a long line of those defending dark words in the ClassicalChristian hermeneutic tradition in which faith is accompanied by a growth in spiritual interpretive understanding. Indeed, Grace Abounding delineates just such a process of placing oneself in the light of faith, albeit through a long and arduous struggle. In the Apology of The Pilgrim's Progress, then, Bunyan is similarly urging not merely an engagement in the 'scrutiny of the verbal medium', as Quilligan suggests, but an exhortation to test one's faith - to 'let Truth be free/To make her Salleys upon thee'. His advice to the carper, and any other objector, is thus to look first to the book of his own life before lodging

\footnotetext{
${ }^{39}$ See II Cor. 3. 12-18 in which Christ is depicted removing the veil of the old Covenant of the Law. Bunyan refers to this specifically in his depiction of the pilgrims' experience of Beulah in which the 'Instrument' of grace allows them (as allegory and Scriptural similitude does Bunyan and the reader) to see the glory of the Celestial City - that is, to see that which cannot be seen otherwise (Bunyan, The Pilgrim's Progress, p. 156). See also Valentine Cunningham's incisive comments on Bunyan's veil image in, 'Glossing and Glozing: Bunyan and Allegory', in Conventicle and Parnassus, pp. 217-240 (pp. 223-224).

40 Gerald L. Bruns, 'Midrash and Allegory: The Beginnings of Scriptural Interpretation', in The Literary Guide to the Bible, ed. by Robert Alter and Frank Kermode (London: Collins, 1987; repr. 1988), pp. 625-646 (p. 638). See also, Lynn M. Poland, 'Augustine, Allegory, and Conversion', Journal of Literature and Theology, 2 (1988), 37-48.
} 
any complaint against the method of The Pilgrim's Progress, 'And find There darker lines, then in my Book/He findeth any.'

For Bunyan, as Grace Abounding shows, a typological and figurative understanding of Scripture is a form of conversion in itself - of turning the dark night of the ignorant soul into bright daylight. As he writes in Solomon's Temple Spiritualized (1688), a tract dedicated to the process of reading Scripture grace-fully, Bunyan views figurative interpretation as a method of converting the 'dead' ordinances of 'the old [Judaic] church', so that 'when compared to the gospel' they 'may minister light to us.' This is a time-honoured tradition according to Bunyan who notes that 'the New Testament ministers, as the apostles, made use of Old Testament language, and ceremonial institutions, as to their signification, to help the faith of the godly in their preaching of the gospel of Christ.' That figures have a restorative and enlightening function for Bunyan there can be no doubt, therefore: 'we may, yea, we ought to search out the spiritual meaning of them', he writes, 'because they serve to confirm and illustrate matters to our understandings.' Here, as in the Apology, Bunyan asserts the efficacy of metaphor and figure in terms of Scriptural and Christian hermeneutic example. Moreover, the use of figure being importantly grounded in Christian Scriptural tradition, here, Bunyan warns against any invention in such matters: 'I give no encouragement to any now, he writes, 'to fetch out of their own fancies figures or similitudes to worship God by.' As with false idols, God will punish, Bunyan asserts, those who 'would add to these [ordained 'types, shadows, and figures'] inventions of their own.'41

Yet the imaginary carper's objections in the Apology of The Pilgrim's Progress are not based upon a notion of inappropriate invention, even in Bunyan's feigned words. Rather, this objector questions Bunyan's methodology in terms of its efficacy for conveying 'Truth', the greatest issue being that Bunyan's style has a great potential to beguile and mislead the reader through its use of dark, mysterious, and figurative words. As a consequence, we may indeed wonder at Bunyan's complicated defence of metaphor and allegory as special forms of language in the Apology if only because elsewhere he so vigorously attacks the notion of presenting his doctrine in anything but the plainest and most accessible of styles. In the

\footnotetext{
41 John Bunyan, Solomon's Temple Spiritualized (1688), in The Works of John Bunyan, ed. by Offor, III, 462-
} 464. 
'Epistle to Four Sorts of Readers' of The Holy City (1665), for instance, Bunyan clearly admonishes the 'language of the learned', stating that:

words easy to be understood do often hit the mark, when high and learned ones do only pierce the air. He also that speaks to the weakest, may make the learned understand him; when he that striveth to be high, is not only for the most part understood but of a sort, but also many times is neither understood by them nor by himself. 42

In the Apology, however, Bunyan actually sides with those writers 'as high as Trees' whose 'Dialogue-wise' style is to be admired and not slighted (that is, as long as 'Truth' is not abused in the process or 'cursed be they'). For Bunyan, this is not a stylistic turnabout, though, for here speaking in metaphors, he argues, simply is the plainest way of revealing 'Truth'. But even with this argument put forth by Bunyan, the objector still voices significant concerns about Bunyan's representational methodology nevertheless, plain or otherwise. Most importantly, for instance, the imaginary carper accuses Bunyan of using a style that damages the reader in no uncertain terms: metaphors drown 'the weak' and 'make us blind', he states. Not surprisingly, the main body of Bunyan's following defence of metaphor offers a rigorous refutation of such claims and for a reason beyond the formal surface of his lexical preferences. Indeed, any objection to Bunyan's metaphorical method is not simply a comment on style but is necessarily a protestation against how he expresses his faith as a whole. Consequently, any disapproval of Bunyan's use of similitude in The Pilgrim's Progress is so significant because it threatens Bunyan's text with a force more powerful than just a criticism of words alone: in discrediting Bunyan's use of metaphor, the very discourse of Bunyan's theology, the 'Truth' inherent within it, and Bunyan's ontological poetics all come under attack simultaneously.

With this point in mind, Bunyan's defence of metaphor in the Apology is so important because it is obviously rooted in the late seventeenth-century debate between Nonconformists and their numerous enemies over a 'plain style'. As Roger Pooley and Neil Keeble have pointed out, however, there is nothing plain about this issue whatsoever, the whole debate about what is plain and not in the late seventeenth century depending, as with one's understanding of dark similitudes, upon where one is standing. As such, there is a

\footnotetext{
42 John Bunyan, The Holy City (1665), in The Miscellaneous Works of John Bunyan III, ed. by J. Sears McGee
} (Oxford: Clarendon Press, 1987), p. 71. 
certain amount of circularity and confusion involved in this matter. As Pooley points out, the terms of the argument over plain style 'between Puritans and Laudians in the 1630s (plainness versus ostentation) are almost exactly reversed in the 1660 s and 1670s, when it is the new Anglicans who emphasise plainness against what they see as Puritan or Nonconformist excess.' But if by plain style we understand 'an attempt to cut down on the penumbra of associations around words for clarity's sake', then, as Pooley and Keeble both point out, either party in the dialogue could legitimately claim true plainness: 'It would [...] be entirely possible to assemble extracts', Keeble notes, 'to prove that nonconformist writing was plain, or, equally, that it was not.' 43

It is not important, therefore, to defend Bunyan's 'plainness' in itself but rather to understand the implications of his own defence in terms of the general debate over style. In fact, conformists and Nonconformists, Keeble suggests, 'were not actually arguing about style at all, or rather, were arguing about it only as a consequence of a deeper disagreement.' One aspect of this disagreement can be viewed broadly as political, Roger Pooley clearly seeing important polemical implications in any defence or attack on style during the Restoration. 'The hegemony of the plain style,' Pooley writes, 'has its roots in theological, political and philosophical developments after 1660', and he sees definite party-line divisions evident in one's mode of expression at this time. At the heart of such matters, however, lies the issue of metaphor. In determining 'whether plain style does imply a sort of party loyalty', it is necessary 'to consider the crucial role of metaphor in the changes in the standard of plainness in scientific, religious and political discourse.' Indeed, in 'religious language metaphor becomes a battleground for a new set of doctrinal issues. The political overtones are complex, but they centre around the conflict of authority and liberty.' 44

The centrality of metaphors and similitudes in Bunyan's theological stance as a whole marks him out, therefore, as Nonconformist in both religious and, necessarily, political terms

\footnotetext{
43 Roger Pooley, 'Language and Loyalty: Plain Style at the Restoration', Literature and History, 6 (1980), 2-18 (pp. 4, 13) and N. H. Keeble, The Literary Culture of Nonconformity in Later Seventeenth-Century England (Leicester: Leicester University Press, 1987), pp. 240-262 (p. 246). See also Roger Pooley, 'Plain and Simple: Bunyan and Style', in Conventicle and Parnassus, pp. 91-110; Harold Fisch, 'The Puritans and the Reform of Prose Style', ELH, 19 (1952), 229-248; Gordon Wakefield, John Bunyan: The Christian (London: HarperCollins, 1992; repr. 1994), pp. 74-75.

44 Keeble, Literary Culture of Nonconformity, p. 246; Pooley, 'Language and Loyalty', pp. 3-4.
} 
as well, implying a rejection not only of the prevailing religion of civility, morality, and latitude but, potentially, of the social and political structures and precepts that endorse such a religion: 'The language of nonconformity could not conform to a model which expressed values from which it dissented.' 45 As such, the use of metaphors and similitudes was seen, by conformists, not only to be anachronistic but uncivil, barbarous, and seditious: the Nonconformist 'shifting of Phrases, and hiding [...] in a maze of words' could be seen as reflecting the 'Fanatique Tempers and Principles' of 'the rudest and most barbarous people in the world' who threaten to 'blow up the very Foundations of Government' ${ }^{46}$ For this reason, metaphor also comes to be seen, as Hill suggests, as 'a way of circumventing the censor, of speaking to an audience fit though few' in a time of persecution. ${ }^{47}$ The Royalist censor Sir Roger L'Estrange certainly viewed Nonconformist use of allegory and metaphor as antisocial, anti-patriotic and dangerously subversive: Nonconformist style, he writes, 'is not to be taken now, as the Language Currant of the Nation, but only as a Privy Cypher of Intelligence betwixt Themselves, and the Cant, or Jargon of the Party. Nay, they fly from us in their Speech, their Manners, their Meaning, as well as in their Profession. [...A]nd they make it a point of Honour to maintain the Freedome of their Own Tongue, in token, that they are not as yet a Conquer'd Nation.' 48

L'Estrange is contemptuous of the claim to political liberty Nonconformist 'cant' represents but is also clearly disturbed by its exclusive sectarianism: his scornful words betray a military fear of ciphers and intelligence. In this sense, Bunyan's defence of metaphorical discourse has a strong polemical bias and is, consequently, as much a part of a political controversy as a stylistic one. ${ }^{49}$ Equally, however, the disagreement manifesting itself in the form of a debate over style has deeper implications for one such as Bunyan: 'contesting arguments' over plain style 'are usually indices of something more - in this case,

\footnotetext{
45 Keeble, Literary Culture of Nonconformity, p. 246.

46 Samuel Parker, A Discourse of Ecclesiastical Politie (London: 1670), from 'The Preface to the Reader', pp. pp. xii-xiii, xxii.

${ }^{47}$ Christopher Hill, A Turbulent, Seditious, and Factious People, p. 201.

48 Sir Roger L'Estrange, The Casuist Uncas'd, 2nd edn (1680), A2`-A3, cited in Keeble, Literary Culture of Nonconformity, pp. 245-246.

${ }^{49}$ For a useful investigation into The Pilgrim's Progress in the context of conscience and toleration in the late 1660s, see Richard L. Greaves, ' "Let Truth be Free”: John Bunyan and the Restoration Crisis of 1667-73', Albion 28 (1996), 587-605.
} 
class, doctrine, politics, and spirituality', and it is over issues of doctrine and spirituality ('Truth') especially (rather than overt political liberty) that Bunyan's Apology presents itself. $^{50}$ In terms of doctrine, the new moralism of the Anglicans leads to an attack on metaphor as the mode of expressing a Calvinist theology of grace which comes to be derided, not being based upon visible works, as merely fantastical. As Pooley notes, 'the crucial Reformation doctrine of justification by faith [...] needs an analogical imagination to grasp it.' To apprehend things unseen, figure, similitude, and metaphor are vital. Thus, the plain style debate is "not simply a question of the "primitive ferocity" of Calvinism being tamed; it is a new round in the constantly recurring Christian debate between the supporters of Augustine and Pelagius - faith versus works. The language of faith has to be metaphorical; the language of works need not be. 51

Bunyan's Apology is, then, a part of the dialogue over changing religious attitudes in the Restoration at the heart of which lies an increasingly hostile denunciation of his theology of grace and its mode of discourse. The Latitudinarian Bishop Samuel Parker, in his Discourse of Ecclesiastical Politie (1670) makes such an attack explicit. In assailing Nonconformist style, and the use of metaphor and allegory in particular, Parker (like Bunyan's imaginary objector) simultaneously denounces the very theology of grace Bunyan's style embraces. At the heart of Parker's discourse, therefore, lies an assault upon 'the Puritan distinction of faith and works' in which metaphor 'as the basis for the distortion of true religion, is the main target.' 'The villainy of those Men's religion, that are wont to distinguish between Grace and Vertue', Parker writes, lies in the fact that they 'exchange the substance of true Goodness for meer Metaphors and Allegories. ${ }^{52}$ We can see parallels already between Parker's comments and those of Bunyan's objector who similarly rails against lack of 'substance' in allegory. The similarities are even more significant when Parker's remonstrance becomes theologically specific:

And what is it than Men set up against Morality, but a few figurative Expressions of it self, that without it are utterly insignificant? 'Tis not enough (say they) to be completely Vertuous, unless we have Grace too: But when we

50 Pooley, 'Plain and Simple', p. 97.

51 Pooley, 'Language and Loyalty', pp. 5, 16.

52 Parker, A Discourse of Ecclesiastical Politie, pp. 65-66, and cited in Pooley, 'Language and Loyalty', pp. 6-

7. 
have set aside all manner of Vertue, let them tell me what remains to be call'd Grace, and give me any Notion of it distinct from all Morality, that consists in the right order and government of our Actions in all our Relations, and so comprehends all our Duty: and therefore if Grace be not included in it, 'tis but a Phantasm, and an Imaginary thing. So that if we strip those Definitions that some Men of late have bestowed upon it, of Metaphors and Allegories, it will plainly signifie nothing but a vertuous temper of mind.

Parker's discourse certainly is an index of the prevailing religious and political culture of late seventeenth-century England. His concerns here are for order, morality, and 'Vertue', implying that if only 'figurative Expressions' are dispensed with what lies beneath a theology of grace is, indeed, an intrinsically reasonable morality.

But Parker does not stop here. For him, 'Moral Vertue' must prevail as 'a more spiritual and intimate way of Communion with God' over 'a Spiritual Divinity' which 'in truth consists in little else but meeting together in private to prate Phrases, make Faces, and rail at Carnal Reason':

whereby they have effectually turn'd all Religion into unaccountable Fansies and Enthusiasms, drest it up with pompous and empty Schemes of Speech, and so embrace a few gaudy Metaphors and Allegories, instead of the substance of true and real Righteousness. And herein lies the most material difference between the sober Christians of the Church of England, and our modern Sectaries, That we express the Precepts and Duties of the Gospel in plain and intelligible Terms, whilst they trifle them away by childish Metaphors and Allegories, and will not talk of Religions but in barbarous and uncouth Similitudes. ${ }^{53}$

It is worth quoting Parker at length not only to see a precursor, in some ways, to Swiftian satire on enthusiasm but to note the range of his polemic: Parker accuses those like Bunyan of lacking true righteousness, of being childish and irrational, and, like L'Estrange, of being remiss (if not treasonous) in one's lack of duty to Church and nation (hence the profound distrust of those meeting in private). Indeed, Parker's most outrageous suggestion is that there should be 'an Act of Parliament to abridge Preachers the use of fulsom and lushious Metaphors' as 'an effectual Cure of all our present Distempers': 'For were the Men obliged to speak Sense as well as Truth', Parker asserts, 'all the swelling Mysteries of Fanaticism would immediately sink into flat and empty Nonsense'.54 Parker's railing against

53 Parker, A Discourse of Ecclesiastical Politie, pp. 71-2, 74-5, and cited in Keeble, Literary Culture of Nonconformity, pp. 247-248.

54 Parker, A Discourse of Ecclesiastical Politie, p. 76. Parker's rhetorical positioning is, of course, quite ingenious in $A$ Discourse, as is shown in the way he differentiates his own extravagantly vehement and bitterly hateful style of writing from the 'mere Imposture' of an enthusiastic, 'Varnish of fine Metaphors and Glittering Allusions', with its 'clownish and slovenly Similitudes', and its 'wanton and lascivious Allegories' (pp. 75-77). 
Nonconformist faith and expression is particularly relevant to Bunyan, moreover, as it was to be answered by Bunyan's Nonconformist friend and colleague John Owen in the latter's Truth and Innocence Vindicated (1671). For this reason alone, Bunyan could not have been ignorant of Parker's Discourse. Given the emphasis on the importance of grace over works throughout The Pilgrim's Progress, from Christian's encounter with Mr. Worldly-Wiseman to his dialogue with that most reasonable lad Mr. Ignorance, it would seem that the text as a whole is steeped in the polemics of Nonconformist debate: Bunyan is answering a very specific type of objector in his Apology and one who is far from being in any sense 'imaginary'.55

It is clear that Parker's aggressive denunciation of the language of grace is hardly based on aesthetic principles, then. Rather, what is involved here is an attempt to eradicate the very theology of grace Bunyan's whole faith is founded upon, Parker's attack, along with those of other conformists, being an attempt to re-order religious perceptions of faith away from what is, potentially at least, radically and politically unstable. Such irritation with Nonconformity is indeed 'a reproof of its way of thinking, a way of thinking which to conformists seems not to deserve the name of "thought" at all. The style of nonconformists is berated as a glaring example of the culpable consequences of erroneous conceptions.' For Keeble, the debate over plain style 'resolves itself into a debate over what constituted "sense", what “senselessness"; what was affected, what genuine.' Equally, though, Keeble recognises that the stakes in this debate, as Bunyan's Apology illustrates, are far higher than simply what makes sense or not: 'It was, in fact, a debate', he states, 'about the nature of truth.' While Parker 'is unable to accept truth except as "sense", the terms of the new empiricism', for

\footnotetext{
Parker justifies using such 'Vehemence and Severity' in his choice of address not only by stating that Nonconformists do not deserve to be treated 'with gentle and civil Language' but in order to demonstrate just how much rational and moral control Parker himself, unlike his seditious and uncouth Dissenter, has over language: 'if there be any Tart and Upbraiding Expressions', Parker writes of his tract, they are 'not the Dictates of Anger or Passion, but of the Just and Pious Resentments' of his Latitudinarian 'Mind' ('Preface', pp. iii, xii).

55 Keeble even goes as far to say that 'Parker, in fact, is Bunyan's Ignorance' (Literary Culture of Nonconformity, p. 249). For another discussion of this debate over style, see also Paul J. Korshin, Typologies in England, 1650-1820 (Princeton: Princeton University Press, 1982), pp. 44-49.
} 
Bunyan 'Truth' means the reality of things unseen, of things beyond sense, and which can be expressed only through figures and similitudes. 56

What really lies at the heart of Parker's attack upon and Bunyan's defence of metaphorical style, then, is a wrangle over how reality - 'Truth' - is perceived, it being through metaphor that Bunyan can 'Seek the advance of Truth', a 'Truth' privileged in the Apology of The Pilgrims' Progress as synonymous with the new life of conversion and which, subsequently, is figured forth in the similitude of the new born saviour himself: 'although in Swaddling-clouts', this 'Truth' Bunyan tells us, 'Informs the Judgement, rectifies the Mind,/Pleases the Understanding, makes the Will Submit', while serving to fill the memory, 'please' the 'Imagination', and 'appease' troubles. Clearly, Bunyan has important positive and restorative functions in mind for the truths communicated through his use of similitude, metaphor thus bearing a purpose very much divorced from Parker's socially and radically dysfunctional vision of Nonconformist life and language. What is at stake for Bunyan, in fact, is not simply doctrinal but metaphysical, his whole concept of conversion being one in which faith, 'not only realizes the invisible but metamorphoses the visible', altering 'the perception, both of the self and the world the self inhabits'. Such a transformation can only be conveyed by similitude because, for one such as Bunyan, conversion 'brings metaphor inevitably after it.' Nonconformist style, be it Bunyan's or Quaker, thus 'deals in ultimate realities', in a 'determination to render what was seen in terms of the unseen, the only true reality' and, as such, biblically figurative precedents are intrinsic to it. ${ }^{57}$ Because any attempt to discredit Bunyan's expression evidently represents a scrutinising of his theology of grace as a whole, Bunyan's Apology becomes not simply a defence of metaphor, allegory, and style but an apology in terms of how we understand Christian apologetics in general: it is, more than anything, a defence not of words but of faith.

What Bunyan's Apology evinces, then, is what Maureen Quilligan refers to as a 'crisis for the English language' which, occurring towards the end of the seventeenth century, 'radically affected our culture's attitude toward the relationship between language and

56 Keeble, Literary Culture of Nonconformity, p. 247. Pooley, 'Language and Loyalty', p. 8.

57 Keeble, Literary Culture of Nonconformity, pp. 250-1, 253, 255. 
truth.' 58 Opposed to Bunyan's proposition of the spiritual truth of things unseen came the 'scientific conviction that truth is objective, a fact independent of the individual who observes it and incomprehensible only in so far as it has not yet yielded to rational investigation'. In contrast, Nonconformists like Bunyan 'inhabited a universe neither mechanistic nor self-containedly comprehensible, but vital, animistic and significant, a revelation of its divine creator and providential sustainer.' Accordingly, Bunyan 'is habituated to treating the visible as an allegory of the invisible, to discerning in the sublunary translunary truths', whereas '[t]he conformist and scientific plain style could not answer to a world so vibrantly significant and instinct with the divine.'59 Moreover, understanding this disparity over 'shifting cultural attitudes' to language and truth becomes 'a necessary part of the description of the genre' of allegory as whole which 'always presupposes at least a potential sacrilizing power in language', it being 'possible to write and read allegory intelligently only in those cultural contexts which grant to language a significance beyond that belonging to a merely abstract system of signs. Allegory will not exist as a viable genre', Quilligan insists, 'without this “suprarealist” attitude toward words.' Viewing allegory as a genre collapsing in the wake of the 'vast epistemological shift' of the Enlightenment, Quilligan notes that towards the end of the seventeenth century 'words lost the battle to "things" and language disappeared as a potent force for shaping man's sense of his cosmos.' 60 For the allegorist, and for Bunyan in particular, therefore, metaphorical language has an obviously privileged place in communicating 'Truth'.

But Bunyan's defence of similitude, aside from participating in an important cultural debate over doctrine and truth in the Restoration, also proposes an attitude toward the figurative that

\footnotetext{
58 Quilligan, The Language of Allegory, p. 154. See also Stanley E. Fish's, 'Epilogue: The Plain Style Question', in Self- Consuming Artifacts, pp. 374-382.

59 Keeble, Literary Culture of Nonconformity, pp. 249, 257, 260.

60 Quilligan, The Language of Allegory, pp. 154-157. Unfortunately, though, while Quilligan's observations on shifting cultural assumptions about language are significant, she seems confused when it comes to Bunyan. Indeed, she regards the production of allegory in the Restoration as anomalous within the prevailing cultural shift 'away from assumptions inherent in the suprarealist attitude toward language', viewing the use of allegory and metaphor by Puritans as paradoxical in view of the Puritan 'condemnation of rhetorical embellishment and its rigorous demands for a neutral plain style.' Indeed, Bunyan's allegory is possible only, she mistakenly suggests, because Bunyan ignores 'Puritan restraints on style'. Such a viewpoint reveals Quilligan's evident confusion over the terms of Puritan plainness and should take Roger Pooley's account of style in the Restoration into consideration (The Language of Allegory, pp. 176-187).
} 
still provides contention among contemporary theorists of language in the post-structuralist twentieth century - that metaphor has a cognitive function: it communicates meaning. Bunyan's defence is indeed vigorous, advancing his method in the name of 'Truth' so strongly, as he holds what Janet Martin Soskice refers to as an 'incremental' approach to metaphor through which metaphor (and figurative language as a whole) is seen 'as a unique cognitive vehicle enabling one to say things that can be said in no other way', providing 'an increment to understanding.' Importantly, such an approach directly confronts what can be identified as substitution and emotive theories of metaphor. The substitution theory is held by those who 'see metaphor as a decorative way of saying what could be said literally' and by whom metaphor (as a form of 'deviant word meaning') 'is regarded as an improper word which substitutes for the proper one but which is, presumably, replaceable by it any time'. In the substitutive sense, metaphor simply does not possess ' a cognitive content not provided equally by the literal term for which the metaphor is the figurative replacement.' In a similar way, the emotive theory, regarding metaphor 'as original not in what it says but in the affective impact it has', takes it as providing merely dramatic effect with no cognitive content at all. Both theories offer a view of metaphor as 'a consequence of deviancy in word usage' which 'could be suppressed with no detriment to the cognitive content of the text in which it was found. Indeed its suppression might clarify the meaning of the text.' In contrast, an incremental theorist would argue 'that what is said by the metaphor can be expressed adequately in no other way' and that 'the particularity of a metaphorical description is not that it translates literal thought, but that the very thinking is undertaken in terms of the metaphor.' In this way, metaphor is a source of 'new and unique agents of meaning': in Bunyan's terms, it communicates and advances 'Truth' ${ }^{61}$

61 Janet Martin Soskice, Metaphor and Religious Language (Oxford: Clarendon Press, 1985; repr. 1987), pp. 24-31. Again, like Quilligan and Keeble, what Soskice reinforces is the importance of metaphor in terms of shifts in cultural assumptions. Soskice purports that it is a fallacy to consider ornamentalist attitudes to metaphor as originating from classical precedents in the writings of Aristotle and Quintilian. What these classical theorists suggest is, rather unhelpfully, that metaphor (as the term's etymology denotes) involves transference, but of what and to what (or how it functions) is not always clear. More important to note is that 'Aristotle by no means considered metaphor as simply a substituted name. A metaphor may name that which has no name.' That is, metaphor has a cognitive and catachretal role. In contrast, Soskice suggests that '[p]erhaps the real source of the idea that ornament and style [exemplified by metaphor] have no place in pure argument is to be found in those philosophers of the seventeenth century who chose as their model the arguments of mathematics and the new sciences.' Locke's chapters on, 'Of the Abuse of Words', in his Essay Concerming Human Understanding thus act as the most influential and eloquent statement of 'the rationalist and 
Samuel Parker's assault on Nonconformist use of metaphor and allegory clearly reveals prevailing substitutive and an emotive attitudes to figurative language in which metaphor is seen as superfluous and reducible hyperbole, on the one hand, and a verbal counterpart to affective face-pulling on the other. Recognising Bunyan's attitude to metaphor as essentially incremental, in which metaphor possesses a communicative and cognitive function, is thus important: for a Nonconformist, metaphors do possess a distinct 'substance'. But Bunyan's defence of metaphor in the Apology of The Pilgrim's Progress also raises the question of cultural attitudes to figurative language in general. From the seventeenth century onwards, for instance, the terms 'literal' and 'metaphorical' come to imply 'a distinction between kinds of significance or kinds of truth', the literalism of 'words proper' taking a cultural prominence in terms of expressing a 'truth' over and above anything merely metaphorical. In this way, the terms themselves become synonymously entangled in value-judgements and, consequently, it is important for us to recognise that '[a] given truth may be expressed by a metaphor, but this is not to say that it exemplifies a sort of "metaphorical truth" distinguishable from and inferior to "literal truth".' Indeed, 'to say that a statement is metaphorical is a comment on its manner of expression and not necessarily on the truth of that which is expressed.' In this way, Soskice writes '[i]t is important to see [...] that it is particular usages that are literal or metaphorical, and not particular facts', and that 'the history of consciousness is bound up with metaphor', it being not mere embellishment on literal description but 'a wholly different way of seeing the world.'62

In any debate over style and metaphor, then, '[t]he point at issue is not really whether we have metaphor here, but what the metaphor is doing: is it simply an ornamental redescription or is the metaphor [...] disclosing for the first time?' In posing this question, Soskice asserts, it is 'one's metaphysics, not metaphor, which is at issue': 'the question is not simply whether we have a metaphor here or not, but what, if anything, the metaphor refers to or signifies.' For Bunyan, metaphor is to be championed against Hobbes's 'words proper'

empiricist critique of rhetoric and figurative speech', and it is here that 'we find the ancestor of the commonplace that metaphor is a decorative but strictly expendable substitute for what can [...] be stated plainly' (Soskice, Metaphor and Religious Language, pp. 3-13).

62 Soskice, Metaphor and Religious Language, pp. 67-75. 
because 'words proper' do not, indeed cannot, communicate what Bunyan has to say. ${ }^{63}$ In matters of faith and grace, as with other 'abstract states of affairs, entities, and relations', 'if we do not speak figuratively, we can say very little.' 64 For this reason, Bunyan's attitude to metaphor in his particular religious discourse presents not only a defence of 'Truth' and a way of viewing the world but ultimately a source of anxiety for an empiricist culture generally. Bunyan maintains a view of metaphor as cognitive and communicative in terms of faith, as able to refer without 'proof', and that such metaphor can still be 'reality depicting' without involving any positivist notions of presenting an 'unreviseable description' of that to which the metaphor refers. As such, 'it is not surprising that Locke [among others] is so vehement in his condemnation of the "figurative application of words" when discussing "things as they are",' because he must recognise 'the damage these same figures could do to more general theories of naming and reference'. Indeed, 'it must be pointed out', Soskice asserts, 'that to allow inexact figures lacking fully specifiable referents into descriptions of "things as they are" is to threaten the nominalist base of empiricist accounts of meaning and reference' as a whole.65 Bunyan's approach to metaphor clearly marks him once more, therefore, as contra-current in terms of shifting cultural attitudes to language and theological reality in the seventeenth century, Soskice highlighting how the 'traditional empiricist criticisms of "non-literal" speech' by the likes of Hobbes, Parker, and Locke are 'in the end, attacks on the possibility of any metaphysics' .66

What is perhaps more important in relation to Bunyan's Apology, though, is the way in which Bunyan illustrates how metaphors do both refer to and disclose things unseen. Indeed, to appreciate Bunyan's defence of metaphor more fully we must revise our understanding of metaphor as a whole not only in terms of cognitive value but in terms of its place in the social context of shared assumptions. It is important to note, for instance, 'that it is not strictly words which refer but speakers using words' in 'contexts of use', and 'not

\footnotetext{
63 For Hobbes on 'the use of Metaphors, Tropes, and other Rhetoricall figures, in stead of words proper', see Thomas Hobbes, Leviathan, ed. by Richard Tuck (Cambridge: Cambridge University Press, 1991; repr. 1994), chapter 5, 'Of Reason and Science', pp. 34-35. Of related interest, see also chapter 4, 'Of Speech' (pp. 23-31). 64 Soskice, Metaphor and Religious Language, pp. 90, 96.

65 Soskice, Metaphor and Religious Language, pp. 124-125. For Locke's attitude towards language, see Book III of An Essay Concerning Human Understanding, ed. with a foreword by Peter H. Nidditch (Oxford: Clarendon Press, 1975; repr. 1979), pp. $402-524$ (esp. Chapters X-XI, 'Of the Abuse of Words', pp. 490-524).

66 Soskice, Metaphor and Religious Language, p. 145.
} 
simply by individual speakers but by communities of speakers whose language provides access' to a shared reality. Consequently, what determines reference and meaning does not depend on unreviseable or definitive description, or even on a speaker being correct in his referencing, but rather on the fact that the speaker is a member of a linguistic community which shares his world view. What is important to maintain, particularly in terms of religious language and metaphor, is a 'separation of referring and defining' which lies 'at the very heart of metaphorical speaking and is what makes it not only possible but necessary that in our stammering after a transcendent God we must speak, for the most part, metaphorically or not at all.'67 While the theist can rely on metaphor to be 'reality depicting without pretending to be directly descriptive' (something Parker and Locke either cannot understand or refuse to acknowledge), the implications of this approach hold a deeper resonance for Bunyan. This 'realism', Soskice argues, 'has even more to commend itself to the Christian [...] for it emphasises, in a way that neither an empiricist nor an idealist position does, the importance in Christian belief of experience, community, and an interpretive tradition': ' $[e] x p e r i e n c e$ is essential, for ultimately it is in experience that reference is grounded - thus, without being empiricist, this realism is an empirical theory. Community is essential because each speaker is a member a particular community of interest, which provides the context for referential claims.' Bunyan's defence of metaphor must be seen, therefore, as a defence of the language of his community in terms both of the Bedford church and Nonconformist culture generally, as well as of the spiritual uniformity of shared hermeneutic traditions (and of similitude particularly), from the Gospels to St. Paul through Reformation theologians to Bunyan himself. 68

It is in terms of metaphor's relation to these traditions that Bunyan's defence of his method according to the precedent of 'holy Writ' becomes most interesting. Bunyan's Apology clearly bears witness, for instance, to the way in which, over time,

there comes into being a rich assortment of models whose sources may be unknown but which have been gradually selected out by the faithful as being especially adequate to their experience. This accumulation of favoured models, embellished by the glosses of generations, gives the context for Christian reflection and provides the matrix for the descriptive vocabulary

67 Soskice, Metaphor and Religious Language, pp. 127-140

68 Soskice, Metaphor and Religious Language, pp. 148-149 
which Christians continue to employ in attempts to describe their experience. This accretion of images, all of them hesitant and approximating, yet confirmed by generations of belief, constitutes much of what Christians call revelation. 69

Thus, terms such as 'spirit' are used by one such as Bunyan not through 'rigid definition' but "by considering the way in which the term is variously used in the community and tradition, and importantly, the way it is used in Christianity's sacred texts.' 70 This approach to metaphor naturally places great emphasis on the allusive techniques adopted by religious communities to communicate spiritual truths.

Like Bunyan's Apology, therefore, Soskice identifies typology as the most prominent source of metaphor in the language of religious traditions: 'to explain what it means to Christians', Soskice observes, 'to say that God is a fountain of living water, or a vine-keeper, or a rock, a fortress, or king requires an account not merely of fountains, rocks, vines, and kings but of a whole tradition of experiences and of the literary tradition which records and interprets them.' As such, the importance of Old Testament imagery is, as Bunyan similarly notes in Solomon's Temple Spiritualized, 'not principally as a set of propositions but as the milieu from which Christian belief arose and still arises'. In the books of the Old Testament lies the source of 'Christian descriptive language and particularly of metaphors which have embodied a people's understanding of God.' As is revealed in Christian's instruction in the armoury of the House Beautiful, Bunyan's Apology champions the sacred texts of Christianity precisely because they are "chronicles of experience, armouries of metaphor, and purveyors of an interpretive tradition. The sacred literature', Soskice concludes, 'thus both records the experiences of the past and provides the descriptive language by which any new experience may be interpreted.'71

Bunyan's Apology is, then, not merely a methodological or artistic defence of metaphor. Rather, it is an assertion of the traditions of spiritual experience and the language through which such experience can be communicated. Unlike Parker, for whom such allegories and metaphors signify nothing but airy phantasm, Bunyan views any discrediting of Biblical metaphor and typological interpretation as an 'assault' on 'The highest Wisdom'.

\footnotetext{
69 Soskice, Metaphor and Religious Language, p. 153.

70 Soskice, Metaphor and Religious Language, pp. 153-154.

71 Soskice, Metaphor and Religious Language, pp. 158-160.
} 
According to Bunyan, the believer who can read the book of Scripture typologically is, no less, spoken to by God: for that reader, Bunyan asserts, comes happiness, light, and grace. ${ }^{72}$ In this respect, metaphor is so important in terms of Bunyan's 'Truth' precisely because it has a cognitive and communicative role in a community which has not yet abandoned its theology of grace for one of moralism. The Apology thus testifies, in a way that would perhaps enrage Samuel Parker, not only to an abstract linguistic phenomenon but to a community of speakers for whom such language communicates central truths about a Nonconformist faith. Bunyan's Apology is not merely an aesthetic document, therefore, but the printed confirmation of a dissenting counter-culture with very specific roles for metaphor within a very particular framework of Puritan interpretive traditions.

Such an understanding of Bunyan's defence of metaphor and 'Truth' necessarily leads us to revise some of the traditional readings of the Apology. For example, Bunyan's defence of metaphor, now understood in terms of its cultural and spiritual implications, goes some way in undermining the notion that the Apology sanctions a use of the imagination generally alien to Puritanism and Puritan writings. Kaufmann's renowned analysis of The Pilgrim's Progress, which is centred upon this premise, suggests that at the heart of Bunyan's allegory and its Apology lies a tension between imaginative form (mythos or event) and a literal understanding of the Word (logos or doctrine). In order to explain the imaginative or fabulist content of a work so deeply immersed in a Puritan hermeneutics that usually ruled out mythos (which naturally appeals to the imagination), Kaufmann subsequently views The Pilgrim's Progress as embracing a tradition not only of logos or doctrine-oriented practices of devotion and meditation but of the more imaginatory heavenly meditations as encouraged by the Puritan Richard Sibbes and Bunyan's contemporary Nonconformist, Richard Baxter. For Kaufmann, Bunyan's use of allegory (with its apparent defence of specifically imaginative procedures) is thus justified as it 'appeared at a moment when the Puritan mind was opening to the imaginative apprehension of scriptural truth. 73

\footnotetext{
72 Bunyan, The Pilgrim's Progress, pp. 6-7.

73 Kaufmann, The Pilgrim's Progress and Traditions in Puritan Meditation, pp. 5, 24. For a supporting view of Kaufmann, especially in relation to Luther's influence on Bunyan's use of metaphor, see Vera Camden, "Most
} 
But as we have seen, in the Apology Bunyan is not sanctioning the freedom of the imagination per se nor the use of metaphor as a legitimation of it. Kaufmann, it seems, mistakenly posits in imagination the communicative value that Soskice posits in metaphor, suggesting that ' $[\mathrm{t}] \mathrm{o}$ call up past experience in the fullness of feeling which could effectively forecast heavenly experience plainly required exercise of the imagination', through which 'the conception of Scripture as logos is significantly qualified'. The sources that Kaufmann calls upon to support this assertion do indeed testify to the use of both imagination and sense in conveying other-worldly matters (Sibbes and Baxter are quoted championing fancy and reason respectively), but such viewpoints sit ill upon Bunyan's own defence of method. Indeed, Kaufmann, paraphrasing Baxter to some extent, reveals little faith at all in the power of 'abstract terminology with the sensory suggestiveness of scriptural image' to offer anything cognitively enriching. Rather than increasing 'the content of truth in such conceivings', he views such a procedure simply as 'more useful in the practical matter of exciting spiritual-mindedness'.$^{74}$

Moreover, it seems that Kaufmann's approach inadvertently asserts not imagination but metaphor in Nonconformist spiritual discourse in any case. ${ }^{75}$ Sibbes's declaration that putting 'lively colours upon common truthes hath oft a strong working [...] upon the fancy' indeed seems but one way of formulating that 'God hath condescended to represent heavenly things to us under earthly termes' ${ }^{76}$ Thus, in offering the necessity of analogy and similitude in communicating things spiritual, Kaufmann more unconsciously confirms Richard Baxter's warning to '[t]alk not [...] against all Allegorical expressions about God, till you would forbid Mortals to talk of God at all.'77 That is to say, allegorical expressions for those such as Bunyan convey a 'Truth' which has little to do with the pleasures of the fancy but a great deal to do with the reader's faith and its communication. In these terms, there simply is no

\footnotetext{
Fit for a Wounded Conscience": The Place of Luther's “Commentary on Galatians' in Grace Abounding', Renaissance Quarterly, 50 (1997), 819-849 (pp. 835-846).

74 Kaufmann, The Pilgrim's Progress and Traditions in Puritan Meditation, pp. 139, 148.

75 Indeed, see the whole of Chapter 6, 'Two Divergent Traditions in Puritan Meditation', in The Pilgrim's Progress and Traditions in Puritan Meditation, pp. 120-150.

76 Richard Sibbes, The Soules Conflict (London, 1635), pp. 256-258, cited in Kaufmann, The Pilgrim's Progress and Traditions in Puritan Meditation, pp. 144-145.

77 Richard Baxter, Preface to John Bryan's Dwelling with God (1670), quoted in N. H. Keeble, Richard Baxter: Puritan Man of Letters (Oxford, 1982), p. 54 and cited in Pooley, 'Plain and Simple', p. 94.
} 
aesthetic tension in Bunyan's Apology between imagination and the Word because, for Bunyan at least, there could never be any qualifying of 'the conception of Scripture as logos' by either 'sense' or 'fancy'.78

Because Bunyan attests to figure and similitude as incremental and reality depicting, possessing a unique cognitive function within the linguistic and spiritual context of his faith, the point of the Apology is not to sanction any extravagance of the imagination, then, but to assert that 'metaphoric language is capable of delivering reality to men and [thus] Bunyan is justified in using it.'79 It is in these terms, moreover, that we are also obliged to understand Bunyan's use of allegory as a whole, particularly given that his concept of allegory is so markedly different from attitudes held towards it by Renaissance theorists (such as George Puttenham) and rationalist empiricists (such as John Locke) alike. It is from these latter sources in particular, for instance, that a cultural tradition has been inherited in which both metaphor and allegory have been upheld as semantically deceitful, saying one thing but meaning another, and blocking effective communication through its disjunction of tenor and vehicle, word and meaning, or (as post-structuralists may have it) signifier and signified. As a result, allegory in general has been approached (in terms of an English literary tradition, at least) as demanding what Valentine Cunningham views as a postmodernist 'double-reading', through which no matter how much of 'a univocity and equality of the separate sense is sought for', the reader of allegory can never escape 'the divisiveness that comes from the dividedness of attention it incites - that invitation to the reader to keep two levels of reference in mind.' ${ }^{80}$ In this way, allegory is often considered in terms of a negative propensity to subvert ostensible and 'true' literal meanings: because 'allegory says one thing and means another', it thus serves to destroy 'the normal expectation we have about language, that our words "mean what they say".'81

\footnotetext{
78 Kaufmann, The Pilgrim's Progress and Traditions in Puritan Meditation, p. 139, 149-150.

79 Johnson, 'Falling into Allegory', p. 123.

80 Valentine Cunningham, 'Glossing and Glozing: Bunyan and Allegory', in Conventicle and Parnassus, pp. 217-240 (p. 219).

81 Angus Fletcher, Allegory: The Theory of a Symbolic Mode (Cornell University Press: Ithaca and New York, 1964), p. 2. The concept of allegory operating as a substitutive mechanism or according to strict hierarchy of literal-metaphorical correspondences goes back at least to Romantic literary critics' distinctions between symbol and allegory, as in Samuel Taylor Coleridge's famous comments on the subject (see The Statesman's Manual, ed. by W. G. T. Shedd (New Yorker: Harper and Bros., 1875), pp. 437-438, and Miscellaneous Criticism, ed. by T. M. Raysor (London: Constable, 1936), p. 30, both cited in Fletcher, Allegory: Theory of a Symbolic Mode, pp. 15-19). For a continuation of this mode of thinking about allegory, see Herbert Eveleth
} 
But such an approach ignores the incremental and communal nature of figurative language that Bunyan reveals as implicit in his allegorical method. Far from being a source of cognitive anxiety for Bunyan, allegory and metaphor provide the only way of communicating 'Truth' effectively. Any approach which views figurative language as offering a divisive double-reading ignores the fact that it is not words that refer but speakers using words who refer, that a metaphor is specifically cognitive in its intended context: out of context, that metaphor can simply become ambiguous. Moreover, understanding figurality in terms of merely redescribing something more literal, offering a hidden meaning in double readings, is not only an inadequate way of explaining how metaphor works: simultaneously (and most dangerously for Bunyan's theological project) it eliminates 'the possibility that a metaphor may be genuinely, even ontologically, novel' or cognitive. 82 Indeed, because '[a]

Greene, 'The Allegory as Employed by Spenser, Bunyan, and Swift', PMLA, 4 (1888-1889), 145-193; Henry James, 'Hawthorne', in The Shock of Recognition, ed. by E. Wilson (1943), cited in Edwin Honig, Dark Conceit: The Making of Allegory (London: Faber and Faber, 1959), p. 52; C. S. Lewis, The Allegory of Love: A Study in Medieval Tradition (Oxford: Clarendon Press, 1936), pp. 45, 48; James F. Forrest, 'Allegory as Sacred Sport: Manipulation of the Reader in Spenser and Bunyan', in Bunyan in Our Time, pp. 93-112. Not surprisingly, the idea that allegory can 'subvert language itself' has also become a popular notion amongst poststructuralists. As Joel Fineman notes, allegory has recently achieved a supreme position in the hierarchy of disjunctive communication: it now has 'the status of trope of tropes, representative of the figurality of all language, the distance between signifier and signified, and, correlatively, the response to allegory becomes representative of critical activity per se.' For post-structuralists, all that is said and written is thus potentially 'allegorical': 'The Structure of Allegorical Desire', October, 12 (Spring, 1980), p.48, cited in Zhang Longxi, 'Historicizing the Postmodern Allegory', Texas Studies in Literature and Language, 36 (1994), 212-231 (p. 214). For other recent accounts of allegory, see Paul de Man, 'Pascal's Allegory of Persuasion', in Allegory and Representation, ed. with a Preface by Stephen J. Greenblatt (Baltimore and London: John Hopkins University Press, 1981), pp. 1-25 (pp. 1-3). Joel Fineman's essay, 'The Structure of Allegorical Desire', is also included in Allegory and Representation (pp. 26-60), Fineman viewing the Apology to The Pilgrim's Progress as indicative of 'the infinite intentions of allegory, its intention to enclose its own infinities' (p. 58). See also Paul de Man, 'The Rhetoric of Temporality', in Blindness and Insight: Essays in the Rhetoric of Contemporary Criticism, 2nd edn. revised, with an intro. by Wlad Godzich (London: Routledge, 1983; repr. 1993), pp. 187228; Deborah L. Madsen, The Postmodern Allegories of Thomas Pynchon (Leicester, London: Leicester University Press, 1991), pp. 1-28, and Rereading Allegory: A Narrative Approach to Genre (London: Macmillan, 1995); Hans Kellner, 'The Inflatable Trope as Narrative Theory: Structure or Allegory?', Diacritics: A Review of Contemporary Criticism, 11 (1991), 14-28.

82 'To show how unhelpful this, "two meanings" thesis is', Soskice writes, 'we need only notice that with many metaphors [...] the alternative to understanding them as metaphors is not to understand them at all' (Soskice, Metaphor and Religious Language, pp. 84-85). A way of avoiding discussion of metaphor in dualistic terms is, Soskice suggests, to use I. A. Richards's long-established interanimation theory in which metaphor is understood in terms of 'tenor, or the underlying subject of the metaphor, and the vehicle that presents it.' The advantage of such a formulation is simply that 'it allows us to distinguish between the tenor and the vehicle of the metaphor without suggesting that the metaphor has two subjects': a metaphor 'has one true subject which tenor and vehicle conjointly depict' in its intended context (Soskice, Metaphor and Religious Language, pp. 467). Hence, Barbara Johnson asserts that in the Apology Bunyan 'transposes the very idea of metaphor from the realm in which Puttenham located it, the realm in which tenor and the vehicle are in opposition, to the realm of scriptural truth' where 'tenor and vehicle are intrinsically connected' not by 'the incongruity and distance which fuel Renaissance allegory, but by an intrinsic resemblance which makes the true meaning an extension of the ostensible meaning.' Johnson's mistake, however, is to posit in Bunyan's approach to metaphor a mystical supernaturalism: tenor and vehicle are connected, she suggests, 'because God has made the world in such a way that these connections exist', and through a Bible in which 'word and meaning meet': ('Falling into Allegory', 
metaphor does not exist by itself but only in the context of interpretation', when a proposition is encountered which 'taken by itself or as it stands, is false', a way of reading is found that will 'make it come out true.' This is the whole point of Bunyan's learning to read in Grace Abounding. Similarly, the logic of allegory, as Gerald L. Bruns asserts, 'operates on this metaphorical principle of saving propositions from the charge of falsehood or nonsense' ${ }^{83}$ This sense of a meaning being communicated through figure and similitude according to a 'rule of faith', a shared context of belief, presents a far more positive (albeit limiting) function for allegory than that posited by conventional double-readers for whom, as Cunningham notes, allegorical 'rereading' has become 'an inviting fall into the joys of Midrash, that endless, exfoliating process of comment upon comment, reinterpretation layered upon reinterpretation, a licensed game of commentary that resists closure, defies certainty, and puts off conclusion', and which ultimately 'gets interpretation on to a busy unstoppable escalator of interpretive opportunism, an activity flushed with the prodigality of the free imaginative rein it sanctions, unperturbed by the undecidability of the texts it promotes'. Allegory viewed in terms of the unbridled postponement of meaning becomes not only synonymous with midrash for Cunningham, therefore, but 'symptomatic of deconstructive textuality per se', being merely one of many 'instructive emblems of a totalizing post-modernist hermeneutics' ${ }^{84}$

In these terms alone, allegory comes to be seen as undermining 'the authorizing status of texts as original, authoritative, final, necessary and self-sufficient source[s] and guarantor[s] of meaning'. Such a view, of course, misses the point of Bunyan's Apology entirely. Indeed, by returning to Cunningham's invocation of midrash (the rabbinical hermeneutic process of accounting for what is written in the Torah and, in particular, addressing its teachings to one's life at present) we can illustrate exactly how far Bunyan's allegorical method actually is from the all-deconstructing, all-deferring process of interpretation celebrated by post-structuralists. Indeed, Bunyan's Apology, in fact, defends

p. 123, and Reading Piers Plowman and The Pilgrim's Progress, pp. 49-54). Rather, word and meaning meet for Bunyan because of similitude's place in the context of the traditions of Scriptural figurality and its interpretation which provides a descriptive language for Bunyan's faith, experience, and religious identity.

83 Bruns, 'Midrash and Allegory', p. 641.

84 Cunningham, 'Glossing or Glozing', p. 220. 
an allegorical method which is far more akin to midrash, for all the latter's transgressive and excessive commentary, than double-read allegory. Because midrashic interpretation 'does not involve merely construing meaning', but showing how a Scriptural text 'still bears upon us, still speaks to us and exerts its claim upon us even though our situation is different from anything that has gone before', it must be thought of 'not simply as a method of exegesis but also as a form of life; its concern is not just with meaning but also with action in the world. 85 Midrashic and allegorical understanding (at least as Bunyan understands it) are thus both 'reflexive and reciprocal: we take the text in relation to ourselves, understanding ourselves in its light, even as our situation throws its light upon the text'. As the Apology of The Pilgrim's Progress testifies, then, Bunyan's allegorical method shares a midrashic concern for interpretation not simply in terms of knowing how the 'words work' on the page but how they apply to oneself and one's life: in reading Bunyan's allegory the reader is urged to 'Read thy self'. For Bunyan, just as in midrash, '[u]nderstanding is always ultimately selfunderstanding', for which interpretation involves 'a dialectical movement of selfunderstanding and the understanding [...] of what comes down to us from the past.' It is precisely because biblical texts in midrash and allegory are always situated not only in interpretive traditions but, more importantly, in terms of present circumstances, 'our situation', that a 'so-called excessiveness (as opposed to literalness) of interpretation' results. ${ }^{86}$

Viewing Bunyan's allegorical method in terms of the aims and demands of midrash is, then, significant after all. Far from revealing Valentine Cunningham's innate sense of a deconstructive deferral of meaning, midrash and allegory both demand a type of interpretation which 'is not a species of technical knowledge' (as in any conventional notion of allegorical rereading) nor 'a methodological approach to texts that might be compared with other approaches ancient and modern.' Because midrash involves and effects an understanding of self and Scripture in the world at present, because it 'gives us an insight into what interpretation always is [...] when interpretation matters to human life', it

\footnotetext{
85 Bruns, 'Midrash and Allegory', pp. 627-628, 634.

86 Bruns, 'Midrash and Allegory', pp. 633, 635-636. For another discussion of the relationship of allegory, typology, and midrash, see also Korshin, Typologies in England, pp. 27-30.
} 
represents something far different from Cunningham's totalising deconstructive hermeneutics. Consequently, "it makes no sense to wonder whether one could "apply" midrashic techniques as a method of literary criticism, say, by interpreting wildly, [and] saying whatever one pleases', simply because 'saying whatever one pleases is not midrash.' Nor can it be the basis for our understanding of Bunyan's allegorising. Indeed, Bunyan's defence of similitude according to the Biblical precedence of typology and Scriptural metaphor in the Apology is 'absolutely continuous with midrash' as it is rooted within 'the hermeneutical circle of Christian understanding: the Old Testament is to be read as a midrash of the New, just as the New Testament is to be read as a midrash upon the Old.' Consequently, it is from this 'midrashic circle' that 'the theological structure of promise and fulfilment' has arisen in Christian interpretive traditions, the two texts throwing a mutually elucidating light on each other 'and on all those who come within their range. This,' Bruns asserts, 'is the point that Luther and the tradition of reformist hermeneutics constantly stress, namely that to understand a scriptural text means to understand how it applies to oneself and one's life.'87

Bunyan's allegorical method is midrashic, then, in the sense that it demands a form of understanding based upon a 'rule of faith': Bunyan's allegorical method requires a form of interpretation which is 'a way of life - life with a text that makes claims upon a whole community [...] and not just as a technique of exegesis that anyone might pick up or put down at any time.' Bunyan's allegory thus effects 'a basic hermeneutic principle, which is that the understanding of a text can never remain simply a mental state or the conceptual grasp of the mental state of another.' Understanding Bunyan's allegory must show itself 'in action in the world', 'not by filling the mind with concepts [...] but by directing the one who understands along a certain path.' Bunyan's allegorical method, like midrash, thus offers itself as both an interpretation of Scripture and instruction about belief and, mediating between the two, conventional distinctions between 'text and tradition', 'interpretation and composition' become effaced for allegorist and reader alike. For Bunyan, interpretation is always to be 'from logos to praxis, from words to deeds', in which allegory becomes 'a

${ }^{87}$ Bruns, 'Midrash and Allegory', pp. 635-636. 
function of spiritual life rather than a technique of reading'. That is, reading itself becomes a province of one's faith. ${ }^{88}$

What is clearly demanded in understanding Bunyan's use of allegory, therefore, is a shift away from any 'modern concept of exegesis as a type of objective analysis', which often dismisses allegory simply as 'pseudo-exegetical'. Hence, mapping onto allegory 'the structure of romantic hermeneutics in which a subject deploys itself analytically against an object', and through which the text becomes 'an objective entity that is subjected to some sort of mental operation', is 'unhistorical' in terms of how Bunyan's allegory should be read - it does not take into account either 'the historicality of human life' or the grace-ful understanding The Pilgrim's Progress ultimately demands. Consequently, the idea of a conceptualisation of allegory as interpretively mechanical becomes 'not so much historical as romantic; it assigns truth conditions that will make the text right according to nineteenthcentury standards of what is right', and for which texts become 'documents', 'formal or aesthetic objects - writings that we try to operate on at a distance', exempt from any engagement with faith. It is this distance, this mistaking of reading allegory for an allegoresis, that Bunyan's metaphorical method attempts to overcome in The Pilgrim's Progress. ${ }^{89}$

${ }^{88}$ Bruns, 'Midrash and Allegory', pp. 629-633, 639-640.

${ }^{89}$ Bruns, 'Midrash and Allegory', pp. 640, 644, 629. Important distinctions in reapproaching the conventional notion of allegory (in which duality of meaning is reified in a hierarchy of hidden and 'true' meanings) have recently been made by Carolyn Van Dyke who notes how the 'other-speech' denoted in allegory's etymology has come to represent a concept of allegory as 'abnormal language' and that a split-level approach to its meaning (literal versus metaphorical) is deeply and cognitively flawed. 'If a text says one thing it also means that thing: we cannot separate speech from meaning. Thus if it says one thing and means another, it both says and means two things. And', Van Dyke asserts, 'unless we are linguistic schizophrenics or are willing to ignore half of what we read, a text that says and means two things must say and mean one complex thing.' Indeed, with allegory 'the identification of levels of reference is not equivalent to reading' but is, rather, 'a preliminary or heuristic stage' which merely prepares the reader 'to understand what can be said.' What is identified as crucial to understand is the distinction between the concept of allegory as a narrative text and of allegory as a method of revealing and identifying hidden truths in texts, a procedure properly named allegoresis, 'the [medieval exegetical] process whereby meanings not originally intended were extracted from [non-allegorical] texts', and which provides a 'conception of allegory' which has since been 'applied whole to actual allegorical narratives.' It is allegoresis, 'the identification of a set of authentic referents not [as] a heuristic stage but the proper goal of reading', which provides 'the most persistent form assumed by the phantom of split-level semiosis' and which, in discovering implicit while denouncing explicit readings, actually represents 'a method of suppressing meaning': (Van Dyke, The Fiction of Truth, pp. 27, 42-45; Quilligan, The Language of Allegory, p. 31). In these terms, The Pilgrim's Progress requires a type of interpretation greatly removed from any mechanistic and abstract exegetical process. As Quilligan asserts, moreover, in accepting The Pilgrim's Progress as primarily narrative, the 'vertical conceptualization of allegory' offered through allegoresis (in which reading becomes an identification of layers of meaning with an emphasis upon disjunct 'levels') becomes 'absolutely wrong' because reading Bunyan's text 'proceeds linearly, in a word-by-word fashion' which the 
Grounded as it is upon empirical notions of 'truth', then, any conceptual 'doubleness' of metaphor can have no place in Bunyan's allegory, intent as it is upon communicating and advancing an unequivocal spiritual 'Truth'. As is suggested most strongly in the Apology (indeed, it is the whole point of Bunyan's defence of similitude), it is the reader who is ultimately under scrutiny here, whose reading of The Pilgrim's Progress must go far beyond any mechanistic matching of allegorical correspondences and into faithful action. Consequently, a reader who does not understand the importance of Bunyan's use of figures in the context of a collective faith and a shared Scripture-centred interpretive and descriptive tradition can, perhaps, do little other than 'mis-interpret' The Pilgrim's Progress. For this reason, in Bunyan's allegory, as in all allegory (as Quilligan sees it, at least), the reader becomes undoubtedly 'the central character', whose 'participation in the fiction must be active and self conscious, and [...] will ultimately take the form of gradual self-discovery.' In this sense, '[r]eaders of allegory, unlike allegorical critics [practising allegoresis on texts] but very much like allegorical protagonists, read an allegory by learning how to read it.' Indeed, Bunyan's text asserts the fact that 'the reader of an allegory does not merely reject or accept a text, he embraces or denies his own capacity for rejecting or accepting meaning as a coherent unifying truth, or as a coherent unifying untruth. The choice', Quilligan suggests, 'is not aesthetic but ethical.' 90

Bunyan's Apology for The Pilgrim's Progress not only defends a use of metaphor and allegory in terms of a 'suprarealist attitude toward words', then, or simply as a response to the 'shifting cultural attitudes' to 'language and truth' in the wake of the 'vast epistemological shift' of the Enlightenment, but because, as in Grace Abounding, at the heart of Bunyan's narrative practice is a concern for the reader reading both doctrine and story. ${ }^{91}$ Allegory is supremely suited to Bunyan's ontological poetics, therefore, because by nature, it would seem, allegory acts to make the reader self-conscious about interpretation while

\footnotetext{
allegory institutionalises in the episodic journey or quest-form of its plot. Allegory can be said to work more precisely horizontally, therefore, 'so that meaning accretes serially': (Quilligan, The Language of Allegory, pp. 26-28). What Van Dyke's and Quilligan's understandings of allegory do not show, however, is that meaning in allegory and metaphor resides for Bunyan not within the words and similitudes themselves but in the reader sharing the assumptions and beliefs that make those words not merely significant but reality depicting.

90 Quilligan, The Language of Allegory, pp. 226-227, 241.

91 Quilligan, The Language of Allegory, pp. 154-157.
} 
enabling the author to dramatise such procedures of interpretation in the very action of the narrative. In the case of The Pilgrim's Progress, however, and as the following chapter will illustrate, the reader is required to share Bunyan's theology of grace (or at least be teachable in such matters) before such a 'right reading' can be achieved. Allegory thus offers Bunyan an ideal opportunity not only to teach the reader how to read the spiritual texts of Scripture and his or her own life grace-fully, to 'Read thy self', but to understand and confirm the doctrine of grace in its own terms - and this is exactly what Christian's journey to the Celestial City does indeed 'chaulketh out' before the reader's eyes. 


\title{
5 \\ 'Sweet fiction and sweet truth': Theology and Narrative in The Pilgrim's Progress
}

\begin{abstract}
Worl. How camest by thy burden at first?
Chr. By reading this Book in my hand.

Worl. I thought so; and it is happened to thee as to other weak men, who meddling with things too high for them, do suddenly fall into thy distractions; which distractions not only unman men, (as thine I perceive has done thee) but they run them upon desperate ventures, to obtain they know not what.
\end{abstract}

Bunyan's marginal notation at this point in Christian's encounter with the wily WorldyWiseman reads, quite simply, 'Worldly-Wiseman does not like that Men should be Serious in reading the Bible.' 1 For the likes of Worldy-Wiseman, serious reading can only be a destructive and destabilising process, encouraging those such as Christian to pursue the perilous paths of Nonconformist (and therefore uncivil) individualism exemplified in 'desperate ventures' and 'meddling with things too high'. This Wiseman's worldly (not to mention wordy) advice to the convert-to-be of The Pilgrim's Progress is clearly dangerous for those of Bunyan's faith because only by reading 'seriously' in the Bible can any Christian begin the process of conversion with an acceptance both of one's own innate sinfulness and of the redeeming power of Christ's blood shed upon the cross. It is 'Serious' (in the sense of spiritually and soterially crucial) reading that Bunyan always advocates and that WorldlyWiseman, for all his civil words of 'remedy', wishes to discourage.

Consequently, Worldly-Wiseman's concern over Christian's reading reflects, on one level, a clear variance in doctrine: Evangelist's Calvinist theology of grace is being confronted by the old legalism of a new morality, a religious difference that both reflects and

\footnotetext{
1 John Bunyan, The Pilgrim's Progress, ed. by James Blanton Wharey, 2nd edn, rev. by Roger Sharrock (Oxford: Clarendon Press, 1960), p. 18.
} 
restates the profound incompatibility of Restoration conformist life and politics with its dissenting counter-culture. On another level, however, the brief excerpt quoted from Christian's dialogue with Worldy-Wiseman also exemplifies a problem any reader of The Pilgrim's Progress potentially faces - that of reading itself becoming a burdensome and troubling task. Indeed, many readers, noting Worldy-Wiseman's particular abhorrence of a process of reading which leads to personal anguish (and even political radicalism, perhaps) might agree with his solution: why read seriously at all when the result, as in Christian's case, is grief and pain? Is Bunyan's sudden fall into allegory in The Pilgrim's Progress simply to lead its reader, along with its protagonist, to 'suddenly fall' not into spiritual comfort but interpretive distress?

Given the predominant relationship between reading and burdens in Bunyan's allegory, it may seem odd to argue (along with the likes of Maureen Quilligan and Stanley Fish) that the central concern of the text is the reader's spiritual well-being, particularly considering the inordinate anxiety reading itself seems to bring upon converts-to-be not only in Bunyan's allegory but in Calvinist conversion generally.2 In fact, it may seem particularly difficult to accept any view that privileges the reader as the 'central character' of The Pilgrim's Progress, suggesting that its real action centres upon the reader's learning to read the text properly (as suggested in the last chapter), when the same text can be seen as evincing a severe Calvinist doctrine of election and reprobation, a doctrine that ultimately threatens to exclude the reader either from its soteriological scheme specifically (is the reader 'saved' or not?), or from its bleak ontological world-view generally (can the reader be comfortable with a text that consigns all but a few of its characters to damnation?). How can the reader really be the central concern of such a text? With this is mind, WorldlyWiseman's response to Christian's anxiety seems not only civil but wholly understandable: he offers the burdened pilgrim-reader a means of remedy without recourse to further serious reading and its consequent soteriological 'distractions'.

It is perhaps not surprising that such a response is, in one form or another, often reproduced in critical discourse on The Pilgrim's Progress, through which the reader, like

2 For this kind of a reading see especially Dayton Haskin, 'The Burden of Interpretation in The Pilgrim's Progress', Studies in Philology, 79 (1982), 256-278. 
Christian, can be directed away from the path of Bunyan's repugnant doctrine of damnation to follow a narrative way far less cruel, obnoxious, and socio-spiritually disturbing. F. R. Leavis, for example, (a veritable worldly-wiseman of literary criticism) repeatedly wonders how Bunyan's 'fanatical treadmill-concentration' on the issue of 'assurance of Election and salvation by Imputed Righteousness' could 'issue in or be compatible with a generous humane art - a creative presentment of human life' that The Pilgrim's Progress has bequeathed to the art of prose fiction. ${ }^{3}$ Leavis, for whom 'to say anything positive about the religious quality of The Pilgrim's Progress is a delicate matter', guides himself (and any other reader potentially vexed by the soteriological implications inherent in Bunyan's text) away from its austere Calvinist theology (in a way Mr. Worldly-Wiseman would most certainly applaud) by acknowledging the 'religious depth' of the text rather than its severe doctrinal message. In this way, Leavis can return the burdened reader to a Pilgrim's Progress which, rather than evincing a threatening and unwholesome doctrine of 'Total Depravity', conveys and celebrates 'the religious feeling, the unquestioned spirituality' of 'earthly life in relation to the eternal'. It is with no uncertain amount of confidence, then, that Leavis both opens and concludes his 'afterword' on Bunyan's allegory by stating that '[i]t is possible to read The Pilgrim's Progress without any thought of its theological intention.' Indeed, it would seem not only possible but, for Leavis at least, imperative to do so. $^{4}$

Responding to the text in the specifically non-doctrinal way that Leavis encourages is not free of its critical trap-doors, though. In one sense, any reading that ignores Bunyan's theology in favour of a religious universalism is (in accordance with Leavis's critical legacy as a whole) profoundly ahistorical: it disregards the importance of that theology contextually both in terms of Bunyan's life's work as the minister for the Bedford Church and of the

\footnotetext{
${ }^{3}$ F. R. Leavis, 'The Pilgrim's Progress', in Anna Karenina and other Essays (London: Chatto and Windus, 1967), pp. 33-48 (p. 40). 'How could an imagination possessed by such a creed', asks Leavis incredulously, 'create a humane classic', admitting frankly that it is hard for him to conceive of 'the sectarian exclusiveness of his polemical and damnation-dispensing theology as conducive to a generous creative power' (p. 37). Similarly, in his essay 'Literature and Society', Leavis refers to The Pilgrim's Progress as 'a humane masterpiece', 'in spite of the bigoted sectarian creed that Bunyan's allegory, in detail and in sum, directs itself to enforcing' (in The Common Pursuit (London: Chatto and Windus, 1952), pp. 182-194 [pp. 188-189]).

${ }^{4}$ Leavis, 'The Pilgrim's Progress', pp. 44, 48. This essay was originally written as an 'afterword' to the Signet Classics edition of The Pilgrim's Progress (New American Library, 1964).
} 
politics of late seventeenth-century Nonconformity as a whole. There can be no doubt, for instance, that Bunyan's writing of The Pilgrim's Progress, as with his imprisonment, is an act of faith and conscience and any reading which seeks to efface this all-important aspect of the text is at fault not merely doctrinally but, arguably, socially and historically. For Leavis, though, the problem with any reading which takes into account 'Bunyan's allegorical intentions in terms of the theological doctrines [of predestination, total depravity]' is that it 'would convey something very different' from the venerated text he celebrates as a 'humane classic'.5 Soundly repudiating such a universalist and non-contextual stance is made difficult, however, by the fact that even the most recent accounts of the theology of The Pilgrim's Progress evidently leave Leavis's anxieties about serious doctrinal reading hardly misplaced.

A. Richard Dutton, for example, is but one commentator who champions the need to read The Pilgrim's Progress in the light of its 'interesting, but tough' doctrine of justification. Astutely noting that what is essentially missing from 'attempts to universalize The Pilgrim's Progress, to see it as a repository of moral exempla or to regard Christian's journey as a "quest" [...] can be summed up in the word, "predestination",' Dutton's acceptance that 'it is not everyone who can succeed on the pilgrimage', and that ' $[\mathrm{t}] \mathrm{he}$ book is about the race of saints - the Puritan elect - not ordinary mankind', is indeed nonuniversalist - but it does not serve to alleviate any concerns about Bunyan's abhorrent creed. ${ }^{6}$ In fact, Dutton's assertion that The Pilgrim's Progress is in no sense to be understood as the moral journey of another Everyman appears merely to validate Leavis's position. For Dutton, Bunyan's predestinarian theology makes The Pilgrim's Progress perhaps more 'tough' than 'interesting', a text difficult to read 'as a coherent piece either of fiction or of doctrine, much less as a fusion of the two: it is a book for an "awakened" reader,' he asserts, 'as much as it is about the "awakened" condition, and only for such a reader is it genuinely intelligible.' 7 If this were the case absolutely, then Leavis's universalist approach would indeed bear validity simply in terms of saving the text's readership from extinction. But

\footnotetext{
5 Leavis, 'The Pilgrim's Progress', p. 48.

6 A. Richard Dutton, “"Interesting, but tough": Reading The Pilgrim's Progress', SEL, 18 (1978), 439-456 (p. 441).

${ }^{7}$ Dutton, 'Interesting, but tough', p. 444.
} 
clearly the problem here is not with the logic of Dutton's argument: he, along with numerous other Bunyan critics, merely elucidates and systematically pursues the scheme of Calvinist predestination within The Pilgrim's Progress to its unavoidably dismal conclusion. Rather, the trouble lies with the issue of predestination itself. Before any attempt can be made to consider how The Pilgrim's Progress teaches its reader about grace-ful reading, therefore, it is necessary first to re-address Bunyan's allegory in relation to this most uncompromising of doctrinal tenets.

What Dutton's analysis exemplifies most of all is the commonplace acceptance of the theology of The Pilgrim's Progress as primarily, fundamentally, and irrefutably predestinarian. As was explored in the first chapter, the two terms (theology and predestination) have become virtually synonymous in Bunyan criticism. But while Bunyan's overall theology of grace is obviously informed by English Calvinism, and though elsewhere his adherence to its doctrines of election and reprobation may seem clear, interpreting The Pilgrim's Progress through the concept of predestination nevertheless fits uneasily, first and foremost perhaps, upon our own experience of reading of it. While John Stachniewski asserts, with a somewhat bleak rigorousness, that Calvinist predestination (as the tool of the oppressive God of the persecutory imagination of a Puritan ideology) remains the cornerstone of The Pilgrim's Progress's theological and narrative structure, 'a grid through which the providential text of the world and self is organized and read', such a view may jar against our own perception of the text as something far from onerous, anxiety-ridden, and bereft of joy. ${ }^{8}$ Indeed, as Coleridge famously remarks, The Pilgrim's Progress gained its reputation by being a 'wonderful work' that 'delights every one', Coleridge himself hardly

\footnotetext{
8 John Stachniewski, The Persecutory Imagination: English Puritanism and the Literature of Religious Despair (Oxford: Clarendon Press, 1991), p. 167. This is certainly the case for Gordon Campbell who (albeit generally condemnatory of Bunyan's predestinarian tendencies) notes that the doctrine of election though 'crucial both to Bunyan's theology and to his own experience of salvation [...] does not affect the Christian of The Pilgrim's Progress.' While the doctrine of reprobation clearly 'explains the fate of Pliable and Ignorance', Campbell asserts, 'neither election nor reprobation touches Christian's own experience.' It must be noted, however, that Campbell wishes to dispel the predestinarian element of Bunyan's allegory largely to emphasise (along with Leavis) that 'The Pilgrim's Progress is a religious work rather than a theological work.' See Gordon Campbell, 'The Theology of The Pilgrim's Progress', in The Pilgrim's Progress: Critical and Historical Views, ed. by Vincent Newey (Liverpool: Liverpool University Press, 1980), pp. 251-262 (p. 257).
} 
believing 'that Calvinism could be painted in such exquisitely delightful colours.' 9 For $\mathrm{U}$. Milo Kaufmann, furthermore, any notion of prevenient grace not only places a strain both on Bunyan's narrative practice ('if too evident in the springs of the narrative, [it] is likely to destroy the illusion of a dynamic career') but remains somewhat incongruous with his own voluntarist reading of the text in which individual will becomes the 'real locus' of the journey, with 'Christian's success dependent on the quality of his intent' more than anything else. Albeit tentatively, then, Kaufmann tenders forth an admission that in The Pilgrim's Progress 'Bunyan is not at great pains to keep before the reader this [predestinarian] element of his theological brief: Christian and the other pilgrims of the first and second parts,' he observes, 'spend no time worrying about the illusoriness of their freedom.'10

It is easy to understand Kaufmann's will-ful and non-predestinarian reading of The Pilgrim's Progress given the oft repeated exhortations from the characters within it to will one's own salvation. After all, the lesson Hopeful learns from his own conversion is famously: 'That believing and coming was all one, and that he that came, that is, run out in his heart and affections after Salvation by Christ, he indeed believed in Christ.' This is, moreover, the very keynote of Christian's own pilgrimage which, it would appear, has little to do with predestination at all: 'If we be truly willing to have it,' Christian reveals of salvation very early on in the journey, '[God]will bestow it freely.'11 It is difficult to reconcile such promising statements of one's will-to-deliverance with a brutal doctrine of predestination, other than by tortuously suggesting that believing and coming are all one for the predestined elect alone of which Hopeful and Christian could be classified as members. ${ }^{12}$ But it is also crucial to note other reasons why the doctrine of predestination sits uneasily

\footnotetext{
9 Samuel Taylor Coleridge, in Coleridge on the Seventeenth Century, ed. by Roberta Florence Brinkley (Duke University Press, 1955), pp. 475-476, and reprinted in The Pilgrim's Progress: A Casebook, ed. by Roger Sharrock (London: Macmillan, 1976), pp. 52-53.

${ }^{10}$ U. Milo Kaufmann, The Pilgrim's Progress and Traditions in Puritan Meditation (New Haven and London: Yale University Press, 1966), pp. 116-7. In the same way, Brian Nellist notes: 'Even if we assume he [Christian] must always be right because he is elect, he himself is unconcerned with that election': 'The Pilgrim's Progress and Allegory', in The Pilgrim's Progress: Critical and Historical Views, pp. $132-153$ (p. 135).

11 Bunyan, The Pilgrim's Progress, pp. 143, 14.

12 Stachniewski, for example, refuses to accept a voluntarist reading of The Pilgrim's Progress, particularly when it comes to interpreting the pilgrims' escape from Doubting Castle as an 'act of will': 'It is God', Stachniewski asserts, 'who exerts pressure on the will': Persecutory Imagination, pp. 202-3. For a more voluntarist reading of the text see Vincent Newey, 'Bunyan and the Confines of the Mind', in The Pilgrim's Progress: Critical and Historical Views, pp. 21-48 (p. 24).
} 
upon The Pilgrim's Progress beyond any sense of voluntarism. It would be more accurate, for instance, to suggest that the most important doctrinal tenet of Bunyan's text (indeed, of his whole divinity) resides not in the concept of predestination but, as has been noted already, in his covenant theology, in the doctrine of Law and grace which is integral to Bunyan's faith as a whole.

More precisely, then, it is by Bunyan's explicit concerns over the impossibility of justification by the Law and the necessity of salvation by grace (rather than any overt concern over predestination) that the doctrinal structure of The Pilgrim's Progress is clearly punctuated. From Christian's encounter with Worldly-Wiseman to the final damnation of Ignorance, Bunyan's text repeatedly recounts and recapitulates a basic covenantal lesson in Law and grace, urging the reader not towards an introspection in matters of election or reprobation but a need to understand, accept, and have faith in a justification by imputed righteousness through Christ. Bunyan's theological concerns in these matters are revealed most baldly, for example, in Hopeful's conversion, recounted while passing through the spiritually numbing 'Inchanted ground'. As noted in the last chapter, Hopeful's narrative of religious experience illustrates, on the one hand, the necessity for saints to reiterate such matters in order to thwart spiritual apathy: 'Good discourse prevents drowsiness', reads the wise marginal note. ${ }^{13}$ Equally, though, this timely conversion narrative acts as a vehicle for teaching (or at least reminding) any reader perhaps enchanted by the story rather than the doctrine at this stage in the allegory about the importance of Law and grace in any successful spiritual journey.

In basic terms, Hopeful's conversion narrative compresses the whole of Bunyan's covenant theology within just a few pages, illustrating the convert's transition from lawlessness, to a religious existence under the Law, to a serious reading of the Word culminating in an understanding and acceptance of the two central tenets of Bunyan's faith: firstly that 'If all my righteousnesses are filthy rags, if by the deeds of the Law, no man can be justified; And, if when we have done all, we are yet unprofitable: Then 'tis but a folly to think of heaven by the Law.' Following such a conviction, Hopeful then asserts that

13 Bunyan, The Pilgrim's Progress, p. 137. 
Christ Jesus came into the World to save sinners. He is the end of the Law for righteousness to every one that believes. He died for our sins, and rose again for our justification: He loved us, and washed us from our sins in his own blood: He is Mediator between God and us. He ever liveth to make intercession for us. From all which I gathered, that I must look for righteousness in his person, and for satisfaction for my sins by his blood; that what he did in obedience to his Father's Law, and in submitting to the penalty thereof, was not for himself, but for him that will accept it for his Salvation, and be thankful. ${ }^{14}$

Though this is perhaps not the most memorable passage from The Pilgrim's Progress, nor is it particularly illustrative of the rich and dynamic creativity that Bunyan's allegory often reveals elsewhere, doctrinally it is a particularly important passage, encapsulating with brevity and force the nature of conversion into saving faith through grace. A beginner's pack for those uninitiated in experience and a survival kit for those suffering from spiritual uncertainty or drowsiness, Hopeful's account represents the fundamental and overriding theological message of The Pilgrim's Progress as a whole: righteousness must come through faith in Christ alone and that, far from stressing a harshly predestinarian and limited atonement, emphasis is placed here (as throughout the allegory) on salvation 'for him that will accept it'. With this doctrine in mind, it is important to note that the central text both Christian's and Hopeful's conversions share (and which lies at the heart of Bunyan's doctrine of salvation in general) is the particularly non-predestinarian 'And him that cometh to me, I will no wise cast out (John 6. 37)'.15

Hopeful's account is thus, on one level, little more than a vehicle for Bunyan to teach an explicit lesson in doctrine. Understanding this doctrine as central to The Pilgrim's Progress is, moreover, crucial in revising our conception of the allegory's theology as a whole: by positing a structure of Law and grace upon the text (as opposed to Calvinist predestination) we can understand the doctrine of The Pilgrim's Progress as more comforting than harsh, more conciliatory than terrifying. In Faithful's recounting of religious experience, for instance, he describes how, having been tempted into carnal sin by the old man 'Adam the first', Faithful (just like Christian and Hopeful) becomes wracked with guilt

\footnotetext{
14 Bunyan, The Pilgrim's Progress, pp. 139, 143.

15 Bunyan, The Pilgrim's Progress, pp. 143, 27. As the first chapter of this thesis discusses, this Scriptural reference is, of course, the starting point for whole tract by Bunyan on 'coming and believing' - Come, \& Welcome, to Jesus Christ (1678), in The Miscellaneous Works of John Bunyan VIII, ed. by Richard L. Greaves (Oxford: Clarendon Press, 1979).
} 
and rendered helpless by a conviction of fleshly sinfulness. The Law, figured forth in the form of a 'Man' who 'was but a word and a blow' and who almost beats Faithful to death ('I lay at his foot as dead as before'), is shown to be spiritually merciless in the light of such convictions. The point of Faithful's brief narrative of experience is simply that, as Christian learns in his encounter with Worldly-Wiseman, any submission to justification by the Law is both spiritually tyrannical and destructive - ceaselessly so, in fact, until a faith in grace through Christ is sought for. Hence, just as Christian loses his burden of guilt before the cross, Faithful is relieved of the blows of Moses only when Christ 'came, and bid him forbear.' 16

Though not as spectacular as Hopeful's later conversion account, Faithful's experience here presents yet another parable of Bunyan's covenant theology, stressing once more the consolation that a faith in grace brings to the believer: conviction in Christ's redemption of man's sins, more than anything, alleviates the burden of guilt made heavier by the oppressiveness of a religious legalism. This is the whole point of Christian's encounter with Worldly-wiseman who, directing the pilgrim towards one 'Legality' in the village of 'Morality', only causes Christian's burden to grow unbearably heavier. ${ }^{17}$ Faithful's conversion is especially important to note, though, as it so clearly follows and illustrates a strict and quite obvious Calvinist tenet: in order to put off the old man (in this case, quite literally), Faithful must die to the Law and be revivified through Christ. What is emphasised here is not a Calvinist predestination but a basic need to recognise the impossibility of fulfilling the Law. As such, and despite his lapse into legalism, Faithful is allowed to continue along the way through a grace that allows for, but does not condone, an innate corruption and a natural propensity to sin. The theology of The Pilgrim's Progress is thus one of a humane accommodation of human failings and mistakes, stressing not a harsh predestinarianism but a fundamental tenet in Christian theology as a whole: those who come to Christ will be relieved of the burden of guilt over sin. In this sense, Leavis's abhorrence of the text's doctrine of 'Total Depravity' is wholly inappropriate for, in terms of Bunyan's doctrine of Law and grace at least, it becomes a key factor in any pilgrim's progress in faith.

16 Bunyan, The Pilgrim's Progress, pp. 69-71.

17 Bunyan, The Pilgrim's Progress, pp. 19-20. 
It becomes important to remember, then, that Christian's journey, though presenting him with many unpleasant doctrinal burdens and battles, is also one involving much emphasis on recuperation, healing, and the pleasantness of the 'Golden hours' he discourses of with Prudence in the House Beautiful. ${ }^{18}$ Christian's is indeed a journey of mistakes made and rest given: the 'Arbour' set upon the hill Difficulty (in which Christian mistakenly oversleeps) is not, as it may at first seem, a trap set for unwary pilgrims but a place 'made by the Lord of the Hill, for the refreshing of weary Travailers', and which, as the marginal hand tells us, specifically denotes an 'Award of grace'. ${ }^{19}$ Christian's over-sleeping and leaving behind his roll here is depicted as an easily made yet readily reparable mistake (the point of which should have been remembered in his later imprisonment in Doubting Castle, where he similarly 'forgets' the Scriptural promises in his bosom). In this way, Christian's being healed by 'an hand with some of the leaves of the Tree of Life' after his battle with Apollyon, or his sleeping in the chamber of 'Peace' in House Beautiful, or the refreshing pre-celestial delights of the land of Beulah are as emblematically important to The Pilgrim's Progress as the more horrifying Slough of Despond, Doubting Castle, or the Man in the Iron Cage of despair. Indeed, Bunyan's benign emblems of comfort serve to emphasise that The Pilgrim's Progress is not a text solely or wholly characterised by religious despondency and soterial anguish.

Understanding the theology of The Pilgrim's Progress in terms of Law and grace rather than Calvinist predestination is also crucial, however, for any accommodating reading of those episodes that often prove most burdensome (if not abhorrent) to the reader. The damnation of Ignorance is perhaps the most important case in point, the alarming expulsion of this seemingly affable and well-intentioned allegorical character from the gates of heaven unto a side-door of hell often being held as theologically (and narratively) problematic. Unlike other false pilgrims encountered by Christian on the 'way', Ignorance is neither overtly malicious nor vicious, neither obviously atheistical nor carnal: like Christian and Hopeful, he has left his 'Countrey' for the Celestial City, revealing himself to be faithful ('I believe Christ died for all sinners') and, in many ways, more hopeful than Hopeful about

\footnotetext{
18 Bunyan, The Pilgrim's Progress, p. 50.

19 Bunyan, The Pilgrim's Progress, p. 42.
} 
accepting his place in his heavenly destination. As a keeper of all decent duties with an innate humanist optimism in the goodness of the heart, it is unsurprising that commentators turn to the doctrine of predestined reprobation to explain (and condemn) the morally unjust damnation of this most humanely (and humanly) drawn allegorical character. As a consequence, Ignorance is often seen as finally damned for no reason other than Bunyan's adherence to an execrable creed of Calvinist predestination: reeking of 'carnal security' and a conspicuous lack of soterial anxiety, he is but a victim of an inhumane and utterly abominable doctrinal premise, to be eternally punished for being guilty of a predetermined reprobation and for not possessing a 'Certificate' always-already impossible for him to obtain..$^{20}$

Of course, it is neither as straightforward nor as convoluted as this. Any reading of Ignorance's damnation as merely illustrative of a Calvinist theology of predestination is inaccurate and inappropriate in terms of Bunyan's faith in general while being, in particular, ignorant of the significance of Ignorance's discourse with Christian and Hopeful prior to their arrival at the Celestial Gate, a conversation specifically structured to preclude such an immoderate and inhumane judgement of Ignorance's unfortunate ending. Curiously, for instance, Ignorance's words with his co-pilgrims at first reveal no apparent ignorance of religious feeling or duties at all: the gate of the Celestial City will be opened for him because, he reasonably professes, 'I know my Lords will, and I have been a good Liver, I pay every man his own; I Pray, Fast, pay Tithes, and give Alms'. Ignorance is, then, a valuable and sociable member of any church community, a tolerationist as well as a moral individualist not afraid to suffer solitude for the sake of his faith: 'Gentlemen', he addresses the pilgrims courteously, "be content to follow the Religion of your Countrey, and I will follow the Religion of mine', before walking behind alone.21 But despite his affability, the keynote of Ignorance's damnation is signalled by the very fact that he is not only socially but

${ }^{20}$ For such a view see Maurice Hussey, 'Bunyan's "Mr Ignorance"', Modern Language Review, 44 (1949), 483-489; Stuart Sim, " "Safe for Those for Whom it is to be Safe": Salvation and Damnation in Bunyan's Fiction', in John Bunyan and His England, 1628-88, ed. by Laurence, Owens, and Sim (London: Hambledon Press, 1990), pp 149-160, and Negotiations With Paradox: Narrative Practice and Narrative Form in Bunyan and Defoe (London: Harvester Wheatsheaf, 1990), pp. 51-59; Stachniewski, The Persecutory Imagination, pp. 208-214; James Forrest, 'Bunyan's Ignorance and the Flatterer: A Study in the Art of Damnation', Studies in Philology, 60 (1963), 12-22.

21 Bunyan, The Pilgrim's Progress, pp. 123-124. 
soteriologically law-abiding. No matter how sensible or civil Ignorance's religious and social moralism may seem, his initial emphasis on the fulfilment of church-duties should be enough to alarm any reader aware of Bunyan's doctrine of Law and grace that something is indeed amiss with this pilgrim's faith.

This predicament is made more obvious in Ignorance's second, more detailed exchange with Hopeful and Christian. Here, after having left this brisk lad of religion 'to think of what he hath heard already', the travellers resume their discussion, Bunyan now focusing the reader specifically upon the issue of justification by faith. Once more, the overwhelming sense of Ignorance's character and religion is one of a humane moralism with which it is difficult (certainly for any present day reader) not to sympathise. But the crux of Ignorance's doctrinal flaw (and hence of his whole damnation) is that he has faith in a justification not by grace but by the Law, and the whole dialogue between the pilgrims balances upon the revelation of this very specific form of soteriological blindness. As such, Ignorance's denial of the doctrine of total depravity, with a conviction in the innate goodness of his own heart, is but a prelude to the more devastating profession that he believes 'that I shall be justified before God from the curse, through his gracious acceptance of my obedience to his Law: Or thus, Christ makes my Duties that are Religious, acceptable to his Father by vertue of his Merits; and so I shall be justified.' 22

What is most disconcerting about this profession of faith is not only its reasonableness, however, but the fact that, in some ways, it may seem barely distinguishable from Bunyan's own doctrine: justification for Ignorance, as for Bunyan, comes through Christ as the mediator between man and God's eternal justice. It is for this reason, then, that Christian's edifying response to Ignorance's confession of faith is particularly vehement. Ignorance's doctrine is condemned unequivocally by Christian as 'Fantastical', 'False', and 'deceitful' precisely because it is wholly legalistic. Consequently, the lesson Ignorance is taught by Christian, as one pilgrim trying to show another the true 'way', is not one of predestination but, more basically, of covenant doctrine: 'For true Justifying Faith', he preaches,

22 Bunyan, The Pilgrim's Progress, p. 147. 
puts the soul (as sensible of its lost condition by the Law) upon flying for refuge unto Christs righteousness: (which righteousness of his, is, not an act of grace, by which he maketh for Justification thy obedience accepted with God, but his personal obedience to the Law in doing and suffering for us, what that required at our hands.) This righteousness, I say, true faith accepteth, under the skirt of which, the soul being shrouded, and by it presented as spotless before God, it is accepted, and acquit from condemnation.

Christian's use of the 'skirt' image, here, is particularly important to mark not only because it figures forth a parental security in Christ's righteousness over the soul but because, as a covert reference to Ruth's 'redemption' by Boaz (a reference not signalled by any marginal note, either), it anchors Christian's assurance of salvation in a Biblically traditional language of covenantal contract and rights of inheritance that Ignorance ignorantly refuses to acknowledge. ${ }^{23}$ Consequently, Ignorance's rebuttal of this doctrinal sermon on Law and grace, like the lesson itself, evinces but a compressed version of the controversy Bunyan's theology would often raise, and which he would defend, from his earliest tracts onwards. Indeed, while Christian's speech could be a passage found almost anywhere in Bunyan's The Doctrine of Law and Grace Unfolded (1659), Ignorance's consequent accusations of an antinomian 'conceit' that 'would loosen the reines of our lust, and tolerate us to live as we list' is a reaction worthy of an Edward Fowler or a Samuel Parker. As such, Ignorance's response to Christian's doctrinal conversation here simply marks the final (and, for Bunyan, a well-practised) stage in a debate that is carefully structured towards the revelation of Ignorance's damning ignorance: 'Ignorance is thy name', Christian retorts,

and as thy name is, so art thou [...]. Ignorant thou art of what Justifying righteousness is, and, as Ignorant how to secure thy Soul through the faith of it from the heavy wrath of God. Yea, thou also art Ignorant of the true effects of saving faith in this righteousness of Christ, which is, to bow and win over the heart to God in Christ, to love his Word, his Ways and People, and not as thou ignorantly imaginest. 24

\footnotetext{
${ }^{23}$ See Ruth 3. 9 and 4. 1-11. Here, spreading the skirt of Boaz's cloak over her signals a 'right of redemption over Ruth'. Boaz's marriage to Ruth is then negotiated with those who have rights of inheritance to Ruth's dead husband's (Elimelech's) land. The emphasis is thus on property-rights and covenants, it thus being obvious why Bunyan chooses such an image when talking of salvation. For a feminist reading of this image (but which ignores the doctrinal significance entirely), see Louise Schleiner, 'Gendered Journeys in The Faerie Queene and The Pilgrim's Progress', in Women and the Journey: The Female Travel Experience, ed. by Bonnie Frederick and Susan H. McLeod (Pullman, Washington: Washington State University Press, 1993), pp. 145-169 (p. 159).
}

${ }^{24}$ Bunyan, The Pilgrim's Progress, p. 148. 
The somewhat uncharacteristic harshness of this rebuke may, to some readers, seem shocking, coming as it does from the otherwise gently spoken and humble Christian. But the effectiveness of Christian's reply lies not only in the crucial doctrinal point he makes about faith nor in the ferocity of its expression, but in the repetitive play on the word 'ignorant' itself: in this speech, it becomes a lethal condition, infecting any wayfarer's faith with a falseness that breeds in every facet of the pilgrim-to-be's spiritual life. Moreover, the insistent repetition of the word also stresses that this ignorance is never to be misunderstood as predetermined. Ignorance, both as the abstract construct and the fictional character, is revealed here as nothing less than a wilful dismissal of the 'Truth' of Bunyan's faith. In The Pilgrim's Progress, ignorance is a choice made and sustained, not foreordained.

But Ignorance's soteriological position, it must be noted, is also informed by a crucial phrase in Christian's former lecture on justification by faith: only the soul 'sensible of its lost condition by the Law' can arrive at a saving faith, he affirms. This phrase signals Ignorance's doctrinal error not merely as notional or conceptual but as fundamentally experimental. Ignorance simply has not undergone any experience of conversion in grace, a matter emphasised in the fact that, like the wall-tumbling Formalist and Hypocrisie whom Christian encounters soon after his own conversion, Ignorance pays little heed to the need to enter the way of faith by the Wicket-gate. Hence, Ignorance's discourse becomes but a redramatisation of the doctrinal errors made much earlier on in the text by other false-pilgrims who similarly refuse to adhere to Christian's warnings over justification by 'Laws and Ordinances': because he has not undergone conversion in grace, Ignorance, like Formalist and Hypocrisie before him, is referred to as a faithless robber and a thief. With this in mind, it is with added resonance, therefore, that Bunyan carefully positions Hopeful's own (and exemplary) conversion account (with its emphatic doctrinal summation of Law and grace) immediately prior to this damning dialogue with Ignorance. Indeed, it is through Hopeful's experimental discourse alone that Ignorance is cleverly re-introduced to the text's narrative and doctrinal focus: spiritual rebirth for Hopeful, we are told, 'made me greatly ashamed of the vileness of my former life, and confounded me with a sense of my own Ignorance'.25 
The allegorical figure of the same name is thus called once more to the fore of the narrative through a wordplay innately immersed in Bunyan's theology of grace and its specific process of regeneration. Hopeful's account of experience, then, is not only a means of keeping the pilgrims from lapsing into spiritual drowsiness: it is a doctrinal summary of Law and grace carefully situated in The Pilgrim's Progress to ensure that there can be no misunderstanding as to why Ignorance is finally damned.

The matter of the all-important 'Certificate' to be submitted at the gates of the Celestial City is also significant in this respect, particularly as Christian's possession of his roll or 'Certificate' has long been interpreted within the compass of a theologically predestinarian framework as the sign of an unalterably elect status, a document of assurance after the receipt of which there can be 'no real doubt as to the outcome of Christian's journey.' 26 In these terms, Ignorance's fate seems, like the roll he does not possess, soterially sealed. Indeed, it would seem that 'the absence of a certificate of election', as Stuart Sim asserts, 'is enough to condemn this meek and essentially well-meaning character' to everlasting perdition. ${ }^{27}$ But interpreting the roll as a guarantee of Christian's individual elect status is problematic. As Gordon Campbell notes, it is ludicrous to suggest that the 'roll represents assurance' as 'one clearly does not submit one's assurance at the Heavenly Gate.' Nor does it make any sense, doctrinally or narratively, to have Christian very nearly lose an assurance of election (as he does in the arbour) which is guaranteed forever through predestination. For this reason, Campbell cites the roll as a clear instance of Bunyan's imaginative art eclipsing the doctrinal narrowness of his allegorical symbols: by the end of the text ' $[t]$ he narrative function of the roll has superseded its allegorical function.'28

The only problem with Campbell's argument, though, is that any understanding of the roll as an emblem of predestined election is not really being challenged - it is merely being seen as allegorically ineffective. In order to appreciate and understand its doctrinal significance more fully (and to dispel any sense of it being some kind of certified proof of elect status) one need only note, for instance, the role Christian's roll plays elsewhere in The

\footnotetext{
26 Dutton, 'Interesting, but tough', p. 448.

27 Sim, 'Safe for Those for Whom it is to be Safe', p. 153.

28 Campbell, 'The Theology of The Pilgrim's Progress', p. 260.
} 
Pilgrim's Progress. It is not conviction of one's election, for instance, which enables Christian to escape with Hopeful from Doubting Castle but a remembrance that he has had within his bosom the spiritually liberating key of 'Promise' all along. ${ }^{29}$ Here, Christian's despair manifests itself, in one sense, in a forgetting to adhere to the 'shining one's' advice (given at the time of his conversion) to look upon the roll throughout his journey, a practice through which he has been spiritually 'refreshed' previously. ${ }^{30}$ Far from being theologically untranslatable, then, as Gordon Campbell suggests, the roll (received after Christian's revelation in grace before the cross) seems intimately bound up not with election but with faith in the Scriptural promises of deliverance: more than anything else, it represents the Word of Christ as redeemer through a covenant of grace and which is to be looked upon and remembered in times of doubt and despair. The 'Certificate' Christian and Hopeful submit at the Celestial Gate is not of their election, then, but of their faith in the efficacy of salvation by grace alone. It is thus quite fitting that Ignorance's final fumbling in his bosom for his own roll represents little more than an emblematic searching of his heart for a faith he has never attained and so does not possess.

Consequently, Ignorance's pathetic searching through his pockets for a missing 'Certificate' is in itself designed not only to show 'that there was a way to Hell, even from the Gates of Heaven' but to make the reader look back within the text to understand the process of conversion in grace as a whole. As such, Ignorance's damnation should not be read as an episode isolated from or incongruent with the rest of the text, either narratively or theologically, but as an index of the allegory's doctrinal concerns from beginning to end. ${ }^{31}$ It is at this point, for instance, that we are to remind ourselves how, when, and why Christian received his roll: it was not through an inevitable process of election but through a spiritually arduous arrival at a faith in Christ's redemption of fallen man, exemplified in his experience

\footnotetext{
29 Thomas Luxon also reads the 'Roll' as synonymous with the 'Key' Christian remembers possessing in Doubting Castle. See, 'The Pilgrim's Passive Progress: Luther and Bunyan on Talking and Doing, Word and Way', ELH, 53 (1986), 73-98 (p. 80).

30 Bunyan, The Pilgrim's Progress, pp. 118, 41.

31 As Forrest notes, Ignorance's damnation has often been read as a failing in the text's overall narrative and doctrinal scheme: 'it becomes hard not to feel', he writes, 'the incident an outrageous flaw in the work': 'Bunyan's Ignorance and the Flatterer', p. 12.
} 
before the Cross. ${ }^{32}$ That we are also encouraged all along to view Ignorance's discourse as but a re-playing of errors revealed much earlier in the text by the likes of Formalist and Hypocrisie similarly emphasises the overarching doctrinal frame of Law and grace within The Pilgrim's Progress, signalling the self-reflexive nature of the text in the important matter of coming and believing. We are in no sense encouraged to consider Ignorance's damnation as beyond his own responsibility, therefore, for it is nothing less than the same wilful doctrinal error of legalism evinced throughout The Pilgrim's Progress not only by WorldlyWiseman and the reprobate wall-tumblers, Formalist and Hypocrisie, but by the likes of Talkative and By-Ends, for all of whom Ignorance is but a spiritual doppelganger.

What makes Ignorance's damnation so horrifying over and above his doctrinal counterparts', however, is not only its vivid (and sudden) depiction but that we feel overwhelmingly the personal proximity of its pathos. Bunyan's presentation of Ignorance's damnation is, after all, as a very human tragedy that could have been avoided (a concept impossible within the frame of predestination), Ignorance being the victim of a doctrine of moralism attractive both in its modesty and in its sociability but which is, according to Bunyan, soterially devastating. What is most horrifying about Ignorance's fate, then, is not its demonstration of a heartless doctrine of predestination but its illustration that such a reasonable profession of faith necessarily leads to damnation. Indeed, what horrifies us most about Ignorance's fate is the fact of damnation itself and this is Bunyan's point entirely.

Our dismay at Ignorance's fate is, then, a result of Bunyan's carefully constructed narrative intention. Only through such horror can the impact of Ignorance's doctrinal errors really take hold and force the reader to question his or her own theological convictions. Any reading of Ignorance's reprobation as merely predestined must ultimately make such self-reflection futile. Moreover, reading the theology of The Pilgrim's Progress as predominantly informed by the doctrine of predestination can have little bearing upon the socio-political resonances of Bunyan's faith nor upon his constant warnings against the dangers of legalism, no matter how it is disguised. Ignorance's damnation is a violent warning to any would-be pilgrim to

32 Bunyan, The Pilgrim's Progress, p. 38. Significantly, it is directly after this episode that Christian encounters Ignorance's early counterparts, 'Formalist' and 'Hypocrisie' (The Pilgrim's Progress, pp. 39-41). 
avoid the trappings of a soterially deadly legalism clothing itself most dangerously in social forms of religious conformity, civility, and latitude prevailing in the Restoration period. ${ }^{33}$ What Ignorance's doctrine evinces is the seductiveness, in Bunyan's terms at least, of Edward Fowler's religious moralism that is worldy and without redemption, legalism writ new and sanctioned by both the established church and, it seems, society at large: as By-ends professes of his own convictions, in The Pilgrim's Progress Bunyan is writing against those 'most zealous when Religion goes in his Silver Slippers'. ${ }^{34}$

In condemning the cultural shift towards a religion of moralism, Bunyan is, moreover, defending a theology of grace which the likes of Ignorance denounce and marginalise as 'but the fruit of distracted brains'. Christian's encounters with WorldlyWiseman, By-ends, and Ignorance do not simply exemplify doctrinal lessons in legalism and carnality, therefore, but a serious clash between Bunyan's Nonconformist faith and his society's growing religion of morality and civility. Reading Bunyan's allegory in terms of a doctrine of grace thus emphasises not only the dryly doctrinal need for a 'true' faith but places that need within a specific cultural context. By taking the text as evincing a harsh doctrine of predestination, we can get no sense of Bunyan's theology as offering hope and comfort to the believer burdened not only by guilt but by a more political and specifically Nonconformist conscience in a time of continued persecution. By reading according to the doctrine of Law and grace, however, we can begin to address the theology of The Pilgrim's Progress not only conceptually but culturally as very much a part of Bunyan's political world.

But in refuting predestinarian prejudices in approaches to The Pilgrim's Progress it is equally important to note that the text itself, like Grace Abounding before it, actually

\footnotetext{
${ }^{33}$ Richard Draper views Ignorance as 'a disciple of Natural Religion' whose belief 'may be summarized as an humanitarian faith in justification by philanthropic works and a sentimental faith in the innate goodness of his heart.' Draper thus concludes that in his depiction of Ignorance, Bunyan 'is expressing the evolution of bourgeois thought of the late seventeenth century from Calvinism to Deism and Sentimentalism': 'Bunyan's Mr. Ignorance', Modern Language Review, 22 (1927), 15-21 (pp. 18, 21). Isabel Rivers's work on Bunyan and Latitudinarianism reflects and supports such a reading, viewing the doctrine of The Pilgrim's Progress as inherently in conflict with late seventeenth-century religious moralism: see 'Grace, Holiness, and the Pursuit of Happiness: Bunyan and Restoration Latitudinarianism', in John Bunyan: Conventicle and Parnassus, Tercentenary Essays, ed. by N. H. Keeble (Oxford: Clarendon Press, 1988), pp. 45-69. See also Thomas H. Luxon's excellent analysis of Bunyan's Mr. Ignorance in, Literal Figures: Puritan Allegory and the Reformation Crisis in Representation (Chicago and London: University of Chicago Press, 1994), pp. 182-185 (esp. p. 184).

34 Bunyan, The Pilgrim's Progress, p. 99.
} 
encourages the reader to avoid framing one's thoughts about salvation and damnation within the compass of a foreordained election and reprobation in the first place. One of the principal hazards of reading The Pilgrim's Progress in terms of predestination is that, as Grace Abounding evinces, it can lead the reader into a maze of paradoxical syllogisms. Stuart Sim, whose own interpretation embraces the paradoxes of predestinarian theology as central to Bunyan's narrative art, illustrates this a-mazing consequence quite effectively. For Sim, the case of Ignorance's damnation, to cite a good example, is clearly the result of this character's inability to negotiate the antilogies of a Calvinist doctrine of predestination: because ' $[t]$ he only certainty that the Calvinist can countenance as regards individual consciousness of salvation, is the certainty of its uncertainty', then in his lack of soterial anxiety 'Ignorance signals his reprobation as much by his failure to observe the contradictions of Calvinist soteriology as anything else [...]. In the dialogue on salvation,' he asserts, 'Ignorance's simple faith is confounded by Calvinist deviousness of reasoning.'35

While Sim's analysis ignores this dialogue's unmistakable emphasis on justification by faith, his conclusions on the matter of Ignorance's damnation reveal that a profound 'deviousness of reasoning' is also required of the text's reader in order to make sense of its doctrine: hence,

Ignorance's blend of under-despairing and over-presumption involves a state of psychological equilibrium foreign to the Calvinist mind. Engagement with the paradoxes [of predestination] demands that awareness of the contradictories to one's present psychological condition must always impinge, such that presumption becomes merely a prelude to the inevitable onset of despair, and despair to presumption, in an endless series of bewildering transitions; the result being what Royce, in his analysis of Bunyan's psychology, has called the 'chaos of motor processes' of the author. ${ }^{36}$

What is disconcerting about this approach is, on the one hand, its devolving into psychological commentary: the Calvinist believer is apparently subject, through harsh doctrine alone, to immense mental instability, a concept not too far removed from Ignorance's own assertion that Christian's Nonconformist faith is similarly but 'the fruit of distracted brains'. At the same time, Sim's presentation of Bunyan's faith as inexorably paradox ridden, leading its pilgrims into 'an endless series of bewildering transitions',

35 Sim, Negotiations With Paradox, pp. 57, 58.

${ }^{36}$ Sim, Negotiations With Paradox, pp. 59. 
smacks too uncomfortably of the labyrinth of predestination that Calvin warns against in Institutes of Christian Religion, and which Bunyan reveals as spiritually nightmarish in Grace Abounding. In fact, just as Bunyan's autobiography teaches the reader to avoid the amazing consequences of a doctrine of predestination, it seems that a central tenet of the didactic structure of The Pilgrim's Progress is similarly to reinforce this same narrative and doctrinal lesson through the depiction of Christian's journey of grace and mistaking.

In fact, it is just Sim's Calvinist 'deviousness of reasoning', the rational contemplation of one's elect status, that is particularly warned against throughout The Pilgrim's Progress (despite the Apology's perhaps misleading assertion that in reading the lines of this text the reader will 'know whether thou art blest or not'). It seems significant, for example, that Christian's initial out-cry at the beginning of his journey is 'What shall I do to be saved?' and not how do I know I am saved. While John Knott would like to explain this issue in terms of The Pilgrim's Progress being concerned mostly with 'the process of sanctification' (whereas Grace Abounding 'turns on the question of justification'), it seems more important for readers simply to take note of how Christian's quest for salvation begins from the start - it is a journey of experience (doing), not one of rationalising about one's elect status (knowing). ${ }^{37}$ Christian's out-cry thus signals the desire for action, the will to come and believe (something which can only be explained with some ingeniousness in terms of predestination). But it is also clear that, as in Grace Abounding, the spiritual business of 'knowing' is nevertheless a crucial issue in Bunyan's narrative of Christian's progress, particularly in relation to how this protagonist and his allegorical counterparts often confuse the term's meaning (and not without some a-mazing effects either).

Talkative is, of course, perhaps the best example to illustrate this issue of 'knowing', revealing his reprobate nature not only by wilfully separating talking and doing but by mistaking different types of 'knowing' completely. Indeed, Talkative is able neither to distinguish between conceptual 'knowing' (learned through conversation) and experimental 'knowing' (gained through religious conversion) nor, as Christian puts it, to connect 'the Soul of Religion' with its 'practick part'. That Talkative finds such distinctions a-mazing is

37 John R. Knott, Jr., The Sword of the Spirit: Puritan Responses to the Bible (Chicago and London: University of Chicago Press, 1980), p. 142. 
revealed not only in his final disgust with the ungenerous conversation of his fellow pilgrims but, moreover, in his difficulty in differentiating between the two forms of knowing exemplified in Faithful's discourse: there is, Faithful assures us, 'knowledge and knowledge. Knowledge that resteth in the bare speculation of things, and knowledge that is accompanied with the grace and faith of love.' 38 Distinctions between 'knowledge and knowledge' here, then, rest in a doctrine which extends beyond the surface significance of words that provides the epistemological basis of Talkative's doctrinal comprehension: when it comes to the matters of faith and salvation, Talkative is literally all talk.

For the faithful, on the other hand, such distinctions are obvious, Talkative's conversation thus re-enacting the same faithless conceptual error that Formalist and Hypocrisie famously make about the 'way'. As these false wayfarers memorably declare to Christian, 'so be we get into the way, what's matter which way we get in; if we are in, we are in: thou art but in the way, who, as we perceive, came in at the Gate; and we are also in the way that came tumbling over the wall: wherein now', they ask, 'is thy condition better than ours?' 39 This certainly is a deviousness of reasoning and its relevance to Formalist's and Hypocrisie's later counterpart, Ignorance, is clear. But what signals the reprobate nature of these inveterate wall-tumblers is, more than anything, their refusal to consider the nature of the way experimentally. Like Talkative, they have a merely notional sense of being in the way and, in contriving to make the way one of laws and ordinances, of works and not faith, they deliberately confuse not only the literal and metaphorical sense of the way that Stanley Fish celebrates as indicative of the text's imaginative self-referentiality but refuse to understand the way as a way of grace alone - they do this, moreover, in a discourse which is conceptually a-mazing and yet utterly reasonable. ${ }^{40}$

Although there is much that can be learned from Faithful's dialogue with Talkative, and though Christian resists entanglement in the maze-like equivocations of Formalist and Hypocrisie concerning the way, nevertheless elsewhere we do find Christian himself failing

\footnotetext{
38 Bunyan, The Pilgrim's Progress, p. 82.

39 Bunyan, The Pilgrim's Progress, p. 40.

40 See Stanley E. Fish, Self-Consuming Artifacts: The Experience of Seventeenth Century Literature (Berkeley, L. A. and London: University of California Press, 1972), pp. 227-229. For a similar reading, see also Thomas H. Luxon's insightful comments on the likes of Talkative, Formalist and Hypocrisie in Literal Figures, pp. 171178, and (though largely the same argument is being presented) in 'The Pilgrim's Passive Progress', pp. 73-98.
} 
to sustain the Calvinist condition of spiritual teachableness (alien to the likes of Talkative and Ignorance) necessary to remain in the true way of faith. While his early diversion by Worldly-Wiseman can be excused in terms of the young convert-to-be's doctrinal naiveté when faced with the seductive sophistry of this tempter's 'civil' discourse (and it is seductive precisely because its moralism so authoritatively apes Calvin's discourse in warning of how 'weak men, who meddle with things too high for them, do suddenly fall into [...] distractions'), Christian's later lapses in understanding serve to re-instruct him (and the reader) most importantly about the nature of 'knowledge and knowledge' in one's spiritual pilgrimage, particularly in terms of one's status as elect or reprobate.

Such re-edification, for instance, comes no clearer than in Christian's and Hopeful's encounter with the Shepherds of the Delectable Mountains. The initial exchange between Christian and the Shepherds is, indeed, particularly a-mazing (in both style and content) for both reader and pilgrim alike:

Chr. Is this the way to the Celestial City?

Shep. You are just in your way.

Chr. How far is it thither?

Shep. Too far for any, but those that shall get thither indeed.

Chr. Is the way safe or dangerous?

Shep. Safe for those for whom it is to be safe, but transgressors shall fall therein. ${ }^{41}$

While one observer likens the Shepherds' responses to 'the equivocations of a Buddhist master', such riddling is clearly in-line with the puzzling prevarications of Bunyan's initial Apology, of Formalist and Hypocrisie's reasoning on the way, and of Faithful's discourse with Talkative. ${ }^{42}$ What is striking about this exchange, however, is not only the evasiveness of the Shepherds' answers but the apparent harshness of them too. As such, commentators traditionally cite the Shepherds' responses here in stressing the severity of Bunyan's Calvinist doctrine as a whole. For A. Richard Dutton, 'safe for whom it is to be safe [...] is predestination in its baldest terms', just as Stuart Sim asserts that 'there is an entire theological position encapsulated in that line, one unmistakably based on the Calvinist

\footnotetext{
${ }^{41}$ Bunyan, The Pilgrim's Progress, p. 119.

42 Carolyn Van Dyke, The Fiction of Truth: Structures of Meaning in Narrative and Dramatic Allegory (Ithaca and London: Cornell University Press, 1985), p. 179.
} 
doctrines of election and justification by faith, that is central to Bunyan's narrative practice.' 43 John Stachniewski takes this approach even further, however, by proposing that the sights shown to the pilgrims by the Shepherds are specifically engineered to induce further anxiety over one's elect status: 'the terror of the inauthenticity of elect experience is what impels the pilgrims forward. It is to secure this effect,' Stachniewski contends, 'that the euphemistic "wonders" were put on show.' Here, '[t]he familiar system of mind control, playing on fears of hypocrisy and rejection, is being practised,' he writes, 'on the contemporary reader as well as the characters.' 44

But is it really the intention of the Shepherds (and of Bunyan) to induce anxiety over one's soterial status? Hasn't Grace Abounding already taught us that interrogating the self in terms of damnation and salvation inevitably leads to a torturous and tortuous reasoning, a sliding into the labyrinth of predestination? Yet, if this is so, how do we equate the harsh implications of the Shepherds' answers with this didactic cautioning? One way of doing so is to follow John Knott's suggestion that this episode merely reflects and reinforces 'the subjectivity of the way of faith': 'To give definite answers to the pilgrims' questions would be to ignore the uncertainty with which faith must live.' Thus:

The response of the shepherds to Christian's inquiries has the [...] effect of turning the questions back on the questioner, though they can offer no assurances that Christian will get anywhere at all, because they are talking about a metaphorical way that depends upon a faith that may collapse at any moment. ${ }^{45}$

Such a response, however, seems to imply but a milder admission of the Calvinist will-touncertainty, and the fact that the way of faith may give way beneath one's feet at any time. But in any case, the issue at stake is far greater than that of a metaphorical understanding of the way per se. Christian is indeed in danger of falling into soteriological a-mazement here not because the Shepherds' replies are simply baffling but because his mode of questioning demands such equivocating answers. Christian's interrogations here are, like the discourses of Talkative, Formalist and Hypocrisie beforehand, dangerously governed by a worldly epistemology: he is asking the type of questions that Calvin warns against asking and is

\footnotetext{
${ }^{43}$ Dutton, 'Interesting, but tough', p. 449. Sim, 'Safe for Those for Whom it is to be Safe', p. 149.

44 Stachniewski, Persecutory Imagination, p. 207.

${ }^{45} \mathrm{Knott}$, The Sword of the Spirit, pp. 141-142.
} 
attempting to consider the way not in spiritual but in carnal terms. Christian's overriding need, therefore, is to know in a very worldly sense if he is geographically and situationally secure ('Is this the way [...]?' and 'How far is it thither?') before, and without getting the hint, boldly asking whether the way is 'safe, or dangerous'. In doing so, as Thomas Luxon points out, 'Christian gives every indication that he has not yet relinquished his carnal notions of the outward thingness of the way', Christian's need for certainties thus prompting the kind of questions that 'must also prompt doubtful answers.' 46 The Shepherds responses, therefore, are geared not to induce anxiety over one's elect status (although to a rationalising pilgrim this could quite conceivably be the result) but to thwart such epistemologically and carnally determined reasonings from the outset: they tell the pilgrims that there are no worldly answers to the questions they are asking. Significantly, this tactic seems to work, too: the dumbfounded Christian and Hopeful query the Shepherds no further about the way from this point onwards.

But learning to avoid the labyrinth of predestination is often a painful process for Christian. Indeed, what his education by the Shepherds of the Delectable Mountains seems to emphasise is that it is not one's status as elect or reprobate one should be anxious about but rather the spiritual implications of one's complacencies in other areas of one's spiritual journeying - particularly that of hermeneutics. For example, the Shepherds' discourse merely emphasises, as one commentator has recently observed, that because '[h]uman understanding cannot comprehend the pure reality of God [...] any claim to absolute knowledge must be indicative of hermeneutic delusion.' In The Pilgrim's Progress, therefore, '[o]nly reprobates are confident of their own capacities to read and understand.' In this way, Protestant allegory could be said to valorise 'uncertainty in interpretation' but not necessarily the uncertainty of one's election. ${ }^{47}$ It is in this sense, then, that the pilgrims' experiences in the Delectable Mountains provides a particular form of much needed re-instruction. It is important to note, for instance, that the 'wonders' shown here are not dissimilar to the spiritually edifying visions revealed in Interpreter's House, the Shepherds' teachings thus acting to humble the

\footnotetext{
${ }^{46}$ Luxon, Literal Figures, p. 183.

47 Deborah L. Madsen, Rereading Allegory: A Narrative Approach to Genre (London: Macmillan Press, 1995), p. 104.
} 
pilgrims in terms of any interpretive complacencies they may have acquired (or re-acquired) along the way. Hence, as the pilgrims are shown the sights to be seen on their tour of the Delectable Mountains, Christian's questions become more simple ('What means this?', he now repeatedly asks) and, after having been taught some significant lessons, the pilgrims leave the Mountains praising the Shepherds in song as being supreme hermeneutic instructors: 'Thus by the Shepherds, Secrets are reveal'd', they carol forth, 'Things deep, things hid, and that mysterious be.' 48

That Christian needs such lessons both in matters of predestination and interpretation is evinced not only by his initial (and dangerously rational) questions about the way but, more seriously, by the a-mazing consequences of an earlier, almost unremarkable episode: the pilgrims' judgement on the monument of Lot's wife. This particular encounter is so important to The Pilgrim's Progress, however, because there are specific aspects of it which, from the outset, should alarm the reader into reconsidering what would otherwise appear to be a benevolent and unexceptional (if a little self-congratulatory) conversation between Christian and Hopeful. The initial warning sign for the wary reader, for instance, is that the memorial for Lot's wife is described by the narrator as a 'sudden and amazing sight' (my emphasis) from which arises the 'discourse' following. Yet it would seem that Lot's wife causes the pilgrims (and the reader) little interpretive amazement at all, being expounded upon easily and conclusively before the way rewardingly brings them by a 'pleasant River' for rest and spiritual nourishment. Yet it is in the very method of this discoursing that the pilgrims' fault finally lies. The reader should be doubly alarmed, for example, at Christian's last words on the matter of the monument:

And it is most rationally to be concluded, that such, even such as these are, that shall sin in the sight, yea, and that too in despite of such examples that are set continually before them, to caution them to the contrary, must be partakers of the severest Judgements. ${ }^{49}$

The emphasis here, as throughout the discoursing, is not only upon 'severest Judgements' but upon rational conclusions and, as both Grace Abounding and Calvin's Institutes teach, such reason can often lead men into mazes of their own spiritual

\footnotetext{
48 Bunyan, The Pilgrim's Progress, pp. 119-123.

49 Bunyan, The Pilgrim's Progress, pp. 109-110 (my emphasis).
} 
considerations. Nevertheless, though, the accent in this episode is just upon such use of reason, with Christian's lawyer-like (and therefore dangerously legalistic) summing-up here, comprised of complex clauses and sub-clauses, smacking not a little of pompous sophistry and heartless rhetoric. Indeed, what the monument initially represents to the pilgrims is little more than a puzzle to be solved through logical deduction alone: they are attracted to 'the strangeness of the form thereof' and are 'concerned' by it. After spying the monument's marginal gloss in 'a Writing in an unusual Hand', moreover, the stress is immediately placed upon reason and knowledge: Christian is called upon as one who 'was learned' not only to pick out the letters but 'to pick out the meaning' (my emphasis). What follows is a discourse based not upon faith, grace, and forgiveness, then, but on reason and conclusions of God's mercilessness. A-mazing (and distressing) consequences follow hard upon this episode (in the gruesome form of despair) not simply because the pilgrims' reveal themselves to be spiritually complacent here but because they read the monument of Lot's wife epistemologically instead of grace-fully or, as Stanley Fish might put it, by the light of reason rather than by the light of faith.

Not only do the pilgrims reveal a somewhat disconcerting reprobate certitude in interpreting the monument of Lot's wife, but, according to Fish, are supremely at fault, moreover, for contriving 'to turn remembering Lot's wife into a forgetting of mercy and therefore when they lead themselves out of the way, they have no mercy left for themselves'.50 This self-enactment of the 'severest Judgements', Fish insightfully notes, ultimately manifests itself, of course, in the horribly tangible form of Giant Despair and the pilgrims' imprisonment in Doubting Castle, an episode which Fish views as the inevitable result of the Christian's earlier severe conclusions on Lot's wife. Bunyan's point all along, therefore, is that the pilgrims' legal and logical discourse on Lot's wife does indeed lead to spiritual despair: with a typical but subtle word-play, the pilgrims' earlier conversation rationally and effectively dis-pairs sin from forgiveness, severing the unity of God's

50 Fish, Self-Consuming Artifacts, p. 255. 
covenants, and the wholeness of the Old and New Testament doctrine made one through grace and faith. 51

It is for this reason that, coming immediately after their miraculous escape from Doubting Castle, the re-instruction of Christian and Hopeful by the Shepherds in matters of mystery and interpretation is finally so important. In fact, it is precisely because of the pilgrims' prior trespass into despair that the Shepherds are so unwilling to let such complacency go uncorrected, either in the text's protagonists or in its reader. Consequently, among the truly fearsome visions that the Shepherds show the pilgrims we are offered one of the most powerful and terrifying emblems of spiritual a-mazement in all of Bunyan's works. The pilgrims are taken 'to the top of another mountain' the name of which, significantly, is 'Caution', and from which

they perceived, as they thought, several men walking up and down among the Tombs that were there. And they perceived that the men were blind, because they stumbled sometimes upon the Tombs, and because they could not get out from among them. ${ }^{52}$

These blind wanderers are apparently lost within an appalling spiritual wasteland. As such, this vision represents nothing less than a chilling, spatially-inverted image of the Man in the Iron Cage witnessed much earlier by Christian in Interpreter's House: such sightless and confused wandering on Mount Caution is but the figure of the Man's imprisonment in despair turned inside-out. ${ }^{53}$ That such a connection is relevant is made clear upon Christian's asking the Shepherds, 'What means this?', to which he is, this time, given an alarmingly unequivocal answer. These blind men 'came once on Pilgrimage', he is told, and, like Christian and Hopeful, had trespassed into By-Path Meadow only to be taken (as they were)

\footnotetext{
51 Maureen Quilligan makes this point effectively about Spenser's Redcrosse Knight in his encounter with Despaire in The Faerie Queene: 'Despaire is not simply the personification of the lack of hope, which is what his name means etymologically (de-spero), he is one who "dispairs" the natural wholeness of Christian teaching. By emphasising the Old Testament virtue of justice to the exclusion of the New Testament virtue of love or mercy he [Despaire] "dis-pairs" this true pair of testaments' (The Language of Allegory: Defining the Genre (Ithaca and London: Cornell University Press, 1979), p. 36).

52 Bunyan, The Pilgrim's Progress, p. 121.

53 Interestingly, the narrative of Francis Spira (which, as Grace Abounding relates, Bunyan had read and upon which the emblem of the Man in the Iron Cage is based, presumably) repeatedly instructs its reader to avoid despair through the example of its protagonist whose fate is likened in the narrative's concluding note to the pillar of 'Lot's wife'. Moreover, what is driven home in the narrative of Francis Spira is the warning 'to take heed of Spira's principall Errors; which were, to dispute with Satan over-busily in time of weakness; especially to reason, and conclude from present sense, to Gods past Reprobation, and future Damnation; both of which is hard, if possible, for any man to determine': A Relation of the Fearful Estate of Francis Spira in the year 1548 - compiled by Nathaniel Bacon (London: 1649), pp. 78-80.
} 
by Giant Despair who 'did put out their eyes, and led them among these Tombs, where he has left them to wander to this very day.' The doctrinal point here is driven home by Bunyan through the use of a spatial image for spiritual distraction, despair procuring an endless roaming in a maze of living death. Evidently, the Shepherds use this vision to reinforce what may appear to be the providence of God's severest judgements - such a vision is presented, apparently, to fulfil 'the saying of the wise Man [...], He that wandereth out of the way of understanding, shall remain in the Congregation of the dead.' But the more important point to recognise, however, is that the blind men represent something very different from the harshness of God's judgements (or those of a Calvinist predestination). Rather, the emphasis is finally upon remaining in 'the way of understanding'. Here, as in Grace Abounding, understanding becomes the 'way' in itself. Consequently, there is no complacent and rationalised discourse from the pilgrims now. More simply, 'Christian and Hopeful looked one upon the other, with tears gushing out; but yet said nothing to the Shepherds.' 54

It is through episodes such as Christian's lessons amidst the Delectable Mountains that we can discern a process of grace-ful reading emerging in The Pilgrim's Progress which, it seems, must be observed by both pilgrim and reader alike in order to stay within the 'way of understanding'. What is emphasised in The Pilgrim's Progress at this point, for example, is that it is simply inappropriate to consider 'the mind of Christian' as containing 'little besides the doctrines of election and reprobation', or that 'Christian devotes most of his energy to sizing up the meaning, in the light of the decrees of election and reprobation, of each step of the journey.' 55 Christian's pilgrimage is not so obsessively informed by an anxiety over his own soterial destiny. As his dialogue with the Shepherds reveals, seeking such knowledge is simply discouraged through the maze of equivocations that such a questioning naturally leads one into. What is more important both for Christian and the text's reader is, therefore, one's education in matters of understanding. The fact that Christian and Hopeful move amongst the Delectable Mountains from the hill of 'Errour' to a hill called 'Clear' (whereupon they manage shakily to perceive the gates of the Celestial City through the 'Perspective Glass' of

\footnotetext{
54 Bunyan, The Pilgrim's Progress, p. 121.

55 Stachniewski, Persecutory Imagination, p. 167.
} 
the Word) is, for example, emblematic of the progress in spiritual understanding, or grace-ful reading, that The Pilgrim's Progress in its entirety both requires of and cultivates in its reader. What Christian learns from his experiences between discerning the monument of Lot's wife and the visions of the Delectable Mountains, therefore, is not a lesson in predestination but in interpretation, a type of doctrinal reading that requires an understanding of grace and forgiveness, not merely notionally but experimentally and which The Pilgrim's Progress's reader is required, in turn, to bear in mind both in terms of the text itself and his or her own spiritual condition.

What the text thus teaches the reader is that interpreting the texts of the Word and the self in the light of a faith in a doctrine of grace is inseparable from a revolution in what Fish refers to as one's 'perceptual habits'.56 What The Pilgrim's Progress continually emphasises, in fact, is that interpreting and understanding correctly in spiritual matters is subject to and conditional upon an experimental knowledge of faith in grace that has little to do with conventional processes of rationalisation or epistemology. Indeed, it is for this reason that a character like Talkative is given such an important role in The Pilgrim's Progress and why, consequently, it is crucial not to misunderstand the significance of this kind of character within the didactic scheme of the allegory as a whole. For instance, far more insidiously than the more unassuming Mr Ignorance, Talkative is presented by Bunyan, initially at least, as somewhat doctrinally faultless. After discoursing finely (as the sarcastic marginal note puts it) upon 'the necessity of the New-birth, the insufficiency of our works, the need of Christs righteousness, \& $c .^{\prime}$, he bravely goes on to claim that
Alas! the want of this is the cause that so few understand the need of faith, and the necessity of a work of Grace in their Soul, in order to eternal life: but ignorantly live in the works of the Law, by which a man can by no means obtain the Kingdom of heaven. [...] For a man can receive nothing except it be given him from Heaven; all is of Grace, not of works: I could give you an hundred Scriptures for the confirmation of this. ${ }^{57}$

So convincing and articulate is Talkative in matters of Law and grace and in the knowledge of all things spiritual that, even when challenged by Faithful's assertion that 'Heavenly knowledge of these, is the gift of God; no man attaineth to them by humane

\footnotetext{
56 Fish, Self-Consuming Artifacts, pp. 1-4, 237.

57 Bunyan, The Pilgrim's Progress, pp. 76-77.
} 
industry, or only by the talk of them', he can respond both confidently and knowledgeably, quite nonplussed. In fact, it is only when he reveals a lack of differentiation in all matters religious, evinced in his willingness to talk of anything 'Moral' or 'Evangelical', 'Sacred' or 'Prophane', that Faithful begins 'to wonder' about this pretty man. But it is in the context of Talkative's discourse on profiting 'by such things in our talk', with its emphasis on gaining knowledge about spiritual matters through talk alone, that Faithful's most important sermon on knowledge and knowledge arises. Talkative is revealed as a false pilgrim not simply for separating talking from doing but because his spiritual knowledge is not spiritual at all but wholly carnal and notional. Faithful's discourse on knowledge is so extensive, therefore, precisely because Talkative has no experience of the religious doctrines he verbally adheres to. Thus, Faithful's assertions that true knowledge is a gift that no man may attain through his own efforts and that 'A man may know like an Angel, and yet be no Christian' address not so much a difference between talking and doing, or even Fish's distinction between reason and faith, but the contrast of two important types of understanding evinced throughout The Pilgrim's Progress - the epistemological and the ontological, the notionally known and the spiritually experienced.

While Talkative refuses to be lectured in matters of epistemology and ontology, of knowledge and knowledge, Christian, it seems, never stops learning to understand such a crucial difference, as his interpretation of the emblem of Lot's wife reveals. Unlike Talkative, however, Christian (along with the reader) has the benefit of a more formal and experimental education in grace-ful understanding through his earlier, most important visit to the House of the Interpreter. It is here, for instance, that Christian learns most about the 'way of understanding' that the Shepherds, largely by re-enacting the emblematic lessons given in Interpreter's House, impress once more upon him. In general terms, therefore, Christian's experiences at Interpreter's House have traditionally been understood as representing a basic lesson in Puritan hermeneutics, Christian undergoing 'a crucial confrontation with the Word as it was understood within Puritanism', signifying the type of interpretive ability necessary for any successful pilgrimage. ${ }^{58}$ Because it is after this episode, moreover, that Christian

58 Kaufmann, The Pilgrim's Progress and Traditions in Puritan Meditation, p. 61. Alternatively, some commentators view Christian's education in hermeneutics with slightly different emphases: for David Alpaugh, 
loses his burden before the emblematic figure of the crucifixion (as if only able to do so after learning about interpretation in general), Christian's experience in Interpreter's House seems to indicate a distinct growth in this pilgrim's faithful hermeneutics. Thus, as U. Milo Kaufmann has most persuasively argued, in Interpreter's House Christian learns to interpret in a saving way: lead by the Holy Spirit (Interpreter) into the Word with the aid of 'Illumination' (the candle), Christian's understanding is now guided emblematically by 'the hand of faith'. Indeed, what can be stressed here is that Christian's learning, more than anything, 'demands the constant exercise of faith', for it was only to faith 'that revealed interpretations could address themselves, and to faith the Spirit sealed interpretation as authoritative, the very word of God.' 59

But while such an analysis seems to point quite straightforwardly towards a sense of Christian's grace-ful (or at least faith-ful) reading, there are reasons why we should not take such an interpretation of interpretation in The Pilgrim's Progress for granted. Such an approach, for instance, largely side-steps the doctrinal importance of Christian's understanding of the visions shown to him in the significant rooms of Interpreter's House. If we are to understand that Christian is lead by the hand of faith in this episode, then it must be in terms of a particular faith - that of Law and grace. Thus, as one commentator puts it, Interpreter's sequence of emblems represents not Bunyan's method of illustrating a coming to terms with the Word as much as it provides a 'tool for dramatically representing the new covenant of salvation which Christian has entered in passing through the Wicket-gate. As such, it is an explicit representation of Bunyan's theology rather than a representation of theological method' that we are introduced to in Interpreter's House. 60

This is most obviously the case in the second vision Interpreter shows Christian, the Parlour full of dust which represents, in the most basic terms, a parable of the covenant theology embraced by The Pilgrim's Progress throughout: 'when the Gospel comes in the

\footnotetext{
for example, in Interpreter's house Christian learns to understand the 'emblems' that 'proliferate throughout the Pilgrim, becoming metaphors for experience as it is perceived by the elect', while Carolyn Van Dyke sees it as crucial for the pilgrim's progress in metaphorical understanding as a whole, a 'training in metaphoric vision which [Christian] clearly needs.' See David J. Alpaugh, 'Emblem and Interpretation in The Pilgrim's Progress', ELH, 33 (1966), 299-314 (p. 301), and Carolyn Van Dyke, The Fiction of Truth, p. 173.

59 Kaufmann, The Pilgrim's Progress and Traditions in Puritan Meditation, pp. 62-65.

${ }^{60}$ David Robinson, 'Bunyan's House of Interpreter and the Structure of The Pilgrim's Progress', Dutch Quarterly Review of Anglo-American Letters, 7 (1977), 100-113 (p. 102).
} 
sweet and precious influences thereof to the heart,' we learn, 'even as [...] the Damsel lay the dust [Original Sin violently agitated through the Law] by sprinkling the Floor with Water, so is sin vanquished and subdued, and the soul made clean, through the Faith of it'. ${ }^{61}$ From the imaginative and dramatic nature of this scene alone we are forced to recognise that, despite the traditional notion that Christian learns to interpret the Word here, it is clearly not the Word which is being presented to him by Interpreter. As Thomas Luxon notes: 'None of the seven emblem scenes in Interpreter's House represent specific Bible passages', and so we should recognise "that what Christian learns to read and interpret in the "Significant Rooms" is not, at least at first glance, the Bible.' 62

What Christian does learn at Interpreter's House is evidently a little more complex than Scriptural reading alone. After all, even such a one as graceless as Talkative can learn of Law and grace and boast of how he can offer over a hundred Biblical references to prove it. Rather, what is gained through Christian's tour of Interpreter's House is an experimental understanding of Bunyan's doctrines, an education involving more than 'historical' interpretation. Hence, Christian does not simply read the visions and emblems that Interpreter shows him but actually experiences them as events largely indistinguishable from the reality of his other encounters beyond Interpreter's House. What lies behind Christian's education here, then, is not merely interpretation but a fundamental change in his 'perceptual habits'. In Interpreter's House, Christian learns to read grace-fully not only Scripture but one's spiritual existence as a whole. As this involves a faithful understanding of Bunyan's covenant theology, what Christian gains from Interpreter is not so much a rational methodology of hermeneutics as 'a state of mind [...] most conducive to his maintaining a realistic faith', 'an attitude characterised by total dependence on God['s grace] and total distrust of human capabilities.' 63 Hence, while this non-rationalising frame of mind can be epitomised in various ways in Interpreter's House (as an ability to maintain both hope and fear simultaneously, for instance, or to distinguish between 'carnal sense' and 'things to come'), what Interpreter teaches Christian most is to read the world around him ontologically

\footnotetext{
${ }^{61}$ Bunyan, The Pilgrim's Progress, pp. 29-30.

62 Thomas H. Luxon, 'Calvin and Bunyan on Word and Image: Is there a Text in Interpreter's House?', ELR, 18 (1988), 438-459 (pp. 438-439).

${ }^{63}$ Robinson, 'Bunyan's House of Interpreter', p. 113.
} 
and experimentally as opposed to epistemologically and rationally. As Interpreter comments after revealing the second emblem of his House, the lesson Christian (and the reader) must learn to apply in interpreting not only The Pilgrim's Progress but one's entire spiritual life is that which is emphasised throughout the ontologically dominant spiritual narrative of Grace Abounding: 'For the things that are seen, are Temporal; but the things that are not seen, are Eternal'. ${ }^{64}$

As this point is made after an emblematic parable about Patience and Passion, it is clear that seeing with eyes of understanding in matters of the temporal and the eternal emphatically requires perseverance and long-sufferance, particularly as Interpreter goes on to note how 'things to come, and carnal sense, are such strangers to one another.' It seems, though, that Christian's education in matters of 'carnal sense' and things unseen is to begin more immediately through the very next image he is shown - that of the 'Fire burning against a Wall, and one standing by it always, casting much Water upon it to quench it: Yet did the Fire burn higher and hotter.'65 What is most interesting about this vision is the openness of its symbolism, the fact that the component parts of this emblem, like those in the other rooms so far, are apparently under-determined. It is in no sense obvious, for instance, prior to Interpreter's explanation of this vision, what the significance of this dramatic moving-picture is. In fact, while Interpreter goes on to answer Christian's 'What means this?' by offering a reading in terms, once more, of grace (the fire being a grace that can never be put out by the Devil), this emblem could so easily be interpreted in any number of other ways. If the water is taken as Gospel truth, for example, as it is represented in the first emblem of the dusty room, and the fire is understood as the innate corruption of man which, without grace, can lead the sinner only to hell's flames, this emblem could signify the dismal impossibility of man achieving salvation without divine intervention. But, equally, this emblem could be construed and re-construed in an almost endless variety of ways, including quite grace-less interpretations too. After all, this could be an image adopted to stress something far different from the reassuring constancy of grace that Interpreter offers: as with the monument of Lot's wife, this emblem could indeed be understood in harsher, less compromising terms of man's

64 Bunyan, The Pilgrim's Progress, p. 32.

65 Bunyan, The Pilgrim's Progress, pp. 32-33. 
total depravity, his inability to quench the fires of sin, and God's ultimately unmoving demand for justice.

The reason why Interpreter's reading finally reveals other interpretations as misconstrued relates, however, to the need to see that which is unseen. In the case of this emblem in particular, it becomes patently clear that no reading of this emblem can have full significance before we do indeed see that which is quite literally hidden from view: both Christian and the reader can only understand the vision fully when Interpreter reveals 'the back side of the Wall, where he saw a Man with a Vessel of Oyl in his Hand, of the which he did also continually cast, but secretly, into the fire.' Subsequently, the point of this lesson is, on the one hand, to show to Christian how 'it is hard for the tempted to see how this work of Grace is maintained in the soul': this is a strictly doctrinal lesson, therefore, about continuing in one's faith in a continual grace. On the other hand, though, it is also an emblematic fleshing-out of the need to interpret not merely according to what appears superficially and rationally to be significant (as Christian later interprets Lot's wife) but according to that which is 'Eternal' and which awaits revelation. What Christian learns about in Interpreter's House is, therefore, not an interpretation of the Word specifically but, more generally, an understanding of 'the Puritan concept of the experience of the Word', in terms of the visible and the invisible, the temporal and the eternal: it is a recognition synonymous with Faithful's distinction between notional and experimental knowledge, between 'grammar-knowledge, word-knowledge, concerned more with signs than the thing they point to' and a spiritual knowledge that transcends the rational and speaks of signs and images 'not on the eye, but in the heart.' 66

What is reinforced in Interpreter's House, then, is that for one such as Bunyan (and especially his reader) it is 'not enough to exercise reason; one had to learn to experience divine truth' in spiritual matters. While the Word inevitably needs interpreting, 'truly saving knowledge of God's Word involves more than interpretation; it must be experienced in the heart.' Interpreter thus gives a lesson not in interpretation but about interpretation, teaching that salvation cannot be had by 'hermeneutic exercise' alone, and indicating that it is

\footnotetext{
${ }^{66}$ Luxon, 'Calvin and Bunyan on Word and Image', pp. 449-450.
} 
Christian's 'experience of the word that finally delivers him of his burden.' Hence, 'Experience of the Word is the final goal in Interpreter's House; interpretation is merely the first step on the way to the goal'. ${ }^{67}$ It is for this reason that Kaufmann's understanding of Christian's growth in an interpretive knowledge in Interpreter's House is ultimately misguided, based as it is upon a Puritan revelation of 'Truth' that is pre-eminently rationalist: Kaufmann's assertion that in Puritan hermeneutics 'reason was no pawn of instinct or imbibed convention, no chance product of blind process [...]; it was the faculty which bore the stamp of the divine image, which God could address in revelation', has little place in the grace-ful scheme of Interpreter's House. Indeed, Kaufmann's reading insists that the emblems in the significant rooms are 'not tableaux but dramas' in the vein of the 'exemplary history of Scripture', 'parabolic drama, or event-as-example', the only function of which is 'to dramatize [a] simple rational truth' ${ }^{68}$

Even a cursory reading of the first (and in many ways most difficult) emblem in Interpreter's House stands to refute such a reasoning approach to understanding in The Pilgrim's Progress. Indeed, the 'Picture of a very grave Person' is unreasonably and hermeneutically problematic through its very simplicity: as the most 'static and twodimensional', the 'most emblem-like' of all Interpreter's lessons, more than any other 'it seems to invite interpretation rather than participation.' 69 Interpreter's explanation of the picture, however, is not so straightforward, opening with a series of riddling paradoxes reminiscent of the 'Author's Apology' to The Pilgrim's Progress: the grave (or 'brave', as the marginal note confusingly suggests) man in the picture, like the author whose allegorical thoughts 'breed so fast' producing the spiritually pregnant text in 'the bigness which you see', 'can beget Children, Travel in birth with Children, and Nurse them himself when they are born', Interpreter tells us. Although it is obvious that we are to understand the life-giving nature of this 'Man' in the spiritual terms of new-birth alone, nevertheless the specific identity of this figure (and consequently its meaning) largely remains elusive (despite Interpreter's fine explanation and the reassuring marginal note that we are in fact being given

${ }^{67}$ Luxon, 'Calvin and Bunyan on Word and Image', pp. 459, 456. See also, Literal Figures, pp. 188-189.

68 Kaufmann, The Pilgrim's Progress and Traditions in Puritan Meditation, pp. 58-59, 81-85.

${ }^{69}$ Luxon, 'Calvin and Bunyan on Word and Image', p. 452. 
'The meaning of the Picture.') Interpreter's instruction that 'the Man whose Picture this is, is the only Man, whom the Lord of the Place whither thou art going, hath Authorized, to be thy Guide in all difficult places thou mayest meet with in the way', explains very little at all about who this 'Man' actually is: he could be interpreted as much as a figure known to Bunyan historically (Gifford, his former pastor in the Bedford Church, or even Bunyan himself), a biblical figure (Paul or even Christ), or a figure represented within the allegory itself (Evangelist or Interpreter). ${ }^{70}$ None of these interpretations is necessarily wrong or even mutually exclusive. Like 'Bunyan's similitudes, this [emblem] is polysemic, capable of a remarkable number of interpretations', pointing to the fact that gathering an understanding upon a rationalist hermeneutic basis is not the point of entering Interpreter's House at all: 'Interpretation merely multiplies meanings; experience is what fuses these meanings together and transforms a host of figures into literal ("experimental") truth.'71

Although one commentator quite ingeniously suggests that the picture represents the Word itself 'in its power literally to gather all interpretations into itself', this particular emblem-text undoubtedly indicates the way that we are to understand the allegorical nature of The Pilgrim's Progress as a whole. Just as reading the picture stresses that interpretation is not synonymous with understanding, that grace-ful reading requires experience and not just conception, it evinces this necessary reliance on experience or ontology in the reader by foregrounding a basic interpretive hesitancy. Indeed, trying to understand the picture allegorically, as one reader puts it, 'performs a familiar function of analysis', but 'far from providing a closed system, it opens a dialectical space between the figurative and the literal.' As an allegory-in-miniature (and along with all of Interpreter's emblems), the picture destabilises conventional interpretive procedures and assumptions about reading by blurring interpretive distinctions between the literal and the metaphorical. Hence, what we learn

\footnotetext{
70 Bunyan, The Pilgrim's Progress, p. 29. See Sharrock's note on this emblem in The Pilgrim's Progress, p. 316; Robinson, 'Bunyan's House of Interpreter', pp. 101-103; Kaufmann, The Pilgrim's Progress and Traditions in Puritan Meditation, p. 62; Kiely, 'Angelic Discourse or Unstable Allegory?', pp. 123-125. The biographical emphasis of this picture seems especially strong given its imagistic echoing of Bunyan's account of his ministry in Grace Abounding: 'In my preaching,' he writes, 'I have really been in pain, and have as it were travelled to bring forth Children to God' (Grace Abounding to the Chief of Sinners, ed. by Roger Sharrock (Oxford: Clarendon Press, 1962), p. 89).

${ }^{71}$ Luxon, 'Calvin and Bunyan on Word and Image', p. 456.
} 
about reading here is that '[t]he efficiency of the allegorical equation', both in Interpreter's House and The Pilgrim's Progress in general, 'depends on its not being taken too literally or with too high an expectation of consistency' as the act of interpretation 'only partially literalizes the figurative terms [...] leaving on both sides of the figurative/literal equation some irreducible, uninterpreted residue of its opposite.' 72

The fact that there is more to understanding than interpretation and that the relationship between the literal and the figurative is always presented as 'radically unstable' in Interpreter's House thus allows us to reassess certain assumptions about The Pilgrim's Progress overall. The text's inherent complexity in its use of figurative language, for example, refutes any conception of The Pilgrim's Progress as 'an allegory that is too mechanically consistent and simple to work as a compelling narrative. ${ }^{73}$ Rather, it leads to a process of reading which, as celebrated by Stanley Fish and others since, requires a certain amount of resistance to conventional modes of interpretation from the outset. ${ }^{74}$ Hence, one commentator accurately describes Interpreter's House as being filled with 'holographs projected from the invisible world' that teach 'not merely doctrine but perception' and which, even while we view them empirically, 'transgress empirical limits, gradually redefining sight as the imaginative apprehension of allegorical meaning. ${ }^{75}$ But whereas Thomas Luxon views Christian's growth in altered perception as epistemological ('[e]ach successive Significant Room represents a progression from one epistemological level to the next', he writes), this pilgrim's progress is more accurately ontological in terms of acquiring an 'experimental understanding of his lessons.'76 As we have learned from Brian McHale's analysis of postmodernist textual strategies, interpretive hesitancy between the literal and the figurative is a basic way of foregrounding specifically ontological (in this case spiritually other-worldly) concerns. What is clear about both Interpreter's House and The Pilgrim's Progress, however, is that this process of learning to foreground the ontological over the

\footnotetext{
72 Kiely, ‘Angelic Discourse or Unstable Allegory?', pp. 124-125.

73 Kiely, 'Angelic Discourse or Unstable Allegory?', pp. 115, 122.

74 For an excellent analysis of Stanley's Fish's famous critique of The Pilgrim's Progress (and a re-playing of it), see Thomas H. Luxon, who views 'Fish's (non) method' of reading The Pilgrim's Progress as 'a barely secularized version of Bunyan's own anti-hermeneutics of experience': Literal Figures, pp. 159-169 (p. 169).

75 Van Dyke, The Fiction of Truth, p. 173.

76 Luxon, 'Calvin and Bunyan on Word and Image', p. 452, 454.
} 
epistemological, the spiritual over the rational, is not just being delineated through the actions of an allegorical protagonist who, as Quilligan notes, largely re-enacts the reader's own reading habits and the lessons to be learned. Rather, foregrounding ontology is embodied in the reader's experience of reading The Pilgrim's Progress as a narrative, in the way Bunyan presents Christian's journey, and no less so than in the episode of Interpreter's House itself.

It is, for example, not just the emblems within Interpreter's House that violate empirical limits and force the reader into a consideration of the text's ontological concerns but Christian's progress through the House as a whole. As Christian is led from the initial picture of the grave man to the rooms that follow, each successive 'emblem' becomes increasingly more transgressive of our epistemological expectations, to the extent that what Christian is being shown is often hardly emblematic at all. While the 'Parlour' being swept by a 'Damsel' is not just an image but an actual room which Christian can stand in, the later 'emblem' of the Man in the Iron-Cage of Despair is even less distinguishable ontologically either from Christian himself or any other figure in the main body of the allegory. Neither a static emblem nor a more fully humanised allegorical figure like Christian, this man's despair is emphatically restated by the representational opalescence of his condition: as Luxon puts it, 'having despaired of salvation [...] and denied the efficacy of scriptural promises, he has begun to turn into an emblem; he is on the way to becoming a personification of despair.' 77

What is interesting here, moreover, is that by this point (as all the way through Interpreter's House, perhaps) we are not encouraged to question the metaphorical or merely emblematic nature of the 'Iron Cage' in which the 'Man' is imprisoned: we are to accept it, rather, as both physical and spiritual, metaphorical and literal, present and not-present, opalescing between concrete and abstract frames of reference within the compass of the allegorical dream-narrative's representational parameters as a whole. In the case of the Man in the Iron-Cage of Despair, then, it seems that interpretation is not the point of Christian's lesson at all. Christian (along with the reader) is not being asked to ponder on the nature of the presentation of this emblem, nor on the remarkable fact that he can interact with it no

77 Luxon, 'Calvin and Bunyan on Word and Image', p. 454. 
differently from any other allegorical figure to be met on the 'way', nor on the status of this figure as empirically 'real' or not. Bunyan's point in this case is that the only ontological reality of any importance now is simply that of terrifying religious despair itself. As such, the Man in the Iron-Cage is to be understood according to a bare doctrinal didacticism that transcends the issue of learning about hermeneutics in this instance to teach a more immediate lesson about faith and faithlessness to the reader.

The fact that allegorical consistency is finally sacrificed in hammering home this warning about despair is particularly important for the reader to note, however, because in The Pilgrim's Progress it soon becomes evident that even the narrative and its allegorical frame can be contravened (and frequently is) in order to teach the reader more baldly about spiritual matters alone. Hence, Interpreter's House in its entirety seems to transcend all epistemological conventions merely through the fact that it represents an obviously impossible space: Christian not only repeatedly shatters the frame of the emblem texts he is shown by stepping into and communicating with them but is unperturbed even when shown a room that literally opens unto a whole other world, one inexplicably and impossibly containing 'a stately Palace, beautiful to behold' and which is guarded by a small army of men. ${ }^{78}$ In this way, we are never allowed any easy satisfaction in any interpretation of Interpreter's House itself which is, we soon realise, not to be read as a House at all but as a nonsensical place in which spiritual lessons alone are to be learned by reader and pilgrim alike.

Moreover, the ontological irregularities of Interpreter's House act to halt any interpretive complacencies the reader may be holding too. For example, Interpreter's House demolishes any sense that The Pilgrim's Progress is a realistic narrative mimetic of an empirically verifiable world, the rooms and Christian's experience of them merely reinforcing the fact that we are not allowed to get carried away in a reading of Christian and the world in which he inhabits as being drawn along lines of verisimilitude, despite the narrative being particularly verisimilar in other places. As such, Christian's distinct lack of surprise at Interpreter's House being structured like some postmodernist fun-house of infinite

${ }^{78}$ Bunyan, The Pilgrim's Progress, pp. 33-34. 
space and an apparently endless variety of rooms serves to remind us that his delineation as the realistic hero of his own life-story is never to be relied upon as absolute within the shifting, iridescent allegorical world of the text. ${ }^{79}$ While 'the continuous focus on a human protagonist' does indeed imply 'a realistic treatment of time and space, a respect for the empirical continuities', episodes such as Interpreter's House nevertheless remind the reader that the text finally acts to dislocate the kind of epistemological coherence usually associated with a 'realistic' or mimetic fiction through its 'tangle' of narrative and ontologically dominant referential frames. ${ }^{80}$

In this sense, the narrative construction of The Pilgrim's Progress evidently has more in common with a more contemporary kind of 'magic realism' than with the type of verisimilar naturalism usually associated with the rise of the novel in the seventeenth century and which reached its apotheosis in nineteenth-century fiction. Consequently, what Bunyan's depiction of Interpreter's House draws attention to most of all is, in fact, the convention of fictional verisimilitude in itself, The Pilgrim's Progress frequently 'exposing' its own 'artificiality' in order to emphasise not the realism of the fictive world it creates but the metaphysical 'reality' of the doctrine which it attempts to communicate. ${ }^{81}$ As with all metafictional and 'situationally self-referential' forms of fiction, therefore, The Pilgrim's Progress teaches its reader from the outset that conventional assumptions about realist fiction simply do not apply in its case. ${ }^{82}$

\footnotetext{
79 Both Kiely and Kaufmann have noted how Interpreter's House (and the text as a whole) has qualities of a fun-house, but not in a postmodernist sense. See Kaufmann, The Pilgrim's Progress and Traditions in Puritan Meditation, p. 84; Kiely, 'Angelic Discourse or Unstable Allegory', p. 127.

80 Van Dyke, The Fiction of Truth, pp. 160-161.

81 Wallace Martin, Recent Theories of Narrative (Ithaca and London: Cornell University Press, 1986; repr. 1994), pp. 69-70. In this extremely useful study of contemporary narrative theories, Martin suggests that realism in narrative bears three traits conventionally, all of which The Pilgrim's Progress largely (and often subtly) denies - that the central character is merely ordinary and yet universally representative, that it involves an objective form of narration, and that it invokes 'natural causality' (pp. 59-61). While the former two issues are debatable in relation to The Pilgrim's Progress, Stanley Fish's famous analysis (in Self-Consuming Artifacts) has more than adequately shown that Bunyan's allegory hardly conforms to a presentation of 'natural causality'. As self-conscious literary dream-vision, this is, of course, hardly surprising of The Pilgrim's Progress. Moreover, the temporality of cause and effect that Martin sees as essential to narrative and which fictive forms of 'plot' fundamentally share with the modes of autobiography and history is obviously problematic in terms of Bunyan's conscious negation of reading for the 'historical' parts (see Recent Theories of Narrative, pp. 71-80).

82 Martin, Recent Theories of Narrative, pp. 28, 175-178, 185-187. While Brian McHale's Postmodernist Fiction (London and New York: Methuen, 1987; repr. 1993), largely explores these issues, see also Patricia Waugh, Metafiction: The Theory and Practice of Self-Conscious Fiction (London and New York: Methuen, 1984; repr. 1985) for a further discussion of metafiction's relationship to 'realism' (pp. 1-19). For a discussion of conventions of realism and verisimilitude in narrative as relativistic in terms of any audience's concepts and
} 
Such narrative lessons recur, moreover, throughout the text. In case we have been too absorbed in the excitement of Christian's battle with Apollyon (albeit an episode more romantic than verisimilar in any case) we are nevertheless reminded that this is a battle fought on purely spiritual grounds by the restorative hand that 'came to him [...] with some of the Leaves of the Tree of Life' after Christian's victory is assured.83 Stanley Fish, within his own anti-rationalist reading of The Pilgrim's Progress, subsequently understands this event as indicative of a need to read according to the unseen: Christian is victorious in battle because he has maintained his faith in the face of 'the interpretive pressure of the evidence of things seen' evinced by Apollyon, and so the 'appearance of the hand, unbidden and unattached to anything in the visible landscape, is a dramatic validation of the lesson we have learned[...]: cause and effect are independent of the sequence of events and the operation of visible forces.' 84

But while, for Fish at least, this episode merely reinforces a sense of how reasonable reading practices are constantly confounded in Bunyan's allegory, the emergence of the healing hand also has a particularly odd effect textually. Firstly, it represents but another transgression of any verisimilar narrative frame: emerging from nowhere, it is a spectacular appearance either of the hand of faith or that of God but which is related, nonetheless, in particularly unspectacular and commonplace prose. This is, quite evidently, both an unusually usual event, it would seem. Secondly, the appearance of this hand represents not only Fish's lesson in resisting 'the interpretive pressure of evidence of things seen' but serves to undermine the whole basis of any typical fictive response to the story at this point through its deliberate complication of the text's literal and figurative frames of reference. Are we to understand this curative hand as an allegorised externalisation of Christian's spiritual healing, or as an actual hand reaching down from another world within the fictional realm of Christian's journey? Clearly, the hand can in no sense be made sense of in terms of being logically either literal or metaphorical, actual (real within the world of the narrative) or merely an allegorical representation of spiritual comfort. The hand is a supreme

beliefs about 'reality', see Menachem Brinker, 'Verisimilitude, Conventions, and Beliefs', $N L H, 14$ (1983), 253-267 (p. 255).

83 Bunyan, The Pilgrim's Progress, p. 60.

${ }^{84}$ Fish, Self-Consuming Artifacts, pp. 235-236. 
representational excluded middle, both literal and figurative, actual and metaphorical, possessing an ontological significance marking not the rationality of an epistemological representation but, for Bunyan at least, the ultimate reality of spiritual experience. Significantly, therefore, this hand is also a curiously powerful symbol of the role Bunyan himself plays in The Pilgrim's Progress as an unobtrusively intrusive author-narrator constantly contriving to make the reader always conscious of the fictive nature of his allegory, attempting to ensure that his feigning never overtakes the doctrine in the reader's reading of it.

Bunyan's depiction of this restorative hand represents much of what is central to Bunyan's allegorical art in The Pilgrim's Progress generally, his narrative practice here being very similar to some of the textual strategies that Brian McHale views as central to much postmodernist fiction and which evidently are in operation in Grace Abounding. The appearance of the hand, for instance, simultaneously illustrates a conscious iridescence, a hesitation between the literal and the metaphorical, as well as what McHale refers to as the 'rhetoric of contrastive banality' exemplified by the matter-of-fact style in which this singularly bizarre event is couched. It also illustrates a great sense of different ontological realms in collision or, in the case of the hand bearing healing leaves, intruding upon one another. Indeed, and above all else, the hand represents the reality (for those such as Bunyan, at least) of the spiritual world co-existing with and being inseparable from the physical world of everyday experience. The Pilgrim's Progress is thus structured around a series of these collisions or intrusions by the spiritual upon the physical, one of the best examples, as Stanley Fish notes, being Bunyan's presentation of the more verisimilar and this-worldly Vanity Fair, from which Faithful departs in a violent martyrdom spectacularly completed through the agency of a distinctly other-worldly flying Chariot that, suddenly appearing from a wholly different dimension, transports him safely to the Celestial City. ${ }^{85}$

As the fulfilment of Evangelist's words to the pilgrims not only to be 'faithful unto death' but to 'let the Kingdom be always before you, and believe steadfastly concerning things that are invisible', Faithful's majestic salvation is, then, but one of a number of

\footnotetext{
85 Bunyan, The Pilgrim's Progress, p. 97. For an excellent reading of Faithful's departure according to
} Bunyan's ontological poetics, see Fish, Self-Consuming Artifacts, pp. 248-250. 
structural and narrative incidents in The Pilgrim's Progress clearly aimed at discouraging a rationalist and realist interpretive approach in order to privilege a grace-ful or faith-ful reading of things unseen. As with Faithful, it is the reader who is also being encouraged to let 'nothing that is on this side the other world get within you' while reading The Pilgrim's Progress. ${ }^{86}$ The principal means by which Bunyan does this, as is clear from Faithful's ascension and Christian's battle with Apollyon, is to make its reader continually aware of The Pilgrim's Progress as a narrative that demonstrates an obvious self-consciousness about its own fictionality. In doing so, total absorption into the text-as-story becomes largely impossible (or at least difficult), Bunyan thus being able to drive his doctrine home in spite of the fable in which it is couched. Hence, the dreamer of the text's dream repeatedly shatters any illusion of being an objective narrator by discoursing with the very figures in his dream (in a way that mirrors Christian's position in Interpreter's House), while, in a particularly ingenious way (as Stanley Fish and Brain McHale both illustrate), the allegory offers a series of 'endings' that contravene what we may come to expect in terms of narrative closure, before offering a 'Conclusion' which, warning so explicitly about misinterpreting the text, cannot do anything other than make the reader pre-eminently self-conscious about how he or she reads it. ${ }^{87}$

In this way, The Pilgrim's Progress, from its opening 'Apology' to its final 'Conclusion', betrays a distinct metafictional agenda, revealing itself to be supremely concerned with 'an extreme self-consciousness about language, literary form, and the act of writing', 'a pervasive insecurity about the relationship of fiction to reality', and, 'a parodic, playful, excessive or deceptively naive style of writing.' The Pilgrim's Progress is metafictional, then, as it 'self-consciously and systematically draws attention to its status as an artefact in order to pose questions about the relationship between fiction and reality.' It does this, moreover, strictly according to Bunyan's metaphysics, abandoning the 'real world'

\footnotetext{
${ }^{86}$ Bunyan, The Pilgrim's Progress, pp. 97, 86-87.

87 Bunyan, The Pilgrim's Progress, pp. 154-164. On the importance of 'endings' in both The Pilgrim's Progress and narrative in general see, Fish, Self-Consuming Artifacts, pp. 260-261; McHale, Postmodernist Fiction, p. 109; Martin, Recent Theories of Narrative, pp. 83-85; J. Hillis Miller, 'The Problematic of Ending in Narrative', Nineteenth-Century Fiction, 33 (1978), pp. 3-7. For a discussion of 'situationally self-referential' narrative practices which, like Bunyan's 'Conclusion', encourage the reader to recognise that they have misread a text and to re-read it in a more informed way, see Martin, Recent Theories of Narrative, pp. 175-178.
} 
not 'for the narcissistic pleasures of the imagination' but in order to show, ultimately, how a reality of unseen things 'is similarly constructed, similarly "written" ' in a realm of faith.88

What The Pilgrim's Progress shares with contemporary metafictional writing (at least as those such as McHale and Waugh view it) is, moreover, a 'thoroughgoing sense that reality or history are provisional', that the world cannot be conceived as holding 'eternal verities' but, rather, only 'a series of constructions, artifices, and impermanent structures' (particularly, for Bunyan, in comparison to the permanency of the 'world that is to come'). In this sense, the 'materialist, positivist and empiricist world-view' upon which 'realistic fiction' is conventionally based is rejected by (or, perhaps, simply cannot be applied to) The Pilgrim's Progress. As a consequence, The Pilgrim's Progress seems both to question and subvert the conventions that typically correspond to a narrative depiction of reality based primarily on the seen and the this-worldly. As Patricia Waugh lists them, Bunyan's narrative practice necessarily involves a repulsion of conventions such as 'the well-made plot, [...] the authoritative omniscient author, the rational connection between what characters "do" and what they "are", the causal connection between "surface" details' and deeper 'laws of existence'. ${ }^{99}$ Such ur-postmodernist anti-narrative traits in The Pilgrim's Progress inculcate a mistrust of conventional interpretive procedures and frustrate expectations of it as a fable or romance. But central to all this, we should remember, lies Bunyan's foregrounding of the ontology of spiritual reality as the most important factor of all: a steadfast belief in 'things that are invisible' is precisely what, with all its concretising of metaphor and other-worldly experience and its narrative self-referentiality, lies at the heart of Bunyan's allegorical method.

But, for all its advantages in conveying and confirming things spiritual, Bunyan's adoption of an allegorical fictive form also bears some potential problems of response. How can Bunyan, for instance, ensure that it is the 'sweet truth' of his doctrine that is finally absorbed by the reader and not, more simply, a delight in his 'sweet fiction'?90 After all, for

\footnotetext{
88 Waugh, Metafiction, pp. 2, 4, 9, 18.

89 Waugh, Metafiction, p. 7.

90 The terms 'sweet fiction and sweet truth' are taken from William Cowper's Tirocinium, or, a Review of Schools (1784), 1. 136, in The Poems, ed. J. C. Bailey (1905), cited in N. H. Keeble, ' "Of him thousands daily
} 
all its raising of questions about reality, even metafiction is still fiction, in which case we might wonder how far the nature of Bunyan's allegorical feigning, no matter how it is buttressed by biblical precedent or self-consciously foregrounded as fictive, does finally endanger the validity of his presentation of 'reality' according to fiction's associations (for the 'Puritan', at least) with deceit and untruth, fantasy and fable. With these points in mind, it seems evident that Bunyan's panoply of textual strategies in The Pilgrim's Progress function not simply to re-orient the reader's mode of perception in terms of a theology of grace and a faith in things unseen but to discourage a wholehearted interest in reading for story alone. The anti-narrative strategies Bunyan utilises throughout the allegory are, therefore, just that: anti-narrative in the sense that they prevent an absorption into the fictional realm of The Pilgrim's Progress for its own sake.

The reader of The Pilgrim's Progress, for instance, may find any enjoyment of the 'plot' (which Wallace Martin denotes as the 'literary term' for 'narrative' and which constitutes 'a combination of temporal succession and causality' within a series of events) seriously hindered by some of its most basic structural features. ${ }^{91}$ As Stanley Fish has so eloquently and eruditely pointed out, it is precisely the causality and sequentiality of the 'plot' of Christian's 'progress' as a 'temporal organization' that is continually being undermined in Bunyan's allegory, both conceptually and textually. ${ }^{92}$ For example, Christian's constant and laborious recapitulation, throughout his journey, of experiences that the reader has already witnessed (and cannot have so soon forgotten), set amidst the long and wholly doctrinal dialogues around which the text as a whole is ostensibly structured, seems to frustrate the very unfolding of its 'plot' by having the narrative go back on itself continually. ${ }^{93}$ But, more than this kind of basic narrative repetition, we are even denied the most necessary feature of a good story in The Pilgrim's Progress, its happy ending, not only through the text's series of multiple conclusions but through the awful reminder of our own potential faithless failings in the damnation of Mr Ignorance. What purpose does this ending

Sing and talk": Bunyan and his Reputation', in Conventicle and Parnassus, pp. 241-263 (p. 248). Lines 131146 of this poem are also reprinted in The Pilgrim's Progress: A Casebook, pp. 51-52.

${ }^{91}$ Martin, Recent Theories of Narrative, p. 81.

92 See Fish's classic reading of Christian's meeting with Faithful for an example of this kind of conceptual turnaround: Self-Consuming Artifacts, pp. 225-227. Martin, Recent Theories of Narrative, p. 187.

93 Bunyan, The Pilgrim's Progress, pp. 21, 26, 41, 48-50, 74-75. 
to Christian's successful pilgrimage have other than to upset the reader in his or her moment of most narrative complacency?

But there are more subtle textual strategies than this that Bunyan adopts in order to prevent his reader from reading The Pilgrim's Progress for the 'historical part' alone. While Christian's repeated recapitulations of experience, for example, can be explained in terms of the value Nonconformists like Bunyan evidently placed upon continually communicating their spiritual lives to one another, it is not so easy to account for other kinds of narrative anomalies that frequently appear in The Pilgrim's Progress. A good example of such a narrative 'hole' lies in Christian's recounting at one point of how, as has happened to Littlefaith, 'these three Villains ['Faint-heart, Mistrust, and Guilt'] set upon me', a narrative wholly novel to the text's reader and one which, in itself, acts as a prelude to the further relation of Christian's encounter with their master, 'the King of the Bottomless Pit' (which may or may not be a reference to the battle with Apollyon). Because the reader has no knowledge either of this 'experience' with the three thieves or the subsequent 'battle' then, as Sharrock notes, Bunyan includes this detail 'at the risk of reporting his own narrative wrongly' ${ }^{94}$ Indeed, we may even begin to suspect that Christian may be something of a romancer himself when it comes to the telling of his own troubles. As a consequence, the effect of this newly revealed but otherwise unseen encounter is to undermine the reader's confidence not only in the story-teller but in the very idea that The Pilgrim's Progress has been a coherent and verifiable narrative all along. Because there now seem to be parts of The Pilgrim's Progress that operate autonomously beyond the reader's actual reading of the story itself, any sense of having a privileged and all-seeing perspective of the whole of Christian's journey is effectively destroyed.

Of course, it is equally important to recognise that The Pilgrim's Progress is hardly unique in demonstrating this kind of contravention of a reliable narratorial position or in its transgression of a sense of 'plot' as a distinctly unified movement 'from a stable beginning through complications to another point of equilibrium at the end.' As Wallace Martin points out, '[f]ew narratives if any display the tight-knit unity that Aristotle found in some plays', it

${ }^{94}$ Bunyan, The Pilgrim's Progress, pp. 129-130, and see Sharrock's editorial note, p. 334. 
being impossible, he suggests, to affix definite 'principles for narrative structure' at all largely because narratives, even from the earliest times 'have never really been characterised by the unity of action and meaning that critics find in them.' 95 As such, it is important not to stress too much that Bunyan's narrative practice in The Pilgrim's Progress is wholly unconventional. In fact, its inconsistencies could be seen as precisely conventional according to how narratives are often structured, it would seem. But even if we finally agree with Martin that any idea that 'narration involves a structural integration from beginning to end' is 'at best dubious', the textual incongruities of The Pilgrim's Progress are nevertheless important to note if only because they are, on the one hand, made so overtly conspicuous by Bunyan and, on the other, because they contravene so much of what we may expect of The Pilgrim's Progress as a narrative that seems, at least in certain respects, to assume a basic romance or fairy-tale structure largely dependent upon a stock source of fixed plot conventions. 96

By consciously exaggerating in The Pilgrim's Progress the kinds of narrative discrepancies that are natural to all forms of story-telling, Bunyan is, of course, not simply exploring the boundaries of his fiction but, more crucially, presenting his point about the need for grace-ful perception as clearly as possible to the reader. Hence, in the very act of reading of The Pilgrim's Progress, the reader is frequently required to abandon any faith in the text's narrative unity and read even the plot in terms of a faith in events which are empirically, or even narratively, unverifiable (as in Christian's 'encounter' with the three thieves). With our conviction in things unseen being apparently, if not unmistakably, incompatible with the very story that conveys it, reading The Pilgrim's Progress thus demands a negation of any sense of the text as embracing a conventional novelistic or mimetic narrative methodology, one that conforms to 'conceptions of narrative and history' dependent upon 'a shared set of assumptions about causality, unity, origin and end that is characteristic of Western thought.'97 Instead, what is required is an acceptance of The

\footnotetext{
95 Martin, Recent Theories of Narrative, pp. 81-85.

96 Martin, Recent Theories of Narrative, p. 84. For Martin's comments on how more rigid forms of plot and story do engender definite narrative and textual expectations (as in romance, for instance), see pp. 84, $166-167$. 97 Martin, Recent Theories of Narrative, p. 85. Here, Martin is largely paraphrasing J. Hillis Miller's argument in, 'Narrative and History', ELH, 41 (1974), 455-473 (pp. 460-461).
} 
Pilgrim's Progress in terms of a more 'Christian' notion of 'plot', one which is inherentiy 'haphazard, random in its order, heedless of visible cause and effect, episodic, inconclusive, consisting of events that are both reversible and interchangeable'. Because, moreover, this kind of conceptualisation of narrative finally rests upon 'a question of epistemology', in which 'knowing is exactly the opposite of what we naturally assume', then the conventional narrative forms of the rational, the seen, and the 'historical' (those of 'logic, subordination, definition, sequence') are subsequently revealed as 'conspicuously irrelevant to the meaning which overwhelms them' .98

In these terms, Coleridge's famous comment that The Pilgrim's Progress can be read 'with the same illusion as we read any tale known to be fictitious', that is 'as a novel' the characters of which are 'as real persons, who have been nicknamed by their neighbours' seems somewhat problematic. ${ }^{99}$ It seems to indicate either an implicit misreading of the allegory on Coleridge's part or, conversely, a failing in Bunyan's ability to prevent the reader reading The Pilgrim's Progress for story alone, particularly in the face of its profoundly imaginative (if not novelistic) genius. But clearly not all readers feel as at ease with The Pilgrim's Progress 'as a novel' as Coleridge. Indeed, the text's inherent narrative resistance to conventions of plot and character is signalled most often not by those readers intent upon reading The Pilgrim's Progress theologically or doctrinally but by those who do try to treat it precisely 'as a novel'. The result is often a compromised or disappointed response. Given that The Pilgrim's Progress clearly does not work very well 'as a novel', such a reader may be forced into accepting the idea that a latent 'aesthetic tension' (as Kaufmann puts it) is operating within the text between story and doctrine, mythos and logos, and which would explain why the imaginative elements are always to be tempered by the work's didacticism. Alternatively, though, the reader may also feel that Bunyan's allegory is just artistically flawed.

\footnotetext{
98 Stanley Fish, 'Sequence and Meaning in Seventeenth-Century Narrative', in To Tell a Story: Narrative Theory and Practice, intro. by Robert M. Adams (Los Angeles: William Clark Memorial Library, University of California, 1973), pp. 57-76 (pp. 74-75). Fish's analytical position is stated here most baldly: 'Christianity', he states, 'is structuralism with a transcendental signifier' (p. 59). This essay is reprinted as 'Structuralist Homiletics', MLN, 91 (1976), 1208-1221, and again in Is There A Text in This Class: The Authority of Interpretive Communities (Cambridge, Massachusetts and London: Harvard University Press, 1980), pp. 181196

${ }_{99}$ Coleridge, as cited in The Pilgrim's Progress: A Casebook, pp. 52-53.
} 
In literary criticism, especially, we are often given a sense not only of the Bunyan of 'Parnassus' being at odds with the Bunyan of the conventicle, but of the latter, quite unfortunately it seems, having had the upper hand in the imaginative composition of The Pilgrim's Progress. Indeed, what annoys some readers and critics most about Bunyan's famous allegory is its distinct lack of a consistent adherence to the novelistic illusions it frequently seems to promote, a dissatisfaction with the fact that its fictional verisimilitude is constantly shattered 'by didactic intrusions that reduce mimetic material to the status of illustrations, impede narrative movement, destroy visual clarity or dramatic immediacy, or, in other ways, either dampen interest in characters and events or inhabit imaginative expansions of meaning.' In other words, the whole basis of Bunyan's anti-narrative procedure, in which the reader is encouraged into grace-ful perception and away from story-interest alone, is often mistakenly appropriated as the result of artistic failure - Bunyan's inability to 'balance mimetic and didactic elements' in creating 'the basic illusion necessary to effectual narrative art.' 100

Any attempt wilfully to ignore the doctrinal or theological import of the allegory and read the text simply as Bunyan's 'Novel-ty' is, therefore, strenuously rebutted by the allegory itself: the reader must quickly learn that any indulgence solely in the fictive world of The Pilgrim's Progress must eventually give way to an alternative, less novelistic response (or at least one which accepts a denial of narrative causality, logic, and 'realism'). ${ }^{101}$ However, it is not only through Bunyan's anti-narrative and self-referential 'tendency to throw away his

100 Charles Baird, John Bunyan: A Study in Narrative Technique (Port Washington, New York and London: Kennikat Press, 1977), p. 14.

${ }_{101}$ For this reason, N. H. Keeble has impressively argued that any attempt to read The Pilgrim's Progress as a novel is inappropriate not only because its 'inhibiting and incongruous didacticism' keeps 'destroying the imaginative consistency of the fable' but because approaching the text in this way is, more than anything else, profoundly ahistorical. Astutely redefining the conventicle-parnassus equation about Bunyan, Keeble suggests that the realism which readers have found so novelistic and creative in The Pilgrim's Progress actually has its source far more in the dissenting preaching minister than in the parnassian proto-novelist. For Bunyan's theological teaching to be effective, for it 'to be practical, to apply to ordinary men,' Keeble argues, 'counsel must be realistic', and the fact that Christian and the other true pilgrims are indistinguishable from ordinary human beings 'is both the theological point and the source of the fictional verisimilitude': 'Bunyan's concrete realisation of the Puritan conviction that any man may become a Christian hero does here create the hero of a realistic story', he admits, 'but only incidentally. It is the fortunate literary consequence of a theological conviction, not the creation of an artist liberated from his theology.' By regarding the text's realism as inseparable from its evangelism, as a natural consequence of the Puritan contemplation of experience, the long dialogic passages which continually interrupt the story in their assessment of experience and doctrine can thus be reviewed as theologically integrative in terms of the text as a whole: 'these passages are the story', Keeble argues, '[for] it is here real progress occurs' in Christian's journey of faith. 'The Pilgrim's Progress: A Puritan Fiction', Baptist Quarterly, 28 (1980), 321-336 (pp. 321, 325-327, 330). 
fiction, to turn up his own metaphors', as Sharrock puts it, that The Pilgrim's Progress teaches the reader not to read it either 'as a novel' or simply for the plot. ${ }^{102}$ Bunyan also, and most importantly, achieves this aim through the appropriation of the very technology of the seventeenth-century printed page itself, evinced in the ever present marginal glosses which, in a very physical sense function in a fundamentally anti-narrative way. Indeed, the marginal matter of The Pilgrim's Progress's pages both continually and blatantly interrupts any process of reading-for-the-plot simply by 'tugging the eye past the story into another discourse mode signalled by a different size of print, another length of line'. Hence, the allegory's margins, at the very least, 'act as a brake to slow the reading, to force the reader to stop and consider' its doctrinal meaning. Indeed, because 'marginal glosses', as one commentator puts it, 'always cry out for attention' they 'threaten to split the process of reading asunder', consequently making 'Bunyan's use of marginal comments [...] unique among writers of fiction'. 103

There are, of course, many ways that Bunyan's marginal notes achieve such a basic interference with a linear reading of the plot. Some of the marginal references are, for example, simply distracting, lying upon the page somewhat redundantly as mnemonic summaries of what is being described or discussed at any particular point: the marginal echo of 'Christian gives God thanks for deliverance' after the battle with Apollyon is, for instance, but one of many examples of this form of notation given in The Pilgrim's Progress. ${ }^{104}$ As such, these marginal references are simply reiterative and, as exemplified in Hopeful's recounting of his conversion, they largely re-narrate and condense the main text for the reader at the edges of the page. ${ }^{105}$ In a similar way, many of the Biblical references also work quite functionally to identify the Scriptural texts and the sources of the doctrinal 'truths' that Bunyan's narrative often illustrates. Indeed, these can become long lists of

102 Roger Sharrock, 'Life and Story in The Pilgrim's Progress', in The Pilgrim's Progress: Critical and Historical Views, pp. 49-68, (p. 65).

103 Maxine Hancock, 'The Key in the Window: Marginal Notes in Bunyan's Narratives' (unpublished doctoral thesis, University of Alberta, 1992), pp. 117, 183. Lawrence Lipking, 'The Marginal Gloss', Critical Inquiry, 3 (1976-77), 609-655 (p. 640); Paul J. Korshin, Typologies in England, 1650-1820 (Princeton: Princeton University Press, 1982), p. 188.

104 Bunyan, The Pilgrim's Progress, p. 60.

105 Bunyan, The Pilgrim's Progress, pp. 137-143. Although William E. Slights has identified no less than fourteen functions of notes and figures in the margins of Renaissance texts, in 'The Edifying Margins of Renaissance English Books', Renaissance Quarterly, 42 (1989), 682-716 (pp. 685-687), Hancock reduces these to four basic uses: 'to refer, to index, to interpret, and to generalize' ('The Key in the Window', p. 123). 
references at times serving to affirm the Biblical authority of Bunyan's fiction while simultaneously encouraging the more zealous reader (in a way that would most definitely interrupt any conventional reading method) to turn away from the text and to consult the Word of Scripture itself. 106

But while such referencing serves to clarify certain aspects of the story, Bunyan's marginal voice also makes our understanding of The Pilgrim's Progress more complex at times. In Christian and Faithful's dialogue with Talkative, for example, the marginal notes serve not so much to echo the main text as actively to remark upon it, peppering the pages with a running commentary that implicitly judges Talkative on the reader's behalf before any hypocrisy is actually revealed within him: 'Talkatives fine discourse', ' $O$ brave Talkative', they state somewhat sarcastically. But this notation also goes on to add descriptive touches not implicit in the narrative itself ('Talkative flings away from Faithful', for instance), before finally offering its own conclusion to the episode as a whole: Talkative leaves with a definite 'good riddance' from the marginal authority. ${ }^{107}$ In such a case, the marginal notes clearly invite (if not coerce) the reader's collusion with its own judgements in condemning Talkative just as some of the Biblical references (as with the Shepherds' 'Instrument' for beholding the Celestial City) demand an explicit and strict alignment of the text's allegorisations with a doctrine of Law and grace. ${ }^{108}$

Bunyan's marginal notes, then, act to emphasise, in a particularly obvious way, the self-referential nature of The Pilgrim's Progress in general, ensuring 'that we remain conscious as we read that we are reading, alive to our obligation to seek out the 'Truth' within this 'Fable'.' Bunyan's marginalia are thus 'essential to his literary purposes', as one commentator puts it, simply because they act as a constant reminder to the reader that The Pilgrim's Progress is to be read 'as a means, not an end', not as 'mere entertainment' but as 'commentary and teaching'. ${ }^{109}$ It is through the marginal notes and comments, therefore, that Bunyan can impose (or at least attempt to impose) his authorial control over the reader's

\footnotetext{
106 See, for example, the lists of Scriptural references on pp. 13 and 36 of The Pilgrim's Progress.

107 Bunyan, The Pilgrim's Progress, pp. 75-85.

108 Bunyan, The Pilgrim's Progress, p. 156.

109 Keeble, The Literary Culture of Nonconformity in Later Seventeenth-Century England (Leicester: Leicester University Press, 1987), pp. 149, 146. Hancock, 'The Key in the Window', p. 12.
} 
response to the text most effectively: from the margins, where he is 'so persistently and conscientiously present', Bunyan can police the narrative 'constantly watching and guiding his reader's responses', fully aware that 'printed marginalia [...] open doorways specifically, insistently for the purpose of crossing the text-context threshold. And [...] at the whim of the author', not of the reader. 110

With this in mind, it is not surprising that the narrative itself often re-dramatises the implicit function of Bunyan's marginal presence in the interpretive experiences of its own reader-protagonists. For instance, in continually returning the reader to the spiritual and doctrinal significance of the plot, the marginal notes conspicuously act to keep the reader from being overly enchanted by the overtly imaginative aspects of the narrative: keeping the reader awake to spiritual things, like Christian and Hopeful's discourse while passing over the Inchanted ground, is the office Bunyan performs for the reader in the text's margins. ${ }^{111}$ At the same time, the Apology's warning that to prevent being 'drownded in 'Contemplation' the reader must simply read the text's 'Riddles' alongside 'their Explanation' is an indication that the marginalia can act for the reader as Interpreter acts for Christian in the emblematic rooms of Interpreter's House, marking the need for a specifically spiritual reading of things often most puzzling. ${ }^{112}$ As such, it is through the margins that Bunyan is able to transcend his role simply as narrator or author and adopt a most Interpreter like role indeed, guiding the reader through his often 'interesting, but tough' text as something of an angelus interpres. ${ }^{113}$

Viewing Bunyan's use of margins as a means of controlling the reader's understanding of The Pilgrim's Progress is not wholly unproblematic, though. Even

\footnotetext{
110 Keeble, Literary Culture of Nonconformity, p. 146; Slights, 'The Edifying Margins of Renaissance English Books', p. 687.

111 Keeble, Literary Culture of Nonconformity, p. 149. See, for example, Bunyan's astute use both of Biblical referencing and marginal notation-as-interpretation in Christian's discourse and subsequent battle with Apollyon, one of the most conspicuously 'romantic' episodes of The Pilgrim's Progress as a whole (pp. 56-60). 112 Bunyan, The Pilgrim's Progress, p. 7.

113 The angelus interpres or 'interpreting angel' is a traditional figure in visionary literature, from the apocalyptic Biblical books of Daniel and Revelation to Dante's The Divine Comedy. In the latter, Virgil acts as the allegorist's 'heavenly guide', existing 'within the vision and who interprets it for the benefit of the visionary (as in Dan. 8: 16-26 and Rev. 17: 1-18)'. It is this role that Bunyan provides through his marginal presence, Bunyan thus standing within (or at least beside) his 'vision' and acting as 'the vital liaison between two worlds', explaining the dream 'with the authority that comes from either experience or deeper insight'. This information about the angelus interpres is given in Bryan Shelley's Shelley and Scripture: The Interpreting Angel (Oxford: Clarendon Press, 1994), pp. 161-164, 172-173.
} 
Interpreter does not (or cannot) explain, for example, the whole meaning of the first emblemtext in his House (that of the 'Picture of a very grave Person') to either Christian or the reader, the marginal notes at this point in the allegory similarly reflecting a distinct lack of any certain solution. In fact, in this instance the margins simply lead to further confusion, offering a verbal interference through the marginal substitution of ' $a$ brave Picture' for the main text's 'grave' one, and affirming Interpreter's words as actually presenting 'The meaning of the Picture' when this clearly is far from the case. ${ }^{114}$ As such, it seems important to recognise that even Bunyan's careful use of the margins is always potentially prone to the kind of uncertain signification that, as Valentine Cunningham astutely notes, has marked post-structuralist accounts of marginalia recently. Indeed, with marginal comments (at least according to a deconstructive understanding of them) pointing towards a multiplicity (if not an infinity) of possible meanings, any confidence in The Pilgrim's Progress as conveying a final 'Truth' could be seen as being effectively undermined through Bunyan's adoption of such alternative textual material. In these terms, as Cunningham feels forced to concede, what could be seen as hovering over even Bunyan's 'triumphalist interpretive' marginal notes is a spectre of divisive doubt that what they present are not integrative but alternative (or even disintegrative) readings. ${ }^{115}$

Asserting that Bunyan's margins perform an essentially anti-narrative role is, however, quite different from suggesting that they actually threaten to destroy the text's overall 'Truth'. Even at their most obscure, Bunyan's marginal notes can be said to be divisive only in that they often direct the reader away from the text and to the Word beyond the narrative, the many Scriptural references thus drawing 'the text of the narrative back into the Biblical intertext', as one commentator puts it. As such, the 'divided page' of (post)modern reading, 'where knowledge is severed from faith and the text from its interpretation', is something Bunyan can be seen as striving to 'knit up' (either successfully or not) in the margins of The Pilgrim's Progress. ${ }^{116}$ In this sense, Bunyan's use of the

\footnotetext{
${ }^{114}$ Bunyan, The Pilgrim's Progress, p. 29.

115 Valentine Cunningham, 'Glossing and Glozing: Bunyan and Allegory', in Conventicle and Parnassus, pp. 217-240 (pp. 235-237).

116 Hancock, 'The Key in the Window', pp. 134-135. Lipking, 'The Marginal Gloss', p. 629. See also, Sharrock, 'Life and Story' for a similar understanding on the complex relationship between page and marginal note, p. 64
} 
marginal space represents something far different from the divisiveness and uncertainty in meaning that has been celebrated through recent deconstructionist readings of both allegory and marginalia. ${ }^{117}$ Understanding Bunyan's margins in terms of a Derridean dé-bordement (in which the edges of the printed page become 'a locus of reproductive energy, creating endless opportunities for further interpretation which infinitely defer meaning') is inappropriate in Bunyan's case not only because it ignores the overtly anti-narrative function of his marginal notes but because it fails to acknowledge that, like Interpreter, they actually attempt (and without claiming any final success, either) to contain 'excess signification' in guiding the reader towards a grace-ful reading.

Indeed, just as the marginal notes in Protestant English Bibles have been seen to arise from the need to consolidate doctrinal positions in Biblical interpretation, to 'restrain the interpretive excesses of the more radical preachers' and to discourage 'rebellious, idiosyncratic, undisciplined acts of reading', so too do Bunyan's margins act as guards against the hermeneutic angst of limitless and grace-less meaning. 118 Moreover, because the marginalia of The Pilgrim's Progress place its discourse firmly in the realm of things invisible, pointing the reader towards the metaphysical 'truths' (the words of the Word) within the allegory as a whole, the marginal notes merely make visible the way that, for Bunyan at least, allegory itself 'bears witness to a belief structure which relates the seen and known to an unseen, all-encompassing reality.' Bunyan's marginal presence on the page thus illustrates most visibly not allegory's regressive de(con)struction of meaning but the 'faithful rendering of a view of a dual reality', a transcendental 'Truth'.119

117 Cunningham's 'Glossing and Glozing' is especially useful in summarising post-structuralist attitudes towards both the marginal and allegorical as giving a divisive double readability to texts.

118 William Slights makes the excellent point that Bunyan's marginal notes function to guide the reader away from or out of this 'luxuriant maze of "Bypaths" that continually threaten to divert the unwary traveller' upon his or her interpretive journey: " "Marginal Notes that spoile the Text": Scriptural Annotation in the English Renaissance', The Huntingdon Library Quarterly, 55 (1992), 255-278 (pp. 256, 268, 271-272).

${ }_{119}$ Hancock, 'The Key in the Window', pp. 110-111. Any sense that margins merely defer signification is also profoundly ahistorical in Bunyan's case as it ignores the fact that his marginal notes point towards an ontology shared by many as a part of seventeenth-century religious life. Bunyan's marginal notes are not merely textual appendages but a part of a culture in which the integration of marginal notes with the main text enacts that of the spiritual with the worldly and in which multiple-meanings are ontologically constructive not epistemologically deconstructive: 'So long as books kept their sacred ties to the Author of All, so long as the notion that the world was a book to be read by men', Lawrence Lipking observes, 'glossing could be regarded as a logical extension of the text: an unfolding of parallel, equally authoritative meanings'. It seems significant, then, that in the advent of late seventeenth-century religious moralism and scientific empiricism, Bunyan's ontological reading of the self and the world as margins to be read parallel to the text of Scripture, and subsumed within an unseen spirituality, was losing its cultural authority. Within such cultural shifts, the 
Rather than being deconstructively divisive of the text's integral construal of meaning, then, Bunyan's use of his pages' margins can indeed be seen as a part of a wide variety of antinarrative strategies adopted in The Pilgrim's Progress to prevent the reader from engaging with the fictive plot (the historical part) alone. But, even with such complex and technical metafictional strategies, it is surprising how the reader almost inevitably gravitates towards the fable of The Pilgrim's Progress nevertheless. For all of Bunyan's textual trickery it seems that The Pilgrim's Progress, as evinced in its gradual evolution both as children's classic and proto-novel, has been (and presumably always will be) read as just a story (albeit a profoundly religious one). To some degree, however, this is a consequence inextricable from Bunyan's choice of literary mode. Although it is only through allegory that Bunyan can translate 'the life of the spirit into a physical landscape' (and vice versa), it is perhaps only natural that, when confronted with the 'palpable enchantment' of The Pilgrim's Progress as fable (with its teleological plot and imaginative episodes), 'the reader is that much more likely to take things into his own hands and wind up with a disenchantment.' That is, the 'literal plot' of the allegorical spiritual journey almost inevitably endangers its particular spiritual meaning, its doctrinal 'enchantment' of the world, to such an extent that the success of Bunyan's spiritualising allegory seems 'inseparable from the perpetual possibility of its total failure': because its 'concreteness' continually 'threatens to preclude the process of allegorical translation altogether' then 'the reader consents to put up with a story that has foresaken the task of mediation [...], a story that must make sense in and of itself, without the intrusion of otherworldly meanings.' 120

In other words, although Bunyan's whole narrative aim is one of blatantly forcing 'otherworldly' concerns upon the reader, it seems difficult not to be tempted to read The

marginal gloss was, Lipking asserts, ultimately replaced by the Enlightenment footnote, testifying to the way that epistemological truth, fact, and the 'hard knowledge' that 'flows over great depths of footnotes' demolished the role of marginal notes upon the page. As Lipking astutely notes, it would be absurd to think of marginal glosses offering, according to the traditional scheme of glossing 'moral or allegorical interpretations as footnotes to the literal or anagogical' as 'every faithful reading is equally scriptural, equally true.' In a similar way, Bunyan's marginal notes testify to the fact that for him there is indeed knowledge and knowledge, an ontological scheme of 'parallel knowledges' as opposed to the empirical knowledge of the footnote that not only affirms 'the hierarchy of the certain over the conjectural, true over false' but the seen over the unprovable and unfootnotable reality of things invisible. See Lawrence Lipking, 'The Marginal Gloss', pp. 622, 625-6.

120 Michael McKeon, The Origins of the English Novel 1600-1740 (Baltimore: John Hopkins University Press, 1987; repr. 1991), pp. 295-297. 
Pilgrim's Progress for the 'plot' in any case. What The Pilgrim's Progress testifies to, in this way, is the fact that 'narrative' by nature tends to engender 'too many interpretations', any control over its final meaning thus being continually thwarted by the ability and desire of readers to bring multi-faceted understandings to it.121 As such, for Bunyan to attempt to control his reader's response to what is an innately imaginative adventure-allegory seems to suggest that Bunyan's concept of reading narrative is, in the first place, fundamentally naive. But beyond such an admission as this, however, any reader's reading of The Pilgrim's Progress as a 'story' must doubly be forgiven given even Bunyan's evident susceptibility to the literalist tensions of his own fictional plot.

This is especially in the case, for example, with the matter of Christian's leaving of his wife and children. In doctrinal terms, this traumatic beginning to Christian's pilgrimage is simply a blunt visualisation of a specific Scriptural instruction. As indicated by the various marginal notes, Christian's action is but a literal enactment of the spiritual 'truth' of Christ's words in Luke 14.26: 'If any man come to me, and hate not his father, and mother, and wife, and children, and brethren, and sisters, yea, and his own life also, he cannot be my disciple.' 122 Only if we read this action grace-fully, understanding Christian's desertion of his family within the compass of an allegorical mode that takes advantage of literalmetaphorical hesitations in making the unseen visible, can we accept such apparently unChristian behaviour unproblematically. Christian is embarking upon an allegorical journey in faith, his literal abandonment of his family merely being emblematic of the beginning of a spiritual quest not within the physical world but within in his soul. In these terms, therefore, it is a supreme representational iridescence that the reader must navigate here, a flickering between the metaphorical and the literal, the spiritual and the physical, the allegorical and the realistic that lies at the heart of Bunyan's entire narrative procedure.

The problem here, though, is that Christian's running away impresses itself upon the reader almost too literally, causing its allegorical opalescence to freeze and the representation of spiritual truth to crack under the pressure of its overt realism: indeed, 'taken literally' the

121 Martin, Recent Theories of Narrative, p. 187.

122 Bunyan, The Pilgrim's Progress, p. 10. 
jolt with which this journey begins is, as Christopher Hill notes, simply 'horrifying.' 123 The actuality Bunyan's narrative conveys at this point thus makes a spiritual understanding of the protagonist who abandons his family practically impossible. It seems, moreover, that even Bunyan could find no way to resolve this problem. His revisions of this matter, painstakingly pointed out in Roger Sharrock's noting of Bunyan's textual corrections, seemingly act to soften the narrative (rather than enhance the allegorical) implications of Christian's un-Christian (if not unmanly) behaviour. With the addition of over thirty lines at the beginning of the narrative along with Christian's lengthy dialogue with Charity in the House Beautiful (both included from the publication of the second edition onwards), what has appeared to be a heartless act of familial disloyalty is explained-away and ameliorated according to its literalist implications. ${ }^{124}$ Not only do these additions make Christian's actions more acceptable and less unreasonable but, with a firmer sense of how this pilgrim had little choice but to flee from a family 'implacable to good', we can rest assured that Christian's soul is now 'delivered [...] from their blood'. For all these additions, though, it seems that even Charity's forgiving assertion cannot manage to banish the painful ghost of Christian's literal action completely: arguably, it takes Bunyan a second Pilgrim's Progress to do this finally.

Christian's flight from his wife and children along with Bunyan's consequent additions indicate something of the complexity of his allegorical endeavour as a whole as well as the extent to which the plot of The Pilgrim's Progress can, and often does, proclaim its autonomy over and above its spiritual meaning. It is not surprising, then, that given the potential for even relatively minor elements in the plot to explode in the face of the narrative's grace-ful composition, Bunyan is most careful in trying to suppress the imaginative independence of the more overtly fictive episodes in the text - particularly those that seem deliberately, if not dangerously, rooted in the narrative traditions of romance, folk-

123 Christopher Hill, A Turbulent, Seditious, and Factious People: John Bunyan and his Church, 1628-1688 (Oxford: Oxford University Press, 1988; repr. 1989), p. 227. For Hill, this is because Christian's escape is historically literal, 'unpleasantly true to the life of the poor in the seventeenth century', a time in which '[a]bandoning his family to the mercies of the parish was just about the most brutal act a man could commit (p. 227). Compare, moreover, Christian's fleeing from his home with Bunyan's own evident anguish on leaving his wife and family prior to imprisonment (Grace Abounding, pp. 97-98).

124 Bunyan, The Pilgrim's Progress, pp. 8-9; 50-2. 
lore, and fairy-tale. Indeed, at times, Christian's journey seems almost formulaic in its use of the conventions of such basic fictive forms. Christian's imprisonment by Giant Despair in Doubting Castle, for example, is an episode which (as many commentators have noted) most obviously draws upon romance and folk-tale narrative motifs in its construction. ${ }^{125}$ Accordingly, it also has the most potential for tearing the doctrinal fabric of the spiritualising allegory through its evident imaginative self-sufficiency. Perhaps more than with any other episode in the allegory, in fact, it is here that Bunyan's reader may be most sorely tempted to play with the 'out-side' of the dream, indulging in the fictive suspense and terror this most harrowing Giant Despair provides (along with the excitement of the pilgrims' miraculous escape) rather than trying to read the episode grace-fully.

Responding to this episode can, therefore, be particularly problematic. Though traditionally read as indicative of Bunyan's profound indebtedness (conscious or not) to chap-book romances like Bevis of Southampton and The Seven Champions of Christendom, and consequently viewed as exemplary of what makes The Pilgrim's Progress a unique 'Puritan folk-tale' by ensuring that both tough theology and an indulgence in fictive escapism are made more palatable by marrying romance with evangelism, Christian's encounter with Giant Despair (as with Bunyan's allegory as a whole) is nevertheless clearly informed by more than just the desire to make harsh doctrine imaginatively pleasing. Although Christian's escape from Doubting Castle is quite memorably one of the most fabulous scenes in the narrative, Bunyan cannot allow it simply to be so. On the contrary, rather than simply making a fairy-tale out of doctrine Bunyan, in his translation of Despair into a typical folkstory monster, is far more intent upon actively deconstructing the conventions of romance narrative than making them doctrinally agreeable, and he does this by purposefully reconstructing them within the specifically theological framework of grace. In the case of the pilgrims' trespass along 'By-Path Meadow', therefore, we have the most obviously folk-tale

125 See Harold Golder, 'John Bunyan's Hypocrisy', North American Review, 223 (1926), 323-332, 'Bunyan's Valley of the Shadow', Modern Philology, 27 (1929), 55-72, and 'Bunyan's Giant Despair', Journal of English and Germanic Philology, 30 (1931), 361-378; Henri Talon, John Bunyan: The Man and his Works, trans. by Barbara Wall (London: Rockliff, 1951), pp. 172-177; Paul Salzman, English Prose Fiction: A Critical History (Oxford: Clarendon Press, 1985), pp. 243-44; Margaret Spufford, Small Books and Pleasant Histories: Popular Fiction and its Readership in Seventeenth Century England (London: Methuen, 1981), pp. 6-8; Roger Pooley, 'The Structure of The Pilgrim's Progress', Essays in Poetics, 4 (1979), 59-70; Keeble, Literary Culture of Nonconformity, pp. 154-5; Roger Sharrock, 'Life and Story', pp. 56, 62. 
elements (a giant, a grim castle, dungeons for the captured trespassers, and a semi-comic though conventionally malicious gigantic spouse) re-formulated to represent arguably the most important theological point of the whole text : that is, to escape from Despair one must simply apply the grace-ful promises of Scripture to oneself. As such, far from being an episode stressing the harsh Calvinism of a theology at the centre of which is tyrannical and arbitrary God, overcoming despair here is a success story of faith in grace and forgiveness through remembrance of the Word. 126

It seems important to note, therefore, that Christian's decision to follow the false way of 'By-path Meadow' (an action upon which despair follows hard for this pilgrim) is simultaneously a decision to enter the world of romance narrative, Bunyan thereby subtly implying that the pilgrim-reader is similarly capable of trespassing not only upon the theological territory of doubt and despair in his or her life but upon a way of reading The Pilgrim's Progress itself that seems far more 'easie' than the 'rough' and arduous path of the text's doctrinal message. Along with Christian at this point, the reader of The Pilgrim's Progress must decide which path of interpretation to choose - the by-path of romance or the way of doctrine. It must be noted, however, that Bunyan does not make such a decision straightforward for the reader, either. His revisions of this episode, again from the second edition onwards, involve almost four pages in which the 'story' is apparently not restrained but elaborated upon. In introducing the character of Giant Despair's wife (a somewhat faithless and evil 'Diffidence'), for instance, Bunyan inaugurates both narrative suspense and a more conventional romance structure to this episode (and which are missing from the original version) by having the dialogue between Despair and his mistress about how to force the pilgrims into self-murder develop gradually over a definite period of time (from 'Thursday' to the 'Saturday', as the margins tell us).127 This additional material to the narrative thus allows Bunyan to develop Christian's encounter with Despair more as a story, and one in which a plot is literally being hatched (to scare or persuade the prisoners into suicide) and in which a careful attention to detail becomes paramount: Despair wounds his victims with 'a grievous Crab-tree Cudgel', we are told, the Giant now acting not

126 See Stachniewski on this point: Persecutory Imagination, pp. 193-206.

127 Bunyan, The Pilgrim's Progress, pp. 114-117. 
autonomously but, rather, on the advice of a partner who counsels her inept husband (in the stereotypical manner of the scheming spouse) while 'in bed' after a hard day's torturing. ${ }^{128}$

Given Bunyan's own re-construction of this episode, then, it is easy to see how the reader could indeed, or at least to some degree, blatantly ignore the theological import of the scene and simply enjoy the tale for its own imaginative sake. But Bunyan, for all his fictively indulgent revisions, clearly aims to curb such a reading nevertheless. The additions, while creatively fulfilling, also afford Bunyan an opportunity to explore despair in terms of its consequent temptations to suicide, exemplified in the incarcerated pilgrims' discourse. Hence, Hopeful's counsel to the Christian who can only bring damning Scriptures to bear on their situation ('My soul chuseth strangling rather than life', he cries) comes in a form reminiscent of Bunyan's pastoral address in the preface of Grace Abounding. Hopeful thus not only argues against suicide according to the fact that 'all the Law is not in the hand of Giant Despair' but encourages Christian to remember 'how valiant thou hast been heretofore' in order to 'bear up with patience as well as we can.' ${ }^{129}$ Here, then, Bunyan's fleshing-out of the story clearly offers him a discursive space to present some very practical advice to potentially despairing wayfarers tempted 'to commit murder' upon their 'selves'.

At the same time, however, whole-hearted absorption into the romance of Christian's escape from Doubting Castle is actually prevented by Bunyan in any case through the fact that it is a story pivoted upon anti-climax: Christian and Hopeful escape neither through guile, cunning, nor the bravery that Hopeful, at one point, resolves to 'pluck up' should the Giant suffer from one of his 'fits' again. Rather, they escape in a moment almost of narrative bathos, Christian suddenly remembering that he has had the means of escape upon him all along. The significance of this escape is, therefore, both narratively conventional and unconventional simultaneously. On the one hand, Christian and Hopeful escape from Doubting Castle through a typically romance strategy: via the agency of a key that almost magically releases them from a doomed fate. On the other hand, however, this single means of liberation performs a role far from solely narrative, turning (quite literally) upon a more important doctrinal premise: the 'Key' is nothing less than Scriptural 'Promise' constantly 
present for the backsliding pilgrim and always available throughout his journey despite any trespass committed. ${ }^{130}$ Hence, whereas desperate romance heroes may indeed typically escape through the means of some enchanted artefact, Bunyan's deconstruction of romance's mythical conventions here comes in the form of a magic key that is nothing less than the Word. It is at this point, therefore, that Bunyan pulls the rug from beneath the narratively vain-confident reader's feet. Far from any romancing, it is simply another comforting lesson in Law and grace that Bunyan offers his reader here.

In order truly to understand the doctrinal significance of Christian's spiritual backsliding into despair and his release from it, then, the reader seems to be being asked to discard wholly the shell of folk-tale conventions in which Bunyan encases this episode in order to read the doctrine within. It is precisely in this episode, it would seem, that it is most important for the reader to acknowledge a difference between the 'out-side' of the dream and its theological or pastoral significance. Hence, depicting despair as a terrifying and violent monster serves its purpose in conveying the fear and brutality of spiritual hopelessness which, taking gargantuan proportions at times, can indeed beat spiritually uncertain backsliders 'as if they were dogs'. But, ultimately though, the point Bunyan seems to be making here is actually one of disenchanting myths, not reinforcing them. This episode as whole, for instance, serves to de-mystify the horrendous emblem of despair presented by the Man in the Iron-Cage shown to Christian much earlier on in Interpreter's House. What Christian and Hopeful's later escape from a greatly exploded Giant Despair effectively demonstrates is that, through the remembering of the promises of Scripture alone, the narrative of that Man's incarcerating despair actually need dominate neither Christian's own soterial story nor his grace-ful faith. For this reason, Despair is finally presented in The Pilgrim's Progress in recognisably folk-tale terms not to present a harsh aspect of Bunyan's theology in an easily acceptable way but in order to reinforce a de-mythification about hopelessness all along: far from being an irremovable iron-cage after all, Despair becomes a bogey-man of children's stories that can be left crippled and impotent through the efficacy of the promises of the Word.

130 Bunyan, The Pilgrim's Progress, p. 118. 
This is not to say that Bunyan is making a fable of religious despair, though. Rather, Bunyan is simply making it clear that hopelessness can be dispelled through remembering God's mercy. What this episode affords Bunyan, therefore, is the opportunity not only to make a central point about forgiveness and salvation in his theology of grace but to re-write romance narrative as a whole. Consequently, The Pilgrim's Progress offers not so much a process of the sanitisation of romance within a doctrinal frame as is often suggested of Bunyan's narrative art, as it does the complete re-formation of the stuff of vulgar chap-books - even to the extent that the folk-tale conventions Bunyan adopts are ultimately to be abandoned by the reader serious about matters of salvation. In this way, not playing with the 'out-side' of the dream, not reading for the story, does indeed seem an inherent part of Bunyan's reconstruction of his reader's interpretive habits, especially at those points when that reader may feel most inclined to read The Pilgrim's Progress as romance fiction rather than as theological allegory. ${ }^{131}$

There are, of course, numerous examples that illustrate this kind of undoing of traditional folk-tale narrative by Bunyan: Christian's miraculous release from imprisonment in Vanity Fair, for example, is even more anti-climactic than his later escape from Doubting Castle, while that most traditional feature of fairy-stories, the Inchanted ground, (as noted in the last chapter) has been converted by Bunyan from a feature of typically romantic danger into one of the most doctrinally significant (and narratively crippling) dialogues between Christian and Hopeful in the whole text. ${ }^{132}$ Again, such romance conventions can be seen as being introduced by Bunyan simply to be overturned, the real interest about the Inchanted ground episode lying not in its narrative satisfaction but in the doctrinal import of Hopeful's discourse on conversion through Law and grace. Equally, therefore, Christian's other most romantic episode, his encounter with Apollyon, offers a similar sense of the subversion of folk-tale conventions but, interestingly, not simply in terms of a solely doctrinal reading this time. Apart from Stanley Fish (whose idiosyncratic interpretation has already been noted),

131 Indeed, the kind of reading of The Pilgrim's Progress via a syntagmatic approach to folk-tale narrative (such as Vladimir Propp's Morphology of the Folk Tale), as in Pooley's 'The Structure of The Pilgrim's Progress' (and Golder's articles), tends to be merely descriptive rather than analytical for, as Wallace Martin puts it, any 'search for the origins of plot structure in primeval myths is different from the study of plot in itself': Recent Theories of Narrative, pp. 86-91 (p. 91).

132 Bunyan, The Pilgrim's Progress, pp. 97, 136-154. 
most commentators view this episode as the externalisation of a spiritual battle in Christian's soul. Read almost autobiographically, then, Apollyon is seen as representing the temptations Bunyan describes suffering after conversion in Grace Abounding but cast within the style of chivalric romance. ${ }^{133}$ Because Apollyon is a common seventeenth-century type for both the devil and sin as well as a character in a story evidently known by Bunyan - Bevis of Southampton - it is as a consequence quite easy to read this scene as an example of Bunyan's artful fusion of folk-tale narrative with spiritual instruction: in facing Apollyon, Christian becomes a knight who must overcome the temptations of his own pride armed only with faith, prayer, and the sword of the spirit.

But Bunyan's adoption of romance motifs here seems distinctly different from its use elsewhere in the text. Here, the fictive element cannot be so easily or straightforwardly discarded in favour of a reading of the battle as synonymous either with a doctrinal truth or the kind of spiritual trials the believer may go through while (or shortly after) conversion. This is, however, not simply because the episode so effectively imitates a chap-book heroism, either. Rather, the reason why this battle has a different significance from Bunyan's re-writing of romance elsewhere in The Pilgrim's Progress is largely because Christian's encounter with Apollyon has an index beyond the more mystical kind of spiritual temptations Bunyan describes facing in Grace Abounding. While, of course, it is possible to read, say, psychological meanings and conflicts into Christian's encounter with Apollyon, it would be more accurate, it seems, to suggest that the counterpart to the autobiographical temptations found in Grace Abounding lies far more securely in Christian's passage through the Valley of the Shadow of Death rather than in the Valley of Humiliation. In fact, rather than just a spiritual temptation, it seems that Apollyon more precisely represents a political danger in The Pilgrim's Progress. Indeed, this monster appears to figure forth not only persecution by the devil or by one's own sins but, in a more controversial sense, the tyranny of Restoration

\footnotetext{
133 See Fish, Self-Consuming Artifacts, pp. 235-236; Roger Sharrock, 'Spiritual Autobiography in The Pilgrim's Progress', RES, 24 (1948), 102-120 (p. 118); Knott, The Sword of the Spirit, pp. 147-148; William York Tindall, John Bunyan, Mechanick Preacher (New York: Columbia University Press, 1934; repr. 1964 ), p. 40.
} 
conformism that imprisoned Bunyan himself and which tests Nonconformist faith in a different but equally harrowing way. ${ }^{134}$

To some degree, such a politicised reading is signified quite obviously even from the verbal surface of the encounter between Apollyon and Christian: theirs is a battle over loyalty in service, Christian being claimed by Apollyon as one of the latter's 'Subjects' and in which Christian's refusal to conform to this Prince's domination is couched in the overtly political terms of 'Government', 'Company', and 'Countrey'.135 The Valley of Humiliation seems to represent far more than just the temptation of spiritual pride, then. That The Pilgrim's Progress has suddenly turned into political allegory at this point is evinced further by this episode's similarity to Bunyan's own exchange over his loyalty and faith while on trial by Restoration authorities before his imprisonment. Indeed, in Bunyan's Relation of Imprisonment, we see him, like Christian against Apollyon, not only steadfastly refusing to flee from imminent persecution ('I will not stir', he asserts) but, when arrested, having to defend his faith in contests over interpreting Scripture and accusations of sedition. Although Bunyan reports his exchanges with 'Mr Foster' and 'Justice Keelin' as battles over reading Scripture literally and adhering to the Common Book of Prayer, it is Bunyan's dialogue with ' $M r$ Cobb' that is most akin to Christian's political debate with Apollyon. Accused by Cobb of encouraging the kind of 'insurrection' witnessed at the time by Fifth Monarchists and which apparently 'intended no less than the ruin of the kingdom and commonwealth', Bunyan responds in a way that is both patriotic and yet, potentially at least, profoundly radical. As in Christian's exchange with Apollyon, in which the political language of kings and government refers ambiguously both to the spiritual rule of God and the tyranny of temporal governors, here Bunyan's retort is couched in similarly ambiguous political rhetoric. Like Christian, when questioned about loyalty and service Bunyan simply professes, 'I will look upon it as my duty to behave myself under the King's government, both as becomes a man and a Christian; and if an occasion was offered me, I should willingly manifest my loyalty to my Prince, both by word and deed.' 136 But which 'King' and 'Prince'

\footnotetext{
134 For a similar historical/political reading of this episode, see E. P. Thompson, The Making of the English Working Class (Harmondsworth: Penguin Books, 1963; rev. and repr. 1972), pp. 32-38.

135 Bunyan, The Pilgrim's Progress, pp. 56-60.

136 John Bunyan, A Relation of My Imprisonment, in Grace Abounding, pp. 105, 110-111, 114-115, 119-121.
} 
Bunyan is ultimately professing loyalty to here, the 'King' of Christian's highway or Restoration England's Charles II, is finally unclear.

Such a political reading of Christian's encounter with Apollyon as the representative of Restoration persecution is also supported, moreover, by Bunyan's reference to Apollyon elsewhere in his writings. For example, in his Exposition on the Ten First Chapters of Genesis, Apollyon (unlike in The Holy War where he is simply one of the devils besieging Mansoul) is clearly aligned with the political oppression of Nonconformist faith. Advocating that, when faced with persecution from 'the brood of Cain', the faithful church will be replenished just as Seth took the place of the murdered Abel, Bunyan asserts that, as evinced by Christian, 'the way to weary out God's Enemies, [...] is to maintain, and make good the Front against them': 'Now if the Captain, their King Apollion, be made to yield,' he states, 'how can his Followers stand their ground?' With this in mind, Christian's battle with Apollyon clearly has its allegorical index not only in the figure of Seth as successor to the murdered Abel (and who will make persecutors 'cease from oppressing the Truth') but in the cosmic Scriptural battles occurring in heaven before the creation of man and at the Apocalypse: only 'by fighting', Bunyan confirms, were the 'Dragon' and 'his Angels' cast out of heaven by 'Michael and his Angels' through 'the Blood of the Lamb, by the Word of their Testimony, and by not loving their lives unto death.' 'Let this', Bunyan writes, 'serve for Persecutors'. ${ }^{137}$ Christian's battle with an Apollyon is thus framed in a distinctly political typology: the victorious Christian therefore gives thanks, with much significance for persecuted Nonconformists too, that he has not only been delivered 'out of the mouth of the Lion', but, as the concluding verse states a little more apocalyptically, that 'blessed Michael helped $m e^{\prime}$ in the battle. ${ }^{138}$

Reading Christian's battle with Apollyon as an allegory of the attempted suppression of Nonconformity during the Restoration would not only be absolutely congruous with the kind of socio-political comment on corrupt authority Bunyan is making in his depiction of

137 John Bunyan, An Exposition on the Ten First Chapters of Genesis, in The Miscellaneous Works of John Bunyan XII, ed. by W. R. Owens (Oxford: Clarendon Press, 1994), pp. 179-180.

138 On the political implications of Bunyan's posthumous works see Christopher Hill, A Turbulent, Seditious, Factious People, pp. 323-334, and Richard Greaves, 'The Spirit and the Sword: Bunyan and the Stuart State', in John Bunyan and English Nonconformity (London: Hambledon Press, 1992), pp. 101-126 (pp. 118-25). 
the trial at Vanity Fair but also supports a growing critical sense that The Pilgrim's Progress actually has a 'more radical' dimension than even the later The Holy War, addressing itself specifically to the crisis over conscience evident in the late 1660s. ${ }^{139}$ But while Richard Greaves has more than adequately illustrated that Bunyan's attitude towards persecution was one of absolute 'passive resistance', in which the saint must 'actively suffer for righteousness by willingly accepting affliction' within the compass of an 'ethic of suffering', and through which Bunyan 'insisted that this spiritual war is not offensive, but defensive', it seems that in Christian's combat with Apollyon distinguishing between a defence of faith and a call to arms against one's persecutors, between 'Political quietism' and 'slumbering Radicalism', becomes far more difficult. ${ }^{140}$ Although Christian's fighting is overtly out of self-defence, clearly illustrating that for Bunyan 'fidelity to the Gospel outweighed obedience to the state', both his valour and his victory nevertheless smack of something a little more radical and distinctly non-passive. ${ }^{141}$ In the battle with Apollyon, in fact, we see Christian 'draw' only at an opportune and decisive moment: 'for he saw 'twas time to bestir him'. The martial struggle that follows bears, therefore, not only the suspense and syntactical tension of a chivalric trial-by-combat, along with the cut-and thrust of spiritual conflict, but, moreover, all the implications of a carefully timed and innately radical taking-up of arms. ${ }^{142}$

Bunyan's adoption of a typical folk-tale structure and language in this episode thus serves a purpose beyond the transformation of romantic reading habits that we see elsewhere

139 This was the subject of a paper delivered by Richard Greaves, " "Let Truth be Free": John Bunyan and the Restoration Crisis of 1667-73', at the International John Bunyan Society Conference, Alberta, October 1995, since published in Albion 28 (1996), 587-605. Here, Greaves suggests that 'Bunyan intended The Pilgrim's Progress in part to reiterate in dramatic fashion the basic case for Protestant freedom of conscience and the right of assembly that he had been espousing since 1660', concluding that 'The Pilgrim's Progress may be more radical than The Holy War' in this respect (pp. 590, 604). For Greaves's discussions of Bunyan's politics and the persecution of Nonconformity in relation to The Holy War, see 'The Holy War and London Nonconformity' and 'Amid The Holy War: Bunyan and the Ethic of Suffering', in John Bunyan and English Nonconformity, pp. 155-167 and 169-183. Of related interest see also Barrie White, 'John Bunyan and the Context of Persecution', in John Bunyan and his England, pp. 51-62.

140 Richard Greaves, 'The Spirit and the Sword', pp. 110, 116, 121-125. Thompson, Making of English Working Class, p. 33.

141 Greaves, 'The Spirit and the Sword', p. 102.

142 Bunyan, The Pilgrim's Progress, pp. 59-60. For similar radical implications in The Pilgrim's Progress see also the emblem of 'A valiant man' who is shown to Christian in Interpreter's House as 'cutting and hacking most fiercely' with a sword in order to into 'a stately Palace'. A marginal reference to Acts 14.22 is given (a text about having 'fresh heart', 'persevering in faith', and 'experiencing hardships before entering the kingdom of God'). Even with this Scriptural aid, however, the socio-political overtones are obvious and, moreover, the meaning this emblem-text is left as deliberately ambiguous by Bunyan. Indeed, it is not explained to the reader at all. Rather, 'Christian smiled, and said I think verily I know the meaning of this', but without further elucidation (The Pilgrim's Progress, pp. 33-34). 
in The Pilgrim's Progress. Here, the chivalric mode provides an ideal narrative cover for the delineation of a political battle over Nonconformist faith and its practice by opportunely utilising the conventions of romance literature: knights questing for 'Truth', tyrannical Princes, and spectacular battles all offer Bunyan a certain amount of representational indeterminacy through the disguise of which he can depict a political warfare of conscience. Should the fictive vehicle be discarded here completely, therefore, as it must be with the doctrinal Giant Despair, we could only be left with an unbending and unsettling political implication: persecution must be met with fighting. Consequently, the chivalric model, at least as it is adopted in the case of Apollyon, offers Bunyan perhaps the only way of representing the issue of the oppression of Dissenting Churches (and of any resistance to it) allegorically. Thus, while Christian's combat with Apollyon is potentially the most radical episode in the whole text, Bunyan is astute enough to make it excusable simply as fable. Bunyan's narrative art in this case succeeds by making any conclusively political reading indefinite - this battle can be read as either political comment, spiritual allegory, psychological myth, or romance adventure. Finally, of course, it is all of these, the folk-tale structure serving to shield the overt political implications of this scene with a necessary amount of narrative ambiguity.

Bunyan's adoption of romance conventions and folk-tale structures in The Pilgrim's Progress should, then, be seen far beyond either the influence of his supposedly youthful indulgence in chap-book fiction or his intention to construct a 'profitable tension' between romance and doctrine. ${ }^{143}$ Although such readings of The Pilgrim's Progress have become practically institutionalised in Bunyan criticism, simply tracing the indebtedness of certain episodes in The Pilgrim's Progress to specific romance narratives or asserting that Bunyan triumphantly transcends the theological limitations of his allegory (and his faith) by transforming Calvinist dogma into a unique Puritan fiction is not only ineffective but can raise certain problems too. Reading Bunyan's adoption of romance-motifs and structures in these terms, for instance, must somehow be equated not only with Puritanism's general 
hostility towards all things 'feigned' but with Bunyan's own oft-professed contempt for the likes of 'George on horseback, or Bevis of Southampton', 'beastly Romances, and books full of Ribbauldry, even such as immediately tended to set all fleshly lusts on fire.' 144 In the face of such comments, are we to agree with Harold Golder that Bunyan was simply hypocritical in such matters, that while he 'outwardly abhorred romance' Bunyan 'secretly lived in a romantic world'? Can we adhere to Golder's conclusion that not only is the influence of the Bible within The Pilgrim's Progress 'everywhere compounded with and dependent upon the influence of romance' but that Bunyan ultimately read the Bible as a substitution for secular fiction? Or that '[t]o Bunyan', as Golder asserts, 'the Bible was a romance'?145

Clearly, any sense of Bunyan approaching the Word as fiction or even 'biblical mythos' can only remain patent nonsense, no matter how it is explained. ${ }^{146}$ Moreover, privileging the romance elements in this unquestioning way is not only indicative of a reading that evidently plays too much with the 'out-side' of the dream but which patently ignores what Bunyan is actually doing with fictive narrative conventions in The Pilgrim's Progress. There can be no compromise for Bunyan, even in allegorical narrative, of his convictions that his faith is no 'fable' and that romances are but sinful and crude distractions from life's more important spiritual concerns. Far from celebrating the appeal of romance, then, in The Pilgrim's Progress Bunyan simply seeks to convert it. In so doing, Bunyan reforms rather than rehabilitates 'the fiction-reading impulse', dismantling the fleshly seductiveness of chivalric tale-telling within the compass of a theology of grace and Nonconformist faith. ${ }^{147}$ In this sense, Bunyan's narrative reconstruction of seventeenth-

\footnotetext{
144 John Bunyan, A Few Sighs From Hell, or The Groans of a Damned Soul (1658), in The Works of John Bunyan, ed. by George Offor, 3 vols (Glasgow: Blackie and Son, 1854; repr. by The Banner of Truth Trust, 1991), III, p. 711; The Life and Death of Mr. Badman, ed. by James F. Forrest and Roger Sharrock (Oxford: Clarendon Press, 1988), p. 40; see also Bunyan's description of Mr. Filth's licensing of 'Odious Atheistical Pamphlets and filthy Ballads \& Romances full of baldry' and its effects upon Mansoul in The Holy War, ed. by Roger Sharrock and James F. Forrest (Oxford: Clarendon Press, 1980), pp. 31-2.

145 Golder, 'John Bunyan's Hypocrisy', p. 31; 'Bunyan's Valley of the Shadow', pp. 66, 68.

$146 \mathrm{U}$. Milo Kaufmann, however, suggests that the Bible could have been read in terms of imaginative story due to developments in Restoration interpretive practice. In terms of Puritan meditational hermeneutics, Kaufmann argues that 'by the time of the Restoration the imaginative approach to scriptural metaphor and event was, in heavenly meditation, itself a distinct convention.' Hence, '[t]he carryover of attitudes from secular to sacred texts becomes more plausible in the light of biblical mythos' (The Pilgrim's Progress and Traditions in Puritan Meditation, p. 162).

147 Leopold Damrosch, God's Plot and Man's Stories: Studies in the Fictional Imagination from Milton to Fielding (Chicago and London: University of Chicago Press, 1985), p. 174.
} 
century popular fictional modes amounts to little less than a form of narrative, if not cultural, iconoclasm.

Bunyan's engendering a process of grace-ful reading in the reader of The Pilgrim's Progress is, therefore, not only in terms of an ontological faith in things unseen but in a text that, incorporating both anti-narrative strategies and the transformation of romance, makes any reading of the literal narrative or story alone a distinctly wilful mis-reading. ${ }^{148}$ The consequent reception of The Pilgrim's Progress (both in literary studies and amongst its many general readers of the last three centuries) as either a fore-runner of the novel or an imaginatively didactic children's story says much about both its gradual de-radicalisation as a Nonconformist text as well as the cultural climates in which such mis-readings have been authorised since the text's initial publication. ${ }^{149}$ Evidently, the relationship between Bunyan's 'sweet truth' and his 'sweet fiction' is narratively more complex and contextually more important than such readings would have today's reader of The Pilgrim's Progress believe.

\footnotetext{
148 See Michael McKeon's chapter on The Pilgrim's Progress in The Origins of the English Novel (pp. 295314) for an excellent (and overtly self-conscious) example of such wilful mis-reading.

${ }_{149}$ For accounts of this cultural appropriation of The Pilgrim's Progress, see Michael A. Mullett, John Bunyan in Context (Keele: Keele University Press, 1996), pp. 191-192. For a more detailed study of the reception of The Pilgrim's Progress and its social implications see also Barbara A. Johnson, Reading Piers Plowman and The Pilgrim's Progress: Reception and the Protestant Reader (Carbondale and Edwardsville: Southern Illinois University Press, 1992).
} 


\title{
6 \\ First Amongst Sequels: John Bunyan's Other Allegories
}

\begin{abstract}
It hath been observed of late years, that peoples minds are so vitiated and debauched, that no books will please them to read, but novels, romances and plays, with others of the like nature; which have been brought up at a strange and prodigious rate, in vast and incredible numbers, while tracts of divinity are almost slighted and neglected; \& their stomachs turn upon them with loathing, unless they contain something that is new and unusual, either for matter, method or Stile; by which means debauchery is not only maintained and continued, but heightened and increased thereby, to the sensible discouragement and decay of piety and religion. ${ }^{1}$
\end{abstract}

From the opening lines of this prefatory 'Apology' for Thomas Sherman's Second Part of The Pilgrim's Progress (first published in 1682), it seems clear that, regardless of any doctrinal differences evident between the General Baptist author and his Particular Baptist counterpart, John Bunyan, the two Nonconformist writers have at least one thing in common: both share a profound concern over seventeenth-century reading habits. ${ }^{2}$ In Bunyan's case, we should remember that in The Holy War (also published in 1682) the dangerously deleterious reading matter of chap-book romances and ballads is marginalised (quite literally) as odious, filthy, atheistical, and full of ribaldry, consumables for the prurient readers of Restoration England and exemplary of the period's moral laxity in general. ${ }^{3}$ It would be safe to assume, therefore, that Bunyan, while differing from Sherman in issues doctrinal and ecclesiological, would hardly object to his alarmed (and alarmist) observation that pious books have become

\footnotetext{
1 T.[homas] S.[herman], The Pilgrim's Progress from this Present World of Wickedness and Misery, to an Eternity of Holiness and Felicity - The Second Part (London: 1682; repr. in The Pilgrim's Progress (Glasgow: Messrs. Carmichael and Millar in Company, 1736), this edition of The Pilgrim's Progress being in three parts with Sherman's text as part two), from 'The Author's Apology for his Book', p. viii.

2 In terms of doctrinal differences, William York Tindall views Sherman as being provoked into publishing a sequel to The Pilgrim's Progress through Bunyan's 'emphasis upon the individual saint and his neglect of church discipline and the ordinances, as well as his treatment of rebirth' in Part I. Consequently, in his text Sherman dwells 'upon the organized church, its sacraments, and the general rather than the particular call' (John Bunyan, Mechanic Preacher (New York: Russell \& Russell, 1934; repr. 1964), p. 64). See also Roger Sharrock, John Bunyan (London: Macmillan, 1954; repr. 1968), p. 139, and his note in The Pilgrim's Progress, ed. by James Blanton Wharey, 2nd edn., rev. by Roger Sharrock (Oxford: Clarendon Press, 1960), pp. 338-339.

${ }^{3}$ See Bunyan's depiction of Mr. Filth in The Holy War, ed. by Roger Sharrock and James F. Forrest (Oxford: Clarendon Press, 1980), pp. 31-32. Some critics have, moreover, noted this as a satirical figuring of Charles II's official Censor, Roger L'Estrange - see the editor's notes in The Holy War, pp. xxxiii, 257, and Christopher Hill, A Turbulent, Seditious, and Factious People (Oxford: Oxford University Press, 1988; repr. 1989), p. 246.
} 
indigestible to a literate public afflicted by a plague of novels and plays the epidemic scale of which leaves 'debauchery' not assuaged but 'heightened and increased thereby'. The reformation of readers and their books is, it seems, something to which both authors aspire: Bunyan in terms of rewriting romance within the frame of a theology of grace and 'things unseen', and Sherman in terms of providing an ideal devotional gift for the recently bereaved his Second Part, he freely suggests, could be given 'at funerals, instead of rings, gloves, wine or bisket'.

While we may be bemused by the alleged funereal function of Sherman's Second Part, the real reasons for providing a supplementary edition to Bunyan's allegory are made patently obvious in this 'Apology'. Although he praises Bunyan 'upon composing and publishing that necessary and useful tract, which hath deservedly obtained such an universal esteem and commendation', and notes that, like other 'ingenious persons', Bunyan has adopted a 'method' of 'religious discourse' which 'might incline' readers otherwise wholly disinterested in matters of salvation, Sherman nevertheless remains doubtful as to the efficacy of this 'method'. He seems, on the one hand, to betray both admiration and learned contempt for a narrative style of 'so much plainness and familiarity' that it 'may be understood by most illiterate persons, and meanest capacities; and yet afford pleasure, delight and satisfaction to the most judicious, learned and knowing reader.' At the same time, though, Sherman is keen to protest more openly against what he views as a basic 'four-fold defect' in Bunyan's text:

First, There is nothing said of the State of man in his first creation. Nor Secondly, Of the misery of man in his lapsed estate before conversion. Thirdly, A too brief passing over the methods of divine goodness, in the convincing, converting, and reconciling sinners to himself. And Fourthly, I have endeavoured to deliver the whole in such serious and spiritual phrases, that may prevent that lightness and laughter, which the reading some passages therein, occasion in some vain and frothy minds. ${ }^{4}$

Evidently, the two writers do not share so much in common after all. While Sherman's numerous theological objections serve to provide at least some doctrinal justification for what is, largely, a criticism of Bunyan's spiritually frivolous style, it is made clear that, far from venerating Bunyan's masterpiece, Sherman actually suspects it for being one of those texts resting beneath the categorical umbrella of books currently popular because 'they contain

\footnotetext{
${ }^{4}$ Sherman, Second Part, pp. viii-ix.
} 
something that is new and unusual, either for matter, method or Stile.' Indeed, at the heart of Sherman's suspicions and objections lies the implication that The Pilgrim's Progress, despite its obvious theological function as a 'useful tract', is in effect indistinguishable from the romances and folk-stories which it aims to rewrite. Sherman's initial show of outrage at seventeenth-century pulp fiction, therefore, is not so much a demonstration of approval for (or consolidation with) the 'method' that has made The Pilgrim's Progress so successful but, ultimately, a prelude to its condemnation. Sherman's Second Part is, he proudly claims, to be different from the original Pilgrim's Progress not only doctrinally: it is to be a revised version in which the imaginative indulgence and surface froth apparent in Bunyan's book is to be septically treated and sceptically scraped away.

Even the most cursory reading of the Second Part shows that Sherman undoubtedly achieves this aim. His protagonist, for instance, (whose theologically specific name changes from 'Reprobate' to 'Believer' after conversion through a narrow gate) is left to face none of the narrative dilemmas or adventures that Christian battles through in Bunyan's text (and which would presumably cloud the minds of readers particularly prone to the vain and frothy). Hence, after an opening that sets its following discourse firmly in a meditational (rather than a fabulous or imaginatively allegorical) mode, Sherman is careful to side-step one of Bunyan's initial narrative dilemmas (of having an allegorical hero literally abandon his wife and children) by avoiding realism and characterisation completely: to effect the start of his journey on the path of 'Conversion' leading to 'Celestial Paradise', Sherman's somewhat depersonalised pilgrim is simply and unproblematically drawn away from the mouth of a fiery pit (a literal hellhole) around which he and many other sinful folk are dancing. 5

From then on, although this journeyman's spiritual pilgrimage may seem typical (like Christian he too encounters false-pilgrims and frightening fiends, experiences the heights and depths of converted life, and crosses a river of 'Dissolution' at the end), it is throughout encompassed by Sherman's revisionist scheme of representation: Believer suffers from a harrowing bout of despair in which Bunyan's ogres and fairy-tale dungeons are replaced by long and detailed doctrinal meditations and pious praises; false-pilgrims (like one 'Desire-to-be-

\footnotetext{
5 Sherman, Second Part, pp. 10-22.
} 
Good') are given soterial second-chances and become true converts; even Believer's death is marked not by lingering doubts and final fears but by a secure equanimity, his traversing of the river of Dissolution being aided not by allegorical characters like Faithful and Hopeful but, more simplistically, by two distinctly characterless and more abstract doctrinal 'friends', 'Faith and Hope'. 6

In this way, although Sherman's pilgrim experiences almost exactly the same theological crises as Bunyan's Christian (temptation, conversion, backsliding), his journey is continually presented in a format which implicitly sanitises anything overtly fabulous. Perhaps the best example of this, however, lies in Sherman's blatant re-writing of Christian's battle with Apollyon. Here, Sherman's wayfarer faces a monster whose description could not be mistaken as that of either a chap-book dragon or an allegory of political persecution (as with Bunyan's Apollyon): the fiend now is just that, a 'fiend' with a countenance 'grim and terrible' and, for added diabolical authenticity, a suffocatingly 'offensive and sulphurie smell'. Whereas Bunyan exploits such a confrontation to re-present romance heroism within the frame of Christian steadfastness, a socio-political battle full of both suspense and spiritual significance, Sherman allows his reader nothing but narrative bathos. His devil, having (to no avail) tempted the pilgrim with everyday thoughts of social derision and loneliness, with taverns in which 'to drink healths, and huzzas' (along with the promise of a relaxing afternoon 'comedie'), eventually begins to roar 'in a most hideous manner, breathing forth immediate ruin and destruction to the poor trembling wretch'. However, no sooner has this pitiful pilgrim 'nimbly' drawn his sword and begun to 'to lay about him wonderfully' that the fiend 'found himself under a necessity to go back and flee'. ${ }^{7}$

While the spiritual message of this disappointingly abortive and disengaged 'battle' is synonymous with that of Christian's victory over Apollyon - 'resist the devil and he will fly from you' - Sherman nevertheless ensures that such an episode, central to both the allegory and the ontology of Bunyan's Pilgrim's Progress, is effectively reduced and defused (if not simply refused) in his own version. In the few lines it is grudgingly given, the battle's climax is deliberately and deflatingly premature: there is to be no room for the chivalric (or even the

\footnotetext{
6 Sherman, Second Part, pp. 126-137; 103-113; 144-145.

7 Sherman, Second Part, pp. 44-50.
} 
allegorical or political) imagination to take the narrative reins here. But in order to drive his point about the dangers of fictive romance home, Sherman finds it necessary to rewrite the encounter even further. Far from being indefinitely banished (like Apollyon), Sherman's offending demon is, rather, shown retreating cravenly 'to take breath, and contrive some new stratagem for the renewing the battle with better advantage to himself'. Here, the term 'battle' is, once again, a deliberate misnomer, as the diabolic figure's next step in his unholy war is to use 'craft' and 'subtility' where 'violence' has so far failed. To assail the pilgrim next, therefore, Sherman has his fiend employing someone 'naturallie inclined to froth and vanity' the allegorical figure of 'Phansie' - who with apparent ease then succeeds in 'representing and guilding things over with such artificial glosses and smooth appearances of delight and advantage', that Sherman's poor pilgrim 'was absolutely bewitched and inchanted thereby, so that he presently forgot all the terrors of Conscience, and all the solemn promises and protestations he had made'. 8

Phansie's methods of beguiling the pilgrim-reader out of the 'terrors of conscience' are, it seems, significantly framed in terms that replicate what Sherman views in his preface as central to Bunyan's phansie-ful allegorical style - gilding and glossing, bewitchment and enchantment, froth and vanity. Sherman's revisionist point here thus becomes clear. Because it cleverly figures forth the reader's own susceptibilities to the kind of romantic imaginings that Sherman views operating throughout Bunyan's allegory, but especially in Christian's prototypical folk-tale episodes, the character of 'Phansie' enables Sherman to embody his criticism of The Pilgrim's Progress within the very texture of his own narrative and not just from the distant pages of a prefatory Apology. Thus, Sherman not only restructures Christian's battle with Apollyon by de-romanticising and de-radicalising his wayfarer's spiritual mêlée, but seizes the moment as an opportunity to gloss the dangers of Bunyan's imaginative allegorical method as a whole: 'Phansie' is unambiguously a most manipulative servant of Satan astutely insinuated into the text by Sherman at a point when the reader is most likely to feel narratively swindled and, in relation to the original Apollyon episode, expectant of something more fabulously fulfilling. What the reader is disappointingly left with, then, is the allegorisation of

\footnotetext{
${ }^{8}$ Sherman, Second Part, pp. 50-51, 63.
} 
his own 'Phansie', Sherman thereby attempting to demonstrate in his own text just how Bunyan's romancing of even the most pious matters is ultimately pernicious, even Satanically deceptive. Indeed, just as Bunyan emphasises in his pilgrims' discovery of 'By-Path Meadow', any trespass for Sherman into the realm of frothy fable can lead only to a disastrous spiritual forgetfulness.

It is worth dwelling on Sherman's Second Part in some detail not only because it has been notoriously ignored in Bunyan scholarship (analysis rarely ever gets beyond the first page) but because it so clearly articulates concerns central to this thesis. ${ }^{9}$ On the one hand, in publishing his Second Part Sherman is not merely attempting to exploit the success of one of the most popular books ever printed (although he is certainly guilty of this to some extent) but voicing profound concerns about the dangers of accepting Bunyan's allegory in terms of narrative 'froth' alone - a reading for the 'story' which, according to Sherman at least, Bunyan has evidently failed to discourage. For Sherman, Bunyan's careful rewriting of romance within the frame of a theology of grace (along with his adoption of anti-narrative strategies which, in places, certainly make The Pilgrim's Progress 'interesting, but tough') does not go far enough (if at all) in militating against its potency as sheer fable. Consequently, Sherman's answer to this problem is his remedial Pilgrim's Progress, a text not so much the sequel or second part to the original as it is Bunyan's Pilgrim's Progress completely de-scribed and rewritten. At the same time, moreover, Sherman's Second Part also importantly prefigures considerations central in many contemporary critical responses to The Pilgrim's Progress. Indeed, as the first in a long line of Bunyan critics, Sherman is as intent as F. R. Leavis or Stuart Sim upon illustrating and resolving the fundamental tensions evident in Bunyan's book between theology and narrative, story and doctrine, allegory and imagination.

\footnotetext{
9 For the brief references to Sherman's Second Part in Bunyan criticism see, for example, Sharrock, John Bunyan, p. 139; Barbara A. Johnson, Reading Piers Plowman and The Pilgrim's Progress: Reception and the Protestant Reader (Carbondale and Edwardsville: Southern Illinois University Press, 1992), pp. 220-221; James Turner, 'Bunyan's Sense of Place', in The Pilgrim's Progress: Critical and Historical Views, ed. by Vincent Newey (Liverpool: Liverpool University Press, 1980), pp. 91-110 (pp. 91-92); N. H. Keeble, “"Of him thousands daily Sing and talk": Bunyan and his Reputation', in John Bunyan: Conventicle and Parnassus, Tercentenary Essays, ed. by N. H. Keeble (Oxford: Clarendon Press, 1988), pp. 241-263 (p. 245).
} 
But whereas most modern criticism emphasises how the story of Bunyan's text can and should be read in spite of its abhorrent theological content, Sherman's response evinces an exact inversion of this approach: for him, the problem with The Pilgrim's Progress is not that theology gets in the way of the fable but that the fable obfuscates the theology. Because Bunyan's 'useful tract' bears the traits of the worst kind of book - comedy, vanity, romantic nonsense - Sherman can evince only horror and disgust at the very aspects of The Pilgrim's Progress which have since secured its place as a classic of children's literature and the most famous Puritan fiction. Of course, it could be argued that what Sherman and his modern counterparts do share in their readings of The Pilgrim's Progress is a basic ignorance of Bunyan's overall attitude towards romance and his allegorical manipulation of it, and that this is what lies behind both Sherman's and more contemporary misreadings of the text. But, at the same time, it would also be fair to say that such criticisms register the degree not to which readers respond mistakenly to The Pilgrim's Progress but, rather, to which Bunyan simply fails in re-presenting romance clearly enough: for Sherman and his modern critical counterparts, The Pilgrim's Progress is finally flawed and in need of rewriting (or at least some reconsideration) because Bunyan has made it either too much like a fairy-story or too exact as a 'useful tract' for it to remain comfortable reading.

Contrary to the assumption lying behind the publication of Sherman's Second Part and much twentieth-century criticism, though, Bunyan was not unaware of this problem, being sensitive to his text's ambivalences and the opprobrium which they prompted. Although in the prefatory verses to his own 'Second Part of the Pilgrim' Bunyan, with the flourish of a successful author, confidently rebuts Sherman's systematic faultfinding about his first 'Pilgrim' laughing 'too loud' and it being counted as mere 'Romance' (as well as the general problem of it being mistaken for just another 'Counterfeit'), he does not take such criticism lightly, particularly when it takes the shape of a re(in)scription of his own narrative. Nor is Bunyan really all that assured in the face of such reproaches. The Pilgrim's Progress, Part II, for instance, while denouncing Sherman's stylistic criticisms in its preface, clearly follows some of his doctrinal implications: hence, its overt emphasis upon the role of the Church community in the believer's spiritual life. Similarly, The Holy War, although published in the 
same year as Sherman's Second Part, seems to address specifically those theological aspects that Sherman notes as distinctly lacking in The Pilgrim's Progress - the fall of man and the condition of man's soul before, during, and after conversion. ${ }^{10}$

Of course, Bunyan must have been patently aware of the tensions within The Pilgrim's Progress long before Sherman's Second Part was published. This is evident not only in the Apology to The Pilgrim's Progress, a document in Bunyan's methodological (as well as publicational) anxieties, but, and more importantly, in Bunyan's consequent allegorical works The Life and Death of Mr. Badman, (1680) The Holy War (1682), and, of course, The Pilgrim's Progress, Part II (1684). It is in these narratives more than in any of his verse prefaces that Bunyan reveals his implicit concern over the textual romancing that seems to distract the reader of The Pilgrim's Progress all too easily from its salvationary message. With these works, indeed, Bunyan aims to provide edifying fictions that avoid The Pilgrim's Progress's problems of romantic response. These texts are, therefore, sequels to The Pilgrim's Progress in the way that Sherman's Second Part is: they are generated not from a need to continue the story of The Pilgrim's Progress (with the exception of Part II) but from a careful consideration of that allegory's failings in terms of narrative and doctrine. Consequently, these are to be books notoriously difficult to read just for the story. The Life and Death of Mr. Badman and The Holy War, in particular, far from representing Bunyan's failed attempts to seize upon the success of The Pilgrim's Progress, or even provide it with a worthy successor stylistically, are attempts to rectify the problems and failings which Bunyan, as well as Sherman, recognises as inherent within that text. ${ }^{11}$ As much as any spurious Second Part, then, Bunyan's other narratives are, in many ways, remedially inspired responses to the issues and problems raised in his first allegory.

This is most obviously the case in The Life and Death of Mr. Badman, a text as deliberately and self-consciously different from The Pilgrim's Progress as possible, its distinctness being

\footnotetext{
${ }^{10}$ Indeed, it would seem that both the feasting and the meditative riddling which characterise so much of these later allegories could be derived directly from Sherman's Second Part in which, oddly, similar allegorical figures also appear - Boanerges and Conscience, for example, are as central to Sherman's text as they are to The Holy War.

11 Some commentators view The Holy War and Badman merely as failed sequels much inferior to The Pilgrim's Progress. See, for example, Sharrock, John Bunyan, pp. 106-7, 120.
} 
telegraphed to the reader from the prefatory address to the reader onwards. Here, unlike the sophisticatedly constructed verse Apology for The Pilgrim's Progress, Badman's preface is in noticeably unpretentious prose, a stylistic medium that reflects the blunt narrative and didactic intentions of this text as a whole: Badman will deal with the rawest and most concrete of social, moral, and soteriological issues unmediated, this time, by the overtly literary conventions of either dream or allegory. This time, the reader is not asked to find the 'Truth' within or behind the fable or unveil the text's figures but to 'behold with thine own eyes' events repeatedly emphasised in themselves as eye-witnessed and not to be considered, therefore, as merely fictive. Bunyan need present no articulate defence of dark similitude and 'Truth', here, because the representational and spiritual priorities of this text are to be completely different from those of The Pilgrim's Progress: 'England shakes and totters already', he states, 'by reason of the burden that Mr. Badman and his friends have wickedly laid upon it'. The imaginatively metaphorical burden of Christian's spiritual guilt is thus replaced by the palpably socio-political and realist 'burden' of Badman's 'wickedness', 'Debauchery', and 'sin' presently 'swallowing up a Nation, sinking of a Nation, and bringing its Inhabitants to temporal, spiritual, and eternal ruine' ${ }^{12}$ Bunyan's initial exchange of verse for prose in this text, therefore, merely exemplifies its fundamental transition from individual to communal (if not national) salvationary concerns and from the literary froth of allegorical dream-vision to a down-to-earth realism in which the delights of Biblical metaphor give way to descriptions often uncomfortably coarse and grossly unpleasant. ${ }^{13}$

The Life and Death of Mr. Badman is to be distinct from its predecessor, then, both through its dispensing with allegorical style (a source of The Pilgrim's Progress's perceived frivolity, perhaps) and its focus on the practical (as opposed to theological) issues of everyday moral and spiritual life - apprenticeship, marriage, trade. Structurally, moreover, Bunyan does

\footnotetext{
12 John Bunyan, The Life and Death of Mr. Badman, ed. by James F. Forrest and Roger Sharrock (Oxford: Clarendon Press, 1988), pp. 2, 7-8.

13 See, for example, Bunyan's descriptions of God's judgements against informers upon conventicles, one of whom was 'stricken by the hand of God' so that 'he was taken with a drauling, or slabbering at his mouth, which slabber sometimes would hang at his mouth well nigh half way to the ground', while another was bitten by a dog and, contracting 'Gangrene', did not die until 'his flesh rotted off him' (Badman, pp. 81-82). Similarly grotesque descriptions of bodily corruption and physical decay can be found throughout Badman, Bunyan even condemning coquettish women's fashions in these terms as they reveal 'naked shoulders, and Paps hanging out like a Cows bag' (Badman, p. 125).
} 
away with the complex narrative frames of author/narrator/dreamer and replaces them with the most basic of expository devices - the dialogue. Bunyan's reasons for doing this are clear. Although he claims that by putting his discourse 'into the form of a Dialogue [...] I might with more ease to my self, and pleasure to the Reader, perform the work', the reader's 'pleasure' is not important here - at least in terms of gratifying the imagination. In fact, the dialogue form provides Bunyan with 'more ease' precisely because it offers less of this kind of 'pleasure' to the reader: in evoking the solid, authoritative, and traditionally didactic example of Arthur Dent's Plaine-Man's Path-Way to Heaven, as opposed to the experimental 'Novelty' of allegorical dream-vision, the dialogic structure of Badman enables Bunyan to proceed with his moral and spiritual 'work' without the kind of fictive interference that may have obscured the doctrine of The Pilgrim's Progress. Indeed, the fact that dialogue has now become the governing structural feature of Badman, as opposed to the doctrinally digressive role it plays in The Pilgrim's Progress, merely confirms that for Bunyan the fundamental function of this text is not narrative or imaginative but overwhelmingly didactic. ${ }^{14}$

This point is, moreover, emphasised throughout the text: hence, Wiseman astutely notes of such providential tales as Badman's that 'There can be no pleasure in the telling of such stories, though to hear of them may do us a pleasure'. Again, this is not to be the pleasure of lurid sensationalism but the strictly doctrinal security (or anxiety) of knowing 'that there is a God that judgeth in the earth'. 'Let us tremble at the Judgements of God, and be afraid of sinning against him', are Wiseman's final words on how to respond to such narratives, indicating that The Life and Death of Mr. Badman does indeed engender a very different sense of reading for pleasure. ${ }^{15}$ This is hardly surprising, though, given that the biography of Mr. Badman is being recounted not to provide the reader with an enjoyable story but 'that thou mayest, as in a Glass, behold with thine eyes, the steps that take hold of Hell; and also discern, while thou art reading of Mr. Badmans Death, whether thou thy self art treading in his path thereto.' With its emphasis on death and Hell, the witnessing of Badman's demise is intended to inspire not allegorical laughter but the most sombre spiritual reflection in

14 Roger Sharrock, 'The Life and Death of Mr. Badman: Facts and Problems', Modern Language Review, 82 (1987), 15-29 (p. 19). For a similar view, see also Paul Salzman, English Prose Fiction: A Critical History (Oxford: Clarendon Press, 1985), pp. 254-5, 258.

is Bunyan, Badman, pp. 82-83. 
the reader. The emphasis placed here on the reader's self-searching for sin as well the need for experiential testimony to the narrative's veracity ('behold with thine own eyes') merely reinforces the sense that, for Bunyan to succeed in his 'endeavour [...] to stop an hellish Course of Life, and to save a soul from death', the reader's active participation is vital. ${ }^{16}$ To be spiritually efficacious, Badman is not a text that can be read for either escapist or prurient 'pleasure', like the romances, picaresque novels, or criminal biographies with which it is often compared. ${ }^{17}$ As in The Pilgrim's Progress, this text similarly demands full spiritual investment from its reader.

In order to prevent story dominating the text and impeding this kind of textual selfapplication, Badman welds doctrine and narrative together in a far more complex and successful way (at least in Bunyan's terms) than is achieved in The Pilgrim's Progress. It is for this reason, perhaps, that Badman has received a generally poor reception amongst modern commentators: not only is it not imaginative enough, it lacks coherence as a story being, as Sharrock notes, barely distinguishable from the tracts that comprise nine-tenths of Bunyan's theological output. 18 But Sharrock is wrong to denigrate this text as practically indiscernible from a doctrinal treatise, though, because Badman is distinctly if not self-consciously aware of itself as a narrative. Indeed, at the heart of Badman lies a profound concern over the very 'story' of Badman's life and death itself. This book's stultified texture and didactic heavyhandedness, for which it has been criticised so often, simply marks the degree to which Bunyan succeeds in subordinating story to doctrine in this text and, far more so than in The Pilgrim's Progress, how Badman is constructed to subvert itself as story for doctrine's sake. When Bunyan refers to the ease of the dialogic structure of Badman, therefore, he is being deliberately misleading: we are not to confuse this claim with the promise of an uncomplicated narrative style as Badman's is anything but that. Indeed, as author of this book, Bunyan's

\footnotetext{
16 Bunyan, Badman, pp. 1, 5.

17 See, for example, the introduction to The Life and Death of Mr. Badman, pp. xxvi-xxx; Salzman, English Prose Fiction, pp. 250-252; Alexander A. Parker, Literature and the Delinquent: The Picaresque Novel in Spain and Europe 1599-1753 (Edinburgh: Edinburgh University Press, 1967; repr. 1977), pp. 100-102; James Blanton Wharey, 'Bunyan's Mr. Badman and the Picaresque Novel', University of Texas Studies in English, 4 (1924), 49-61.

18 Sharrock, 'The Life and Death of Mr. Badman: Facts and Problems', p. 19. For other less favourable responses to Badman, see James Blanton Wharey, 'Bunyan's Mr. Badman', MLN, 36 (1921), $65-79$ (p. 79); Sharrock, John Bunyan, pp. 106-107, 113.
} 
figuring of himself as 'The valiant man' of The Pilgrim's Progress (who, in one of the rooms in Interpreter's House, must fight his way into 'a Stately palace') is pertinent. ${ }^{19}$ This is an image reflecting not only the perseverance necessary to tackle full-on the wickednesses of the nation (for which Bunyan expects to be vilified in due course) but of the authorial persistence required in ensuring that this time the tale will most definitely be collateral to the teaching - an arduous task indeed.

Bunyan principally achieves this safeguarding of doctrine over and above narrative interest alone in Badman, however, by ensuring that Badman's life both is and is not the central issue within the dialogue of Attentive and Wiseman. Consequently, the first impression any reader may have of Badman is that it is simply an unstructured moral and spiritual commentary on whatever happens to be the subject of the two men's conversation at any given time, in and out of which the figure of Badman himself merely flickers. For example, prompted by discussion of Badman's villainous companions, Wiseman takes his cue to reveal to Attentive (quite misogynistically) the moral and spiritual, social and physical problems of whoring: 'it is a deadly thing to young men', acquiesces Attentive, 'when such beastly queans, shall, with words and carriages that are openly tempting, discover themselves unto them; It is hard for such to escape their Snare.' What follows is an exposition of Scripture that cries out against this sin, from Genesis to Paul, and a description of its 'other evil effects', which include not only 'the Pox', a 'disease so nauseous and stinking' that one man 'had his Nose eaten off, and his Mouth almost quite sewed up thereby', but the murder of bastard infants. In hot pursuit of this lead, then, comes the story of the 'Gentleman' who throws his new-born illegitimate child upon a fire. In turn, this anecdote acts as but a prelude to a discussion on the damning nature of extramarital sex illustrated by another story about a 'Maid' tempted 'to commit uncleanness' and whose unwanted pregnancy is to be explained away as the work of 'the Holy Ghost' ('it was in Olivers dayes', Wiseman admits). But all this, though, is just a prologue to the final discussion of Joseph (Genesis 39. 10) as the exemplary figure of steadfastness in the face of sexual temptation. By this point, of course, Badman's career in sin has become far from the centre of attention. Indeed, we may well have forgotten entirely that

${ }^{19}$ Bunyan, Badman, p. 5. See Bunyan, The Pilgrim's Progress, pp. 33-34. 
this is supposed to be a narrative of his life and times. Yet, just as the digressiveness seems most exasperating, Bunyan easily and unproblematically returns Badman to the fore of the narrative once more: 'Blessed Joseph! I would thou hadst more fellows!' Attentive finally exclaims, upon which Wiseman sagaciously (and punningly) notes, 'Mr. Badman has more fellows than Joseph, else there would not be so many Whores as there are' ${ }^{20}$

In this way, Badman's life-story performs a distinctly subdued and secondary narrative function: it not only initiates the saintly discussions between Attentive and Wiseman but, because the dialogue inevitably returns to Badman, also provides a much needed anchor for a conversation continually on the verge of forgetting its story altogether. Moreover, the textual effect this structuring of The Life and Death of Mr. Badman has is important, particularly in revealing its eclectic and elastic didacticism. Although the instructional formula is frequently fixed (a type of sin is discussed, reflected upon through Scripture or doctrine and exemplified through Biblical, eye-witness, or judgement-book account), this does not make the text inflexible. Indeed, the fact that the dialogue is often narratively digressive merely allows Bunyan to be doctrinally progressive: because the sin of drunkenness often leads to theft, for example, the conversation can shift from the one topic to another (or many others) quite easily. Thus, just as 'Sins go not alone, but follow one the other as do the links of a Chain', so too is the dialogue holistically constructed through a complex doctrinal connectedness. ${ }^{21}$ What Badman presents structurally, then, is nothing less than a seamless whole of instructional discussion which can turn to any topic at any given moment with or without reference to the supposedly central figure, Mr. Badman. The narrative role of the 'life' of Mr. Badman is thus clear: it supplies the central thread of the text's teleology (no matter how circuitously it is pursued) while offering at least some kind of focal centre to prevent the didacticism from becoming too independent or static. It is important to recognise, then, that Badman is undeniably the story of Badman's life - and not just another treatise - but that it is also patently impossible for the reader to extract anything other than moral and spiritual lessons from it as a story.

\footnotetext{
20 Bunyan, Badman, pp. 49-55.

21 Bunyan, Badman, p. 47.
} 
While the relationship between narrative and doctrine is both more complex and more clearly delineated in Badman than in The Pilgrim's Progress, it is not only Mr. Badman's life that becomes notoriously difficult to read for pleasure but, more importantly, his death. Although the account of Badman's wicked ways is important to the text's structure, it is hardly the source of any narrative urgency. Indeed, Badman's life-story is not only fragmented by the meandering conversation of Attentive and Wiseman but could hardly be called, in any real sense, a comprehensive biography at all: we are informed only of three most general aspects of his sinful life - his youth, his marriages, and his years as a tradesman. What is presented with strategic emphasis and what apparently keeps the story in at least some suspense and intrigue, then, is the promise of Badman's death - his much needed just desserts - which Bunyan deliberately and with much narrative suspense develops throughout Badman. Thus, our expectations of a horrible death as retribution for Badman's gratuitously sinful life are signalled from the outset by Wiseman's initial words on the subject: he considers Badman to be in Hell principally because of 'His wicked life, and fearful death, specially since the Manner of his death was so corresponding with his life.' When pressed further, Wiseman says quite ominously, 'I was there when he died: But I desire not to see another such man (while I live) die in such sort as he did. 22

Such an introduction naturally makes for compelling reading and serves, initially at least, to entrap Attentive (as well as the reader) into a hearing of Badman's unwholesome life. From then on, the tension over Badman's expiration is constructed through Attentive who, while freely participating in the text's all-encompassing didacticism, regularly and sometimes impatiently prompts Wiseman to get to the point of Badman's demise. ${ }^{23}$ This suspense is maintained further through the narrative's many judgement stories, the gruesomeness and frequency of which undeniably prepares the reader, if Wiseman's words about Badman's death are to be believed, for the worst (or perhaps the best) of all judgement tales - one which must surely make Dorothy Mateley's end or Ned's possession by the devil pale by comparison. ${ }^{24}$ But, of course, by the time we are told of Badman's death, for which we have been so

\footnotetext{
22 Bunyan, Badman, p. 16.

23 Bunyan, Badman, p. 117, but contrast with p. 151.

24 Bunyan, Badman, pp. 33, 37.
} 
carefully prepared, it becomes apparent that Bunyan has been playing an elaborate narrative trick upon his reader all along. Badman's final dying 'As quietly as a Lamb' turns out to be but a well-planned and extremely well-executed exercise in narrative anti-climax. ${ }^{25}$ Should the reader have had any purely prurient interest in Badman's death, if he or she has been reading just for the story, it is at this point that punishment comes indeed: 'When a wicked man dyes in his sins quietly,' Bunyan's margin affirms, 'it is a Judgment of God' not only on the man himself but, more significantly, 'upon his wicked beholder.'26

Because it is the reader who becomes the focus at this crucial point in the text, Badman's death clearly provides Bunyan with more than just an opportunity to comment upon false or Papist notions of death-bed repentances or "to controvert the "frivolous and vain" opinion "among the ignorant" that a quiet death means a safe transfer to heaven.'27 Rather, it offers Bunyan the means whereby he can ensure, in a way The Pilgrim's Progress perhaps does not, that the text will finally frustrate any reader's narrative over-indulgence in the story. In this sense, although The Life and Death of Mr. Badman claims to share at least a basic teleological similarity with its predecessor (whereas Bunyan wrote 'the Progress of the Pilgrim from this World to Glory', in Badman he writes, 'of the Life and Death of the Ungodly, and of their travel from this world to Hell'), the two texts are very different in this respect. Whereas the telos of Christian's journey is fulfilled for the reader, that of Mr. Badman is finally denied: there is no description of his hellish after-life nor any sense of soterial finality. But while there seems to be an absence of a seen justice being exacted here (which may disappoint some readers), equally Bunyan is careful to make sure there is little sense of unjust perdition either. Bunyan's tactic in Badman is thus to ensure that the issue of his protagonist's damnation is not to be problematic in the way Mr. Ignorance's is in The Pilgrim's Progress: Badman's soterial fate is to be clouded by neither the reader's sympathy nor any sense of human frailty (as in Ignorance's case). As such, Badman's death and assured damnation consequently provide the starting point for a discourse indicating what Bunyan's real concerns are here: centring upon the issue of Badman dying in his sins, we can be sure that Badman has in fact gone to Hell not

\footnotetext{
25 Indeed, all the expected ghastliness of Badman's end is merely shifted by Bunyan upon someone else much less deserving, it seems. See the account of John Cox's horrific suicide in Badman, pp. 158-160

${ }^{26}$ Bunyan, Badman, pp. 151, 157, 166.

27 Hill, A Turbulent, Seditious, and Factious People, p. 239.
} 
because of anything to do with his manner of dying but because he was finally unrepentant and, according to Attentive and Wiseman, had hard-heartedly not even desired to undergo conversion unto salvation even in the throes of his last moments. ${ }^{28}$ For Bunyan, the most important issues in relation to Badman's life and death, therefore, are not to be any depiction of Hell or one's manner of extinction: as ever, the point of this text has been, all along, one of converting aright and living in faith and grace. ${ }^{29}$

Badman's death, then, finally provides an important insight into how, despite its radically different composition, style, and structure, The Life and Death of Mr. Badman surprisingly shares a purpose and function synonymous with those of The Pilgrim's Progress. This is evident not only in the text's doctrinal emphasis upon the importance of following an ordo salutis of repentance and faith but, moreover, in the commensurate stress it places on the need to perceive that which is unseen, a point most obviously driven home by the manner of Badman's dying. Because Badman's peaceful death can only be read in terms exactly opposite to the given evidence, Bunyan encourages the reader to contemplate the reality of a distinctly unseen Hell without recourse to its narrative depiction or physical signs of its existence. But, of course, the text alerts us to such a conclusion all along. The fact that Wiseman begins his conversation by bemoaning the double-death of Mr. Badman should, for instance, inform us of the covert nature of this story as a whole: 'He died that he might die,' Wiseman tells us, 'he went from Life to Death, and then from Death to Death, from Death Natural to Death Eternal.'30 What is to be most important, therefore, about Badman's dying is not the external confirmation, the 'Death Natural', but what lies incontrovertibly behind its physical or outward surface. In this way, Badman's slipping into death like a 'Chrisom child' can indeed provide Attentive with 'an uncontrollable proof of his damnation' but only by being construed in experimental terms of faith: because Badman 'lived wickedly even to the last', without experiencing repentance or faith, 'therefore Mr. Badman is gone to Hell.'31 Empirical evidence, that of one's eyes and senses, is useless in such matters. Rather, and in order to avoid the traps that await Badman's friends and 'wicked beholders', what is required of the

28 Bunyan, Badman, pp. 161-169

29 See Bunyan, Badman, pp. 161-169.

30 Bunyan, Badman, p. 14.

31 Bunyan, Badman, p. 161. 
reader at this crucial point in the text is the ability to read Badman's death ontologically, an interpretation which far from ignoring the available material signs actually inverts them in a contemplation of things invisible.

Wiseman's first piece of advice to Attentive in such matters is, therefore, telling: 'Make no Conclusions, man', he states, warning his youthful companion not only against preempting the end of the story but, more importantly, against a kind of reading which applies epistemological frames of logic and proof to what is ultimately open only to faithful spiritual discernment. Again, the text's many judgement stories are central to this design. Throughout the text, they appear to provide at least some sort of epistemological demonstration of the working of God's providence (its unequivocal physical operation confirmed by eye-witness testimony) and promise the same of Badman's life and death. But though the inclusion of such exemplary tales can be viewed as indicative of the ontological realm which Bunyan perceived mankind to exist within generally, a reality in which God's judgements do occur in many shapes and forms, this is not why they are primarily invoked. Rather, just as they function to create a narrative expectation of Badman's demise that is finally negated, so too do the supernatural tales reinforce a need to recognise the need for a faith in things unseen in matters of one's spiritual life - but especially in relation to the providence of God.

Not drawing conclusions is, in fact, imperative for the reader as, despite Badman's multifarious judgement tales, Badman himself seems to undergo no external punishment for his sins whatsoever, much to the wonder of Attentive: 'Certainly some wonderfull Judgment of God must attend and overtake such wicked men as these', he cries at one point, and to which Wiseman responds, 'You may be sure that they shall have Judgment to the full, for all these things, when the day of Judgment is come. But as for Judgment upon them in this life, it doth not alwayes come, no not upon those that are worthy thereof.' 32 Consequently, the point of Badman's life and death, it seems, is to show that while providential examples can provide important instances of God's will and justice, they can in no sense be relied upon as unequivocal proofs of divine mercy or displeasure. ${ }^{33}$ Hence, just as Grace Abounding and The

\footnotetext{
32 Bunyan, Badman, pp. 68.

33 See Bunyan's comments on trade and providence and the patient sufferance of economic hardship in Badman, pp. 90-96.
} 
Pilgrim's Progress warn against attempting to discern one's soterial status as elect or reprobate, so too does Badman discourage an over-reliance on the more physical and spectacular instances of God's judgements as confirmation of salvation or damnation: the only 'proof' of such matters is, as Badman's death reveals, repentance, conversion, and faith (or, conversely, a lack of them). In this way, Bunyan deliberately adopts the out-moded form of judgement-book examples not only to bolster his text's carefully contrived ant-climax but in order to discard them as narratively sensationalist and spiritually inappropriate: they conspicuously provide insight into neither the life nor death of Mr. Badman. ${ }^{34}$

Moreover, it is because understanding God's providences can be a dangerous or, at best, a misleading hermeneutic business for Bunyan (as he writes in The Saints Knowledge of Christ's Love (1692) they can be either 'seemingly good' or 'seemingly bad' at any given point) that the narrative's many example stories actually serve to warn the reader against making any judgements about Badman - at least in terms of outward appearances or effects. ${ }^{35}$ What the text consequently teaches the reader is that Badman's biography as a whole requires a distinctly grace-ful reading, one in which the reader learns, on the one hand, to avoid the wickedness exemplified in Badman's behaviour and, on the other, to recognise an ontological otherness beyond the empirically or carnally visible. Hence, throughout Badman's narrative the reader may frequently be confounded by actions or events which, appearing to be nothing but favourable to Badman's intemperate lifestyle (such as his running away to a wicked master, his choice of villainous companions, or his second marriage), are actually confirmed by Bunyan as being neither freely willed nor unpunished, even though there is little in the story itself to suggest that this is the case. Rather, Badman's wicked successes and triumphs are in themselves, Bunyan assures us, 'a sign of the Anger of God', and evidence, in the most unseen way possible, of 'Gods hand upon him, that he might receive not the love of the Truth that he might be saved.' Indeed, God has chosen Badman's 'Deluders and Delusions for him [...] that he might be destroyed.' 36

\footnotetext{
34 In terms of being a judgement-book, the editors of Badman view it as but 'a late representative of an increasingly old-fashioned genre' (pp. xxiv-xxv).

35 John Bunyan, The Saints Knowledge of Christ's Love (1692), in The Miscellaneous Works of John Bunyan XIII, ed. by W. R. Owens (Oxford: Clarendon Press, 1994), pp. 357-358.

36 Bunyan, Badman, pp. 57, 43.
} 
While important theological implications about the reprobate's will and God's ways are at stake in such reversed judgements, it seems that Bunyan's aim in Badman's case is not to point out the complexities and anxieties of Calvinist soteriology but to indicate the need to interpret the providences of one's spiritual life very carefully indeed. Despite his easy manner of departure, for instance, Badman's death is unequivocally confirmed as 'a deep Judgment towards ungodly sinners' sufficient 'to stagger a whole world', precisely because discerning such 'deep' judgements is inevitably connected to the greater, eschatological issue of final 'Judgement' for Bunyan. Indeed, it is one's ability to read judgements and acts of providence correctly (that is, grace-fully) that ultimately signals the division between the faithful and the faithless for Bunyan and for the simple reason that 'only the Godly that are in the world', he asserts, "have a Sanctuary to go to, where the Oracle and Word of God is, by which his judgments, and a reason of many of them are made known to, and understood by them.' 37 Understanding judgements thus lies in the remit of an acceptance of the Word which can subsequently provide assurance in terms of the greater 'Judgement'. Hence, what Bunyan stresses throughout Badman is nothing less than what is emphasised throughout The Pilgrim's Progress and his theology as a whole: the 'Godly' can find spiritual 'Sanctuary' from soteriological perplexity, especially when it comes to difficult matters of providence, only through a faithful understanding of the Word.

With this point in mind, it becomes easier to see how certain aspects of Badman's manner of living become doubly affirmative of his sure damnation, no matter how peacefully he died. As is summarised for us at one point in the dialogue, Badman not only lives according to amoral domestic and commercial principles but is, in spiritual terms, completely unseeing. Hence, throughout his life we find him consistently refusing (just as God refuses to allow him) to consider the nature of things invisible: he ascribes 'the glory' of God's providences and mercies, for example, to 'Fortune, ill Luck, Chance, the ill management of matters, the ill will of neighbours'. More importantly, far from taking sanctuary in the Word he actively despises it, objecting 'against the authority, harmony, and wisdom of the Scriptures', interrogating them sceptically and epistemologically in order to dismiss outright

37 Bunyan, Badman, pp. 168. 
any validity in their interpretation. In fact, Badman concludes upon them as merely being a labyrinth 'of a thousand impossibilities' ${ }^{38}$ As someone whose 'way' it is deliberately not 'to acknowledge God, (that is, graciously) or his hand in things', Mr. Badman is thus damned for being (among many other things) Bunyan's exemplary bad reader: substituting romances and bawdy ballads for the Word, he wilfully and hard-heartedly refuses to read the providential texts of his life and all-important Scripture in the light of grace. ${ }^{39}$

What is undoubtedly remarkable about The Life and Death of Mr. Badman is that, without recourse to any potentially frivolous allegory, metaphor, or fable, it manages to achieve the same spiritual and textual effects as The Pilgrim's Progress: in Badman also the reader is finally the focus of the text, subject to Bunyan's teachings about faith and grace, moral behaviour and things unseen, story and theology. In Bunyan's and Sherman's terms, then, Badman is by far more successful than The Pilgrim's Progress in that it conveys its doctrine effectively while rigorously containing the 'story' in the ways already shown. But at the same time, this is precisely why Bunyan's first sequel has enjoyed neither the success nor the longlasting reputation of its allegorical forbear: with its gruesome realism and distinct lack of romantic froth, it would be hard to imagine The Life and Death of Mr. Badman as a children's classic. For this reason, Bunyan's apparent accomplishment in mastering a narrative technique which discourages a reading for 'pleasure' is often simply disregarded as an artistic failure, Bunyan's sequels in general being frequently viewed as but poor imaginative seconds to the more powerful and universally enduring tale of Christian's pilgrimage.

This is as true, moreover, of Bunyan's The Holy War as it is of The Life and Death of Mr. Badman. Like Badman, The Holy War has neither received the critical attention nor achieved the popularity of The Pilgrim's Progress: Sharrock describes it as a 'magnificent failure', an 'attempt at a complex and allusive grandeur' that ultimately 'tends to defeat itself', and which can only be explained as analogous to the successful writer's weak 'second

\footnotetext{
38 Bunyan, Badman, pp. 126-128.

39 U. Milo Kaufmann's article, 'Spiritual Discerning: Bunyan and the Mysteries of the Divine Will', in Conventicle and Parnassus, pp. 171-187, provides an excellent understanding of Badman in these terms. For Kaufmann, Badman's spiritual corruption is marked most prominently by the disorder of his life in general, a disintegrative evil reflected in the fractured nature of the narrative. Badman thus lacks an ordering faith that enables those who do believe to read providence (pp. 184-187).
} 
novel' ${ }^{40}$ Again, like Badman, The Holy War is vilified most often for the very reasons that, in Bunyan's terms, make it so apt as a theological narrative - its structural diffuseness, digressiveness, and repetitions. We may indeed get the sense that, far more so than even in Badman, Bunyan's 'theology' has palpably 'got in the way' of the story in The Holy War. ${ }^{41}$ It is perhaps not surprising then that, although there is a clear return to the mode of allegory here, and a far more complex and involved one at that, readers and commentators are generally disappointed by this text. Altering the central metaphor from wayfaring to warfaring, Bunyan not only denies the story a sense of definite telos and closure (making The Holy War something of an allegorised Grace Abounding) but deprives it of the perceived kind of universality that has made The Pilgrim's Progress such a success. While a 'journey metaphor is faithful to the variety and unexpectedness of human life', as Sharrock puts it, evidently 'the metaphor of a military campaign is not.' 42

Comparisons with The Pilgrim's Progress are rarely beneficial for an appreciation of The Holy War, then, because, like Badman, it too is a sequel only in the sense that it is constructed in terms of avoiding its allegorical predecessor's potential problems of response. In The Holy War, therefore, the presentation of a believer's spiritual life before, during, and after conversion is framed within an allegorised battle precisely because it provides a less certain spiritual and narrative teleology, allowing Bunyan to be both more specific theologically and, in a sense, more realistic (as opposed to romantic) in his allegorisation - as Grace Abounding shows, experiencing the 'new birth' is hardly without uncertainties, digressions, and regressions. At the same time, the elaboration upon a metaphor of 'perpetual warfare' also enables Bunyan to present the heights and depths of spiritual experience as something far different from (and not to be confused with) a romantic or fabulous adventure. In presenting man's soul as a town under constant siege, Bunyan 'appears more determined than ever to

\footnotetext{
40 Sharrock, John Bunyan, pp. 136, 128, 119.

41 Sharrock, John Bunyan, p. 129 and Hill, A Turbulent, Seditious, and Factious People, p. 249.

42 Sharrock, John Bunyan, p. 119. For similar comparisons, see Hill, A Turbulent, Seditious, and Factious People, p. 252; Salzman, English Prose Fiction, p. 264. Newey makes important comparisons between Grace Abounding and The Holy War in, "With the eyes of my understanding": Bunyan, Experience, and Acts of Interpretation', in Conventicle and Parnassus, pp. 189-216 (p. 214).
} 
make the unseen world visible', albeit at the expense of a story that is hardly to be read for pleasure and which, unlike The Pilgrim's Progress, does not really end at all. ${ }^{43}$

It would be more appropriate, therefore, to note a comparison between Badman and The Holy War because, although they differ in terms of form (the one being dialogic and the other allegorical), nevertheless they share some fundamental features in their self-conscious remedying of The Pilgrim's Progress's narrative and imaginative autonomy. Both texts, for instance, place great importance upon the veracity of their subject matters via eye-witness accounts in a way that The Pilgrim's Progress, as fabulous dream-vision, does not and cannot. Throughout Badman, Bunyan is careful not only to encourage the reader to 'behold with thine own eyes' the related events and stories but to stress the authenticity of a fiction pre-eminently based on fact, truths not metaphorical but actual. Thus, in explaining his inclusion of many providential stories in Badman, Bunyan makes it clear that he is no longer relying upon any allegorical mediation in his representation of spiritual reality: these 'are things', he asserts, 'either fully known to me, as being eye and ear witness thereto, or that I have received from such hands, whose relation as to this, I am bound to believe.' And in case the reader is not reminded of this enough in the dialogue itself, Bunyan ensures through his marginal omnipresence in Badman that such truths are not to be overlooked, either: imitating God's providential hand textually, Bunyan has, 'pointed to them in the Margent, as with a finger'.$^{44}$

While Bunyan is at pains throughout Badman to ensure that 'these Stories', including that of Badman's life and death, are recognised by the reader as 'True stories, that are neither Lye, nor Romance', he takes this stance one step further in The Holy War.45 Claiming that The Holy War is an eye-witness record, despite its form as an allegorical fiction, Bunyan can disclaim himself in the prefatory verses as any mere 'Fable-maker', asserting that the 'records' of Mansoul's wars are 'true', principally because ' $I$ was there' and, consequently, 'what is here in view,/Of mine own knowledg, I dare say is true'. While this assertion is undoubtedly corroborated by the experiences described in Grace Abounding, it is not through the medium of personal testimony alone that Bunyan can emphasise 'That Mansouls matchless Wars no

\footnotetext{
43 John R. Knott, Jr., The Sword of the Spirit: Puritan Responses to the Bible (Chicago and London: University of Chicago Press, 1980), pp. 154-155.

44 Bunyan, Badman, pp. 3-4

45 Bunyan, Badman, p. 82.
} 
Fables be' but, more significantly, through its distinctly authoritative status as a 'history'. Indeed, now Bunyan can rightly claim that his allegory is no fable (unlike The Pilgrim's Progress which defends itself distinctly as fictive) because it relates the unequivocal 'truths' of man's conversion and redemption, on both an individual and a cosmic scale, as historically verifiable. Hence, as a chronicle of 'Mansoul's wars', The Holy War is thus presented by Bunyan as both fictional and factual, allegorical and realist, narrative and yet non-fabulous. As J. Hillis Miller puts it, by calling his fictive allegory 'history', Bunyan 'at one stroke covers all the implications of gratuitousness, of baseless creativity and lie involved in the word "fiction", while simultaneously affirming for The Holy War 'that verisimilitude, that solid basis in a preexisting fact, which is associated with the idea of history.' 46

In case we are concerned that Bunyan's allegorising is falling conspicuously into an oft warned against interest in 'historical parts', however, Bunyan carefully explains the narratology behind The Holy War before the 'history' proper begins. The verse preface to The Holy War consequently offers once again a sophisticated and profound explanation (or exploration) of Bunyan's self-conscious artistic method, here, but in a way far different from how The Pilgrim's Progress is introduced. As in Badman, The Holy War's prefatory lines present no defence of metaphor, style, or story. In fact, this is no guarded 'apology' at all. Rather, it is a clear illustration of both the narrative and imaginative concerns behind The Holy War which, as a true history, Bunyan is encouraging the reader to place in comparison with those books that will always remain but 'vain stories', despite the 'Disciples they obtain', books that are 'sage' in their raising of 'mountains', comprehensive in their study of whole nations (fictitious or otherwise), and confident in their contemplations on the science-fiction of 'brave Creatures' in 'residence' amongst the 'stars'. In contrast, Bunyan's intention in The Holy War is not 'to amazel The People' with such feigned delights. Conscious, perhaps, that he too has raised fictive mountains in the past (delectable though they may be), Bunyan now aims to present a spiritual 'Historiology' which, unless it be seriously considered, will leave 'men [...] to themselves unknown.' In this way, Bunyan's verse preface manages to outdo even Sherman in its condemnation of impious seventeenth-century reading habits: while

46 J. Hillis Miller, 'Narrative and History', ELH, 41 (1974), 455-473 (p. 457). 
Sherman rails at romances, plays, and novels, Bunyan articulates a more profound concern at the fact 'that they that love to tell/Things of old' and, indeed, excel in 'Historiology,/ Speak not of Mansoul's wars, but let them lye/Dead, like old Fables'. This is not just a criticism of Restoration history books, either, or a valorisation of the 'historical parts' of Scripture. Rather, because Mansoul's 'Histories' are, as Bunyan's marginal note reveals, 'The Scriptures' themselves, Bunyan's focus goes beyond Sherman's worries over the decline in sales of devotional tracts. Bunyan's concern in The Holy War is over nothing less than the Word and, in noting its degeneration to the status of 'old' and 'Dead' 'Fables', it is the purpose of The Holy War to give the 'truths' of the Scriptures something of a re-birth. 47

Bunyan principally achieves this aim by ensuring that the Scriptural stories and fables most relevant to the salvation of the soul, the Old Testament account of the Fall of Adam and the New Testament account of Christ's redemption, are re-presented (if not re-written) in The Holy War with an emphasis upon their doctrinal rather than narrative importance. Because Bunyan's concern in The Holy War is from the outset over any Badman-like dismissal of Scriptures as but old stories, through which men can only remain spiritually and damningly ignorant ('to themselves unknown'), it is Bunyan's aim to ensure that the salvatory message of the Word is conveyed in The Holy War without the danger of being considered antique legend. Hence, when Mansoul, as representative of the soul of mankind, undergoes its Fall it is in a manner which self-consciously revises the original Genesis account. The central ingredients to the story of the Fall certainly exist here (Diabolus assumes 'the body of one of these beasts that Mansoul deems to be wiser than any of the rest', tempts Mansoul with cunning rhetoric, and succeeds in encouraging the town to partake of the forbidden fruit of the 'Tree of knowledge of good and evil'), but this is a very different version of that story nevertheless. Most obviously, the figures of Adam and Eve themselves are erased, so there is no real construction of suspense nor any apportioning of personal blame here. Because the fallibility cannot be identified in any specific character other than a collective humanity ('the Towns-folk'), Bunyan simultaneously

47 John Bunyan, The Holy War, ed. by Roger Sharrock and James F. Forrest (Oxford: Clarendon Press, 1980), pp. 1-5. 
shifts our attention away from the Fall as a 'story' about Adam and Eve and upon the implicit fallenness and complicity of all mankind. ${ }^{48}$

Moreover, the account of Mansoul's lapse is wholly governed by Bunyan's doctrine, too. Diabolus, for instance, only achieves his initial victory through the specific murder of the town's 'Captain Resistance' along with the wiliness of a 'subtilty made up of lies', a rhetoric not only of temptation to knowledge but, more importantly, of freedom from the Law, ' $a$ bondage that unawares to yourselves, you are captivated and inslaved under', and from which Diabolus promises to deliver Mansoul. Diabolus's first speech to the town is important not only because he beguiles its inhabitants with a post-lapsarian concept of legal obedience as 'unreasonable, intricate and intolerable', engendering nothing but 'fear of the greatest punishments' even before the Fall has occurred, but because it indicates that theologically this is a most particular recounting: here begins the struggle over liberty from or bondage to the Law that is to continue throughout Mansoul's history (and which frequently becomes embodied in the flourishing rhetoric of both Diabolus and Emanuel), but which can end only through Emanuel's grace. In this way, Bunyan's depiction of Diabolus's taking of Mansoul becomes not only a re-writing of the Fall as it is related in Genesis but, more significantly, a commentary upon the Scriptural Fall itself, a grand gloss in which the implications for man's soul are (as is the nature of a gloss) made palpably more important than the original story itself. Not surprisingly, this rendering of Scriptural history into doctrinal commentary has a somewhat dizzying effect upon the texture of The Holy War at this point: the 'Towns-men' of a non-Biblical Mansoul 'Fall' by consuming the fruit of a tree that exists only in a Scripture beyond the fictionality of Mansoul - that is, it resides in a doctrinally discursive space extraneous to the town's allegorical perimeters and anomalous to the text's allegorising paramaters. ${ }^{49}$

Such a re-writing of Scriptural narrative is even more blatant, however, in Emanuel's actual redeeming of Mansoul. While the heart of Christ's atonement for man's sins lies in the crucifixion, and although some of Bunyan's tracts emphasise an almost idolatrous meditation on the saving nature of Christ's blood shed upon the cross, the historicality of Christ's

\footnotetext{
48 Bunyan, The Holy War, pp. 12-17.

49 Bunyan, The Holy War, pp. 12-17.
} 
sacrificial role is effectively removed from the salvatory scheme of The Holy War. In fact, there is absolutely no hint whatsoever as to the nature of Emanuel's reparation for Mansoul's lapse nor the terms of the bargain struck with Shaddai for Mansoul's recovery. Indeed, instead of dwelling on practically any aspect of the Scriptural actualities of Christ's sacrificial role, Bunyan chooses, rather, to allegorise the purely covenantal character of Emanuel. Having revealed to Mansoul the form of the covenant made 'a surety' to 'make amends for Mansoul's transgressions' Emanuel simply states: 'So when the time appointed was come, I gave body for body, soul for soul, life for life, blood for blood, and so redeemed my beloved Mansoul.'50

The fact that the reader is not privy to the actual story of this mediatory exchange, which has occurred somewhere beyond the narrative vision of this text, is again significant. It indicates once more the extent to which Bunyan refuses to let even Scriptural story dominate the narrative of The Holy War, a fact that, in turn, forces us to reassess the text's initial emphasis upon the importance of Christian historiography as a whole. In The Holy War it is clear that Bunyan is not interested in simply recounting events from Christianity's ancient past. Rather, this account of Mansoul's wars records what John von Rohr refers to as a 'divine history', a trans- or metahistorical chronicling of God's salvationary plan which, for Bunyan, has its beginning and its end beyond the historical, outside time itself, in the covenant of grace between God and Christ and the glorification of the saints at the final Judgement, as promised by Emanuel at the close of The Holy War. ${ }^{51}$ Hence, whereas The Pilgrim's Progress has at its centre the figure of the historical cross before which Christian loses his burden, such iconography gives way in The Holy War to the fundamental tenets of Bunyan's covenant theology in which such imagery has been stripped away: what is most important now is not the manner of Emanuel's redemption but the timeless assurance that, through his covenant with Shaddai, Mansoul is saved. In shedding even the mediation of Scriptural narrative to ensure the conveyance of his doctrine of Law and grace, Bunyan is neither re-writing the Bible with complacent self-satisfaction nor taking Reformation iconoclasm to an extreme. Rather, assuming that his reader already knows the Scriptural detail of Christ's atonement (his death on

\footnotetext{
${ }^{50}$ Bunyan, The Holy War, p. 75. For the covenant struck between Shaddai and Emanuel, see pp. 28-30.

51 John von Rohr, The Covenant of Grace in Puritan Thought (Atlanta, Georgia: Scholars Press, 1986), pp. 4344.
} 
the cross), Bunyan ensures that this knowledge is not just notional or historical: as ever, what The Holy War endeavours to achieve here is the instilling of a doctrinal understanding of (and a faith in) an atonement based not on facts or story but on the everlasting covenant of grace alone.

Commentators are correct, therefore, in noting that doctrine 'gets in the way' when trying to read The Holy War. It certainly and purposefully does, with the result that The Holy War seems to lack the kind of teleology and the type of narrative sugaring of the doctrinal pill that makes a book like The Pilgrim's Progress such a success for many readers. But, of course, there is an obvious agenda at stake here. The fact that The Holy War seems as diffuse, as repetitive, and as much without 'plot' as, say, Grace Abounding merely marks, in fact, the degree to which the text is similarly engaged in foregrounding its own anti-narrativity, especially as a supposed treatise in historiography which succeeds only (but quite deliberately) in negating and frustrating anything that we may expect of it narratively as a 'history'. Indeed, while the very concept of 'history' can be said to exemplify how all '[n]arratives concern the past', and that in any story it is usually 'the end of the temporal series - how things turned out that determines which event began it', in The Holy War such narrative interest and structuring could be said to apply only to the grander metahistory of salvation and Judgement that lies beyond the actual events of Mansoul's history as Bunyan presents it. The given (hi)story of The Holy War, therefore, conspicuously has no ending for Bunyan's reader and is concerned not with the past but only with a future redemption in any case. Moreover, the fact that 'history' notoriously shares the same problems and methods of narration as fiction (and therefore may be indistinguishable from it) seems both to be recognised and side-stepped by Bunyan in The Holy War. In this text, Bunyan cleverly lays claim to the veracity of historical 'Truth', on the one hand, and yet, on the other, he carefully avoids the kind of 'temporal progression' and 'human interest' in a conventional plot ('with a beginning and an end') that could otherwise threaten to render his doctrine (and his reader's reading of it) as merely 'historical' .52

52 For a concise discussion of the narrative nature of written history and its relation to fictional narrative, see Wallace Martin, Recent Theories of Narrative (Ithaca and London: Cornell University Press, 1986; repr. 1994), pp. 71-75, 80, 87. Among the most interesting articles on the subject of history and/as narrative (and which offer extremely interesting insights into The Holy War as 'history'), see Louis Mink, 'History and Fiction as 
As a consequence, with the lack of narrative linearity and 'temporal organisation' associated with either history or romance, and with its re-presentation of Scriptural event and fable so distinct, Bunyan's second allegory differs from a work like The Pilgrim's Progress principally because it seems to be more of a book-length emblem than any kind of a conventional chronicle or 'story'.53 Indeed, the emblematic nature of The Holy War is signalled not only by its predominantly static nature (as opposed to the 'progressive' nature of Christian's journey) but by the way in which it is a story not to be enjoyed for itself but, rather, to be discovered as an imaginative gloss upon both Scriptural truths and the nature of conversion as a whole. Like the moving images in the 'Significant Rooms' of Interpreter's House, though, The Holy War does not present or represent the Word per se, either: as we have seen, neither Christian nor the reader of The Holy War is asked to interpret Scripture. Rather, in witnessing Mansoul and its wars as an ongoing emblem we are, like Christian in Interpreter's House, expected to be teachable in matters of faith and doctrine and, as we know from The Pilgrim's Progress, such teachableness demands a certain type of reading.

It is for this reason, it would seem, that in The Holy War's opening verses Bunyan's figuring of his book as a house to be entered by the reader is intended to remind us so explicitly of Interpreter's House: Bunyan apologises for having held the reader too long 'in the Porch' and from the 'Sun-shine' of the text's spiritual enlightenment with what is, after all, only a prefatory 'Torch'. While such an image may remind us of how Christian makes his way through Interpreter's House with the 'Candle of Illumination', the promise of beholding 'five hundred times more Rarities' as will 'please the mind' and 'feed the eyes' through which 'if a Christian, thou wilt see/Not small, but things of greatest moment be', effectively seals the connection: The Holy War is presented as a conscious extension of Interpreter's House and, functioning in the same edifying way, must be read as such. While Christian is notably aided

\footnotetext{
Modes of Comprehension', NLH, 1 (1970), 541-558; J. Hillis Miller, 'Narrative and History'; Hayden White, 'The Value of Narrativity in the Representation of Reality', Critical Inquiry, 7 (1980), 5-27, and 'The Question of Narrative in Contemporary Historical Theory', History and Theory, 23 (1984), 1-33. For a view of 'the present tendency to view history as narrative' as 'unfortunate' (arguing that history is not centred in story-telling but in inquiring into what happened in the past), see Maurice Mandelbaum, 'A Note on History as Narrative', History and Theory, 6 (1967), 413-419 (pp. 419, 413-414).

53 'What histories and biographies', Wallace Martin asserts, 'share with novels and romances is temporal organisation', with 'human interest' determining 'whether events and causes fit together in a plot with beginning and end' (Recent Theories of Narrative, pp. 187, 87).
} 
in his readings by Interpreter himself, Bunyan is once more careful to point out that the reader of this enormous emblem also has a guide - the 'Key' in the text's 'window' which the reader must turn 'right' (or rather turn to aright) in order to 'know' Bunyan's 'riddle' and avoid losing one's 'way' in the text's 'mysteries' ${ }^{54}$ As in The Pilgrim's Progress, the margins of The Holy War will offer some interpretive support for its reader, providing explanations to the allegorical 'riddles' in a way that The Pilgrim's Progress's marginalia often do not. Yet, even with this framework there is still the danger that reading this text could be potentially anxietyinducing if not approached properly. Clearly, many modern commentators appear to have lost their way in reading The Holy War, finding it a text of labyrinthine complexity and mystery. To a large extent, however, this only typifies Bunyan's point: the text must be approached via its 'Key', which is not just its marginal notation but, as we learn in The Pilgrim's Progress, what they represent upon the page - a guiding by the light of faith.

Consequently, spiritual reading, being guided by Bunyan and the Spirit in one's interpretation, is a central issue in The Holy War for both Mansoul's inhabitants and any reader trying to understanding this text as a whole. A crucial turning point for Mansoul occurs, for example, when the victorious Emanuel, having recaptured and new-modelled the rebellious town, establishes a 'Ministry' to teach the town's populace 'both law and judgment, statute and commandment; that they might be documented in all good and wholsome things.' This Ministry is, moreover, two-fold, and strictly so. Emanuel's 'high and mighty Secretary', the allegorised Holy Spirit, is appointed as 'chief Teacher' to Mansoul in all matters of God's will and ways, to instruct 'in all high and supernatural things', and to illuminate 'in all high and sublime Mysteries', while 'Mr. Conscience' is to provide the more 'terrene \& domestick' teaching 'of Moral Vertues, to Civil and Natural Duties'. Apparently, never the twain shall meet: Mr. Conscience, as well as Mr. Recorder ('Knowledge'), is warned unequivocally not even to 'attempt to presume to be a revealer of those high and supernatural Mysteries that are kept close in the bosome of Shaddai [...]: for those things know no man, nor can any reveal them but my Father's Secretary only.'55

\footnotetext{
54 Bunyan, The Holy War, p. 5.

55 Bunyan, The Holy War, pp. 138-142.
} 
The point of this new Ministry in Mansoul is to ensure that true understanding for its inhabitants necessarily involves spiritual experience and that interpreting God's ways and mysteries, be they in the text of the Word or that of one's life, demands something other than the merely moral or civil, terrestrial or natural - it demands an other-worldly turning of the interpretive key gained only through the turning of oneself in conversion. While Mansoul thus gives up any presumption to discern unseen supernatural things without experiential revelation, it seems that the reader of this text must similarly interpret The Holy War in a strictly experimental, or at least doctrinal, sense in order to avoid becoming lost in it's complexities. If the reader presumes to approach the text in a 'terrene \& domestick' manner, using the kind of critical faculties associated with the study of history books or the consumption of romance, only disappointment, confusion, and boredom can follow: The Holy War simply becomes a story that repeats itself and ends dissatisfactorily. In contrast, it is only if the reader takes Bunyan at his word and follows the text according to its doctrinal key that any sense of repetition can begin to be perceived as merely superficial.

The second fall of Mansoul, for example, is not just a long and drawn-out replaying of the original lapse but an important depiction of the backsliding of the converted soul into doubt and despair, the theological importance of which is pointed to by the marginal guide in a most Interpreter-like manner: ' 'Tis not Grace received, but Grace improved, that preserves the soul from temporal dangers.' 56 Similarly, Diabolus's final deployment of the Bloodmen to harass poor Mansoul is not to be read as just another attack indistinguishable from the rest: it is a specific representation of the spiritual doubt and torment caused by the political persecution of Nonconformity and which must be dealt with by ('Captains') 'Credence' (Faith), 'Patience', and 'Self-Denial' ${ }^{57}$ Consequently, without a recognition of the way that the text as a whole presents spiritual life as a continuum of similar but finally different experiences the doctrinal point of Bunyan's The Holy War will always be missed. ${ }^{58}$ It is this fact, moreover, that

\footnotetext{
56 Bunyan, The Holy War, p. 152.

57 Bunyan, The Holy War, p. 232. For comments on the political role of the Bloodmen see Hill, A Turbulent, Seditious, and Factious People, p. 247, and Richard Greaves, 'Amid The Holy War. Bunyan and the Ethic of Suffering', in John Bunyan and English Nonconformity (London: Hambledon Press, 1992), pp. 169-183 (pp. 173-4).

58 For more reliable accounts of the theology of The Holy War as a conversion narrative, see Christine W. Sizemore, 'Structural Repetition in John Bunyan's Holy War', Tennessee Studies in Literature, 24 (1979), 7181, and Daniel Lamont, 'Bunyan's Holy War', Theology Today, 3 (1946-7), 459-472.
} 
indicates just how different The Holy War is from The Pilgrim's Progress. While Bunyan's first allegory could be read largely as a religious romance in which the doctrine can be ignored if necessary, as an extended emblem The Holy War avoids such a danger. The Holy War undoubtedly teaches the same doctrine as The Pilgrim's Progress and explores the same issues of conversion, backsliding, and assurance. But unlike its allegorical predecessor, it refuses to allow any separation between story and doctrine, faith and interpretation. Along with Sherman's Second Part, The Holy War is The Pilgrim's Progress re-written and re-presented by a Bunyan painfully aware (as the concluding 'Advertisement to the Reader' shows) of his critics' comments. The Holy War is consequently a text which presents despair no longer as a romance adventure of giants and dungeons but as a relentless, drawn-out, and painful assault by Satan through which the believer frequently and remorsefully forgets Emanuel's everlasting promises and covenant.

Being a narrative in which doctrine demands practically all of the reader's faithful attention we must not, however, fall into the trap of thinking that it is Bunyan's 'harsh' Calvinist theology that makes The Holy War difficult to read, although this is often how commentators both explore and explain the text. ${ }^{59}$ Any reading of The Holy War as an account that emphasises the agonies of Calvinist soteriology or encourages an unhealthy introspection is misguided if only for being doctrinally non-specific: such an approach ignores the fact that predestination in The Holy War is, as in The Pilgrim's Progress, far from the central theological issue for Bunyan.60 It seems of great import to note, for instance, that any soteriological anxiety in The Holy War is generated not by Mansoulians but strictly by

\footnotetext{
59 Despite 'Bunyan's best efforts', for instance, The Holy War has been criticised for lacking a 'sense of drama' largely because it 'rests, when interpreted soteriologically, on a Calvinist foundation' that renders 'any real doubt about the fate of Mansoul', groundless: Richard Greaves 'Tercentenary Reflections', in John Bunyan and English Nonconformity, pp. 193-206 (pp. 197-8).

60 Stuart Sim seems most uncompromising in this respect, regarding The Holy War as a text 'deeply imbued with Calvinist soteriological assumptions', its dynamism generated only by 'an unending dialectical conflict between good and evil, free-will and necessity [...] conceived within a rigidly predeterminist soteriological scheme.' Because 'anxiety' once more provides the key to this text for Sim, with Bunyan 'as severe as ever in his theology' in a text that merely emphasises the uncertainty of reprobation and election while encouraging a torturous introspection, The Holy War is viewed as exemplifying an 'impersonal, indeed inhuman process', a conversion account structured like some vast Ramist maze 'with divisions remorselessly spilling out into the future towards an impossibly remote goal' (Stuart Sim, Negotiations with Paradox: Narrative Practice and Narrative Form in Bunyan and Defoe (London: Harvester Wheatsheaf, 1990), pp. 92-94, 105-6). With a similar concern over the psychological damage Calvinist soteriology can do to the convert-to-be, Roger Sharrock most disconcertingly views The Holy War as but a flash-back 'to the terrible private universe of [Bunyan's] Elstow days, when voices contended against voices', a veritable return to 'the mental hiding-places of Bunyan's past' (John Bunyan, pp. 119, 136).
} 
Diabolonians intent upon harrowing the town: it is from 'old Incredulity' that Mansoul is encouraged to despair over how 'you indeed know, when you are [Shaddai's]' or 'which of you he will kill, and which of you he will save alive?' Because such reckoning is clearly identified by Bunyan as synonymous with the most evil kind of unbelief, any question over being saved or not is safely displaced in the text as the work of Satanic agency. As such, it becomes the duty of the reader to recognise, as the etymology of Incredulity's name suggests, the detrimental effect such questioning can have on a believer's faith. ${ }^{61}$

It is for this reason, moreover, that the final trial of the three Doubters (to whom Evilquestioning offered his 'charity') re-emphasises an overt theological emphasis on Law and grace to be found throughout the text. The self-martyring 'Election-doubter', for instance, is put on trial not because he represents a refutation of a doctrine of predestination but, more simply, because he doubts the promise of the covenant and the possibility of election: 'to question Election is to overthrow a great Doctrine of the Gospel', we are told, 'to wit, the Omnisciency, and Power, and Will of God, to take away the liberty of God with his Creature, to stumble the faith of the Town of Mansoul, and to make Salvation to depend upon works, and not upon Grace.' Because this Election-doubter has 'belyed the Word, and disquieted the minds of the men of Mansoul' he must be executed. Indeed, one 'Grace-doubter', who believes 'that Mansoul shall never be saved freely by Grace', is tried and put to death to make the same point: the theology of The Holy War is quite simply a covenant one in which conversion in Law and grace is paramount and for which the question of predestination figures only to exemplify faithlessness. 62

Of course, this is not to deny that there is a distinct dialectic at work in The Holy War. there clearly is, but it is not one that rests in the paradox of predestination. Rather, in accord

\footnotetext{
${ }^{61}$ Bunyan, The Holy War, p. 57. A similar point is made towards the close of The Holy War in the case of one 'Evil-questioning' who, upon being arrested and tried for having 'questioned the truth of [Mansoul's] Doctrine and State' and 'wishing that ten thousand Doubters were in her', defends himself by innocently suggesting that his real name is 'Honest-Enquiring'. This Diabolonian's hopeful plea 'that a man [...] may make an honest enquiry after things, without running the danger of death' is doubly grievous to Bunyan: not only is the Diabolonian exploiting the fact that innocent and pernicious reasoning can become so easily blurred in spiritual affairs but such 'questioning', whether evil or not, blatantly goes against Emanuel's command to turn only to the Lord Secretary (the Holy Spirit) in matters of great mystery. The likes of Evil-questioning thus serve to warn against the kind of soteriological investigations that send Bunyan astray in Grace Abounding. See The Holy War, pp. 237-238.

62 Bunyan, The Holy War, pp. 240-242. Introspection in the text is, moreover, never in terms of seeking evidence of election but is rather a searching-out of sin and sinfulness. See, for example, the roles Willbewill, Prywell, and Diligence play in discovering Diabolonians in Mansoul, pp. 144-5, 181-2, 195-6, 202, 225, 236.
} 
with Bunyan's theology of free grace as a whole, The Holy War illustrates a more basic tension between the believer's own role in faithful conversion and a reliance solely upon Christ's mediation as saviour, a conflict between voluntarism and absolute passivism. This dialectic is, however, conspicuously brought to the fore of the reader's attention in The Holy War only at the very end of the narrative when Emanuel, in his final speech to Mansoul, suddenly claims sole and absolute responsibility for the town's recovery at every stage of its many crises. Affirming divine sovereignty in all things spiritual, such a statement is obviously problematic here. For instance, although the declarations 'I have taken thee out of the hands of thine enemies' and 'I came to thee first by my Law, then by my Gospel to waken thee, and shew thee my glory' are irrefutable descriptions of what we have been witness to in the first half of Bunyan's record of Mansoul's wars, the same cannot be said of Emanuel's assertions concerning the town's experience of backsliding: 'The way of back-sliding was thine', we are informed,

but the way and means of thy recovery was mine. I invented the means of thy return; it was I that made an hedge and a wall, when thou wast beginning to turn to things in which I delighted not. [...] 'Twas I that set Mr. Godlyfear to work in Mansoul. 'Twas I that stirred up thy Conscience and Understanding, thy Will and thy Affections, after thy great and woful decay. 'Twas I that put life into thee, $O$ Mansoul, to seek me, that thou mightest find me, and in thy finding thine own health, happiness and salvation. 'Twas I that fetched the second time the Diabolonians out of Mansoul; and 'twas I that overcame them, and that destroyed them before thy face. ${ }^{63}$

Although the basic sense of this statement (that without Emanuel Mansoul would undeniably be in Diabolus's possession) is true, as a recounting of past events it does not conform to the history to which we have all along been witness. Emanuel, we must remember, withdrew himself from Mansoul very early on in the town's backsliding and does not return visibly until the final battle, between which Mansoul is, it seems, very much left to its own devices. ${ }^{64}$ Because of this sequence of events, it seems difficult to reconcile Emanuel's version of Mansoul's recovery (in which he apparently orchestrated everything, as the oft repeated ' 'Twas I' so forcefully drives home) with the narrative we have just read in which Mansoul succeeds in rallying itself quite autonomously, it seems, in a time of doubt and despair. Emanuel's last speech, therefore, creates something of a dilemma for its reader. We are told

\footnotetext{
63 Bunyan, The Holy War, pp. 245-6.

64 Bunyan, The Holy War, pp. 153-4, 221-4.
} 
here that Mansoul was responsible for no part of its return from spiritual apostasy, that all was co-ordinated by divine influence alone, when the narrative itself (and our testimony to it as readers) reveals that such a triumph has been achieved largely through Mansoul's sheer effort and persistence in the apparent absence of Emanuel. Willbewill, for example, though entirely ignored in the final speech of The Holy War, is actually crucial to Mansoul's on-going victories and becomes something like one of the heroes of the text as a whole. As the regenerate will, Willbewill not only continually terrorises those Diabolonians still at large in the town but is central to the final defeat of Diabolus's army of Doubters: in a powerfully emblematic description, Diabolus himself is faced in battle with 'Captain Credence on the one hand, and the Lord Willbewill on the other'. Willbewill's strokes being 'like the blows of Giant', he is apparently as valiant as Faith itself in any battle against despair and yet is given no credit at all by Emanuel for his endeavours. ${ }^{65}$

Bunyan's reasons for deliberately negating Mansoul's wilful self-achievements are, however, obvious. Emanuel's final address simply reasserts the fact that, in Bunyan's ordo salutis, salvation must not be merited by any of the believer's actions or deeds. As Emanuel's speech as a whole makes clear, salvation must come through faith in Christ alone and not works. Hence, despite the obvious role the will and other human attributes play in Mansoul's spiritual survival, it becomes necessary to accept that all is ultimately of Christ. In turn, this demands something of a conceptual turn-about from The Holy War's reader. In order to reconcile Emanuel's words with a narrative that seems to contradict those words, we are required to deny the evidence of our own eyes in what we have so far accepted as the unequivocal 'Truth': even the factuality of Mansoul's records, it seems, is to be undermined in favour of a faith in Christ's actions alone, the reader being obliged to accept Emanuel's account as the 'Truth' nevertheless. Consequently, in order to avoid becoming lost in the text's final riddle over divine responsibility for Mansoul's feats the reader must, as is taught in Interpreter's House, finally understand the text in terms of things unseen. In this case

65 Bunyan, The Holy War, p. 220; for the regenerated Willbewill's other activities, see pp. 195-6, $202,225$. Willbewill is also made keeper of Mansoul's gates, pp. 235-6. 
Emanuel, having visibly forsaken Mansoul, has apparently achieved his victory nevertheless from behind the scenes: he has worked for Mansoul all along in a literally unseen way. ${ }^{66}$

It is clear to see, then, how The Holy War, despite its general unpopularity, can be said to represent Bunyan's greatest narrative achievement in balancing story against theology, fiction against 'Truth', the carnal and the seen against the spiritual and the invisible. In answering any criticisms of The Pilgrim's Progress as too vain and frivolous, The Holy War is, it seems, more than a fitting response to the comments published by Sherman in the same year: though it tells a doctrinal story synonymous with that of The Pilgrim's Progress, this complex and sobering allegory could hardly be criticised for being mere romance or froth. At the same time, however, there are undoubtedly elements of The Holy War which prepare the reader for Bunyan's final (and in many ways much more fictively frivolous) allegory, The Pilgrim's Progress, Part II. Like The Holy War, for example, Part II no longer presents conversion and its trials as a lone crusade but as a corporate, co-operative, and collective mission. ${ }^{67}$ Moreover, in openly exploring a dialectic in which human effort and persistence come to play an undeniably important role in spiritual affairs, and in closing with a deferral of Mansoul's soterial fate to embrace hope within uncertainty ('hold-fast till I come'), The Holy War also seems to forecast Part II's more relaxed theological scheme. With damnation and salvation lying beyond the narrative scope of The Holy War, the doctrinal tone of this allegory may appear, at first glance, to be greatly different from that of either The Pilgrim's Progress or The Life and Death of Mr. Badman, texts which may seem more uncompromising in matters of soteriology and more isolating in their depiction of spiritual anguish.

\footnotetext{
66 Although the believer must employ will and conscience as well as reason and knowledge in any battle against doubt and sin, this cannot be at the expense of faith in Christ's free grace. In advcocating both the activity and passivity of the will, Bunyan is asking the reader to step into the excluded middle-ground of spiritual perception: a recognition of the invisible beyond the visible and which precludes any either/or rationalising of the way of faith. Such a view effectively revises Sharrock's view, for instance, that the will's positive and active role in The Holy War is largely a result of the fictionality of the text overwhelming its theological consistency, a tension between symbol and idea (see introduction to The Holy War, pp. xxxvi and John Bunyan, pp. 129-130). For an excellent discussion, though, of the combined nature of divine and human agency in Puritan conversion and perseverance, see von Rohr, The Covenant of Grace in Puritan Thought, pp. 135-153.

67 Vincent Newey points out that The Holy War is distinguished from Grace Abounding and The Pilgrim's Progress as it presents conversion as a distinctly 'corporate' affair ("With the eyes of my understanding', p. 215).
} 
It would be tempting, therefore, to interpret the inconclusive conclusion of The Holy War as marking 'a development in Bunyan's soteriological thinking: a progressive disengagement from the rigidity of Calvinist doctrine', a clear expression of mellowing theological convictions in Bunyan preliminary to the more comprehensive soteriological softening apparently evident in The Pilgrim's Progress, Part II. ${ }^{68}$ In these terms, both The Holy War and Part II could be taken to be indicative of a general amelioration in Bunyan's doctrinal thinking during the years towards the end of his life. With their emphasis upon communal rather than individual experience, upon integration instead of isolation, these later allegories may be seen as reflecting biographically 'the capacity of middle-age, whether in an individual or a community, to reduce an overwhelming spiritual experience to more manageable proportions.' 69 This is particularly the case with The Pilgrim's Progress, Part II, however, which readers and commentators have long found more humane (though not necessarily more appealing as a story) than Part $\mathbf{I . 0}^{70}$

In theological terms especially, Part II has been seen as offering what seems a distinct shift in Bunyan's presentation of fundamental doctrine: in relation to her husband's, Christiana's journey illustrates a conspicuous change 'from a prioritized self to prioritized others', 'from an exclusive Christianity toward an inclusive one', in which the covenant of grace is apparently displaced by a 'church covenant' and for which the Word acts as a 'guide' rather than as a 'weapon'. With the emphasis now on the enfeebled protected by the strong, on generations rather than regeneration, and with Bunyan the introspective hell-fire preacher of Part I maturing into the 'formidable preacher of assurance' of Part II, it has been generally noted how the 'tormented' and 'dangerously destructive' theology of the original Pilgrim's Progress has finally given way to a more 'wholesome and normative' religious outlook within

\footnotetext{
${ }^{68}$ Stuart Sim, " "Safe for Those for Whom it is to be Safe": Salvation and Damnation in Bunyan's Fiction', in John Bunyan and His England, 1628-1688, ed. by Laurence, Owens, and Sim (London: Hambledon Press, 1990), pp. 149-160 (p. 158). Sim finally regards this largely as illusory, of course, and views The Pilgrim's Progress, Part II as a return to rigid and fixed Calvinist dogma ('Safe for Those for Whom it is to be Safe', pp. 158-60).

69 Sharrock, John Bunyan, p. 153. Kathleen Swaim, Pilgrim's Progress, Puritan Progress: Discourses and Contexts (Urbana and Chicago: University of Illinois Press, 1993), p. 172.

70 Sharrock, John Bunyan, pp. 153, 141. Some critics, though, do consider The Pilgrim's Progress, Part II as Bunyan's masterpiece in literary and artistic terms - see Michael A. Mullett, John Bunyan in Context (Keele: Keele University Press, 1996), p. 259, and Charles W. Baird, John Bunyan: A Study in Narrative Technique (Port Washington, New York: Kennikat Press, 1977), pp. 53-56, 88-93.
} 
its albeit less-compelling, 'muted and humdrum' sequel.71 But it is wrong, of course, to oversentimentalise an ageing Bunyan and his apparently more compromising theology in this way. As we have seen in The Holy War, Bunyan's doctrine of Law and grace is as firmly in place as ever during his 'late' years. Indeed, it seems that The Holy War presents a revision of harsh Calvinist doctrine only for those readers who view it, along with The Pilgrim's Progress, Part $I$, as embracing an anxiety-ridden policy of predestination.

In the same way, therefore, we should be careful not to consent too rapidly to a view of the theology of The Pilgrim's Progress, Part II as overtly progressive or subdued. Although the way of spiritual conversion seems much easier, more sociable, and less anxious for Christiana and her company, and while the question of soteriological anxiety is almost entirely absent from the discourse of this text as a whole, this is not to say that Bunyan's doctrinal emphasis has somehow altered (no matter what personal or cultural changes were taking place). ${ }^{72}$ Indeed, it seems palpably absurd to suggest that in the two years following the publication of The Holy War, a text so deeply imbued with the same theology of grace as Grace Abounding (1666) and The Doctrine of Law and Grace Unfolded (1659), Bunyan would offer a work in which 'imputed righteousness' should suddenly be replaced by 'moral righteousness' and in which 'Christiana's motherhood and Mercy's works' are 'actions and motives' presented as 'means for meriting salvation'. ${ }^{73}$ The danger with such conclusions is obvious: they not only posit upon the text an ordo salutis based on works righteousness rather than on a faith in grace alone but imply that Bunyan began to favour a doctrine of 'general' (as opposed to 'particular') calling towards the end of his ministry. ${ }^{74}$ Such doctrinal tenets are clearly anathema to Bunyan, and The Pilgrim's Progress, Part II, no less than any of his other texts, aims to refute them thoroughly.

\footnotetext{
71 Swaim, Pilgrim's Progress, Puritan Progress, pp. 219-221, 304, 295, 187; John R. Knott, Jr., 'Bunyan and the Holy Community', Studies in Philology, 80 (1983), 200-225 (pp. 201, 210).

72 Swaim, for example, follows Sharrock in viewing The Pilgrim's Progress, Part II as reflecting in its style and content both a waning Puritan culture as well as a Church 'settling into a longed-for stability and more comfortable religious practice' (Pilgrim's Progress, Puritan Progress, pp. 273, 303-4).

73 Swaim, Pilgrim's Progress, Puritan Progress, pp. 219, 295.

74 See Swaim, Pilgrim's Progress, Puritan Progress, p. 219: 'Technically', she writes, the theological difference between Parts I and II is a move, 'from a particular to a general calling to salvation' (!).
} 
That Bunyan's doctrine remains wholly unaltered in his final allegory is most clear, for example, in Great-heart's discourse with Christiana upon the Cross. ${ }^{75}$ Unlike other revisited features in the landscape of Christian's journey, the Cross is of interest to Christiana not simply out of a marital curiosity about its place in her husband's prior (and now heroically magnified) pilgrimage. ${ }^{76}$ Far from discussing it simply as the place wherein Christian lost his burden, Christiana avoids any dutiful reflection as a penitent wife this time and gets straight to the theological point: remembering what was told her by the gate-keeper upon converting through the Wicket-gate, Christiana asks her guide to expound upon having 'Pardon, by Word and Deed; by word, that is, by the promise; by Deed, to wit, in the way it was obtained.'77 What follows is not so much a meditation upon the Cross as a detailed theological explanation of 'our being justified by Christ' (as the margin tells us) in which Great-heart propounds at great length upon the nature of righteousness imputed to man through the mediational redemption by Christ as both man and God. In other words, Bunyan is preaching once more a salvation through Law and grace alone. 'Sin has delivered us up to the just curse of a Righteous Law', Great-heart (in the barely veiled voice of Bunyan) tells us:

Now from this Curse we must be justified by way of Redemption, a price being paid for the harms we have done, and this is by the Blood of your Lord: Who came and stood in your place, and stead, and died your Death for your Transgressions. Thus has he ransomed you from your Transgressions by Blood, and covered your poluted and deformed Souls with Righteousness: For the sake of which, God passeth by you, and will not hurt you, when he comes to Judge the World.78

Clearly, this is far from a doctrinal exposition warranting justification through morality or good deeds but an expression once more of the fundamental basis of Bunyan's whole theology: justification by imputed righteousness. Indeed, for a text so often viewed and discussed as being doctrinally 'reductive' and simplistic, this long and detailed theological account of the meaning of the Cross, with its emphasis upon the 'poluted and deformed Souls' of a Fallen mankind, comes as something of a surprise. ${ }^{79}$ Yet, this discourse in itself is but the

\footnotetext{
75 Bunyan, The Pilgrim's Progress, pp. 209-213.

76 Compare the discourse on the Cross, for example, with that upon Christian's battle with Apollyon in the Valley of Humiliation, The Pilgrim's Progress, pp. 236-240 and pp. 271-273. For other references to the landmarks of Christian's previous journey in Part II see, for example, pp. 214, 244, 246, 272, 285.

77 Bunyan, The Pilgrim's Progress, p. 209.

78 Bunyan, The Pilgrim's Progress, p. 211.

79 Again, see Swaim for just such a reductive attitude, Pilgrim's Progress, Puritan Progress, p. 272.
} 
climax of Christiana's continuous doctrinal lesson-learning which begins from the moment she passes through the Wicket-gate onwards (the importance of which is signalled by the narrative shift from Mr. Sagacity to the dreamer). ${ }^{80}$ It is at the gate, for instance, that the Cross in the distance is revealed to Christiana who is thereby 'shewed by what deed they were saved', even though no full understanding of Christ's role as redeemer is held by her yet. Indeed, like her husband before, it is in order to be prepared for such an understanding that Christiana must pass through Interpreter's House where she too is given instruction in both spiritual teachableness and things unseen.

The 'Significant Room' in Interpreter's House containing the spider, for example, is most important in this respect for its significance, as ever, lies largely in the pilgrims' doctrinal misinterpretation of it. Unseen at first by Mercy and then taken by Christiana to exemplify her spiritual ugliness, the revealed meaning of the spider is actually far from legalistic or condemnatory, as the women initially fear: it is 'but to show you, that how full of the Venome of Sin soever you be, yet you may by the hand of Faith lay hold of, and dwell in the best Room that belongs to the Kings House above.' Evidently the emblem, its preliminary misunderstanding, and the subsequent revelation of its 'true' meaning enact in miniature the overall conversion movement from ignorance, fear, and sinful self-reproach to faith and a forgiving acceptance that Bunyan's theology consistently promotes. In order to understand this emblematic vision, then, one must contrive (as we learn from all Bunyan's narratives) to understand its meaning not in terms of nature but of grace: what at first seems an unpleasant reminder of sinfulness must be converted into something hopeful. Consequently, Christiana's teachableness in interpreting even the harshest texts in terms of faith and mercy becomes exemplary here: 'that by this Spider, this venomous and ill favoured Creature, we were to learn how to act Faith', she admits both amazed and humbled, 'that came not into my mind.' 81 It is precisely this kind of understanding about grace and salvation that she needs, however, in order later to 'lay hold of' the meaning of the cross 'by the hand of Faith'. Interpreter's House, therefore, serves to prepare Christiana in lessons of spiritual comprehension that come to fruition, just as in Christian's journey, before the emblem of Christ's sacrifice.

80 Bunyan, The Pilgrim's Progress, pp. 188-193.

81 Bunyan, The Pilgrim's Progress, pp. 200-201. 
But there is more to learn about faith yet, apparently, for it is also before the Cross that Christiana marvels at how anyone beholding it (no matter how sinful or hard-hearted) could be anything other than whole-heartedly 'affected with the way and means' of such a 'Redemption'. But despite Christiana's charming incredulity about such matters, the Cross itself, this episode tells us, does not necessarily bring salvation for all. While Christiana can bear witness (in a manner, it seems, characteristic of Bunyan's demonstrative female figures) to the 'warmth' of her 'Affections' by crying out, 'it makes my heart bleed to think that he should bleed for me', Great-heart responds sombrely that such faithful sensitivity 'is not communicated to everyone, nor to every one that did see your Jesus bleed.' In finally encouraging the pilgrims to recall the emblem of 'the Hen' in Interpreter's House that 'by her common call, gives no meat to her Chickens', the women converts are revealed by Great-heart as being under nothing less than 'a special Grace' here. ${ }^{82}$ The real lesson of the Cross, therefore, is that to anyone who experiences the merely 'common' call God 'gives nothing'.$^{83}$ It thus becomes clear that what lies at the heart of Christiana's pilgrimage is not a softening doctrine of universal salvation at all but, rather, a re-statement of doctrinal tenets fundamental to Bunyan's stead-fast theological convictions: salvation must come through faith in Christ's redemption alone (something that essentially involves passing through the Wicket-gate), while any notion of a 'general' or 'common' call is soteriologically fallacious - it is, as Great-heart puts it, to see Christ's 'Blood run from his Heart to the Ground' and, 'instead of lamenting', to laugh. ${ }^{84}$

It is worth pointing out this obvious soteriological message of The Pilgrim's Progress, Part II not only because so many commentators have apparently been oblivious to it but because it informs us, in many ways, of the fundamentally doctrinal nature of the text as a whole. At the same time, though, it seems important to note that, in viewing Part II as no different theologically from any of Bunyan's other works, this sequel to The Pilgrim's Progress has, nevertheless, evidently been constructed largely as a response to doctrinal criticism of the original. It would seem that Bunyan uses his Part II to bolster a theological

82 Bunyan, The Pilgrim's Progress, pp. 212-3.

83 Bunyan, The Pilgrim's Progress, pp. 201-2.

84 Bunyan, The Pilgrim's Progress, p. 213. For an illuminating discussion of the often simultaneous universalism and particularism in Puritan thinking, see von Rohr, Covenant of Grace, pp. 123-129. 
message of particular calling, for instance, principally to refute Sherman's doctrine of general calling asserted in the latter's spurious Second Part (despite the fact that this stance conflicts with the general sense of openness to salvation engendered elsewhere in Bunyan's text). In the same way, it has long been noted that the emphasis upon Church communality and spiritual cooperation that features so markedly in Part II is a distinct and deliberate rejoinder to Sherman's allegory which places much more importance upon the Church and its role in salvation than is apparent in Bunyan's Part I. Bunyan's repeated descriptions of resting places, meals, playful riddling, and the general togetherness of a well-established spiritual fellowship in Part II may reflect, therefore, not merely better times for Bunyan's congregation (or, alternatively, a need for more ecclesiological discipline) but a bid to out-do the likes of Sherman in presenting a church community built upon the soundest of theological principles. ${ }^{85}$

It is not surprising, then, that The Pilgrim's Progress, Part II stands not simply as a narrative continuation or a re-telling of The Pilgrim's Progress but as a re-affirming interpretation of it. As is stated in its verse preface, The Pilgrim's Progress, Part II is constructed to reveal and illuminate 'what my first Pilgrim left conceal'd': what 'Christian left lock't up', 'Sweet Christiana opens with her Key'.86 As Great-heart's discourse upon the significance of the Cross shows most clearly, this 'opening-up' of Christian's journey seems fundamentally doctrinal: Great-heart's explanation is a distinct revelation of the theological meaning of Christian's release from his burden before the emblem of Christ's sacrifice, arguably one of Part I's most significant (and yet conspicuously unexplained) episodes. Selfconsciously styled as something of a glossing device for and a marginal reminder of Part I, Christiana's 'Key' functions not only in illustrating the Word or Bunyan's doctrine at the edges of Part II's pages but to anchor this sequel firmly and comprehensively in the theology of its original. Rather than negating the original doctrine of The Pilgrim's Progress with any

\footnotetext{
85 William York Tindall, for instance, views The Pilgrim's Progress, Part II as a response to Sherman's 'implications' of doctrinal 'inadequacy'. Hence, 'as a concession to T. S.', Tindall writes, 'Bunyan described in his own second part the conduct of a church under Great-heart, and gave his attention to the discipline and sacraments which distinguished it as Baptist' (John Bunyan, Mechanic Preacher, p. 64). Alternatively, see Swaim who does see Part II as a reflection of a cultural comfortableness for Dissenting Churches in the 1680s as well as of a decline in Nonconformist commitment to faith and Church discipline (Pilgrim's Progress, Puritan Progress, pp. 303-304, 310-314).

86Bunyan, The Pilgrim's Progress, p. 173.
} 
promise of universal salvation or works righteousness, this sequel upholds, mediates, and develops it.

The only problem with this avowed function of The Pilgrim's Progress, Part II is that it robs the text somewhat of its autonomy as a narrative in its own right: it becomes little more than a book-length gloss on the original, the only purpose of which is to clarify Part I's doctrine where necessary and, if possible, to point back to its allegorical predecessor rather than to itself as an authoritative source of spiritual edification. In these terms Part II, like its female protagonists, would appear to exist solely to reflect the glory of Christian's journey in Part I and maintain the reputation of Bunyan's by now successful 'Pilgrim'. But assigning to Part II a merely secondary role as an illuminator of Part I is, of course, not entirely fair, especially as the feminised and socialised nature of pilgrimage in Part II lends this work such a strong imaginative and doctrinal individuality. Indeed, the shift in attention away from individual conversion and upon Church community, from a masculine quest to a feminised journey, and from a hero-pilgrim to the collectively crippled and weak, means that the theological timbre of this work is bound to seem more subdued, open, and accepting no matter how this conflicts with Bunyan's adherence to more strict doctrinal measures elsewhere. This is a text, after all, in which 'Grace' itself is figured forth in a far less momentous way than we may have expected: as nothing more than the serving-maiden daughter of 'Mr. Mnason', it is hardly surprising that one commentator takes this allegorisation of Bunyan's most important doctrinal concept as exemplary of the theological simplicity of Part II as a whole. ${ }^{87}$

While it is important, then, not to over-exaggerate the differences between the two parts of The Pilgrim's Progress in terms of Part II's apparent ease, comfort, and openness (Part I, we should remember, is not without its hospitable houses, rest, and companionship, just as Part II is not without an allegorised violence, horror, and brutality made all the more shocking by the otherwise gentle and genteel nature of this work and its protagonists), at the same time, it is crucial to appreciate this sequel as a very different Pilgrim's Progress nevertheless. ${ }^{88}$ To

\footnotetext{
87 See Swaim, Pilgrim's Progress, Puritan Progress, p. 272.

88 We should not forget the brutality which emphasises Christiana's and Mercy's commitment to waging a war on sin in Part II. Mercy's words on the fate of Sloth, Simple, and Presumption, for example, betray a distinct mercilessness when it comes to unrepentant sinners: 'No, no, let them hang and their Names Rot, and their Crimes live for ever against them', she cries, 'I think it a high favour that they were hanged afore we came
} 
read, for instance, Bunyan's figurative representation of 'Grace' in Part II as merely doctrinally compromising and simplistic (as Kathleen Swaim has done) is to be insensitive to the distinctive nature of this allegory as a whole. Not only is Grace most suitably allegorised in this text as a lowly servant acting on behalf of a believing community gathered in the true Church (which is precisely what Mnason's house represents), her presence in Part II is but a further indication of Bunyan's commitment to a theology that serves that spiritual fellowship in a very real sense: Grace literally gathers believers together in Part II. ${ }^{89}$ Reminding us, furthermore, of a tradition in which the Saints often named their children to reflect their own faithful convictions, Grace can more accurately be seen as an embodiment of what lies at the heart of The Pilgrim's Progress, Part II: femininity, sociability, and generational growth in the true Church. As such her presence signals not a diminished and sanitised doctrine in The Pilgrim's Progress, Part II but a deliberately more encompassing and expansive one.

More importantly, the figure of Grace serves to remind us that Part II, far from simply being a theologically reductive version of The Pilgrim's Progress, is most different from Part I principally because it is a distinctly gendered text - and it is clear to see why this is so. Part II not only gives Bunyan the opportunity to rebut doctrinal criticism by the likes of Sherman but to offer his final thoughts on the place of women in the Bedford congregation desirous of some ecclesiological autonomy and separate Church meetings.90 At the same time, it also enables him to compensate for what is undoubtedly the largest and most problematic narrative issue in Part I as a whole - Christian's leaving of his family. In fact, these latter two issues are intimately related in this sequel. For example, Bunyan's message to the women of the Bedford Church (or any spiritually aspiring woman, for that matter) is unambiguous in this text. His pilgrimettes are, despite the praise that Gaius gives to women at one point, repeatedly revealed as peculiarly unsuited to spiritual wayfaring unless accompanied by one such as Great-heart: they are constantly forgetful, intellectually and spiritually inferior (they are shown emblems that

hither' (The Pilgrim's Progress, pp. 213-214). See also The Pilgrim's Progress, pp. 218 and $243-245$ for further examples of this allegory's explicit violence.

89 Grace is asked by her father, Mnason, to gather Vanity Fair's converts to meet Christiana and her party, The Pilgrim's Progress, p. 274.

90 For details of the controversy over women and the right to separate meetings in the Bedford Church see Hill, A Turbulent, Seditious, and Factious People, pp. 296-303; Swaim, Pilgrim's Progress, Puritan Progress, pp. 227-231; and Mullett, John Bunyan in Context, pp. 246-249. 
are not only deliberately gendered in Interpreter's House but easier to understand too), and have, it seems, stereotypical roles to perform as women of the Church - they must accomplish domestic acts of charity and raise children. ${ }^{91}$ Independence for these ladies can only lead to a most non-allegorical and indecent exposure, their attempted rape on the highway being but the darker, more vulnerable side to their sexualised function as fertile and productive mothers and wives but for which (as the pilgrims themselves find out) they are also pre-eminently to blame. 92

It comes as no surprise to find, then, that Bunyan exploits his protagonist's femininity and all its implications in order to revise our understanding of why Christian leaves his family in Part I. Indeed, Bunyan can now re-define for the reader the harsh implications of The Pilgrim's Progress, Part I's opening simply by resorting to Christiana's inherent failings as a woman. Christiana thus begins her spiritual journey by blaming herself and 'her unbecoming behaviour' for Christian's desertion: 'I have sinned away your Father', she cries to her children, 'I also have hindred you of Life.' 93 It is, then, specifically as an undutiful wife and an inadequate mother that Christiana finally puts Christian's desertion into a whole new and distinctly gendered context: rather than abandoning his wife and children, we are now told that Christian was actually driven out of his own home, a fact that Christiana is continually reminded of during her pilgrimage and which she demonstrates a more than suitable guilt over. ${ }^{94}$ However, it seems the purpose of this sequel to exonerate Christian even further in this respect: although Christiana forced her husband to flee, Christian's unseemly action, as N. H. Keeble points out, is nonetheless finally contrived in this text as providing the whole basis for his family's subsequent salvation. ${ }^{95}$ Not even his own fault, now, Christian's un-Christian behaviour in running away from his familial duties is thus reviewed here as nothing less than

\footnotetext{
91 This is exemplified, perhaps, by Mercy, The Pilgrim's Progress, pp. 126-127.

92 See Bunyan, The Pilgrim's Progress, pp. 194-197. For excellent discussions of this paradox (and Bunyan's considerations of female spirituality in general) see, Margaret Olofson Thickstun, Fictions of the Feminine: Puritan Doctrine and the Representation of Women (Ithaca and London: Cornell University Press, 1988), pp. 88-104 (esp. pp. 90-91, 94-95, 97); Margaret Soenser Breen, 'The Sexed Pilgrim's Progress', SEL, 32 (1992), 443-460; N. H. Keeble, "Here is her Glory, even to be under Him: The Feminine in the Thought of John Bunyan', in John Bunyan and His England, pp. 131-147. For a reading which suggests that Christiana's is, in fact, a richer spirituality that her husband's, see Knott, 'Bunyan and the Holy Community', p. 208.

93 Bunyan, The Pilgrim's Progress, pp. 177-8.

94 See, for example, Bunyan, The Pilgrim's Progress, pp. 177-178, 181-182, 197-198.

95 N. H. Keeble, 'Christiana's Key: The Unity of The Pilgrim's Progress', in The Pilgrim's Progress: Critical and Historical Views, pp. 1-20 (pp. 10-11). See also Swaim, Pilgrim's Progress, Puritan Progress, pp. 168169.
} 
an heroic act of mercy. Indeed, it is something that other men in Part II, like Messrs 'Standfast' and 'Valiant-for-truth', certainly consider to be exemplary. ${ }^{96}$

But accounting for Christian's unfamilial behaviour via the confessions of an undutiful wife and mother in turn raises its own problems. On a narrative level, for instance, we are left with a version of events which is clearly different from what we know occurs in Part I: Christiana's is a blatantly revisionist account which aims, along with the rest of the text, to leave Christian's original character and motivation not only unspotted but apotheosised. More importantly, though, we are also left with something of a theological anomaly, here, as Christiana begins her pilgrimage and conversion in a way conspicuously different from Christian. Whereas Christian is deeply affected by the Word, possesses all the signs of conviction of sinfulness achievable only through contemplation of legalism, and goes on to shed his burden of guilt in a clearly delineated ordo salutis, Christiana has none of this. Her motivation for conversion, it seems, is largely domestic: she wishes to make amends for her failure as wife and mother and must, therefore, follow in her husband's footsteps in order to redeem her former female faults. ${ }^{97}$ For this reason, the burden Christiana bears at the beginning of Part II teeters dangerously upon the brink of not being one of guilt over sin at all: it seems to be a more specifically gendered anxiety over being an unworthy spouse. Christiana's pilgrimage thus appears to border on being motivated not by the desire to gain salvation for its own sake but by the less theologically (and more womanly) driven wish to reunify her family as a spiritual daughter, mother and wife. Hence, Christiana's salvation comes in the evidently gendered form of a promise to be reunited with her husband and to reestablish her children's rights to their eternal inheritance but only when, she is told, 'thy feet step over thy Fathers Threshold' 98

Spiritual wayfaring is evidently a gender-conscious process, then, in Part II, with the 'way' for Christiana being clearly marked by Christian's prior achievements, on the one hand, and navigated by the overtly masculine Great-heart on the other. Going solo is simply not an option for pilgrimesses. Moreover, while Christiana and Mercy pass through the all-important

\footnotetext{
96 Bunyan, The Pilgrim's Progress, pp. 293-295, 309-310.

97 See, for example, The Pilgrim's Progress, pp. 177-178.

98 Bunyan, The Pilgrim's Progress, pp. 179, 181.
} 
Wicket-gate, the sub-text of their conversion seems, nevertheless, to be that serious issues such as spiritual angst over Law and grace need not apply to them. Despite this being anathema to Bunyan's doctrine of salvation for mankind in general, women, it would appear, need not worry so much about weighty doctrine or a strict ordo salutis: the temptations they are faced with in Part II are fundamentally gender-biased than doctrinal (such as being unneighbourly, un-motherly, un-wifely, or basely sexual) and all but fade away soon after the pilgrimage begins. ${ }^{99}$ As a sequel which records the fate of Christian's family Part II, therefore, is somewhat self-complicating theologically. Although both Christian's pilgrimage and conversion are continually upheld as exemplary in this text, for the women and their children the message does seem to be that salvation can indeed be generational rather than regenerational: Part II focuses, it seems, upon a feminised and familiarised spirituality in which feebleness and duty, family unity and reproductivity are paramount qualities for the wives of believers and the daughters of God.100 Even the unmarried Mercy's redemption is obviously feminised along these lines: she is described as a 'poor Maid' prevailed upon to undertake pilgrimage not by being encouraged to consider the inefficacy of works righteousness but by being persuaded more romantically (and as befits a young woman, it would seem) 'to fall in love with her own Salvation.' 101

Bunyan's intention to exonerate Christian from any un-Christian behaviour towards his wife and family in Part I thus leads to some important and not altogether resolvable theological and gender-oriented implications in Part II. Equally, though, Bunyan's revisionist stance in this sequel indicates that there are also other significant matters this text must address aside from responding to theological criticism of Part I or engaging with ecclesiological matters of women and the Church. Bunyan's sequel is, after all, also written as a defence against criticism of The Pilgrim's Progress as a fictional narrative and an allegorical text. Indeed, the veritable and legend-like mythification that Christian undergoes in Part II (he is compared with Hercules at one point) seems to spring not only from a need to defend Part I's theology or to re-write its

\footnotetext{
99 See, for example, the discourse of 'Mrs. Timorous' whose arguments against Christiana undertaking pilgrimage are distinctly gendered in this way: Bunyan, The Pilgrim's Progress, pp. 181-185.

100 For this argument see Swaim, Pilgrim's Progress, Puritan Progress, pp. 197, 308.

101 Bunyan, The Pilgrim's Progress, p. 186.
} 
opening but to defy any criticism of its method as a whole. By passing-through, learningfrom, revising, and finally glorifying Christian's original journey (making it almost unrecognisable in some places), Bunyan's depiction of a next generation of pilgrims boldly going where Christian most certainly has been before, illustrates and indicates just how Bunyan's readers are supposed to read and learn from the original allegory. Indeed, Christiana and her troop are no less than Bunyan's ideal readers, figured forth in Part II as interpreting Christian's journey of Part I in the best way possible: inspired by his pilgrimage at every stage, they translate Part I not merely into an entertaining myth or a moral education but, more importantly, into the faithful action of spiritual wayfaring itself.

Clearly, it is important for Bunyan to show this. While the practically global success of The Pilgrim's Progress is acknowledged in Part Ir's verse preface, such renown is not enough in itself to combat either counterfeit versions or any direct criticism of his method and matter. ${ }^{102}$ In relation to Sherman's specific charges against his first 'Pilgrim' as laughing too loud, having a 'Cloud' of similitude and metaphor within its head, and being mere 'Romance', Bunyan's Part II is specifically constructed to demonstrate such criticisms as erroneous and to refute the accusation that his allegorising is detrimental to the transmission of doctrine. Interestingly, though, Bunyan's prefatory defensiveness is markedly different here than in any of his other narrative works. Whereas The Life and Death of Mr Badman and The Holy War both seem to be written most self-consciously in terms of avoiding the narrative traps that Bunyan's first Pilgrim's Progress is criticised for enticing the reader to fall into, Part II, paradoxically, seems to embrace Part I's controversial methodology to an extreme (if not celebratory) extent. Hence, while Badman and The Holy War are texts each with a highly complex structure of exposition and which reveal a Bunyan strenuously determined to pre-empt any possible accusation of being either lie or romance, Part II does no such thing. This sequel has no qualms whatsoever over its use of metaphor ('a dark Similitude', Bunyan writes assuredly this time, 'will stick faster in the Heart and Head,/Then things from Similies not

\footnotetext{
102 The international and omnisocial success of The Pilgrim's Progress, Part 1 is remarked upon both in Part IT's, 'The Authors Way of Sending forth his Second Part' (pp. 169-170) and in Mr Sagasity's comment that 'all our Countrey rings' of Bunyan's first pilgrim's 'hazzardous Journey': 'there are', this wiseman notes, 'but few Houses that have heard of him and his doings, and have sought after and got the Records of his Pilgrimage' (The Pilgrim's Progress, p. 175).
} 
borrowed'), and with the same confidence makes no attempt to apologise for its overt use of romance motifs. ${ }^{103}$ In fact, almost as if in sheer defiance of Sherman's pedantic comments over Part I's style, Part II seems to revel in its almost over-exaggerated use of chap-book stereotypes and themes, along with their often comical implications.

Indeed, practically no feature of The Pilgrim's Progress, Part II remains untouched by Bunyan's deliberate over-romancing. The basic structure of the narrative is, after all, as archetypally governed as that of Christian's 'quest' for salvation: Part II is a re-writing of the most basic of romance themes - the reunification of a separated family. Of course, for Bunyan this not only involves Christian being reunited with his wife and children but, as we are reminded throughout the text, the unification both of the daughters of God with their eternal Father in the Celestial City and of the family of visible Saints comprising the Church. But the romance elements are often more blatantly signalled than this in Part II. Mercy's description as a 'poor Maid' who falls in love with salvation, for example, simply registers the degree to which this is a narrative self-consciously drawing upon legends of damsels in distress to be rescued by the kind of hero Great-heart ultimately embodies. Needless to say, it is perhaps through the figure of Great-heart himself that Bunyan confidently and defiantly explodes Sherman's criticisms of The Pilgrim's Progress the most. Whereas Part I has Christian facing only one Apollyon and encountering only one or two theologically determined romancemonsters, Part II accounts for the explicit dispatching of no less than four Giants and, amongst other dangers, a most Apollyon-like monster that periodically terrorises Vanity Fair. ${ }^{104}$ Not only does such ferocity become bathetically commonplace towards the end of Part II, particularly with the extraordinary destruction of Doubting Castle, it also achieves a reversal of what is the commonly held view of the difference between Parts I and II of The Pilgrim's Progress: in comparison to Great-heart's eloquently recounted martial achievements, it is undoubtedly Christian's pilgrimage that seems to be more of a 'walking-tour' now. ${ }^{105}$

It is tempting to think, then, that Bunyan responds to Sherman's concerns over froth and nonsense in this way in order to rankle the General Baptist even further, but such

\footnotetext{
103 Bunyan, The Pilgrim's Progress, p. 171

104 Bunyan, The Pilgrim's Progress, pp. 218, 244-245, 266-267, 277-278, 281-283.

105 Ronald A. Knox originally made the famous comment about Part II being a 'walking tour' in comparison to Part I (Essays in Satire (1928), quoted in Sharrock, John Bunyan, p. 140).
} 
gratuitous chivalric violence and overt romancing by Bunyan in Part II does have a more serious point. Because The Pilgrim's Progress, Part II stands as a testimony to the success of an allegorical method which, despite Sherman's or even Bunyan's own concerns over its interference with doctrine, made The Pilgrim's Progress one of the most popular religious texts of its time, Part II seems to impart a sense that perhaps a romancing of doctrine is not so harmful after all. This would certainly seem the case in terms of the market success of The Pilgrim's Progress, Part I: by 1684 it was undergoing its ninth edition while, as the verse preface of Part II shows, enjoying no uncertain fame abroad.106 What Part II aims to offer, therefore, is not only a rebuttal of Sherman's comments upon Bunyan's frivolous method (nor a celebration of its commercial success) but a concerted reflection upon an international community of readers who, despite the criticism of those such as Sherman, have quite literally taken The Pilgrim's Progress to their hearts and minds. ${ }^{107}$

Christiana and her pilgrim troop not only represent the Church, therefore, but an idealised readership of The Pilgrim's Progress, Part I itself - those 'wel-wishers' that 'Mr. Sagasity' refers to at the very beginning of Part II who, for one reason or another, have been inspired so much by Christian's example (despite it being such a 'hazzardous Journey') that they decide to follow 'his ways' and too go on pilgrimage. 108 Interestingly, though, it is neither Mercy nor Christiana nor any of their children who figures as the most exemplary of Bunyan's readers in Part II. Rather, it is one 'Valiant-for-Truth', a pilgrim who joins the group toward the end of their expedition 'with his Sword drawn, and his Face all bloody'. This figure is perhaps one of the most significant characters in Part II (despite his belated entry into the narrative) principally because his accounting for how he 'came to go on Pilgrimage' serves as a specific reflection upon the methodological success of The Pilgrim's Progress, Part $I$ as an inspiring tale: living in the country of 'Dark-Land', Valiant-for-Truth hears Christian's story as narrated by one 'Mr. Tell-true' and is so moved that, in a way clearly emulative of

\footnotetext{
106 Bunyan, The Pilgrim's Progress, pp. 169-170.

107 For accounts of the various editions of The Pilgrim's Progress published in England and abroad from the 1680s onwards (and of its global popularity), see John Brown, John Bunyan: His Life, Times, and Work (London: The Hulbert Publishing Co., 1885; Tercentenary Edition, rev. by Frank Mott Harrison, 1928), pp. 439-456; Hill, A Turbulent, Seditious, and Factious People, pp. 373-375.

108 Bunyan, The Pilgrim's Progress, p. 175.
} 
Christian's adventure, neither the guileful pleadings nor terrible tales of his parents could keep him from following such an example. 109

While this in itself may not be such a remarkable conversion account, its implications are nonetheless far-reaching. In many ways, for instance, Valiant-for-Truth's conversion almost exactly mirrors Christian's own: he is forced to make the decision, like Christian, to flee from his family in pursuit of faith. But whereas Christian is inspired solely by the Word, Valiant-for-Truth is prompted by the story of Christian's spiritual adventures alone. Indeed, the overwhelming emphasis in Valiant-for-Truth's discourse is (as his name indicates) exactly upon how Christian's romantic chivalry, far from being a mere entertainment, has been effectively life-changing: mediated by Tell-true as nothing less than the 'Truth' (for all its fictionality), Christian's story is now depicted as a most significant source of spiritual stimulation for other potential wayfarers. Consequently, what Valiant-for-Truth ultimately represents is Bunyan's final rebuttal of Sherman's worries over the froth and vanity of Part I, for it is not in spite of but because of Christian's romance-chivalry that Valiant-for-Truth embarks on his valorous pilgrimage. Combating Sherman's critical comments with exceptional romantic zeal, therefore, Bunyan allegorically figures forth his ideal reader as nothing less than what Sherman himself would surely have recoiled from in horror: being the most gallant knight-errant of all, bearing his 'right Jerusalem Blade', and having courageously 'fought till my Sword did cleave to my Hand', Valiant-for-Truth is quite simply the epitome of the Christian war-farer whose 'Victory' ultimately is his 'Faith'.110 As such, Valiant-for-Truth represents nothing less than the efficacy of Bunyan's spiritualising of chivalric narrative personified.

Through his series of sequels to The Pilgrim's Progress, Bunyan's concerns over narrative and doctrine seem to have come full circle with the publication of The Pilgrim's Progress, Part II. While Bunyan is obviously concerned, if not acutely defensive, over the nature of allegory, fiction, and 'Truth' in Part I, a fact which is similarly reflected in his publication of The Life and Death of Mr Badman and The Holy War, such issues are dealt with in an almost (in not

109 Bunyan, The Pilgrim's Progress, pp. 289-295.

110 Bunyan, The Pilgrim's Progress, pp. 289-90, 295. 
literally) cavalier manner in Part II. Here, with the conspicuous success of his 'Pilgrim' behind him, Bunyan can review any anxiety over theology and fictionality in a more relaxed manner, presenting a text which, though maintaining its profound interest in salvation, positively lauds a style of writing which, he can now claim unconditionally, fuses the devotional with the romantic most successfully. A marked turn-about, indeed. As Valiant-forTruth himself sings at one point, the key-note to The Pilgrim's Progress, Part II is hardly one that has its roots in any stark tales of discouragement and fear, or uncertainty and despair, over one's spiritual journeying. As in Part I, 'to be a pilgrim' here is to persevere in grace through courage, faith, and hope. But Valiant-for-Truth's song not only encapsulates the theologically uplifting timbre of this work, though. Equally, it signals Bunyan's greater ease with his fictive medium. Indeed, Bunyan is as keen to celebrate his use of romance in Part II, it would seem, as he is to contain it in Part I. Hence, as Valiant-for-Truth carols forth, any who 'beset' a pilgrim 'With dismal Stories', Bunyan now confidently asserts, 'Do but themselves Confound.'111 It is precisely against this concept of 'dismal Stories', then, that the overtly romantic Pilgrim's Progress, Part II seems to have been written.

For this reason, Bunyan's Part II not only abounds in joyful stories of spiritual success for all those faithful (no matter how weak or frail) but seems specifically written, at times, almost as a rebuke for any reader (such as Sherman, for instance) unwilling either to lend Bunyan's allegorical protagonists their imaginative charity or to receive from them any redeeming doctrinal convictions: 'True', Part II's narrator says of those residents of Vanity Fair unimpressed by Great-heart's heroism, 'there were some of the baser sort that could see no more than a Mole, nor understand more then a Beast' who hold 'no reverence' for Bunyan's heroes, 'nor took they notice of their Valour or Adventures.' 112 Such a comment reflects, on one level, a need for Bunyan to remind his readers to respect the perhaps easily forgotten fortitude of Nonconformists still being persecuted for their faith (for this is what the periodic harrowing of Vanity Fair by the monster undoubtedly represents). ${ }^{113}$ At the same

111 Bunyan, The Pilgrim's Progress, p. 295.

112 Bunyan, The Pilgrim's Progress, p. 278.

113 This is certainly how Mullett views this episode in John Bunyan in Context, p. 255. Indeed, for all that Swaim considers Bunyan's 'mellowing' in Part II a reflection of ease and complacency amidst a Church no longer troubled either in itself or with its surrounding culture, we should not forget that the early 1680s was still a time of persecution and great uncertainty for Nonconformists and Dissenters. See, for example, Richard 
time, though, the condemnation of those blind either to the spiritual import behind Bunyan's narratives or to the efficacy of their style is also telling for the likes of both Thomas Sherman and F. R. Leavis - readers who, indeed, seem unseeing when it comes to the complex nature of Bunyan's enduring doctrinal adventures and their protagonists' unerring spiritual valour. 1689', pp. 207-222 (pp. 218-221), in John Bunyan and English Nonconformity. 


\title{
Conclusion: The Legacy of The Pilgrim's Progress
}

\begin{abstract}
'We are never too old for this, my dear, because it is a play we are playing all the time in one way or another. Our burdens are here, our road is before us, and the longing for goodness and happiness is the guide that leads us through many troubles and mistakes to the peace which is a true Celestial City. Now, my little pilgrims, suppose you begin again, not in play, but in earnest, and see how far you can get before father comes home."

Just such, said the Interpreter, is the condition of you Travellers, who come from the Valley of Destruction, and are going to the Region of Life and Glory: The King of that place only requires of you to husband well his Gifts and Graces, to improve your Talents, and persevere to the End of your Pilgrimage, and then you will be translated to eternal Mansions. ${ }^{2}$
\end{abstract}

Despite the fact that almost two hundred years (and an Atlantic ocean) separate the publication of the two books from which these quotations are taken, an unmistakable synonymy can be recognised not only in the tone and instructive purpose of these passages but in what they communicate about the cultural legacy of Bunyan's The Pilgrim's Progress. Arguably, what Louisa May Alcott's novel Little Women (1868) and the anonymously authored Third Part of The Pilgrim's Progress (1693) both signal is the overwhelming global success that Bunyan's allegory has achieved over the last three centuries. Indeed, since the 1680s, The Pilgrim's Progress has been translated into practically every written language in the world, while its idiosyncratic blend of uncompromising didacticism with an imaginative and mythic resonance has made it an enduring influence on many subsequent works of literature - from Charles Dickens's Oliver Twist to C. S. Lewis's The Pilgrim's Regress to the postmodernist parable of Kurt Vonnegut's Slaughterhouse $5 .^{3}$ In this context, the spurious Third Part of 1693 can be

\footnotetext{
${ }^{1}$ Louisa May Alcott, Little Women, World's Classics Series, ed. with an intro. by Valerie Anderson (Oxford: Oxford University Press, 1994), p. 13.

${ }^{2}$ The Pilgrim's Progress [...]: The third part (1693), author anonymous, 13th edn (London: 1738), pp. 11-12.

${ }^{3}$ For an account of the influence of Bunyan on authors and novelists, particularly of the Victorian period, see N. H. Keeble, " "Of him thousands daily Sing and talk": Bunyan and his Reputation', in John Bunyan: Conventicle and Parnassus, Tercentenary Essays, ed. by N. H. Keeble (Oxford: Clarendon Press, 1988), pp. 241-263. See also Monica Furlong, Puritan's Progress: A Study of John Bunyan (London: Hodder and Stoughton, 1975), pp. 180-202, and Richard L. Greaves, 'Bunyan through the centuries: some reflections', English Studies, 64 (1983), 113-121.
} 
seen as but the first of many imitations, continuations, and adaptations of The Pilgrim's Progress which, though 'a clear attempt to profit from Bunyan's success', also provides the kind of edifying fictive food that readers (even well into the nineteenth century) 'were hungering for' and which Bunyan, quite evidently, had not supplied in his own sequels to the original. ${ }^{4}$ Similarly, a work like Little Women not only exemplifies the extent to which Bunyan's The Pilgrim's Progress has long been appropriated as an emblematic and moral frame for other works of fiction, but, in its presentation of a family unified by the story of perseverance and courage offered by The Pilgrim's Progress, depicts a world-wide cross-class readership for whom Bunyan's 'little book' is of immense religious and artistic significance.

Of course, Alcott's somewhat idealised representation of the cultural centrality of The Pilgrim's Progress in the nineteenth century is not wholly unproblematic. On the one hand, it elides any regard for the role a world-wide dissemination of The Pilgrim's Progress undoubtedly played in the last century's European policy of colonisation and imperialism, an aspect of the 'success' of Bunyan's book that post-colonial literary commentators may find questionable ethically. 5 On the other hand, however, a more basic anachrony can be noted, here. The March family's whole-hearted love of Bunyan's most famous allegory in Little Women would not, it may be safe to assume, reflect any twentieth-century British readership which (certainly over the last forty years, at least) has become unarguably more secular in its outlook and less prone to the kind of outright evangelism that The Pilgrim's Progress uncompromisingly promotes. The consequence of such a change seems to be that (aside from those readers who still have a genuine Christian interest in it) The Pilgrim's Progress has most definitely moved over the last hundred years from its secure place in the hearts of Victorian

\footnotetext{
${ }^{4}$ Barbara A. Johnson, Reading Piers Plowman and The Pilgrim's Progress: Reception and the Protestant Reader (Carbondale and Edwardsville: Southern Illinois University Press, 1992), p. 222. The spurious Third Part was greatly popular, being reprinted at least fifty-nine times throughout the eighteenth century and becoming almost standard in many nineteenth-century editions of The Pilgrim's Progress. For accounts of the various adaptations and imitations of The Pilgrim's Progress from the 1690s onwards see Johnson, Reading Piers Plowman and The Pilgrim's Progress, pp. 220-250, and John Brown, John Bunyan: His Life, Times, and Work (London: The Hulbert Publishing Co., 1885; Tercentenary Edition, rev. by Frank Mott Harrison, 1928), pp. 456-461.

${ }^{5}$ On the problematics of the world-wide popularity of The Pilgrim's Progress in relation to imperialism and colonialism see, Christopher Hill, A Turbulent, Seditious, and Factious People: John Bunyan and his Church, 1628-1688 (Oxford: Oxford University Press, 1988; repr. 1989), pp. 373-380. See also, Tamsin Spargo, 'The Purloined Postcard: Waiting for Bunyan', Textual Practice, 8 (1994), 79-96 (pp. 85-90), and The Writing of John Bunyan (Aldershot: Ashgate, 1997), pp. 96-130.
} 
readers to the minds of contemporary academic scholars of literature and history, from the bookshelves of nineteenth-century homes to the twentieth-century bookshops of most Universities. ${ }^{6}$

While Bunyan would undoubtedly have been horrified that the works which he wrote so specifically to save the souls of sinners are now not only rarely read even for their 'historical parts' but, in fact, as archaeological artefacts in the study of English literary, ecclesiastical, and political history, it should be noted that any remarking upon such a shift in Bunyan's reception is not intended to idealise any pre-contemporary acceptance of his writings. As the two quotations given at the start of this conclusion reveal, the kind of appropriation of The Pilgrim's Progress evinced in many of the imitative works and novels published throughout the eighteenth and nineteenth centuries would, undoubtedly, have been as abhorrent to Bunyan as any current academic interest in his texts. Indeed, what Alcott's Little Women and the spurious Third Part share is more than a basic desire to celebrate and participate in the successful legacy of The Pilgrim's Progress. Rather, these texts seek to re-inscribe The Pilgrim's Progress as a universally religious and moralistic as opposed to a strictly Reformed (if not Calvinist) theological work, a fact that Bunyan indeed would have considered an outright abuse of his original creation.

For example, although far more faithful to Bunyan's own allegorical method than Sherman's prior (and much sanitised) continuation, the Third Part of The Pilgrim's Progress effectively re-writes Bunyan's text not in terms of removing its 'froth' and romance but, rather, by completely erasing Bunyan's doctrines of salvation by grace and justification by faith. Although all the same features of The Pilgrim's Progress are here for both reader and protagonist (one 'Tender-conscience') to pass through (including Good-will's Wicket-gate, Interpreter's House, the House Beautiful, and the Delectable Mountains), the emphasis is always on a distinctly non-Bunyanesque legalism. As the passage quoted stresses, the

\footnotetext{
${ }^{6}$ See Hill's comments on the decline in the readership of The Pilgrim's Progress, in A Turbulent, Seditious, and Factious People, pp. 372-373. Spargo suggests that in contemporary Britain 'Bunyan seems to figure either as an object of academic study or as a [presumably quite limited] tourist attraction, as a part of a heritage industry', noting that today 'Bunyan's writings are published primarily by Christian presses, the majority based in the USA' where 'Bunyan is deployed as a far more active figure in an ongoing evangelical project' than in 'his country of origin' (The Writing of John Bunyan, pp. 132-133). Spargo draws these conclusions upon the basis of a web-search for references to Bunyan on Internet sites made in September 1996.
} 
message of this Pilgrim's Progress is that 'to husband' one's 'Gifts' and 'to improve one's Talents' is all that is required for a successful pilgrimage. As such, Bunyan's doctrine of Law and grace is replaced by a far more reasonable and socially appropriate doctrine of fasting and temperance, of 'Moderation in Eating and Drinking', in the Third Part.' Indeed, this is a pilgrimage in which strictly immoral and uncivil ills (as embodied in the wanton 'House of Mirth') are to be avoided and in which the misleading scientific discourse on a strictly rational faith by one 'Human-reason' is offered as reprehensible, but only before conceding that 'Natural Reason' must play a crucial part in any reasonable believer's salvation nevertheless. ${ }^{8}$

With the theological differences so evident, it is hardly surprising that Nathaniel Ponder (Bunyan's principal publisher) disclaimed this Third Part as an outright 'impostor', nor that Coleridge (for whom Bunyan's The Pilgrim's Progress was 'incomparably the best SumMA THEOLOGLE Evangelicae ever produced by a Writer not miraculously inspired') finally considered such a counterfeit continuation to have been 'written by a Roman Catholic Priest, for the very purpose of counteracting the doctrine of Faith so strictly enforced in the genuine Progress.' What is obvious about the Third Part, therefore, is that it offers a wholesale doctrinal reorganisation of Bunyan's Pilgrim's Progress, one which removes any Calvinist theology and replaces it with something that conforms far more easily to the kind of rational moralism that Bunyan himself fought so bitterly against in his debate with Edward Fowler. The evident success of this Third Part throughout both the eighteenth and nineteenth centuries is somewhat problematic, therefore. ${ }^{10}$ It would seem that post-Restoration readers were indeed 'hungering', as Barbara Johnson puts it, for more of The Pilgrim's Progress, but it was to be a socially and morally informed (as opposed to a soteriologically uncomfortable) Pilgrim's

\footnotetext{
${ }^{7}$ Third Part, pp. 11-20, 34-35, 45-47, 52-59.

${ }^{8}$ Third Part, pp. 93-106 (esp. p. 103).

${ }^{9}$ Nathaniel Ponder appended an advertisement to the 13th edn of The Pilgrim's Progress (1693) denouncing the Third Part as an 'impostor' (see Brown, John Bunyan: His Life, Times, and Work, p. 457). Similarly, Sharrock and Wharey also denounce this spurious continuation as 'a brazen attempt to deceive' (The Pilgrim's Progress, ed. by James Blanton Wharey, 2nd edn, rev. by Roger Sharrock (Oxford: Clarendon Press, 1960), p. cxvi). The Collected Works of Samuel Taylor Coleridge: Marginalia, ed. by George Whalley, 5 vols (London: Routledge and Kegan Paul, in association with Princeton University Press, 1980), I, 802, 811, 826.

${ }^{10}$ The British Museum General Catalogue of Printed Books, Photolithographic edition to 1955, 263 vols (London: British Museum, 1965), 29, records at least fifty-nine editions of the Third Part printed in the eighteenth century and its inclusion in various editions of The Pilgrim's Progress, Parts I and II until at least 1843.
} 
Progress that was demanded, one more reasonable doctrinally as well as one untainted by the radical and schismatical implications of Bunyan's religious (and therefore political) Nonconformity.

It is important to pay some attention to this Third Part, therefore, as both its publication and its popularity signal concerns that lie at the heart of this thesis as a whole. The enduring success and re-publication of a work like the Third Part of The Pilgrim's Progress, for example, offers in microcosm one of the principal ways Bunyan's texts have been (mis)read and (re)appropriated from the end of the seventeenth century onwards. The fact that no commentator other than Coleridge (not even Bunyan's Romantic editor, Robert Southey) seems to acknowledge the inherent theological differences between Bunyan's allegory and its bogus sequel seems indicative of the fact that, even by the beginning of the eighteenth century, works like The Pilgrim's Progress were being read by many (except the hyper-Calvinist Methodists, presumably) as essentially moral rather than experimental, according to reason rather than faith." As the eighteenth-century hand of Samuel Richardson notes, for instance, 'the Works of all even fine Writers' could not compare to Bunyan's 'in their Morality and Piety', Bunyan's writings evidently being 'of greater Use to the Multitude who cannot taste, or edify by, the Superlative' than the more refined and complex Augustan satires of 'Mr. Pope'. ${ }^{12}$ While there is an undoubted literary snobbery inherent in such an inverted compliment to Bunyan, this comment seems to indicate not only a distinct deprecation of Bunyan as a chapbook writer for the ignorant masses but a misunderstanding of Bunyan as promoting, above all else, a simple morality and a homely piety that Richardson (whose religious sentiments are distinguished from Bunyan's by his quite different concern over a 'Historical Faith') condescends to find so commendable. ${ }^{13}$

\footnotetext{
${ }^{11}$ For an account of Bunyan's popularity amongst Methodists of the eighteenth century, see Keeble, 'Of him thousands daily Sing and talk', pp. 248-251.

${ }^{12}$ Selected Letters of Samuel Richardson, ed. by John Carroll (Oxford: Clarendon Press, 1964), pp. $56-57$ (letter to George Cheyne, 21 Jan. 1742/3).

${ }^{13}$ Selected Letters of Samuel Richardson, pp. 85-86 (letter to William Warburton, 19 April 1748, in which Richardson discourses on how his use of epistolary form in works like Pamela and Clarissa is intended to maintain 'the Air of Genuineness [...] tho' I want not the letters to be thought genuine', his aim being 'to avoid hurting that Historical Faith which Fiction itself is generally read with, tho' we know it to be Fiction' (p. 85).
} 
By the time, Alcott's Little Women is published, however, such admiration for the purely moral value of The Pilgrim's Progress's Christian ethos has been institutionalised even further. Reflecting the more Victorian habit of reading The Pilgrim's Progress as a didactically useful children's story rather than as a serious theological document (a trend evinced by the many adaptations, editions, and continuations published for children throughout the nineteenth century), Alcott's conduct-book 'for Girls' not only utilises The Pilgrim's Progress as an authoritative intertextual frame of reference (with chapters entitled 'Jo Meets Apollyon' and 'Meg Goes to Vanity Fair') but transforms The Pilgrim's Progress into an indoor game (involving 'lovely things' to 'collect') that can be played as a means to learn about the way to 'goodness and happiness' ${ }^{14}$ In the face of a particularly Bunyan-like crisis (the absence of the father from the family unit), the March girls are clearly made to represent the female counterparts to Christiana's boys of Bunyan's Part II but in such a way that the religious message of Bunyan's original allegories becomes both ludicrously domesticated and sentimentally gendered. The 'burdens' for these young pilgrimettes are nothing more than the household responsibilities, moral duties, and social problems that affect them as little women 'dishes and dusters, and envying girls with nice pianos, and being afraid of people.' In this context, The Pilgrim's Progress becomes an aid to persevering in little more than faithful housewifery, Bunyan's text lending 'a little romance' and 'fancy' to the 'very dull' (and preeminently legalistic) 'task' of doing one's 'duty' and trying 'to be good'. ${ }^{15}$ For Alcott's March family, Bunyan's Nonconformist theology of grace simply no longer exists.

Whereas Barbara Johnson has recently argued that the Victorian relegation of The Pilgrim's Progress 'to the status of a children's book' (as exemplified in Alcott's Little Women) is the result of the failure of nineteenth-century commentators (such as Robert Southey and Sir Walter Scott) 'to turn the fabric of The Pilgrim's Progress into a work of literature', it has nevertheless been the aim of this thesis throughout to assess the reading and the critical

\footnotetext{
${ }^{14}$ Alcott, Little Women, pp. vii, 13. For details of children's versions and editions of The Pilgrim's Progress produced in the nineteenth century see Johnson, Reading Piers Plowman and The Pilgrim's Progress, pp. 232244, and The British Museum General Catalogue of Printed Books, vol 29, columns 933-944.

${ }^{15}$ Alcott, Little Women, pp. 13-14.
} 
reception of Bunyan's works precisely as 'literature'. ${ }^{16}$ As such, what seems most interesting is not only that, in the twentieth century at least, The Pilgrim's Progress has undoubtedly become canonised as a classic work of English fiction (even if it is no longer widely read, it is certainly marketed as a 'classic' both by publishers and in literature courses at Universities) but that the academic study of Bunyan's works as 'literary' has so often replicated the kind of problems of response to (and (mis)appropriations of) Bunyan's writings that are evinced in adaptations and revisions of The Pilgrim's Progress from the anonymous Third Part to Alcott's Little Women. There has been all along, for instance, a clear attempt in much literary criticism of Bunyan's work, from its Romantic beginnings onwards, to segregate an evangelising Calvinist Bunyan from the innate genius who unwittingly seems to have produced a work primarily of enduring moral and literary merit. ${ }^{17}$ As a result, until quite recently much literary criticism of Bunyan's writing has tended (like the Third Part and Little Women) to universalise, decontextualise, and moralise a work like The Pilgrim's Progress on the grounds that, as F. R. Leavis has discussed, if it were to be read alone as Coleridge's 'Summa Theologicæ' it would become both irrelevant and unreadable to a contemporary audience, a text holding forth theological doctrines not only out-moded but, given their apparent abhorrence, rightly so.

Consequently, the continued conversion of The Pilgrim's Progress from a narrowly theological seventeenth-century tract into a work worthy of twentieth century literary study, either because of its pre-novelistic narrative 'realism' or because of the simplistic imaginative creativity and the general 'religious' message that made it such a widely read children's story in the nineteenth century, could be seen as a profoundly positive transformation for many readers and critics. Not only does such a reading assert both the vitality and the potent universalism of The Pilgrim's Progress as a text that transcends its particular doctrinarianism but indicates, one could suppose, something deeply positive about how readers read and give meaning to books over time, despite profound religious and cultural differences. As Martin Wallace points out, because the 'meaning' of a narrative 'comes into existence only in the act of reading', then '[s]ocial, cultural, and literary change' can often 'combine to produce new kinds of narrative

\footnotetext{
${ }^{16}$ Johnson, , Reading Piers Plowman and The Pilgrim's Progress, p. 236.

${ }^{17}$ For an account of the Romantic reappraisal of Bunyan see Keeble, 'Of him thousands daily Sing and talk', pp. 251-256.
} 
and new methods of interpretation', readings which allow, if not create the opportunity, for an acceptance of a work like The Pilgrim's Progress to convey important human truths beyond its doctrinal dogma. ${ }^{18}$ Indeed, the fact that, potentially at least, there are as many readings of a text's meaning as there are readers to read it will, it seems, ensure that The Pilgrim's Progress is relevant to a twentieth century audience whose 'experience' of it will make Bunyan still worth reading. ${ }^{19}$

Of course, such an approach to Bunyan is largely antithetical to the kind of understanding of Bunyan's narrative works that has been offered throughout this thesis. What this study has argued all along, in fact, is that Bunyan's writings demand a reading that is essentially non-literary, his allegories consistently encouraging the reader to turn away from the page and any 'historical' interest in it and focus instead on the Word and one's heart for a particular kind of saving faith. The problem in asserting that Bunyan's texts are finally constructed to encourage little other than a 'grace-ful reading' is, however, obvious - it denies the possibility (or at least the correctness) of other readings of Bunyan's works, especially those interpretations that enable him still to have 'literary' or 'moral' relevance today. Indeed, by arguing that Bunyan's narratives attempt to direct, contain, and limit the reader's responses to them, the kind of openness and generosity of interpretation that twentieth century criticism can so often lend a work like The Pilgrim's Progress may appear to be being denied outright, here. As such, to assert that Bunyan's works both require from and inculcate in their readers a particular kind of 'grace-ful reading' may seem both interpretively narrow and literarily parsimonious, succeeding only in reducing 'a meaningful story' to 'a story that has only one interpretation', leaving a work like The Pilgrim's Progress to become 'meaning-impoverished and $[\ldots]$ not very interesting. ${ }^{20}$

\footnotetext{
${ }^{18}$ Wallace Martin, Recent Theories of Narrative (Ithaca and London: Cornell University Press, 1986; repr. 1994), pp. 160-161.

${ }^{19}$ Stanley Fish, Is There a Text in This Class?: The Authority of Interpretive Communities (Cambridge, Massachusetts and London: Harvard University Press, 1980), p. 17. Fish's interpretive turnaround from reading texts as determining specific readings from the reader is the subject of this collection of essays as a whole, a shift which begins with his essay 'Interpreting the Variorum', Critical Inquiry, 2 (1975-1976), (465-485) reprinted in Is There a Text in This Class?, pp. 147-173.

${ }^{20}$ Martin, Recent Theories of Narrative, p. 169.
} 
But there are distinct reasons why such a constricted reading of Bunyan is nevertheless important. Whereas literary studies, for instance, can often celebrate the fact that '[i]nterpretations differ because readers differ' and that such differences positively reflect, over time, not only the 'personalities' of individual readers but 'the conventions they employ in reading', it has been the purpose of this thesis to show how such interpretive potential and variety is not always beneficial in the case of John Bunyan. ${ }^{21}$ In fact, the development of different 'conventions' in reading often seem to be more detrimental to a fuller understanding of Bunyan's works than anything else. For example, a twentieth century critical habit of reading texts according to the tenets of psychological analysis may allow readers to understand Bunyan's religious temperament as revealing the kind of mental condition (albeit in disorder and psychosis) that prefigures him as a more 'modern', individualised, and complex self. But, as has been shown, such a reading ignores the fact that this kind of interpretation has its roots in a discourse that sought to suppress and marginalise the very Nonconformist faith that inspired Bunyan to write his works in the first place. In other words, such a development in one's reading habits, while rendering Bunyan perhaps more understandable to a modern audience, nevertheless leads to an interpretation of Bunyan's experimental religious convictions in terms of a madness and mental instability originally sanctioned by Bunyan's own conformist persecutors and in the context of an obvious political agenda.

In a similar way, therefore, any tendency to treat The Pilgrim's Progress as worthy of literary critical attention on account of its general religious or moral sentiment, or simply as a work of great imaginative genius, seems to be guilty of re-inscribing into Bunyan's narrative practice a latitude that effectively erases its more difficult theological (and epistemologically radical) aspects. Not only does such an interpretation make The Pilgrim's Progress indistinguishable from any spurious Third Part (and only through a concerted ignorance in one's understanding of the very words on Bunyan's pages) but it implies, once more, something unsettling about the de-radicalisation of Bunyan's writings over time. If we can only read The Pilgrim's Progress as 'literature' by claiming for it a moralism and an imaginative or narrative dimension which are largely secondary to it (and often misunderstood

\footnotetext{
${ }^{21}$ Martin, Recent Theories of Narrative, p. 161.
} 
in any case), does not this elide its 'meaning' as a Nonconformist text written in the teeth of persecution by those who considered Bunyan a seditious and refractory Calvinist? Isn't such a rendering of The Pilgrim's Progress into either a 'classic' of English fiction, a children's tale, or a proto-novel but a continuation of the suppression of a religious and social Nonconformity perhaps still considered too unsettling to warrant anything other than its safe containment as a moral and 'novel' story?

To ask such questions, however, is not simply to view Bunyan as being engaged in a kind of historical grand-narrative of class conflict that Christopher Hill implies when referring to Bunyan as 'a man of the people' writing 'for the people' and whose works reside uneasily within a distinctly upper-class concept of literary taste. ${ }^{22}$ It is more complex than this. What this thesis suggests, in fact, is that attempts to read Bunyan as 'literature' are often problematic largely because they tend to bring assumptions about reason, knowledge, and epistemological categorisation to a text like The Pilgrim's Progress which Bunyan's experiential theology continually seeks to subvert. To try to universalise and generalise The Pilgrim's Progress is not problematic in terms of class or social status alone, therefore, but in terms of refusing to acknowledge the essential nature of Bunyan's Nonconformist faith as concerned with something radically other than the rational, moral, and sociable religious sentiment that has prevailed since the Restoration in an increasingly secularised and empirically centred English (if not Western) culture.

In part, therefore, what this thesis has attempted to address is the failure of literary criticism to deal with The Pilgrim's Progress (as well as Bunyan's other works which, conspicuously, cannot be so easily classicised or canonised) in terms of the theology and the Nonconformity which has so often been amputated from a study of Bunyan's writings as 'literature'. This failure is evident, on the one hand, in the writings of those such as F. R. Leavis, Stuart Sim and John Stachniewski who, rather than challenging the myth of Bunyan's faith as something abhorrently Calvinist, wish either to ignore or to perpetuate it in their 'literary' readings of Bunyan's works. On the other hand, though, that Bunyan's 'interesting, but tough' theological narratives are difficult to assimilate into 'literary studies' as a whole is

\footnotetext{
${ }^{22}$ Hill, A Turbulent, Seditious, and Factious People, pp. 372-377.
} 
also signalled by the fact that the most important scholarship on Bunyan of this century, quite arguably, has not been done by 'literary' critics at all. Rather (and with but a few notable exceptions) it has largely been left to social, theological, and cultural historians like Richard Greaves, Christopher Hill, and Neil Keeble to assess the continuing importance of Bunyan's writings but often in terms beyond the strictly 'literary'.

For this reason, it has been the purpose of this thesis to reconsider how we can read Bunyan's complex and difficult writings meaningfully through (rather than apart from) a theology that is clearly central to them. By understanding how Bunyan's doctrine of grace informs every aspect of his narrative practice, texts like Grace Abounding and The Pilgrim's Progress can be seen as incredibly sophisticated both in their manipulation of their readers' expectations and in their deconstruction of themselves as literary forms (as autobiography, romance, and history). As such, Bunyan's books demand a kind of literary analysis that distinctly recognises the doctrinally informed aspect of their rhetorical make-up, an analysis that is inherently historicist, in some respects, and practically postmodernist on the other. It is in these terms, therefore, that this thesis reaffirms Bunyan as a writer pre-eminently concerned with very literary concepts indeed - with narrative, reading, and the problems of meaning and interpretation - and not in spite of but wholly because of his Nonconformist theological convictions. Because the temper of Bunyan's Nonconformity involves not only dissent from legalistic moralism and carnal reason but, moreover, from 'the world's literary presuppositions, prejudices, and traditions', then it is precisely this Nonconformity that the continuing literary study of Bunyan's narratives must seek more precisely to address. ${ }^{23}$ Indeed, such has been the purpose of this study's 'grace-ful reading' of the works of John Bunyan.

\footnotetext{
${ }^{23}$ N. H. Keeble, The Literary Culture of Nonconformity in Later Seventeenth-Century England (Leicester: Leicester University Press, 1987), p. 285.
} 


\section{Appendix: \\ Bunyan and Medical Discourse in the Restoration}

The predominance of medical imagery in Bunyan's writings should come as no surprise. After all, Bunyan's is a doctrine at the heart of which lies a concept of grace that heals where the Law wounds and in which the sinner must realise that his soul is indeed sin-sick before any progress in faith can be made at all. Utilising medical metaphors for expressing the sinner's conviction of sin and subsequent conversion, therefore, would seem natural for Bunyan who commonsensically states that the "man that knoweth not himself to be sick, that man will not look out for himself a Physician'. The 'Physician' here being Christ whose remedy is grace, Bunyan similarly notes that any man 'that can make himself clean hath no need of Christ [...] but those that are foul and needy'. Because Bunyan's doctrine of grace recognises the innate corruption of all men, moreover, he can present the sinner's willing recognition of sin and need for grace quite appropriately in medical terms: 'Physicians', he writes, 'if they love to be honoured, they will not bid the Patients first to make themselves whole, and then come to them: no but bid them come with sores all running on them'.1

While Bunyan evidently relishes the graphic imagism that the medical metaphors afford here, the basis for such language is, as we have seen, clearly one of comfort for any sinner convinced of his damnation under works. There is an obvious Scriptural precedent for such imagery too. Bunyan, always careful to place his discourse in the context of the Word, frequently cites Mark 2. 17 in such matters, wherein Jesus rebukes the Pharisees (who represent perfectionist legal righteousness for Bunyan) with the retort that, 'The whole have no need of the Physician [...]. I come not to call the righteous, but sinners to repentance.'2 Such

\footnotetext{
1 John Bunyan, The Doctrine of Law and Grace Unfolded (1659), in The Miscellaneous Works of John Bunyan II, ed. by Richard L. Greaves (Oxford: Clarendon Press, 1976), pp. 12-13, 175.

2 John Bunyan, Saved by Grace (1676), in The Miscellaneous Works of John Bunyan VIII, ed. by Richard L. Greaves (Oxford: Clarendon Press, 1979), p. 194.
} 
Scriptural referencing of the medicinal power of grace is not, of course, idiosyncratic to Bunyan though. In using medical and bodily images, Bunyan is largely following a mode of discourse traditional to the expression of Christian faith since the Reformation and beyond: 'How can I be holy', Luther can be found asking of himself, 'when I have and feel sin in me? I answer $[\ldots]$ it is one step of health, when the sick man doth acknowledge and confess his infirmity.'3

Although it would seem that there is nothing original about Bunyan's use of such metaphors for grace, that he is simply following a tradition bequeathed to all seventeenthcentury preachers by the Gospels and its exegetes throughout Christian history, there is more to note about Bunyan's use of medical metaphors yet. It is interesting to see, for example, how the theological debate over justification by faith between Bunyan and the Bedfordshire Latitudinarian Edward Fowler is conducted at one point as something of a tug-of-war over the appropriation of medical discourse itself. In The Design of Christianity (1671), Fowler can be found taking Bunyan's kind of medical imagery and re-constructing it to support a view of Christianity centred in rational moralism with Christ's example of holiness, rather than imputed righteousness, being the soteriological focus. Whereas Bunyan asserts that grace eases the conscience in the face of continuing sinfulness and the impossibility of fulfilling the Law, Fowler maintains that 'Our Saviour giveth ease to our Sin-sick Souls by recovering them to health' through the pardon of a Gospel that 'doth chiefly discover itself in curing men of their sins; in delivering them from the power of them, rather than from the mere punishment due to them.' Not surprisingly, then, does Fowler consider any man

a perfect Ideot, who being sorely hurt should expect from his Chirurgeon perfect ease, when he will not permit him to apply any plaister for the healing of his wound? Or that being deadly sick should look that his Physician should deliver him from his pain, when he will not take any course he prescribes for the removal of the distemper that is the cause of it?

\footnotetext{
${ }^{3}$ Martin Luther, Commentary On Galatians, I, 244-246; ii, 80, 87; cited in Christopher Hill, A Turbulent, Seditious, and Factious People: John Bunyan and his Church 1628-1688 (Oxford: Oxford University Press, 1988; repr. 1989), p. 159. On the proliferation of medical metaphors in Reformation divinity, see David N. Harley, 'Medical Metaphors in English Moral Theology, 1560-1660', Journal of the History of Medicine and Allied Sciences, 48 (1993), 396-435, and Andrew Wear, 'Puritan perceptions of illness in seventeenth century England', in Patients and Practitioners: Lay Perceptions of Medicine in Pre-Industrial Society, ed. by Roy Porter (Cambridge: Cambridge University Press, 1985), pp. 55-99 (pp. 67-69).
} 
Behind Fowler's discourse here is the barely veiled accusation of antinomianism: the medical metaphor is adopted (and adapted) to show how those such as Bunyan are guilty of the 'folly' of refusing to 'be perswaded to part with their Sins, and yet hope for the Salvation of their Souls', a stance which Fowler recognises as 'excessively mad' and apt to 'turn the grace of God declared in the Gospel into wantonness.' 4 As we have seen, however, it was exactly such an accusation that Bunyan strenuously tried to avoid when advocating his doctrine of grace and, not surprisingly, his response to Fowler is vehement: 'it is evident that healing beginneth at pardon, and not pardon after healing', Bunyan retorts, asserting that Fowler's 'comparison of the plaister, and the physician's portion' are both an 'abuse' of the reader and a means whereby Fowler can 'muddy the way of the gospel.'5 Although Bunyan is obviously secure enough in his faith to remain unconvinced by Fowler's Design, the latter's appropriation of medical imagery nevertheless rattles him somewhat. In Saved By Grace, for instance, written four years after this controversy, Bunyan can be found grace-fully restructuring Fowler's image of the 'plaister' still, while in the posthumously published Justification By An Imputed Righteousness (in which Bunyan reiterates the arguments of A Defence of the Doctrine of Justification), Bunyan explodes such imagery even further: here, 'Christ's Church' is a veritable 'Hospital of sick, wounded, and afflicted people', with Jesus Christ as its most notable 'Physician'.6

The point here, of course, is that medical analogy finally becomes an important medium for theological dispute for Bunyan and Fowler: depending upon how either the Anglican or the Baptist preacher uses the metaphor, a strong argument either for or against any view of grace, man's relationship to God, and the meaning of the Gospel can be asserted. It is hardly surprising that Fowler and Bunyan battle so fiercely for control of such metaphors, then, for what lies at stake here, as in Bunyan's use of figurative language as a whole, is not some minor issue of theological sophistry but, most crucially, a defence of one's view of salvation.

\footnotetext{
${ }^{4}$ Edward Fowler, The Design of Christianity (London, 1671), pp. 216-217.

5 John Bunyan, A Defence of the Doctrine of Justification (1672), in The Works of John Bunyan, ed. by George Offor, 3 vols, (Glasgow: W. G. Blackie \& Son, 1854; repr. by The Banner of Truth Trust, 1991), II, 314.

6 Bunyan, Saved by Grace, pp. 169-170; John Bunyan, Of Justification by an Imputed Righteousness, in The Miscellaneous Works of John Bunyan XII, ed. by W. R. Owens (Oxford: Clarendon Press, 1994), p. 336. See also Bunyan's verse 'On Physick', poem LXII in A Book for Boys and Girls (1686), in The Miscellaneous Works of John Bunyan VI, ed. by Graham Midgley (Oxford: Clarendon Press, 1980), pp. 261-263.
} 
At the same time, though, it is important to recognise that this wrangle over language between Bunyan and Fowler also acts as an index of significant social change in the Restoration. Indeed, the language of medical analogy is such a battleground for the likes of Bunyan and Fowler not only because of their very different understandings of grace but because of cultural developments in medicine and medical practice in the Restoration period as a whole.

Fowler's Latitudinarianism signals, for example, what various commentators have referred to as the eclipse or death of Calvinism with the post-Civil War rise of Anglican moralism, the accent of which is placed distinctly upon the reasonable duties of the believer as opposed to the more metaphysical and irrational faith of spiritual 'experience'. ${ }^{7}$ Hand in hand with the rise of Latitudinarianism in the Anglican Church and Restoration society, moreover, came the dawning of Enlightenment rationalism and scientific empiricism, all of which contributed to the corrosion of a Calvinist world view in which God's divine sovereignty and providence were seen as influencing all aspects of life. Consequently, the bitter war of words and pamphlets Bunyan waged in defence of his faith against the likes of Edward Fowler (and even Edward Burrough) can be seen largely as a response 'to wider ideological changes' occurring in this period, effecting 'a different cultural climate' in which many people 'were growing sceptical of Christianity and many more had bidden Calvin good-night.'8

It is important to note that in the midst of such cultural change there came a fresh confidence in the authority of medicine, physicians, and their discourse to describe the world of illness anew, particularly in terms of healing and medical psychology. For anyone of a Calvinist doctrinal faith, such progress did not necessarily present wholly a positive development, though. Indeed, medicine and medical discourse in the Restoration ostensibly provided but one of the means whereby a Calvinist faith (which largely favoured a

\footnotetext{
7 See, for example, Isabel Rivers, 'Grace, Holiness, and the Pursuit of Happiness: Bunyan and Restoration Latitudinarianism', in John Bunyan: Conventicle and Parnassus, Tercentenary Essays, ed. by N. H. Keeble (Oxford: Clarendon Press, 1988), pp. 45-69, and Reason, Grace, and Sentiment: Studies in the Language of Religion and Ethics in England, 1660-1780 (Cambridge: Cambridge University Press, 1991); Dewey D. Wallace, Puritans and Predestination: Grace in English Protestant Theology, 1525-1695 (Chapel Hill: University of North Carolina Press, 1982), pp. 158-190.

8 John Stachniewski, The Persecutory Imagination: English Puritanism and the Literature of Despair (Oxford: Clarendon Press, 1991), p. 59.
} 
providentialist view of sickness and healing as evidence of the operation of God's will on earth as well as an important reflection of the patient's spiritual condition as a whole) could be challenged and debased by its practitioners and proponents.

The shift in medical practice from the supernatural to the rational seems to be, moreover, a distinctly post-Civil War phenomenon. Various studies of the practice of medicine in the seventeenth century have shown, for example, that for Puritans and Protestant believers of the early years of the century, dualistic explanations of both bodily and mental disorders were largely harmonised between the supernatural and the natural, the spiritual and the medicinal. The late sixteenth and early seventeenth century, therefore, 'was a period, like all others, when there existed a plurality of explanations for illness, and people moved easily between them'. Indeed, having 'a religious view of illness did not exclude recourse to the physician and his remedies', which is perhaps why clergymen and physicians of the early seventeenth century often provided both medical and spiritual treatments simultaneously. 9

During the Restoration, however, this alliance between spiritual and natural medicine, between 'Galenism and Calvinism', apparently altered quite radically. ${ }^{10}$ While most commentators are tentative in making generalisations about attitudes towards medicine in the seventeenth century, and although providential and medical approaches to healing were held simultaneously by many both during the Restoration and beyond, one can state that important shifts in approaching sickness were taking place in this period nevertheless. Although it may be true that physical illness was 'spiritualised' by Puritans 'only partly', it is also generally held that 'post-1660s Anglicans', who on the whole 'tended not to refer to providence so much', did indeed move 'to a more secular, rational view of illness'.11 With the general

\footnotetext{
9 Andrew Wear, 'Puritan perceptions of illness', pp. 72-73, 69; see esp. pp. 70-84. See also David Harley, 'Spiritual Physic, Providence and English Medicine, 1560-1640', in Medicine and the Reformation, ed. by Ole Peter Grell and Andrew Cunningham (London and New York: Routledge, 1993), pp. 101-117; Lucinda McCray Beier, Sufferers and Healers: The Experience of Illness in Seventeenth-Century England (London and New York: Routledge and Kegan Paul, 1987), esp. pp. 154-181; Peter Elmer, 'Medicine, religion and the puritan revolution', in The Medical Revolution of the Seventeenth Century, ed. by Roger French and Andrew Wear (Cambridge: Cambridge University Press, 1989), pp. 10-45; Roy Porter, 'The patient in England, c. 1660-c. 1800', in Medicine in Society: Historical Essays, ed. by Andrew Wear (Cambridge: Cambridge University Press, 1992; repr. 1994), pp. 91-118.

10 Harley, 'Medical Metaphors', pp. 434-435.

11 Wear, 'Puritan perceptions of illness', pp. 87, 75, 57.
} 
erosion of Calvinism in Restoration religious belief, therefore, there also emerged an attitude towards sickness and medicine based not on faith but on physic alone.

This change severed the natural connection not between the Anglican clergyman and the physician, however, but between the physician and the Nonconformist, the reasons for which seem clear. On the one hand, it was largely Nonconformists and Dissenters (such as Bunyan) who alone 'seemed to view the occurrences of life in spiritualised and providential terms', and who consequently maintained a view of illness and healing in terms of spiritual implications unacceptable (if not fanatical) to rational moralists like Fowler and Samuel Parker. ${ }^{12}$ On the other, however, there seems to be something of a natural political allegiance between Anglicans and physicians in this period in any case: Latitudinarian Anglicans openly supported the rationalistic physic and scientific medicine that challenged a providentialist world view. The 1665 Episcopal Licensing decree issued by Bishop Sheldon, moreover, gave Anglican bishops a monopoly in offering licences to those seeking to practise medicine. Hence, although there were many Dissenting doctors at large in this period, the confederacy between Restoration clergy and medical physicians is nevertheless quite clear. ${ }^{13}$

Behind Bunyan's debates over medical discourse, therefore, lies a distinct political agenda (if not a cultural divide) in terms of one's view of faith and, consequently, one's religious position in society. Unsurprisingly, and given that there are obvious social and intellectual reasons why Restoration culture favoured a shift towards the rational not only in terms of moral religion but in terms of healing, it would seem natural for there to be no little antagonism between Nonconformists such as Bunyan (whose faith was experiential, nonrational, and Dissenting) and those who might prefer to treat mental and physical illness in a purely scientific, as opposed to spiritual, context. Whereas today it would seem only natural to approach sickness in physiological terms alone, for anyone whose priority is to save both body

12 Wear, 'Puritan perceptions of illness', p. 76.

13 See, for example, William Birken, 'The Dissenting Tradition in English Medicine of the Seventeenth and Eighteenth Centuries', Medical History, 39 (1995), 197-218 (p. 199); Christopher Hill, 'The Medical Profession and Its Radical Critics', in Change and Continuity in Seventeenth-Century England (London: Weidenfeld and Nicolson, 1974), pp. 157-178. For studies of the Latitudinarian bias towards the scientific, see Robert L. Martenson, " "Habit of Reason": Anatomy and Anglicanism in Restoration England', Bulletin of the History of Medicine, 66 (1992), 511-535, and Barbara Shapiro, 'Latitudinarianism and Science in SeventeenthCentury England', in The Intellectual Revolution of the Seventeenth Century, ed. by Charles Webster (London: Routledge \& Kegan Paul, 1974), pp. 286-316. 
and soul (and particularly the latter most of all) the scepticism Restoration physicians (not unlike Latitudinarians like Fowler) often brought with their physic was nothing less than horrifying. A good example of the conflict in interests between the spiritual and the medical doctor is depicted, for instance, by Bunyan himself in The Life and Death of Mr Badman (1680). Following a particularly severe bout of illness which (at last) leaves Bunyan's protagonist with some 'sick-bed fears' of damnation, Mr Badman confides in his doctor 'how he would cry out, tremble, and express his fears of going to Hell when his sickness lay pretty hard upon him.' These are, of course, the classic symptoms of pre-conversion anxiety, to which Badman's physician replies with much authority:

That those fears and Out-cries did arise from the height of his distemper, for that disease was often attended with lightness of the head, by reason the sick party could not sleep, and for that the vapours disturbed the brain: But you see Sir, quoth he, that so soon as you got sleep and betook your self to rest, you quickly mended, and your head settled, and so those frenzies left you. ${ }^{14}$

Bunyan's point here seems not to dispute the illness of Mr Badman or, presumably, the doctor's diagnosis of the patient's symptoms (although there is without doubt something cuttingly satirical in Bunyan's mimicry of such scientific bombast). What truly affronts Bunyan about such discourse, in fact, is the sheer lack of faith it has in anything spiritual, that everything is finally reducible to bodily vapours and carnal cogitations alone. Indeed, it is the blatant disregard for the well-being of the patient's soul that irks Bunyan the most, here: be it a physical or spiritual malady that Badman is finally suffering from, the physician effectively talks Badman out of a religious conversion that the illness seems to have been on the verge of initiating. Clearly, this is an opportunity missed in terms of saving a sinner. Hence, 'Ignorant physicians kill souls while they cure bodyes', the sage marginal voice reminds us at this point, just as Badman himself concludes (and on the authority of his doctor no less) that 'since my Physician was my Saviour, my Lust again shall be my God.'15 Badman's phrase here more than resonates with ominous significance for those of Bunyan's faith: with doctors becoming the saviours of those in desperate need both of a spiritual physician and a non-earthly Saviour,

\footnotetext{
14 John Bunyan, The Life and Death of Mr Badman, ed. by James F. Forrest and Roger Sharrock (Oxford: Clarendon Press, 1988), p. 138.

15 Bunyan, Badman, p. 138.
} 
it is hardly surprising that Bunyan is intent upon revealing such doctors as meddlesome enemies to 'true' faith and salvation. 16

With this in mind, it is also hardly surprising that Bunyan is so keen to wrestle the medical language from such physicians for the promotion of his own beleaguered faith. That it is necessary for Bunyan to do so is particularly important to recognise, moreover, given that the rise of the new scientific jargon for illness and madness that accompanied a growing medical practice (as parodied by Bunyan in Badman) has an arguably more insidious aspect yet. Michael MacDonald, for instance, suggests that the emergence of medical discourse to explain bodily, mental, and, most significantly, what had previously been denoted as spiritual malady (such as melancholy or despair), has a distinctly social and political function in the late seventeenth century. Whereas preachers and physicians once held a common linguistic base of metaphors and terms for both spiritual and physical healing, a linguistic union which reflected a shared interest in the well-being of their 'patients' in general, Restoration medical practice sought to appropriate medical terminology from Nonconformist preachers through purely rational explanations for illness (especially mental, according to MacDonald) and for reasons other than a desire for a more efficient mode of health care.

On the one hand, for example, medical discourse and practice emerge so authoritatively in the Restoration largely because of the reaction by 'the governing elite' to the radicalism evinced by religious sects in the Civil War period. Scientific and medical theories about illness and despair became so proliferate in the Restoration, therefore, because they provided the relevant authorities with

the only kind of explanation for mental disturbance entirely free from controversial religious associations; medical treatments were the only methods of healing insanity that did not meet with the disapprobation of the established clergy. ${ }^{17}$

\footnotetext{
16 Charles Lloyd Cohen also takes note of the conflict between Puritan faith and a non-providentialist, materially-based view of illness and the mind: 'Physicians often spoke as if the soul either does not exist', he comments, 'or plays only a minor role in human operating, and they quickly turned away from speculating about it to contemplate the body's ills. [...T] hey grounded morality in physiology and denied the importance of self-reflection': God's Caress: The Psycholgy of Puritan Religious Experience (New York and Oxford: Oxford University Press, 1986), p. 43.

17 Michael MacDonald, Mystical Bedlam: Madness, Anxiety, and Healing in Seventeenth Century England (Cambridge: Cambridge University Press, 1981), p. 226. See also Michael MacDonald, 'Religion, Social Change, and Psychological Healing in England, 1600-1800', in The Church and Healing: Studies in Church History, Volume 19, ed. by W. J. Sheils (Oxford: Basil Blackwell, 1982), pp. 101-125.
} 
At the same time, however, medical discourse could also be utilised as a formidable means of wrestling authority away from anyone who could be labelled as doctrinally (and therefore politically) radical. Medical practice and its language could thus be used to undermine the popularity of 'Religious therapy' and a language of religious healing which continually remained a 'potent political weapon in the Dissenters' battle to capture the hearts of the English people.' Despite the blatant practical inadequacies of both medicine and doctors in the Restoration, then, medical psychology

became the sole basis for treatments of insanity sanctioned by the ruling elite. There was no alternative. Religious therapies were politically dangerous and magical remedies were slowly being discredited by a combination of factors: their association with political radicalism during the Interregnum, the advance of natural science, and the growth of the medical profession. ${ }^{18}$

MacDonald's point here is that the challenge that medical psychology posed to the 'puritan tradition of psychological healing' (which had long 'provided a coherent and comprehensive response to metal disorder' based on 'beliefs widely held among the common people', and which was rejected from the Restoration onwards 'as a subversive medley of superstition and fanaticism'), finally had 'catastrophic consequences for the treatment of the insane.'19 For Nonconformists such as Bunyan, however, the growth in the scientific authority of medicine had different detrimental effects. Medical discourse, for example, ostensibly usurped a view of reality based on 'experience' and spirituality by appropriating the language of healing and remedy adopted by Nonconformists and using it to authorise a distinctly non-spiritual and rational perception of the world. Whereas 'protestant religious healing' had always been 'particularly attractive because its curative methods expressed beliefs about the human condition that harmonised with popular psychology', the medical discourse and practice of conformist Restoration physicians sought to dismantle such belief structures, making the language of spiritual remedy wholly meaningless. ${ }^{20}$

In order to achieve this effect, moreover, the authority posited in medical discourse also gave Latitudinarians, and conformist society in general, the means to disparage the likes of Bunyan further. Most perniciously, the language of medicine and medical psychology could

\footnotetext{
18 MacDonald, Mystical Bedlam, pp. 228-229.

19 MacDonald, 'Psychological Healing', pp. 106-107, 122.

20 MacDonald, 'Psychological Healing', p. 112.
} 
be used to sanction the further marginalisation of the already peripheral Nonconformists by denoting them as nothing less than insane. 'Horrified by the proliferation of radical sects with politically subversive doctrines, the governing elite', MacDonald notes, 'fashioned a polite culture, founded on rational religion, natural philosophy, and neoclassicism that repudiated the intellectual bases of spiritual healing.' Within this culture, the members of its 'polite society' 'sought to discredit enthusiasm by representing it as a kind of mental disease.' As a consequence, the 'arguments that discredited the inspirations and spiritual experiences of the enthusiasts emptied the language of religious psychology of its significance.'21

Bunyan's wrangles over medical discourse present far more than just a war of words, therefore. When Bunyan is accused of enthusiastic madness by the likes of Edward Fowler, or when the Church of England Bishop, Samuel Parker, attacks Nonconformists and Dissenters as dangerously fanatical schismatics, there is a distinct political agenda at stake. The likes of Parker and Fowler intend to make the religious practice of those such as Bunyan appear not only doctrinally fallacious but politically seditious and medically insane. Hence, while Fowler wonders how any Calvinist like Bunyan can hold such antinomian doctrines when 'compos mentis, and not utterly deprived of his Intellectuals', more viciously Parker attacks Nonconformists as a 'Wild and Fanatique Rabble' of 'Brain-Sick People' whose 'Consciences are seized on by such morose and surly Principles, as to make them the rudest and most barbarous people in the world'. For Parker, the 'Fanatique Tempers and Principles' of Nonconformists like Bunyan threaten 'the Welfare and Security of Government'. As such, this Latitudinarian's scornful and uncompromising denunciation of Dissenters in A Discourse of Ecclesiastical Politie (1670) is presented as nothing less than a means to cure them of their radically ill-humour, and with some surgically precise rhetoric too: 'we must point our Reproofs with Sharp Invectives', Parker asserts, 'we must discover them to themselves; we must lance their Tumour, and take out the Core of their proud Flesh before we can cure them'. 'Anodyn and softer Medicines make no impressions upon them', he writes: 'to treat them smoothly does but feed the humour'.22

\footnotetext{
21 MacDonald, 'Psychological Healing', pp. 119-120.

22 Fowler, Design of Christianity, pp. 217, 220. Samuel Parker, A Discourse of Ecclesiatical Politie (1670), from 'The Preface to the Reader', pp. iv-xiv. For similar comments, see also pp. 56-57, 75-77, $197,269$.
} 
The language of medical psychology (as well as of surgical anatomy) is thus being used by Latitudinarians such as Fowler and Parker for a number of reasons: to render Bunyan's spiritualised theology impotent, to demonise it as radically subversive, and to marginalise it as fanatical. In such a context, it is hardly surprising that Bunyan is so vehement in defending his faith against accusations of political radicalism and sedition as well as enthusiastic excess. Nor is it surprising that medical metaphors are finally so important to Bunyan: they represent not only the comforts his doctrine of grace can offer the believer but the very stronghold for the expression of a faith beset upon from all sides.

But Bunyan does more than cling passively to the metaphors that traditionally inform his doctrine of grace, though. As his skirmishes with Fowler show, Bunyan is always keen to ensure that, amidst any struggle for the commandeering of medical imagery, he can reappropriate the very analogies taken from and used against him as effectively as any learned Latitudinarian. Bunyan's active engagement with medical discourse can be seen, for example, in his tract The Water of Life (1688). Here, Bunyan begins by advertising the doctrine of his treatise in terms which are derived not from the Gospels or from any Reformed theologian but from the proliferation of medical cures for bodily ills available in the late seventeenth century. Bunyan thus proclaims his doctrine of grace and its Scriptural water of life in a way consciously imitative of the medicinal 'bills' offered by physicians, apothecaries, and quacks in giving 'an account to the country of the persons cured, and the diseases that have been removed by liquors and preparations [...] made for that end'.23 Bunyan's water of life, therefore, is nothing less than an 'aquae vitae' which 'will certainly make thee well, let thy disease, or trouble, or malady, be what it will.' 'No disease comes amiss to it', Bunyan informs us for, 'it cures blindness, deadness, deafness, dumbness', it will 'beget in you a good appetite to that which is good; it will remove obstructions in the stomach and liver' and,

23 John Bunyan, The Water of Life (1688), in The Works of John Bunyan, ed. by Offor, III, 539-540. See Graham Midgley's editorial comments on Bunyan's sources for this language, The Miscellaneous Works of John Bunyan VII, ed. by Graham Midgley (Oxford: Clarendon Press, 1989), p. 233. For a contextual discussion of such potions and medicines in late seventeenth-century society, see Roy Porter, 'The Language of Quackery in England, 1660-1800', in The Social History of Language, ed. by Peter Burke and Roy Porter (Cambridge: Cambridge University Press: 1987), pp. 73-103. 
most importantly, 'it will drive away devils and spirits; it will cure enchantments and witchcraft; it will heal the mad and lunatic.'24

It is perhaps the latter effects of Bunyan's aqua vitae that bear the most resonance in the Restoration context: Bunyan is clearly reconstructing the discourse of seventeenth-century medical practice within the frame of his doctrine of grace, positing the attributes associated with the physician's remedy wholly within the realm of spiritual healing. Bunyan, moreover, relishes the figurative opportunities this language offers him in being able to discourse about grace. 'There are many diseases in the world', Bunyan writes, 'and there are also remedies for those diseases; but there is a disease that nothing will, can, or shall cure, but a dram of this bottle, a draught of this aquae vitae, this water of life.' Here, Bunyan utilises the discourse of medical illness and cure in order to re-convert it into a figure for his doctrine of Law and grace. As with other medical metaphors, Bunyan can use this language to show how, above all else, the Law and sin infect man with a 'disease' which 'nothing can cure but the grace of God by the gospel, called here the water of life.' 25

Although there is nothing new in the meaning posited in these terms, it is the concerted effort Bunyan makes in appropriating the discourse of medical remedy that is remarkable in The Water of Life. Bunyan now presents his doctrine not only as a source of comfort and assurance (this is a tract, after all, remarkable for its openly voluntaristic message) but as a distinct alternative to the purely bogus trickery of medicinal potions. In being said to cure indigestion and madness, be they physical or spiritual, Bunyan's water of life presents itself as a viable alternative to the most current physic while simultaneously denouncing the latter as mere quackery indeed. Unlike spurious medicines, Bunyan's water of life is, he assures us, no trick: it is 'probatum est'. Nor is it expensive or to be enjoyed by the social elite alone, as are the restorative waters at 'Tunbridge, Epsom, the Bath, and other places'. Bunyan's water of life is free for anyone willing to be cured by it: his water of life 'brings all that is wanting to the soul', he writes, 'Thou, therefore hast nothing to do, I mean as to the curing of thy soul of its doubts, and fears, and despairing thoughts, but to drink and live forever.'26

\footnotetext{
24 Bunyan, Water of Life, pp. 540-542, 557-558.

25 Bunyan, Water of Life, p. 542.

26 Bunyan, Water of Life, pp. 558-559.
} 
In developing the analogy of the water of life (grace) as an aquae vitae Bunyan undoubtedly achieves a number of effects. Firstly, he maintains the comforting nature of his doctrine of grace and the openness of salvation for anyone willing to have it. Secondly, and more importantly, he radically re-spiritualises a discourse of healing and medicine which has been wrestled from the language of his faith by the likes of Fowler. He does so, moreover, while simultaneously denouncing any alternative to grace (be it medicinal, doctrinal, or both) as mere hocus-pocus. In other words, Bunyan effectively throws back any accusation of purveying enthusiastic nonsense into the faces of his Latitudinarian and scientific accusers and does so using their own terms. Beyond this, Bunyan's adoption and adaptation of medical discourse also provide him with new and up-dated metaphors for grace in any case. Bunyan is clearly not one to miss a creative opportunity to discourse about the benefits and comforts of grace, particularly when it involves the absorption of cultural values other than those of his own faith.

Bunyan's ability as a writer and defender of his faith is, therefore, more than evidenced in his entwining of Biblical exegesis with socio-cultural comment, assessment, and parody in a tract like The Water of Life. Bunyan's use of medical metaphor shows him actively dismantling the social and linguistic constructs of belief systems which threaten his own theology (such as rational moralism and medical psychology) and rebuilding them in order to strengthen and protect his own Nonconformist faith. Bunyan's use of medical discourse is, therefore, a reconstruction (as well as a reappropriation) of a specific kind of metaphor from without to within Bunyan's theology of grace. Perhaps the best example of this, however, lies in The Pilgrim's Progress, Part II where Bunyan presents Christiana's eldest son, Mathew, at one point, as suffering from a 'Sickness' that 'pained in his Bowels, so that he was with it, at times, pulled as 'twere both ends together.' To combat this allegorical sickness, a 'well approved Physician', one 'Mr. Skill', is called in to provide a remedy for the child's 'Gripes' (caused, it appears, by the fruit stolen from 'Belzebubs Orchard'). The medicine administered by this doctor takes a particularly doctrinal form, though: after the failure of some Old Testament remedy (the Law), the good doctor presents a 'Purge', 'ex Carne \& Sanguine Christi', 'made up into Pills with a Promise or two, and a proportionable quantity of Salt.' 
These pills are, moreover, only ever to be taken 'in half a quarter of a Pint of the Tears of Repentance.'27

Here, Bunyan is fully aware of how he is appropriating medical discourse directly from non-allegorical physicians in order to describe the healing effects of grace anew. Although there is, as Roger Sharrock has pointed out, a distinct parodying of seventeenth-century 'pharmaceutical jargon' in operation here ('You know Physicians give strange Medicines to their Patients', Bunyan writes), Bunyan draws upon and transforms the likes of an existing contemporary alchemical product, 'Mathew's Pills', in order to make what is nothing less than a crucial theological point. ${ }^{28}$ Only through the blood of Christ, the promises of the Word, and heartfelt repentance can any sinner combat the disease of sin. Mr. Skill's remedy is thus, in the allegorical guise of bodily physic, nothing other than the most central tenet of Bunyan's doctrine as a whole: salvation by grace. For this reason, Mr. Skill describes his cure as 'an universal Pill' which 'if a man will but use this Physick as he should, it will make him live forever. 29

In this way, Bunyan achieves a supreme reappropriation of medical metaphor: through the representation of a bodily illness cured by a physician who tenders a medicine of grace alone (and for whom Christ is the 'Master of the Colledge of Physicians'), Bunyan manages to invert an established (and Establishment) language of carnal physic for the purely spiritual purpose of promoting his Nonconformist faith. Within such allegorical figuring, moreover, Bunyan finally subordinates the lexis of medicine to his comforting doctrine of salvation and, in doing so, can repudiate any alternative to grace, be it legalistic or scientific. Bunyan's use of medicine as an analogy for grace not only reflects a need to comfort the sinful nor does it

27 John Bunyan, The Pilgrim's Progress, Part II, ed. by James Blanton Wharey, 2nd ed. rev. by Roger Sharrock (Oxford: Clarendon Press, 1960), pp. 230-231.

${ }^{28}$ See Roger Sharrock's note to this in The Pilgrim's Progress, pp. 345-346, and his article, 'Mathew's Pills and The Pilgrim's Progress', Notes and Queries, 199 (1954), 246-247.

${ }^{29}$ Bunyan, The Pilgrim's Progress, Part II, p. 230. That this medicine represents grace operating over Law and sin has largely been missed by commentators on this episode. Tindall and Swaim, for example, view Mr. Skill's pill as a eucharistic representation of communion bread, a reading which seems somewhat misguided and inadequate given the implications and the cultural context of Bunyan's medical language here. See William York Tindall, John Bunyan Mechanick Preacher (New York: Columbia University Press, 1934; repr. 1964), pp. 64-65, and Kathleen M. Swaim (who seems to follow Tindall), Pilgrim's Progress, Puritan Progress: Discourses and Contexts (Urbana and Chicago: University of Illinois, 1993), pp. 215-216. 
merely mark Bunyan's stylistic heritage, therefore: it acts as a surprising gauge for the cultural, political, and religious shifts occurring within the Restoration period and Bunyan's response to them. It is for this reason that at the heart of The Pilgrim's Progress, Part II we find Bunyan's allegorical art reaching into the realm of contemporary medical and theological controversy and transforming the language of this realm into a remarkable parable of his own faith. For Bunyan, as Christiana's words suggest, anyone who is willing to take the water of life will indeed 'never take other Physick' again. 


\section{Bibliography}

Where the same author has published more than one article or book, the details are given below in chronological order of publication (including modern editions of individual works by Bunyan). For the full details of those journals the titles of which have been abbreviated in this bibliography, please consult the 'Note on Texts and Abbreviations' at the beginning of this thesis (p. v).

\section{Primary Sources}

Alcott, Louisa May, Little Women, World's Classics Series, ed. with an intro. by Valerie Anderson (Oxford: Oxford University Press, 1994)

Ashton, John, ed,. Chap-Books of the Eighteenth Century (New York: Benjamin Blom, 1966; originally published 1882)

The Confessions of Saint Augustine, transl. by E. B. Pusey (London: J. M. Dent, 1907; repr. 1936)

B., J., The Pilgrim's Progress [...]: The third part (1693), author anonymous, 13th edn (London: 1738)

Baily, Lewes, The Practise of Piety, 3rd edn (London: 1613)

Baxter, Richard The Scripture Gospel Defended (London: 1690)

Baxter, Richard, The Autobiography of Richard Baxter, ed. with an intro. by J. M. Lloyd Thomas (London: J. M. Dent, 1931)

The Narrative of the Persecution of Agnes Beaumont in 1674, with an intro. by G. B. Harrison (London: Constable, 1929)

The Bible and Holy Scriptures Conteyned in the Olde and Newe Testament (Geneva: 1562)

The Jerusalem Bible, Popular edn, ed. by Alexander Jones (London: Dartman, Longman, and Todd, 1974)

The British Museum General Catalogue of Printed Books, Photolithographic edition to 1955, 263 vols (London: British Museum, 1965)

The Works of John Bunyan, ed. by George Offor, 3 vols (Glasgow: W. G. Blackie and Son, 1854; repr. by The Banner of Truth Trust, 1991)

The Miscellaneous Works of John Bunyan, 13 vols, General Editor: Roger Sharrock (Oxford: Clarendon Press, 1976-1994) 
Bunyan, John, The Pilgrim's Progress, an exact replica of the first edition, 1678 (London: Noel Douglas, 1928)

Bunyan, John, The Pilgrim's Progress, ed. by James Blanton Wharey, 2nd edn, rev. by Roger Sharrock (Oxford: Clarendon Press, 1960)

Bunyan, John, Grace Abounding to the Chief of Sinners, ed. by Roger Sharrock (Oxford: Clarendon Press, 1962)

Bunyan, John, The Pilgrim's Progress, ed. by Roger Sharrock (Harmondsworth: Penguin, 1965; repr. 1987)

Bunyan, John, The Holy War, ed. by Roger Sharrock and James F. Forrest (Oxford: Clarendon Press, 1980)

Bunyan, John, The Pilgrim's Progress, World's Classics Series, ed. by N. H. Keeble (Oxford: Oxford University Press, 1984)

Bunyan, John, Grace Abounding to the Chief of Sinners, ed. by W. R. Owens (Harmondsworth: Penguin, 1987)

Bunyan, John, The Life and Death of Mr. Badman, ed. by James F. Forrest and Roger Sharrock (Oxford: Clarendon Press, 1988)

Burrough, Edward, The True Faith of the Gospel of Peace (London: 1656)

Burrough, Edward, Truth (the Strongest of all) (London: 1657)

Burton, Robert, The Anatomy of Melancholy, intro. by Holbrook Jackson (London: J. M. Dent, 1932; repr. 1949)

Calvin, John, Institutes of Christian Religion, ed. by John T. McNeill, transl. by Ford Lewis Battles, 2 vols (Philadelphia: Westminster Press, 1960)

Clarkson, Laurence, Lost Sheep Found (London: 1660)

The Collected Works of Samuel Taylor Coleridge: Marginalia, ed. by George Whalley, 5 vols (London: Routledge and Kegan Paul, in association with Princeton University Press, 1980)

Dent, Arthur, The Plaine-Man's Path-Way to Heaven (London: 1601)

Doe, Charles, A Collection of Experience of the Work of Grace (London: 1700)

Evans, Arise, An Eccho to the Voice from Heaven (London: 1652)

Fowler, Edward, The Design of Christianity (1671)

Fowler, Edward (attributed only), Dirt Wipt Off (London: 1672)

The Journal of George Fox, revised edition by John L. Nickalls, with an epilogue by Henry J. Cadbury and an introduction by Geoffrey F. Nuttall (Cambridge: Cambridge University Press, 1952)

Foxe, John, The Booke of Martyrs: Acts and Monuments of matters most speciall and memorable, happening in the Church, with an universall Historie of the same, 3 vols (London: 1641) 
Hobbes, Thomas, Leviathan, ed. by Richard Tuck (Cambridge: Cambridge University Press, 1991; repr. 1994)

James, Samuel, ed., An Abstract of the Gracious Dealings of God with Several Eminent Christians, in their Conversion and Sufferings (London: 1760)

Jessey, Henry, The Exceeding Riches of Grace Advanced [...] in Mris Sarah Wight (London: 1647)

Locke, John, An Essay Concerning Human Understanding, ed. with a foreword by Peter H. Nidditch (Oxford: Clarendon Press, 1975; repr. 1979)

A Commentarie of Master Doctor Martin Luther Upon the Epistle of S. Paul to the Galathians (London: 1644)

The Journal of Richard Norwood, with introductions by Wesley Frank Craven and Walter B. Hayward (New York: Scholars' Facsimiles \& Reprints, 1945)

The Oxford English Dictionary, 2nd edn, prepared by J. A. Simpson and E. S. C. Weiner, 20 vols (Oxford: Clarendon Press, 1989)

Parker, Samuel, A Discourse of Ecclesiastical Politie (London: 1670)

The Works of William Perkins, intro. and ed. by Ian Breward (Abingdon: The Sutton Courtenay Press, 1970)

Petto, Samuel, The Voice of the Spirit [...] To which is added: Roses from Sharon; or Sweet Experiences reached out by Christ to some of his beloved ones (London: 1654)

Powell, Vavasor, Spiritual Experiences of Sundry Beleevers (London: 1653)

Selected Letters of Samuel Richardson, ed. by John Carroll (Oxford: Clarendon Press, 1964)

Salmon, Joseph, Heights in Depths and Depths in Heights (London: 1651)

S.[herman], T.[homas], The Pilgrim's Progress from this Present World of Wickedness and Misery, to an Eternity of Holiness and Felicity - The Second Part (London: 1682); repr. in The Pilgrim's Progress (Glasgow: Messrs. Carmichael and Millar in Company, 1736), this edition of The Pilgrim's Progress being in three parts with Sherman's text as part two

Smith, Nigel, ed., A Collection of Ranter Writings from the 17th Century (London: Junction Books, 1983)

A Relation of the Fearful Estate of Francis Spira in the year 1548 - compiled by Nathaniel Bacon (London: 1649)

Tibbutt, H. G., ed., The Minutes of the First Independent Church (now Bunyan Meeting) at Bedford, 1656-1766, The Publications of the Bedfordshire Historical Record Society, volume 55 (Bedford: BHRS, 1976)

Trapnel, Anna, A Legacy for Saints; Being Several Experiences of the Dealings of God with Anna Trapnel (London: 1654)

The Life of the Reverend Mr. George Trosse, ed. by A. W. Brink (Montreal and London: McGill-Queen's University Press, 1974) 


\section{Secondary Sources}

Alexander, Gillian, 'Politics of the Pronoun in the Literature of the English Revolution', in Carter, Ronald, ed., Language and Literature, pp. 217-235

Alpaugh, David J., 'Emblem and Interpretation in The Pilgrim's Progress', ELH, 33 (1966), 299-314

Alter, Robert and Frank Kermode, eds, The Literary Guide to the Bible (London: Collins, 1987; repr. 1988)

Backscheider, Paula R., A Being More Intense: A Study of the Prose Works of Bunyan, Swift, and Defoe (New York: AMS Press, 1984)

Baird, Charles, John Bunyan: A Study in Narrative Technique (Port Washington, New York and London: Kennikat Press, 1977)

Baker, Wayne, 'Sola Fide, Sola Gratia: The Battle for Luther in Seventeenth-Century England', Sixteenth Century Journal, 16 (1985), 115-133

Ban, Joseph D., 'Was John Bunyan a Baptist?', Baptist Quarterly, 30 (1984), 367-76

Barrett, David, Roger Pooley, and Leland Ryken, eds, The Discerning Reader: Christian perspectives on literature and theory (Leicester: Apollos/Inter-Varsity Press, 1995)

Bartell, Shirley Miller, 'Uncertainty in Bunyan versus Assurance in Fox', Quaker History: Bulletin of the Friends Historical Association, 58 (1969), 93-103

Barth, John, 'The Literature of Exhaustion', in Bradbury, Malcolm, ed., The Novel Today, pp. 71-86

Batson, E. Beatrice, John Bunyan: Allegory and Imagination (London: Croom Helm, 1984)

Beal, Rebecca S., 'Grace Abounding to the Chief of Sinners: John Bunyan's Pauline Epistle', SEL, 21 (1981), 147-160

Beier, Lucinda McCray, Sufferers and Healers: The Experience of Illness in SeventeenthCentury England (London and New York: Routledge and Kegan Paul, 1987)

Bell, M. Charles, 'Calvin and the Extent of the Atonement', Evangelical Quarterly, 55 (1983), $115-123$

Bell, Robert, 'Metamorphoses of Spiritual Autobiography', ELH, 44 (1977), 108-126

Bierma, Lyle D., 'Federal Theology in the Sixteenth Century: Two Traditions', Westminster Theological Journal, 45 (1983), 304-321

Bierma, Lyle D., 'The Role of Covenant Theology in Early Reformed Orthodoxy', Sixteenth Century Journal, 21 (1990), 453-462

Birken, William, 'The Dissenting Tradition in English Medicine of the Seventeenth and Eighteenth Centuries', Medical History, 39 (1995), 197-218 
Bloom, Edward, 'The Allegorical Principle', ELH, 18 (1951), 163-190

Board, C., 'Maps as Models', in Chorley, Richard J. and Peter Haggett, eds, Models in Geography, pp. 671-725

Bottrall, Margaret, Every Man A Phoenix: Studies in Seventeenth-Century Autobiography (London: John Murray, 1958)

Bradbury, Malcolm, ed., The Novel Today (London: Fontana, 1977; repr. 1990)

Brauer, Jerald C., 'Conversion: From Puritanism to Revivalism', Journal of Religion, 58 (1978), 227-243

Breen, Margaret Soenser, 'The Sexed Pilgrim's Progress', SEL, 32 (1992), 443-460

Breward, Ian, 'The Significance of William Perkins', Journal of Religious History, 4 (19661967), 113-128

Bridges, Margaret, 'The Sense of an Ending: The Case of the Dream-Vision', Dutch Quarterly Review of Anglo-American Letters, 14 (1984), 81-96

Brinker, Menachem, 'Verisimilitude, Conventions, and Beliefs', NLH, 14 (1983), 253-267

Brittain, Vera, In the Steps of John Bunyan: An Excursion into Puritan England (London: Rich and Cowan, 1950; repr. 1987)

Brooks, Peter, Reading for the Plot: Design and Intention in Narrative (Oxford: Clarendon Press, 1984)

Brooks, Peter Newman, ed., Reformation Principle and Practice: Essays in Honour of Arthur Geoffrey Dickens (London: Scolar Press, 1980)

Brown, John, John Bunyan: His Life, Times, and Work (London: The Hulbert Publishing Co., 1885; Tercentenary Edition, rev. by Frank Mott Harrison, 1928)

Bruns, Gerald L., 'Midrash and Allegory: The Beginnings of Scriptural Interpretation', in Alter, Robert and Frank Kermode, eds, The Literary Guide to the Bible, pp. 625-646

Bruss, Elizabeth W., Autobiographical Acts: The Changing Situation of a Literary Genre (Baltimore and London: John Hopkins University Press, 1976)

Burke, Peter and Roy Porter, eds, The Social History of Language (Cambridge: Cambridge University Press: 1987)

Butler, George, 'The Iron Cage of Despair and "The Unpardonable Sin" in The Pilgrim's Progress', English Language Notes, 25 (1987-1988), 34-38

Caldwell, Patricia, The Puritan Conversion Narrative: The Beginnings of American Expression (Cambridge: Cambridge University Press, 1983)

Camden, Vera, 'Blasphemy and Belief in Grace Abounding', American Baptist Quarterly, 7 (1988), 460-471

Camden, Vera, 'Blasphemy and the Problem of the Self', Bunyan Studies: John Bunyan and his Times, 1 (1989), 5-21 
Camden, Vera, " "Most Fit for a Wounded Conscience": The Place of Luther's "Commentary on Galatians' in Grace Abounding', Renaissance Quarterly, 50 (1997), 819-849

Campbell, Gordon, 'Fishing in Other Men's Waters: Bunyan and the Theologians', in Keeble, N. H., ed., Conventicle and Parnassus, pp. 137-151

Campbell, Gordon, 'The Theology of The Pilgrim's Progress', in Newey, Vincent, ed., The Pilgrim's Progress: Critical and Historical Views, pp. 251-262

Campbell, Gordon, 'The Source of Bunyan's Mapp of Salvation', Journal of the Warburg and Courtald Institutes, 44 (1981), 240-241

Canary, Robert H. and Henry Kozicki, eds, The Writing of History (Madison, Wisconsin and London: University of Wisconsin Press, 1978)

Cantarow, Ellen, 'A Wilderness of Opinions Confounded: Allegory and Ideology', College English, 34 (1972), 215-252

Carlton, Peter J., 'Bunyan: Language, Convention, Authority', English Literary History, 49 (1982), 17-32

Carter, Ronald, ed., Language and Literature (London: Allen and Unwin, 1982)

Champion, James, 'The Parable as an Ancient and a Modern Form', Journal of Literature and Theology, 3 (1989), 16-39

Chatman, Seymour, Story and Discourse: Narrative Structure in Fiction and Film (Ithaca and London: Cornell University Press, 1978), extracts included in Walder, Dennis, ed., Literature in the Modern World

Chorley, Richard J. and Peter Haggett, eds, Models in Geography (London: Methuen, 1967)

Cohen, Charles Lloyd, God's Caress: The Psychology of Puritan Religious Experience (New York and Oxford: Oxford University Press, 1986)

Collmer, Robert, ed., Bunyan in Our Time (Ohio and London: Kent State University Press, 1989)

Connor, Steven, Postmodernist Culture: An Introduction to Theories of the Contemporary (Oxford: Blackwell, 1989; repr. 1991)

Coolidge, John S., The Pauline Renaissance in England: Puritanism and the Bible (Oxford: Clarendon Press, 1970), pp. 81-89, 101-110

Cunningham, Valentine, 'Glossing and Glozing: Bunyan and Allegory', in Keeble, N. H., ed., Conventicle and Parnassus, pp. 217-240

Damrosch, Leopold, God's Plot and Man's Stories: Studies in the Fictional Imagination from Milton to Fielding (Chicago and London: University of Chicago Press, 1985)

Danielson, Dennis, 'Catechism, The Pilgrim's Progress, and the Pilgrim's Progress', Journal of English and Germanic Philology, 94 (1995), $42-58$

Davie, Donald, A Gathered Church: The Literature of Dissenting Interest 1700-1930 (London: Routledge and Kegan Paul, 1978)

Davies, Horton, 'Calvinism and Literary Culture', John Donne Journal, 3 (1984), 105-112 
Delany, Paul, British Autobiography in the Seventeenth Century (London: Routledge and Kegan Paul, 1969)

de Man, Paul, 'Autobiography as De-facement', $M L N, 94$ (1979), 919-30

de Man, Paul, 'Pascal's Allegory of Persuasion', in Greenblatt, Stephen J., ed., Allegory and Representation, pp. 1-25

de Man, Paul, 'The Rhetoric of Temporality', in de Man, Paul, Blindness and Insight, pp. $187-228$

de Man, Paul, Blindness and Insight: Essays in the Rhetoric of Contemporary Criticism, 2nd edn. revised, with an intro. by Wlad Godzich (London: Routledge, 1983; repr. 1993)

de Vries, Pieter, John Bunyan On the Order of Salvation, transl. by C. van Haaften (New York: Peter Lang, 1994)

Diehl, Huston, 'Into the maze of self: the Protestant transformation of the image of the labyrinth', Journal of Medieval and Renaissance Studies, 16 (1986), 281-301

Draper, Richard, 'Bunyan's Mr Ignorance', Modern Language Review, 22 (1927), 15-21

Dunbar, Gary S., Modern Geography: An Encyclopedic Survey (Chicago and London: St James Press, 1991)

Dutton, A. Richard, 'Interesting, but tough: Reading The Pilgrim's Progress', SEL, 18 (1978), 439-456

Ebner, Dean, Autobiography in Seventeenth Century England: Theology and the Self (The Hague: Mouton Press, 1971)

Edwards, Philip, 'The Journey in The Pilgrim's Progress', in Newey, Vincent, ed., The Pilgrim's Progress: Critical and Historical Views, pp. 111-117

Elbaz, Robert, 'Autobiography, Ideology, and Genre Theory', Orbis Litterarum: International Review of Literary Studies, 38 (1983), 187-204

Ellens, J. H., 'The Psychodynamics of Christian Conversion', Journal of Psychology and Christianity, 3 (1984), 29-36

Elmer, Peter, 'Medicine, religion and the puritan revolution', in French, Roger and Andrew Wear, eds, The Medical Revolution of the Seventeenth Century, pp. 10-45

Emerson, Everett H., 'Calvin and Covenant Theology', Church History, 25 (1956), 136-144

Evans, W. N., 'Notes on the Conversion of John Bunyan: A Study in English Puritanism', International Journal of Psycho-Analysis, 24 (1943), 176-185

Feinstein, Howard M., 'The Heart Prepared: A Comparative Study of Puritan Theology and Psychoanalysis', American Quarterly, 22 (1970), 166-176

Fineman, Joel, 'The Structure of Allegorical Desire' in Greenblatt, Stephen J., ed., Allegory and Representation, pp. 26-60

Finley, C. Stephen, 'Bunyan Among the Victorians: Macaulay, Froude, Ruskin', Journal of Literature and Theology, 3 (1989), 77-94

Fisch, Harold, 'The Puritans and the Reform of Prose Style', ELH, 19 (1952), 229-248 
Fish, Stanley E., 'Literature in the Reader: Affective Stylistics', NLH, 2 (1970-1971), 123162, reprinted in Fish, Stanley E., Self-Consuming Artifacts, pp. 383-427, and in Fish, Stanley E., Is there a Text in This Class?, pp. 21-67

Fish, Stanley E., 'Progress in The Pilgrim's Progress', ELR, 1 (1971), 261-293, reprinted in Fish, Stanley E., Self-Consuming Artifacts, pp. 224-264

Fish, Stanley E., Self-Consuming Artifacts: The Experience of Seventeenth-Century Literature (Berkeley, LA and London: University of California Press, 1972)

Fish, Stanley E., 'Sequence and Meaning in Seventeenth-Century Narrative', in To Tell a Story: Narrative Theory and Practice, intro. by Robert M. Adams (Los Angeles: William Clark Memorial Library, University of California, 1973), pp. 57-76, reprinted as 'Structuralist Homiletics' in $M L N, 91$ (1976), 1208-1221, and Fish, Stanley E., Is There a Text in This Class?, pp. 181-196

Fish, Stanley E., 'Interpreting the Variorum', Critical Inquiry, 2 (1975-1976), 465-485, reprinted in Fish, Stanley E., Is There a Text in This Class?, pp. 147-173

Fish, Stanley E., 'Interpreting "Interpreting the Variorum" ', Critical Inquiry, 3 (1976-1977), 191-196, reprinted in Fish, Stanley E., Is There A Text in This Class?, pp. 174-180

Fish, Stanley E., Is There A Text in This Class: The Authority of Interpretive Communities (Cambridge, Massachusetts and London: Harvard University Press, 1980)

Fletcher, Angus, Allegory: The Theory of a Symbolic Mode (Cornell University Press: Ithaca and New York, 1964)

Forguson, Lynd, 'Autobiography as History', University of Toronto Quarterly, 49 (19791980), 139-155

Forrest, James F., 'Bunyan's Ignorance and the Flatterer: A Study in the Art of Damnation', Studies in Philology, 60 (1963), 12-22

Forrest, James F., 'Mercy with her Mirror', Philological Quarterly, 42 (1963), 121-126

Forrest, James F., 'Patristic Tradition and Psychological Image in Bunyan's Three Shining Ones at the Cross', Harvard Theological Review, 68 (1975), 61-65

Forrest, James F., 'Vision, Form, and the Imagination in the Second Part of The Pilgrim's Progress', Journal of Narrative Technique, 13 (1983), 109-116

Forrest, James F., 'Conspectus: The Critical Reception of The Pilgrim's Progress, Second Part', Bunyan Studies: John Bunyan and his Times, 1, no. 1 (1988), 36-42

Forrest, James F., 'Allegory as Sacred Sport: Manipulation of the Reader in Spenser and Bunyan', in Collmer, Robert, ed., Bunyan in Our Time, pp. 93-112

Frederick, Bonnie and Susan H. McLeod, eds, Women and the Journey: The Female Travel Experience (Pullman, Washington: Washington State University Press, 1993)

French, Roger and Andrew Wear, eds, The Medical Revolution of the Seventeenth Century (Cambridge: Cambridge University Press, 1989)

Freund, Elizabeth, The Return of the Reader: Reader-Response Criticism (London and New York: Methuen, 1987) 
Furlong, Monica, Puritan's Progress: A Study of John Bunyan (London: Hodder and Stoughton, 1975)

Golder, Harold, 'John Bunyan's Hypocrisy', North American Review, 223 (1926), 323-332

Golder, Harold, 'Bunyan's Valley of the Shadow', Modern Philology, 27 (1929), 55-72

Golder, Harold, 'Bunyan's Giant Despair', Journal of English and Germanic Philology, 30 (1931), 361-378

Greaves, Richard L., 'The Doctrine of Grace in the Writings of John Bunyan' (unpublished doctoral thesis, University of London, 1964)

Greaves, Richard L., 'Luther's Doctrine of Grace', Scottish Journal of Theology, 18 (1965), 385-395

Greaves, Richard L., 'The Authorship of Reprobation Asserted', Baptist Quarterly, 21 (1965), 126-31, reprinted in Greaves, Richard L., John Bunyan and English Nonconformity, pp. 185-191

Greaves, Richard L., 'John Bunyan and Covenant Thought in the Seventeenth Century', Church History, 36 (1967), 151-169

Greaves, Richard L., 'The Origins and Early Development of English Covenant Thought', The Historian, 31 (1968), 21-35

Greaves, Richard L., John Bunyan (Abingdon: The Sutton Courtenay Press, 1969)

Greaves, Richard L., 'Bunyan through the centuries: some reflections', English Studies, 64 (1983), 113-121

Greaves, Richard L., 'John Bunyan: The Present State of Historical Scholarship', in van Os, M. and G. J. Schutte, eds, Bunyan in England and Abroad, pp. 29-43, reprinted in Greaves, Richard L., John Bunyan and English Nonconformity, pp. 37-50

Greaves, Richard L., John Bunyan and English Nonconformity (London: Hambledon Press, 1992)

Greaves, Richard L., 'The Sword and the Spirit: Bunyan and the Stuart State', in Greaves, Richard L., John Bunyan and English Nonconformity, pp. 101-126, originally published in Collmer, Robert, ed., Bunyan in Our Time, pp. 138-160

Greaves, Richard L., 'Amid The Holy War: Bunyan and the Ethic of Suffering', in Greaves, Richard L., John Bunyan and English Nonconformity, pp. 169-183, originally published in Laurence, Anne, Owens, and Sim, eds, John Bunyan and his England, pp. 63-75

Greaves, Richard L., 'The Holy War and London Nonconformity', in Greaves, Richard L., John Bunyan and English Nonconformity, pp. 155-167, originally published in Baptist Quarterly, 26 (1975), 158-168

Greaves, Richard L., 'Conventicles, Sedition, and the Toleration Act of 1689', in Greaves, Richard L., John Bunyan and English Nonconformity, pp. 207-222, originally published in Eighteenth-Century Life, 12, n. s. (1988), 1-13

Greaves, Richard L., 'Tercentenary Reflections', in Greaves, Richard L., John Bunyan and English Nonconformity, pp. 193-206, originally published in American Baptist Quarterly, 7 (1988), 496-508 
Greaves, Richard L., " "Let Truth be Free": John Bunyan and the Restoration Crisis of 166773', Albion 28 (1996), 587-605

Green, I. M., 'Bunyan in Context: The Changing Face of Protestantism in SeventeenthCentury England', in van Os, M. and G. J. Schutte, eds, Bunyan in England and Abroad, pp. 1-27

Greenblatt, Stephen J., ed., Allegory and Representation (Baltimore and London: John Hopkins University Press, 1981)

Greene, Herbert Eveleth, 'The Allegory as Employed by Spenser, Bunyan, and Swift', PMLA, 4 (1888-1889), 145-193

Grell, Ole Peter and Andrew Cunningham, eds, Medicine and the Reformation (London and New York: Routledge, 1993)

Gutierrez, Donald, 'The Labyrinth as Myth and Metaphor', University of Dayton Review, 16 (1983-1984), 88-99

Hagen, Kenneth, 'From Testament to Covenant in the Early Sixteenth Century', Sixteenth Century Journal, 3 (1972), 1-24

Haller, William, The Rise of Puritanism, Or, The Way to the New Jerusalem as Set Forth in Pulpit and Press from Thomas Cartwright to John Lilburne and John Milton, 15701643 (New York: Columbia University Press, 1938; repr. 1947)

Hancock, Maxine, 'The Key in the Window: Marginal Notes in Bunyan's Narratives' (unpublished doctoral thesis, University of Alberta, 1992)

Hancock, Maxine, 'Bunyan as Reader: The Record of Grace Abounding', Bunyan Studies: John Bunyan and his Times, 5 (1994), 68-82

Hardin, Richard F., 'Bunyan, Mr. Ignorance, and the Quakers', Studies in Philology, 69 (1972), 496-508

Harley, David, 'Mental Illness, magical medicine and the Devil in northern England, 16501700', in French, Roger and Andrew Wear, eds, The Medical Revolution of the Seventeenth Century, pp. 114-144

Harley, David, 'Spiritual Physic, Providence and English Medicine, 1560-1640', in Grell, Ole Peter and Andrew Cunningham, eds, Medicine and the Reformation, pp. 101-117

Harley, David N., 'Medical Metaphors in English Moral Theology, 1560-1660', Journal of the History of Medicine and Allied Sciences, 48 (1993), 396-435

Harley, J. B. and David Woodward, eds, The History of Cartography, Volume One: Cartography in Prehistoric, Ancient, and Mediaeval Europe and the Mediterranean (Chicago and London: University of Chicago Press, 1987)

Harley, J. B., 'The Map and the Development of the History of Cartography', in Harley, J. B. and David Woodward, eds, The History of Cartography, pp. 1-42

Harris, Tim, Paul Seward, and Mark Goldie, eds, The Politics of Religion in Restoration England (Oxford: Blackwell, 1990)

Harris, Victor, 'Allegory to Analogy in the Interpretation of Scriptures', Philological Quarterly, 43 (1966), 1-23 
Harrison, Frank Mott, John Bunyan: A story of his life (London: The Banner of Truth Trust, 1964; originally published 1928 )

Haskin, Dayton, 'Bunyan, Luther, and the Struggle with Belatedness in Grace Abounding', University of Toronto Quarterly, 50 (1980-81), 300-313

Haskin, Dayton, 'The Burden of Interpretation in The Pilgrim's Progress', Studies in Philology, 79 (1982), 256-278

Haskin, Dayton, 'The Pilgrim's Progress in the Context of Bunyan's Dialogue with the Radicals', Harvard Theological Review, 77 (1984), 73-94

Haskin, Dayton, 'Bunyan's Scriptural Acts', in Collmer, Robert, ed., Bunyan in Our Time, pp. $61-92$

Hawkins, Anne, 'The Double-Conversion Narrative in Bunyan's Grace Abounding', Philological Quarterly, 61 (1982), 259-276

Helm, Paul, 'John Bunyan and "Reprobation Asserted” ', Baptist Quarterly, 28 (1979), 87-93

Helm, Paul, 'Calvin and the Covenant: Unity and Continuity', Evangelical Quarterly, 54 (1982), 65-81

Hill, Christopher, 'Puritanism and Revolution: Studies in Interpretation of the English Revolution of the 17th Century (London: Secker and Warburg, 1958; repr. Harmondsworth: Penguin, 1986)

Hill, Christopher, The World Turned Upside Down: Radical Ideas During the English Revolution (Harmondsworth: Penguin, 1972; repr. 1991)

Hill, Christopher, Change and Continuity in Seventeenth-Century England (London: Weidenfeld and Nicolson, 1974)

Hill, Christopher, 'The Medical Profession and Its Radical Critics', in Hill, Christopher, Change and Continuity in Seventeenth-Century England, pp. 157-178

Hill, Christopher, 'John Bunyan and the English Revolution', American Baptist Quarterly, 7 (1988), 443-459

Hill, Christopher, A Turbulent, Seditious, and Factious People: John Bunyan and his Church 1628-1688 (Oxford: Oxford University Press, 1988; repr. 1989)

Hoekema, Anthony A., 'The Covenant of Grace in Calvin's Teaching', Calvin Theological Journal, 2 (1967), 133-161

Honig, Edwin, Dark Conceit: The Making of Allegory (London: Faber and Faber, 1959)

Hudson, Winthrop S. and Leonard J. Trinterud, Theology in Sixteenth and SeventeenthCentury England (Los Angeles: William Andrews Clark Memorial Library, University of California, 1971)

Hussey, Maurice, 'Arthur Dent's Plaine Mans Path-Way to Heaven', Modern Language Review, 44 (1949), 26-34

Hussey, Maurice, 'Bunyan's “Mr Ignorance” ', Modern Language Review, 44 (1949), 483489 
Hussey, Maurice, 'John Bunyan and the Book of God's Judgements: A study of The Life and Death of Mr. Badman', English, 7 (1949), 165-167

Hussey, Maurice, 'Bunyan's The Life and Death of Mr. Badman', Congregational Quarterly, 28 (1950), 359-366

Hussey, Maurice, 'Christian Conduct in Bunyan and Baxter', Baptist Quarterly, 14 (19511952), 75-83

Hussey, Maurice, 'Bunyan's Map', Baptist Quarterly, 14 (1951-52), 227-231

Hussey, Maurice, 'The Humanism of John Bunyan', in Ford, Boris, ed., The Pelican Guide to English Literature, volume 3, From Donne to Marvell (Harmondsworth: Penguin, 1956; rev. 1982; repr. 1984), pp. 317-331

Iser, Wolfgang, 'The Reading Process: A Phenomenological Approach', $N L H, 3$ (19711972), 279-299

Iser, Wolfgang, The Implied Reader: Patterns of Communication in Prose Fiction from Bunyan to Beckett (Baltimore and London: John Hopkins University Press, 1974)

Iser, Wolfgang, The Act of Reading: A Theory of Aesthetic Response (Baltimore and London: John Hopkins University Press, 1978; repr. 1980)

James, William, Varieties of Religious Experience: A Study in Human Nature (London: Longmans, 1902; repr. 1952)

Jauss, Hans Robert, 'Literary History as a Challenge to Literary Theory', $N L H, 2$ (19701971), 7-37, and reprinted in Jauss, Hans Robert, Toward an Aesthetic of Reception, pp. 3-45

Jauss, Hans Robert, Toward an Aesthetic of Reception, transl. by Timothy Bahti, intro. by Paul de Man (Brighton: Harvester Press, 1982)

Johnson, Barbara A., 'Falling into Allegory: The Apology to The Pilgrim's Progress', in Collmer, Robert, ed., Bunyan in Our Time, pp. 113-137

Johnson, Barbara A., Reading Piers Plowman and The Pilgrim's Progress: Reception and the Protestant Reader (Carbondale and Edwardsville: Southern Illinois University Press, 1992)

Johnston, R. J., Derek Gregory, and David M. Smith, eds, The Dictionary of Human Geography, 3rd edn (Oxford: Blackwell, 1994)

Kaufmann, U. Milo, The Pilgrim's Progress and Traditions in Puritan Meditation (New Haven and London: Yale University Press, 1966)

Kaufmann, U. Milo, 'Spiritual Discerning: Bunyan and the Mysteries of the Divine Will', in Keeble, N. H., ed., Conventicle and Parnassus, pp. 171-187

Keddie, Gordon J., “ "Unfallible Certenty of the Pardon of Sinne and Life Everlasting": The Doctrine of Assurance in the Theology of William Perkins', Evangelical Quarterly, 48 (1976), 230-244

Keeble, N. H., 'The Pilgrim's Progress: A Puritan Fiction', Baptist Quarterly, 28 (1980), 321-336 
Keeble, N. H., 'Christiana's Key: The Unity of The Pilgrim's Progress', in Newey, Vincent, ed., The Pilgrim's Progress: Critical and Historical Views, pp. 1-20

Keeble, N. H., 'The Way and the Ways of Puritan Story: Biblical Patterns in Bunyan and his Contemporaries', English, 33 (1984), 209-232

Keeble, N. H., The Literary Culture of Nonconformity in Later Seventeenth Century England (Leicester: Leicester University Press, 1987)

Keeble, N. H., ed., John Bunyan: Conventicle and Parnassus, Tercentenary Essays (Oxford: Clarendon Press, 1988)

Keeble, N. H., “ "Of him thousands daily Sing and talk”: Bunyan and his Reputation', in Keeble, N. H., ed., Conventicle and Parnassus, pp. 241-263

Keeble, N. H., " "Here is her Glory, even to be under Him: The Feminine in the Thought of John Bunyan', in Laurence, Anne, Owens, and Sim, eds, John Bunyan and His England, pp. 131-147

Keller, Katherine Z. and Gerald J. Schifforst, eds, The Witness of the Times: Manifestations of Ideology in Seventeenth-Century England (Pittsburgh, Pennsylvania: Duquesne University Press, 1993)

Kellner, Hans, 'The Inflatable Trope as Narrative Theory: Structure or Allegory?', Diacritics: A Review of Contemporary Criticism, 11 (1991), 14-28

Kelman, John, The Road: A Study of John Bunyan's Pilgrim's Progress, 2 vols (Edinburgh and London: Oliphant, Anderson, and Ferrier, 1911)

Kendall, R. T., Calvin and English Calvinism to 1649 (Oxford: Oxford University Press, 1979)

Kendall, R. T., 'The Puritan Modification of Calvin's Theology', in Reid, W. Stanford, John Calvin: His Influence in the Western World, pp. 197-214

Kiely, Robert, 'Angelic Discourse or Unstable Allegory? The Play of the Literal and Figural in Augustine's Confessions, The Little Flowers of St Francis, and Bunyan's Pilgrim's Progress', Stanford Literature Review, 5 (1988), 105-130

Knott, Jr., John R., The Sword of the Spirit: Puritan Responses to the Bible (Chicago and London: University of Chicago Press, 1980)

Knott, Jr., John R., 'Bunyan and the Holy Community', Studies in Philology, 80 (1983), 200-225

Knott, Jr., John R., Discourses of Martyrdom in English Literature, 1563-1694 (Cambridge: Cambridge University Press, 1993)

Korshin, Paul J., 'The Development of Abstracted Typology in England, 1650-1820', in Miner, Earl, ed., The Literary Uses of Typology, pp. 147-203

Korshin, Paul J., Typologies in England, 1650-1820 (Princeton: Princeton University Press, 1982)

Kort, Wesley A., 'Narrative and Theology', in Journal of Literature and Theology, 1 (1987), 27-38

Lamont, Daniel, 'Bunyan's Holy War', Theology Today, 3 (1946-7), 459-472 
Laurence, Anne, W. R. Owens, and Stuart Sim, eds, John Bunyan and his England, 16281688 (London: Hambledon Press, 1990)

Leavis, F. R., 'Literature and Society', in The Common Pursuit (London: Chatto and Windus, 1952), pp. 182-194

Leavis, F. R., 'The Pilgrim's Progress', in Anna Karenina and Other Essays (London: Chatto and Windus, 1967), pp. 33-48

Lerner, L. D., 'Puritanism and the Spiritual Autobiography', Hibbert Journal, 55 (19561957), 373-386

Lettinga, Neil, 'Covenant Theology Turned Upside Down: Henry Hammond and Caroline Moral Anglicanism: 1643-1660’, Sixteenth Century Journal, 24 (1993), 653-669

Lewalski, Barbara Kiefer, "Typological Symbolism and the "Progress of the Soul" in Seventeenth-Century Literature', in Miner, Earl, ed., Literary Uses of Typology, pp. 79-114

Lewis, C. S., The Allegory of Love: A Study in Medieval Tradition (Oxford: Clarendon Press, 1936)

Lewis, C. S., 'The Vision of John Bunyan', in Selected Literary Essays, ed. by Walter Hooper (Cambridge: Cambridge University Press, 1969), pp. 146-153

Lindsay, Jack, John Bunyan: Maker of Myths (London: Methuen, 1937; repr. 1969)

Lipking, Lawrence, 'The Marginal Gloss', Critical Inquiry, 3 (1976-77), 609-655

Longxi, Zhang, 'Historicizing the Postmodern Allegory', Texas Studies in Literature and Language, 36 (1994), 212-231

Luxon, Thomas H., 'The Pilgrim's Passive Progress: Luther and Bunyan on Talking and Doing, Word and Way', ELH, 53 (1986), 73-98

Luxon, Thomas H., 'Calvin and Bunyan on Word and Image: Is there a Text in Interpreter's House?', ELR, 18 (1988), 438-459

Luxon, Thomas H., 'Not I But Christ: Allegory and the Puritan Self', ELH, 60 (1993), 899937, and reprinted in Luxon, Thomas H., Literal Figures, pp. 1-33

Luxon, Thomas H., “ “Other Men's Words” and “New Birth”: Bunyan's Antihermeneutics of Experience', Texas Studies in Literature and Language, 36 (1994), 259-290, reprinted in Luxon, Thomas H., Literal Figures, pp. 130-158

Luxon, Thomas H., Literal Figures: Puritan Allegory and the Reformation Crisis in Representation (Chicago and London: The University of Chicago Press, 1995)

Lyall, Francis, 'Of Metaphors and Analogies: Legal Language and Covenant Theology', Scottish Journal of Theology, 32 (1979), 1-17

MacDonald, Michael, 'Religion, Social Change, and Psychological Healing in England, 16001800', in Sheils, W. J., ed., The Church and Healing, pp. 101-125

MacDonald, Michael, Mystical Bedlam: Madness, Anxiety, and Healing in Seventeenth Century England (Cambridge: Cambridge University Press, 1987) 
McGee, J. Sears, The Godly Man in Stuart England: Anglicans, Puritans, and the Two Tables, 1620-1670 (New Haven and London: Yale University Press, 1976)

McGiffert, Michael, ed., God's Plot: The Paradoxes of Puritan Piety, Being the Autobiography and Journal of Thomas Shepherd (Massachusetts: University of Massachusetts Press, 1972)

McGiffert, Michael, 'Covenant, Crown, and Commons in Elizabethan Puritanism', Journal of British Studies, 20 (1980), 32-52

McGiffert, Michael, 'William Tyndale's Conception of Covenant', Journal of Ecclesiastical History, 32 (1981), 167-184

McGiffert, Michael, 'Grace and Works: The Rise and Division of Covenant Divinity in Elizabethan Puritanism', Harvard Theological Review, 75 (1982), 463-502

McGiffert, Michael, 'God's Controversy with Jacobean England', American Historical Review, 88 (1983), 1151-1174

McGiffert, Michael, 'From Moses to Adam: The Making of the Covenant of Works', Sixteenth Century Journal, 19 (1988), 131-155

McGregor, J. F., 'The Baptists: Fount of All Heresy', in McGregor, J. F., and B. Reay, Radical Religion in the English Revolution, pp. 23-63

McGregor, J. F., and B. Reay, Radical Religion in the English Revolution, (Oxford: Oxford University Press, 1984)

McHale, Brian, Postmodernist Fiction (New York and London: Methuen, 1987; repr. 1993)

McKeon, Michael, Origins of the Novel, 1600-1740 (Baltimore and London: John Hopkins University Press, 1987; repr. 1991)

McKeon, Michael, 'Politics of Discourse and the Rise of the Aesthetic in Seventeenth-Century England', in Sharpe, Kevin and Steven N. Zwicker, eds, Politics and Discourse: The Literature and History of the Seventeenth Century England, pp. 35-51

Macaulay, Thomas Babington, 'John Bunyan', in Critical and Historical Essays, 2 vols, ed. by A. J. Grieve (London: J. M. Dent, 1907), II, 399-410

Madsen, Deborah L., The Postmodern Allegories of Thomas Pynchon (Leicester, London: Leicester University Press, 1991)

Madsen, Deborah L., Rereading Allegory: A Narrative Approach to Genre (London: Macmillan, 1995)

Mailloux, Steven, 'Evaluation and Reader Response Criticism: Values Implicit in Affective Stylistics', Style 10 (1976), 329-343

Mailloux, Steven, 'Stanley Fish's "Interpreting the Varorium": Advance or Retreat?', Critical Inquiry, 3 (1976-1977), 183-190

Mailloux, Steven, 'Persuasions Good and Bad: Bunyan, Iser, and Fish on Rhetoric and Hermeneutics in Literature', Studies in the Literary Imagination, 28 (1995), 43-61

Mandel, Barrett John, 'Bunyan and the Autobiographer's Artistic Purpose', Criticism, 10 (1968), 225-243 
Mandelbaum, Maurice, 'A Note on History as Narrative', History and Theory, 6 (1967), 413419

Manlove, C. N., 'The Image of the Journey in Pilgrim's Progress: Narrative versus Allegory', Journal of Narrative Technique, 10 (1988), 16-38

Marsden, George M., 'Perry Miller's Rehabilitation of the Puritans: A Critique', Church History, 39 (1970), 91-105

Martenson, Robert L., " "Habit of Reason": Anatomy and Anglicanism in Restoration England', Bulletin of the History of Medicine, 66 (1992), $511-535$

Martin, Wallace, Recent Theories of Narrative (Ithaca and London: Cornell University Press, 1986; repr. 1994)

Matthews, W. H., Mazes and Labyrinths: A General Account of their History and Developments (London: Longmans, 1922; repr. Detroit: Singing Tress Press, 1969)

Miller, J. Hillis, ed., Aspects of Narrative: Selected Papers from the English Institute (New York and London: Columbia University Press, 1971)

Miller, J. Hillis, 'Narrative and History', ELH, 41 (1974), 455-473

Miller, J. Hillis, 'The Problematic of Ending in Narrative', Nineteenth-Century Fiction, 33 (1978), 3-7

Miller, Perry, The New England Mind: The Seventeenth Century (Cambridge, Massachusetts and London: Harvard University Press, 1939; repr. 1982)

Miller, Perry, 'The Marrow of Puritan Divinity', in Miller, Perry, Errand Into the Wilderness, pp. 48-98

Miller, Perry, Errand Into the Wilderness (Cambridge, Massachusetts: Harvard University Press, 1956; repr. 1970)

Mills, David, 'The Dreams of Bunyan and Langland', Newey, Vincent, ed., The Pilgrim's Progress: Critical and Historical Views, pp. 154-181

Miner, Earl, ed., Literary Uses of Typology: from the late Middle Ages to the Present (Princeton: Princeton University Press, 1977)

Mink, Louis, 'History and Fiction as Modes of Comprehension', $N L H, 1$ (1970), 541-558

Mink, Louis O., 'Narrative Form as a Cognitive Instrument', in Canary, Robert H. and Henry Kozicki, eds, The Writing of History, pp. 129-149

Møller, Jens G., 'The Beginnings of Puritan Covenant Theology', Journal of Ecclesiastical History, 14 (1963), 46-67

Moore, W. G., The Penguin Dictionary of Geography, 6th edn (Harmondsworth: Penguin, 1981)

More, Paul Elmer, Studies of Religious Dualism, Shelburne Essays, 6th series (New York: Phaeton Press, 1967; originally published 1909)

Morgan, Edmund S., Visible Saints: The History of a Puritan Idea (New York: New York University Press, 1963) 
Morgan, John, Godly Learning: Puritan Attitudes Towards Reason, Learning, and Education, 1560-1640 (Cambridge: Cambridge University Press, 1986)

Morris, John N., Studies in English Autobiography from John Bunyan to John Stuart Mill (New York \& London: Basic Books, 1966)

Muller, Richard A., 'Covenant and Conscience in English Reformed Theology', Westminster Theological Journal, 42 (1980), 308-334

Muller, Richard A., 'Perkins' A Golden Chaine: Predestinarian System or Schematized Ordo Salutis?', Sixteenth Century Journal, 9 (1978), 69-81

Mullett, Michael, Radical Religious Movements in Early Modern Europe (London: Allen and Unwin, 1980)

Mullett, Michael, A., John Bunyan in Context (Keele: Keele University Press, 1996)

Murphey, Murray G., 'The Psychodynamics of Puritan Conversion', American Quarterly, 31 (1979), 135-147

Myers, William, Restoration and Revolution: Political, Social, and Religious Writings, 16601700 (London: Croom Helm, 1986)

Nash, Christopher, ed., Narrative in Culture: The Uses of Storytelling in the Sciences, Philosophy, and Literature (London and New York: Routledge, 1990)

Newey, Vincent, 'Wordsworth, Bunyan and the Puritan Mind', ELH, 41 (1974), 212-232

Newey, Vincent, ed., The Pilgrim's Progress: Critical and Historical Views (Liverpool: Liverpool University Press, 1980)

Newey, Vincent, 'Bunyan and the Confines of the Mind', in Newey, Vincent, ed., The Pilgrim's Progress: Critical and Historical Views, pp. 21-48

Newey, Vincent, “ "With the Eyes of My Understanding”: Bunyan, Experience, and Acts of Interpretation', in Keeble, N. H., ed., Conventicle and Parnassus, pp. 189-216

Newman, S. J., 'Bunyan's Solidness', in Newey, Vincent, ed., The Pilgrim's Progress: Critical and Historical Views, pp. 225-250

Nicole, Roger, 'John Calvin's View of the Extent of the Atonement', Westminster Theological Journal, 47 (1985), 197-225

Nojoumian, Amir Ali, 'The Representation of Space and Time in Postmodern Narrative' (unpublished master's thesis, University of Leicester, 1994)

Nussbaum, Felicity A., “'By These Words I was Sustained”: Bunyan's Grace Abounding', $E L H, 49$ (1982), 18-34

Nuttall, Geoffrey F., The Holy Spirit in Puritan Faith and Experience (Oxford: Basil Blackwell, 1946; 2nd ed. 1947; repr. with an introduction by Peter Lake, Chicago and London: University of Chicago Press, 1992)

Nuttall, Geoffrey F., Visible Saints: The Congregational Way, 1640-1660 (Oxford: Blackwell, 1957)

Nuttall, Geoffrey F., 'The Heart of The Pilgrim's Progress', in Brooks, Peter Newman, ed., Reformation Principle and Practice, pp. 229-239 
Olney, James, Metaphors of Self: The Meaning of Autobiography (Princeton: Princeton University Press, 1972)

Olney, James, ed., Autobiography: Essays Theoretical and Critical (Princeton: Princeton University Press, 1980)

Olney, James, 'Autobiography and the Cultural Moment: A Thematic, Historical, and Bibliographical Introduction', in Olney, James, ed., Autobiography: Essays Theoretical and Critical, pp. 3-27

Olney, James, 'Some Versions of Memory/Some Versions of Bios: The Ontology of Autobiography', in Olney, James, ed., Autobiography: Essays Theoretical and Critical, pp. 236-267

Owens, W. R., “ "Antichrist must be Pulled Down": Bunyan and the Millennium', in Laurence, Anne, Owens, and Sim, eds, John Bunyan and his England, pp. 77-94

Owens, W. R., 'The Reception of The Pilgrim's Progress', in van Os, M. and G. J. Schutte, eds, Bunyan in England and Abroad, pp. 91-104

Owst, G. R., Literature in the Pulpit in Medieval England: A Neglected Chapter in the History of English Letters and of the English People (Cambridge: Cambridge University Press, 1933; rev. 2nd edn Oxford: Blackwell, 1961)

Ozmant, Steven, ed., Reformation Europe: A Guide to Research (St. Louis: Center for Reformation Research, 1982)

Parker, Alexander A., Literature and the Delinquent: The Picaresque Novel in Spain and Europe 1599-1753 (Edinburgh: Edinburgh University Press, 1967; repr. 1977)

Pascal, Roy, Design and Truth in Autobiography (London: Routledge and Kegan Paul, 1960)

Pennington, Donald and Keith Thomas, Puritans and Revolutionaries: Essays in SeventeenthCentury History presented to Christopher Hill (Oxford: Clarendon Press, 1978; repr. 1982)

Pettit, Norman, The Heart Prepared: Grace and Conversion in Puritan Spiritual Life (New Haven and London: Yale University Press, 1966)

Philips, Marion J., 'Inimitable Bunyan', Bunyan Studies: John Bunyan and his Times, 1, no. 2 (1989), $42-48$

Philips, Marion J., 'Inimitable Bunyan Stands his Ground', Bunyan Studies: John Bunyan and his Times, 2, no. 1 (1990), 26-31

Poland, Lynn M., 'Augustine, Allegory, and Conversion', Journal of Literature and Theology, 2 (1988), 37-48

Pooley, Roger, 'The Wilderness of This World', Baptist Quarterly, 27 (1978), 290-299

Pooley, Roger, 'The Structure of The Pilgrim's Progress', Essays in Poetics, 4 (1979), 59-70

Pooley, Roger, 'Language and Loyalty: Plain Style at the Restoration', Literature and History, 6 (1980), 2-18

Pooley, Roger, Spiritual Autobiography: A DIY Guide (Bramcote: Grove Books, 1983) 
Pooley, Roger, 'Plain and Simple: Bunyan and Style', in Keeble, N. H., ed., Conventicle and Parnassus, pp. 91-110

Pooley, Roger, 'Spiritual Experience and Spiritual Autobiography: Some Contexts for Grace Abounding', Baptist Quarterly, 32 (1988), 393-402

Pooley, Roger, 'Grace Abounding and the New Sense of Self', in Laurence, Anne, Owens, and Sim, eds, John Bunyan and his England, pp. 105-114

Porter, Roy, ed., Patients and Practitioners: Lay Perceptions of Medicine in Pre-Industrial Society (Cambridge: Cambridge University Press, 1985)

Porter, Roy, 'The Language of Quackery in England, 1660-1800', in Burke, Peter and Roy Porter, eds, The Social History of Language, pp. 73-103

Porter, Roy, 'The patient in England, c. 1660-c. 1800', in Wear, Andrew, ed., Medicine in Society: Historical Essays, pp. 91-118

Quilligan, Maureen, The Language of Allegory: Defining the Genre (Ithaca and London: Cornell University Press, 1979)

Rabinow, Paul, ed., The Foucault Reader An Introduction to Foucault's Thought (Harmondsworth: Penguin Books, 1991)

Rabinowitz, Peter, 'Truth in Fiction: A Re-examination of Audiences', Critical Inquiry, 4 (1977), 121-144

Rambo, L. R., 'Conversion: Towards a Holistic Model of Religious Change', Pastoral Psychology, 38 (1989), 47-63

Reay, Barry, ed., Popular Culture in Seventeenth-Century England (London: Croom Helm, 1985)

Reid, W. Stanford, John Calvin: His Influence in the Western World (Grand Rapids, Michigan: Zondervan, 1982)

Renza, Louis A., 'The Veto of the Imagination: A Theory of Autobiography', in Olney, James, ed., Autobiography: Essays Theoretical and Critical, pp. 268-295, originally published in $N L H, 9$ (1977), 1-26

Rhodes, J. Steve, 'Conversion as Crisis and Process: A Comparison of Two Models', Journal of Psychology and Christianity, 5 (1986), 20-27

Rivers, Isabel, 'Grace, Holiness, and the Pursuit of Happiness: Bunyan and Restoration Latitudinarianism', in Keeble, N. H., ed., Conventicle and Parnassus, pp. 45-69

Rivers, Isabel, Reason, Grace, and Sentiment: Studies in the Language of Religion and Ethics in England, 1660-1780 (Cambridge: Cambridge University Press, 1991)

Robinson, David, 'Bunyan's House of Interpreter and the Structure of The Pilgrim's Progress', Dutch Quarterly Review of Anglo-American Letters, 7 (1977), 100-113

Ross, Aileen M., 'Millenarianism in the Works of John Bunyan' (unpublished doctoral thesis, University of Alberta, 1986)

Ross, Aileen M., 'Paradise Regained: The Development of John Bunyan's Millenarianism', in van Os, M. and G. J. Schutte, eds, Bunyan in England and Abroad, pp. 73-89 
Royce, Professor Josiah, 'The Case of John Bunyan', Psychological Review, 1 (1894), 22$33,134-151,230-240$

Salzman, Paul, English Prose Fiction: A Critical History (Oxford: Clarendon Press, 1985)

Schellenberg, Betty A., 'Sociability and the Sequel: Rewriting Hero and Journey in The Pilgrim's Progress, Part II', Studies in the Novel, 23 (1991), 312-324

Schleiner, Louise, 'Gendered Journeys in The Faerie Queene and The Pilgrim's Progress', in Frederick, Bonnie and Susan H. McLeod, eds, Women and the Journey: The Female Travel Experience, pp. 145-169

Sena, John F., 'Melancholic Madness and the Puritans', Harvard Theological Review, 66 (1973), 293-309

Shapiro, Barbara, 'Latitudinarianism and Science in Seventeenth-Century England', in Webster, Charles, ed., The Intellectual Revolution of the Seventeenth Century, pp. 286-316

Sharpe, Kevin and Steven N. Zwicker, eds, Politics and Discourse: The Literature and History of the Seventeenth Century England (Berkeley, LA and London: University of California Press, 1987)

Sharrock, Roger, 'Spiritual Autobiography in The Pilgrim's Progress', RES, 24 (1948), 102120

Sharrock, Roger, 'The Trial of Vices in Puritan Fiction', Baptist Quarterly. 14 (1951-1952), 312,48

Sharrock, Roger, 'Mathew's Pills and The Pilgrim's Progress', Notes and Queries, 199 (1954), 246-247

Sharrock, Roger, John Bunyan (London: Macmillan, 1954; repr. 1968)

Sharrock, Roger, 'Personal Vision and Puritan Tradition in Bunyan', Hibbert Journal, 56 $(1957-58), 47-60$

Sharrock, Roger, John Bunyan: The Pilgrim's Progress, Studies in English Literature 27 (London: Edward Arnold, 1966)

Sharrock, Roger, ed., The Pilgrim's Progress: A Casebook (London: Macmillan, 1976)

Sharrock, Roger, 'Life and Story in The Pilgrim's Progress', in Newey, Vincent, ed., The Pilgrim's Progress: Critical and Historical Views, pp. 49-68

Sharrock, Roger, 'The Life and Death of Mr. Badman: Facts and Problems', Modern Language Review, 82 (1987), 15-29

Sharrock, Roger, 'Temptation and Understanding in Grace Abounding', Bunyan Studies: John Bunyan and his Times, 1 (1988), 5-14

Sharrock, Roger, 'Bunyan Studies Today: An Evaluation', in van Os, M. and G. J. Schutte, eds, Bunyan in England and Abroad, pp. 45-59

Sharrock, Roger, 'Spiritual Autobiography: Bunyan's Grace Abounding', in Laurence, Anne, Owens, and Sim, eds, John Bunyan and his England, pp. 97-104 
Sheils, W. J., ed., The Church and Healing: Studies in Church History, volume 19 (Oxford: Basil Blackwell, 1982)

Shelley, Bryan, Shelley and Scripture: The Interpreting Angel (Oxford: Clarendon Press, 1994)

Sim, Stuart, 'Bunyan's Holy War and the Dialectics of Long-Drawn Outness', Restoration, 9 (1985), 93-98

Sim, Stuart, " "Vertuous Mediocrity" and "Fanatick Conventicle": Pilgrimage Styles in John Bunyan and Bishop Simon Patrick', English Studies, 68 (1987), 316-324

Sim, Stuart, " "For some it driveth to despaire": Calvinist Soteriology and Character Models in Arthur Dent's Plain-Man's Pathway to Heaven', English Studies, 69 (1988), 38-48

Sim, Stuart, 'Isolating the Reprobate: Paradox as a Strategy for Social Critique in The Life and Death of Mr. Badman', Bunyan Studies: John Bunyan and his Times, 1, no. 2 (1989), $30-41$

Sim, Stuart, " "Safe For Those For Whom it is to be Safe": Salvation and Damnation in Bunyan's Fiction', in Laurence, Anne, Owens, and Sim, eds, John Bunyan and his England, pp. 149-160

Sim, Stuart, Negotiations With Paradox: Narrative Practice and Narrative Form in Bunyan and Defoe (London: Harvester Wheatsheaf, 1990)

Sizemore, Christine W., 'Structural Repetition in John Bunyan's Holy War', Tennessee Studies in Literature, 24 (1979), 71-81

Slights, William E., 'The Edifying Margins of Renaissance English Books', Renaissance Quarterly, 42 (1989), 682-716

Slights, William E., " "Marginal Notes that spoile the Text": Scriptural Annotation in the English Renaissance", The Huntingdon Library Quarterly, 55 (1992), 255-278

Small, John and Michael Witherick, A Modern Dictionary of Geography, 3rd edn (London: Edward Arnold, 1995)

Smith, Nigel, Perfection Proclaimed: Language and Literature in English Radical Religion 1640-1660 (Oxford: Clarendon Press, 1989)

Smith, Nigel, 'Bunyan and the Language of the Body in Seventeenth-Century England', in Laurence, Anne, Owens, and Sim, eds, John Bunyan and his England, pp. 161-174

Sommerville, C. J., 'Conversion Versus the Early Puritan Covenant of Grace', Journal of Presbyterian History, 44 (1966), 178-197

Sondergard, Sid, " "This Giant Has Wounded Me as Well as Thee": Reading Bunyan's Violence and/as Authority', in Keller, Katherine Z. and Gerald J. Schifforst, eds, The Witness of the Times, pp. 218-237

Soskice, Janet Martin, Metaphor and Religious Language (Oxford: Clarendon Press, 1985; repr. 1987)

Spargo, Tamsin, 'The Purloined Postcard: Waiting for Bunyan', Textual Practice, 8 (1994), 79-96

Spargo, Tamsin, The Writing of John Bunyan (Aldershot: Ashgate, 1997) 
Spufford, Margaret, 'First steps in literacy: the reading and writing experiences of the humblest seventeenth-century spiritual autobiographers', Social History, 4 (1979), 407-435

Spufford, Margaret, Small Books and Pleasant Histories: Popular Fiction and its Readership in Seventeenth Century England (London: Methuen, 1981)

Stachniewski, John, The Persecutory Imagination: English Puritanism and the Literature of Despair (Oxford: Clarendon Press, 1991)

Starobinski, Jean, 'The Style of Autobiography', in Olney, James, ed., Autobiography: Essays Theoretical and Critical, pp. 73-83

Steinmetz, David C., 'The Theology of Calvin and Calvinism', in Ozmant, Steven, ed., Reformation Europe: A Guide to Research (St. Louis: Center for Reformation Research, 1982), pp. 211-232

Stewart, Ralph, 'Bunyan's The Pilgrim's Progress, "The Author's Apology For His Book" , Explicator, 52 (1993-1994), 211-213

Stranahan, Brainerd P., 'Bunyan's Special Talent: Biblical Texts as Events in Grace Abounding and The Pilgrim's Progress', ELR, 11 (1981), 329-343

Stranahan, Brainerd P., 'Bunyan and the Epistle to the Hebrews: His Source for the Idea of Pilgrimage in The Pilgrim's Progress', Studies in Philology, 79 (1982), 279-296

Stranahan, Brainerd P., " "With Great Delight": The Song of Solomon in The Pilgrim's Progress', English Studies, 68 (1987), 220-227

Stranahan, Brainerd P., 'Bunyan's Satire and its Biblical Sources', in Collmer, Robert, ed., Bunyan in Our Time, pp. 35-60

Stromberg, Peter G., 'Ideological Language in the Transformation of Identity', American Anthropologist, 92 (1990), 42-57

Sturrock, John, The Language of Autobiography: Studies in the First Person Singular (Cambridge: Cambridge University Press, 1993)

Suleiman, Susan, 'Introduction: Varieties of Audience-Oriented Criticism', in Suleiman, Susan and Inge Crosman, The Reader in the Text, pp. 3-45

Suleiman, Susan and Inge Crosman, The Reader in the Text: Essays on Audience and Interpretation, (Princeton: Princeton University Press, 1980)

Summers, Joseph H., 'Stanley Fish's Reading of Seventeenth-Century Literature', Modern Language Quarterly, 35 (1974), 403-417

Sutherland, James, Restoration Literature 1660-1700: Dryden, Bunyan, Pepys (Oxford: Clarendon Press, 1969; repr. 1990)

Swaim, Kathleen M., 'Mercy and the Feminine Heroic in the Second Part of Pilgrim's Progress', SEL, 26 (1986), 439-453

Swaim, Kathleen M., 'Christian's “Christian Behaviour” to his Family in Pilgrim's Progress', Religion and Literature, 21 (1989), 1-15

Swaim, Kathleen, Pilgrim's Progress, Puritan Progress: Discourses and Contexts (Urbana and Chicago: University of Illinois Press, 1993) 
Swinburne, Richard, Revelation: From Metaphor to Analogy (Oxford: Clarendon Press, 1992)

Talon, Henri, John Bunyan: The Man and his Works, transl. by Barbara Wall (London: Rockliff Publishing, 1951; originally pub. in French, 1948)

Thickstun, Margaret Olofson, 'The Preface to Bunyan's Grace Abounding as Pauline Epistle', Notes and Queries, n.s. 32 (1985), 180-182

Thickstun, Margaret Olofson, 'From Christiana to Stead-Fast: Subsuming the Feminine in The Pilgrim's Progress', SEL, 26 (1986), 439-453

Thickstun, Margaret Olofson, Fictions of the Feminine: Puritan Doctrine and the Representation of Women (Ithaca and London: Cornell University Press, 1988)

Thomas, J. Hobson, 'Bunyan the Baptist', Baptist Quarterly, 4 (1928), 97-103

Thompson, E. P., The Making of the English Working Class (Harmondsworth: Penguin Books, 1963; rev. and repr. 1972)

Thorson, Stephen, 'Tensions in Calvin's View of Faith: Unexamined Assumptions in R. T. Kendall's Calvin and English Calvinism to 1649', Journal of the Evangelical Theological Society, 37 (1994), 413-424

Thumma, Scott, 'Seeking to be Converted: An Examination of Recent Conversion Studies and Theories', Pastoral Psychology, 39 (1991), 185-194

Tillyard, E. M. W., The English Epic and its Background (London: Chatto and Windus, 1954)

Tindall, William York, John Bunyan, Mechanick Preacher (New York: Columbia University Press, 1934; repr. 1964)

Tipson, Baird, 'A Dark Side of Seventeenth-Century English Protestantism: The Sin Against the Holy Spirit', Harvard Theological Review, 77 (1984), 301-30

Trinterud, Leonard J., 'The Origins of Puritanism', Church History, 20 (1951), 37-57

Trinterud, Leonard J., 'A. D. 1689: The End of the Clerical World', in Hudson, Winthrop S. and Leonard J. Trinterud, Theology in Sixteenth and Seventeenth-Century England, pp. 25-51

Turner, James, 'Bunyan's Sense of Place', in Newey, Vincent, ed., The Pilgrim's Progress: Critical and Historical Views, pp. 91-110

Underwood, A. C., A History of the English Baptists, with a foreword by J. H. Rushbrooke (London: The Carey Kingsgate Press, 1947; repr. 1956)

Underwood, T. L., “ "It pleased me much to contend": John Bunyan as Controversialist', Church History, 57 (1988), 456-469

Underwood, T. L., 'John Bunyan: A Tercentenary', American Baptist Quarterly, 7 (1988), 438-442

Van Dyke, Carolyn, The Fiction of Truth: Structures of Meaning in Narrative and Dramatic Allegory (Ithaca and London: Cornell University Press, 1985)

van Os, M. and G. J. Schutte, eds, Bunyan in England and Abroad (Amsterdam: VU University Press, 1990) 
von Rohr, John, 'Covenant and Assurance in English Puritanism', Church History, 34 (1965), 195-203

von Rohr, John, The Covenant of Grace in Puritan Thought (Atlanta, Georgia: Scholars Press, 1986)

Wakefield, Gordon, John Bunyan: The Christian (London: HarperCollins, 1992; repr. 1994)

Walder, Dennis, ed., Literature in the Modern World: Critical Essays and Documents (Oxford: Oxford University Press, 1990)

Wallace, Dewey D., Puritans and Predestination: Grace in English Protestant Theology, 15251695 (Chapel Hill: University of North Carolina Press, 1982)

Ward, Graham, 'To Be a Reader: Bunyan's Struggle with the Language of Scripture in Grace Abounding to the Chief of Sinners', Journal of Literature and Theology, 4 (1990), 2949

Watkins, Owen C., The Puritan Experience (London: Routledge and Kegan Paul, 1972)

Watson, Melvin R., 'The Drama of Grace Abounding', English Studies, 46 (1965), 471-482

Watt, Tessa, Cheap Print and Popular Piety, 1550-1660 (Cambridge: Cambridge University Press, 1991; repr. 1994)

Watts, Michael R., The Dissenters: From the Reformation to the French Revolution (Oxford: Clarendon Press, 1978)

Waugh, Patricia, Metafiction: The Theory and Practice of Self-Conscious Fiction (London and New York: Methuen, 1984; repr. 1985)

Wear, Andrew, 'Puritan perceptions of illness in seventeenth century England', in Porter, Roy, ed., Patients and Practitioners, pp. 55-99

Wear, Andrew, ed., Medicine in Society: Historical Essays (Cambridge: Cambridge University Press, 1992; repr. 1994)

Webber, Joan, The Eloquent "I": Style and Self in Seventeenth-Century Prose (Madison, Wisconsin and London: University of Wisconsin Press, 1968)

Weber, Max, The Protestant Ethic and the Spirit of Capitalism, transl. by Talcott Parsons, with an intro. by Anthony Giddens (London: HarperCollins, 1930; repr. London and New York: Routledge, 1992; originally published in German 1904-1905, and repr. 1920)

Webster, Charles, ed., The Intellectual Revolution of the Seventeenth Century (London: Routledge and Kegan Paul, 1974)

Webster, Charles, The Great Instauration: Science, Medicine and Reform, 1626-1660 (London: Duckworth, 1975)

West, Alick, 'John Bunyan', in Crisis and Criticism and Selected Literary Essays, with a foreword by Arnold Kettle and intro. by Elizabeth West (London; Lawrence and Wishart, 1975), pp. 131-177

Wharey, James Blanton, 'Bunyan's Mr. Badman', MLN, 36 (1921), 65-79 
Wharey, James Blanton, 'Bunyan's Mr. Badman and the Picaresque Novel', University of Texas Studies in English, 4 (1924), 49-61

Wharey, James Blanton, A Study of the Sources of Bunyan's Allegories (New York: Gordian Press, 1968; originally published 1904)

White, B. R., The English Baptists of the Seventeenth Century (London: The Baptist Historical Society, 1983)

White, Barrie, 'John Bunyan and the Context of Persecution', in Laurence, Anne, Owens, and Sim, eds, John Bunyan and his England, pp. 51-62

White, Hayden, 'The Historical Text as Literary Artifact', in Canary, Robert H. and Henry Kozicki, eds, The Writing of History, pp. 41-62

White, Hayden, 'The Value of Narrativity in the Representation of Reality', Critical Inquiry, 7 (1980), 5-27

White, Hayden, 'The Question of Narrative in Contemporary Historical Theory', History and Theory, 23 (1984), 1-33

Winslow, Ola Elizabeth, John Bunyan (New York: Macmillan, 1961)

Wootton, Rayman J. and David F. Allen, 'Dramatic Religious Conversion and Schizophrenic Decompensation', Journal of Religion and Health, 22 (1983), 212-220

Wright, T. R., Theology and Literature (Oxford: Blackwell, 1988)

Zaret, David, The Heavenly Contract: Ideology and Organization in Pre-Revolutionary Puritanism (Chicago and London: University of Chicago Press, 1985)

Zinck, Arlette Marie, 'Of Arms and the Heroic Reader: The Concept of Psychomachy in Spenser, Milton, and Bunyan' (unpublished doctoral thesis, University of Alberta, 1993) 